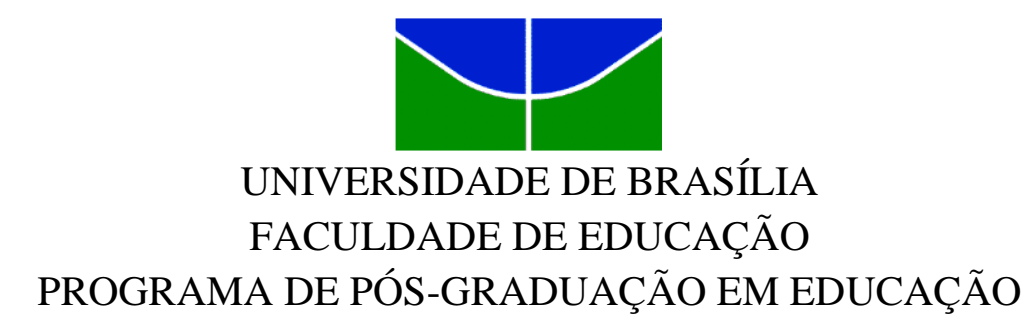

\title{
APRENDIZAGEM CRIATIVA DA LEITURA E DA ESCRITA E SUAS INTER-RELAÇÕES COM O DESENVOLVIMENTO DA SUBJETIVIDADE DA CRIANÇA
}

LUCIANA SOARES MUNIZ

Brasília, 2015 


\author{
UNIVERSIDADE DE BRASÍLIA \\ FACULDADE DE EDUCAÇÃO \\ PROGRAMA DE PÓS-GRADUAÇÃO EM EDUCAÇÃO
}

\title{
APRENDIZAGEM CRIATIVA DA LEITURA E DA ESCRITA E SUAS INTER-RELAÇÕES COM O DESENVOLVIMENTO DA SUBJETIVIDADE DA CRIANÇA
}

\author{
LUCIANA SOARES MUNIZ
}

Tese apresentada ao Programa de Pós-Graduação em Educação da Faculdade de Educação da Universidade de Brasília/UnB como parte dos requisitos para a obtenção do título de Doutor em Educação, na área de Escola, Aprendizagem e Trabalho Pedagógico.

Orientadora Profa Dra Albertina Mitjáns Martínez

Brasília, abril de 2015. 


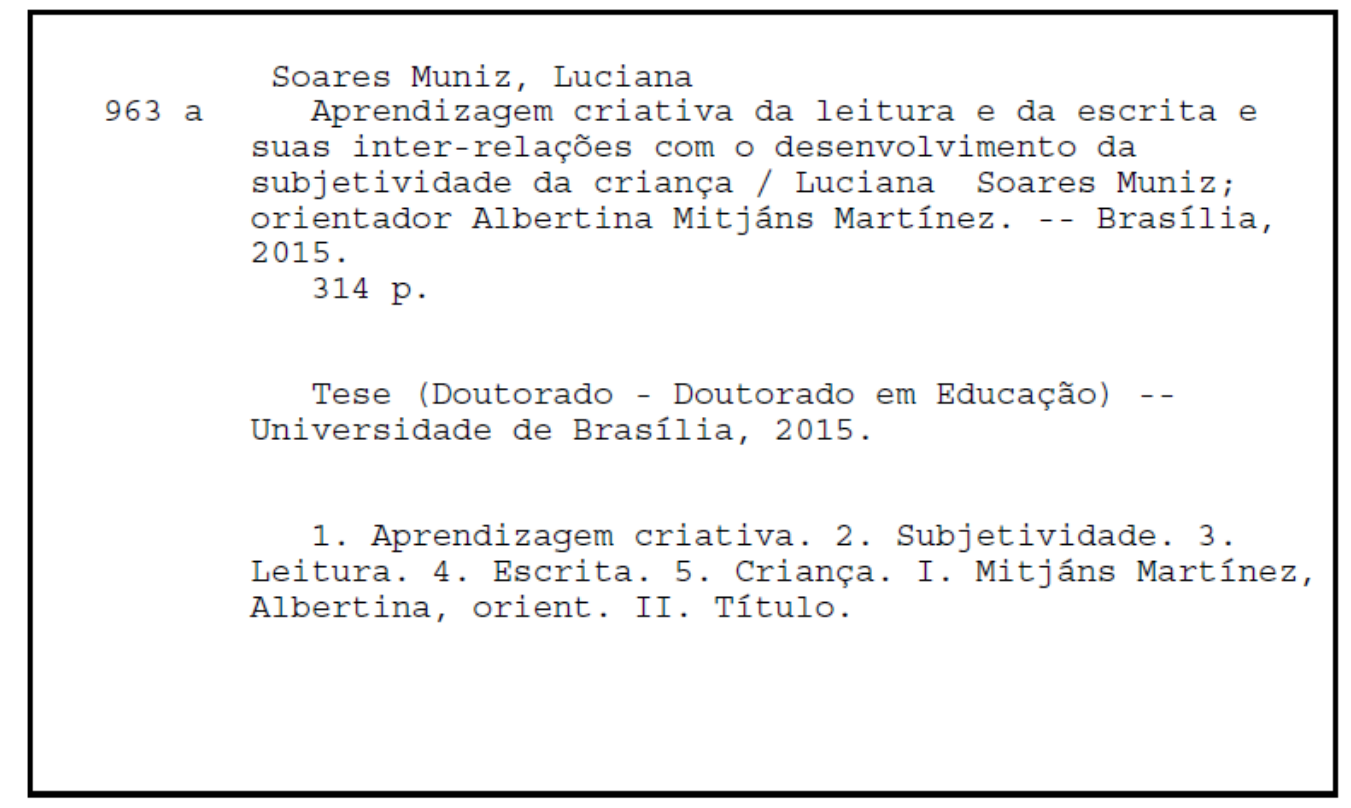




\section{APRENDIZAGEM CRIATIVA DA LEITURA E DA ESCRITA E SUAS INTER-RELAÇÕES COM O DESENVOLVIMENTO DA SUBJETIVIDADE DA CRIANÇA}

BANCA EXAMINADORA:

Profa Dra Albertina Mitjáns Martínez

Faculdade de Educação - UnB Orientadora

Profa Dra Myrtes Dias da Cunha

Faculdade de Educação - UFU

Examinadora externa
Profa Dra Claisy Maria Marinho-Araujo
Instituto de Psicologia - UnB
Examinadora externa

Profa Dra Stella Maris Bortoni-Ricardo

Faculdade de Educação - UnB

Examinadora interna

Profa Dra Cristina Madeira Coelho

Faculdade de Educação - UnB

Examinadora interna

Profa Dra Maria Carmen Villela Rosa Tacca

Faculdade de Educação - UnB

Examinadora suplente 


\section{AGRADECIMENTOS}

Agradeço a Deus pela vida e as oportunidades que nos permitem mudanças em nós mesmos.

Agradeço a meu esposo Carlos, por seu apoio, companheirismo e pelos intensos diálogos que edificaram este trabalho. Aos meus filhos Hiago e Yasmin, pelo carinho e amor que me fortalecem. Ao filho que neste processo foi gerado e que já cumpriu sua jornada conosco. À minha avó Lina, meus pais, Lucimar e Osiris, e irmãs Vanessa, Lara e Larisse pela admiração e orgulho de minhas escolhas e conquistas. Ao meu sobrinho Igor, por me ensinar a simplicidade da vida pelo sorriso de uma criança. À minha cunhada Kátia, pela alegria de têla ao meu lado. À memória de minha bisavó Ótilia, por me ensinar, dentre tantas virtudes, a força e a alegria de viver.

Agradeço, em especial, à minha querida orientadora professora Albertina, pela caminhada de aprendizagem e desenvolvimento que me possibilitou. Seu apoio, compreensão e incentivos foram fundamentais para a realização deste trabalho. Sou grata pela sua abertura às minhas ideias e pelo respeito ao meu percurso singular de aprendizagem.

Ao professor Fernando González Rey, pessoa que admiro profundamente. Criador de uma teoria, que, em minha relação com a mesma, pude experienciar a metamorfose do sujeito pela leitura. Agradeço a oportunidade única de aprender com os próprios autores da teoria.

À professora Myrtes Dias da Cunha, pessoa especial, que admiro e tenho o maior respeito. Às professoras Angela Maria Cristina Uchoa de Abreu Branco, Stella Maris Bortoni-Ricardo, Cristina Madeira Coelho, Claisy Maria Marinho-Araujo e Maria Carmen Villela Rosa Tacca por aceitarem o convite de compor a banca e me presentearem com mais um momento de troca e aprendizagem.

Às colegas de formação: Maristela e Ana Luiza que, nos momentos iniciais de aprendizagem no doutorado, estiveram ao meu lado. Em especial, à Lu Campolina, pela acolhida em Brasília. Agradeço imensamente à amiga Francisca, pela confiança e oportunidade de conhecer e conviver com sua linda família. À amiga Valdívia, pelas caronas e telefonemas em que ousávamos em discussões profícuas sobre nossos estudos. À querida Pilar, companheira de caronas e encontros online para troca de ideias. À amiga Tati, companheira de momentos em que emoções diversas perpassaram esta caminhada de construção do trabalho. Aos novos colegas da equipe, Cristiano Muniz, Simão de Miranda, Mariângela, Gláucia, Mônica, Carolina, Talyta e Victor, pelos momentos de troca de ideias e de aprendizagem conjunta.

Agradeço a todos da escola da pesquisa, os quais foram fundamentais para a concretização da mesma. Escola acolhedora e aberta a novas ideias. Em especial, meu agradecimento aos aprendizes Murilo, Adriana e Gabriel, e seus familiares, assim como às professoras Melissa e Flávia por estarem comigo nesta caminhada da pesquisa. Muito obrigada!

Aos colegas de profissão, da Escola de Educação Básica da Universidade Federal de Uberlândia, por me concederem apoio à minha liberação para qualificação. 
"Se olho demoradamente para uma palavra descubro, dentro dela, outras tantas palavras.

Assim, cada palavra contém muitas leituras e sentidos. $O$ meu texto surge, algumas vezes a partir de uma palavra que, ao me encantar, também me dirige.

$E$ vou descobrindo, desdobrando, criando relações entre as novas palavras que dela vão surgindo.

Por isso digo sempre:

é a palavra que me escreve."

(Bartolomeu Campos de Queirós) 


\section{RESUMO}

O objetivo central da presente pesquisa foi compreender como a criatividade emerge na aprendizagem da leitura e da escrita e suas inter-relações com o desenvolvimento da subjetividade da criança. Como aporte teórico, embasamo-nos na Teoria da Subjetividade de González Rey, na qual a subjetividade é compreendida em sua dupla condição social e individual. Buscamos também subsídio na concepção de aprendizagem criativa desenvolvida por Mitjáns Martínez para a qual este tipo de aprendizagem constitui-se como processo complexo da subjetividade humana. Para a pesquisa empírica, orientamo-nos pelos princípios da Epistemologia Qualitativa desenvolvida por González Rey, em um processo construtivointerpretativo. Realizamos três estudos de caso em que acompanhamos três aprendizes durante o $1^{\circ}$ ano e $2^{\circ}$ ano do ensino fundamental, em uma escola pública da rede Municipal de ensino de Uberlândia/MG. Utilizamos para o estudo instrumentos diversificados, tais como: observação e sistemas conversacionais que envolveram a participação dos estudantes, professores e familiares. Assim como recorremos a instrumentos que envolveram apenas a participação das crianças, dos quais citamos: trilha das frases, oficinas de leitura e escrita, brincando de escolinha e outros. Dentre os principais resultados, identificamos, na singularidade de cada caso desenvolvido, as três características da criatividade na aprendizagem definidas por Mitjáns Martínez, quais sejam: personalização da informação, confrontação com o dado e produção, e, ainda, geração de ideias próprias e novas que transcendem o dado. Apresentamos, ainda, outra característica, a qual definimos como relação lúdica e que se integra às anteriores. Tais características se organizaram em unidade às estratégias de aprendizagem que, em seu conjunto, estiveram associadas à configuração subjetiva da ação de aprender criativamente. Essa se expressou por núcleos de sentidos subjetivos, constituídos por elementos da subjetividade individual, da subjetividade social e dos processos relacionais vinculados ao sujeito no contexto da ação. Concluímos que, na recursividade entre as ações de aprender criativamente e o movimento da subjetividade, pela produção de sentidos subjetivos na ação, ocorreram mudanças subjetivas que se tornaram mais estáveis, capazes de reconfigurar a organização subjetiva atual e reverberar para novas expressões da criatividade. Nesta dinâmica, a configuração subjetiva da ação de aprender criativamente se organizou como unidade subjetiva do desenvolvimento. Esse movimento, em sua complexidade, permitiu-nos fundamentar a tese de que, na aprendizagem da leitura e da escrita, a criatividade emerge de forma sistêmica e constitui-se processo de desenvolvimento da subjetividade da criança.

Palavras-chave: aprendizagem criativa; aprendizagem da leitura e da escrita; desenvolvimento da subjetividade. 


\begin{abstract}
The main purpose of the current research was to understand how the creativity emerges on reading and writing learning as well as its interrelationships with child's subjectivity development. As a theoretical support, we were based on González Rey's Subjectivity Theory, in which subjectivity is understood in its double condition: social and individual. We have also searched subsidy on the creative learning conception developed for Mitjáns Martínez in which this kind of learning constitutes itself as complex process of human subjectivity. For empirical research, we were guide for Qualitative Epistemology principles developed for González Rey, in a constructive-interpretative process. We have performed three case studies in which we followed three learners during their $1^{\text {st }}$ and $2^{\text {nd }}$ year on basic education, in a public school on the Municipal School System of Uberlândia/MG. For the trial were used several instruments, as: observation, conversational systems involving the participation of students, teachers and familiars. We also resort to instruments involving children participation alone, of which we may mention: track of sentences, reading and writing workshops, playing school, among others. Among the main results, we could identify on the singularity of each developed case, the three attributes of creativity on learning, defined by Mitjáns Martínez, being: information personalization, confrontation with the data and production, and, yet, generating own and new ideas transcending the data. We still present another quality, defined as playful relationship, integrating itself to the ones before. These characteristics organized themselves into unit to the learning strategies that, in its group, had been associated to the subjective configuration of the action to learn creatively. This last configuration expressed itself through nuclei of subjective senses, formed by elements of individual subjectivity, social subjectivity and the relational processes bounded to the subject on action context. We conclude that, on recursion between the action to learn creatively and the subjectivity motion, for production of subjective senses on action, there were subjective changes that became stable, able to reset the current subjective organization and to reverberate to new creativity expressions. On this dynamics, the subjective configuration of the action of learn creatively organized itself as development's subjective unit. This motion, in its complexity, allowed us to fundament the thesis that in the learning of reading and writing, creativity emerges in a systemic way and constitutes itself as a process of child's subjectivity development.
\end{abstract}

Keywords: creative learning; learning of reading and writing; subjectivity development. 


\section{RÉSUMÉ}

Cette recherche a eu pour objectif central de comprendre comment la créativité émerge dans l'apprentissage de la lecture et de l'écriture et leurs inter-relations avec le développement de la subjectivité de l'enfant. L'approche théorique vient de la Théorie de la Subjectivité de González Rey, à l'intérieur de laquelle la subjectivité est comprise dans sa double condition sociale et individuelle. Nous avons aussi recouru à la conception d'apprentissage créative développée par Mitjáns Martínez qui considère que ce type d'apprentissage se constitue comme un processus complexe de la subjectivité humaine. Pour la recherche empirique, nous nous sommes orientés par les principes de l'Épistémologie Qualitative développée par González Rey, dans un processus constructif-interprétatif. Nous avons réalisé trois études de cas dans lesquels nous avons accompagné trois apprenants pendant la $1^{\text {ère }}$ et la $2^{\text {ème }}$ année de l'enseignement fondamental, dans une école publique du réseau municipal d'enseignement d'Uberlândia/MG. Nous avons utilisé, pour l'étude, plusiers instruments, tels que: observation et systèmes de conversation qui ont engagé la participation des étudiants, des professeurs et leurs famille. Nous avons aussi recouru à des instruments qui ont engagé seulement la participation des enfants dont lesquels nous citons : piste des phrases, ateliers de lecture et écriture, jeu de rôle d'école et d'autres. Parmi les résultats principaux, nous avons identifié, dans la singularité de chaque cas développé, les trois caractéristiques de la créativité dans l'apprentissage définies par Mitjáns Martínez: personnalisation de l'information, confrontation avec le donné et production, et encore, génération d'idées propres et nouvelles qui transcendent le donné. Nous avons encore présenté une autre caractéristique qui nous avons définie comme relation ludique et qui s'intègre aux antérieures. Ces caractéristiques se sont organisées en unité aux stratégies d'apprentissage qui, dans son ensemble, ont été associées à la configuration subjective de l'action d'apprendre créativement. Cette configuration subjective s'est exprimée par des noyaux de sens subjectifs, constitués par des éléments de la subjectivité individuelle, de la subjectivité sociale et des processus rélationnels attachés au sujet dans le contexte de l'action. Nous avons conclu que, dans la récursivité entre les actions d'apprendre créativement et le mouvement de la subjectivité, par la production de sens subjectifs dans l'action, il y a eu des changements subjectifs qui se sont devenus plus stables, capables de réconfigurer l'organisation subjective actuelle et réverbérer vers de nouvelles expressions de créativité. Dans cette dynamique, la configuration subjective de l'action d'apprendre créativement s'est organisée comme unité subjective du développement. Ce mouvement, dans sa complexité, nous a permis de valider la thèse de que dans l'apprentissage de la lecture et de l'écriture, la créativité émerge de façon systémique et se constitue comme un processus de développement de la subjectivité de l'enfant.

Mots-clé: apprentissage créative; apprentissage de la lecture et de l'écriture; développement de la subjectivité. 


\section{LISTA DE QUADROS}

Quadro 1 - Síntese dos focos conceituais sobre aprendizagem da leitura e da escrita no campo científico. 50

Quadro 2 - Momentos de realização dos instrumentos e procedimentos da pesquisa durante os anos de 2012 e 2013. 110

Quadro 3 - Relações entre a expressão da criatividade na aprendizagem da leitura e da escrita e as estratégias de aprendizagem de Murilo 128

Quadro 4 - Inter-relações entre a expressão da criatividade e o desenvolvimento da subjetividade de Murilo 156

Quadro 5 - Relações entre a expressão da criatividade na aprendizagem da leitura e da escrita e as estratégias de aprendizagem de Adriana. 172

Quadro 6 - Inter-relações entre a expressão da criatividade e o desenvolvimento da subjetividade de Adriana. 195

Quadro 7 - Relações entre a expressão da criatividade na aprendizagem da leitura e da escrita e estratégias de aprendizagem de Gabriel. 209

Quadro 8 - Inter-relações entre a expressão da criatividade e o desenvolvimento da subjetividade de Gabriel. 234 


\section{SUMÁRIO}

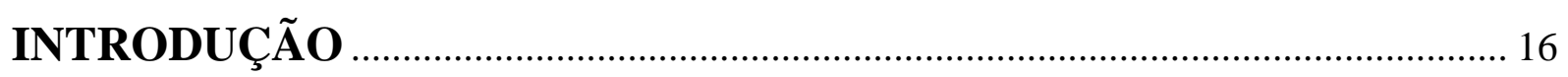

1 REVISÃO DA LITERATURA ……............................................................... 22

1.1 APRENDIZAGEM DA LEITURA E DA ESCRITA: PRODUÇÃO CIENTÍFICA

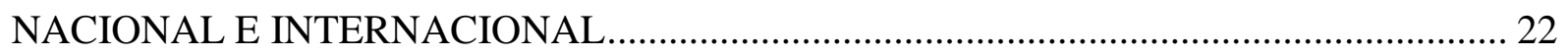

1.1.1 Contribuições das pesquisas de revisões bibliográficas ao campo da aprendizagem da

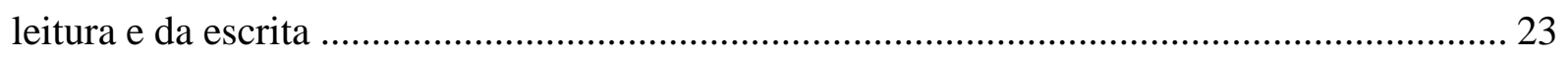

1.1.2 Aprendizagem da leitura e da escrita: estágios e processos operacionais ....................... 26

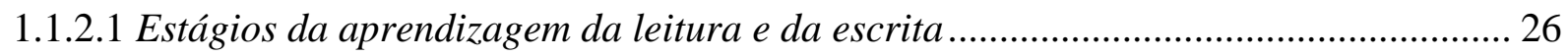

1.1.2.2 O operacional no processo de aprender a ler e a escrever ....................................... 29

1.1.3 A aprendizagem da leitura e da escrita: relações com a inventividade e a semântica .... 33

1.1.3.1 Caráter inventivo no processo de aprendizagem da leitura e da escrita .................... 33

1.1.3.2 Semântica e o processo de aprendizagem da leitura e da escrita ............................... 36

1.1.4 A aprendizagem da leitura e da escrita: relações com os processos interativos e

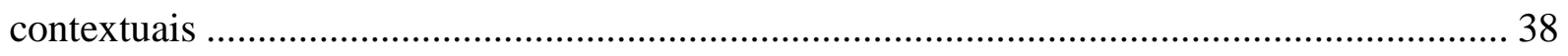

1.1.4.1 Processos interativos na aprendizagem da leitura e da escrita .................................. 38

1.1.4.2 Elementos contextuais: usos e funções da leitura e da escrita ................................... 41

1.1.5 Aprendizagem da leitura e da escrita: relações com o desenvolvimento humano e os

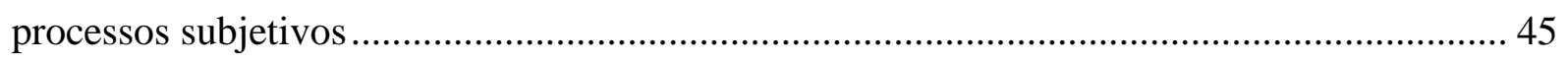

1.1.5.1 A aprendizagem da leitura e da escrita e suas relações com o desenvolvimento humano.

1.1.5.2 Processos subjetivos na aprendizagem de crianças: pesquisas no âmbito da Teoria da Subjetividade. 48

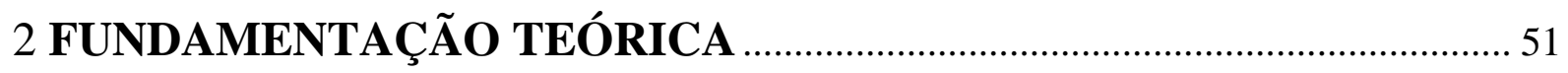

2.1 BASE TEÓRICA DA PESQUISA I: TEORIA DA SUBJETIVIDADE .......................... 51

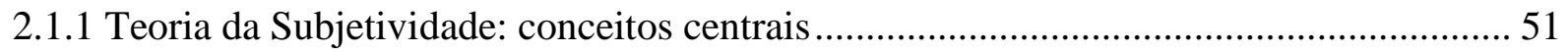

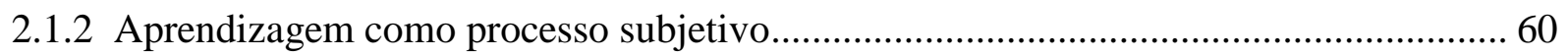

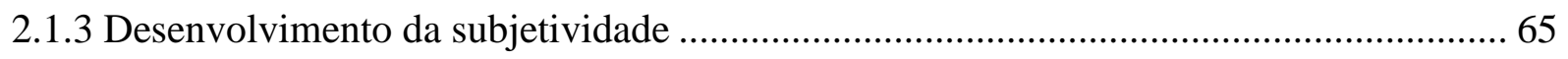

2.2 BASE TEÓRICA DA PESQUISA II: CRIATIVIDADE NA APRENDIZAGEM .......... 71

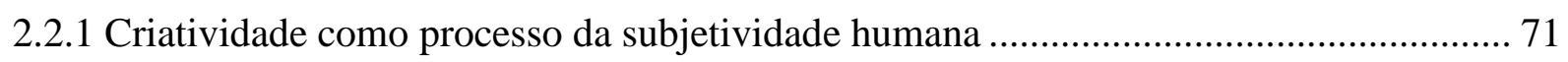

2.2.2 Aprendizagem criativa no contexto escolar e suas inter-relações com outros tipos de

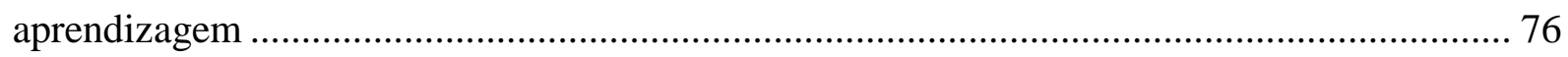


2.2.3 O papel da escola na constituição e desenvolvimento da criatividade: as múltiplas possibilidades de relação entre o ensino e a aprendizagem da leitura e da escrita 88

\section{BASES EPISTEMOLÓGICAS E METODOLÓGICAS DA PESQUISA 95}

3.1 A EPISTEMOLOGIA QUALITATIVA E O MÉTODO DA INVESTIGAÇÃO ............ 95

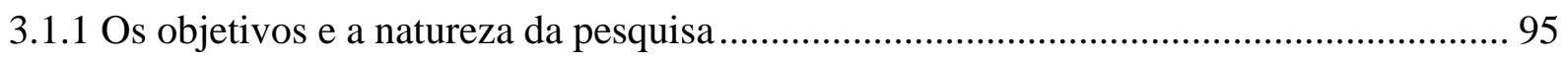

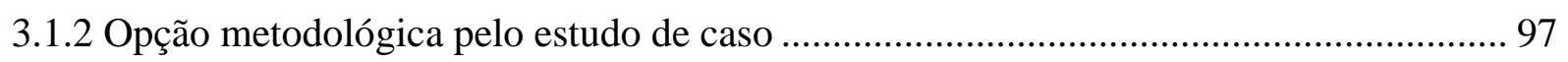

3.1.3 Local da pesquisa: caracterização da escola onde foi realizada a investigação .............. 97

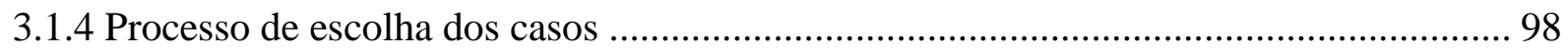

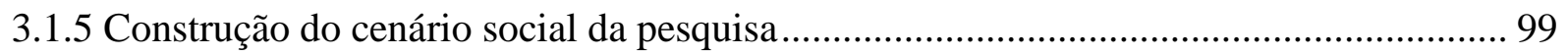

3.1.5.1 A entrada na escola: abertura para um processo colaborativo ................................ 99

3.1.5.2 Contato com os professores: diálogos preliminares............................................... 100

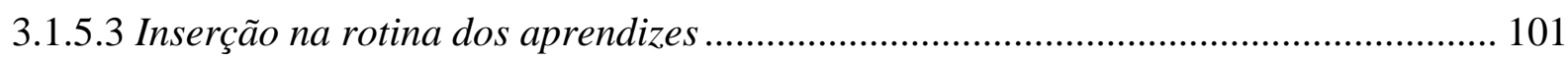

3.1.5.4 Contato com as famílias: um processo de parceria ................................................. 102

3.1.6 Produção de informação: itinerário da pesquisa de campo .......................................... 102

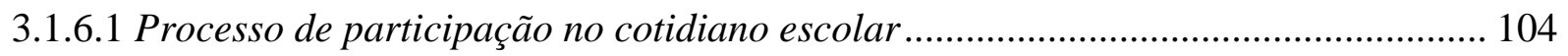

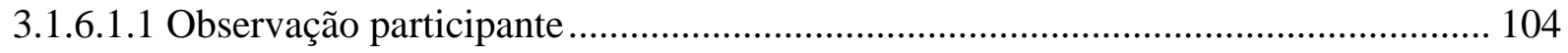

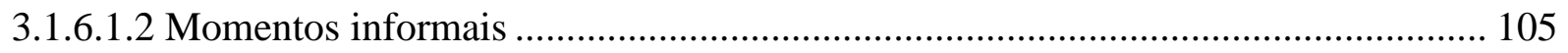

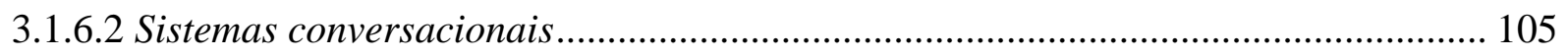

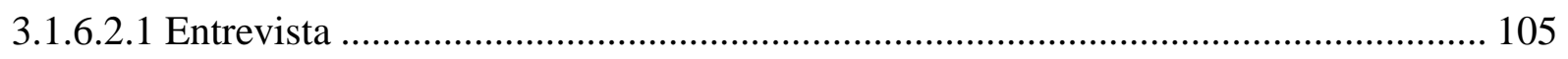

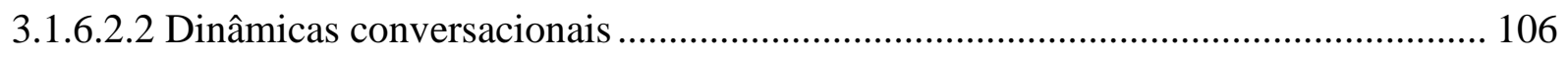

3.1.6.3 Instrumentos apoiados em registros escritos e não escritos..................................... 106

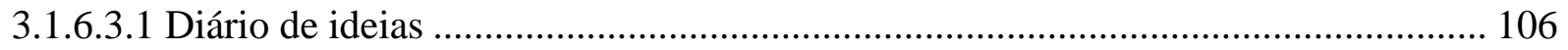

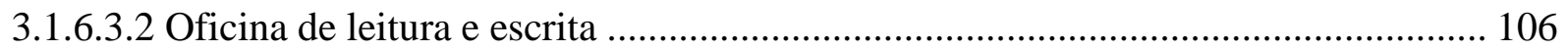

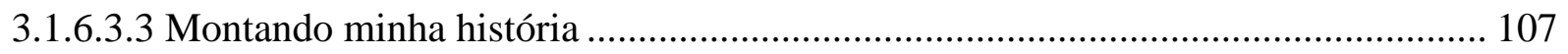

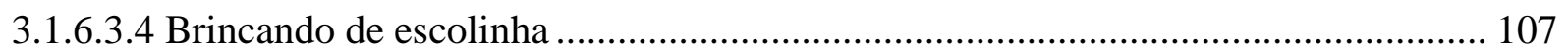

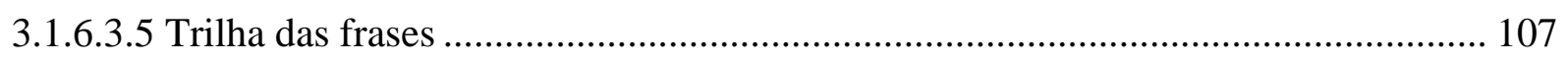

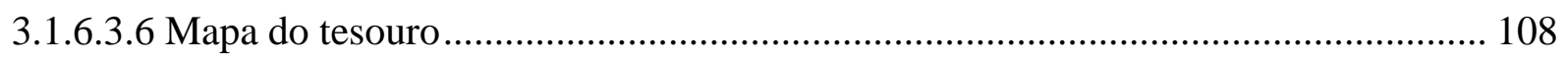

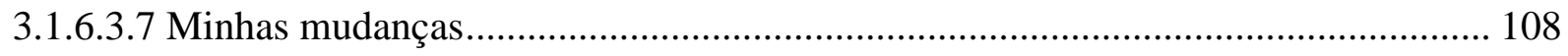

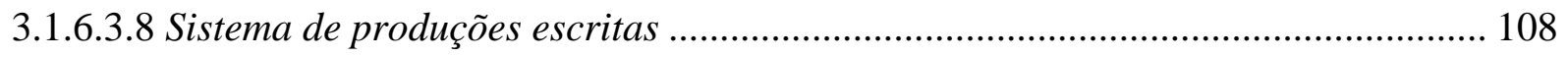

3.1.7 Momentos de utilização dos instrumentos no devir da pesquisa .................................. 109

3.1.8 Processo construtivo-interpretativo: configuração do modelo teórico ........................... 111

4 PROdUÇÃo TEÓRICA DA PESQUISADORA I: PROCESSO CONSTRUTIVO-INTERPRETATIVO …………………………………….... 113 
4.1.1 Caracterização de Murilo

4.1.2 Expressão da criatividade na aprendizagem da leitura e da escrita e suas relações com as estratégias de aprendizagem de Murilo

4.1.2.1 Personalização da informação

4.1.2.2 Confrontação com o dado.....

4.1.2.3 Produção, geração de ideias próprias e novas que vão além do dado

4.1.2.4 A relação lúdica no processo de aprendizagem criativa da leitura e da escrita

4.1.3 Configuração subjetiva da ação de aprender criativamente a leitura e a escrita de Murilo

4.1.3.1 Núcleo de sentidos subjetivos associados à mudança da educação infantil para o ensino fundamental

4.1.3.2 Núcleo de sentidos subjetivos associados à necessidade de estabelecer vínculos afetivos com o outro.

4.1.3.3 Núcleo de sentidos subjetivos relacionados à aprendizagem da leitura e da escrita como processo relacional

4.1.4 Mudanças e novas constituições subjetivas vinculadas ao processo de aprendizagem criativa da leitura e da escrita de Murilo 148

4.2 O CASO DE ADRIANA

4.2.1 Caracterização de Adriana

4.2.2 Expressão da criatividade na aprendizagem da leitura e da escrita e suas relações com as estratégias de aprendizagem de Adriana 158

4.2.2.1 Personalização da informação 158

4.2.2.2 Confrontação com o dado. 161

4.2.2.3 Produção, geração de ideias próprias e novas que vão além do dado 165

4.2.2.4 A relação lúdica no processo de aprendizagem criativa da leitura e da escrita 169

4.2.3 A configuração subjetiva da ação de aprender criativamente a ler e a escrever de Adriana.

4.2.3.1 Núcleo de sentidos subjetivos associados à relação com a mãe: alto grau de exigência

4.2.3.2 Núcleo de sentidos subjetivos relacionados à experiência de brincar de ser professora

4.2.3.3 Núcleo de sentidos subjetivos associados à relação com o conhecimento: a dimensão proativa para a pesquisa. 
4.2.4 Mudanças e constituição de novos aspectos na subjetividade de Adriana vinculados ao processo de aprendizagem criativa da leitura e da escrita .................................................. 189

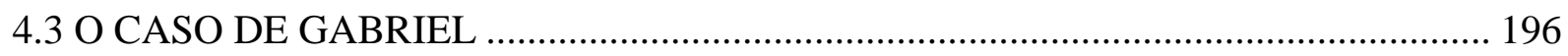

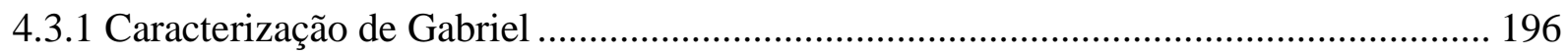

4.3.2 Expressão da criatividade na aprendizagem da leitura e da escrita e suas relações com as

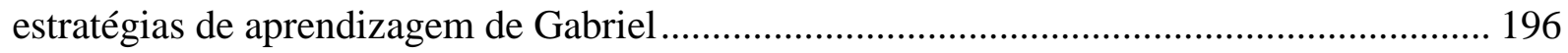

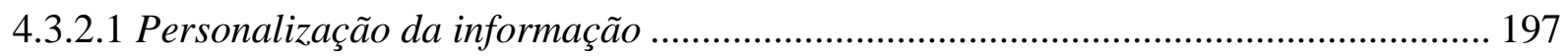

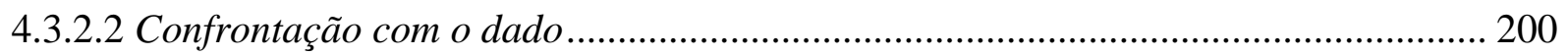

4.3.2.3 Produção, geração de ideias próprias e novas que vão além do dado ...................... 202

4.3.2.4 A relação lúdica no processo de aprendizagem criativa da leitura e da escrita....... 205

4.3.3 A configuração subjetiva da ação de aprender criativamente a ler e a escrever de Gabriel 210

4.3.3.1 Núcleo de sentidos subjetivos associados à relação com a mãe: o cuidado com o outro 210

4.3.3.2 Núcleo de sentidos subjetivos relacionados à relação com o desenho: o vínculo com o pai. 220

4.3.3.3 Núcleo de sentidos subjetivos associados à relação com o esporte 226 4.3.4 Mudanças e constituição de novos aspectos na subjetividade de Gabriel vinculados ao processo de aprendizagem criativa da leitura e da escrita 230

5 PRODUÇÃo TEÓRICA DA PESQUISADORA II: ANÁliSE INTEGRATIVA DOS CASOS. 235

5.1 PRODUÇÃO TEÓRICA SOBRE A EXPRESSÃO DA CRIATIVIDADE NA APRENDIZAGEM DA LEITURA E DA ESCRITA E SUAS RELAÇÕES COM AS ESTRATÉGIAS DE APRENDIZAGEM. 235

5.2 PRODUÇÃO TEÓRICA SOBRE A CARACTERIZAÇÃO DA CONFIGURAÇÃO SUBJETIVA DA AÇÃO DE APRENDER CRIATIVAMENTE A LER E A ESCREVER 245 5.3 PRODUÇÃO TEÓRICA SOBRE MUDANÇAS E CONSTITUIÇÃO DE NOVOS ASPECTOS NA SUBJETIVIDADE VINCULADOS AO PROCESSO DE APRENDIZAGEM CRIATIVA DA LEITURA E DA ESCRITA: FUNDAMENTAÇÃO DA

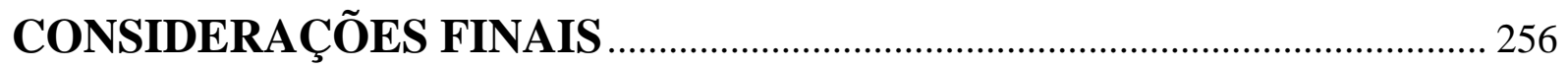

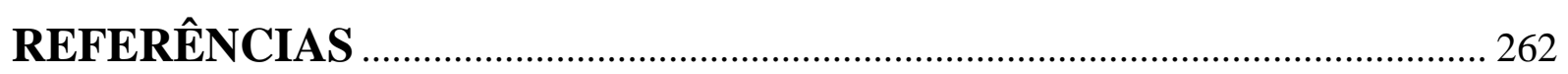

APENDICES 
APÊNDICE A - Elementos para a criação do cenário social de pesquisa ............................ 284

APÊNDICE B - Roteiro da observação participante .......................................................... 285

APÊNDICE C - Roteiro da entrevista I com as crianças participantes da pesquisa............. 287

APÊNDICE D - Roteiro da entrevista II com as crianças participantes da pesquisa ........... 288

APÊNDICE E - Roteiro da entrevista III com as crianças participantes da pesquisa .......... 289

APÊNDICE F - Roteiro da entrevista IV com as crianças participantes da pesquisa .......... 290

APÊEDICE G - Eixos temáticos da dinâmica conversacional I com os familiares das crianças participantes da pesquisa

291

APÊNDICE H - Eixos temáticos da dinâmica conversacional II com os familiares das crianças participantes da pesquisa.

APÊNDICE I - Eixos temáticos da dinâmica conversacional I com as professoras das crianças participantes da pesquisa.

APÊNDICE J - Eixos temáticos da dinâmica conversacional II com as professoras das crianças participantes da pesquisa.

APÊNDICE K - Eixos temáticos da dinâmica conversacional III com as professoras das crianças participantes da pesquisa.

APÊNDICE L - Eixos temáticos da dinâmica conversacional I com as crianças participantes da pesquisa sobre os seus próprios registros. .296

APÊNDICE M - Diário de ideias 297

APÊNDICE N - Oficina de leitura e escrita 298

APÊNDICE O - Montando minha história 299

APÊNDICE P - Brincando de escolinha 300

APÊNDICE Q - Trilha das frases 301

APÊNDICE R - Mapa do tesouro 302

APÊNDICE S - Minhas mudanças . 303

APÊNDICE T - Termo de Consentimento Livre e Esclarecido para familiares responsáveis pelas crianças participantes da pesquisa 304 APÊNDICE U - Termo de Consentimento Livre e Esclarecido para as professoras participantes da pesquisa. 305 306

ANEXO A - Autorização para realização da pesquisa na escola I 307

ANEXO B - Autorização para realização da pesquisa na escola II. 308 ANEXO C - Imagens I referentes ao estudo de caso Murilo 309 
ANEXO D - Imagens II referentes ao estudo de caso Murilo. 310

ANEXO E - Imagens I referentes ao estudo de caso Adriana............................................. 311

ANEXO F - Imagens II referentes ao estudo de caso Adriana 312

ANEXO G - Imagens I referentes ao estudo de caso Gabriel 313

ANEXO H - Imagens II referentes ao estudo de caso Gabriel. 314 


\section{INTRODUÇÃO}

No contexto atual das sociedades ocidentais em que a cultura letrada se torna presente em nossa forma de estar e relacionar com o mundo e com as pessoas, somos convidados a refletir sobre os processos que envolvem a aprendizagem da leitura e da escrita. Às vezes, temos a impressão de que, com o advento das Tecnologias da Informação e Comunicação (TICs), as crianças e mesmo os adultos estão deixando a leitura e a escrita para um segundo plano, devido ao avanço do cinema, da televisão e da internet. Porém, como bem ressaltou Meier (2011), em uma reportagem à revista Veja, o advento da internet fez com que a leitura, e nós acrescentamos a escrita, passasse cada vez mais a fazer parte da vida das pessoas mediante novas maneiras de utilização.

Ademais, diferentes informações, de uso cotidiano de cada um, são veiculadas via escrita e diversificados materiais para leitura estão presentes na vida da criança desde muito cedo, a qual tem experiências singulares que são, inicialmente, significadas no âmbito familiar e também social e, posteriormente, na escola. O que nos indica a relevância de pensarmos a educação na sua relação com a vida da criança, em que a leitura e a escrita se constituam como recursos de autoria e atitude frente ao mundo. Uma vez que, ler e escrever como salienta Freire (2011a, p. 19) “[...] não se esgota na decodificação pura da palavra escrita ou da linguagem escrita, mas que se antecipa e se alonga na inteligência do mundo.”

Neste viés, Vigotski (1995, p. 183, tradução nossa) já destacava em seu tempo década de 1920 - a ênfase que o ensino conferia aos aspectos técnicos da linguagem escrita. “Até agora, o ensino da escritura se restringe a um sentido prático. À criança se ensina a traçar as letras e a formar palavras, porém não se ensina a linguagem escrita". Essa reflexão se encontra atual, pois o ensino da linguagem escrita tem se restringindo mais à sua técnica e menos como um processo constituído na própria relação com o outro que traz implicações para o desenvolvimento humano. Antunes (2007) também ressalta a importância de um ensino em que não haja predomínio dos aspectos técnicos da gramática, ou seja, das nomenclaturas e regras, mas sim, uma relação com a vida do aprendiz, a partir dos usos e funções da gramática como possibilidade de adequação nas múltiplas nuances da comunicação.

Discussão que se alinhava aos debates que envolvem as políticas públicas, primeiramente pelo próprio objetivo posto pela Lei de Diretrizes e Bases da Educação Nacional (LDB $n^{\circ}$ 9394/96), de que a finalidade da educação é o desenvolvimento do educando. Assim como pela experiência cada vez mais cedo da criança no contexto escolar, o 
que se presentifica no panorama atual da educação com a implementação de duas Leis Federais (Lei $n^{\circ}$ 11.114/05 e Lei $\left.n^{\circ} 11.274 / 06\right)$ que alteraram a LDB para instituir a ampliação do ensino fundamental para nove anos de duração, com a incorporação do último ano da educação infantil no ensino fundamental. O objetivo dessa mudança é assegurar maior tempo de convivência da criança com o ambiente escolar e ampliar as oportunidades de aprendizagem (BRASIL, 2004, 2005, 2006a, 2006b).

Esta nova configuração da educação emanou do quadro de altas taxas de analfabetismo, evasão e repetência expressas nos mais diversificados sistemas de avaliação $\left(\mathrm{SAEB}^{1}, \mathrm{PISA}^{2}\right.$, Provinha Brasil ${ }^{3}$, dentre outros). Estes impactos da realidade resultaram nas prioridades que organizam o Plano Nacional de Educação (PNE) que vigora de 2011 a 2020, no qual consta, dentre outras metas, alfabetizar todas as crianças até, no máximo, os oito anos de idade. O PNE propõe avaliações externas das crianças por instâncias superiores por meio de provas, as quais acompanharão o nível de alfabetização das crianças, bem como investimentos em formação dos professores, recursos materiais, dentre outras estratégias.

Mais recentemente foi lançado pelo Ministério da Educação o programa Pacto Nacional pela Alfabetização na Idade Certa (2012), apoiado no PNE, principalmente na meta 5 sobre a qual fizemos referência anteriormente. O Pacto constitui “[...] um compromisso formal assumido pelos governos federal, do Distrito Federal, dos estados e municípios de assegurar que todas as crianças estejam alfabetizadas até os oito anos de idade, ao final do $3^{\circ}$ ano do ensino fundamental.” (BRASIL, 2012).

A proposta de alfabetizar plenamente as crianças até os oito anos de idade “[...] não é apenas uma peça estratégica para o desenvolvimento sustentável do país, mas também um importante passo na promoção da cidadania plena para todos os brasileiros." (RAMOS, 2012, p. 19). Segundo o próprio autor, a alfabetização necessita ser olhada, problematizada uma vez que ela constitui a "pedra angular da educação". Neste viés, a alfabetização pode ser considerada como o alicerce básico e fundamental sobre o qual se organiza e se funda toda a educação do ser humano. Estar alfabetizado significa, segundo o documento oficial:

\footnotetext{
${ }^{1}$ O Sistema Nacional de Avaliação da Educação Básica consiste em avaliações que produzem informações a respeito da realidade educacional brasileira. Se organiza por regiões, redes de ensino pública e privada nos estados e no Distrito Federal, por meio de exame bienal de proficiência, em Matemática e em Língua Portuguesa (leitura), aplicado em amostra de alunos de $4^{\mathrm{a}}$ e $8^{\mathrm{a}}$ séries do ensino fundamental e da $3^{\mathrm{a}}$ série do ensino médio.

${ }^{2}$ O Programa Internacional de Avaliação de Estudantes é uma avaliação comparada, que envolve estudantes na faixa dos 15 anos, faixa etária escolhida por ser o término da escolaridade básica obrigatória na maioria dos países.

${ }^{3}$ A Provinha Brasil constitui uma avaliação diagnóstica do nível de alfabetização das crianças matriculadas no segundo ano de escolarização das escolas públicas brasileiras, acontecendo em duas etapas, sendo uma no início do ano letivo e outra ao final do mesmo ano letivo.
} 
[...] ser capaz de interagir por meio de textos escritos em diferentes situações; significa ler e produzir textos para atender a diferentes propósitos. A criança alfabetizada compreende o sistema alfabético de escrita, sendo capaz de ler e escrever, com autonomia, textos de circulação social que tratem de temáticas familiares ao aprendiz (BRASIL, 2012).

Essa concepção de alfabetização nos remete a pensar na abrangência e complexidade da condição de estar alfabetizado e no percurso para que este processo se realize. Não se limitando à reprodução ou memorização, estar alfabetizado relaciona-se com processos de autoria, de utilização da escrita para a interação com o outro, como um meio de comunicação, na relação de autonomia frente ao processo de ler e escrever, tudo isso requer o envolvimento da criança em sua condição ativa, consciente e participativa diante do próprio processo de aprender.

Disso decorre uma relação diferenciada com a leitura e a escrita como processos de produção e não apenas associados a um sentido canônico, prescrito, para ser interpretado ou mesmo utilizado. A leitura e a escrita como processos de produção estão vinculadas a múltiplas dimensões que configuram o seu acontecer como uma experiência da subjetividade humana. Requer um tipo de aprendizagem mais complexa em que a criatividade possa se expressar, mediante uma relação diferenciada com o próprio objeto de conhecimento, como propõe Mitjáns Martínez (2012b), de confrontação com o dado, de geração de ideias próprias e novas que transcendem o mesmo, assim como pela personalização do aprendido. Processo em que a função da escrita e da leitura assume status de desenvolvimento subjetivo da pessoa.

A universalização do ensino é uma proposta das Políticas Públicas e tem destacado como prioridade investimentos na educação. No entanto, vale perguntar: existe uma idade certa para estar alfabetizado? Qual o impacto desta concepção de alfabetização como processo meramente técnico, nas práticas escolares cotidianas e mais especificamente para a aprendizagem? Como é possível limitar a alfabetização a um único aspecto, como o cognitivo, tendo em vista um processo complexo e por isso mesmo dinâmico e multifacetado?

Neste âmbito, se insere o objetivo geral de nossa pesquisa: Compreender como a criatividade emerge na aprendizagem da leitura e da escrita e suas inter-relações com o desenvolvimento da subjetividade da criança. Assim como nossos objetivos específicos:

a) Identificar a expressão da criatividade na aprendizagem da leitura e da escrita e suas relações com as estratégias de aprendizagem;

b) Caracterizar a configuração subjetiva da ação de aprender criativamente a ler e a escrever;

c) Analisar mudanças e constituição de novos aspectos na subjetividade da criança vinculados ao processo de aprendizagem criativa da leitura e da escrita. 
Tendo em vista os objetivos de pesquisa, elencamos as razões que justificam nosso estudo. No âmbito das políticas públicas, há a necessidade de trabalhos que não privilegiem uma ou outra dimensão da aprendizagem da leitura e da escrita, mas busque entendê-la em sua complexidade. Assumimos um aporte teórico que possibilita compreender a aprendizagem como processo da subjetividade humana, em sua simultânea constituição individual e social. Essa perspectiva torna-se essencial pelo início da vida escolar da criança, que ocorre cada vez mais cedo e com a necessidade intensa de leitura e de escrita nos diversos contextos sociais dos quais participa. Aspectos que fazem emergir a necessidade de estudos que compreendem o como ocorrer a aprendizagem e seus impactos para o desenvolvimento da criança em uma dimensão mais ampla, que não apenas associadas ao ato de ler e escrever.

A articulação desses estudos a aspectos mais processuais da aprendizagem é relevante para contribuir com a possível mudança dos resultados negativos obtidos em indicadores educacionais, tais como o SAEB e o PISA, que revelam o fracasso brasileiro na área de alfabetização das crianças. Esses contribuem para a promoção de reflexões sobre as possibilidades que a criatividade, na aprendizagem da leitura e da escrita, pode ter para o desenvolvimento da subjetividade da criança e para o próprio desempenho escolar.

No que diz respeito ao campo teórico, destacamos nossa investigação realizada no Banco de Teses da CAPES sobre o que se tem produzido sobre a temática aprendizagem da leitura e da escrita, com foco na expressão da criatividade e no desenvolvimento da subjetividade. Processo que nos possibilitou identificar que tal foco de investigação não é algo presente na bibliografia existente até o presente momento.

Ademais, tendo em vista que os estudos sobre a criatividade têm demonstrado a sua relevância para a aprendizagem em níveis de ensino como o ensino médio e ensino superior, necessário se faz explorarmos suas possibilidades em etapas anteriores, como nos anos iniciais do ensino fundamental. O estudo sobre a aprendizagem criativa de crianças consiste em um importante viés de investigação para o qual corrobora Mitjáns Martínez (2012b), ao destacar a necessidade de pesquisas na etapa de alfabetização, destinadas a caracterizar e conhecer os processos específicos que se organizam e emergem neste momento de aprendizagem, caminho que nos responsabilizamos em construir.

Outra razão no campo teórico, associa-se à necessidade de estudos que visem compreender as relações entre a aprendizagem criativa da leitura e da escrita e o desenvolvimento da subjetividade, no âmbito da perspectiva histórico-cultural. Estudos já desenvolvidos nesta perspectiva, tem demonstrado que a superação das dificuldades de aprendizagem escolar de crianças se articula ao desenvolvimento da subjetividade, como os 
trabalhos de Rossato (2009) e Cupolillo (2013). O que abre novas zonas de sentido ${ }^{4}$ para caracterizar estes impactos em tipos de aprendizagem mais complexas, que envolve a expressão da criatividade.

Como razões de natureza prática associamos a necessidade posta ao cotidiano escolar, de ruptura com o caráter utilitário e prático da aprendizagem da leitura e da escrita, pelas possibilidades que a aprendizagem criativa favorece e que estão associados à autoria, à formação de opinião própria, à expressão livre de ideias e à qualidade com que o aprendiz utiliza o que aprende com impactos em sua vida. Outra razão que justifica nosso trabalho se relaciona ao desconhecimento de professores e familiares, das possibilidades que a criatividade pode ter para a qualidade da aprendizagem e para o desenvolvimento da subjetividade, ao enfatizarem apenas um aspecto do aprender, o cognitivo, e desconsiderando momentos essenciais de interação família e escola.

A urgência de conhecermos a aprendizagem criativa e os processos subjetivos que nela subjazem, dentre os quais citamos a imaginação e o pensamento, se relaciona à necessidade de que à criança sejam oferecidas condições para que estabeleça uma relação com a aprendizagem, capaz de produzir emoções que em unidade aos processos simbólicos, lhe permitam empreender ações com impactos em seu modo de vida, tendo em vista os distintos contextos sociais dos quais participa.

Como razões pessoais, nosso questionamento de pesquisa se articula com inquietações advindas de estudos, como em pesquisa realizada no Mestrado, intitulada de $O$ Fórum de Classe na escola pública: significados e práticas direcionados à construção de uma coletividade (MUNIZ, 2006). Com base nessa pesquisa, percebemos práticas pedagógicas direcionadas à homogeneização e obediência, que se apresentam nos comportamentos dos alunos no dia a dia da escola, como formas de garantir a aprendizagem. A ênfase nos aspectos comportamentais dos alunos esteve relacionada às possibilidades cognitivas. Tal elaboração nos indicava aspectos importantes a serem pesquisados e estudados como os processos subjetivos envolvidos na aprendizagem, com o intuito de romper com tais práticas que negam à criança o direito de se posicionar e refletir sobre o que aprende.

Em nossa trajetória profissional, como alfabetizadora ${ }^{5}$, temos nos deparado com questões instigantes sobre a leitura e a escrita que mobilizam nossa necessidade de estudar,

\footnotetext{
${ }^{4}$ As zonas de sentido são definidas como sendo "[...] os espaços de inteligibilidade que se produzem na pesquisa científica e não esgotam a questão que significam, senão que pelo contrário, abrem a possibilidade de seguir aprofundando um campo de construção teórica" (GONZÁLEZ REY, 2005a, p.06).

${ }^{5}$ Sou professora do quadro efetivo de servidores, da Escola de Educação Básica da Universidade Federal de Uberlândia/MG, atuando na referida escola desde 2005.
} 
pesquisar e teorizar, dentre as quais estão: Como a criança aprende a ler e a escrever? Como o aprendiz utiliza o que aprende? Qual o impacto da leitura e da escrita para a vida da criança de forma mais ampla? Consideramos a relevância do presente estudo uma vez que ele nos permitiu fundamentar a tese de que, na aprendizagem da leitura e da escrita, a criatividade emerge de forma sistêmica e constitui-se processo de desenvolvimento da subjetividade da criança.

Como organização do trabalho, no primeiro capítulo, apresentamos nossa construção da Revisão da Produção Científica no período de 2000 a 2014 tendo como eixo norteador trabalhos voltados à aprendizagem da leitura e da escrita da criança. No segundo capítulo, destacamos as Bases Teóricas da Pesquisa, desenvolvida em dois momentos que se interrelacionam. No primeiro trazemos nosso diálogo com a Teoria da Subjetividade de González Rey, sob a qual enfatizamos seus conceitos centrais, assim como apresentamos a concepção da aprendizagem como processo subjetivo e a discussão sobre o desenvolvimento da subjetividade. O segundo apresenta um diálogo com as construções de Mitjáns Martínez ao campo da criatividade relacionadas à aprendizagem escolar, tendo em vista a definição da criatividade como processo da subjetividade humana, assim como o papel da escola na constituição e desenvolvimento da criatividade.

No terceiro capítulo, apresentamos as Bases Epistemológicas e Metodológicas da Pesquisa, mediante nossa opção pela Epistemologia Qualitativa. Nesta ocasião, detalhamos os objetivos de pesquisa, elegemos o trabalho com estudo de caso, caracterizamos a escola onde foi realizada a pesquisa, destacamos o processo de seleção dos participantes, a construção do cenário social, assim como organizamos os instrumentos e a forma como procedemos à análise construtivo-interpretativa das informações.

No quarto capítulo, apresentamos nossa produção teórica a partir do processo construtivo-interpretativo, caracterizando os três casos estudados no âmbito de nossos objetivos de pesquisa. O quinto e último capítulo constituiu nossa produção teórica mediante a análise integrativa dos casos, momento em que fundamentamos nossa tese.

Como uma forma de conclusão do trabalho, trouxemos as considerações finais, etapa em que organizamos as contribuições da pesquisa, suas limitações, desafios enfrentados, desdobramentos da investigação e elencamos propostas para pesquisas futuras. 


\title{
1 REVISÃO DA LITERATURA
}

\author{
"O leitor que mais admiro é aquele que não \\ chegou até a presente linha. \\ Neste momento já interrompeu a leitura e \\ está continuando a viagem por conta própria." \\ Mário Quintana ${ }^{6}$
}

\subsection{APRENDIZAGEM DA LEITURA E DA ESCRITA: PRODUÇÃO CIENTÍFICA NACIONAL E INTERNACIONAL}

A aprendizagem da leitura e da escrita, desde longa data, tem sido foco de interesse de pesquisadores de diferentes áreas, como a Pedagogia, Psicologia, Linguística, dentre outras, voltadas à compreensão dos diferentes processos envolvidos em seu curso. Por conseguinte, compreender, de forma geral e crítica, o que tem sido estudado neste campo, torna-se necessário, tendo em vista a possibilidade de encontro com novas zonas de sentido para estudos, dada a complexidade que perpassa esse aprender que nos inclui na sociedade de uma maneira única e pode promover mudanças substanciais ao nível subjetivo.

Sendo assim, apresentamos no presente capítulo, algumas reflexões tecidas a partir de uma densa revisão bibliográfica da produção científica referente à aprendizagem da leitura e da escrita, considerando o período de 2000 a 2014. As consultas foram realizadas na base de dados da $\mathrm{CAPES}^{7}$, da $\mathrm{BDTD}^{8}$ e do $\mathrm{SCIELO}^{9}$, para identificar os trabalhos científicos do país e os bancos de dados da ProQuest ${ }^{10}$ e NDLTD $^{11}$ com foco nas produções internacionais. Optamos por apresentar de forma conjunta, as produções nacionais e internacionais, trazendo uma discussão contínua sobre elas ao longo do texto.

Dentre as fontes de busca estão dissertações, teses e artigos científicos que tiveram como foco a aprendizagem da leitura e da escrita no primeiro e segundo ano do ensino fundamental. E, pela relevância de alguns estudos, também apresentamos aqueles direcionados a outras etapas de ensino. Livros e capítulos de livros fizeram parte de nossas construções, uma vez que se relacionavam e apresentavam questões relevantes para o tema em estudo.

\footnotetext{
${ }^{6}$ QUINTANA, Mário. Caderno H. Porto Alegre: Globo, 1983.

${ }^{7}$ CAPES - Coordenação de Aperfeiçoamento de Pessoal de Nível Superior.

${ }^{8}$ BDTD - Biblioteca Digital Brasileira de Teses e Dissertações.

${ }^{9}$ SCIELO - Scientific Electronic Library Online.

${ }^{10}$ ProQuest - Base de dados que possui um banco de teses e dissertações internacionais.

${ }^{11}$ NDLTD - Networked Digital Library of Theses and Dissertations.
} 
Recorremos aos descritores: aprendizagem da leitura e da escrita, alfabetização, leitura e escrita, criatividade na aprendizagem da leitura e da escrita, criatividade e subjetividade na aprendizagem da leitura e da escrita. Tais descritores se justificam pelo nosso interesse em compreender a forma como a criatividade e a subjetividade estão presentes no campo científico da aprendizagem da leitura e da escrita. A análise ocorreu mediante a leitura dos resumos dos textos e, de acordo com a relevância e proximidade ao nosso tema de pesquisa, optamos por realizar a leitura completa de alguns trabalhos.

É importante destacar que, por não identificarmos trabalhos específicos referentes ao tema de nossa pesquisa, recorremos à análise da forma como a aprendizagem da leitura e da escrita tem sido discutida e apresentada no campo científico. Pudemos observar que a aprendizagem da leitura e da escrita constitui-se como uma área consolidada no campo científico, com uma vasta produção de pesquisas, com diferenciações de enfoques, conceitos e metodologias de pesquisa.

Mediante cuidadosa análise das produções, organizamos os trabalhos identificados em nossas buscas em cinco eixos, tendo em vista as aproximações das temáticas em relação ao objeto de estudo:

a) voltados para revisões bibliográficas;

b) com foco em estágios e processos operacionais da aprendizagem;

c) referentes ao caráter inventivo e à semântica;

d) direcionados aos processos interativos e contextuais;

e) relacionados ao desenvolvimento humano e aos processos subjetivos.

Pela diversidade de estudos e, para fins de diálogo com as produções, apresentamos os itens abaixo a partir dos eixos próximos para discussões.

\subsubsection{Contribuições das pesquisas de revisões bibliográficas ao campo da aprendizagem} da leitura e da escrita

Soares (1989) realizou um trabalho de sistematização da produção acadêmica e científica publicada em periódicos sobre alfabetização no Brasil no período de (1954-1986), em que destaca estudos que se efetivaram na década de 80, abrangendo as áreas da Linguística, Psicolinguística e Sociolinguística, as quais somadas totalizavam $18 \%$ da produção acadêmica e científica. Neste período, a autora destaca que a alfabetização já constituía um tema de estudo em diferentes áreas, com ênfase na: Psicologia, Pedagogia, Linguística, Psicolinguística, Sociolinguística, Sociologia, Literatura, Educação Artística: 
Artes Plásticas, Educação Artística: Música, Audiologia, Estatística, Interdisciplinaridade. A autora aponta como enfoque predominante no período analisado, o psicopedagógico em primeiro lugar e posteriormente o linguístico.

Frente ao aumento considerável dos estudos e pesquisas na área de alfabetização, Soares e Maciel (2000, p.7) realizaram um estado da arte com foco em teses e dissertações publicadas no período de 1961 a 1989. As autoras destacam um número significativo de pesquisas que focam a alfabetização da criança apenas no processo de escolarização formal e ressaltam que “[...] à perspectiva psicológica vieram juntar-se perspectivas que explicam outras facetas da alfabetização: a perspectiva psicolinguística, a sociolinguística e a propriamente linguística."

Dando continuidade à pesquisa de Soares e Maciel (2000), Márcia Guimarães (2011) fez um levantamento e uma análise dos estudos da alfabetização no Brasil no período de 1944 a 2009. Ressalta que as concepções de alfabetização que predominam no campo da educação referem-se à Emilia Ferreiro, Magda Becker Soares e Ana Teberosky. Enfatiza mudanças no conceito de alfabetização no decorrer de sete décadas, em que escrever o próprio nome era significado de pessoa alfabetizada, porém atualmente é preciso mais do que assinar o nome, torna-se fundamental a utilização da escrita em práticas sociais. A autora apresenta a intensa discussão sobre letramento na alfabetização, bem como identifica a tendência dos estudos com foco no professor, tendo em vista o processo de alfabetização. A concepção de alfabetização, a caracterização do alfabetizador e a formação do alfabetizado são os temas mais encontrados. A autora também destaca a produção do conhecimento da temática alfabetização por diferentes áreas, indicando como necessário o diálogo entre elas.

A diversificação das diferentes áreas de conhecimento de pesquisas sobre alfabetização, leitura e escrita, foi expressamente apontada em pesquisa, por Goulart e Kramer (2002), ao analisarem os 25 anos de ANPEd encontrando trabalhos em diferentes GTs, como em História ou Sociologia da Educação, Educação da Criança de 0 a 6 anos, Psicologia da Educação e Educação de Jovens e Adultos. Tal estudo demarca a relevância que o tema assume nas discussões científicas nacionais.

Ribeiro (2011, p. 32) realizou um estado da arte em alfabetização (1989-2008) em periódicos com conceito A1, de publicação internacional do Qualis. Identificou que dentre os diferentes percursos metodológicos, concepções e áreas de conhecimento os trabalhos voltaram-se para seis preocupações: “[...] como ocorre a aprendizagem da língua escrita, os instrumentos que auxiliam nesta aprendizagem, o profissional que alfabetiza, letramento, política pública e estado da arte.” A autora faz uma análise quantitativa e percebe que o tema 
da Aprendizagem da Língua Escrita foi o mais encontrado com 63\%; em segundo lugar, o tema do Professor que Alfabetiza, com 14\% e, em terceiro, destaca o tema Livros e Cartilhas Instrumentos que auxiliam na Alfabetização com $9 \%$.

Nas conclusões de Ribeiro (2011) sobre o tema aprendizagem da língua escrita, são destacados os seguintes focos: ambientes virtuais; competências metalinguísticas; avaliação; leitura e produção de histórias e Educação Física. Há uma constância nos estudos da abordagem Cognitiva (Psicogênese), da Psicolinguística e da Sociolinguística, o que Soares (1989), apontava como pouco presente nos estudos por ela analisados, mas com perspectivas de crescimento.

Podemos inferir que os estudos e as pesquisas realizados no Brasil indicam um caminho importante, uma vez que a ideia é colocar a criança no centro das preocupações de pesquisas, passando a mesma a configurar um papel relevante para a compreensão dos processos envolvidos na aprendizagem da leitura e da escrita. Tais processos estão voltados à constituição de "[...] uma identidade nacional única e brasileira, pautada nas nossas próprias características fonéticas de linguagem, frente à aprendizagem da leitura e escrita, o que até então era ignorado." (RIBEIRO, 2011, p. 94). O interesse dos estudos tem se restringido à análise das habilidades metalinguísticas com ênfase na consciência fonológica.

Tal perspectiva, com foco na consciência fonológica, é reforçada por meio de nossa análise do documento publicado pela Comissão de Educação e Cultura da Câmara dos Deputados, intitulado "Grupo de trabalho Alfabetização Infantil: os novos caminhos Relatório Final.” (BRASIL, 2007). Com os avanços da Ciência Cognitiva da Leitura, mais especificamente nos últimos 30 anos, é possível encontrar no referido Relatório, a preocupação de especialistas nacionais e internacionais desta área, em fazer com que conheçamos tal perspectiva teórica, com o intuito de analisar a realidade da alfabetização no Brasil e contribuir com propostas para o avanço do debate e das políticas e práticas do país. Com base na análise do documento, é possível perceber que o foco está nos processos cognitivos que permeiam a aquisição das competências de ler e escrever. Baseado nos estudos de Gombert (2003), os quais enfatizam a importância da consciência fonêmica e do princípio alfabético, registra-se no Relatório, a aprendizagem da leitura e da escrita a partir da relação entre letra-som.

Neste viés, Maluf, Zanella e Pagnez (2006) fizeram um levantamento de pesquisas com falantes do português brasileiro sobre a relação entre o desenvolvimento de habilidades metalinguísticas e a aquisição da linguagem escrita, no período de 1987 a 2005 . Concluíram que o enfoque metalinguístico vem perfazendo uma crescente presença nas investigações dos 
estudiosos, tendo como ênfase a consciência fonológica, em detrimento às demais habilidades metalinguísticas, realizados principalmente com crianças. Tais análises foram reafirmadas por Maluf e Zanella (2011) no "Seminário Internacional de Alfabetização na Perspectiva da Psicologia Cognitiva da Leitura", no qual apontam para um avanço significativo de pesquisas e publicações no período de 2000 a 2010, com ênfase na consciência fonológica.

Nazari (2010, p. 17) faz um panorama de pesquisas realizadas no período de 1991 a 2009 sobre consciência fonológica de crianças realizadas no Brasil. Em suas conclusões, a autora aponta para a existência de trabalhos a partir de diferentes áreas e conclui que é possível assegurar a "[...] relação existente entre as hipóteses de escrita e os níveis de leitura com as habilidades fonológica, comprovando que a consciência fonológica é uma ferramenta fundamental no processo de alfabetização".

Do nosso ponto de vista, os estudos de revisão bibliográfica indicam um cenário que reconhece, entre outros, dois pontos que, para nós, são essenciais: um primeiro ponto refere-se a um isolamento das abordagens presentes nas pesquisas e um predomínio da abordagem cognitiva e fonológica do processo de alfabetização. $\mathrm{O}$ segundo diz respeito à mudança no conceito de alfabetização, tendo em vista os usos sociais da leitura e da escrita pela criança. Isso nos remete a novas construções teóricas na área da alfabetização, na busca de compreender a expressão da criatividade neste percurso e suas relações com as produções subjetivas.

Nos próximos itens, adentramos na análise dos trabalhos sobre a aprendizagem da leitura e da escrita, à luz de diferentes autores, em um diálogo que permite delimitar a inserção da nossa pesquisa no campo.

\subsubsection{Aprendizagem da leitura e da escrita: estágios e processos operacionais}

Reunimos neste tópico, pesquisas em que a aprendizagem da leitura e da escrita foi analisada com ênfase nos processos cognitivos, na tentativa de compreender como a criança elabora hipóteses, constrói o seu próprio conhecimento e as estratégias que utiliza no processo de aprender.

\subsubsection{Estágios da aprendizagem da leitura e da escrita}

O foco das pesquisas no Brasil se volta mais para compreender a criança na sua relação com a escrita mediante a forte influência da teoria desenvolvida por Ferreiro e Teberosky (1999), a partir da década de 80. Em uma abordagem cognitivista, as autoras se 
atentam para os estágios pelos quais as crianças passam na aquisição do sistema escrito, caracterizando uma concepção evolutiva na aprendizagem da escrita.

Numa matriz epistemológica construtivista, Ferreiro e Teberosky (1999, p. 32) realizam pesquisas com crianças em fase de alfabetização, tendo como objetivo identificar os processos cognitivos no curso de aquisição da escrita destacando a noção de assimilação e que “[...] o ponto de partida de toda a aprendizagem é o próprio sujeito (definido em função de seus esquemas assimiladores à disposição), e não o conteúdo a ser abordado.” Embasadas pelos pressupostos teóricos da Psicogênese de Piaget, as autoras ressaltam a escrita como objeto do conhecimento com ênfase no sujeito da aprendizagem, ou seja, no sujeito ${ }^{12}$ cognoscente, em que, o conhecimento é obtido pelo próprio resultado da ação do sujeito.

De acordo com Ferreiro (1995), a aprendizagem se realiza na construção da própria criança sobre o objeto a ser conhecido, neste caso, a escrita. Assim, a aprendizagem ocorre na interação entre o objeto do conhecimento (língua escrita) e o sujeito cognoscente (que quer conhecer). Mediante essa concepção, a criança não reproduz a escrita tal qual ela se encontra na realidade, mas reinventa esse sistema, num movimento de construção própria, a partir da compreensão pessoal da criança de regras e de suas construções.

Consideramos relevante o caráter ativo do sujeito enfatizado pelas autoras, porém não nos aludem ao processo gerador do sujeito, ou seja, a construção está sobre as bases da apropriação ativa do dado e desconsideram o caráter gerador, transgressor e de ruptura em relação ao dado, capaz de transcendê-lo (MITJÁNS MARTíNEZ, 2012b). Vale destacar nossas diferenciações em relação à abordagem apresentada, uma vez que partimos de uma concepção de sujeito, como “[...] momento vivo da organização histórica da subjetividade e está implicado de forma constante nos diversos espaços sociais dentro dos quais organiza suas diferentes práticas" (GONZÁLEZ REY, 2003a, p. 241).

A escrita, na abordagem construtivista, é uma representação da linguagem e não um código de transcrição gráfica das unidades sonoras. Com foco nos aspectos internos da criança, Ferreiro e Teberosky não avançam na forma como a criança reorganiza para si as suas experiências no contexto social, como se neste contexto, a escrita fosse a principal fonte de informação, deixando como lacuna a participação do outro, das relações tecidas entre os envolvidos no aprender.

Vale ressaltar que a evolução da escrita está estruturada, segundo Ferreiro e Teberosky (1999) por fases que se mantêm comuns às mais variadas crianças, diferenciando-se no ritmo

\footnotetext{
${ }^{12}$ Sujeito cognoscente está aqui sendo definido a partir da teoria de Piaget e não se refere à categoria de sujeito elaborada por Gonzáles Rey (2003a).
} 
de aprender de cada uma. Neste ponto, Ferreiro (1995) explica que a escrita infantil segue uma linha de evolução regular que se organiza em três períodos que se subdividem. O primeiro estágio se refere à distinção entre o modo de representação icônico e o não-icônico, o segundo, à construção de formas de diferenciação e o terceiro, à fonetização da escrita.

No Brasil, Telma Weisz tem desenvolvido seus trabalhos na perspectiva da psicogênese da língua escrita de Emília Ferreiro, viabilizando uma vasta produção de materiais para formação de professores. A referida autora foi a criadora do "Programa de Formação de Professores Alfabetizadores (Profa)", lançado em 2001, pelo Ministério da Educação e atualmente coordena o programa "Letra e Vida". Neste viés, Grossi (1990), juntamente com o Grupo de Estudos e Pesquisas sobre alfabetização/GEEMPA, embasada pelas ideias de Ferreiro e Teberosky (1999), busca compreender o processo de construção da escrita pela criança e amplia os estudos de Ferreiro (1985), trazendo o nível ortográfico como uma etapa de aprendizagem.

Ehri (2013) também apresenta níveis de desenvolvimento da habilidade de crianças para lerem e escreverem palavras. Com foco em estudos na língua inglesa, apresenta a progressão das crianças em quatro fases, as quais se relacionam pela relação entre a consciência crescente dos sons nas palavras e os símbolos que representam tais sons. Como um modelo vinculado à consciência fonêmica, a autora define os estágios como sendo: préalfabética; alfabética parcial; alfabética completa e alfabética consolidada.

Para Ehri (2013), a passagem de uma fase para outra é gradual e o desenvolvimento é regido pelo próprio conhecimento alfabético da criança e sua utilização, não estando vinculado à idade ou mesmo à escolaridade. Em cada fase, Ehri (2013) ainda ressalta o predomínio da conexão entre letra-som com vistas a armazenar palavras na memória, o que só não ocorre na fase pré-alfabética, a qual é desprovida da relação letra-som, predominando as relações visuais. Já na fase alfabética parcial, já existem algumas conexões entre algumas letras das palavras e os sons que são emitidos em sua pronúncia. As conexões mais complexas entre grafema-fonema são organizadas na fase alfabética completa, ao passo que, na fase alfabética, consolidada já se utilizam padrões ortográficos.

Neste viés, estão os estudos de Cardoso-Martins e Correa (2008) e Cardoso-Martins (2013), ao trabalharem com crianças falantes do português. Esses autores explicam que, na fase silábica, ao contrário do que destaca Ferreiro em suas pesquisas, as crianças prestam atenção não apenas à quantidade de letras utilizadas na escrita, mas também aos sons que já identificam. Em consonância, tais estudos corroboram Cardoso-Martins e Batista (2005) de identificação com o modelo de desenvolvimento da escrita proposto por Ehri, destacando que 
a etapa silábica corresponde à etapa de alfabetização parcial, que se relaciona ao que as crianças já sabem sobre os nomes e sons das letras em estreita relação com a consciência fonológica.

Recorrendo a um referencial teórico de orientação fonológica, Moreira (2009) analisa a aquisição da escrita pela criança nas relações som-letra. Define quatro estágios experienciados pela criança: escrita icônica, escrita grafemática, escrita fonográfica e escrita ortográfica. Pelas produções escritas das crianças, percebe-se que a aquisição da escrita tem início com a ausência de relação grafo-fônica, e passa por etapas cíclicas de relações som/letra, chegando às relações ortográficas, na qual a dependência som/grafia é superada.

No presente trabalho, assumimos a criança também como ponto de partida, mas nela estão configuradas experiências diversas que constituem o próprio aprender. Na concepção a qual nos embasamos, a de González Rey (2003a, 2012a), a aprendizagem é um processo subjetivo de natureza social, em que o conhecimento é subjetivado pela criança e não se restringe a etapas universais. Importante destacar que a aprendizagem se organiza na singularidade da produção subjetiva do aprendiz, em seu caráter gerador, tendo em vista experiências em diferentes contextos, que tomam formas diversas no momento de aprender. Além dos estágios de aprendizagem, dentre os processos cognitivos na aprendizagem, encontramos trabalhos voltados aos aspectos operacionais da aprendizagem com os quais buscamos dialogar no tópico a seguir.

\subsubsection{O operacional no processo de aprender a ler e a escrever}

Um número expressivo de trabalhos tem se preocupado com as relações que a criança estabelece entre o oral e o escrito, bem como com as estratégias utilizadas para aprender. Estudos referentes às reflexões da criança sobre a língua têm tratado das relações entre metalinguagem e alfabetização, sendo em sua maioria relacionados à Psicologia Cognitiva. A consciência metalinguística, como destaca Maluf, Zanella e Pagnez (2006, p. 68) consiste em “[...] um objetivo básico a ser alcançado na fase inicial de escolarização e dele depende o sucesso da aprendizagem escolar nas fases posteriores."

O termo metalinguístico é definido por Maluf e Gombert (2008, p. 125) como a “[...] capacidade de reflexão e autocontrole intencional dos tratamentos linguísticos", sendo o indivíduo capaz de refletir e monitorar seus processos cognitivos. Para os referidos autores, "É na interface dos conhecimentos não conscientes e dos conhecimentos refletidos que se constroem as competências de manipulação da linguagem escrita" (MALUF; GOMBERT, 
2008, p. 132). As investigações têm demonstrado que a capacidade de refletir sobre a língua e sua utilização são condições para que a aprendizagem da leitura e da escrita ocorra (BARRERA; MALUF, 2003; MALUF, 2010).

Neste viés, identificamos estudos que têm como foco as relações entre metalinguagem e a aquisição da língua escrita (GUIMARÃES, S; PAULA, 2010; MAREC-BRETON; BESSE; ROYER, 2010; MOTA et al., 2009; OLIVEIRA, J. 2010; SANTOS; MALUF, 2000, 2007; SPINILLO; MOTA; CORREA, 2010; URQUIJO, 2010; VALENTE; MARTINS, 2004; ZANELLA; MALUF, 2004), trazendo o aprender a ler como “[...] um processo através do qual o aprendiz começa por compreender que se pode escrever aquilo que se fala, o que inclui um conhecimento prático da língua falada.” (MALUF, 2005, p. 57). Sousa e Maluf (2004) destacam que as crianças falantes do português brasileiro, em fase de alfabetização, quanto mais estiverem avançadas na aquisição do princípio alfabético, maiores habilidades na leitura terão em relação à escrita.

Spinillo (2013) aponta uma importante discussão entre as relações da consciência metalinguística e o estabelecimento de inferências no momento da leitura. Para a autora, quanto mais se avança na escolaridade, menores são os efeitos da decodificação sobre a leitura, ao passo que a atribuição de significados assume lugar fundamental para a compreensão na leitura. Assim, a inferência, definida pela autora como novas proposições a partir do que se tem no texto, envolvendo os conhecimentos prévios do leitor, favorece a compreensão do texto e se inter-relaciona à consciência metalinguística.

A consciência fonológica é definida por Morais (1997) como "[...] a consciência de que as palavras são constituídas por diversos sons", e está presente em um número considerável de pesquisas, relacionando-a ao processo de aquisição da língua escrita em crianças brasileiras (BASSO, 2006; CAPOVILLA; CAPOVILLA, 2004; CARVALHO, 2010; MOUSINHO; CORREA, 2009; SILVA, A., 2004; VELASQUEZ, 2007). Tais autores apresentam como conclusões a importância da consciência fonética para a aprendizagem da leitura e da escrita, nas relações entre som-letra, enfatizando a necessidade de um ensino que possibilite à criança compreender a organização do código escrito, constituindo uma variável cognitiva mediando o processo de alfabetização.

A partir dos estudos referidos acima, temos contribuições importantes para o campo da alfabetização, por constituírem trabalhos voltados à compreensão da criança falante de português, considerando a especificidade da nossa língua materna e do processo que demanda quanto ao seu aprender infantil. Contudo, a forma como estas pesquisas chegam aos espaços escolares e constituem as práticas dos professores, tem sido distorcida, em uma ênfase em 
processos técnicos, e, por isso mesmo, a perspectiva da Psicologia Cognitiva tem sido criticada. No entanto, como destaca Mota (2007, p. 485) “[...] levar a criança a refletir sobre os aspectos estruturais da língua não significa voltar a práticas pedagógicas que tratam a criança como um ser passivo que recebe a informação sem atuar sobre ela ou transformá-la".

No âmbito das estratégias de aprendizagem, Solé (1998) destaca a importância do ensino de estratégias de leitura para favorecer a compreensão do texto. Para a referida autora, as estratégias não são receitas ou habilidades específicas, mas envolvem a presença de objetivos, planejamento das ações e a própria avaliação, o que demanda um processo de previsão e inferência. Assim, no momento da leitura, há uma conexão entre os conhecimentos prévios do leitor e o próprio conteúdo, que, mediante o objetivo do leitor com a leitura, são responsáveis pela construção da interpretação do texto. Isso requer autonomia, que implica na possibilidade de aprender a partir da leitura. Nesta direção, diferentes trabalhos têm enfatizado a importância dos conhecimentos prévios que o leitor ativa no momento da leitura, relacionados aos saberes do mundo e ao conteúdo lido, assim como os conhecimentos linguísticos e textuais, como estratégia fundamental para a compreensão (SMITH, 1991; GIROTTO; SOUZA, 2010).

Seibt (2004) buscou compreender o desenvolvimento do processo de construção dos sentidos $^{13}$ viabilizados pela leitura de textos em ambiente escolar e conclui, dentre outros aspectos que, no início da aprendizagem da leitura, as crianças recorreram mais ao uso da estratégia de inferência, tendo em vista os conhecimentos prévios. Porém, ao longo do processo de aprendizagem, passaram a utilizar estratégias metacognitivas.

Monteiro e Soares (2014) realizaram uma investigação sobre as estratégias utilizadas pelas crianças que apresentavam dificuldades na alfabetização. A pesquisa ocorreu mediante teste de leitura, tendo em vista o reconhecimento de palavras escritas. Com base em critérios linguísticos, que envolviam as propriedades das palavras (estrutura interna da sílaba e os grafemas), as autoras concluíram que as estratégias de dissociação entre conhecer as letras e a consciência fonológica relacionam-se às dificuldades das crianças, assim como o baixo conhecimento das correspondências letra-som e a dificuldade do mecanismo de decodificação na análise de estruturas silábicas, são elementos que se aliam às dificuldades encontradas pelas crianças.

Um importante trabalho de Rowe e Neitzel (2010), em estudo com crianças em idade de dois a três anos, demonstra que os interesses pessoais da criança organizam a forma como

\footnotetext{
${ }^{13}$ É importante demarcar aqui, que a palavra "sentidos" está se referindo ao termo usado na linguística e não corresponde à categoria sentido subjetivo, sobre a qual discutiremos no capítulo seguinte.
} 
operam sobre materiais e atividades. As autoras observaram que, nas crianças em que os interesses eram de base conceitual, a exploração e o registro das ideias foi de cunho pessoal, ao passo que, para crianças com interesses processuais, a escrita teve um funcionamento convencional voltado para o registro de letras do próprio alfabeto. Chamou-nos a atenção a forma como as crianças com interesses criativos exploravam os materiais de escrita e geravam novos processos de alfabetização e novas maneiras de utilizar o material. Rowe e Neitzel (2010) também identificaram que crianças com interesses orientados socialmente usam a escrita para mediar a interação social.

Portilho e Küster (2006) realizaram estudo com crianças de $1^{\mathrm{a}}$ série ${ }^{14}$ do ensino fundamental, sobre estratégias de aprendizagem, com foco na personalização, memorização, atenção, processamento da informação e metacognição. Dentre as conclusões apresentadas, as autoras apontam a relação existente entre as estratégias de aprendizagem utilizadas pelas crianças e o ensino do professor.

Contamos também com as contribuições de Dreher (2009), para a qual as estratégias metacognitivas estão relacionadas às atividades de leitura e escrita, na especificidade das crianças se autorregularem no momento de planejar, supervisionar e avaliar. A autora aponta, em suas conclusões, que as crianças de seis a sete anos recorrem à estratégia metacognitiva para aprenderem.

Villas Boas (2008) realizou uma pesquisa com alunos entre 13 e 18 anos com o objetivo de analisar a contribuição do processo de ensino-aprendizagem de produção textual em língua inglesa para o letramento geral do aluno. Além disso, investigou como o ensino de produção textual na escola de inglês relacionava-se com o ensino de produção textual em língua materna, nas escolas regulares. Dentre outros aspectos, a pesquisadora investigou as estratégias mais eficazes que forneciam andaimes ${ }^{15}$ para o aprimoramento da produção textual. A autora conclui que o ensino de produção textual está mais direcionado ao produto que ao processo de produção e que, por isso, as escolas regulares deixam de fornecer andaimes para elementos que compõem o processo de escrita, dentre os quais cita: planejamento de ideias, a obtenção e incorporação de feedback de colegas e professores, estruturação do texto, revisão, reescrita e reflexão a partir dos resultados obtidos. A autora

\footnotetext{
${ }^{14}$ Atual $2^{\circ}$ ano do ensino fundamental de nove anos.

15 O conceito de "andaimes" é trabalhado por Bortoni-Ricardo, e foi inicialmente proposto por Jerome Bruner e se relaciona ao conceito de zona de desenvolvimento proximal proposto por Vigotski, podendo ser definido como: “Andaimes são um conceito metafórico que se refere a um auxílio visível ou audível que um membro mais experiente de uma cultura pode dar a um aprendiz" (BORTONI-RICARDO; SOUSA, 2008a, p. 168).
} 
ainda ressalta que o processo ensino-aprendizagem da escola de inglês pode contribuir sobremaneira para a constituição dos andaimes para a composição textual.

Mediante o exposto, identificamos que os estudos supracitados trazem a relação entre o oral e o escrito, perpassados pela reflexão do aprendiz, assim como exploraram diferentes tipos de estratégias de aprendizagem utilizadas pelas crianças no processo de aprender a ler e a escrever, dentre as quais estão as de autorregulação, que formam parte da expressão da criatividade na aprendizagem, em aprendizes criativos do ensino médio e ensino superior, como tem sido destacado por Mitjáns Martínez (2009b). Nessa direção, nosso trabalho avança em relação aos estudos elencados no presente tópico, por apresentarmos as estratégias de aprendizagem na sua relação com as características da criatividade na aprendizagem da leitura e da escrita, e também por compreendê-las como expressão da configuração subjetiva da ação ${ }^{16}$. Tentando avançar mais em nossas discussões, destacamos, a seguir, os trabalhos que se aproximam da perspectiva histórico-cultural, a qual constitui a base de nosso trabalho e sobre os quais apontamos reflexões.

\subsubsection{A aprendizagem da leitura e da escrita: relações com a inventividade e a semântica}

Na revisão realizada por nós, encontramos trabalhos que versam sobre as relações com os processos inventivos da criança com a escrita e com a leitura, com ênfase nos processos singulares. E, ainda outras pesquisas que apresentam interessantes discussões sobre a relação com os significados e sentidos ${ }^{17}$ atribuídos pelas crianças na interação com tal aprendizagem.

\subsubsection{Caráter inventivo no processo de aprendizagem da leitura e da escrita}

O caráter inventivo da criança com relação à escrita está presente nos estudos como uma forma singular da criança, se relacionar com a linguagem, marcada pela cultura da qual participa e modifica na sua forma única de se relacionar com o mundo. Dentre os estudos que abordam tal questão, encontra-se o trabalho desenvolvido por Bernardin (2003) o qual busca compreender os processos de aprendizagem da cultura escrita, na concretude da sala de aula, onde ele próprio é o professor da turma e também o pesquisador. Acompanhou por dois anos uma turma de primeiro ano e, posteriormente, a mesma turma no segundo ano do ensino fundamental.

\footnotetext{
${ }^{16}$ Categoria definida nas Bases Teóricas da Pesquisa I.

${ }^{17}$ A palavra "sentido" está vinculada à concepção de Vigotski, para o qual o sentido está associado à palavra e ao contexto da ação. Desta forma, não estamos nos referindo à categoria sentido subjetivo que conceituamos no capítulo de Bases Teóricas I.
} 
Bernardin (2003, p. 190) acompanha e analisa o percurso da aprendizagem dos alunos, concluindo que: “[...] a prática da escrita não só influi sobre as competências, mas também sobre a relação com a língua, com o saber, com o mundo circundante." Nesta relação, estão presentes as hipóteses das crianças sobre a escrita, observadas e instigadas pelo referido autor, mediante um trabalho voltado a perguntas espontâneas das crianças e de sua participação efetiva no seu próprio processo de aprendizagem.

Em uma interessante pesquisa com 32 crianças chinesas, de cinco e seis anos de idade, Chen e Zhou (2010) observaram a reflexão das crianças no processo de utilizar as estratégias de aprendizagem no processo de escrita. Os autores concluem que, ao recorrerem a desenhos, rabiscos, tentativas de escritas diversas, as crianças rompem com as barreiras postas pela formalidade na aprendizagem da leitura e da escrita, abrindo espaço para pensar e refletir sobre a própria aprendizagem.

Munhoz (2008, p. 17) reconhece as relações e movimentos de constituição das crianças e suas (im)possibilidades de imaginar e criar por intermédio da linguagem escrita. Defende a tese de que, mesmo em contextos onde predominam aspectos técnicos da linguagem escrita “[...] as crianças, protagonistas deste estudo, são capazes de transcender estas relações e estabelecerem relações estéticas com a linguagem escrita, possibilitando a (re)invenção de si mesmas como sujeitos.”

Neste contexto, a aprendizagem da leitura e da escrita possibilita mudanças nas crianças que vão constituindo-as de uma forma única e possibilitam o ato criativo, por meio da relação da pessoa com a cultura, na qual realiza um processo de produção em meio a “[...] atividades reprodutoras (no sentido de não criar algo totalmente novo) e criadoras, que se instauram no movimento da relação eu-outro, na intersubjetividade, no constituir-se a partir do outro." (MUNHOZ; ZANELLA, 2008, p. 290). Neste viés, Lerner (2002) destaca que o desafio da escola é justamente formar escritores, em que a escrita assuma função de comunicação tanto com os outros, quanto consigo mesmas.

Landsmann (2006) demonstra, com base em argumentos teóricos e empíricos, as relações e os próprios efeitos da escrita sobre o desenvolvimento humano. Segundo a autora, o ambiente social do qual a criança participa é fator predominante para a relação que a mesma estabelecerá com a própria escrita no processo de aprendizagem. Mesmo com foco nas produções de texto, a autora ressalta que a aprendizagem da escrita constitui uma reelaboração das próprias representações. Para a autora, o conhecimento da escrita pode ser transformado pelo aprendiz, uma vez que a escrita facilita e potencializa processos recursivos de redescrição da mente. 
Assim, Landsmann (2006) refere-se à criatividade mediante à transgressão, viabilizada por um trabalho reflexivo e mentalmente comprometido sobre o aprender possibilitando uma aprendizagem para além da reprodução e do armazenamento de informações. Em sua proposta metodológica, trabalha com a ideia de que, para inventar uma nova notação, antes inexistente, a criança necessitaria transgredir algo que já existe e por isso mesmo pensar sobre o que já tem de conhecimento sobre o sistema de notação. Nosso trabalho se aproxima das elaborações da referida autora, na medida em que assumimos que, na criatividade, como bem destaca Mitjáns Martínez (2012a), a transgressão ao dado é um elemento fundamental na geração do novo. No entanto, nossa pesquisa avança em relação ao trabalho de Landsmann (2006), ao apresentarmos outros elementos que também participam da expressão da criatividade, dentre os quais citamos: a personalização da informação e a confrontação com o dado.

Outro importante trabalho foi desenvolvido por Grainger, Goouch e Lambirth (2005), autores que, baseados na concepção de criatividade de Anna Craft, buscaram refletir sobre o papel do professor como envolvimento imaginativo, artístico e como modelo de escritor, no decurso da composição escrita dos alunos. Dentre as contribuições dos autores, está a consideração de um contexto flexível, permeado por situações lúdicas, pela imaginação e pelo diálogo. Essas são práticas fundamentais para favorecer o potencial linguístico e a formação de escritores, mediante um processo de composição criativa, o qual envolve a expressão de ideias próprias das crianças e demanda envolvimento e interesse. Eles também ressaltam que o próprio professor deve ser um modelo de escritor autêntico.

O movimento único de ressignificar o aprendido, que rompe com a ideia de etapas universais na aprendizagem da leitura e da escrita, é destacado por Abaurre, Fiad e MayrinkSabinson (1997). Em seus trabalhos, a autoria está presente desde o início da aprendizagem da leitura e da escrita pela criança sendo que suas marcas se modificam com o tempo, a partir da interação com o "outro" por meio dos diferentes interlocutores. Para Abaurre (1997), a autonomia do sujeito é constituída no contato com a linguagem e isso se faz no decorrer dos anos escolares. Ao atuar em sua própria escrita, o aprendiz atua como sujeito da linguagem.

Os estudos supracitados mostram o movimento singular da criança com seu processo de aprendizagem, marcando na constituição do sujeito da linguagem, a transgressão ao imposto, bem como demonstram que, em uma relação de autoria com a própria escrita, são possíveis mudanças na forma de interagir com o outro e com o mundo. No entanto, há uma certa ênfase em determinados aspectos como o cognitivo, assim como o olhar se volta para os registros escritos das crianças, o que deixa em aberto a complexidade deste processo que envolve compreender outros processos envolvidos, associados à subjetividade da criança. 
Compreendemos que é nesse ponto que nosso trabalho avança, por tratarmos as inter-relações entre aprendizagem criativa e o desenvolvimento da subjetividade.

\subsubsection{Semântica e o processo de aprendizagem da leitura e da escrita}

Para Luria (2006), o campo semântico que envolve uma palavra se relaciona à gama de possibilidades de significados que podem ser associados à palavra. Esses significados surgem de forma involuntária mediante a relação com que a pessoa estabelece com a palavra. Com foco nos processos singulares que envolvem a linguagem, Bakhtin (2010) traz uma diferenciação entre sinal e signo, sendo que a sinalidade tem em si características estáveis e que a fazem ser imutável, ao passo que, o signo é sempre variável e flexível, pois depende do ponto de vista do próprio leitor. Nesta diferença, surge o conceito de descodificação como processo que nos permite, em um processo de enunciação, compreender a forma utilizada pelo interlocutor no âmbito de um contexto singular e específico. Sendo assim, o signo é o que descodificamos e o sinal é apenas identificado. Para Bakhtin (2010, p. 99, grifo do autor): “A palavra está sempre carregada de um conteúdo ou de um sentido ideológico ou vivencial."

Neste viés, Arena (2009) argumenta que a avaliação do desempenho dos alunos com a leitura é feita estritamente em prol de uma boa performance oral e não vincula-se à atribuição de sentido pelo leitor, que envolve compreensão, reflexão e está para além da identificação da sinalidade. Arena (2007) realiza uma pesquisa em situação de locução de um texto, desenvolvida por uma aluna do segundo ano do ensino fundamental, cujo objetivo foi destacar as relações entre oralidade, escrita, leitura e locução. Tendo em vista sua concepção de que ler envolve um processo de atribuir sentido e não a pronúncia da palavra em si, ressalta que a escola do ensino fundamental ensina e treina a locução como se ensinasse o ato de ler, o que acarreta dificuldades na elaboração de sentido pelo leitor.

Os estudos ampliam a função da utilização da escrita pela criança, para além de uma reprodução técnica, mas permeada por sentidos diversos, que são únicos para cada criança. Nesta direção, Arena, Pastorello e Santos (2011) analisam escritas de uma aluna no início da alfabetização em situação de escrita de cartas de correspondência pessoal com o objetivo de verificar quais letras são escolhidas pela aluna e por que são escolhidas para registro do discurso. Suas conclusões destacam que, na escolha das letras, a aluna foca na função da letra na constituição da palavra no processo de enunciação, independentemente de sua correspondência fonética. Ressaltam que o valor da aprendizagem está no sentido empreendido pela criança e não no caráter técnico. 
Bajard (2002, p. 288), dentro desta perspectiva, trata o ato de ler como “[...] uma necessidade ou um desejo e não pode ser divorciado do projeto do leitor; ele requer, por exemplo, informações para traçar um itinerário de viagem, ou pretende se deixar apaixonar com a heroína de um romance." Em suas elaborações teóricas, o autor diferencia a elaboração de sentido, denominada por ele como leitura e uma outra prática que envolve o vocal e o social na relação com o outro mediante o texto, que tem como objetivo a comunicação e é chamada pelo autor como dizer (BAJARD, 2005).

Outra contribuição importante vem de Marcuschi (2008) que reconhece a complexidade do processo de compreensão da leitura e, em seus trabalhos, destaca os processos de inferência diante das informações dos textos, assim como a forma como os conhecimentos prévios do leitor se organizam na ação de ler e favorecem as suposições diante do lido. É neste processo de relacionar conhecimentos prévios, em meio a experiências do leitor, que demandam ações interativas e negociadas, que reside a concepção do autor da compreensão textual, em que seu foco reside no dinamismo da língua e não na sua forma.

Coelho (2009) destaca que os significados das palavras para as crianças não são universais, dados a priori como definições dicionarizadas e nem mesmo são explicitados pela própria palavra, mas se constituem pelas interações comunicativas. Estão associados aos processos que se organizam na interlocução e aos conhecimentos que os participantes da relação têm um do outro e ao pressuposto compartilhado. Para Zilberman (2010), não existe uma significação prévia e uniformizada para a leitura de um texto, uma vez que é o leitor que consegue se tornar proprietário do texto, na medida em que a leitura lhe possibilita invadir o texto e lhe conferir um sentido pessoal. Tal construção relaciona-se às experiências prévias do leitor que, diante do texto, estabelece relações. Assim, Koch e Elias (2012) também destacam que o leitor constrói o sentido do texto de forma ativa, por meio de estratégias, ao preencher as lacunas do texto, em um processo de interação que envolve conhecimentos prévios e a materialidade linguística do texto.

Zasso (2008) investiga a escrita de crianças em processo de alfabetização e defende que o ato de escrever produz cultura e subjetividade, pois se constitui como um ato de enunciação marcado pela singularidade daquele que escreve. Enfatiza que o ato de escrever é conflituoso, pelo fato de o enunciado escrito não representar integralmente a enunciação do autor. Baseada nas teorias da enunciação da linguística, em especial, a autora compreende a escrita como um processo de produção por parte daquele que a utiliza. Suas bases teóricas sobre o tema da subjetividade estão fundamentadas na teoria linguística de Émile Benveniste, que compreende a subjetividade como a inserção do homem na língua. 
Os estudos destacados neste tópico nos possibilitam importantes reflexões sobre o processo de aprendizagem da leitura e da escrita, na medida em que ressaltam a relação dos significados e sentidos tanto na escrita, quanto na leitura. São processos vinculados à singularidade dos aprendizes, aos seus conhecimentos prévios e ao próprio contexto da ação de ler ou escrever. No entanto, com exceção dos trabalhos de Coelho (2009), analisamos, em consonância com González Rey (2011g), que há uma reificação da linguagem, ao aliar o sentido à palavra, em que se sobressai a relação palavra e contexto. Nosso trabalho caminha na direção de compreender a experiência de ler e escrever não apenas como processo de significação e vinculado somente à palavra, mas na unidade dos processos simbólicos e emocionais. No próximo tópico, elencamos os trabalhos associados à aprendizagem da leitura e da escrita com ênfase aos processos interativos e contextuais.

\subsubsection{A aprendizagem da leitura e da escrita: relações com os processos interativos e contextuais}

No presente item, reunimos um número considerável de pesquisas, que têm se dedicado à compreensão dos processos de aprendizagem em uma perspectiva em que processos interativos e elementos contextuais se apresentaram como relevantes no processo de aprendizagem da leitura e da escrita da criança.

\subsubsection{Processos interativos na aprendizagem da leitura e da escrita}

Um número expressivo de investigações, na área da aprendizagem da leitura e da escrita, apresenta a interação como aspecto relevante para que a aprendizagem ocorra. Kramer (2000a, 2000b, 2001) tem destacado que aprendizagem da leitura e da escrita necessita ir além da decodificação e codificação, uma vez que constituem experiências e não hábitos ou habilidades, pois “[...] o que faz da escrita uma experiência é o fato de que tanto quem escreve quanto quem lê enraízam-se numa corrente, constituindo-se com ela, aprendendo com o ato mesmo de escrever ou com a escrita do outro, formando-se." (KRAMER, 2000a, p. 114).

Como via de comunicação, a aprendizagem da leitura e da escrita se constitui como processo interativo, que ocorre mediante a relação que se estabelece com o outro, implicando “[...] mais profundamente, uma forma de interação com o outro pelo trabalho de escritura para quem eu escrevo o que escrevo e por quê?" (SMOLKA, 2008, p. 69). Estudos destacam a relação entre a aprendizagem e os processos interativos na escola, em meio às práticas pedagógicas e os sentidos que a criança apreende do contexto, trazendo o foco para a 
singularidade dos aprendizes (LIMA, 2009; MARCHESANO, 2010; OSTROSKY; GAFFNEY; THOMAS, 2006; SANTOS, 2005).

Nesta perspectiva, Leite (2006, 2011), juntamente com seu grupo denominado "Grupo do Afeto", vem desenvolvendo importantes estudos sobre a dimensão afetiva na mediação pedagógica em sala de aula e aponta que o processo de constituição do leitor é construído por meio de um movimento social, no qual a mediação do outro é fundamental, com destaque às relações de natureza afetiva. Para o autor, há uma constituição social do leitor, o que se relaciona com a história de vida do sujeito, com ênfase nas mediações sociais, que incluem a família e a escola. Tassoni $(2000,2008)$ ressalta que, na dinâmica interativa de sala de aula, a afetividade se relaciona à produção escrita, pela mediação do professor, assumindo a aprendizagem como processo social.

Neste viés, Gontijo (2009) ressalta que o modo como os professores trabalham influencia os processos de apropriação da escrita. Em sua investigação com crianças de cinco e seis anos, percebe que a função da escrita como recurso mnemônico é compreendido pela criança mesmo sem ter o domínio do código alfabético de escrita. Por fim, a autora chama a atenção para a singularidade dos percursos de desenvolvimento da linguagem escrita das crianças, mas ressalta que o desenvolvimento depende da aprendizagem. Desta forma, Gontijo e Leite (2002, p. 148) contribuem para entendermos a relação funcional da criança com a escrita e sua utilização como recurso mnemônico, ou seja, “[...] a linguagem escrita é um sistema de signos que serve de apoio às funções intelectuais, especificamente a memória."

A mediação do professor e dos colegas aparece em diferentes pesquisas como importantes para a construção do conhecimento pela criança para garantir a aprendizagem e o desenvolvimento dos alunos com relação à escrita (ALVES, 2006; ANDRADE, 2011; BOA, 2002; FARIAS, 2006; GOMES, 2006; ISAIA, 2008; LUIZE, 2007; MACEDO; MORTIMER, 2000; PEREIRA, 2007; REIS, 2000). Para Barbato (2007), as relações tecidas entre professores e alunos, assim como entre alunos, envolvem processos de negociação de significados entre os pares e pode ser desenvolvida em trabalhos individuais ou colaborativos.

Solovieva e Quintanar Rojas (2008) realizam estudos com crianças nativas do idioma espanhol, embasados por uma perspectiva psicológica e neuropsicológica histórico-cultural, em uma vertente cognitivista de um dos momentos da obra de Vigotski, conforme foi destacado por González Rey (2011b). Os autores consideram o papel do professor e do método de ensino como fundamental para que a aprendizagem ocorra, além de ressaltarem a aprendizagem da leitura como essencial para o desenvolvimento da psique e da personalidade 
humana. Tais autores, apoiados em Elkonin ${ }^{18}$, partem da concepção de leitura com foco na sonoridade das palavras para posterior aprendizagem da forma gráfica. Teríamos assim um processo de tomada de consciência da criança da forma verbal das palavras que se automatiza e favorece a relação com a representação gráfica dos fonemas. Vale destacar que, neste processo, prioriza-se o simbólico e a mediação, porém não consideram os fatores emocionais.

Wilce (2009), no livro Language and emotion, aponta interessantes discussões sobre o papel das emoções na linguagem, trazendo suas inter-relações e fundamentando a importância da relação com o outro, da comunicação como processos fundamentais que culturalmente são marcados pelas emoções expressas na linguagem. Castanho (2006), ao investigar de que maneira elementos afetivos e cognitivos interagem na formação do leitor, nas suas representações de si, percebe que, das crianças que participaram do referido estudo, os que possuem uma leitura fluente, descrevem-se como leitores ou indicam que o que mais gostam de fazer é ler. A autora conclui que as representações de si relacionadas à leitura, constituemse como fontes mobilizadoras do desenvolvimento de habilidade cognitivas de leitura.

Correa e Maclean (1999) examinam as narrativas orais feitas por crianças da primeira série escolar sobre a alfabetização e observam que as crianças que tiveram dificuldade no processo de alfabetização produziram histórias referentes à descrição da própria rotina escolar ou mesmo de atividades direcionadas à leitura e à escrita. Nesse caso, não ressaltaram o próprio desempenho, ao passo que, as crianças que foram bem sucedidas neste processo de aprender, relatam o sucesso do protagonista. As autoras destacam a importância do professor no processo de aprendizagem da língua escrita, fato presente nas narrativas das crianças, mesmo para as crianças que não foram bem-sucedidas neste processo.

Um outro trabalho de destaque foi desenvolvido por Scheuer, Cruz e Pozo (2010), cujo foco era estudar as concepções das crianças sobre sua própria aprendizagem. Os autores destacaram, dentre outras elaborações, que a concepção que a criança tem de sua própria aprendizagem gera impactos na forma como se relaciona com este processo. Na concepção das crianças, que fizeram parte do estudo, a aprendizagem da escrita se inicia na família e na escola, assim como as motivações para tal aprendizagem estariam nas situações cotidianas experienciadas pelas crianças. Os autores enfatizaram a confiança das crianças no ensino do professor, a forma voluntária de escrever e ler, assim como a consciência de maior autonomia em relação ao outro para aprender e realizar as atividades.

\footnotetext{
${ }_{18}$ Autor russo que se apoiou na teoria da atividade de A. N. Leontiev com ênfase na periodização do desenvolvimento humano. Nossa crítica a tal abordagem se faz pela separação de Elkonin da dimensão cognitiva e da dimensão afetiva no curso do desenvolvimento (GONZÁLEZ REY; MITJÁNS MARTÍNEZ, 1989).
} 
É importante destacar que o papel da família e da escola como fundamentais no processo de alfabetização das crianças, tendo em vista o ambiente alfabetizador e as relações tecidas nos diferentes contextos experienciados pela criança estão presentes nas pesquisas de Andrés et al. (2010) e Mendes (2009). Os trabalhos dos autores enfatizam a importância de o aprendiz experienciar ambientes alfabetizadores próximos do que já conhecem, para poderem atuar com a linguagem escrita de forma efetiva no mundo. Destacam o papel relacional dos diferentes contextos que a criança experiencia, assim como os recursos materiais disponíveis para acesso à leitura e à escrita.

$\mathrm{Na}$ dimensão da relação da família e da escola, no processo de aprendizagem, um trabalho relevante foi realizado por Carnoy (2009), ao buscar compreender como Cuba consegue promover uma educação de qualidade superior a muitos países como Brasil e Chile. Em suas conclusões, o autor aponta o êxito de Cuba como resultado de diversos fatores, dentre os quais se destaca o elevado grau de exigência curricular, o qual tem sido transmitido de modo eficaz, pela qualidade da formação dos professores, que são supervisionados e orientados de forma frequente. Nesse país, a função da educação é atribuída ao Estado que cobra dos pais o apoio necessário para o nível elevado de desempenho acadêmico dos filhos.

Silva, L. (2012) também realizou um estudo comparativo entre o sistema educacional de Cuba, Finlândia e Brasil, com ênfase no trabalho realizado nos anos iniciais do ensino fundamental. Dentre as conclusões, destaca que, tanto na Finlândia quanto em Cuba, há um processo de formação prática do professor, que demanda o contato com outros professores mais experientes, o que não se observa no Brasil.

A partir do exposto, é possível asseverar que não identificamos pesquisas com foco na forma como as relações são subjetivadas pela criança, ou seja, quais são as experiências que se tornam significativas e como elas se organizam subjetivamente. Isso demonstra a relevância de nossa investigação, uma vez que assumimos, nesse trabalho, em consonância com González Rey (2004a), o papel do outro no processo de aprendizagem e desenvolvimento, na medida em que seja portador de sentido subjetivo para o aprendiz.

\subsubsection{Elementos contextuais: usos e funções da leitura e da escrita}

Neste tópico, organizamos os trabalhos que têm a questão cultural, como base para pensar sobre a aprendizagem da leitura e da escrita, com ênfase nos usos e funções conferidos pela criança. Podemos asseverar a relevância dos elementos contextuais para a aprendizagem da leitura e da escrita, aspecto importante de nosso trabalho, uma vez que tentamos romper 
com a dicotomia do social com o individual. No processo de aprender, reconhecemos o valor das formas únicas de experienciar este processo. Nas discussões sobre a língua materna, encontramos trabalhos que conferem valor à forma única com que culturalmente se organiza a linguagem a partir das variantes linguísticas permeando a área da Linguística e da Sociolinguística representada, dentre outros autores, por Bortoni-Ricardo (1995, 2004, 2012).

A Sociolinguística consiste em uma vertente da ciência da linguagem envolvida na investigação da relação dos fenômenos linguísticos e os próprios acontecimentos sociais, nos possibilitando a compreensão da instabilidade e da flexibilidade da língua a partir do tempoespaço em que se concretiza nas chamadas variantes linguísticas, num movimento influenciado pela própria situação social do falante (BORTONI-RICARDO, 1995). BortoniRicardo (2004) ressalta que quando a pressão comunicativa sobre a pessoa é mínima, há uma expressão mais espontânea e liberdade de se colocar frente ao outro.

Nos processos comunicativos do falante nativo, Bortoni-Ricardo (1995) e BortoniRicardo e Oliveira (2013) destacam o papel do professor no conhecimento dos seus alunos em suas variantes linguísticas, para a proposição de um trabalho pedagógico que possa ampliar e diversificar a competência comunicativa dos aprendizes, com vistas à flexibilidade de utilização das competências linguísticas em contextos diversos. Tal perspectiva compreende as especificidades da linguagem, o contexto cultural experienciado pela pessoa e a importância de sua valorização no contexto formal de educação, com impactos sobre o processo de aprendizagem, ampliando a relação entre oralidade e consciência fonológica (BORTONI-RICARDO; SOUSA, 2008b).

Nesta perspectiva, Cagliari (2009) destaca a forma como a escrita representa a linguagem oral, ou seja, o cultural, o lugar em que experienciamos, a forma como falamos, se expressa na maneira como escrevemos. Em consonância com o referido autor, BortoniRicardo (2006) ressalta que, na fase inicial da aprendizagem da leitura, a decodificação, ou seja, a consciência fonológica constitui-se em uma competência primordial a ser desenvolvida e favorece a compreensão do princípio alfabético. Neste viés, Gondim (2007) realiza um trabalho de intervenção na prática pedagógica de uma professora alfabetizadora, buscando refletir sobre os saberes cotidianos dos alunos, mais especificamente os saberes do âmbito familiar, percebendo a importância da oralidade na construção da escrita, concluindo que há relação entre uma prática pedagógica de alfabetizar letrando e a consciência fonológica.

Franco (2002), em pesquisa de mestrado, apresenta como a participação dos alunos em salas de alfabetização muitas vezes é silenciada, dentre outros motivos, pelo confronto com a própria linguagem escolar em relação à que estão acostumados a utilizar. Ressalta, em suas 
conclusões, a importância do incentivo do professor à participação dos alunos em debates, num processo de equidade entre a utilização da fala oral e da linguagem escrita.

A forma própria de a criança utilizar a leitura e a escrita tem sido amplamente estudada na perspectiva do letramento (KLEIMAN, 1995; ROJO, 1998; SOARES, 2005; TFOUNI, 1997) trazendo a possibilidade de analisarmos as dimensões sócio-históricas na aquisição da escrita. Nesta dimensão, as discussões sobre o letramento, termo originado de literacy representa uma mudança para entender a alfabetização, não apenas como aquisição de um código escrito, mas que demanda envolvimento com as práticas sociais de leitura e escrita.

Nesse contexto, tem-se a ideia de que o domínio e o uso da língua escrita influenciam a criança e seu grupo social tanto nos aspectos sociais, culturais, políticos, econômicos, cognitivos, quanto na forma como a linguagem passa a permear as ações e relações humanas. Assim, o letramento, segundo Goulart (2006, p. 452), “[...] estaria relacionado ao conjunto de práticas sociais orais e escritas de uma sociedade." Neste viés, destacamos o trabalho Brian Street (1984), no qual enfatiza que o termo literacy relaciona-se às duas facetas, ou seja, está para o aprendizado de um código alfabético quanto para os usos da leitura e da escrita na vida diária da pessoa. Para o autor, o letramento é um ato social e pela sua diversidade nas diferentes culturas, tem recorrido ao termo letramentos no plural. Collins e Blot (2003) ressaltam que, desde o final do século XVIII, existia uma presença nas elites norte-americanas de associação entre práticas de letramento e a legitimidade.

Estudos na perspectiva da compreensão das relações entre a cultura escrita da criança, tendo em vista as práticas de letramento no âmbito familiar, e a relação desta com a apropriação da escrita pela criança, têm sido desenvolvidos dentre outros, por Caxangá (2007), que destaca a importância de um trabalho construtivo em sala de aula como fator essencial para a superação da limitação de contato com práticas de letramento no contexto familiar. Castro (2010) também centra-se na influência dos aspectos socioculturais e considera que fatores genéticos e sociais são importantes aspectos do desenvolvimento humano e dos caminhos metacognitivos que a criança utiliza para se apropriar do código escrito.

Machado (2012) realiza uma interessante investigação que aborda a relação entre a concepção leitora do PISA e as práticas escolares de leitura. Em suas conclusões, a autora aponta que a concepção de leitura do PISA é mais ampla e que a escola se centra em uma visão particular de leitura com foco no letramento literário e acaba sendo mais restrita, com uma redução em termos de possibilidades de exploração dos gêneros textuais, ao passo que o teste do Pisa prioriza tal diversidade. Para a autora, outro ponto de destaque é a ausência, na 
escola, de um trabalho efetivo com as estratégias de leitura durante a leitura, sendo estas estratégias priorizadas em momentos anteriores e posteriores à leitura em si.

A proposta de Goulart (2010, p. 451, grifo da autora) consiste em letrar alfabetizando uma vez que o processo de aprender a ler e a escrever "[...] envolve circunscrever e especificar, além de alargar e fazer crescer o universo de sentidos na linguagem e com a linguagem, oral e escrita, além de outras formas de expressão." Neste contexto, autores nacionais são representativos nesta mudança que perpassa a aprendizagem da leitura e da escrita, dentre os quais estão Kramer (1986), Leite (1988, 1993, 2011), Rojo (1998), Smolka (1991, 1993, 2000, 2008, 2010b), Soares (2005) e Tfouni (1996), bem como está presente no documento Pró-Letramento ${ }^{19}$. Como define Soares (2010), alfabetização e letramento se diferenciam, porém, são processos indissociáveis e implicam formas de aprender diferentes.

No entanto, há um grande número de pesquisadores (GERALDI, 2011; GONTIJO; SCHWARTZ, 2011; PÉREZ; ARAÚJO, 2011), estudiosos de Paulo Freire, que divergem da diferenciação entre alfabetização e letramento, trazendo o processo de alfabetização como um movimento que abarca os sentidos e reivindicam que seu ensino esteja baseado no "exercício de ser criança", o qual tem sido esmagado pela sociedade do consumo e da produção exorbitante e reprodutiva de que somos acometidos. Para nós, "[...] a transgressão é caminho do novo, de uma educação não para o existente, mas para o (por) vir.” (GERALDI, 2011, p. 31). A alfabetização como um conceito complexo constitui-se como vital para a atuação no mundo e faz-se como condição sine qua non para a transformação do mesmo. Nas palavras de Pérez e Araújo (2011, p. 144, grifo dos autores): "A alfabetização como uma forma de transformação do mundo só encontra sentido no uso que dela fazem indivíduos e sociedades."

As discussões sobre alfabetização e letramento constituem o cenário atual da educação, porém, não avançam na forma como as crianças utilizam o que aprendem, a partir da geração de ideias próprias e novas capazes de transcender o dado e da maneira como confrontam com o dado e personalizam o que aprendem; assim como não trazem elementos sobre a forma como esse aprender promove o desenvolvimento subjetivo, perspectiva que se abre a partir da expressão da criatividade na aprendizagem proposta por Mitjáns Martínez (2012a) e que nos propomos a trabalhar nesta investigação.

Pelas considerações sobre os termos alfabetizar, processo voltado aos aspectos tecnológicos da escrita, e letramento, como o uso social da leitura e da escrita, optamos pela utilização do termo aprendizagem da leitura e da escrita na tentativa de romper com possíveis

\footnotetext{
${ }^{19}$ Programa de Formação Continuada de Professores dos Anos/Séries Iniciais do ensino fundamental: alfabetização e linguagem (2008).
} 
dicotomias entre a aquisição de um código, a utilização do mesmo em contextos sociais e os processos subjetivos envolvidos. No âmbito da perspectiva histórico-cultural, assumida neste trabalho, consideramos as múltiplas nuances que envolvem este aprender e concordamos com Freire (2011a, 2011b), Leite (2008, 2011) e Smolka (2008) que este processo é permeado pelos aspectos culturais, sociais, afetivos e cognitivos. No tópico a seguir, agrupamos os trabalhos vinculados ao desenvolvimento humano e aos processos subjetivos, associados à aprendizagem da leitura e da escrita e à aprendizagem de forma mais geral.

\subsubsection{Aprendizagem da leitura e da escrita: relações com o desenvolvimento humano e os processos subjetivos}

Neste item, organizamos em um primeiro momento os trabalhos que versam sobre as relações entre aprendizagem da leitura e da escrita e o desenvolvimento humano, e no segundo tópico, apresentamos um diálogo com as pesquisas que tratam dos processos subjetivos implicados na aprendizagem da criança tanto no âmbito da leitura e da escrita, quanto de uma forma mais geral. Consideramos relevante abarcar tais trabalhos, uma vez que abordam a aprendizagem como processo subjetivo, no âmbito do que nos propomos a realizar com o presente estudo.

\subsubsection{A aprendizagem da leitura e da escrita e suas relações com o desenvolvimento} humano

A complexidade que permeia a aprendizagem da linguagem escrita foi fundamentalmente ressaltada por Vigotski (1995, p. 184, tradução nossa), em que o seu domínio é resultado de um “[...] longo desenvolvimento das funções superiores ${ }^{20}$ do comportamento infantil." Para o autor, o desenvolvimento da linguagem escrita não segue uma linha única, mas se constitui como um processo revolucionário com interrupções, metamorfoses e involuções. Em seus trabalhos, Vigotski $(1995,2007)$ alerta para a importância do desenvolvimento da linguagem como decisivo para o próprio desenvolvimento da escrita, bem como aponta para a gênese dos processos desta aprendizagem nos gestos, no desenho e no próprio brincar da criança, aspectos que antecedem e contribuem para a aprendizagem da linguagem escrita.

Em seus estudos sobre a pré-história da escrita, Luria (2006, p. 180, grifo do autor) observa que o desenvolvimento da escrita se inicia antes da entrada da criança na escola, ou

${ }^{20}$ Para nós as funções psíquicas superiores representam processos de sentidos subjetivos que se constituem na unidade simbólico e emocional frente à experiência do indivíduo (GONZÁLEZ REY, 2012a). 
seja, a história da escrita está no próprio processo de desenvolvimento cultural da criança. Para o autor, a escrita constitui uma função culturalmente realizada, pela mediação e não segue uma linha de desenvolvimento linear, mas “[...] como uma melhoria gradual do processo de escrita, dentro dos meios de cada técnica, e o ponto de aprimoramento abrupto marcando a transição de uma técnica para outra."

Para Vigotski (1995, p. 184, tradução nossa), a aprendizagem da linguagem escrita, possibilita o desenvolvimento cultural da criança, definindo-a "[...] como um sistema especial de símbolos e signos cujo domínio significa uma mudança crítica em todo o desenvolvimento cultural da criança." Tal aprendizagem pode favorecer o desenvolvimento da personalidade, na medida que a criança tenha necessidade de ler e escrever, ou seja, que este momento faça sentido para a criança e não seja apenas uma forma mecânica de apropriação de um código.

Baseada nos pressupostos de Vigotski, Smolka (2008) destaca que a linguagem é uma atividade de cunho criadora e que, por ser constitutiva de conhecimento, é também transformadora. Em sintonia com tais autores, convalidamos que a aprendizagem da leitura e da escrita possibilita mudanças substanciais na constituição da criança e entendemos que a compreensão dos processos subjetivos que permeiam este aprender, foco de nosso estudo, poderá contribuir para entender as mudanças que um tipo de aprendizagem complexa pode favorecer na subjetividade da criança.

No desenvolvimento cultural, temos os usos e funções da fala egocêntrica, ressaltada por Cavaton (2010), Cavaton e Barbato (2011, p. 81) que analisam suas influências em crianças de seis anos em atividades de desenho e escrita. As autoras indicam a função organizadora da fala egocêntrica nas atividades destacadas. O desenvolvimento cultural das crianças estaria relacionado "[...] à aprendizagem do uso dos sistemas simbólicos como ferramentas culturais, entre eles, a linguagem, a escrita e as imagens." Nesta perspectiva, Smolka (1993) aponta a dialogia e a fala egocêntrica como princípios vinculados à gênese das atividades de escritura pelas crianças. A autora também destaca a leitura como prática discursiva, como trabalho simbólico, trazendo a leitura na sua "[...] constituição sóciohistórica e na diversidade dos contextos de sua produção, articulando a dimensão material, biológica, e a dimensão simbólica, cultural.” (SMOLKA, 2010a, p. 43).

A função simbólica, também é destacada por Couto, Arena e Mello (2007) como necessária à apropriação da leitura e da escrita, tendo em vista um trabalho desenvolvido com crianças de seis anos, em que inserem o brincar na rotina escolar com o intuito de provocar o desenvolvimento de tal função. Como conclusão, o estudo aponta que é fundamental que a leitura e a escrita sejam utilizadas como objetos culturais, tornando-se atividades promotoras 
de humanização. A aprendizagem da leitura e da escrita passa a ser analisada para além de uma mera habilidade a ser adquirida, mas como uma construção própria da criança, em meio à cultura e a forma singular com que experiencia este processo.

Para Freire (2011a), há uma relação dinâmica entre a leitura da palavra, não como um fim em si mesma, mas permeada pela leitura da realidade, própria do mundo experienciado pela criança, em que atribui sentidos sobre a leitura, que são singulares. Para o autor, a escrita e a leitura são processos que, pela autenticidade com que são aprendidos pela criança, em meio a processos de reflexão e diálogo, podem favorecer mudanças tanto na realidade quanto para a própria criança que muda sua forma de estar e relacionar com o mundo.

Para Barbato (2008), o olhar se volta para processos simbólicos, reconhecendo que o brincar e a imaginação constituem fontes essenciais do aprender. Neste viés, a referida autora percebe que "[...] operações do processo de imaginação intervêm [...] como parte inerente das estratégias utilizadas pelas crianças ao aprenderem a ler e escrever.” (BARBATO, 2007, p. 278). Nesta vertente, temos as contribuições de Ezequiel Theodoro da Silva (2010). Esse autor destaca a capacidade de imaginação da criança que contribui para o seu desenvolvimento linguístico mediante a relação inventiva que a mesma tem com a linguagem.

Oliveira (2014), no âmbito da perspectiva histórico-cultural, realiza uma pesquisa cujo tema é a imaginação e as narrativas literárias e orais. A autora analisa como tais narrativas são utilizadas na escola e a forma como constituem o universo imaginativo de crianças dos anos iniciais do ensino fundamental, assim como as narrativas são constituídas por este universo. Dentre suas conclusões, a referida autora destaca que a imaginação está associada às experiências das crianças, às elaborações mentais e à emocionalidade que participam do contexto escolar. Assim como enfatiza que o contexto escolar que contenha estes elementos pode viabilizar a expressão da imaginação e a capacidade para criar.

Apoiamo-nos em Vigotski (2009), que compreende a imaginação como função essencial para o desenvolvimento humano e destaca que suas possibilidades não se restringem ao tempo-espaço da experiência vivida, mas está presente nas mais diversas atividades mentais do homem. Sendo assim, para González Rey (2012a), a imaginação é uma produção simbólica, que expressa um processo subjetivo de uma configuração atual, em que há participação do pensamento e das emoções engendradas pelo mesmo.

Os trabalhos supracitados trazem importantes contribuições sobre as relações entre aprendizagem e desenvolvimento humano, porém não avançam no como a aprendizagem da leitura e da escrita pode se constituir processo de desenvolvimento da subjetividade da criança, em um processo que não segrega o emocional do simbólico, desafio que nos 
propomos a buscar com o presente trabalho mediante aporte teórico da Teoria da Subjetividade de González Rey.

\subsubsection{Processos subjetivos na aprendizagem de crianças: pesquisas no âmbito da Teoria da} Subjetividade

No presente tópico, elencamos pesquisas que explicitam os processos subjetivos associados à aprendizagem da criança, dentro do referencial teórico assumido em nossa pesquisa, ou seja, da Teoria da Subjetividade de González Rey. Neste viés, encontramos o trabalho de Oliveira, M. (2011), que desenvolveu uma interessante pesquisa intentando desvelar as dimensões subjetivas contidas no processo de aprendizagem da leitura e da escrita de crianças da terceira, quarta e quinta série do ensino fundamental. Eram crianças que demonstravam dificuldades de aprendizagem na escola. A partir da criação de estratégias de avaliação e intervenção com os participantes da investigação, a pesquisadora possibilitou momentos de reflexão sobre as dificuldades dos alunos e sobre a valoração negativa em relação à capacidade de aprender. A autora conclui que as necessidades educacionais especiais são temporárias e podem ser modificadas a partir de uma intervenção que ressignifique as trajetórias escolares.

Nesta mesma perspectiva, o trabalho de Bezerra (2004) destaca os elementos contextuais da aprendizagem, com o objetivo de buscar compreender como o processo de conhecimento é subjetivado por crianças das séries iniciais do ensino fundamental, consideradas como fracassadas na escola. A autora parte da compreensão da aprendizagem como um movimento dinâmico de produção de sentido subjetivo vinculado à realidade e à história do indivíduo que aprende. Em suas conclusões, enfatiza as emoções, os padrões culturais e relações de preconceito que permeiam o movimento do aprender gerando formas de subjetivação de impotência no aluno.

Neste viés, Rossato (2009) realizou uma investigação cujo objetivo foi compreender o movimento da subjetividade de crianças no processo de superação das dificuldades de aprendizagem, o que envolveu crianças dos anos iniciais do ensino fundamental. A autora defende a tese de que a superação das dificuldades de aprendizagem requer o desenvolvimento da subjetividade, o que envolve produção de novos sentidos subjetivos que se faz nas ações e relações do sujeito.

Ainda, no âmbito da perspectiva teórica, eleita para este trabalho, encontramos o trabalho de Cupolillo (2013) que realizou uma experiência terapêutico-educacional com uma criança na faixa etária de sete a oitos anos. A pesquisa foi feita com um aprendiz que 
apresentava dificuldade de aprendizagem, com o intuito de compreender a constituição de sua subjetividade. O trabalho apresenta a forma como as histórias de interação da criança engendravam processos que envolviam modelos hegemônicos de beleza e estavam relacionados a diferentes contextos experienciados, capazes de lhe gerar insegurança na relação com o outro e dificuldade em se sentir capaz. A autora apresenta a forma como a não produção de sentidos subjetivos favoreciam o movimento cíclico de sentidos subjetivos e como o processo terapêutico, que envolveu seus familiares, a escola e a própria criança, constituiu um importante espaço para novas produções subjetivas capazes de dinamizar e favorecer a aprendizagem da criança.

As pesquisas anteriores nos fornecem subsídios para compreendermos que há uma relação entre aprender e a subjetividade da criança, o que nos instiga a empreender uma nova jornada para compreender como esta relação se organiza frente a tipos de aprendizagem mais complexas. O que avançamos ao tratarmos da aprendizagem criativa especificamente no campo da aprendizagem da leitura e da escrita.

Frente ao exposto nos itens acima, compreendemos que há uma tentativa dos trabalhos analisados, em interpretar o fenômeno da aprendizagem da leitura e da escrita na sua complexidade. Entretanto, esta aprendizagem tem se constituído em uma área de conhecimento extremamente dividida, acentuando uma preocupação em relação ao contexto atual da educação, cujos índices de analfabetismo ${ }^{21}$ são alarmantes. Como possibilitar uma compreensão dos processos envolvidos na aprendizagem, por nós identificados nos estudos, como a imaginação, o simbólico, o cultural, as emoções, a interação, os aspectos sociais e individuais, bem como o operacional na aprendizagem, em sua complexidade constituidora?

Convalidamos a importância que a Teoria da Subjetividade desenvolvida por González Rey e as contribuições de Mitjáns Martínez ao tema da criatividade, como base para a compreensão dos processos envolvidos na aprendizagem da leitura e da escrita, rompendo com as dicotomias identificadas no campo em análise. Uma vez ressaltada a necessidade de recuperar o sujeito que aprende e isso "[...] implica integrar a subjetividade como aspecto importante desse processo, pois o sujeito aprende como sistema e não só como intelecto." (GONZÁLEZ REY, 2008a, p. 33).

Como síntese, construímos o quadro a seguir, com o intuito de ilustrar os diferentes focos que têm sido atribuídos à aprendizagem da leitura e da escrita, destacando as características que, com nossa análise, foram mais expressivas.

\footnotetext{
${ }^{21}$ Informações sobre as taxas de analfabetismo podem ser encontradas em Bortoni-Ricardo (2004) e Bortoni-Ricardo; Machado; Castanheira (2010).
} 
Quadro 1 - Síntese dos focos conceituais sobre aprendizagem da leitura e da escrita no campo científico

\begin{tabular}{|c|c|c|}
\hline \multicolumn{2}{|c|}{ Aprendizagem da leitura e da escrita } & Características \\
\hline \multicolumn{2}{|c|}{$\begin{array}{l}\text { Pesquisas de revisões bibliográficas ao campo } \\
\text { da aprendizagem da leitura e da escrita. }\end{array}$} & $\begin{array}{l}\text { - Tema de estudo em diferentes áreas: Psicologia, Linguística, } \\
\text { Sociolinguística, Psicolinguística. } \\
\text { - O foco dos estudos tem sido o campo da educação formal; } \\
\text { - Mudanças na concepção de alfabetização; } \\
\text { - Ampliação da discussão sobre letramento e alfabetização; } \\
\text { - O papel relevante conferido à criança neste processo; } \\
\text { - Expressivo avanço da Ciência Cognitiva. }\end{array}$ \\
\hline \multirow{2}{*}{$\begin{array}{l}\text { Pesquisas com } \\
\text { foco nos estágios } \\
\text { e processos } \\
\text { operacionais da } \\
\text { aprendizagem. }\end{array}$} & $\begin{array}{l}\text { Estágios da } \\
\text { aprendizagem da leitura } \\
\text { e da escrita. }\end{array}$ & $\begin{array}{l}\text { - Hipóteses de escrita; } \\
\text { - Evolução da escrita por meio de etapas fixas e universais; } \\
\text { - O sujeito como construtor de conhecimento; } \\
\text { - Foco no indivíduo que aprende. }\end{array}$ \\
\hline & $\begin{array}{l}\text { O operacional no } \\
\text { processo de aprender a } \\
\text { ler e a escrever. }\end{array}$ & $\begin{array}{l}\text { - Estratégias de autorregulação e metacognitivas; } \\
\text { - Relação entre som e letra - consciência fonológica; } \\
\text { - Foco no indivíduo que aprende. }\end{array}$ \\
\hline \multirow[t]{2}{*}{$\begin{array}{l}\text { Pesquisas com } \\
\text { foco no caráter } \\
\text { inventivo e na } \\
\text { semântica. }\end{array}$} & $\begin{array}{l}\text { O caráter inventivo no } \\
\text { processo de aprender a } \\
\text { ler e a escrever. }\end{array}$ & $\begin{array}{l}\text { - Relação inventiva com a escrita; } \\
\text { - Foco nas inter-relações contexto e indivíduo; } \\
\text { - Presença do pensar e da reflexão; } \\
\text { - Processos de autoria e singularidade na escrita; } \\
\text { - Mudanças na forma de se relacionar com o mundo; } \\
\text { - Caráter transgressor da escrita. }\end{array}$ \\
\hline & $\begin{array}{l}\text { Semântica e o processo } \\
\text { de aprendizagem da } \\
\text { leitura e da escrita. }\end{array}$ & $\begin{array}{l}\text { - O sentido da escrita e da leitura; } \\
\text { - A singularidade diante dos significados das palavras e sua } \\
\text { relação com o contexto da ação e com os conhecimentos } \\
\text { prévios dos aprendizes; } \\
\text { - A leitura e a escrita como produção singular. }\end{array}$ \\
\hline \multirow{2}{*}{$\begin{array}{l}\text { Pesquisas com } \\
\text { foco nos } \\
\text { processos } \\
\text { interativos e nos } \\
\text { elementos } \\
\text { contextuais. }\end{array}$} & $\begin{array}{l}\text { Processos interativos na } \\
\text { aprendizagem da leitura } \\
\text { e da escrita. }\end{array}$ & $\begin{array}{l}\text { - A interação com o outro e com o contexto cultural; } \\
\text { - O papel do professor, colegas e da família na aprendizagem; } \\
\text { - A formação continuada dos professores como processo de } \\
\text { interação com o outro. }\end{array}$ \\
\hline & $\begin{array}{l}\text { Elementos contextuais: } \\
\text { usos e funções da } \\
\text { aprendizagem. }\end{array}$ & $\begin{array}{l}\text { - Usos sociais da escrita; } \\
\text { - Cultura escrita da criança; } \\
\text { - Modos de falar e modos de escrever. }\end{array}$ \\
\hline \multirow[t]{2}{*}{$\begin{array}{l}\text { Pesquisas com } \\
\text { foco no } \\
\text { desenvolvimento } \\
\text { humano e nos } \\
\text { processos } \\
\text { subjetivos. }\end{array}$} & $\begin{array}{l}\text { A aprendizagem da } \\
\text { leitura e da escrita e suas } \\
\text { relações com o } \\
\text { desenvolvimento } \\
\text { humano. }\end{array}$ & $\begin{array}{l}\text { - Processo marcado por interrupções, metamorfoses e } \\
\text { involuções; } \\
\text { - A aprendizagem promove o desenvolvimento cultural; } \\
\text { - Processos envolvidos neste aprender: fala egocêntrica, } \\
\text { imaginação, diálogo, função simbólica. }\end{array}$ \\
\hline & $\begin{array}{l}\text { Processos subjetivos na } \\
\text { aprendizagem de } \\
\text { crianças. }\end{array}$ & $\begin{array}{l}\text { - Unidade entre as emoções e os processos simbólicos no } \\
\text { processo de aprendizagem; } \\
\text { - A aprendizagem vinculada à subjetividade da criança; } \\
\text { - Reflexão do aluno sobre o seu próprio processo de aprender. }\end{array}$ \\
\hline
\end{tabular}

Fonte: elaborado pela autora, 2015.

Portanto, a revisão bibliográfica realizada, sem a pretensão de esgotar o tema, nos permitiu um panorama que nos instiga a empreender novos trabalhos em prol da compreensão da expressão da criatividade na aprendizagem da leitura e da escrita e o desenvolvimento da subjetividade da criança, foco do presente trabalho. Para esta aventura pelo tema, mergulhamos a seguir, na fundamentação teórica que constitui o alicerce de nossa investigação. 


\section{FUNDAMENTAÇÃO TEÓRICA}

A presente parte está organizada em dois expressivos eixos que, na sua inter-relação, constitui a base sobre a qual se funda nossa investigação. Buscamos no primeiro momento trazer um diálogo com a Teoria da Subjetividade desenvolvida por González Rey (1997, 2002, 1999a, 2003a, 2004a, 2005a, 2005b, 2005c, 2007a, 2011a) e, no segundo eixo deste capítulo, temos a oportunidade de refletir e dialogar com as construções teóricas de Mitjáns Martínez (1997, 2004, 2008a, 2008b, 2009a, 2012a, 2012b, 2014) no tema da criatividade no âmbito da perspectiva histórico-cultural.

\subsection{BASE TEÓRICA DA PESQUISA I: TEORIA DA SUBJETIVIDADE}

A compreensão das inter-relações entre aprendizagem criativa da leitura e da escrita e desenvolvimento da subjetividade, torna-se possível a partir da seleção de uma teoria que possibilita refletir sobre as múltiplas e complexas relações que se encontram neste processo. Tal necessidade nos levou ao encontro e eleição da Teoria da Subjetividade desenvolvida por González Rey (1997, 2002, 1999a, 2003a, 2004a, 2005a, 2005b, 2005c, 2007a, 2011a), a qual destaca o caráter gerador e produtor da psique humana.

\subsubsection{Teoria da Subjetividade: conceitos centrais}

A Teoria da Subjetividade de González Rey, tem suas bases em autores como Vigotski, Bozhovich, Rubstein, e é fundada na perspectiva histórico-cultural. Em um caráter profundo e investigativo, González Rey lança-se ao desafio de encontrar lacunas, de problematizar o campo de seu estudo, em especial, da psicologia e, de forma criativa, produz ideias novas que transcendem as teorias por ele estudadas. Sua criação de uma teoria própria assume valor heurístico, por contribuir com elementos substanciais para o estudo da psique humana em sua complexidade ${ }^{22}$.

Do nosso ponto de vista, a Teoria da Subjetividade é uma teoria da ruptura de dicotomias como interno e externo, social e individual, simbólico e emocional, ao articular estes elementos de forma sistêmica, em que a psique não estaria definida como reflexo do externo ou mesmo por processos intrapsíquicos, mas permite representá-la como processo gerador frente às experiências. Para tratar a complexidade constitutiva deste sistema e gerar

\footnotetext{
22 Compreendemos a complexidade de acordo com Morin (2011), como forma de entender a realidade em seu caráter desordenado, contraditório, plural, recursivo, singular e histórico; assim como por reconhecer a complexidade na dialógica ordem/desordem/organização. Elementos que configuram, no âmbito da Teoria da Subjetividade, a própria dinâmica do movimento da subjetividade humana (MITJÁNS MARTÍNEZ, 2005).
} 
inteligibilidade sobre o mesmo, González Rey (1997, 2002, 2005b, 2005c, 2007a) cria categorias que em sua articulação, conformam a Teoria da Subjetividade (MITJÁNS MARTÍNEZ, 2005), dentre as quais citamos: subjetividade, sujeito, personalidade, subjetividade individual, subjetividade social, configuração subjetiva, configuração subjetiva da ação, sentido subjetivo.

A subjetividade é uma macrocategoria, na qual se articulam as demais categorias, que se organiza como sistema processual, em constante movimento e organização. A integração das categorias ocorre pela relação entre as mesmas, perpassada por desintegrações, reintegrações e reestruturações no âmbito do sistema. Em que as categorias mantêm uma verdadeira relação de constituição recíproca entre elas, mediante a ação da pessoa em diferentes contextos (GONZÁLEZ REY, 2003a).

Como produção humana, a subjetividade, de acordo com González Rey (2012a), pode ser definida como nível qualitativo em que a psique assume capacidade geradora e está vinculada aos contextos sociais e culturais da ação humana. Uma de suas características é subverter padrões deterministas, pelo caráter gerador do humano frente ao contexto, na configuração de sentidos e significados, o que envolve a relação sujeito-contexto-organização subjetiva. Sendo assim, a subjetividade se constitui na inter-relação de sua dupla dimensão: subjetividade individual e subjetividade social (GONZÁLEZ REY, 2007a).

González Rey (2003a) representa a subjetividade individual como sendo a organização subjetiva da pessoa que, nas múltiplas e irrepetíveis relações que estabelece com o contexto, organiza sua história subjetiva única. Essa história não se constitui pela somatória de fatos vividos, mas sim, pela organização subjetiva das diferentes experiências ao longo da vida. Desta forma, a ação é subjetivada pela pessoa, na tensão entre o produzido subjetivamente na experiência e a expressão do configurado historicamente que organiza-se e atualiza-se na ação. A subjetividade individual representa um novo nível de integração e desenvolvimento da psique humana, que nos permite compreender, em uma forma mais integral, a organização e a expressão da personalidade como momentos das configurações subjetivas (GONZÁLEZ REY, 2011b).

A subjetividade individual estaria assim constituída por dois momentos importantes que se integram entre si, personalidade e sujeito (GONZÁLEZ REY, 2003a). São momentos que se organizam pela forma como um engendra o outro, sem que percam suas especificidades. Demandam uma relação em que a expressão dos processos que conformam a personalidade, os elementos que constituem nossa síntese subjetiva, contribui para a assunção 
do sujeito frente às situações de um contexto, bem como a própria condição de sujeito produz movimento nas configurações subjetivas que organizam a personalidade.

Neste viés, a concepção de personalidade busca romper com a ideia de traços e características universais, para torná-la uma auto-organização da experiência histórica do sujeito, definindo-a como configurações de configurações subjetivas que se organizam na sua diversidade constituidora e forma a unidade integradora que consiste na personalidade (GONZÁLEZ REY, 2003a). A personalidade se organiza como processo dinâmico e flexível, marcado por constantes transformações, mudanças, organizações e reorganizações. Ela representa a subjetividade individual como um sistema integrado por diferentes configurações subjetivas, as quais se constituem pela diversidade de sentidos subjetivos, mantêm relações entre si e estão associadas às múltiplas experiências do sujeito.

É nesta dinâmica que González Rey (2011b) traz a categoria de sentido subjetivo para representar a integração dinâmica dos processos simbólicos e emocionais que caracterizam a subjetivação do vivido. A categoria de sentido subjetivo advém da própria dinâmica da Teoria da Subjetividade como um sistema teórico aberto e em desenvolvimento, que se organiza no movimento pelo qual transita as próprias mudanças nas definições das categorias, com o intuito de tornar cada vez mais inteligível o funcionamento da subjetividade como sistema. Em várias obras, González Rey (2000a, 2004a, 2007a, 2009c, 2008b, 2011b, 2012a) apresenta a forma como o conceito de sentido subjetivo se desenvolveu em seus trabalhos desde suas construções em 1995 até os dias atuais, tendo por base a categoria de sentido desenvolvida por Vigotski, a qual estaria diretamente relacionada à palavra.

González Rey (2003a, 2007a, 2008b, 2012a) reconhece com maior complexidade o sentido, não limitado à palavra, ou mesmo à unidade entre o cognitivo e o afetivo, como postulado por Vigotski, mas vincula-o às produções simbólicas e emocionais que participam da ação humana, considerando o caráter gerador das emoções na ação da pessoa. Desta forma, o sentido subjetivo não estaria restrito às ações conscientes das pessoas, mas transita pelo consciente e inconsciente e reverbera em ações concretas dos sujeitos, sendo estas ações, o que é consciente para a pessoa.

Em suas construções teóricas atuais, González Rey (2003a, p. 127) define a categoria de sentido subjetivo como "[...] a unidade inseparável dos processos simbólicos e as emoções num mesmo sistema, no qual a presença de um desses elementos evoca o outro, sem que seja absorvido pelo outro." Os sentidos subjetivos estão nas diferentes alternativas de expressão da pessoa em sua capacidade de mobilizar o comportamento (GONZÁLEZ REY, 2011c). São 
produções subjetivas que se configuram no âmbito de eventos e práticas culturais, mediante a processos históricos e atuais de relação.

A expressão e a produção de sentidos subjetivos organizam-se frente às diferentes ações da pessoa, em momentos que se implica emocionalmente em uma experiência. Processo que integra em um único momento, a síntese subjetiva de experiências anteriores com o momento atual. Através do estudo dos sentidos subjetivos temos oportunidade de compreender o significado que tem, para a pessoa, as diferentes experiências e processos vividos (GONZÁLEZ REY, 2011b).

Por isso, as experiências vividas não são processos que se interiorizam ou mesmo que se organizam indistintamente nas pessoas, mas se configuram subjetivamente em cada uma pela produção e organização simbólico-emocional geradas pela pessoa. Sendo assim, não há uma relação imediata entre o que ocorre em uma situação social e o comportamento do sujeito no contexto. Mas sim, uma relação mediada pela forma singular com que subjetivamente a pessoa vive a experiência, como uma organização subjetiva das múltiplas influências sociais. Concepção que permite a superação da dicotomia do social e do individual e coloca as produções simbólicas como criações da mente humana que tomam formas diversas nas ações das pessoas.

Alguns aspectos são definidos por González Rey (2005c) como caracterizadores dos sentidos subjetivos, dentre os quais destacamos: a) o caráter versátil e a mudança constante de sua qualidade, ao se integrarem em distintas configurações subjetivas, caracterizando o fluir na subjetividade; b) a relação recursiva entre sentidos subjetivos, em sua integração simultânea em configurações subjetivas; c) a marca singular de sua existência; d) é uma produção subjetiva, configurada sistemicamente na subjetividade, em sua relação com a experiência do sujeito; e) os sentidos subjetivos não se reprimem, mas tornam-se parte do infinito das diversas configurações subjetivas da vida do indivíduo, assumindo formas diversas frente à experiência do sujeito.

Sendo assim, toda produção de sentidos subjetivos resulta da tensão entre os sentidos subjetivos constituídos historicamente no percurso de vida da pessoa - que se atualizam frente à experiência atual - e os sentidos subjetivos que se produzem na ação (GONZÁLEZ REY, 2005c). Desta forma, entendemos que não há como descrever de forma universal os sentidos subjetivos que formam parte de uma experiência atual do sujeito. Como produções dinâmicas, podem assumir expressões psíquicas diferentes a cada contexto ou em um mesmo contexto diante de diferentes ações. Por isso, os sentidos subjetivos não são acessíveis pelo comportamento ou expressões orais e escritas do sujeito. Mas sim, se organizam frente às 
elaborações do pesquisador nas possibilidades de integração das informações, mediante um movimento de elaboração de indicadores, de hipóteses e do modelo teórico, sobre os quais trataremos nas Bases Epistemológicas da presente investigação.

Os sentidos subjetivos não são entidades soltas no funcionamento subjetivo, são produções subjetivas que, pela qualidade assumida para o sujeito, podem adquirir uma forma mais estável e se organizarem em configurações subjetivas, as quais constituem nossa biografia subjetiva e organizam a personalidade (GONZÁLEZ REY, 2012a). As configurações subjetivas não estão constituídas de forma rígida e fixa para se desdobrarem na ação da pessoa, mas se organizam e se expressam, a partir do contexto da ação, tendo em vista sentidos subjetivos constituídos na história de vida da pessoa e outros produzidos na experiência. Como integradora de diversos sentidos subjetivos, nela se expressa em nível subjetivo a unidade indissolúvel do histórico e do atual, a qual se organiza como produção subjetiva da pessoa comprometida com as ações e a organização subjetiva do sujeito (GONZÁLEZ REY, 2009a, 2011a, 2011e). Elas são relativamente estáveis e conferem à subjetividade o caráter sistêmico de sua organização. Estabilidade que se associa à sua relação com produções de sentidos subjetivos que antecedem o momento atual da experiência (GONZÁLEZ REY, 2005c).

Segundo González Rey (2012a), as configurações subjetivas representam a forma como subjetivamente vivemos cada experiência, momento em que são mobilizadas e se expressam configurações subjetivas diversas que podem não ter sua gênese no contexto da ação, mas em outros espaços sociais experienciados pela pessoa (GONZÁLEZ REY, 2011c). Vale destacar que as configurações subjetivas são dinâmicas e se inter-relacionam, representando uma teia simbólico-emocional que integra a variedade de efeitos e desdobramentos do vivido na pessoa. Por isso, em uma mesma ação da pessoa, podem se expressar diferentes sentidos subjetivos advindos de diferentes configurações subjetivas da personalidade.

Atualmente, González Rey (2011c, 2012a) elaborou a categoria das configurações subjetivas da ação com o objetivo de enfatizar as produções subjetivas que se organizam no momento de viver a experiência, assim como a organização atual que o sistema subjetivo, no devir dos acontecimentos, assume em seu desenvolvimento. A configuração subjetiva da experiência não existe $a$ priori da ação do sujeito, mas é uma organização subjetiva que se constitui no fluxo das ações. Nela se integram sentidos subjetivos constituídos na história de vida do sujeito, que se atualizam na ação, outros produzidos no curso da experiência, assim como elementos da subjetividade social e dos sistemas relacionais. 
Ao integrarem os diversos cenários sociais da vida do indivíduo, as configurações subjetivas se constituem e se organizam como momentos que expressam elementos da personalidade que se atualizam a cada nova ação do sujeito, sempre se constituindo como uma organização atual. A configuração subjetiva da experiência constitui a forma que o sistema subjetivo individual assume no decorrer de seu desenvolvimento, mediante o contexto. Nela aparece a relação dinâmica da personalidade e do contexto, representando a expressão da personalidade, momento em que ressaltamos que, na ação do sujeito, a personalidade não se expressa de forma integral, mas por diversos sentidos subjetivos que compõe as diferentes configurações subjetivas que a constituem (GONZÁLEZ REY, 2011c).

A inseparabilidade da organização subjetiva da pessoa e sua produção subjetiva nas diversas ações constitui uma das características essenciais da categoria de sujeito. Essa, dentro da Teoria da Subjetividade, esteve presente nas construções iniciais de González Rey (1995), ao destacar que a condição de sujeito constituía o seu próprio funcionamento psicológico, marcando a relação entre o social e o individual. Em 1989, González Rey e Mitjáns Martínez definiram sujeito como uma categoria particular como base para o estudo da personalidade. González Rey (2003a, 2004b, 2007b, 2011a), em diferentes trabalhos, aponta para características que especificam a categoria de sujeito, definindo sujeito como ativo, atual, emocional, reflexivo, consciente, que assume o compromisso tenso e contraditório de sua subjetividade individual e da subjetividade social do contexto da ação.

A singularidade é uma marca registrada e o caráter produtor e gerador das ações constitui a essência da atuação como sujeito no contexto. Diferenciado da pessoa, do indivíduo, ser sujeito implica posicionamentos críticos, tomar decisões no devir dos acontecimentos e assumir a defesa de suas ideias no contexto em que participa (GONZÁLEZ REY, 2007b). O que é considerado pelo caráter histórico e processual, que configura a condição de ser sujeito, a qual não constitui uma característica arraigada ao indivíduo que se expressará em todos os contextos de ação do mesmo. Ao contrário, a especificidade desta categoria, se associa a um sujeito psicológico que, na sua produção subjetiva, assume uma implicação própria em determinados contextos de ação, que pode não se expressar em outros momentos de sua vida. Sendo assim, uma pessoa pode assumir a condição de sujeito na aprendizagem, porém, na sua relação com a família pode não experienciar a assunção desta condição. Por isso, não podemos falar em um sujeito universal, mas em um sujeito único.

Toda esta singularidade na assunção do sujeito radica dos processos que o tornam possível, uma vez que está relacionado à unidade inseparável dos sentidos subjetivos e da subjetividade individual com a ação em contexto (GONZÁLEZ REY, 2011b). O sujeito 


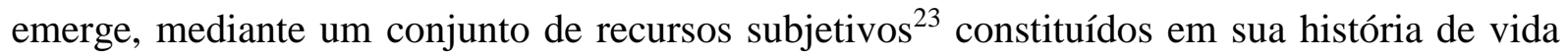
na inter-relação com o contexto social, sobre o qual se organiza as diferentes práticas. Por isso, não é possível "rotular" o indivíduo como um sujeito em determinado campo de ação, uma vez que nossas expressões são permeadas por diversas e múltiplas dinâmicas subjetivas.

Dentre as características destacadas por González Rey (2005b, 2009a), em relação à categoria de sujeito está a congruência, a qual se relaciona à intencionalidade do sujeito, referente às suas escolhas no momento da ação, em meio às experiências. Dinâmica que configura um caminho de produção de sentidos subjetivos que se expressam na congruência e continuidade do sujeito a partir da própria ação. Neste curso “[...] são produzidas rupturas, mas se as mesmas não conseguem romper a identidade, o sujeito as experimentará como parte daquilo que conseguiu obter, como outro momento de sua vida, mas sem perder a congruência com os momentos anteriores." (GONZÁLEZ REY, 2009a, p. 158).

O sujeito também se configura pela ruptura, a qual está relacionada às produções subjetivas que se organizam e se produzem na ação. Para González Rey (2011b, p. 214-215, tradução nossa) o sujeito pode ser definido como "[...] a pessoa capaz de abrir espaços próprios, específicos, de produção subjetiva dentro dos espaços sociais múltiplos e simultâneos em que se desenvolve sua prática social." Por isso, há uma relação de produtor do sujeito frente ao mundo social que experiencia e não de reprodutor das práticas que se configuram nos espaços sociais.

Diante disso, podemos nos perguntar: A condição de sujeito pode se expressar na criança? A resposta, a partir do arcabouço teórico da Teoria da Subjetividade, é afirmativa, uma vez que a condição de sujeito emerge mediante uma implicação subjetiva, um posicionamento ativo, uma reflexão do sujeito, tendo em vista recursos subjetivos constituídos ao longo da história de vida, o que pode ocorrer em qualquer momento da vida do ser humano (Informação verbal) ${ }^{24}$. Essa condição de sujeito não é inata, mas uma produção que geramos pela reflexão e atitude sobre o mundo a partir de ações concretas no mesmo.

O sujeito tem em si uma capacidade geradora subjetiva que se organiza diante de uma situação vivida, em que suas decisões e ações estão constituídas por sentidos subjetivos que organizam a experiência (GONZÁLEZ REY, 2011d). Sendo assim, para que a categoria de

\footnotetext{
${ }^{23}$ Definimos recursos subjetivos a partir dos trabalhos de González Rey (1995) e de Mitjáns Martínez (1997, 2008a), como elementos que mobilizam a direção da ação da pessoa em contexto, dentre os quais podemos citar: interesse, autovaloração, autoconfiança e outros. Estes são constituídos no devir da história de vida da pessoa, porém não determinam a priori a ação, uma vez que se organizam e se expressam mediante a relação sujeito-contexto-organização subjetiva.

${ }^{24}$ Informação fornecida oralmente em aula realizada na Faculdade de Educação (Universidade de Brasília), disciplina Atividades Programadas em Escola, Aprendizagem e Trabalho Pedagógico, pelo professor Fernando González Rey no dia 01/06/2011.
} 
sujeito se expresse é condição sine qua non a produção de sentidos subjetivos, porém, o inverso não necessariamente assume esta relação, pois pode ocorrer produção de sentido subjetivo e a condição de sujeito não se expressar (Informação verbal) ${ }^{25}$. Esta análise nos mostra a singularidade da experiência humana, em que não há variantes universais que delimitam de forma prévia nosso próprio agir sobre o mundo, mas nos insere no mundo com possibilidades que se configuram na nossa forma única de relacionar com o meio.

$\mathrm{Na}$ relação entre as categorias de sujeito e subjetividade, González Rey (2011b) destaca que a subjetividade não se configura apenas na dimensão da pessoa, mas na produção de sentidos subjetivos mediante as experiências da pessoa em diferentes espaços de atuação. Isso nos aponta para o valor heurístico da categoria subjetividade social. Como definimos anteriormente, o sujeito aparece como portador de uma subjetividade, a qual, pela dinâmica de constituição social, não pode estar delimitada a um único contexto de atuação do sujeito, mas se expressa a cada contexto de ação, tendo em vista sentidos subjetivos que podem ter sua gênese em outros espaços da subjetividade social.

Para marcar a relação recursiva entre o social e o individual na constituição do humano, González Rey (2003a) destaca na categoria de subjetividade social, a possibilidade de integrar elementos de sentidos subjetivos como unidades constituídas em diferentes cenários sociais de atuação da pessoa. Com esta categoria, temos oportunidade de compreender a dimensão subjetiva, em seus efeitos colaterais e consequências que os diferentes contextos sociais configuram subjetivamente na pessoa, uma vez que a subjetividade social se associa às produções sociais tendo em vista processos simbólicos e emocionais produzidos e configurados nas diferentes esferas da sociedade, dentre as quais estão a família e a escola (GONZÁLEZ REY, 2007a).

$\mathrm{Na}$ subjetividade social se organizam, em forma de sentidos subjetivos, crenças, representações, tradições, discursos, mitos, padrões de relações, vinculados à dinâmica de ação do sujeito em contexto. A sociedade, assim, não seria regida por leis internas que regulam a priori as ações das pessoas, mas como sistema complexo e em processo. A categoria subjetividade social constitui possibilidade que unifica diferentes instâncias experienciadas pelo sujeito na sociedade, na diversidade do tecido social de seus diferentes espaços, dentre os quais destacamos os recursos desenvolvidos pela própria sociedade, como os programas de televisão, a internet, o cinema, a imprensa, dentre outros (GONZÁLEZ REY,

\footnotetext{
25 Informação fornecida oralmente em aula realizada na Faculdade de Educação (Universidade de Brasília), disciplina Atividades Programadas em Escola, Aprendizagem e Trabalho Pedagógico, pela professora Albertina Mitjáns Martínez no dia 19/10/2011.
} 
2011b). Nesta direção, a cultura não é algo externo à pessoa, assim como não imprime uma relação imediata com o mundo, mas constitui uma produção subjetiva que expressa as emoções geradas na experiência com o mundo e que se integram recursivamente com múltiplos processos simbólicos (GONZÁLEZ REY, 2008b).

Neste viés, o cenário social da sala de aula constitui um local que se humaniza pelas complexas produções de sentidos subjetivos compartilhados pelo grupo na experiência de educar e aprender. A própria sala de aula engendra uma subjetividade social que é perpassada pela subjetividade de outros eventos sociais experienciados pelas pessoas que ali se relacionam. Desta forma, a subjetividade social não é algo que está fora das pessoas, ou mesmo que seja comum a todos que experienciam um mesmo contexto, mas se organiza como produção subjetiva em cada um de forma singular.

Há uma relação permanente e contraditória entre a subjetividade social e a subjetividade individual, em que uma constitui momentos da outra de forma recíproca sem se diluírem um no outro. A subjetividade individual se constitui em inter-relação com a subjetividade social, pois é produzida pelo sujeito concreto em espaços sociais historicamente constituídos, uma vez que, na gênese de toda subjetividade individual está a síntese subjetiva dos mais diversos espaços sociais experienciados pela pessoa (GONZÁLEZ REY, 2003a).

Na dinâmica simultânea do social e do individual na constituição da subjetividade, a ideia de recursividade, na dinâmica processual e de movimento do sistema de categorias, constitui característica da complexidade que se articula com a concepção de Morin (2011). Essa ideia rompe com determinismos ou mesmo causa e efeito nas ações humanas, uma vez que, no paradigma da complexidade, a recursividade se associa ao movimento em que um elemento do sistema é produto e produtor, ou seja, há uma constituição mútua entre os elementos do sistema, o que confere o caráter contraditório, complementar e recursivo da subjetividade humana (MITJÁNS MARTÍNEZ, 2005).

Frente ao exposto, podemos destacar algumas características da subjetividade em sua complexidade, as quais, segundo González Rey (2005c) se referem:

a) ao caráter recursivo entre configurações subjetivas e produção de sentidos subjetivos: em que um é, ao mesmo tempo, gerador e gerado pelo outro.

b) à constante produção de novos elementos advindos da ação do sujeito que se associa às produções de sentidos subjetivos: nas múltiplas ações em que o sujeito emerge, gera-se uma dinâmica de produções de sentidos subjetivos.

c) à permanente tensão entre organização do sistema e processualidade das ações do sujeito. 
d) à configuração de novas qualidades a partir das contradições e confrontações do sistema: como um processo em movimento, o sistema se organiza frente a contradições e confrontações que na tensão, geram novas qualidades de organização.

e) à coexistência do diferenciado, do singular como momento constituinte do sistema: a subjetividade, pelo caráter dinâmico de sua constituição, mesmo com elementos de relativa estabilidade, é sempre um momento único que se organiza na ação do sujeito em contexto.

Diante do diálogo com a Teoria da Subjetividade, tendo em vista as categorias que a constituem, apresentamos a seguir a concepção de aprendizagem assumida em nosso trabalho.

\subsubsection{Aprendizagem como processo subjetivo}

A Teoria da Subjetividade, que assumimos no presente trabalho, converge para múltiplas e férteis relações com a aprendizagem, mais especificamente com a aprendizagem da leitura e da escrita, foco do nosso estudo, campo muitas vezes explorado nas dicotomias cognição/afeto, intelecto/emoções, individual/social. Vale ressaltar que estamos tratando de um tipo específico de aprendizagem que ocorre na instituição escolar (TUNES; TACCA; MITJÁNS MARTÍNEZ, 2006), porém, é um campo que se estende pela vida cotidiana da criança, tendo em vista a sociedade grafocêntrica como a nossa.

Compreendemos que, para aprender, há a demanda de conhecer, processo que nem sempre está implicado pelo fato de estar ou não em contato com, por exemplo, a escrita, mas pela capacidade geradora da pessoa sobre o objeto. Desta forma, não podemos generalizar a aprendizagem da leitura e da escrita de forma indistinta, pela experiência social na vida. Isso seria pressupor que basta estar em contato com algo para que se possa aprender. Entendemos que, para que a aprendizagem se efetive, é necessário que haja uma relação com o objeto a ser conhecido, permeada pela emocionalidade daquele que aprende.

$\mathrm{Na}$ aprendizagem da leitura e da escrita, consideramos que a criança chega à escola com uma carga subjetiva constituída em diferentes contextos de atuação e que se expressa de formas distintas em seu momento atual de aprender. Expressão que pode ou não estar relacionada a processos de leitura e escrita, como também a relações e experiências da criança associadas à família e outras instâncias. Desta forma, muitos comportamentos ou expressões da criança no momento de aprender são configuradas por produções subjetivas que têm sua gênese em outros contextos de experiência da criança. No entanto, estas produções se expressam pela forma como a pessoa subjetiva a experiência atual. 
Partimos do pressuposto essencial da aprendizagem no âmbito da Teoria da Subjetividade, de que este é um processo singular, que acontece na inter-relação do social e do individual, assim como do histórico e do atual (GONZÁLEZ REY, 2009b). Importante ressaltar que conferimos relevância ao estudo da subjetividade da criança no processo de aprendizagem, uma vez que "A produção de condições para um aprendizado que considere a subjetividade da criança permite ter acesso às emoções produzidas em diferentes espaços da vida dos sujeitos e que são levados para a sala de aula." (ROSSATO; MITJÁNS MARTÍNEZ, 2011, p. 334). No processo de aprender são implicados tanto sentidos subjetivos que foram produzidos em diferentes contextos sociais de atuação da criança, quantos os sentidos subjetivos produzidos no contexto da ação de aprender (GONZÁLEZ REY, 2008a).

A compreensão da aprendizagem, como processo subjetivo, rompe com uma representação descritivo-reprodutiva, na qual há um predomínio da reprodução e da memorização sobre o processo de pensamento, sendo este reconhecido como um processo estritamente intelectual. Segundo González Rey (2008a), esta concepção de aprendizagem descritivo-reprodutiva, trabalha com uma visão de conhecimento baseada em uma única verdade, sendo esta absoluta, cabendo ao aluno o papel de apenas assimilar e repetir o que já está pronto. Para o autor, tal abordagem traz, dentre outros, três problemas: a) a representação de objetividade associada ao conhecimento, como verdade; b) a exclusão do erro como momento da produção do conhecimento; e c) a ideia do conhecimento como algo terminado.

Nesta perspectiva, o processo de aprendizagem é despersonalizado, uma vez que se reduz à reprodução, o que se dissocia do desenvolvimento humano. González Rey (2003b) ressalta que, em uma concepção de aprendizagem em que se prioriza os aspectos lógicos e intelectuais, a afetividade e as emoções geradas são desconsideradas e opta-se por uma ideia irreal de um sujeito universal, acarretando a padronização de gestos, posturas e até mesmo dos discursos e formas de aprender.

Essa visão não se alinhava a um dos objetivos da educação escolar, ressaltado por nós na parte introdutória do presente trabalho, o de promover o desenvolvimento da criança. Esse desenvolvimento pode se tornar realidade a partir de uma aprendizagem eficiente, ou seja, em que a condição de sujeito seja uma via para a produção de novos sentidos subjetivos sobre o aprender (MITJÁNS MARTÍNEZ et al., 2003). Podemos destacar três aspectos essenciais que permeiam e definem a aprendizagem escolar, dentro da Teoria da Subjetividade (MITJÁNS MARTÍNEZ et al., 2003; MITJÁNS MARTÍNEZ, 2009b): a) como uma função do sujeito psicológico; b) que na ação conta com a participação de recursos subjetivos; e c) que considera as características dos contextos sociorrelacionais. 
A partir da compreensão da subjetividade, é possível entender a aprendizagem para além de seu aspecto instrumental, com possibilidades de adentrar pelo como a pessoa utiliza suas operações na aprendizagem, voltadas à produção de novas ideias, operações e problemas (GONZÁLEZ REY, 2008a, 2009b). Como destaca Rossato e Mitjáns Martínez (2011), a aprendizagem em uma perspectiva da subjetividade humana é uma ação gerada pelo sujeito, tendo em vista as condições históricas e culturais da experiência. Neste viés, há uma preocupação com a forma como a criança gera e produz saber frente ao que experiencia, assim como com as possibilidades que o conhecimento tem de impactar a vida do aprendiz.

A condição de sujeito na aprendizagem emerge frente a uma provocação ou algo que lhe faça definir um caminho a seguir, o que envolve curiosidade e inquietação sobre o que aprende. Enfatiza-se o sujeito relacional que se constitui em um “[...] contexto social dinâmico e participativo, em que se geram dinâmicas múltiplas e simultâneas com grande capacidade de reorganização no próprio contexto em que a atividade acontece." (GONZÁLEZ REY, 2011a, p. 60). A aprendizagem, neste viés, não é um processo intrapsíquico ou mesmo algo que se internaliza, mas se organiza na inter-relação do social e do individual pelo caráter gerador das emoções nas ações de aprender.

Um sistema relacional é constituído pela pessoa em presença de outro. É no encontro, que ambos se apresentam com suas constituições subjetivas históricas com relativa estabilidade, em que se geram sentidos subjetivos. Em trocas que não dependem da subjetividade individual de um dos participantes da relação, mas da subjetividade individual de ambos, que também se relaciona à subjetividade social, do espaço onde as relações acontecem, da conjuntura e do contexto da experiência (GONZÁLEZ REY, 2004a). Quando há um sistema relacional em que o outro contribui para que a criança produza sentidos subjetivos, este constitui fonte favorecedora do desenvolvimento de recursos subjetivos (TACCA; GONZÁLEZ REY, 2008).

Na sala de aula, em específico, a relação da criança com o professor ou mesmo com os colegas, participa da experiência de aprender e toma formas singulares em seus processos de subjetivação da aprendizagem. Não há padrões de relações que vão definir a qualidade da aprendizagem, mas estas se articulam às produções subjetivas do aprendiz no âmbito desta relação. Essa se configura por elementos da história de vida da criança que se alinhavam ao que se é produzido na relação. É neste tecido social que os sistemas relacionais configuram a subjetividade social do espaço de aprender, não pela somatória das subjetividades individuais dos envolvidos, mas pela produção de sentidos subjetivos no espaço da relação (GONZÁLEZ REY, 2000b, 2011c). Vale destacar que a subjetividade social não se limita aos sistemas 
relacionais, estes fazem parte da constituição da subjetividade social, mas junto se encontram elementos como crenças, valores, normas, dentre outros na forma de sentidos subjetivos.

Nestes espaços sociais, a comunicação se organiza e o diálogo constitui a via que torna possível o desenvolvimento, uma vez que, pelo diálogo, que implique o outro e estimule suas emoções e reflexões, o sujeito pode emergir, em meio a tensões emocionais que permitem mobilizar diferentes recursos subjetivos frente às contradições que enfrenta (GONZÁLEZ REY, 1995). Assim como podem também existir sistemas relacionais que não impliquem diálogo, mas que tornam-se espaços de mobilização subjetiva capazes de favorecer a produção de sentidos subjetivos frente às experiências no processo relacional.

É nesta dinâmica do social e do individual que a aprendizagem se configura como processo subjetivo e que podemos recuperar o sujeito da aprendizagem, como aprendiz que gera, que produz emoções frente ao contexto de aprender. Desta forma, para González Rey (2014a) a produção intelectual do aprendiz pode estar vinculada à assimilação, a qual se pautaria pelo que está fora, resultando em um processo normativo-regulador, ou pode se constituir em ato de imaginação, em que o sujeito gera alternativas frente ao estabelecido e abre novas possibilidades de produção subjetiva. Essa produção intelectual associada às alternativas diante do que está posto, segundo o referido autor, se organiza como um modelo intelectual-subjetivo, em que as ideias são portadoras de sentidos subjetivos que expressam a configuração subjetiva do sujeito envolvido na ação.

Isso implica assumir o pensamento como uma produção subjetiva do sujeito que aprende, como processo que expressa a configuração subjetiva da experiência em seu caráter reflexivo. Por isso, a motivação não é algo externo ao sujeito, ou mesmo estritamente intrapsíquica, que irá definir a priori a ação da pessoa, mas é constitutiva da configuração subjetiva que se organiza no momento da ação, em que sentidos subjetivos se expressam e se produzem mediante esta ação, processos que estão para além da intenção racional da pessoa (GONZÁLEZ REY, 2011c, 2012a, 2014c).

É neste âmbito que a motivação pode ser compreendida como a articulação de sentidos subjetivos na ação do sujeito, que se constitui pela organização subjetiva dos diversos processos que participam da ação da pessoa. O motivo aparece como uma expressão da própria personalidade, momento que emerge em sua condição operacional, a partir da configuração subjetiva da ação, se fazendo presente, como por exemplo, no pensamento, o qual se constitui como processo motivador em si mesmo e se configura como momento atual da organização subjetiva do sujeito (GONZÁLEZ REY, 2012a, 2014c). 
O pensamento como motivação se relaciona com a reflexividade do sujeito a qual não se delimita a uma idade específica " [...] ainda que a capacidade de abstração aumenta com a idade, a capacidade de discernir de forma reflexiva aparece desde muito cedo, sempre em relação aos recursos psicológicos diferenciados da criança." (GONZÁLEZ REY, 2012a, p. 38). A reflexão e a produção de ideias se relacionam à implicação da criança com sua própria aprendizagem, em que a condição de sujeito emerge a partir do desenvolvimento de caminhos alternativos, em que novos recursos subjetivos surgem e possibilitam nova forma de relação com o mundo (GONZÁLEZ REY, 2011a). A expressão do sujeito na aprendizagem se presentifica nas suas decisões, reflexões e também em suas produções. González Rey (2008a) destaca que, ao aprender palavras, a criança precisa experienciar situações que lhe possibilitem inventá-las, imaginá-las em diferentes contextos.

González Rey (2012a) reconhece a singularidade da aprendizagem e destaca o sujeito que aprende como uma categoria que caracteriza um tipo de aprendizagem permeada pela produção de sentidos subjetivos, vinculada ao caráter gerador e produtor do sujeito, em seu papel ativo, reflexivo e consciente frente ao seu próprio processo de aprender. É esta capacidade geradora que o autor define como indicador de um tipo de aprendizagem mais complexa, a maneira singular e diferenciada com que o sujeito faz uso do que aprende diante de diferentes situações e contextos.

A forma como cada aluno elabora a grande quantidade de informação que veicula no cotidiano escolar, é singular e está intimamente relacionada aos sentidos subjetivos que participam do momento de aprender. No entanto, nem toda informação fará parte deste sistema, uma vez que não possibilita processos emocionais e simbólicos que favoreçam o envolvimento ativo da criança. As informações que se desdobram em recursos subjetivos na pessoa são denominadas por González Rey e Mitjáns Martínez (1989) de informação personalizada, a qual está associada à configuração subjetiva da experiência e à ação do sujeito em seu caráter ativo, confrontador e subversivo, sobre a qual trataremos no próximo eixo, referente à concepção de criatividade.

Neste processo, destaca-se um tipo de aprendizagem em que a produção de sentidos subjetivos possibilita o desenvolvimento pessoal da criança, em meio a um caminho próprio, diferenciado e singular, de aprender do sujeito. Percurso em que a aprendizagem se configura em sua forma compreensiva eficiente, o que define o sujeito não “[...] pelas capacidades e processos cognitivos envolvidos no processo de aprender, mas pelas configurações subjetivas que explicam o desenvolvimento dos recursos do aluno nesse processo." (GONZÁLEZ REY, 2012a, p. 36). Neste viés, os conteúdos curriculares assumem valor para o desenvolvimento 
do aprendiz, quando se configuram por processos de produções de sentidos subjetivos, em que o aprendiz é capaz de atuar com o mesmo de forma autônoma (TACCA, 2005).

Vale destacar que a geração de sentidos subjetivos na aprendizagem, não está associada a uma única forma de aprender. Mitjáns Martínez e González Rey (2012) frisam que a produção de sentidos subjetivos está relacionada à implicação do aprendiz com o processo de aprender. Frente ao exposto, sinalizamos que, o que possibilita singularizar um tipo ou outro de aprendizagem vincula-se aos seguintes elementos: a) à configuração subjetiva da ação de aprender; b) ao caráter dos sentidos subjetivos que, constituídos historicamente, se atualizam e por outros que se produzem na ação; c) à condição de sujeito na aprendizagem; d) à qualidade dos sistemas relacionais; e e) a elementos da subjetividade social.

Diante de tais elementos, compreendemos as relações entre a subjetividade e o processo de aprender, o que permite elaborações sobre a aprendizagem criativa, com a qual buscaremos dialogar no tópico referente à criatividade como expressão da subjetividade. Para o momento, destacamos que, em aprendizagens de tipo mais complexas como a aprendizagem criativa e a aprendizagem singularizada na categoria sujeito que aprende, há produções de sentidos subjetivos que são diferenciadas e nutrem o processo de aprender.

Ao considerarmos os aspectos subjetivos no campo da educação, a aprendizagem passa a ser compreendida como processo de desenvolvimento. Desta forma, a aprendizagem e o desenvolvimento constituem "[...] dois processos que devem manter uma verdadeira relação recursiva; toda aprendizagem eficiente se torna um processo de desenvolvimento da pessoa." (GONZÁLEZ REY, 2011a, p. 60). Esta relação recursiva rompe com a ideia de causa e efeito diante das situações experienciadas pelo sujeito, assumindo uma nova forma em que elementos diversos se nutrem um do outro sem perder a sua especificidade constitutiva. Sendo assim, consideramos fundamental apresentar no próximo tópico, a concepção que rege nosso trabalho de desenvolvimento da subjetividade.

\subsubsection{Desenvolvimento da subjetividade}

Abordar o desenvolvimento da subjetividade, na perspectiva teórica assumida no presente trabalho, implica a possibilidade de compreender o funcionamento humano associado a um movimento constante que não está para padrões universais e deterministas. Mas por uma relação que envolve singularidade, em sua organização e processualidade, associada a mudanças favorecedoras de novos níveis de organização subjetiva, possíveis pelo caráter gerador do sistema que constitui a subjetividade. No âmbito das produções de González Rey (1991, 1995, 1999b, 2004a, 2007b, 2008a, 2011a), nas quais o autor explicita 
os elementos sobre o desenvolvimento da subjetividade, encontramos o movimento da teoria em uma dimensão que visa à compreensão dos processos psíquicos em sua complexidade constitutiva. Identificamos que González Rey (1995) utiliza o termo 'forças motrizes’ para os elementos que configuram o desenvolvimento da subjetividade, sendo eles: as unidades subjetivas do desenvolvimento, os sistemas de atividade-comunicação e as contradições.

A categoria de unidade subjetiva do desenvolvimento assume valor heurístico para pesquisas, em especial, para a educação, por romper com determinismos de linearidade em relação aos impactos das atividades sobre a pessoa. Categoria conceituada como "[...] configurações subjetivas com a capacidade de integrar e estimular um conjunto de aquisições do desenvolvimento em determinados momentos da vida da pessoa.” (GONZÁLEZ REY, 2004a, p. 18). Desta forma, as unidades subjetivas do desenvolvimento constituem uma síntese subjetiva das situações experienciadas pelo sujeito em diferentes momentos da vida, que tem caráter de desenvolvimento e se expressa na forma ativa de se implicar na atividade.

A organização das configurações subjetivas em unidades integradoras dos múltiplos sentidos subjetivos, associados a uma atividade específica, aponta para como a leitura pode se constituir em uma atividade dominante, capaz de se consolidar como espaço favorecedor para que a criança produza sentidos subjetivos. Esses podem estar associados às produções intelectuais, aos valores morais, dentre outros. No exemplo da leitura como unidade subjetiva do desenvolvimento, González Rey (1991, 1995, 1999b, 2001, 2004a, 2008a) ressalta que esta atividade pode adquirir sentido para a criança pelo que representa culturalmente, a partir das experiências do cotidiano dela. O desejo e a própria necessidade de ler acaba se organizando a partir das próprias demandas do meio social em que a criança vive, tendo em vista a atuação desse sujeito. Este exemplo da leitura como unidade subjetiva do desenvolvimento nos mostra a importância que este aprendizado tem para a criança e vai além dos aspectos cognitivos que a engendram, consolidando uma teia de sentidos subjetivos e configurações subjetivas capazes de mobilizar e criar novos recursos subjetivos.

Para além de uma habilidade cognitiva e intelectual, a aprendizagem da leitura pode constituir um importante momento de desenvolvimento da subjetividade, uma vez que, para algumas crianças, pode favorecer o desenvolvimento, tanto da condição de sujeito, como de recursos subjetivos, dentre os quais podemos citar: autoestima, autoconfiança e a própria socialização. Em um mesmo momento da vida, podem coexistir diferentes unidades subjetivas do desenvolvimento que configuram as ações do sujeito. Para a criança, os pais, a aprendizagem da leitura, os irmãos, o jogo, dentre outros tipos de atividades e relações, 
assume um valor significativo para a criança, que é capaz de mobilizar e formar parte de seus próprios recursos subjetivos (GONZÁLEZ REY, 1999b, 2004a).

A essência da categoria unidade subjetiva do desenvolvimento alinha-se à assunção da condição de sujeito, que expressa a processualidade de produção de sentidos subjetivos, em meio a posicionamentos, reflexões, frente a uma atividade, em determinado momento da vida e que se estende para outros espaços sociais e experiências. $\mathrm{Na}$ aprendizagem, por exemplo, o sujeito cria caminhos alternativos, que problematizam o dado e lhe permitem seguir em novas direções de pensamentos e ações. Processo em que a aprendizagem e o desenvolvimento avançam de forma conjunta (GONZÁLEZ REY, 2011a). Desta forma, o sujeito se envolve com alto nível de individualização e assume responsabilidade por seu desenvolvimento, em que a capacidade geradora do sujeito torna-se inseparável da produção de novos sentidos subjetivos e de novas práticas (GONZÁLEZ REY, 1995, 2007b).

A constituição da unidade subjetiva do desenvolvimento ocorre de forma complexa, a partir da ação do sujeito, pela expressão de sentidos subjetivos constituídos ao longo de sua história de vida e por sentidos subjetivos produzidos no devir da ação. Na dinâmica de sentidos subjetivos na ação do sujeito temos a possibilidade de novas produções subjetivas e da constituição de novas configurações subjetivas que se organizam no curso da ação. Essas podem se converter em unidades subjetivas de desenvolvimento e também, consolidarem-se em configurações subjetivas da personalidade, o que se articula à qualidade dos sentidos subjetivos mobilizados na ação (MITJÁNS MARTÍNEZ; GONZÁLEZ REY, 2012).

Na processualidade e organização das configurações subjetivas, resultantes de um sistema de relações que permite o engajamento da pessoa como sujeito e que reconhece possibilidades múltiplas de expressão nesse processo, tendo em vista o contexto da ação, o desenvolvimento da subjetividade pode ocorrer, segundo González Rey (2007b, p. 138) pela:

[...] possibilidade de gerar novos repertórios de expressão de uma configuração subjetiva, que podem representar momentos de novos sentidos subjetivos que se integram a essa configuração, como nos momentos de reorganização e ruptura de certos sistemas de configurações subjetivas em face da emergência de outros novos.

Na dinâmica da configuração subjetiva, tendo em vista sentidos subjetivos históricos e atuais, existem núcleos mais estáveis organizados por sentidos subjetivos dominantes em um contexto de ação, que também são procedentes de diferentes zonas de experiências. O desenvolvimento ocorre por reconfigurações nos núcleos de configurações subjetivas, sobre os mais diversos efeitos das variadas experiências do sujeito. Neste processo subjetivo, novas configurações se organizam, mediante à produção de novos sentidos subjetivos e se fazem presentes nas ações do sujeito em diferentes domínios (GONZÁLEZ REY, 2003a, 2005a). 
O desenvolvimento da subjetividade pressupõe mudanças qualitativas nestes núcleos, assim como se produzem novos núcleos, processo capaz de reconfigurar a configuração subjetiva (GONZÁLEZ REY, 2007b). Rossato (2009), a partir da Teoria da Subjetividade, compreende o desenvolvimento da subjetividade como mudanças que se tornam mais estáveis, favorecedoras de novas mudanças e novos níveis qualitativos de organização subjetiva. Assumimos a definição de mudanças a partir da concepção de González Rey (2007b), como possibilidade de gerar alternativas de subjetivação frente às experiências, por meio da produção de sentidos subjetivos alternativos que o sujeito gera, capazes de transformar, em alguma medida, a configuração subjetiva que se organiza na ação.

Neste viés, enfatizamos a possibilidade que a aprendizagem tem em contribuir para que a criança produza sentidos subjetivos capazes de promover o desenvolvimento da subjetividade. Processo configurado por mudanças que não são pontuais, mas estão relacionadas a certa temporalidade, que é singular para cada pessoa. As mudanças necessitam adquirir certa estabilidade no sistema subjetivo para se configurarem como processo de desenvolvimento (GONZÁLEZ REY, 2004a; ROSSATO, 2009).

Por isso, nem toda mudança implicará no desenvolvimento da subjetividade. O que nos permite dialogar com Santos (2010), que, dentro da perspectiva teórica assumida no presente trabalho, apresenta diferentes tipos de mudanças. As mudanças significativas, seriam aquelas que assumem uma movimentação expressiva e com certa estabilidade, em que há produções subjetivas dinamizadoras de reorganização da configuração subjetiva implicada na mudança, o que se aproxima da concepção de Rossato (2009), destacada anteriormente, sobre as mudanças capazes de gerar o desenvolvimento da subjetividade.

No entanto, como a subjetividade é movimento, outras mudanças podem ocorrer e não necessariamente se configurarem como desenvolvimento da subjetividade. Por isso, Santos (2010) destaca as mudanças não significativas que referem-se à coerência com que algumas ações se organizam em relação aos processos subjetivos existentes na configuração subjetiva implicada no momento, o que favorece processos de estabilização de sentidos subjetivos dominantes naquela configuração, capazes de gerar um novo repertório emocional, mas não são capazes de produzir uma organização subjetiva alternativa. Assim como as mudanças pouco significativas em que há impactos que promovem uma movimentação subjetiva mas que são pouco expressivos e não atingem estabilidade no âmbito da configuração subjetiva.

Frente ao exposto, rompe-se com a ideia de desenvolvimento meramente intrapsíquico, para compreendê-lo como processo que envolve a ação do sujeito, elementos da subjetividade individual, elementos da subjetividade social e os sistemas relacionais que 
participam do contexto da ação. Nesta dinâmica, nenhuma ação externa ao sujeito o impactará linearmente, mas se articulará à sua capacidade de gerar alternativas no devir da própria experiência. Por isso, o outro participa do desenvolvimento, quando o sistema relacional permite que se converta em favorecedor para que o sujeito produza sentidos subjetivos, em um processo que dimensões de expressão do outro, no nível da história de relacionamento da criança com o outro, possa se integrar à configuração subjetiva (GONZÁLEZ REY, 2004a).

Neste viés, Tacca (2006) destaca que os processos de comunicação, entendidos como utilização plena do diálogo, se processam na possibilidade de realização de trocas entre os participantes, na dinâmica de sentidos subjetivos que se expressam e se produzem, podendo a mesma favorecer o desenvolvimento da subjetividade no âmbito do próprio sistema da relação. Segundo González Rey (2004a), é nestes espaços de sentido, que os sistemas de atividade e comunicação podem se constituir como possibilidades de novas aquisições do desenvolvimento e favorecer mudanças qualitativas na subjetividade, ao configurarem nova organização subjetiva e pela possibilidade de produção de sentidos subjetivos do sujeito.

Frente ao exposto, não podemos universalizar o desenvolvimento do sujeito ou mesmo estabelecer etapas fixas, mas reportar ao desenvolvimento de cada indivíduo como sendo único e resultante da dinâmica das configurações subjetivas e os diferentes contextos sociais em que a ação se expressa. Os posicionamentos que a pessoa tem, no contexto da ação, podem possibilitar uma experiência de desenvolvimento, na qual a condição de sujeito está diretamente relacionada ao desenvolvimento da pessoa (GONZÁLEZ REY, 2011a, 2012b).

O desenvolvimento não tem um marco, uma idade pré-determinada, pois configura-se na relação, tensa e contraditória, que o sujeito estabelece com o meio social-cultural, nas relações com o outro. Vale destacar que o vínculo com o externo, à medida que o homem se desenvolve, este diferencia-se e torna-se cada vez mais indireto e complexo. Processo acompanhado de contradições pelas problematizações que o sujeito realiza sobre suas representações do mundo, carregadas de emocionalidade e de reflexões.

As contradições podem ser definidas pelas situações sociais qualitativamente diferentes que colocam o sujeito frente à necessidade de uma resposta, em que se organizam novos recursos subjetivos que favorecem mudanças mais estáveis na configuração subjetiva. O que potencializa as contradições como processo capaz de promover mudanças na configuração subjetiva que se organiza na ação, assim como desencadear a assunção da condição de sujeito na ação (GONZÁLEZ REY, 1995). Quando as contradições se tornam foco de reflexão pelo sujeito e expressão de um conjunto de recursos subjetivos podem reverberar para a busca de alternativas do sujeito frente à ação (GONZÁLEZ REY, 1999b). 
Rossato (2009) e Amaral (2011), a partir dos estudos da Teoria da Subjetividade de González Rey, destacam princípios que constituem a base sobre a qual o autor funda o próprio conceito de desenvolvimento da subjetividade. Frente às construções das referidas autoras e das produções teóricas atuais de González Rey (2011a, 2012a) podemos destacar, no mínimo, quatro princípios norteadores do desenvolvimento da subjetividade: a) o caráter configuracional do desenvolvimento, na sua dimensão irregular, descontínua, dinâmica e, em permanente mobilidade e processualidade; b) o sujeito como cenário do desenvolvimento da subjetividade, na relação tensa e contraditória entre a subjetividade individual e a subjetividade social; c) a tensão entre os sentidos subjetivos e as configurações subjetivas; d) as reconfigurações subjetivas e mudanças nos núcleos, frente a novos sentidos subjetivos, constituindo o caráter recursivo e contraditório do desenvolvimento da subjetividade.

Pensar no caráter configuracional do desenvolvimento é atentar para que toda mudança, movimento ou impacto na subjetividade da pessoa, são constituídos em meio a processos de ordem e desordem que são postos em constante articulação e "[...] estão sempre presentes em qualquer processo complexo e subjetivo de modo que uma torna-se necessária para a continuidade da outra, o que confere um caráter mutável e mutante aos mesmos." (NEUBERN, 2004, p. 142). Para González Rey (2011a), o desenvolvimento se associa aos posicionamentos da pessoa como sujeito no contexto da ação, o qual é condição para a produção de sentidos subjetivos que podem reconfigurar a organização atual do sistema. $\mathrm{O}$ desenvolvimento da subjetividade se configura ao favorecer uma trama concreta de novas e diferenciadas ações na vida do sujeito.

Estudos direcionados à compreensão do desenvolvimento da subjetividade têm demonstrado a relevância de tal tema para a educação e estão expressos nos trabalhos de Rossato (2009), a partir do desenvolvimento da subjetividade de crianças no processo de superação de dificuldades de aprendizagem escolar, de Santos (2010), mediante investigação do impacto na subjetividade do professor, do trabalho pedagógico com alunos com desenvolvimento atípico, e também no trabalho de Amaral (2011), com o olhar sobre o desenvolvimento dos processos subjetivos, de forma retrospectiva, analisando sua relação com os processos subjetivos atuais. Desta forma, nos aventuramos a compreender o desenvolvimento da subjetividade e suas inter-relações com a criatividade na aprendizagem da leitura e da escrita, o que nos mobiliza a dialogar com o campo científico da aprendizagem criativa, o qual apresentamos a seguir, como segunda parte das bases teóricas. 


\subsection{BASE TEÓRICA DA PESQUISA II: CRIATIVIDADE NA APRENDIZAGEM}

A expressão da criatividade na aprendizagem constitui nossa direção de trabalho, de investigação e de inquietações, que nos remete a assumir um arcabouço teórico capaz de compreender a criatividade como processo complexo, dinâmico, marcado por mudanças, movimentos e desenvolvimento do sujeito que aprende. Do amplo campo teórico sobre o tema da criatividade, optamos por um referencial que compreende a criatividade como processo complexo da subjetividade humana mediante uma nova e diferenciada forma de entender os processos de aprender. Para isso, elegemos as construções de Mitjáns Martínez (1997, 2000, 2001, 2002, 2004, 2008a, 2008b, 2008c, 2008d, 2009a, 2012a, 2012b) que tem suas bases na perspectiva histórico-cultural e dentro dela a Teoria da Subjetividade de González Rey.

\subsubsection{Criatividade como processo da subjetividade humana}

Mitjáns Martínez (1997, 2000, 2004, 2008a, 2008b, 2008d, 2012a) tem se dedicado a quase duas décadas a estudar o tema 'criatividade'. Reconhecemos o movimento, a dinamicidade e a abertura de suas ideias, consolidadas em uma trajetória envolvida pela descoberta e disponibilidade a possíveis mudanças a partir de suas reflexões em meio a pesquisas e estudos. Em seu arcabouço teórico, a criatividade é compreendida como processo complexo da subjetividade humana na sua simultânea condição de subjetividade individual e subjetividade social.

O interesse da autora é romper com determinismos existentes em estudos no campo da criatividade. Ela enfatiza que a criatividade não constitui um dom, um processo intrapsíquico, mas emerge em ações e contextos específicos, resultante de configurações de processos subjetivos na relação com elementos da subjetividade social. Neste viés, a criatividade é um processo especificamente humano constituído em meio às condições culturais, sociais e históricas (MITJÁNS MARTÍNEZ, 2008b, 2009a, 2012a).

Em sua pesquisa, Amaral (2011) apresenta a constituição histórica de recursos subjetivos caracterizadores da criatividade, em alunos do ensino superior e ressalta que não basta apenas o desenvolvimento dos recursos subjetivos, mas é condição essencial a forma como esses se organizam na ação do sujeito. No enfoque histórico-cultural, que rege nosso trabalho, compreendemos que, no desenvolvimento humano, as produções subjetivas, constituídas na história de vida do indivíduo, se organizam e se constituem na relação com o social, mediante as experiências, nos mais diversos contextos dos quais participa. 
A propósito, a subjetividade individual, que tem na personalidade e no sujeito a sua constituição, representa o caráter social da criatividade, uma vez que os processos subjetivos se organizam na relação sujeito-contexto. Mediante essa organização subjetiva e, em seu caráter interativo, a categoria de sujeito rompe com a separação do individual e do social, por ser ele que se relaciona com os outros em contextos sociais específicos e que nestes contextos produz e experiencia emoções ao assumir posicionamentos próprios (MITJÁNS MARTíNEZ, 2004, 2007).

Para tanto, Mitjáns Martínez (2008b, p. 120) aponta que a criatividade se produz a partir de “[...] contextos e situações concretos, como expressão da articulação sujeitocontexto, ou seja, na confluência dos recursos subjetivos do sujeito e das características e demandas da situação em que está inserido". Hoyer (2010), nesta perspectiva, destaca que, em situações de atividades lúdicas, a criatividade se expressa na inter-relação entre os elementos que participam da subjetividade individual e os elementos contextuais, com destaque ao papel assumido pela família e da escola no desenvolvimento de recursos pessoais que favorecem a criatividade.

Consideramos o social tanto como um espaço em que se constitui a configuração dos recursos subjetivos que tornam a criatividade possível, assim como espaço social de desenvolvimento da ação do sujeito, em que se organiza e participa dessa ação das formas mais variadas. De acordo com Mitjáns Martínez (2004), o social pode se expressar, no mínimo, a partir de duas dimensões:

a) a dimensão macrossocial - abrange a forma com que normas, códigos morais, clima que perpassam os diferentes cenários experienciados pelo sujeito, podem se expressar pela produção de sentidos subjetivos;

b) a dimensão relacional - envolve o outro na geração do espaço social em que a criatividade emerge.

A dimensão macrossocial é caracterizada pela subjetividade social, que constitui o espaço subjetivo em que a pessoa atua, o qual é organizado pela produção de sentidos subjetivos do sujeito frente a este espaço. É importante destacar, que o espaço social, em que as ações se concretizam, não exerce uma relação linear sobre a pessoa. A realidade é subjetivada, mediante a forma singular com que o sujeito a percebe e a produz, tendo em vista o constituído subjetivamente e o produzido na ação (MITJÁNS MARTíNEZ, 2007, 2008d; GONZÁLEZ REY, 2003b).

Neste cenário social concreto, em que a ação se realiza, é que se engendram os sistemas relacionais dos quais a pessoa forma parte. No que tange à perspectiva histórico- 
cultural da subjetividade, os outros estão presentes das formas mais diversas, podendo ser “[...] o outro como interlocutor direto, quanto os outros (reais ou imaginários) constituintes do contexto em que o indivíduo está inserido e de sua história” (MITJÁNS MARTÍNEZ, 2004, p. 89). De acordo com nossa definição de sistemas relacionais, exposta na parte teórica anterior do presente trabalho, destacamos que a produção de sentidos subjetivos na relação com o outro é condição fundamental tanto para o desenvolvimento da subjetividade como para a expressão da criatividade no contexto da ação. Essa produção estará associada à própria dinâmica de expressão das subjetividades individuais dos participantes da relação, de elementos da subjetividade social e da qualidade da relação.

Neste viés, o outro pode tanto favorecer com que a criatividade emerja como constituir barreira para promovê-la, uma vez que os sistemas de atividade-comunicação podem ser geradores do desenvolvimento de recursos subjetivos favoráveis ou não à expressão da criatividade. Como recursos subjetivos que têm se constituído como desfavoráveis à expressão da criatividade, podemos citar: dependência e insegurança (MITJÁNS MARTÍNEZ, 2004). No entanto, o outro na relação com o sujeito pode contribuir para a produção de sentidos subjetivos e dinamizar a expressão da criatividade, o que passa pela forma como o sujeito subjetiva a experiência. Assim, quando um dos participantes da relação emerge em sua condição de sujeito, podemos dizer que há um impacto subjetivo qualitativo, uma vez que este é capaz de abrir caminhos próprios de subjetivação em diferentes âmbitos de sua vida (GONZÁLEZ REY, 1995; MITJÁNS MARTÍNEZ, 2004).

Amaral (2011) enfatiza que os possíveis impactos subjetivos produzidos por sentidos subjetivos que se efetivam numa relação, não necessariamente ocorrem da mesma maneira, ou seja, podem ocorrer de forma indistinta para as pessoas envolvidas em uma mesma relação. Por isso, não podemos generalizar os tipos de produção subjetiva dos aprendizes, uma vez que está perpassada por processos que só podem ser explicados a partir do próprio sujeito.

Mitjáns Martínez (1997, 2004, 2012a) rompe com o encontro de traços universais da personalidade, ao destacar o caráter único e individualizado com que as configurações subjetivas da personalidade se organizam e conformam a ação criativa, uma vez que, na ação criativa, sentidos subjetivos de distintas configurações subjetivas se organizam na ação. Nem todos os recursos subjetivos que o sujeito dispõe se expressam na ação de criar. Sendo que, aqueles que se expressam na ação formam parte do que a referida autora denomina de configuração criativa.

As configurações criativas figuram a organização subjetiva da criatividade no contexto da ação, como expressão de sentidos subjetivos advindos de diferentes configurações 
subjetivas da personalidade. Por isso, as configurações criativas não constituem a totalidade das configurações subjetivas da personalidade, mas a assunção subjetiva de determinadas configurações que se organizam no curso da ação criativa. A configuração criativa demonstra o valor heurístico da subjetividade para a compreensão da criatividade tendo em vista seu caráter dinâmico e complexo de estruturação e funcionamento no sujeito (MITJÁNS MARTÍNEZ, 2004, 2012a). Para o nosso trabalho, optamos pela utilização da categoria de configuração subjetiva da ação, por compreendermos que a mesma transcende a categoria de configuração criativa, por expressar além dos sentidos subjetivos que advém da personalidade, também sentidos subjetivos produzidos na ação.

Mesmo considerando a singularidade da expressão de recursos subjetivos que configuram a criatividade, foram identificados a utilização de recursos comuns em aprendizes criativos do ensino superior, dentre os quais podemos citar: autodeterminação; autovaloração $^{26}$ adequada; segurança; flexibilidade; audácia, dentre outros (MITJÁNS MARTÍNEZ, 2002, 2004, 2008a). A expressão de tais recursos é singular e a própria motivação configura-se de forma diferenciada em cada sujeito, mediante sentidos subjetivos que a engendra (MITJÁNS MARTÍNEZ, 2012a).

Frente ao exposto, compreendemos que a expressão da criatividade articula-se com elementos da subjetividade individual, assim como por elementos da subjetividade social e dos sistemas relacionais dos quais a pessoa participa em contextos sociais concretos (MITJÁNS MARTÍNEZ, 2012a). Neste viés, encontra-se a gênese do conceito de criatividade como processo complexo da subjetividade humana na sua simultânea condição de subjetividade individual e social, a qual se expressa na produção de "algo" que é considerado como "novo" e "valioso" em um determinado campo da ação humana (MITJÁNS MARTÍNEZ, 2001, 2008a).

Os critérios de novidade e valor são relativos e precisam ser compreendidos na singularidade do sujeito que produz. Desta forma, a criatividade pode se expressar em diferentes formas e em contextos muito diversos, configurando-se em níveis e graus também singulares, configurando o caráter heterogêneo da criatividade (MIJTÁNS MARTÍNEZ, 2002, 2007). Partindo desse pressuposto, o "novo" não se constitui em abstrato, mas na ação do sujeito. Considerado sempre em relação à conjuntura em que emerge, o "novo" pode se realizar, dentre outras possibilidades, pelas ideias, pelas soluções estratégias de problemas, por objetos, bem como pelo comportamento do sujeito. Sendo assim, a possibilidade de

\footnotetext{
${ }^{26}$ Compreendemos a autovaloração a partir de Mitjáns Martínez (1997), como elemento que expressa a visão que o sujeito tem de si mesmo, integrada às produções subjetivas associadas à personalidade e ao produzido no devir da ação.
} 
solucionar e também identificar problema em um campo em que o sujeito se encontra envolvido, pode constituir expressão da criatividade (MITJÁNS MARTÍNEZ, 1997).

O "valor" do produto criativo pode estar vinculado a uma dimensão social, em que há um reconhecimento por outros, como por exemplo, do professor às produções do aluno, bem como pode estar associado apenas ao desenvolvimento do sujeito, em que o envolvimento na ação de criar favorece a geração de bem estar com possíveis impactos para o desenvolvimento pessoal. Mozzer (2008), como conclusão de seu trabalho, dentro da perspectiva teórica também assumida por nós mostra que, na atividade de contar histórias, o critério de valor está diretamente relacionado às necessidades da criança, tendo em vista seu próprio desenvolvimento e não se relaciona ao significado social do produto criativo.

Em suas construções atuais, Mitjáns Martínez (2009a, 2012a, 2012b) enfatiza que a criatividade pode se expressar não apenas como produto, mas pelo próprio processo de produção de geração da novidade que transcende o dado. Este princípio rompe com a ideia de que a criatividade está apenas no produto criativo e abre possibilidade de compreender o funcionamento subjetivo como processo que pode se configurar como criativo. A criatividade assume uma dimensão em que, para emergir, deve estar vinculada ao desenvolvimento do sujeito mesmo que permeada por estados emocionais que podem ser positivos e negativos.

Com o olhar para o desenvolvimento humano, dialogamos com Vigotski (2009), ao destacar a atividade criativa da criança como mais pobre em relação à atividade criativa do adulto devido ao acúmulo de experiências que o mesmo tem em relação à criança. Pressupomos que esta distinção entre a criatividade infantil e a criatividade adulta poderia, de certa forma, limitar a expressão da criatividade na infância, no entanto, a partir das análises pertinentes da obra do autor, realizadas por Mitjáns Martínez (2009a, 2010), é no momento que o autor relaciona a criatividade como processo de produção de novidade, seja algo que se concretiza materialmente ou mesmo como uma atividade da organização do pensamento e dos sentimentos, que se efetiva a possibilidade de compreender a criatividade na infância.

Nesta perspectiva, a criatividade se caracteriza como "[...] processo de configuração e reconfiguração da subjetividade que se expressa nas formas singulares e autônomas da ação do sujeito nos contextos sociorrelacionais nos quais está inserido.” (MITJÁNS MARTÍNEZ, 2009a, p. 35). Essa definição abre possibilidades de múltiplas relações entre criatividade e desenvolvimento da subjetividade pelo processo de constituição e reconstituição de configurações subjetivas que formam parte da ação do sujeito (MITJÁNS MARTíNEZ, 2009a). Nessa dimensão funcional, a criatividade pode se expressar como:

a) reestruturações e novas constituições de configurações subjetivas; 
b) nas formas de funcionamento do sujeito psicológico caracterizadas pela assunção de alternativas autônomas perante situações significativas e pelas "rupturas" singulares com o instituído no seu contexto de ação.

É pela intrincada relação sujeito-contexto-organização subjetiva, que se expressam e se produzem novos sentidos subjetivos, ganhando especial valor sentidos subjetivos e significados da subjetividade social e dos sistemas relacionais em que a ação se realiza. Neste contexto, confrontar-se com o instituído, com elementos da subjetividade social, configura autonomia e busca do sujeito na consolidação de caminhos próprios, podendo constituir este um movimento criativo (MITJÁNS MARTÍNEZ, 2012a). Frente ao exposto como arcabouço teórico da criatividade, buscamos dialogar, no próximo tópico, sobre as relações entre criatividade e aprendizagem.

\subsubsection{Aprendizagem criativa no contexto escolar e suas inter-relações com outros tipos de aprendizagem}

A criatividade emerge mediante a ação do sujeito em contexto e sua organização subjetiva, podendo ser estudada em uma área ou campo específico como a aprendizagem escolar. Neste viés, a criatividade pode se expressar em diferentes níveis, sobre os quais estamos tratando na aprendizagem de processos em níveis considerados mais primários, expressos nas múltiplas formas que o aprendiz lança mão para aprender e no "como" essa aprendizagem se concretiza e reverbera para outros campos da vida (MITJÁNS MARTÍNEZ, 1997).

A aprendizagem criativa é uma categoria em desenvolvimento que abre novas zonas de sentido para pensar os processos de aprendizagem complexos. Vale destacar que estudos nesta direção, dentro de uma perspectiva histórico-cultural, têm sido delineados especialmente por Mitjáns Martínez (2000, 2006, 2008a, 2009a, 2012a, 2012b), que tem tido maior ênfase no ensino médio e ensino superior, e por Craft (2005, 2008, 2010), na educação básica. Para nosso trabalho, optamos pelas elaborações da primeira autora citada, por trazer uma concepção de aprendizagem criativa que se alinhava à complexidade do nosso objetivo geral. No entanto, ao longo do presente trabalho, apresentamos as contribuições da segunda autora, que, no âmbito da perspectiva histórico-cultural, apresenta elaborações que se alinhavam à problemática da presente investigação.

Em busca de uma concepção de aprendizagem criativa capaz de envolver a sua complexidade constitutiva, Mitjáns Martínez (2008a, 2012a, 2012b) dialoga com a concepção 
de aprendizagem significativa por descoberta de Ausubel $^{27}$ e também com a concepção de aprendizagem significativa elaborada por $\operatorname{Rogers}^{28}$. A preocupação da autora, bem como a nossa, constitui-se na necessidade de caracterizar a aprendizagem criativa, assim como compreender os processos que a engendram e a tornam uma aprendizagem diferenciada, com múltiplas possibilidades de favorecer o desenvolvimento do educando, não apenas com relação aos conteúdos escolares, mas, precisamente na sua potencialidade de favorecer algum tipo de mudança na subjetividade.

Com as pesquisas realizadas e sua aproximação à Teoria da Subjetividade, bem como pela sua concepção de criatividade, Mitjáns Martínez (1997, 2000, 2004, 2008a, 2009b) avança na definição da categoria aprendizagem criativa compreendendo-a como processo da subjetividade na sua dupla condição: social e individual. Como uma forma complexa de aprender em que processos subjetivos considerados no campo científico como o cognitivo, as emoções, a motivação e os sistemas sóciorrelaconais, se integram e se expressam em configurações subjetivas e sentidos subjetivos (GONZÁLEZ REY, 2008a). Configurações subjetivas que expressam a história de vida da pessoa e sentidos subjetivos que se produzem na ação, na articulação do histórico, do atual, do contextual e do relacional.

O conceito inicial de aprendizagem criativa, elaborado por Mitjáns Martínez (2008a), apresentava-a como uma forma complexa de aprender, caracterizada por estratégias e processos que conformam este aprender. Nesta concepção, o caráter de "novidade" e de pertinência constitui seus indicadores, assim como o caráter produtivo e processual do percurso de aprender relacionados aos recursos subjetivos do sujeito na ação.

Aprender criativamente diferencia-se de outros tipos de aprendizagem, principalmente pelo tipo de produção do aprendiz, pela forma como a novidade se direciona à transcendência do dado, assim como pela configuração de processos subjetivos que a constituem (MITJÁNS MARTÍNEZ, 2014). Por isso, não basta identificar uma produção nova, como por exemplo, uma ideia que se gera no processo de estudo, sobretudo é preciso ter clareza da qualidade deste novo em relação à transcendência do que está aprendendo. Como um tipo de aprendizagem complexa a aprendizagem criativa não é algo simples e comum nos contextos escolares, muitas vezes acometidos pela reprodução e memorização das informações (MITJÁNS MARTÍNEZ, 2012b).

\footnotetext{
${ }^{27} \mathrm{O}$ referido autor traz importantes contribuições ao campo da aprendizagem ao enfatizar que a aprendizagem receptiva apenas requer do aluno memorização e compreensão, ao passo que a aprendizagem significativa por descoberta demanda um posicionamento ativo do aluno em encontrar soluções para possíveis problemas (MITJÁNS MARTÍNEZ, 2008a).

${ }_{28}$ Para tal autor a aprendizagem é um processo que demanda implicação pessoal do aluno sob influências múltiplas no desenvolvimento do aluno (MITJÁNS MARTÍNEZ, 2008a).
} 
Considerando os aspectos acima, Mitjáns Martínez (2008a, 2009b, 2012a, 2012b), mediante suas construções teóricas e, a partir de pesquisas realizadas com alunos criativos, voltadas à etapa do ensino médio e ensino superior (AMARAL, 2006; OLIVEIRA, C. 2010), enfatiza que a criatividade pode se expressar na aprendizagem mediante a articulação de, no mínimo, três elementos: a) personalização da informação; b) confrontação com o dado; c) produção, geração de ideias próprias e novas que transcendem o dado.

O conceito personalização da informação foi elaborado por González Rey e Mitjáns Martínez (1989) como contribuição para pensarmos uma nova e diferenciada forma de relação da pessoa com a variedade de informações a que é submetida e se submete em seu dia a dia. Tais autores destacam que, nem toda informação formará parte da própria constituição subjetiva da pessoa, uma vez que há informações que ganham relevância e se expressam em ações do sujeito, as quais estão associadas com suas motivações, perfazendo um processo que se efetiva pelo caráter ativo, na individualização que o sujeito realiza.

A personalização da informação constitui um conceito fundamental que rompe com a ideia de que a psique reflete o social tal qual se expressa em sua aparência. Pelo contrário, a psique em seu caráter gerador “[...] produz opções diferenciadas com base na forma pela qual esse social se torna significativo para as configurações subjetivas atuais da pessoa que o experiencia.” (GONZÁLEZ REY, 2009b, p. 124). Também nos fornece subsídios para a relação entre aprendizagem e a subjetividade uma vez que, quando a informação se personaliza, o conhecimento passa a ser alvo de constantes reflexões o que favorece a autoorganização e o autodesenvolvimento de elementos da personalidade do sujeito, constituindose como processo de desenvolvimento subjetivo (GONZÁLEZ REY; MITJÁNS MARTÍNEZ, 1989).

Em nosso trabalho, aliamos o conceito de personalização da informação à concepção de modo de vida desenvolvida por González Rey (2011c), a qual não está relacionada a hábitos e comportamentos individuais, mas como sistema de configurações subjetivas em desenvolvimento que se organizam e dinamizam o funcionamento da pessoa na ação. As duas concepções se alinham, uma vez que, assim como destaca González Rey (2004c), a informação personalizada pelo sujeito, implicará em algo relevante para a autorregulação do seu comportamento. O que decorre da capacidade geradora do sujeito em atuar com a informação e promover mudanças em seu modo de vida, capazes de abrir espaços de bemestar em seu cotidiano. Ressaltamos que, assim como se faz importante a aquisição de conhecimentos, deve-se aliar a este processo a formação de um indivíduo seguro, ativo, 
interessado e criativo, que ao personalizar o conhecimento, seja capaz de utilizá-lo para a própria vida, como fonte para novas produções subjetivas (GONZÁLEZ REY, 2004c).

O conhecimento é uma produção subjetiva que demanda envolvimento emocional do sujeito e isso implica uma organização e produção pessoal do aprendido. Por isso, toda ação e produção intelectual que se caracteriza por tal implicação, representa processos imaginativos que formam parte da configuração subjetiva da experiência de aprender. As ideias que emanam da relação com o aprender, constituem atos de imaginação que representam um modelo intelectual-subjetivo capaz de produzir saber no âmbito da configuração subjetiva da ação, uma vez que o conhecimento é constituído por ideias que ganham sentido subjetivo dentro da configuração subjetiva que se expressa no curso da ação do sujeito (GONZÁLEZ REY, 2011c, 2014a).

A transformação da informação recebida ocorre mediante os conhecimentos prévios do aluno, garantindo valor ao que o aprendiz já sabe, e está diretamente associada à própria relação que se estabelece com este novo conhecimento e envolve processos subjetivos como a imaginação (MITJÁNS MARTÍNEZ; GONZÁLEZ REY, 2012). Na aprendizagem criativa na escola, o produto criativo pode estar expresso na personalização das informações pelo aprendiz que transcendem o que está posto, à autoria do pensamento e das produções que individualizam o processo de aprender, às perguntas interessantes e originais que elabora frente à confrontação com o dado, dentre outras possibilidades (MITJÁNS MARTÍNEZ, 2008a; 2009a; AMARAL, 2011). Vale destacar que, para nós, a autoria está associada ao caráter produtor e gerador do sujeito no contexto da ação.

Esta relação do aluno com a informação ou com o conhecimento, não se estabelece de forma passiva, mas é caracterizada pela confrontação com o dado, na possibilidade de problematização das mais diversificadas informações, com valor ao caráter questionador e também transgressor, que configuram a categoria sujeito e a faz essencial para uma aprendizagem criativa. Confrontar-se com algo é se colocar reflexivamente e intencionalmente frente à situação.

Como uma forma diferenciada de relacionar com o percurso do aprender, a aprendizagem criativa pode ser marcada por posições de questionamentos do mundo, do saber cristalizado, das certezas e das verdades que são constantemente apresentadas pela escola. Para esclarecermos nossa construção, dialogamos com Maturana e Varela (2001), para os quais aprender consiste em constantes desconstruções de certezas. Isso nos mobiliza para a ação de conhecer como possibilidades de reflexão sobre o mundo. A aprendizagem criativa está diretamente relacionada à ideia de que somos corresponsáveis pela constituição do 
mundo, ou seja, o mundo é uma produção humana da qual fazemos parte mediante um processo ativo e participativo. Estamos diante de um tipo de aprendizagem que nos coloca como autores de nosso percurso de aprender e nos indica o potencial e o valor de cada um.

É uma verdadeira empreitada marcada pelo movimento de busca, frente às constantes curiosidades, dúvidas, questionamentos, que se tem diante da informação. Implica colocar-se como pensante ante o que se é discutido ou mesmo apresentado, na busca de estabelecer relações, conexões, processo que envolve reorganizar, modificar, na culminância da geração de algo novo que vai além do dado. Gerar uma ideia que vai além do que está posto é uma condição da aprendizagem criativa que rompe com a noção de que aprender é reproduzir, e coloca o pensamento como um processo subjetivo que, no envolvimento com o que está aprendendo, é capaz de produzir ideias diferenciadas e "novas", mesmo que este novo não adquira um valor social, mas um valor para o seu próprio desenvolvimento. Sendo assim, o novo pode se expressar, dentre outras possibilidades, em forma de alternativas e hipóteses sobre o objeto do conhecimento (MITJÁNS MARTÍNEZ, 2012b).

As características da aprendizagem criativa se organizam mediante recursos subjetivos específicos, dentre os quais podemos destacar a imaginação, pelas possibilidades que reúne de favorecer a transcendência da realidade e a geração de algo novo que, em alguma medida vai além do dado. Mitjáns Martínez (2014), a partir dos estudos da obra de Vigotski e da Teoria da Subjetividade de González Rey, destaca importantes ideias que convergem para a imaginação como processo subjetivo que se constitui de experiências e se expressa na interrelação com a configuração subjetiva da ação do sujeito (MITJÁNS MARTíNEZ, 2014; GONZÁLEZ REY, 2014a). Pesquisas têm apontado o valor da imaginação para a criatividade na aprendizagem (MOZZER, 2008; AMARAL, 2006; HOYER, 2010). Mitjáns Martínez (2014) enfatiza que a imaginação é constitutiva da aprendizagem criativa e pode se expressar, no mínimo de duas formas: a) vinculada à produção e geração de ideias próprias e novas que transcendem o dado; e b) como elemento funcional da personalidade, em que não apenas participa das configurações criativas relacionadas à aprendizagem criativa, mas se caracteriza como seu funcionamento subjetivo mais geral.

A imaginação constitui uma condição da aprendizagem criativa, e assim como Vigotski (1984, 1999, 1997, 2009), reconhecemos as possibilidades da criança em realizar combinações que extrapolam o campo concreto de suas experiências. A aprendizagem da leitura e da escrita reúne condições favoráveis para que a criança estabeleça relações diferenciadas com suas próprias experiências, bem como crie novas experiências que não tenha vivido. O referido autor apresenta elementos substanciais para o funcionamento da 
imaginação na ação de criar: a) as experiências anteriores formam a base para as construções da imaginação, mediante a modificação, reelaboração e transformação pelo sujeito; b) amplia a experiência do sujeito para além do que já viveu; c) aponta para a recursividade entre a imaginação e as emoções; e d) o novo pode ser inédito e não se parecer com nada materialmente produzido e ao se concretizar externamente pode trazer modificações.

Pelos pressupostos acima, a imaginação participa da criatividade em sua dimensão funcional, ou seja, não necessariamente requer um produto, mas se organiza como processo de desenvolvimento humano (MIJTÁNS MARTÍNEZ, 2014). Reconhecemos como Egan (2007) e Silva, D. (2012) o importante papel da imaginação para a aprendizagem, a qual é característica da primeira infância, pelas possibilidades de romper com dicotomias que envolvem o cognitivo e as emoções, uma vez que ambos consideram as inter-relações destes aspectos no processo de aprender perpassado pela imaginação.

As formas de expressão da criatividade na aprendizagem acima mencionadas marcam a autenticidade desse processo e não se concretiza pela assunção isolada de um ou outro aspecto, mas pela qualidade com que estas formas se organizam. Assim como Mitjáns Martínez (2012b, 2014) e González Rey (2014a), entendemos que aprender criativamente favorece, dentre outros aspectos, a utilização do aprendido em diferentes contextos experienciados pelo aprendiz, mediante a produção de um conhecimento subjetivado que passa a se organizar como recurso subjetivo que se atualiza frente a situações novas. Por isso, aprender criativamente pode se constituir como força motriz do desenvolvimento da subjetividade do aprendiz, tanto pelo desenvolvimento e pela consolidação da condição de sujeito na aprendizagem, e, ainda, pelo desenvolvimento de novas produções subjetivas.

Em sua complexidade de constituição e expressão, vale ressaltar que não podemos generalizar ou mesmo encontrar processos comportamentais que expressem a totalidade da expressão criativa de forma indistinta para todos os indivíduos. No entanto, algumas expressões comportamentais constituem-se comuns, considerando, é claro, a forma singular em que se organizam em cada sujeito mediante o contexto, dentre as quais podemos destacar: a realização de perguntas interessantes e originais; questionamento e problematização da informação; percepção de contradições e lacunas no conhecimento; estabelecimento de relações remotas e pertinentes; proposição de várias alternativas e hipóteses ante os problemas a resolver; solução inovadora de problemas; elaboração personalizada de respostas e proposições (MITJÁNS MARTÍNEZ, 2002, 2008b).

Toda esta forma de se relacionar e de experienciar o processo de aprendizagem pelo sujeito é favorecida por processos subjetivos, sobre os quais Mitjáns Martínez (2012a, 2012b) 
reconhece como um conjunto de recursos subjetivos que participa da aprendizagem criativa. Neste viés, a referida autora apresenta quatro elementos que se articulam de forma dinâmica e dialética no processo de aprender criativamente:

a) o exercício da condição de sujeito no processo de aprender, no sentido do seu caráter gerador, de ruptura e de subversão/transcendência em relação ao dado.

b) a produção de sentidos subjetivos favorecedores de geração de novidade que recursivamente "nutrem" essa forma de aprendizagem.

c) atualização de configurações subjetivas diversas entre as quais parece se destacar a aprendizagem como configuração.

d) o "operacional" aparece subjetivado, sendo impossível considerar aspectos "operacionais" fora do sistema subjetivo em que tomam forma.

A categoria de sujeito constitui o alicerce da aprendizagem criativa, marcando uma postura, não apenas ativa e intencional do sujeito no devir da aprendizagem, mas principalmente seu caráter gerador e transgressor, expresso na confrontação com as atividades, com as informações e mesmo com o conhecimento. Este caráter confrontador alicerça a busca de transcendência do dado, perante posicionamentos pessoais que expressam o envolvimento e a direção de um caminho neste aprender, ou seja, de não se limitar ao que está dado, mas via elaborações e construções próprias, em meio à recriação crítica e reflexiva do aprendido (MITJÁNS MARTÍNEZ, 2012a; GONZÁLEZ REY, 2009b).

A própria condição de sujeito na aprendizagem não se dá indistintamente, mas está relacionada, segundo Amaral (2011), à importância que a aprendizagem assume na organização subjetiva do sujeito. A qual se constitui em consonância com outras configurações e recursos subjetivos que favorecem a expressão dessa condição em um campo específico como a aprendizagem, o que situa a condição de sujeito no seu caráter histórico, social e cultural. Por isso, a autora ressalta que não basta necessariamente a identificação da condição de sujeito dentre os elementos da criatividade, é fundamental que o sujeito expresse esta condição no campo específico, ou seja, no seu processo de aprender.

A fluidez e dinamicidade que qualificam os sentidos subjetivos demonstram a diversidade de sentidos que coexistem na ação de aprender e esses recursivamente constituem a aprendizagem. Processo em que os sentidos subjetivos são capazes de mobilizar, movimentar, transformar, metamorfosear a experiência de aprender. Segundo Mitjáns Martínez (2012a), na aprendizagem criativa, os sentidos subjetivos: a) são diversos e nem sempre as experiências emocionais que os constituem são positivas; b) em sua multiplicidade 
se organizam e se produzem no curso dos processos criativos de aprender; e c) atuam de forma recursiva em relação à aprendizagem a partir da configuração subjetiva deste processo.

São os sentidos subjetivos que qualificam a aprendizagem criativa em meio a processos dinâmicos e múltiplos de configuração e reconfiguração do sistema subjetivo. Isso decorre de sentidos subjetivos historicamente constituídos e que passam a ter certa estabilidade no funcionamento da subjetividade, vinculados a configurações subjetivas e sentidos subjetivos produzidos no momento da ação (MITJÁNS MARTÍNEZ, 2012a).

Em suas pesquisas, Mitjáns Martínez (2012a, p. 101-102) tem observado a singularidade de sentidos subjetivos, porém, tem encontrado como comum aos sujeitos criativos na aprendizagem, que há uma organização subjetiva que coloca a aprendizagem como uma configuração subjetiva a qual "[...] atualiza-se junto a outras configurações subjetivas no processo de aprender, favorecendo a produção de ruptura e novidade que caracteriza a aprendizagem criativa."

$\mathrm{Na}$ dinâmica subjetiva em que a aprendizagem se organiza, participa diferentes operações que viabilizam a concretização deste processo. Reconhecemos, assim como Mitjáns Martínez (2009b, 2012a), que as estratégias de aprendizagem constituem-se como a união de determinadas ações empreendidas em prol de um objetivo de aprendizagem (FONT, 2000). Para adentrarmos o campo da classificação das estratégias, sobre a qual a base é a aprendizagem autorregulada, concepção que considera os aspectos afetivo-motivacionais e os elementos contextuais na assunção do operacional na aprendizagem, respaldamo-nos em Cabanah et al. (2002), que apresenta os seguintes tipos de estratégias: a) autorregulação: gestão intencional do processo de aprendizagem, demanda atitudes como planejamento, organização, seleção; b) cognitivas: codificam, armazenam e recuperam a informação do material; c) motivacionais: permitem a identificação pelo aluno de influências emocionais; e d) gestão de recursos: envolve gestão do tempo, do ambiente, dentre outros.

Nesta concepção, o aprendiz assume de forma ativa o seu processo de aprender, sendo possível supervisionar, controlar e regular, em algum grau. Pelo elevado nível de implicação do sujeito com sua aprendizagem, estudos com aprendizes criativos do ensino superior (GONZÁLEZ REY; MITJÁNS MARTÍNEZ, 2012; MITJÁNS MARTÍNEZ, 2009b, 2012a; OLIVEIRA, C. 2010), têm demonstrado a inexistência de estratégias motivacionais, uma vez que os sujeitos não requerem apoio externo para se manterem interessados e envolvidos com a ação de aprender. Isso ocorre pela produção de sentidos subjetivos que recursivamente constituem e nutrem o processo de aprender. 
Neste viés, Egler (2013), dentro da perspectiva por nós assumida, em sua pesquisa com aprendizes do ensino superior, contribui para mostrar que, na aprendizagem compreensiva, as estratégias cognitivas assumem a liderança nas ações dos aprendizes, configurando uma aprendizagem voltada para a compreensão ou reprodução e não para a geração e transcendência do dado.

González-Pumariega, Pérez e Rodríguez (2002) destacam a complexidade do processo de leitura e contribuem para pensarmos nas estratégias metacognitivas deste processo como favorecedoras na autorregulação pela pessoa, de seu próprio processo de leitura. Também García e Fuertes (2002) trazem a composição escrita como um processo que exige um extremo esforço mental por parte daquele que escreve e aparecem em funcionamento processos psicológicos de natureza diversa. Badia (2000a, p. 168, tradução nossa), ressalta que "[...] a tarefa de escrever, mais como um problema a resolver que como um jogo de magia e de inspiração."

Em concordância com Badia (2000a; 2000b), compreendemos que a ação de ler e escrever são favorecidas pelo funcionamento do pensamento e contribuem para sua reorganização. Para a referida autora, as estratégias de leitura e escrita como: planejar, regular e avaliar, são fundamentais para a consciência do aprendiz de seu próprio processo de aprendizagem e também para a formação de alunos autônomos nos mais variados momentos de tomada de decisões, tais como: quando, como e por que escrever ou mesmo ler algo.

No que se refere às operações do pensamento, Mitjáns Martínez e González Rey (2012) se baseiam na concepção de funções psíquicas superiores de Vigotski e também em suas próprias pesquisas e destacam a análise, a síntese, a generalização e a abstração. Tendo em vista a complexidade constitutiva da aprendizagem criativa, e em suas pesquisas empíricas, e de orientações, em especial, ao trabalho de Oliveira, C. (2010), Mitjáns Martínez (2012a) observa que há uma condição diferenciada que movimenta e torna possível a expressão do operacional na aprendizagem criativa, que o diferencia de outras formas de aprendizagem, uma vez que se configuram como processos subjetivos e representam a subjetividade em ação.

Sendo assim, na aprendizagem criativa, as estratégias de aprendizagem, as operações do pensamento e os aspectos subjetivos, que conformam o aprender, formam uma unidade. $\mathrm{O}$ que não se restringe à junção destes processos, mas sim, à complexidade constitutiva que os compõem, configurando um momento qualitativamente diferenciado de implicação emocional capaz de gerar formas únicas de expressão em que passam a se organizar como produções subjetivas (MITJÁNS MARTÍNEZ; GONZÁLEZ REY, 2012). 
Vale ressaltar que não almejamos rotular ou mesmo delimitar aprendizes em um tipo ou outro de aprendizagem, mas apresentar especificidades com que a aprendizagem pode se organizar em cada sujeito em contexto. Em um mesmo sujeito, é possível identificar diferentes tipos de aprendizagem, mediante a especificidade de sentidos subjetivos que lhes são constitutivos. Ao identificarmos tipos de aprendizagens diferentes em um mesmo aprendiz, entendemos que sentidos subjetivos que as constituem também serão distintos, mesmo considerando que pode ocorrer uma inter-relação entre eles nos diferentes momentos de expressão destas aprendizagens.

Sendo assim, a possibilidade de compreendermos formas de funcionamento do sujeito em tipos de aprendizagem caracterizadas como mais complexas, por contarem com a participação de produções subjetivas, e como estas aprendizagens se constituem, torna-se uma necessidade ao campo da educação, com vistas a romper com o cenário atual da educação, em que estas aprendizagens têm sido mais exceção do que regra. Na concepção que assumimos de aprendizagem como produção subjetiva, destacam-se aprendizagens complexas como a aprendizagem compreensiva e a aprendizagem criativa. Ambas não se referem a um padrão universal de aluno, a tipos de comportamentos homogeneizados, muito pelo contrário, apontam para elementos do campo da educação, que consolidam aspectos já enfatizados como a diversidade e a singularidade.

O processo de aprender é caracterizado por distintos momentos que se unem no modo como o sujeito funciona para aprender. A compreensão e o próprio ato de reproduzir podem constituir parte da aprendizagem criativa, aliás, estamos considerando que não há aprendizagem criativa sem compreensão. Por isso, convalidamos que a aprendizagem criativa se articula com outros tipos de aprendizagem, em especial, com a aprendizagem compreensiva (MITJÁNS MARTÍNEZ, 2014). Desta forma, estamos cientes de que o processo de aprendizagem da leitura e da escrita envolve momentos de compreensão, memorização e muitas vezes de reprodução e imitação. No entanto, compreendemos que, com a expressão da criatividade, estes processos funcionam qualitativamente diferentes e contam com a assunção de diferentes processos, características e estratégias.

Mesmo considerando possibilidades de inter-relação entre expressão de tipos específicos de aprendizagem na ação de aprender, importantes diferenciações conduzem a determinadas maneiras de relação com as informações. Destacamos que o que distingue a aprendizagem compreensiva da aprendizagem criativa, com particular ênfase, é o objetivo que o sujeito confere à atividade, ou seja, se a intenção é compreender e não há a necessidade de 
transcender, de ir além do que está posto, princípios da criatividade na aprendizagem, estamos diante de um tipo de aprendizagem eminentemente compreensiva (Informação verbal) ${ }^{29}$.

Esta intencionalidade é a marca do sujeito nos diferentes tipos de aprendizagem, por isso, não podemos restringir a categoria sujeito à aprendizagem criativa, mas precisamos destacar que, nesta aprendizagem, o sujeito age em seu caráter transgressor e subversivo. Por isso, as qualidades que tipificam e especificam esta categoria são, em essência, expressas na aprendizagem criativa, na sua condição autônoma e engajada de se relacionar com o seu próprio processo de aprender (MITJÁNS MARTÍNEZ, 2012a, 2012b).

Não obstante, a intencionalidade não é, necessariamente, algo presente nas ações dos indivíduos no movimento da aprendizagem, por isso, podemos afirmar que há aprendizagens de tipos diferenciados, alcançada pelos sujeitos que não necessariamente foi engendrada sobre a intencionalidade para ser de uma ou outra forma. É possível que o aluno compreenda algo, sem necessariamente ter sido seu objetivo consciente, bem como também é possível que a criatividade emerja e favoreça a geração do novo que, em alguma medida, transcenda o estudado e que não passe pela intencionalidade do sujeito.

O que especifica tipos de aprendizagem mais complexas é a geração do novo, que pode estar, dentre outras possibilidades, nas ideias ou mesmo nos registros escolares, ou na própria comunicação estabelecida em sala de aula. Porém, esta novidade tem características relevantes que diferenciam os tipos de aprendizagem. Ao nos referirmos à criatividade na aprendizagem, a novidade é algo que não se limita ao dado, ela extrapola os limites situacionais, e aponta para uma unidade complexa com a imaginação. Já na aprendizagem compreensiva, também observamos que o sujeito produz ideias novas, estabelece relação, mas volta ao que já está posto.

No processo de geração do novo, tanto na aprendizagem criativa quanto na aprendizagem compreensiva, a imaginação aparece como um processo de produção do sujeito, direcionando a orientação do caminho e objetivo que se pretende, ou seja, compreender ou transcender. Necessariamente, o papel da imaginação está na produção de conhecimento novo, seja na forma de compreender o dado ou mesmo na possibilidade de ir além do mesmo. Precisamente a imaginação é o alicerce sobre o qual é possível a transcendência do dado sendo, portanto, elemento constituinte da aprendizagem criativa.

\footnotetext{
${ }^{29}$ Informação fornecida oralmente em aula realizada na Faculdade de Educação (Universidade de Brasília), disciplina Atividades Programadas em Escola, Aprendizagem e Trabalho Pedagógico II, pela professora Albertina Mitjáns Martínez no dia 13/03/2013.
} 
A ação de compreender envolve estabelecer relações, emergir para além da realidade, processos que envolvem a imaginação. No entanto, na aprendizagem criativa, a imaginação aparece como constitutiva do seu processo, podendo se organizar como um elemento funcional da personalidade, em que não necessariamente se limita à participação nas configurações subjetivas relacionadas à aprendizagem ou mesmo às configurações subjetivas da ação, mas constitui o próprio funcionamento subjetivo de uma forma mais integral (MITJÁNS MARTÍNEZ, 2014).

Para Craft (2010), possibilidades de pensamento constituem a força motriz da criatividade. Sendo assim, mesmo que a autora ainda vincule o valor social à criatividade, ela contribui sobremaneira para pensarmos a aprendizagem criativa como uma capacidade de ir além do conhecimento expresso, com possibilidades de aplicar este saber reconfigurado em novos e diferenciados contextos. Neste viés, encontramos pontos de encontro com Mitjáns Martínez (2012a), ao conferir que, em aprendizagens complexas como a aprendizagem criativa e em aprendizagens em que a condição de sujeito participa, se percebe a utilização do aprendido em outros contextos (GONZÁLEZ REY, 2012a).

A aprendizagem criativa não apenas está relacionada com o uso do que se aprende em diferentes contextos, mas com a forma como esta aprendizagem possibilita/promove/favorece novas aprendizagens. Podemos exemplificar tal assertiva pelo próprio processo de aprendizagem criativa da leitura e da escrita, em que a criança começa a fazer tentativas de leitura das regras de um jogo, de um livro de histórias para contar para a irmã e se sentir inserida no contexto cultural do qual participa.

Os diferentes tipos de aprendizagem que aparecem no mesmo sujeito podem ser explicados, ou mesmo compreendidos, pelas configurações subjetivas que estão na base de cada tipo. Neste âmbito, Mitjáns Martínez (2012a, 2012b) destaca que os indicadores de um tipo ou outro de aprendizagem estão resguardados tanto pela produção do aprendiz quanto pelos processos subjetivos nela implicados. Sendo assim, a produção de sentidos subjetivos não é específica da aprendizagem criativa, uma vez está associada ao envolvimento, implicação emocional do aluno com suas atividades, o que pode ocorrer em diferentes tipos de aprendizagem, como a compreensiva. Porém, na aprendizagem criativa, os sentidos subjetivos conferem uma qualidade diferenciada à forma de aprender constituindo-a recursivamente.

Vale frisar que, os elementos destacados anteriormente sobre a criatividade têm sido estudados e relacionados às pesquisas de aprendizagem desenvolvidas com estudantes do ensino médio e do ensino superior. O que constitui nosso desafio em explorar, identificar e 
compreender como a criatividade pode se expressar na aprendizagem da leitura e da escrita de crianças. Segundo Mitjáns Martínez (2012a, p. 105), “[...] os aspectos aqui mencionados como caracterizadores da aprendizagem criativa são válidos para caracterizá-la em outros níveis de ensino, como por exemplo, no processo de alfabetização.” No próximo tópico, realizamos um diálogo sobre o papel da escola na constituição e desenvolvimento da criatividade na aprendizagem da leitura e da escrita da criança.

\subsubsection{O papel da escola na constituição e desenvolvimento da criatividade: as múltiplas possibilidades de relação entre o ensino e a aprendizagem da leitura e da escrita}

Para o presente estudo, almejamos destacar a relevância da escola, na constituição e desenvolvimento da criatividade na aprendizagem (MITJÁNS MARTÍNEZ, 1995a, 1995b, 1997, 1999, 2004, 2008a, 2008b, 2012b). Optamos por destacar a escola como instituição, não como a única da qual a criança participa, mas como a que configura a sua vida por um longo período de tempo e propicia ao indivíduo um espaço sócio relacional imerso em um sistema de atividade-comunicação. No entanto, também queremos frisar que não há uma relação linear entre os processos engendrados neste espaço social e o emergir da criatividade na aprendizagem, uma vez que essa se constitui por elementos da história de vida de cada pessoa e por produções subjetivas associadas à ação do sujeito em contexto. Isso não nos permite predizer que sua expressão se faça a partir de ações intencionais.

Diante da concepção de criatividade assumida no presente trabalho, abordar o desenvolvimento da criatividade só pode ser possível mediante a complexidade que a constitui e a singulariza, o que não condiz com receitas padronizadas que envolvam a prática pedagógica direcionada a uniformização de ações. Nesse enfoque, a educação cumpre um papel essencial no desenvolvimento de recursos subjetivos que podem estar relacionados à criatividade na aprendizagem. Destacamos que o aprendiz não chega à escola de forma neutra, mas já se encontram em desenvolvimento recursos subjetivos que participam de suas ações e que tem sua gênese em outros contextos por ele experienciados. Entretanto, a subjetivação da experiência de aprender, não está definida a priori, mas pela ação mediante a expressão da pessoa na atividade que realiza (GONZÁLEZ REY, 2007a).

Diante da importância e da complexidade que envolve o desenvolvimento da criatividade na aprendizagem, Mitjáns Martínez (2012b) elenca três grandes desafios que se impõe à escola: a) mudar as representações e o sistema valorativo dominante sobre a 
aprendizagem; b) colocar o foco da ação educativa no desenvolvimento de recursos subjetivos e não apenas na transmissão cultural; e c) a personalização do processo de ensino.

Ao professor se atribui um papel fundamental no processo de desenvolvimento da criatividade do aprendiz, uma vez que, é ele quem, muitas vezes, organiza e possibilita tipos específicos de sistemas atividade-comunicação no espaço-tempo da sala de aula, que podem ser capazes de favorecer o desenvolvimento ou a assunção de recursos subjetivos que propiciem ações criativas (MITJÁNS MARTíNEZ, 1995a, 2004). Para isso, é preciso que o professor conheça o aluno, não apenas via atividades diagnósticas que foquem no nível de desenvolvimento da escrita, mas é preciso conhecê-lo de forma integral, tendo em vista seus gostos, preferências e a especificidade de suas formas de aprender, para que possa planejar sua prática pedagógica em prol das necessidades e na busca de instigar novas experiências.

Ao conhecer o aluno em sua complexidade, o professor se mune de possibilidades de processos comunicativos e valorativos que podem favorecer o desenvolvimento de estados emocionais como autovalorização positiva e satisfação frente à ação de desenvolver atividade, com ênfase ao diálogo, ao respeito à singularidade e à valorização das ações dos aprendizes. Nessa direção, tais processos constituem elementos que participam da subjetividade social da sala de aula favoráveis ao desenvolvimento da criatividade (MITJÁNS MARTÍNEZ, 2004).

O cuidado com o contexto de aprendizagem no qual a educação se realiza e as condições sociais, históricas e culturais sob as quais ela emerge, precisa ser considerado e passar pela reflexão do professor. A esse profissional cabe o desafio de propiciar um ambiente encorajador e de valorização das descobertas do aprendiz, favorecendo e instigando a dúvida e expressão espontânea da criança de suas ideias e questionamentos sobre seu processo de aprender (CRAFT, 2008). Neste viés se insere as possibilidades da criança atuar de forma livre com a língua, de questionar o codificado e se imbuir num processo de descobertas pela leitura e a escrita como possibilidades de favorecer a criatividade (RODARI, 1982).

Em consonância com Vigotski, Coelho $(2009,2011)$ ressalta que a escola deve superar a concepção tradicional de linguagem em que se restringe ao produto, padronizando os processos de apender dos alunos. Alinha-se uma concepção mais complexa no trabalho com a linguagem que a considera em seus processos e produtos, assim como em sua forma e substância sonora, na unidade que se organiza do som e do significado. Rompe-se com uma visão estruturalista e normatizada da linguagem que tende a uma orientação para falar sobre a língua e não para dela fazer uso em um processo vivo de expressão.

Neste trabalho, o desenvolvimento da condição de sujeito da aprendizagem se faz necessário, uma vez que o objetivo é a aprendizagem criativa, principalmente, tendo em vista 
a corresponsabilidade que necessita existir no engajamento dos envolvidos no processo de ensinar e aprender. Aprender criativamente implica esforço, dedicação e dispender energia para trabalhar com o objeto a ser conhecido. Isso requer, tanto do professor quanto do aluno, assumir o processo de ensinar e aprender como protagonistas, ou seja, participar como autores do caminho empreendido para chegar ao objetivo almejado (MITJÁNS MARTíNEZ, 1995b, 2008a). É no encontro com o outro entre professor e aluno, no contexto da sala de aula, que se pode criar uma atmosfera de compromisso e responsabilidade na direção dos objetivos de ensinar e aprender (TACCA, 2006).

$\mathrm{Na}$ aprendizagem criativa da leitura e da escrita, queremos destacar um importante trabalho de González Rey (1991), o texto La Personalidad y su importância en la Educación no qual o autor aponta a relevância da escola no ensino da leitura, buscando romper com práticas educativas que consideram o ato de ler como um fim em si mesmo e que desconsiderem o sujeito que aprende. $\mathrm{O}$ autor ressalta a importância da leitura se constituir como unidade subjetiva do desenvolvimento, trazendo alguns pontos essenciais para serem cuidados no contexto escolar, vinculando a leitura para a criança com: a) o interesse por algo particular; b) a necessidade de ler; e c) os conteúdos que lhe resultem instigantes.

Neste viés, o aprendiz poderá viver a experiência da leitura, sendo capaz de transformar o que lê e experienciar o mundo de outra de forma. Por isso, ler não consiste em reproduzir ideias de alguém, mas sim, produção e elaboração própria de algo, constituindo-se como metamorfose do sujeito leitor. Há uma relação do leitor com o texto que o transforma em alguma medida para atuar no mundo de forma diferenciada e, por isso, a leitura não estaria no ato de decodificar, mas no que o leitor é capaz de se transformar pela leitura (LARROSA, 2003, 2010; CANTÚ, 2011, 2014).

A leitura seria assim uma viagem do sujeito leitor pelo texto, criando uma intimidade liberta que tem na autonomia do leitor as possibilidades de sentir o texto como algo pessoal, que se liga às suas experiências e lhe permite configurar uma leitura secreta. A criatividade do leitor estaria, na possibilidade de romper com as amarras do instituído e assumir a liberdade de transitar pelo texto e constituir uma leitura plural pela reciprocidade entre o leitor e o texto (CERTEAU, 2011). A leitura consiste em um processo que envolve certa identidade imposta por outro e descoberta de nossa própria identidade pela leitura, o que demanda pensar por conta própria (MANGUEL, 2009).

Cantú (2011) propõe, a partir de Larrosa (2003), o conceito de experiência da leitura, destacando o valor heurístico do termo experiência para ressaltar "[...] a possibilidade de abordar o encontro subjetivo com um objeto cultural, tal como é o escrito, sem partir de 
'aspectos' ou 'dimensões' prévias ou anteriores ao dito encontro.” (CANTÚ, 2014, p. 128). O autor diferencia compreensão e leitura, ressaltando que compreender significa apropriação do que está instituído pelas significações socioculturais relacionadas ao escrito, ao passo que ler estaria relacionado à experiência favorecedora da produção de novos sentidos subjetivos e enfatiza que o ato de ler envolve o passado, presente e futuro. Na leitura, a experiência se realiza como um encontro com algo diferente que nos coloca em confronto e nos mobiliza à transformação do que lemos e de nós mesmos.

González Rey (2011c) destaca a importância do termo experiência sob dois aspectos principais: a) ela sempre acontece como processo de vida atual; e b) transcende as dicotomias interno e externo, assim como ação e subjetividade. A experiência é a organização da expressão humana na diversidade de processos que a acompanham e está sempre associada à configuração subjetiva da ação. Por isso, a experiência é sempre curso, movimento, devir. A experiência nunca é uma expressão da realidade em sua forma exata, mas uma configuração subjetiva do vivido sendo que "[...] as coisas na experiência humana só existem através do sentido que elas cumprem na própria experiência, e não por aquilo que possam representar fora dessa experiência. Essa é a realidade do humano." (GONZÁLEZ REY, 2014a, p. 41).

Aprender criativamente a ler e a escrever implica na possibilidade de viver uma experiência subjetiva, trazendo a ideia de que ler e escrever são produções do sujeito que aprende e não uma réplica do real que se internaliza. A experiência subjetiva se caracteriza pelas possibilidades que reúne de alternativas subjetivas que não se limitam ao simbólico, como reificação da linguagem escrita e oral, mas em unidade com as emoções geradas na ação se constitui como processo da subjetividade humana.

No ensino da leitura, é preciso considerar, dentre outros aspectos, a fantasia, o interesse por palavras novas e a capacidade para elaborar histórias (GONZÁLEZ REY, 1991). Em consonância com Tolstoi ${ }^{30}$, Vigotski (2009) destaca que a criação literária infantil se entrelaça à autenticidade com que as crianças escrevem, mediante uma necessidade real de se expressarem pela palavra. Assim, elas investem em elementos como a clareza e a individualidade, que são pontos que a diferenciam da linguagem adulta, e, ao expressarem seus sentimentos, trazem emoção na concretude dos relatos, em um processo de desenvolvimento da personalidade da criança (VIGOTSKI, 2004, 1995). Essa ideia se contrapõe àquela de um trabalho pedagógico artificial, que desconsidera os interesses e experiências das crianças.

\footnotetext{
${ }^{30}$ Obra do referido autor citada por Vigotski (2009): TOLSTOI, L. Obras pedagógicas. Moscou: Progresso, 1988.
} 
Neste viés, nos aproximamos das ideias de Freinet $(1975$, 1977), para quem a aprendizagem da leitura e da escrita se relaciona à curiosidade infantil e desenvolve a vida afetiva da criança. Tal aprendizagem precisa basear-se na necessidade de expressão e de comunicação da própria criança. $\mathrm{O}$ referido autor relaciona a aprendizagem ao desenvolvimento da personalidade da criança, a partir do momento em que ela experiencia este aprender como algo de sua vida cotidiana, de suas ações e de seus interesses. O autor ainda defende, no trabalho com as crianças, a utilização do texto livre. Dentre os elementos de desenvolvimento da personalidade, o autor destaca o reconhecimento pela criança de sua capacidade de explorar e descobrir coisas novas e a segurança que adquire no diálogo com o outro. Esse processo se articula às elaborações de Chamberlain (2005), para quem a criatividade pode se expressar na escrita, pelo seu próprio objetivo de compartilhar pensamentos íntimos com os outros e, por isso mesmo, a escrita não é uma técnica, ela é social e implica comunicação.

Frente ao nosso arcabouço teórico e nossas construções mediante o trabalho de campo, elaboramos, na presente pesquisa, nossa concepção de aprendizagem criativa da leitura e da escrita como unidade subjetiva de desenvolvimento, alinhavada às elaborações de González Rey (1991, 1995, 1999b, 2004a, 2008b), que aponta para a relação recursiva entre os processos de aprendizagem e desenvolvimento, em aprendizagens mais complexas, que envolvem a produção de sentidos subjetivos. Concepção que enfatiza que, se o objetivo é favorecer a aprendizagem criativa da leitura e da escrita não é suficiente deter nos processos de codificação e decodificação, estas são ações importantes, mas não expressam a complexidade deste aprender. Como habilidade, o aprendiz pode escrever ou ler algo e quando terminar a atividade não conseguir operar com este aprendizado. Propõe-se que o ensino da leitura e da escrita esteja em consonância com a formação de um aprendiz produtor e não assimilador de ideias, que seja capaz de quando ler ou escrever, realizar estas ações pensando, gerando ideias próprias capazes de transformar suas ações.

Para isso, a sala de aula precisa ser um espaço social dinâmico e dialógico, com abertura à provocação, dúvidas e troca de ideias (GONZÁLEZ REY, 2013 ${ }^{31}$ ). O diálogo constitui a via para favorecer um espaço-tempo de aprender pautado pelo respeito e valorização da produção de ideias e não a reprodução ou mesmo repetição de algo. Ensinar não constitui um momento de depositar ideias que se esvaziam e se desfazem com o tempo,

\footnotetext{
${ }^{31}$ Informação fornecida oralmente em palestra proferida por González Rey intitulada de: Didática e formação de professores na perspectiva histórico-cultural, realizada no Seminário "O Uno e o Diverso na Educação Escolar e Congresso de Psicopedagogia" realizado na Universidade Federal de Uberlândia no dia 14/11/2013.
} 
mas ideias que modificam e transformam os sujeitos ali envolvidos na ação, numa relação dialógica pautada pelo contato vivo e reflexivo, marcado pelo compromisso social no trabalho com o outro (FREIRE, 2011b).

Vale ressaltar que, estudos realizados no contexto escolar têm identificado que a aprendizagem criativa do aluno não está diretamente vinculada a um ambiente de liberdade, que incentive intencionalmente a criatividade. Uma vez que, foram encontrados alunos que demonstraram criatividade na aprendizagem e que experienciaram um contexto tradicional de ensino. Tais estudos apontam para a singularidade e para as múltiplas possibilidades de subjetivar uma experiência social, enfatizando mais uma vez a não linearidade entre ações intencionais do professor e a aprendizagem do aluno (MITJÁNS MARTÍNEZ, 2004, 2008a). Por isso, torna-se também questionável a ideia de ensinar de forma universal estratégias de aprendizagem. Na aprendizagem criativa, o trabalho pedagógico a ser desenvolvido com o operacional na aprendizagem deve considerar a complexidade do processo de aprender e estar em consonância com os recursos subjetivos que favoreçam o emergir da criatividade e sua atualização na própria ação de aprender (MITJÁNS MARTÍNEZ; GONZÁLEZ REY, 2012).

Frente ao exposto, consideramos que pode ocorrer aprendizagem sem a intencionalidade do ensino, bem como o inverso, ou seja, pode ocorrer ensino intencional sem reverberar em aprendizagem. Estamos diante das múltiplas possibilidades de produção do humano, para além de linearidades de causa e efeito. O que coloca a função social da escola para além do ensino de conteúdos, mas juntamente com o trabalho com conteúdos curriculares, favorecer o desenvolvimento de recursos subjetivos que são essenciais para que a criatividade emerja (MITJÁNS MARTÍNEZ, 2001, 2003a, 2003b, 2012b).

Em suma, destacamos, neste trabalho, as contribuições de Mitjáns Martínez (1997, 2008a, 2008c, 2012b) à constituição e desenvolvimento da criatividade, com ênfase ao papel da escola. Elaborações que alinhavam-se à concepção da autora do Sistema Didático Integral. Esse sistema oferece orientações às ações pedagógicas conferindo possibilidades de delineamentos em prol do desenvolvimento da criatividade. A autora destaca que a criatividade como princípio funcional da aula requer mudanças em cada um dos aspectos que envolvem o trabalho pedagógico do professor. De forma geral, o referido Sistema indica ações voltadas ao caráter ativo, intencional e participativo do aprendiz. Para isso, descrevemos brevemente seus princípios:

a) forma de trabalhar com os estudantes a formulação e seleção dos objetivos de aprendizagem: favorecer a participação do aprendiz na elaboração e acompanhamento dos seus próprios objetivos de aprendizagem. 
b) seleção e organização dos conteúdos de ensino e das habilidades e competências a serem desenvolvidas: prezar pela qualidade dos conteúdos trabalhados em sua profundidade e não pela quantidade, favorecendo a imaginação, a curiosidade, o caráter investigativo e a geração de ideias próprias;

c) estratégias e métodos de ensino: Propor atividades que desafiem o aprendiz e que sejam oriundas dos interesses cotidianos do mesmo, que instiguem sua produção como protagonista. Ensino baseado na formulação de problemas e não na busca de verdades absolutas.

d) natureza das tarefas a serem realizadas em classe ou extraclasse e as orientações para sua realização: Atividades que envolvam a produção de ideias próprias do aluno;

e) natureza da bibliografia e do material didático e as orientações para sua leitura: Propor leituras desafiadoras, que instiguem o aluno a pensar e a interagir com a leitura, capaz de ir além das ideias do autor.

f) sistema de avaliação e autoavaliação da aprendizagem: ênfase na produção, elaboração reflexiva e individualizada do conhecimento. Estimular a autoavaliação da aprendizagem;

g) relações professor-aluno e o clima comunicativo-emocional que caracteriza a sala de aula: incentivar a reflexão, a curiosidade, a imaginação. Estabelecer relação de troca, de confiança mútua e de exigência. Valorizar o aluno em seu esforço e propor desafios constantes.

Os itens acima citados constituem uma orientação a favor da singularidade do contexto em que as ações pedagógicas são empreendidas. Entendemos que tal Sistema pode fazer parte dos diferentes níveis que compõem a educação atual, ou seja, desde a educação básica até o ensino superior, conferindo as mudanças e enfoques necessários a cada etapa e se revela potencialmente importante para contribuir para a prática pedagógica direcionada à expressão da criatividade na aprendizagem. Em consonância com o arcabouço teórico desenvolvido, apresentamos no próximo capítulo nossa proposta metodológica. 


\section{BASES EPISTEMOLÓGICAS E METODOLÓGICAS DA PESQUISA}

\subsection{A EPISTEMOLOGIA QUALITATIVA E O MÉTODO DA INVESTIGAÇÃO}

No presente capítulo, destacamos os princípios epistemológicos que permeiam a presente pesquisa e lhe conferem sustentação, bem como os elementos metodológicos que permitem uma organicidade e nos instrumentalizam para a concretização do trabalho de campo. Assim como, justificamos nossa opção pela Epistemologia Qualitativa como norteadora dos processos que delineiam nossa investigação e ressaltamos nossos objetivos de pesquisa. Também apresentamos nossa opção pelo estudo de caso, a caracterização da escola onde realizamos a pesquisa, os critérios para escolha dos participantes da pesquisa, a construção do cenário social da pesquisa, bem como as inter-relações dos instrumentos e objetivos de pesquisa, tornando-se fundamental a explicitação da forma como procedemos no processo construtivo-interpretativo.

\subsubsection{Os objetivos e a natureza da pesquisa}

\section{Objetivo geral}

Compreender como a criatividade emerge na aprendizagem da leitura e da escrita e suas interrelações com o desenvolvimento da subjetividade da criança.

Objetivos específicos

a) Identificar a expressão da criatividade na aprendizagem da leitura e da escrita e suas relações com as estratégias de aprendizagem.

b) Caracterizar a configuração subjetiva da ação de aprender criativamente a ler e a escrever.

c) Analisar mudanças e constituição de novos aspectos na subjetividade da criança vinculados ao processo de aprendizagem criativa da leitura e da escrita.

Frente aos objetivos da presente pesquisa, buscamos uma proposta metodológica que fosse coerente com o nosso referencial teórico e nos permitisse a construção de um percurso investigativo possível de resguardar e valorizar nossas reflexões e a própria expressão humana dos participantes da pesquisa, no fluxo do seu acontecer. Para a investigação delineada, neste texto, adotamos como eixo norteador a pesquisa qualitativa, apoiada nos princípios da Epistemologia Qualitativa, desenvolvida por González Rey (1997, 1999c, 2000, 2005a, 2005c, 2009b, 2011f, 2014b) que fundamenta o estudo da subjetividade. 
Para além de sua coerência com a Teoria da Subjetividade desenvolvida por González Rey, o referido autor buscou elaborar uma proposta metodológica que viabilizasse estudos e produções teóricas sobre a subjetividade, a partir de uma profunda modificação epistemológica, que garantisse o caráter flexível, dinâmico e interativo do seu objeto de estudo. Nossa opção pela metodologia qualitativa, é definida pelos fundamentos epistemológicos que constituem a Epistemologia Qualitativa, na qual se organizam princípios para a produção do conhecimento que concretizam e viabilizam uma proposta metodológica (GONZÁLEZ REY, 1997, 2000, 2005a.).

O caráter construtivo-interpretativo do conhecimento compõe o primeiro atributo geral da Epistemologia Qualitativa, em que se outorga papel fundamental ao pesquisador como sujeito da pesquisa. A inteligibilidade da pesquisa passa a ser considerada uma produção do pesquisador como o guia que orienta o caminho interpretativo, mediante as informações levantadas no decorrer da pesquisa, tendo em vista os instrumentos utilizados e os acontecimentos inesperados no movimento dinâmico e vivo em que se organiza o contexto social (GONZÁLEZ REY, 2014b).

Neste processo, às ideias do pesquisador se confere lugar privilegiado, reconhecendo o conhecimento como uma produção humana ao romper com a dicotomia empírico e teórico, na busca por compreendê-los nas suas inter-relações, em que um se nutre do outro, em um processo recursivo, resguardadas suas especificidades. Neste viés, a investigação constitui-se como processo que rompe com padrões e regularidades que possam moldar as ações do pesquisador, ao abrir possibilidades para o imprevisto, para o não padronizado, o que demanda implicação e envolvimento ativo do investigador com a pesquisa, num diálogo constante com as informações e as formulações teóricas.

O segundo princípio da Epistemologia Qualitativa, consiste na legitimação do singular como instância de produção do conhecimento científico. Tal característica implica compreender a pesquisa como produção teórica, porém não delimitada a priori e que apenas serve para validar ou não o momento empírico, mas na qual o teórico constitui um caminho que em tem como centro as reflexões, elaborações e construções do pesquisador (GONZÁLEZ REY, 2005a). O pesquisador se implica como sujeito pensante e comprometido com uma produção de conhecimento singular que requer aproximação do campo a ser investigado, em que o foco passa a ser as produções e formas de expressão dos participantes, que poderão constituir em indicadores para o problema que se investiga.

A terceira característica da Epistemologia Qualitativa refere-se ao processo de comunicação, como processo dialógico. Para González Rey (2011f), a comunicação constitui 
uma via privilegiada para compreender configurações subjetivas e sentidos subjetivos. Por meio dela o pesquisador e os participantes podem emergir em sua condição de sujeitos da pesquisa, ao implicarem-se de forma responsável e ativa na mesma. O diálogo envolve a possibilidade de expressão dos participantes implicados na relação e constitui elemento fundamental para o estudo da subjetividade, uma vez que, sem a expressão do sujeito se inviabiliza elaborações sobre suas produções subjetivas em determinados campos de sua vida.

\subsubsection{Opção metodológica pelo estudo de caso}

Pelos princípios destacados anteriormente, que regem a Epistemologia Qualitativa, o estudo da subjetividade não pode ser realizado com um número elevado de participantes e de forma indistinta, uma vez que requer um olhar personalizado para o participante, em suas múltiplas expressões. Esse olhar demanda do pesquisador debruçar-se sobre as informações que surgem no decorrer da pesquisa. Desta forma, em coerência com nosso objetivo geral de pesquisa, o estudo de caso se mostrou como possibilidade de compreender a complexidade que envolve as inter-relações entre o emergir da criatividade no processo de aprender a ler e a escrever e o desenvolvimento da subjetividade da criança.

O estudo de caso representa uma possibilidade de um "[...] estudo aprofundado de uma unidade em sua complexidade e em seu dinamismo próprio, fornecendo informações relevantes para tomada de decisão.” (ANDRÉ, 2003, p. 49). É nesta unidade que a diversidade se expressa, a partir da expressão humana e pelo seu caráter único e próprio de cada caso em estudo. Vale ressaltar que o que legitima o estudo de caso não é realmente a quantidade de casos, mas a qualidade das relações que se pode realizar entre cada caso e as inquietações que norteiam a pesquisa. Frente aos princípios epistemológicos e a própria natureza de nossa pesquisa, desenvolvemos, na presente investigação, três estudos de casos.

\subsubsection{Local da pesquisa: caracterização da escola onde foi realizada a investigação}

Realizamos nossa pesquisa em uma instituição pública da rede Municipal de Ensino de Uberlândia, que atende alunos do $1^{\circ}$ período da educação infantil ao $5^{\circ}$ ano do ensino fundamental. Utilizamos o caráter público como único critério para escolha da escola-campo. Um indicador facilitador para optarmos por tal escola, dentre as 38 escolas públicas existentes na cidade de Uberlândia, em Minas Gerais, ocorreu pela concentração de três turmas de primeiro ano em cada turno de funcionamento, matutino e vespertino, o que indicava a possibilidade de termos contato com um número expressivo de alunos para iniciar nossas observações e definir os casos a serem estudados. 
De forma geral, a escola contava com algumas salas de aulas amplas e outras estreitas, o que dificultavam a movimentação das carteiras e sobressaía na organização em fileiras, assim como eram pouco ventiladas. Havia um pátio unido ao refeitório da escola, porém, a escola não contava com parque e os alunos brincavam no recreio com materiais disponibilizados pela escola, por exemplo, corda e bola. No momento do recreio, as professoras ficavam na sala destinada aos professores e eram os profissionais da limpeza, coordenadora pedagógica, vice-diretora e diretora, que acompanhavam os alunos no pátio.

A escola era extremamente limpa. Todos os dias os seis responsáveis pela limpeza mantinham sua organização. O lanche era produzido diariamente pelas três merendeiras, que utilizavam roupas apropriadas. Chamou nossa atenção a forma respeitosa com que todos da escola se tratavam e o envolvimento de cada um em sua função, assim como a disponibilidade de ajudar uns aos outros. Também observamos a forma como, os profissionais da escola de forma geral, conheciam os alunos e os chamavam pelo nome, estabelecendo um processo de cordialidade e respeito para com estudantes. No âmbito pedagógico, aos alunos dos anos iniciais do ensino fundamental, eram oferecidas aulas com professora ${ }^{32}$ regente, responsável pelos conteúdos de Português, Matemática, História, Geografia e Ciências, assim como com professores de aulas especializadas como: Educação Física, Arte, Literatura, Informática. Também eram organizados momentos na biblioteca, destinados a pegar livros para leitura em casa, assistir vídeos e leitura.

\subsubsection{Processo de escolha dos casos}

Nossa opção inicial pelo primeiro ano do ensino fundamental teve por pressuposto, ser esta uma das etapas iniciais em que a criança se insere nos processos mais sistematizados de leitura e escrita. Vale destacar que o referido ano de ensino não se constitui como uma inauguração do processo de aprendizagem da leitura e da escrita, uma vez que estamos inseridos em uma sociedade grafocêntrica, com escrita em diferentes contextos.

Para a escolha dos casos, realizamos, inicialmente, observações de todos os aprendizes das três turmas de $1^{\text {os }} \operatorname{anos}^{33}$ do turno da tarde, totalizando 83 alunos, tendo em vista algumas características que podiam indicar uma relação diferenciada com o processo de aprender, assim como recorremos ao diálogo com os aprendizes e com as professoras. Em nossas observações das crianças, embasamo-nos em alguns critérios essenciais que compõem

\footnotetext{
32 A partir deste momento, quando nos referirmos às professoras participantes da pesquisa, utilizaremos o termo professora, no feminino, por se tratarem de mulheres. Optamos por manter o termo no masculino quando se referir às nossas elaborações sobre os autores citados ao longo do trabalho.

${ }^{33} \mathrm{Em}$ cada turma do $1^{\circ}$ ano havia aproximadamente 26 alunos.
} 
algumas características comportamentais de expressão da criatividade na aprendizagem, mais especificamente nos trabalhos de Mitjáns Martínez (1997, 2003b, 2008a, 2009b, 2012a), Amaral (2006, 2011), Amaral e Mitjáns Martínez (2009), Oliveira, C. (2010), dentre as quais destacamos: atitude questionadora, de dúvida, de interesse, de curiosidade pelo processo de aprender; flexibilidade de pensamento; interesse por temas de áreas diversas que vão além do que está aprendendo; realização dos trabalhos escolares com autoria; manifestação de interesse em conhecer para além do que o professor ensina.

É importante demarcar a singularidade de expressão de cada criança no processo de aprender, sendo que, o que definimos como critérios de escolha, foram elementos iniciais para nos aproximarmos da especificidade da aprendizagem criativa da leitura e da escrita. Os elementos principais que permearam a escolha dos participantes da pesquisa, estiveram organizados pelas três características apontadas por Mitjáns Martínez (2012a), as quais incluem os comportamentos acima destacados: personalização da informação; confrontação com o dado; produção, geração de ideias próprias e novas que transcendem o dado.

Mesmo com tais características, mantivemos nosso olhar aberto e atento para novas possibilidades de expressão da criatividade na aprendizagem da leitura e da escrita da criança. O processo de escolha se organizou por aproximadamente 3 meses, no qual realizamos observações das crianças, diálogos em momentos informais com as professoras, assim como procedemos à análise das produções escritas das crianças.

\subsubsection{Construção do cenário social da pesquisa}

A construção do cenário social da pesquisa consiste no processo de envolver os participantes, momento de decisão quanto à participação na mesma, em que o pesquisador estabelece uma relação de confiança e também se familiariza tanto com os participantes, quanto com o contexto de realização da investigação (GONZÁLEZ REY, 2005a). Abaixo organizamos elementos substanciais que participaram da construção e manutenção do cenário social de nosso trabalho em campo.

\subsubsection{A entrada na escola: abertura para um processo colaborativo}

Nosso contato inicial na escola foi com a diretora e com a coordenadora pedagógica dos primeiros anos do ensino fundamental. Em um processo dialógico, foi possível apresentar nossos objetivos e também conhecer um pouco da escola, em sua organização de turmas, horários e outros elementos de seu funcionamento. Destacamos a receptividade com que 
fomos recebidos e também em relação à nossa pesquisa e, ainda, percebemos o interesse da equipe gestora na realização do trabalho na escola, com o intuito de contribuir com novas reflexões sobre o processo de aprendizagem. A pesquisa foi desenvolvida com a autorização inicial da direção (Anexo A) e posteriormente com a autorização da Secretaria Municipal de Educação de Uberlândia (Anexo B).

\subsubsection{Contato com os professores: diálogos preliminares}

Outro momento da construção do cenário social, que teve duração de aproximadamente três meses, foi associado às conversas informais com as professoras dos primeiros anos do ensino fundamental do turno da tarde. Momento em que explicamos o objetivo da pesquisa e nos inteirarmos da disponibilidade em podermos participar, da dinâmica do trabalho pedagógico e do cotidiano dos aprendizes.

Das três professoras envolvidas, a professora Daniela ressaltou que a pesquisa na escola em questão seria inviável, por se tratar de alunos de baixa renda e que não demonstravam nenhum tipo de criatividade em sala de aula. A professora Eliana enfatizou que sua metodologia não poderia a formação de alunos criativos, pois segundo ela, esta não era associada à liberdade, a recursos lúdicos, ou mesmo à arte, que indicariam criatividade em sala de aula. Apenas a professora Melissa destacou elementos de seus alunos que poderiam indicar criatividade, dentre os quais citamos: interesse, perguntas desafiadoras, dentre outras.

Mesmo diante de tais especificidades, as três professoras se mostraram receptivas à pesquisa e autorizaram nossa entrada em sala de aula. Assumimos o compromisso dialógico com a professoras sobre o processo de identificação dos possíveis participantes, assim como sobre as construções e instrumentos elaborados no decorrer da pesquisa. Durante três meses, nossas observações ocorreram nas três turmas de primeiros anos, assim como participamos de reuniões, dinâmicas conversacionais e momentos informais com as professoras regentes e com as crianças.

Após a definição dos alunos participantes da pesquisa, que explicitaremos logo abaixo, os quais integravam a turma da professora Melissa, passamos a nos reunir apenas com essa professora. Melissa tinha interesse em participar da pesquisa e demonstrava curiosidade em acompanhar as elaborações do presente estudo. Para exemplificarmos apresentamos uma de suas falas em um momento informal, em que conversávamos sobre o curso da pesquisa: “Nossa Lu! Eu estou aprendendo tanto com você. Agora eu entendo quanta coisa eu não 
conseguia ver nos alunos!" 34 Compreendemos que essa fala expressa o seu envolvimento como sujeito na pesquisa e de ser este um espaço de aprendizagem e desenvolvimento, o que, para nós, constituiu uma característica fundamental da organização do cenário social da pesquisa.

\subsubsection{Inserção na rotina dos aprendizes}

Durante os três primeiros meses da pesquisa experienciamos o contexto social da sala de aula e nos aproximarmos cada vez mais dos aprendizes. Recorremos a uma estratégia, que consideramos ser importante via para o trabalho com crianças, a qual refere-se à forma como buscamos sentar próximos aos alunos, em carteiras comuns, momento em que estabelecemos vínculos próximos pautados na confiança. O que ocorreu, dentre outras, pela forma como os alunos nos pediam materiais escolares emprestados, assim como combinavam conosco sobre o que poderíamos brincar no recreio.

Inserimo-nos na dinâmica das experiências das crianças e, em conjunto com as professoras regentes, selecionamos dez crianças, no âmbito das três turmas, que apresentavam características de criatividade na aprendizagem, para uma dinâmica conversacional que envolvia o objetivo da pesquisa. Para isso, utilizamos dois vídeos ${ }^{35}$, e organizamos dois encontros com os aprendizes para assisti-los e dialogar sobre o conteúdo (Apêndice A). Neste momento, identificamos a expressão de euforia das crianças em experienciar situações fora do contexto da sala de aula, assim como foi possível perceber o interesse e a curiosidade de alguns aprendizes pela leitura e pela escrita.

Após as observações, as dinâmicas conversacionais e os momentos informais com as crianças, dentre as 10 crianças, apenas seis mantiveram características de criatividade e após três meses de nosso contato com os aprendizes, apenas três demonstravam interesse pela leitura e escrita no contexto da sala de aula e para além do solicitado nas atividades de sala de aula. Desta forma, ao longo da pesquisa, pelas características da aprendizagem criativa, fizemos opção por estas três crianças. Destacamos que os três aprendizes experienciavam um mesmo contexto de sala de aula, ou seja, os três alunos eram da sala da professora Melissa e que os acompanhamos por dois anos consecutivos (2011 e 2012), totalizando 22 meses.

\footnotetext{
${ }^{34}$ Para o presente estudo optamos por reconstruir as falas dos participantes da pesquisa, de forma a garantir sua inteligibilidade pelo leitor.

35 Os vídeos foram escolhidos pela pesquisadora, por trazerem temas associados à leitura e à escrita, assim como pela qualidade da linguagem e da imagem.
} 


\subsubsection{Contato com as famílias: um processo de parceria}

O contato com os familiares das crianças ocorreu após a nossa definição de quais seriam as crianças que participariam da pesquisa. Por ser uma pesquisa realizada com crianças e no âmbito da temática da subjetividade, buscamos conhecer os familiares mais próximos das crianças, pais, tias e avós, para que pudessem autorizar a participação das crianças na pesquisa, assim como também estivessem conosco na pesquisa, em alguns momentos. Chamou nossa atenção a forma como, principalmente os pais, ao conhecerem os objetivos da pesquisa, ressaltaram que não há criatividade em suas crianças e, ao mesmo tempo, ficaram lisonjeados pela escolha de seus filhos para participação no trabalho.

A participação, em especial das mães, na pesquisa, foi expressiva e demonstraram total disponibilidade para colaborar. Podemos exemplificar por algumas falas das mães, que, em momentos informais durante o primeiro ano da pesquisa disseram: "Eu fiz um caderno pra escrever tudo que o Gabriel está fazendo de diferente em casa. Estou amando vim aqui falar com você sobre ele." (Mãe de Gabriel). "O Murilinho está escrevendo história e eu leio com ele, aí né, eu aprendo também. Eu acho que ele é criativo." (Mãe de Murilo). "A Adriana adora você Luciana. Eu acho que todo ano tinha que ter essas pesquisas na escola, pra poder acompanhar o aluno bem de perto." (Mãe de Adriana). Tais falas expressam que a criação do cenário social implica os participantes de forma ativa e como sujeitos do processo da pesquisa.

Destacamos que os familiares responsáveis pelas crianças participantes da pesquisa e as professoras envolvidas, tiveram acesso ao Termo de Consentimento Livre e Esclarecido (Apêndice T - Familiares; Apêndice U - Professoras), e mediante leitura e assinatura dos envolvidos, iniciamos a pesquisa com a autorização prévia.

\subsubsection{Produção de informação: itinerário da pesquisa de campo}

Acompanhou nosso trabalho efetivo, o diário de campo, que consistiu recurso importante de registro do pesquisador, a partir de situações e reflexões que envolviam os casos em estudo. O diário de campo, indicado por González Rey (2011f), como uma exigência do tipo de pesquisa que empreendemos, não tem como objetivo o relato descritivo dos acontecimentos, mas possibilitar o registro personalizado dos mais variados momentos experienciados pelo pesquisador no campo de pesquisa, com destaque às ideias e reflexões.

Importantes se fizeram as gravações, de alguns momentos em campo, em áudio e vídeo, tendo em vista a sua utilização para posterior análise. Essas gravações ocorreram com 
o intuito de consolidar os registros feitos no diário de campo, tendo em vista a riqueza e a dinamicidade do momento investigado, o qual, ao envolver o pesquisador na produção constante de ideias e nos mais variados processos interativos, faz com que muitas situações sejam preservadas em sua originalidade para subsidiar as construções do pesquisador.

Nosso intuito não foi apreender a totalidade dos acontecimentos, o que é inviável, pois estamos frente a situações humanas que demandam formas próprias de subjetivação das experiências, mas sim, ao recorrermos às gravações em áudio e vídeo, temos a possibilidade de rever acontecimentos que podem ser fontes para novas elaborações que, no momento da experiência pela imersão do pesquisador na situação, podem não serem produzidas.

Neste movimento dinâmico e flexível que caracterizou nossa investigação, lançamos mão da utilização de diferentes instrumentos e procedimentos para elaborações sobre nossos objetivos de pesquisa. Segundo González Rey (2011f), os instrumentos não constituem um fim em si mesmo, mas correspondem a procedimentos direcionados a favorecer a expressão do participante e por isso, constituem indutores de informação que não se limitam ao que é expresso pela linguagem, mas contribui para que o pesquisador elabore indicadores que vão configurando o modelo teórico da pesquisa.

Foi na relação com os participantes da pesquisa que definimos e elaboramos os instrumentos que compõem a presente pesquisa, tendo em vista a especificidade de uma investigação que prioriza a expressão espontânea do participante e o seu envolvimento com o trabalho. Em nossa pesquisa compreendemos que cada instrumento adquire um sentido para o participante da pesquisa, o que se associa às relações que se organizam no curso da realização do instrumento na pesquisa (GONZÁLEZ REY, 2011f). O papel do pesquisador, na criação de um clima interativo e saudável na pesquisa, independe do tipo de instrumento utilizado, mas se concretiza durante a sua elaboração e utilização.

Assumimos que a função dos instrumentos de pesquisa é de se tornarem "[...] verdadeiros 'trechos vivos' de informação quando conseguimos converter nossa relação com os sujeitos estudados em um espaço produtor de sentidos subjetivos, no qual sua expressão com e diante do pesquisador cobra um sentido particular para o sujeito." (GONZÁLEZ REY, 2005a, p. 165). Desta forma, a elaboração e a própria utilização dos instrumentos são guiadas pelos objetivos específicos da pesquisa, na sua inter-relação com as ideias e reflexões vinculadas à simultaneidade entre o campo empírico e teórico, tendo em vista nosso objetivo geral de investigação.

Nesse caso, o investigador qualitativo passa a ser percebido como um sujeito da pesquisa, em seu caráter ativo, reflexivo, atuante, relacional e produtor de experiências e 
caminhos, em suas possibilidades de criação de espaços próprios de atuação em um processo vivo e diferenciado (GONZÁLEZ REY, 2011f). O que nos permite a criação de instrumentos e a utilização de uma variedade de outros instrumentos já utilizados em outras investigações e que são, para nós, relevantes, do ponto de vista da possibilidade de expressão dos participantes. A seguir, explicitamos, de forma detalhada, cada instrumento, seus objetivos e os participantes. A utilização dos instrumentos não seguiu a ordem escolhida para apresentálos no presente tópico, mas se organizaram em momentos distintos da pesquisa.

\subsubsection{Processo de participação no cotidiano escolar}

Do nosso ponto de vista, a Epistemologia Qualitativa (GONZÁLEZ REY, 2005a) abre novas zonas de sentido para a pesquisa que envolve o cotidiano escolar. Desta forma, o pesquisador precisa adentrar pelo cotidiano experienciado pelos participantes da pesquisa, tendo em vista a aproximação aos sistemas relacionais, em que estão presentes comportamentos e processos comunicacionais que envolvem a expressão dos sujeitos. Para isso, nos munimos da qualidade que a observação participante e que os momentos informais oferecem para a geração de informações. Para nosso problema de pesquisa, não podemos encontrar respostas via expressões comportamentais diretas dos participantes. No entanto, essas se tornam fontes que confrontadas com outras informações advindas de diferentes instrumentos da pesquisa, constituem vias favorecedoras da produção de indicadores associados aos nossos objetivos de pesquisa. Para isso, nossa participação no cotidiano escolar, com ênfase à observação e aos momentos informais, se fez presente nos dois anos em que acompanhamos as crianças participantes da pesquisa.

\subsection{Observação participante}

A observação participante consiste em um instrumento utilizado no decorrer da pesquisa de campo, pela possibilidade que engendra de compreendermos aspectos intencionais e não-intencionais que subjazem ao processo de aprendizagem da leitura e da escrita da criança, através de comportamentos, emoções e rituais que compõem a trama social (GONZÁLEZ REY, 1997). Nosso objetivo foi perceber experiências, comportamentos, expressões diversas da criança em seu dia a dia na escola, atentando-nos para as estratégias de aprendizagem, bem como para os aspectos relacionais que envolveram o aprender. Explicitamos no Apêndice B o roteiro de observação participante, a qual ocorreu na sala de aula, no laboratório de informática, na biblioteca; no pátio (momento de recreio/lanche) e na entrada e saída das crianças na escola; nas reuniões pedagógicas e com familiares. 


\subsection{Momentos informais}

Os momentos informais constituíram fontes de produção de informação que se apresentaram como essenciais, pois, na informalidade, a expressão dos participantes pode acontecer, seja esta intencional ou mesmo não intencional, o que nos permitiu a elaboração de indicadores sobre a constituição da subjetividade (GONZÁLEZ REY, 2005a). Os momentos informais se caracterizam por serem momentos não planejados previamente por nós, mas que ocorrem em circunstâncias do cotidiano escolar que nos permitiram dialogar com os participantes e até mesmo confrontá-los com informações advindas de outros instrumentos da pesquisa. Por isso, os momentos informais participaram de todo o processo da pesquisa e envolveu tanto as crianças, quanto professores, familiares e outros participantes.

\subsubsection{Sistemas conversacionais}

A comunicação constituiu o motor que movimentou e conferiu às nossas relações com os participantes da pesquisa, um caráter de abertura e confiança, que viabilizou expressões autênticas dos indivíduos. Assim como González Rey (2005a, 2007b, 2011f), compreendemos que a comunicação perfaz o cenário que facilita e torna possível a assunção do sujeito, que aparece em sua reflexividade autêntica, espontânea e ativa. Organizamos os sistemas conversacionais em dois momentos: entrevistas como processo e dinâmicas conversacionais.

A entrevista assume um caráter dialógico e interativo, que compõem o clima entre pesquisador e participantes da pesquisa, rompendo com a lógica da pergunta e resposta, para se configurar em uma epistemologia da produção. Neste contexto, não se espera apenas respostas dos participantes, mas insere-os em situações que demandam reflexão. Na mesma direção, a dinâmica conversacional, com foco em temas abertos, oportuniza a expressão dos participantes em seu caráter ativo em um processo que os impliquem em transitar pela trama complexa de suas experiências subjetivas (GONZÁLEZ REY, 2005a). Os dois instrumentos envolveram a participação das crianças, das professoras e dos familiares.

\subsection{Entrevista}

O objetivo maior foi possibilitar interação verbal e não verbal entre a pesquisadora e os participantes da pesquisa, em seu caráter flexível, aberto e dialógico. Organizamos os seguintes roteiros: a) Roteiro da entrevista I com as crianças participantes da pesquisa Apêndice C; b) Roteiro da entrevista II com as crianças participantes da pesquisa - Apêndice 
D; c) Roteiro da entrevista III com as crianças participantes da pesquisa - Apêndice E; ed) Roteiro da entrevista IV com as crianças participantes da pesquisa - Apêndice F.

\subsection{Dinâmicas conversacionais}

O objetivo foi propiciar a expressão do participante, a partir de temas vinculados aos objetivos da pesquisa. Destacamos os seguintes eixos temáticos: a) Eixos temáticos da dinâmica conversacional I com os familiares das crianças participantes da pesquisa Apêndice G; b) Eixos temáticos da dinâmica conversacional II com os familiares das crianças participantes da pesquisa - Apêndice H; c) Eixos temáticos da dinâmica conversacional I com as professoras das crianças participantes da pesquisa - Apêndice I; d) Eixos temáticos da dinâmica conversacional II com as professoras das crianças participantes da pesquisa Apêndice J; e) Eixos temáticos da dinâmica conversacional III com as professoras das crianças participantes da pesquisa - Apêndice K; e f) Eixos temáticos da dinâmica conversacional com as crianças participantes da pesquisa sobre seus registros - Apêndice $\mathbf{L}$.

\subsubsection{Instrumentos apoiados em registros escritos e não escritos}

Nossa opção pela diversificação de instrumentos justifica-se pela própria natureza do trabalho, associada à subjetividade humana, o que pressupõe a necessidade de vias de expressão que possam favorecer ao participante transitar por diferentes experiências (GONZÁLEZ REY, 2011f). A seguir, fazemos referência a cada instrumento utilizado e seu objetivo. Esses instrumentos foram realizados com as crianças participantes da pesquisa.

\subsection{Diário de ideias}

O instrumento Diário de ideias (Apêndice M) foi elaborado pela pesquisadora com o objetivo de compreender como a escrita pode possibilitar que a criança gerasse novas ideias a partir de uma atividade que privilegie a necessidade do próprio aprendiz de exercer a escrita, sem a intervenção do pesquisador, escola ou mesmo de qualquer elemento externo. Como espaço de produção espontânea da criança e não só o que a escola a solicita em seu dia a dia. Este material acompanhou as crianças no decorrer dos dois anos de realização da pesquisa.

\subsection{Oficina de leitura e escrita}

O instrumento Oficina de leitura e escrita (Apêndice $\mathbf{N}$ ) foi elaborado pela pesquisadora com o objetivo de propor situações lúdicas que envolvessem a leitura e a escrita. 
$1^{\circ}$ Momento: escolha espontânea de um livro para leitura pela criança. Durante a leitura, solicitamos que expressasse comentários e possibilidades de inserções na história.

$2^{\circ}$ Momento: leitura pela criança da história "Você troca?" da autora Eva Furnari ${ }^{36}$. Proposta de escrita espontânea de uma história sobre um tema de seu interesse.

\subsection{Montando minha história}

O instrumento Montando minha história (Apêndice O) foi elaborado pela pesquisadora com o objetivo de conhecer a história de vida da criança.

$1^{\circ}$ Momento: criação do autorretrato, com argila e/ou massas de modelar coloridas;

$2^{\circ}$ Momento: leitura da história “As Memórias da Bruxa Onilda ${ }^{37 "}$ de Roser Larreula e diálogo sobre a história de vida do participante da pesquisa, tendo em vista suas preferências, gostos, características e outros aspectos que queria destacar.

$3^{\circ}$ Momento: leitura do livro "O pintor de lembranças ${ }^{38 "}$ do autor José Antonio del Cañizo e diálogo sobre momentos felizes da vida familiar ou escolar e outros que gostaria de modificar.

\subsection{Brincando de escolinha}

O instrumento Brincando de escolinha (Apêndice P) foi elaborado pela pesquisadora a partir das ideias germinais de González Rey (2005a), sobre o potencial do uso de fantoches e das dramatizações. Nosso objetivo com o presente instrumento foi compreender a significação das experiências escolares pelas crianças. Propusemos dois momentos para expressão da criança a partir do tema "Minha vida na escola", sendo o primeiro a utilização de fantoches e o segundo dramatização com a utilização de materiais escolares.

\subsection{Trilha das frases}

O instrumento Trilha das frases (Apêndice Q) foi elaborado pela pesquisadora, a partir de Completamento de Frases criado por González Rey e Mitjáns Martínez (1989). Tendo em vista o nosso problema de pesquisa e, considerando que os participantes são crianças em momento de aprendizagem da leitura e da escrita, reelaboramos algumas frases do instrumento original e o utilizamos a partir de um jogo de caminhar com um pino por uma trilha, no qual retirava-se uma carta com descritor e imediatamente a criança falava o que lhe

\footnotetext{
${ }^{36}$ FURNARI, Eva. Você troca? São Paulo: Moderna, 2012.

${ }^{37}$ LARREULA, Roser. As Memórias da Bruxa Onilda. Scipione, 2003.

${ }^{38}$ CAÑIZO, José Antonio del. O pintor de lembranças. Projeto, 1995.
} 
viesse à cabeça referente à comanda. Para o jogo, utilizamos um total de 51 frases. O objetivo foi compreender elementos subjetivos que participavam da aprendizagem da criança.

\subsection{Mapa do tesouro}

O instrumento Mapa do tesouro (Apêndice R) foi elaborado pela pesquisadora, com o objetivo de propiciar a expressão da criança sobre o processo de aprender.

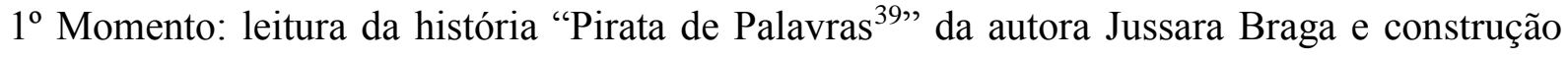
pelos participantes, de um mapa para se chegar ao tesouro da leitura e da escrita, contendo o caminho percorrido. Confecção de um baú de dicas para se alcançar o tesouro.

$2^{\circ}$ Momento: registro da criança por meio de desenho e/ou escrita, a partir de suas reflexões sobre o tema: "Minha aprendizagem da leitura e da escrita". Elaborado mediante as contribuições de González Rey (2005a) sobre o instrumento redação, que permite a elaboração pessoal sobre um tema de interesse para o participante.

\subsection{Minhas mudanças}

O instrumento Minhas mudanças (Apêndice S) foi elaborado pela pesquisadora a partir da proposta de González Rey (2005a) de utilização de filmes e, teve como objetivo conhecer as mudanças dos participantes associadas ao processo de aprender a ler e a escrever. $1^{\circ}$ Momento: assistir ao filme "Robots ${ }^{40 "}$ e dialogar com os participantes.

$2^{\circ}$ Momento: registro pelo participante das mudanças ao longo do processo de aprendizagem. $3^{\circ}$ Momento: escrita espontânea de uma história com o tema: "Minhas mudanças".

\subsection{Sistema de produções escritas}

O sistema de produções escritas consiste em um instrumento criado pela pesquisadora, com o foco para o que é escrito de forma geral, no contexto escolar de uma forma geral. $\mathrm{O}$ objetivo, que ultrapassa uma análise descritiva, foi compreender a processualidade na produção da escrita, em um exercício pleno de diálogo sobre o que é elaborado. Processo que ocorreu tanto associado às produções das crianças, quanto à própria escola de forma geral. Este instrumento foi utilizado no decorrer de toda a pesquisa e foi referência para o trabalho com os instrumentos, acima citados, que contaram com o registro escrito.

\footnotetext{
${ }^{39}$ BRAGA, Jussara. Pirata de Palavras. Editora do Brasil, 2009.

${ }^{40}$ Ficha técnica: Gênero: Animação/Aventura. Direção: Chris Wedge; Carlos Saldanha. Duração: 1h30min. Ano: 2005.

País: Estados Unidos da América.
} 


\subsubsection{Momentos de utilização dos instrumentos no devir da pesquisa}

Sobre os instrumentos e procedimentos da pesquisa, vale destacar que não foram utilizados indistintamente com os participantes mas contaram com o olhar para a singularidade dos interesses e expressão de cada um. Pelo tempo que convivemos com as crianças, foi possível uma relação processual com os instrumentos e procedimentos da pesquisa, os quais foram criados a partir da relação com os participantes. As informações geradas, a partir dos instrumentos, constituíram fontes de elaborações singulares, ou seja, alguns instrumentos expressaram informações que nos possibilitaram um nível de elaboração diferenciado em relação a um caso que, pode não ter o mesmo movimento para os outros.

Foi possível experienciar com cada participante, os diferentes procedimentos e instrumentos, uma vez que fizemos parte do contexto escolar por dois anos consecutivos, em que nossa presença se fez de duas a três vezes por semana na escola. Temporalidade relevante para pesquisas com ênfase no desenvolvimento da subjetividade humana. Em um processo investigativo de caráter aberto e flexível, disponível para o imprevisto, possibilitamos às crianças a expressão por diferentes linguagens: oral, escrita, pictórica, corporal e outras.

A utilização dos instrumentos ocorreu, de formas diversas, em momentos do contexto da sala de aula, assim como em espaços mais individuais de trabalho, em que utilizávamos o próprio pátio da escola ou mesmo uma sala destinada a aulas de reforço escolar para alunos do turno da manhã. As saídas das crianças da sala de aula para os trabalhos da pesquisa, foi algo definido juntamente com a professora regente e com as crianças. Privilegiamos momentos em que os aprendizes terminavam suas atividades em sala de aula e esperavam os colegas para que a professora iniciasse outra atividade, assim como momentos em que as próprias crianças espontaneamente nos convidavam para conversar.

Os instrumentos e procedimentos da pesquisa corresponderam a momentos individuais, grupais e coletivos. Dentre os individuais estiveram: entrevista; dinâmicas conversacionais; montando minha história e minhas mudanças. Nos grupais, que envolveram simultaneamente as crianças da pesquisa, destacamos: oficina de leitura e escrita; brincando de escolinha e mapa do tesouro. O instrumento diário de ideias ocorreu em momentos que foram individuais e grupais. Nos momentos coletivos de sala de aula, contamos com a observação e o próprio trabalho com o filme, processo que envolveu a turma.

Entendemos que o lugar do pesquisador em uma busca por compreender os processos subjetivos da criança, implica confrontar, sacar o participante de sua zona de conforto, para 
que ele possa se expressar de forma livre (GONZÁLEZ REY, 2013 ${ }^{41}$ ). Por isso, pressupomos que nenhuma ação do pesquisador impacta de forma direta o processo de aprender e tira a originalidade da expressão do sujeito, pois, do ponto de vista da subjetividade não há um dado a ser coletado, mas um sujeito gerador que se expressa frente às experiências. $\mathrm{O}$ quadro a seguir, ilustra a utilização dos momentos de utilizados dos instrumentos:

Quadro 2 - Momentos de realização dos instrumentos e procedimentos da pesquisa durante os anos de 2012 e 2013.

\begin{tabular}{|c|c|c|c|c|}
\hline Instrumentos & $\begin{array}{c}\text { Momentos de } \\
\text { utilização na } \\
\text { pesquisa } \\
\end{array}$ & Local & $\begin{array}{c}\text { Tempo } \\
\text { aproximado de } \\
\text { cada sessão } \\
\end{array}$ & Participantes \\
\hline $\begin{array}{l}\text { Cenário social } \\
\text { da pesquisa }\end{array}$ & \multirow{6}{*}{$\begin{array}{c}\text { Durante toda a } \\
\text { pesquisa }\end{array}$} & $\begin{array}{l}\text { Diferentes contextos do } \\
\text { cotidiano escolar }\end{array}$ & $1 \mathrm{~h}$ & \multirow{2}{*}{$\begin{array}{l}\text { Crianças e } \\
\text { professores }\end{array}$} \\
\hline Observação & & $\begin{array}{c}\text { Salas de aulas/recreio/ } \\
\text { Biblioteca/ } \\
\text { entrada e saída da escola }\end{array}$ & $4 \mathrm{~h}$ & \\
\hline $\begin{array}{l}\text { Momentos } \\
\text { informais }\end{array}$ & & $\begin{array}{c}\text { Sala de aula/recreio/ } \\
\text { entrada e saída da escola }\end{array}$ & $30 \mathrm{~min}$ & \multirow{3}{*}{$\begin{array}{c}\text { Crianças, } \\
\text { professores e } \\
\text { familiares }\end{array}$} \\
\hline Entrevista & & \multirow{2}{*}{$\begin{array}{c}\text { Biblioteca/sala de } \\
\text { professores/sala de } \\
\text { apoio }\end{array}$} & \multirow[t]{2}{*}{$1 \mathrm{~h}$} & \\
\hline $\begin{array}{c}\text { Dinâmica } \\
\text { conversacional }\end{array}$ & & & & \\
\hline $\begin{array}{l}\text { Sistema de } \\
\text { produções } \\
\text { escritas }\end{array}$ & & $\begin{array}{l}\text { Biblioteca/salas de } \\
\text { aulas/ sala de } \\
\text { professores/painéis }\end{array}$ & $1 \mathrm{~h} 30 \mathrm{~min}$ & $\begin{array}{l}\text { Crianças e } \\
\text { professores }\end{array}$ \\
\hline Diário de ideias & $\begin{array}{c}\text { Durante toda a } \\
\text { pesquisa }\end{array}$ & \multirow{7}{*}{$\begin{array}{c}\text { Biblioteca/sala de } \\
\text { apoio/refeitório/pátio }\end{array}$} & \multirow{7}{*}{$1 \mathrm{~h} 30 \mathrm{~min}$} & \multirow{7}{*}{ Crianças } \\
\hline $\begin{array}{c}\text { Oficina de } \\
\text { leitura e escrita }\end{array}$ & \multirow{3}{*}{$\begin{array}{l}\text { Seis sessões: } \\
\text { três sessões no } \\
\text { primeiro ano da } \\
\text { pesquisa e três no } \\
\text { segundo ano. }\end{array}$} & & & \\
\hline $\begin{array}{l}\text { Montando } \\
\text { minha história }\end{array}$ & & & & \\
\hline $\begin{array}{l}\text { Minhas } \\
\text { mudanças }\end{array}$ & & & & \\
\hline Trilha das frases & \multirow{3}{*}{$\begin{array}{l}\text { Quatro sessões: } \\
\text { duas sessões no } \\
\text { primeiro ano da } \\
\text { pesquisa e duas } \\
\text { no segundo ano. }\end{array}$} & & & \\
\hline Mapa do tesouro & & & & \\
\hline $\begin{array}{l}\text { Brincando de } \\
\text { escolinha }\end{array}$ & & & & \\
\hline
\end{tabular}

Fonte: elaborado pela autora, 2015.

\footnotetext{
${ }^{41}$ Informação fornecida oralmente em aula realizada na UniCEUB/Brasília, disciplina Atividades Programadas em Escola, Aprendizagem e Trabalho Pedagógico, pelo professor Fernando González Rey em 2013.
} 


\subsubsection{Processo construtivo-interpretativo: configuração do modelo teórico}

Para esse trabalho, assumimos o compromisso construtivo-interpretativo de produção de conhecimento na pesquisa, que implica o caráter simultâneo que as informações advindas dos instrumentos utilizados assumem e o processo interpretativo do pesquisador. A interpretação se organiza como processo gerador de indicadores, como unidades essenciais da informação, construídos pelo pesquisador e que favorecem a rota reflexiva do curso da pesquisa (GONZÁLEZ REY, 1997, 2005a, 2014b). No presente trabalho, optamos pela dinâmica de expor algumas informações para ilustrar nossas elaborações, assim como destacamos algumas produções das crianças em forma de anexos, as quais não representam a totalidade de informações e registros produzidos ao longo da pesquisa.

Nosso movimento metodológico expressa a dinâmica configuracional entre informações de diferentes instrumentos e momentos da pesquisa, assim como demonstra que a interpretação não se expressa na e pela fala do participante, mas está nas elaborações que o pesquisador é capaz de realizar. Desta forma, cuidamos para ter um olhar aberto às expressões do participante, com ênfase à qualidade do processo de linguagem, tendo em vista um conjunto de elementos que, dentre outros, envolveram: gestos; expressões faciais, corporais e orais; intensidade e ênfase conferida a determinados elementos; à processualidade e aos tipos de registros e seus conteúdos.

A elaboração de indicadores ocorreu de forma simultânea e concomitante à utilização dos instrumentos e procedimentos da pesquisa. Movimento que requer do pesquisador a condição ativa, reflexiva e criativa no trabalho de análise das informações e proceder aos encaminhamentos posteriores de continuidade da pesquisa. Sendo assim, toda ação realizada no campo da pesquisa está associado às reflexões que perpassam o curso da investigação.

Os indicadores formam um conjunto de reflexões do pesquisador sobre as informações da pesquisa, que se desdobram em hipóteses teóricas. A constituição de uma hipótese está associada às possibilidades que o pesquisador encontra na elaboração do conjunto de indicadores de organizar momentos qualitativos que em sua configuração compõe uma hipótese. Desta forma, não é apenas um indicador que formará uma hipótese, mas um conjunto de indicadores que não se delimita pela quantidade, mas sim, pela sustentação e constituição de uma trama capaz de subsidiar elaborações mais contundentes de se organizarem como uma hipótese. 
Necessário se faz enfatizar que as construções e interpretações do pesquisador não se organizaram pelo acúmulo de material, mas cada momento empírico experienciado, envolveu uma atitude analítica, na construção de indicadores e hipóteses que foram configurando o modelo teórico em andamento. Em um processo de elaboração de modelo teórico definido por González Rey (2011c) como um sistema que capta a diversidade de hipóteses no seu curso, torna-se possível a organização dos mais diversos sentidos subjetivos em configurações subjetivas. O modelo teórico, como sistema hipotético em desenvolvimento, foi fundamental na geração de inteligibilidade do processo da pesquisa, rompendo-se com a ideia de verdade absoluta.

Perante complexos e irregulares processos que emanam da atividade de pesquisa, González Rey (1997, 2011f) nos brinda com o conceito de lógica configuracional, para dar conta dos complexos processos intelectuais que envolvem o desenvolvimento do conhecimento sobre a subjetividade no processo de produção do modelo teórico. Segundo o autor, não existe uma lógica definida a priori, mas uma elaboração atrelada aos processos reflexivos do próprio pesquisador no curso da pesquisa.

Nesta complexidade que envolve a realidade a ser estudada, González Rey (2005a) cria o conceito de zona de sentido, para destacar espaços geradores de inteligibilidade que se produzem no decorrer da pesquisa e se mantêm abertos à possibilidade de continuidade de seguir aprofundando em um campo teórico. A abertura de novas zonas de sentido, sobre um tema, gera a possibilidade de construção de novos processos de inteligibilidade e não fecham o conhecimento em estruturas rígidas e pré-definidas, com fins de validação. Para esse desafio, nos aventuramos a realizar, no próximo capítulo, nossas elaborações sobre os estudos de caso da pesquisa. 


\section{PRODUÇÃO TEÓRICA DA PESQUISAdORA I: PROCESSO CONSTRUTIVO-INTERPRETATIVO}

No presente tópico, organizamos o processo construtivo-interpretativo gerado no curso do trabalho, mediante as informações que foram produzidas pelos diversos momentos e instrumentos utilizados. Optamos por apresentar cada caso, que, em sua singularidade, contribuíram com elaborações fundamentais para o objetivo geral da presente pesquisa.

\subsection{O CASO DE MURILO}

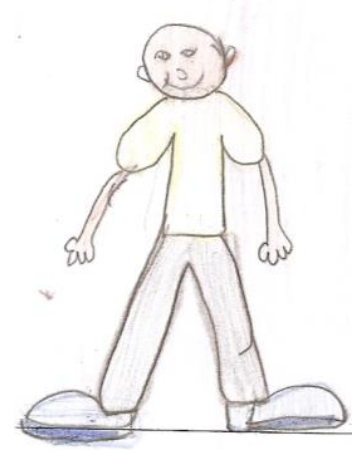

Figura 1: Produção de Murilo a partir do instrumento "Montando minha história" - 2013.

\subsubsection{Caracterização de Murilo}

Murilo iniciou o primeiro ano do ensino fundamental com seis anos de idade e completou nove anos no curso do terceiro ano da referida etapa de ensino. Morava com sua mãe, uma irmã mais nova, a tia e uma prima, assim como recebia constantes visitas do pai biológico da irmã e não conhecia o seu pai. De uma família de baixa renda, não dispunha de livros em casa e contava com o apoio da escola para aquisição de seus materiais escolares como mochila, cadernos e lápis. Pela história escolar do pesquisado, identificamos que ele era um aluno dedicado, interessado e responsável. Segundo avaliação diagnóstica realizada pelas professoras regentes, Murilo iniciou o $1^{\circ}$ ano na hipótese de escrita pré-silábica ${ }^{42}$ e concluiu o $2^{\circ}$ ano na hipótese alfabética ${ }^{43}$ de escrita. Um dos aspectos que chamou nossa atenção foi observar o intenso envolvimento de Murilo com as atividades de leitura e escrita, que estavam para além das exigências escolares.

\footnotetext{
42 De acordo com Ferreiro (1995) na hipótese de escrita pré-silábica a criança ainda não discrimina a grafia de uma palavra com outra e costuma escrever palavras relacionando com o tamanho do que está representando.

${ }^{43}$ Para Ferreiro (1995), na hipótese de escrita alfabética, a criança faz correspondência dos fonemas e sílabas.
} 


\subsubsection{Expressão da criatividade na aprendizagem da leitura e da escrita e suas relações com as estratégias de aprendizagem de Murilo}

No decurso da aprendizagem da leitura e da escrita de Murilo, identificamos características e estratégias que constituíram este processo como eminentemente criativo. Desta forma, compreendemos como as três características destacadas por Mitjáns Martínez (2012a) se expressaram, sendo as mesmas: personalização da informação, confrontação com o dado e produção de ideias próprias e novas que transcendem o dado. Além disso, foi possível identificar uma nova característica, que se alinhava às anteriores, e que denominamos como relação lúdica com a aprendizagem. Essa foi definida por nós como a relação pessoal, espontânea, gratuita, investigativa e voluntária do sujeito com a aprendizagem. Relação que possibilita a evasão da vida real, pela consciência de um faz de conta, de poder ousar nas produções e exceder as experiências vividas, pela criação de regras próprias e de um cenário imaginário. Apresentamos o vínculo entre as características e as estratégias de aprendizagem.

\subsubsection{Personalização da informação}

Interpretamos que a personalização da informação era uma característica que permitia a Murilo experienciar o processo de aprender como algo próprio, ao se inserir como sujeito de sua aprendizagem, com impactos em seu modo de vida. Identificamos que Murilo personalizava o modo de ensinar das professoras ao observar atentamente as explicações e ações das mesmas durante as aulas. Para ilustrar nossa elaboração, trouxemos uma das falas de Murilo no primeiro ano: "É só olhar a tia falar tudo. Eu sei até o que ela vai passar no quadro. Já faço tudo antes pra poder escrever mais coisas na tarefa do que a tia pediu." A compreensão constituiu a base para que Murilo buscasse transcender o que estava aprendendo, articulado às estratégias de autorregulação, relacionadas à atenção deliberada às explicações, o que lhe favorecia ir além do solicitado.

A personalização das explicações das professoras lhe permitia transcender o que era proposto ao confrontar-se com o que era instituído na subjetividade social da sala de aula, associado à necessidade de realizar a atividade da forma como a professora solicitava. A partir de uma de suas falas, podemos ilustrar nossa elaboração: "A tia gosta que faz do jeitinho que ela fala. Eu faço, mas aí eu coloco alguma coisa que fica diferente, mas aí ela nem vê." (Entrevista II). Murilo personalizava a própria metodologia da professora Melissa, por se sentir próximo às explicações e se familiarizar com o ensino voltado para situações da vida cotidiana. Ele recorria à estratégia de autorregulação de associar o conteúdo aprendido com as 
suas experiências. Esse processo pode estar relacionado à flexibilidade da professora Melissa em realizar o seu planejamento de aula, reconfigurando o mesmo a partir da relação com os alunos. Para exemplificarmos elencamos a fala abaixo:

\section{Dinâmica conversacional III}

Professora Melissa: [...] eu não tenho aquela metodologia definida, vai ser assim, agora nós vamos trabalhar só assim, não, né? No decorrer, aquilo que eles vão pedindo vai acontecendo [...] acho que tem que ter alguma coisa para puxar, a partir do interesse deles, uma música, uma dobradura.

A professora Melissa mantinha uma forma de explicação do sistema alfabético de escrita a partir de perguntas, o que favorecia a implicação de Murilo na intencionalidade de refletir. Ela valorizava as respostas individuais da turma e não aquelas em coro, em que todos falavam ao mesmo tempo. Murilo participava e já antecipava algumas respostas, porém nem sempre se expressava oralmente para a turma, muitas vezes respondia baixinho, apenas para ele mesmo e alguns momentos, ele direcionava sua resposta à professora ou colegas.

Interpretamos que a aprendizagem não se derivava diretamente da metodologia utilizada pela professora, mas de como Murilo a personalizava, tornava-a própria em um processo que envolvia transformá-la e configurá-la de forma diferenciada. Essa construção pode ser exemplificada por uma das expressões de Murilo em um momento de escrita da palavra LILA no instrumento "Diário de ideias": "Porque Lila é I, aí tem o mesmo som LILA, I, aí o que eu vi na BOLA, BO - LA, aí eu vi que é o LA. A tia fala que é o som da letra que é pra olhar, mas dá pra saber com outra palavra que a gente já viu ou sabe falar." Outro exemplo que ilustra nossa elaboração foi o registro detalhado de Murilo, no instrumento "Mapa do tesouro" (Anexo C - Figura 4) da forma como a professora Melissa ensinava. No momento do registro, Murilo nos disse: "Tem dia que a tia ensinava aquelas letra A E I O U e eu já queria saber as outras. Aí eu olhava lá naquelas letra da parede e aí eu juntava elas."

O processo de personalizar as explicações e a metodologia da professora, configurava novas possibilidades de Murilo atuar com sua própria aprendizagem, o que, de certa forma, tinha impactos em seu modo de vida. Pela forma como buscava se relacionar com o próprio entorno, na procura intencional por novas palavras, para estabelecer relações com sua escrita, o que o implicava em novas ações no mundo de estar mais atento ao escrito nos lugares, em um movimento de mudanças na forma como passou a querer sair mais de casa para novas descobertas. Podemos exemplificar nossa construção pela informação a seguir:

\section{Diário de ideias}

Murilo: Antes eu pensava assim, para que sai com a minha tia, ela vai só lá naquela loja. Agora eu vou com ela só pra olhar palavras, só pra saber como é que escreve. A tia sempre usa palavra que a gente conhece. Lá na loja que minha tia entrou, tava escrito sapataria, aí a tia um dia deu sapato no ditado e eu já sabia escrever (risos). 
Murilo também personalizava as atividades propostas em sala de aula, de diferentes tipos: ditado de palavras, completar letras, escrita espontânea (de palavras, frases e textos), leitura de livros, cópia da lousa (cabeçalho e atividades), contação e leitura de histórias, músicas, jogos, bem como livros da biblioteca e livro didático. Nestas, Murilo expressava desejo de imprimir uma marca própria em suas atividades, o que pode ser exemplificado a partir de uma de suas expressões:

Dinâmica conversacional I

Murilo: Ah (risos)! É tudo meu. Tudo que escrevo é meu. Eu gosto de fazer do meu jeito. Eu escrevo o meu nome com letra diferente da que a tia usa e também eu fico achando legal quando eu escrevo uma palavra que eu nem conhecia e aí eu escrevo.

O trecho acima expressa o como Murilo se identificava com seu processo de aprender mediante a sua própria inscrição em suas produções. Emoções formavam parte da qualidade de sua fala, mediante a maneira descontraída e segura de ser enfático e afirmar: "É tudo meu" e por vibrar e se encantar com suas produções, o que nos possibilitou compreender que aprendizagem era um processo pessoal. Mesmo sendo atividades comuns para todos os alunos da turma, Murilo gerava uma aproximação particular com as mesmas. Dentre os vários exemplos, destacamos um momento de produção espontânea de texto em sala de aula do primeiro ano, em que Murilo, ao ver-se diante de uma folha em branco e na busca por uma escrita própria, se lembrou do dia em que a colega Aline rasgou um desenho de um bombeiro e arrancou a cabeça dele. Momento em que Murilo disse: "Nossa! Ficou agora um bombeiro sem cabeça, é a lenda do bombeiro sem cabeça! Eu ainda não escrevi isso. Eu só falei."

Murilo transformou a atividade em algo pessoal, ou seja, ele tornou a atividade que lhe era alheia, em algo próprio e particular com implicações para ações que postergavam o ato de escrever, uma vez que passou a contar para os colegas a lenda do bombeiro estabelecendo vínculos afetivos mais próximos, com implicações para a sua qualidade de vida, associada à disponibilidade de tempo para estar com o outro. Compreendemos que Murilo, como sujeito de sua aprendizagem, buscava contextualizá-la, o que corrobora González Rey (2008a) ao afirmar que o sujeito desenvolve-se nas relações que estabelece entre o que aprende e a possibilidade de utilizar este aprender para nutrir a própria vida.

Murilo personalizava o contexto de aprendizagem, o qual consideramos como sendo a organização do espaço da sala de aula vinculado à leitura e escrita. As salas de aula eram organizadas com cartazes, alfabetos afixados acima da lousa, calendários, painéis de aniversariantes, entre outros materiais expostos para serem visualizados pelos alunos. As professoras demonstravam compromisso com a organização do contexto de aprendizagem e a escola dispunha de materiais suficientes para a confecção de cartazes e outros materiais. 
Murilo gerava formas de registrar o conteúdo escrito nos painéis em um caderno pessoal, ao atribuir significado às músicas e às receitas, unida às estratégias de autorregulação de utilização do aprendido em outros contextos, como em sua casa, bem como a forma como criava novas palavras a partir das existentes. Processos que implicavam posicionar-se como sujeito de sua aprendizagem orientado à abertura a novas experiências com impactos em seu modo de vida, pela forma como utilizava a leitura e a escrita como ponte para organizar momentos para estar perto de sua mãe. Ela era cozinheira e Murilo encontrou nas receitas que aprendia, uma maneira de dialogar com a mãe. Os trechos abaixo ilustram nossa elaboração:

\footnotetext{
Diário de ideias

Murilo: Sabe por que eu mandei meu primo fazer aquele caderno? Porque tem coisa na escola que é bão, aí não tem caderno para escrever. Tem aquelas musiquinhas lá, tem vez que faz biscoito, aí eu escrevo a receita lá. Tinha lá CORAÇÃO e eu fiz CÃO e ORAÇ̃̃o. Eu levei para minha mãe fazer aquela receita lá.

Dinâmica conversacional I

Murilo: Sabe aquele cartaz lá. A tia colocou PIPOCA e eu pensei que podia ser MILHO. Sabe por quê? A PIPOCA já é o MILHO que explodiu e na música é tudo PIPOCA. Devia começar com MILHO e só depois PIPOCA.
}

A relação de Murilo com o contexto de aprendizagem, a forma como o explorava, favoreceu a constituição deste espaço-tempo com múltiplas possibilidades em busca de algo novo que aguçava sua curiosidade, o que corrobora Chamberlain (2005) ao trazer a relação da criança com o contexto de aprendizagem como processo a ser descoberto. Murilo estabelecia uma relação personalizada com o contexto de aprendizagem, com o qual se sentia desafiado a aprender. Inferimos que, aprender, para Murilo, não se limitava ao material em si, mas à maneira como ele atribuía significado e gerava ações próprias frente ao contexto.

\subsubsection{Confrontação com o dado}

Murilo confrontava-se com suas próprias produções o que compreendemos estar associada à relação positiva com seus erros. Ele demonstrava uma postura aberta, crítica e descontraída frente aos erros no campo da leitura e da escrita e apresentava autonomia para corrigi-los. Esse processo se constituía no devir das atividades e se concretizava no diálogo consigo mesmo. Para ilustrar apresentamos uma de suas falas: "Eu penso e faço de novo. Eu olho e vejo se está errado mesmo e apago e faço de novo (risos). Eu vi que eu fiz errado. Eu apaguei e fiz com S, mas eu tô achando que é com C." (Entrevista II).

Concordamos com González Rey (2008a), quando ele afirma que a condição de sujeito na aprendizagem, pelo envolvimento com a atividade, pela organização pessoal e diferenciada com o material, está passível de erro. Neste viés, a confrontação com suas próprias produções esteve constituída pelo uso de estratégias de autorregulação associadas à 
supervisão autônoma de suas atividades. Para exemplificar destacamos a forma como leu o texto - com a temática JACA - escrito de forma espontânea por Murilo no instrumento "Diário de ideias". Ao perceber a repetição de uma de suas ideias disse: "Que que isso? E a jaca caiu e a jaca caiu e a jaca caiu, que tanta jaca caiu, a gente já entendeu que a jaca caiu (risos). Eu nem vi que tinha tanta 'jaca caiu', escrevi de uma vez."

Muitas vezes a própria forma que a palavra assumia, favorecia a modificação por Murilo ao comparar a sua escrita inicial com a de outro contexto, recorrendo a estratégia cognitiva associada à relação entre letras, sílabas e palavras. Processo que corrobora Bajard (2002), ao se referir à completude do código escrito - que inclui o fonográfico e está relacionado à imagem, ao contexto real em que se dá a ação, à frase e também à palavra, letra e som - ressalta que na aprendizagem não se foca em um único aspecto. Para o autor, a criança analisa o código gráfico na sua complexidade. Para ilustrar, mostramos um momento de tentativa de escrita de Murilo da palavra MACARRÃO em que se questionava: ' $E$ ' $O A$ ' $e$ $o$ 'T' e o 'til'? Tem acento? Sabia, porque fala assim RÃO se não ia falar assim RÁ, macarrá (risos)" e da palavra MERCEARIA: "Escreve com A ou T? É o C aqui? O S e o C. Mesaria, (risos) já sei, que a tia faz assim, é, Ra, tem um Ra, tem o Re, e tem o Ri o RO e o Ru. RA, RE, RI, RO, RU. Mesaria, ai eu ponho 'I' aqui, pronto." (Oficina de leitura e escrita).

Murilo confrontava-se com suas produções em um movimento dialógico consigo mesmo. Esse movimento lhe permitia atuar de forma investigativa sobre suas elaborações. No instrumento "Oficina de leitura e escrita", ao escrever uma palavra, conversava baixinho com ele mesmo dizendo: "Não. Não é assim que escreve. É com 'A'". Esta linguagem para si expressou o papel fundamental da comunicação, unida à estratégia de autorregulação, de reflexão sobre suas próprias produções. Em outro momento, no mesmo instrumento, após escrever, apagar e escrever novamente e observando a sua própria escrita da palavra PASSARINHO, ele disse para si mesmo: "Pensa que me engana hein letrinha?".

Do nosso ponto de vista, o processo de aprender criativamente de Murilo se constituiu como um modelo hipotético em andamento sobre o sistema alfabético de escrita, que decorria do levantamento de hipóteses sobre a sua escrita e pelos diversos questionamentos. Podemos ilustrar nossa elaboração pela escrita de Murilo da palavra FLOR em que disse: "Está faltando alguma letra, depois do F será qual eu sei que tem outra? Ah, é com L e depois vem o O e o R. É separado o A, eu tô achando que é." (Oficina de leitura e escrita).

A confrontação de ideias se configurava no próprio processo de planejar sua escrita, como uma estratégia de autorregulação que pode ser exemplificada por um dos momentos em que, antes de realizar a escrita de um texto, Murilo disse: “Eu vou pôr o passarinho lá no céu. 
Eu não tenho passarinho. Mas ele come o que mesmo? Se ele tiver voando lá em cima e molhar ele, ele vai morrer. No fio de energia, se ele tomar choque ele morre. Mas ele é forte e não vai morrer. Ele vai morar no ninho." (Oficina de leitura e escrita).

Murilo confrontava-se com as leituras que realizava, em um processo dialógico que demandava questionar o que lia, processo associado às estratégias de autorregulação de fazer inferências a partir de leituras. Interpretamos que ele buscava tornar a leitura algo próprio e pessoal e envolvia relações com suas experiências. Exemplificamos nossa construção, por um momento, no segundo ano, em que Murilo ao realizar a leitura de um livro disse: "Só pode está errado esse livro. Eu nunca vi lobo bonzinho. Eu vou lê até o final e sabe o que que vai acontecer e vê se o lobo pode mesmo ser diferente." (Oficina de leitura e escrita). Assim como por uma das falas de sua mãe: "Ele pega a Bíblia, ele mesmo procura o versículo, lê sozinho a Bíblia. Ele é muito inteligente. Ele dá opinião dele sobre a Bíblia." (Dinâmica conversacional I).

A confrontação também se expressou na utilização de estratégias cognitivas associadas à ação de Murilo em contrapor o que sabia com o que estava escrito em outros lugares. Podemos exemplificar tal construção a partir de um momento de observação, que envolvia a atividade de ditado em sala de aula do segundo ano. Murilo escreveu a palavra FAROFA e enquanto esperava a professora ditar a próxima palavra, ele se interessou por ler a marca de seu próprio apontador. Momento em que Murilo ria e dizia baixinho: "Eu sempre pensei que era CASTELO (risos). Mas será que aqui está certo mesmo? Será que é Faber-Castell?"

A confrontação de ideias com o outro e consigo mesmo se expressou nos processos de correção de atividades de escrita espontânea em que observamos que a professora Melissa, do primeiro ano, chamava individualmente os alunos em sua mesa. Dentre os vários episódios, podemos exemplificar nossa construção a partir de um momento de observação em sala de aula, em que presenciamos a correção da palavra PAPAI, que estava escrita por Murilo da seguinte forma PAPAE. A professora estabeleceu uma relação dialógica, pedindo para que ele lesse a palavra e indagou-o: “Murilo, você acha que tem alguma letra errada?”.

Murilo realizava a leitura silenciosamente da palavra e não identificava nenhuma correção necessária. A professora enfatizava o som das letras e repetia com intensidade a letra I. Ela escreveu a palavra no caderno de Murilo, que, ao retornar para a sua carteira, disse: " $E u$ não vou apagar não. É PAPAE mesmo". No entanto, Murilo se colocou a pensar sobre o que a professora disse e buscou em seu caderno uma atividade que tinha a palavra PAPAI. Após encontrar a palavra, disse em tom baixo: "É com I mesmo! Mas a gente fala PAPAE." 
Ao se confrontar com ideias das professoras, Murilo recorria às estratégias cognitivas vinculadas às relações entre a forma como culturalmente falava e à escrita das palavras. Uma mesma palavra assumia escritas espontâneas diferenciadas em uma única atividade, como na escrita da palavra "HUMANOS" em um de seus livros, em que Murilo escreveu utilizando a forma como a pronunciava: ZUMANOS. Sua mãe realizou a correção da palavra em um dos momentos da produção e mostrou para Murilo. No entanto, na continuidade da escrita do livro, a referida palavra assumia novas formas: ZUMANOS, UZMANOS. Do nosso ponto de vista, cada momento de escrita constituía uma nova oportunidade de refletir sobre a mesma palavra e se interligava à forma como Murilo pronunciava a própria palavra.

Outro exemplo desta elaboração se encontra no processo de reflexão de Murilo sobre a forma de falar e escrever algumas palavras, dentre as quais estão: LEITE, BODE, LUZ. Pela forma como ele as pronunciava às vezes, se expressavam em sua escrita da seguinte forma: LEITI, BODI, LUSI. Murilo questionava sua própria escrita: "Eu vi que a tia escreveu LUSI com Z. E agora? Parece que tem alguma coisa que eu vou ter que mudar." (Observação). Interpretamos que a fala oral e sua relação com o processo de escrita está para uma relação perpassada por processos reflexivos, o que referenda a importância das marcas culturais da linguagem no processo de aprender, conforme apontado por Bortoni-Ricardo (2004).

Interpretamos que o confronto de ideias com o outro e consigo mesmo, configurou-se pela autonomia de Murilo em produzir dúvidas, em unidade às estratégias de autorregulação de buscar respostas para seus questionamentos. Podemos ilustrar isso a partir do instrumento “Trilha das frases" mediante a expressão de Murilo ao indutor "35- QUANDO TENHO DÚVIDAS": "Pergunto pro colega e pra tia." E em um momento do instrumento "Diário de ideias": "Eu queria saber como que escreve NARIZ. Eu escrevi com S, mas eu fiquei com dúvida, parecia o som do Z. Eu fui lá e olhei no meu caderno e vi que tinha NARIZ e aí eu falei 'sabia que era com Z' (risos)."

A confrontação com o instituído como estrutura dos livros foi algo constante nas ações de Murilo em um caminho de buscar conhecer a estrutura dos livros, suas partes, e a forma como eram escritos. Ele questionava alguns padrões dos livros: "Eu não sei para que aquela outra capa do livro. Ela repete tudo da capa. Se já leu uma vez, para que ficar repetindo. Só gasta papel. Eu não faço essa outra capa no meu livro não." (Dinâmica conversacional I). Este questionamento incluía a busca por conhecer profundamente os livros, advindo de sua exploração dos mesmos e o caráter subversivo e transgressor do sujeito, em meio às possibilidades de poder mudar o que era instituído e criar caminhos próprios de 
atuação. Murilo recorria à estratégia de autorregulação, vinculada à aprofundar conhecimentos sobre temas de seu interesse para atuar de forma diferenciada com eles.

\subsubsection{Produção, geração de ideias próprias e novas que vão além do dado}

Em Murilo, a produção, geração de ideias próprias e novas que iam além do que era solicitado ou mesmo dado, organizou-se pelo caráter empreendedor do sujeito, o qual conceituamos como possibilidade de elaborar metas, assumir riscos, encontrar caminhos próprios orientado a realizar, concretizar, tornar suas ideias exequíveis, as quais destoam do inicialmente dado, assim como se propõe ações, que possibilita seguir em direções diferenciadas com suas criações. Tal concepção se associa ao que González Rey (2004c) destaca quanto a utilização pelo sujeito de seu tempo livre, ao assumir a gestão de suas ações em um processo de se responsabilizar pelos seus atos.

Nossa elaboração pode ser ilustrada com a criação espontânea de Murilo da história sobre a fruta JACA no instrumento "Diário de ideias" (Anexo C - Figura 5). A descoberta do significado da referida palavra a partir de uma atividade de ditado em sala de aula, no segundo ano, em meio à própria ação de escrevê-la foi favorecedora da geração de ideias próprias e novas para além da atividade proposta. Em seu caráter empreendedor, Murilo realizou a escrita de uma história sobre a JACA, utilizando momentos livres na escola e em casa. Ele incluiu elementos que participavam de suas experiências, bem como criou novas possibilidades de experiências. A criatividade se expressou pela autoria e pelo caráter empreendedor, na espontaneidade de criar histórias, o que lhe demandava dedicação e disponibilidade para exercer a escrita.

$\mathrm{Na}$ experiência da escrita e da leitura, a imaginação se expressava em uma dimensão funcional, capaz de gerir a ação de criar algo novo na busca de transcender o que estava posto. Nossa elaboração pode ser ilustrada por uma das falas de Murilo: "Lá na minha vó tem o pé de jaca bem grande e tem as galinha, mas eu nunca vi elas fazendo isso da história. Foi tudo da minha cabeça (risos)." Do nosso ponto de vista, havia uma relação próxima de Murilo com a escrita. Esta se expressava na preocupação de tornar a escrita viva, ao recorrer à estratégia de autorregulação de utilizar o próprio vocabulário cotidiano para conferir dinamicidade à sua produção, como expresso na forma como se referiu à sua própria produção sobre a palavra JACA: "Então foi vocês que estavam com fome, né? Eu coloquei assim, 'né' para ver se as galinhas estava mesmo ouvindo (risos)." (Diário de ideias). Do nosso ponto de 
vista, havia um funcionamento da imaginação favorecedor de processos de comunicação consigo mesmo e com sua própria produção que dinamizavam novas ações de Murilo.

A experiência da escrita era assim, uma ação intencional de um sujeito engajado, o que pode ser exemplificado a partir de um diálogo referente ao instrumento "Diário de ideias" em que Murilo disse: "Eu também escrevi que EU NÃO TENHO NADA PARA ESCREVER aí no caderno de ideias. Não veio nada, nada, nada na minha cabeça.” Murilo enfatizava que apenas escrevia o que vinha "na minha cabeça", em que a ação de escrever estava vinculada ao pensamento próprio, constituindo força motriz para a liberdade de se expressar.

Havia, em Murilo, necessidade de elaborações próprias em seus registros que demandavam produções, inicialmente no campo de suas ideias, para posterior concretização de seu registro e com desdobramentos para além da ação de escrever ou ler. A autoria esteve configurada antes, durante e após a ação de escrever. O pesquisado observava atentamente a folha de atividade ou o caderno, olhava para o alto, colocava o lápis na boca para elaborar algo próprio a ser registrado. Interpretamos que havia um processo recursivo entre refletir para realizar a atividade, quanto a própria ação de escrever e ler era geradora de reflexão. Para ilustrar nossas elaborações, apresentamos um momento em que Murilo registrou no instrumento "Diário de ideias" uma escrita pessoal e espontânea sobre o pássaro beija-flor: "O beija-flor, ele gosta de beijar a flor, sabe por quê? Ele gosta de beber água doce." (Transcrição da escrita de Murilo). A própria escrita da frase favoreceu a produção de questionamentos que o moveram para ações posteriores em sua vida:

Diário de ideias

Murilo: Lá na minha vó tem um tantão de beija-flor. Ela coloca água com açúcar para eles. Não sei por que tem que pôr açúcar, acho que não mata a sede deles. Sabe o que que eu vou fazer? Eu vou colocar água com doce e água sem doce e vê qual vai acabar primeiro.

Do nosso ponto de vista, as ações de ler e escrever não se esgotavam em si mesmas, eram geradoras de possibilidades de pensamentos capazes de engendrar ações em Murilo na busca por novas descobertas, conferindo a característica ao novo do seu caráter gerador de outras possibilidades de produção de novidade. Como uma teia de possibilidades, a leitura e a escrita se constituíram para Murilo como um recurso que o possibilitava atuar de forma investigativa e questionadora no mundo. Ele realizava suas leituras transpondo o que estava escrito, a partir da formação de opiniões próprias, de gerar possibilidades de enredos para suas histórias, de favorecer novas produções de escrita e como ponte para novas leituras e ações.

Exemplificamos nossa construção acima, a partir da expressão de Murilo no instrumento "Oficina de leitura e escrita" em que ele realizava a leitura de um livro e, ao final, 
decide mudar todo o enfoque da história: "Eu vou fazer uma história ao contrário dessa aí. Eu vou fazer o burro inteligente e estava ensinando o macaco a gostar de livro. Eu vou até escrever aqui agora para não esquecer. Vai ser o livro que eu vou escrever. O título vai ser assim 'O burro e o macaco burro'." A leitura se constituiu em um processo que esteve para além do escrito tal como ressalta Cantú (2011, p. 46, tradução nossa): "Postulamos que se decodificar e compreender são os processos que dão conta do escrito, ler é o processo que se refere ao que não está escrito. O ler nega o escrito, o põe em entre-dito, o supera, o difere.”

\section{A geração de ideias para além das histórias que conhecia e que culminava na} criação de livros ligava-se à relação que Murilo estabeleceu com os livros, a qual se associava à admiração por tais materiais, assim como por estratégias de autorregulação de procurar formas diferenciadas de criação de situações próprias de registro. Ele terminava as atividades de cópia da lousa de forma rápida para poder pegar livro para ler. Isso nos chamou a atenção por não se tratar de uma prática da sala de aula do primeiro ano, porém, foi criada por Murilo e adotada pela professora Melissa e que se estendeu para toda a turma. Ele foi capaz de modificar elementos configurados na subjetividade social da sala de aula, o que corrobora González Rey (2007b, p. 144) como sendo o sujeito “[...] a pessoa apta a implicar sua ação no compromisso tenso e contraditório de sua subjetividade individual e da subjetividade social dominante."

Pelo seu gosto por histórias e principalmente pela forma espontânea como as inventava e as escrevia, Murilo começou, no segundo ano, a registrar suas ideias por meio da produção de livros. Em seu caráter empreendedor, ele se empenhava em construir materiais para registros próprios, pegava papéis jogados no chão e também pedia folhas para as professoras em um processo ativo de criar seus próprios materiais. Percebemos isso pelo caráter subversivo e transgressor de Murilo que buscava caminhos próprios de superação de uma condição posta social e economicamente.

\footnotetext{
Entrevista I

Murilo: Eu pedi as folhas para tia Flávia. Ela me deu as folhas. Eu colei cada folha, dobrei uma por uma e colei e fiz o livro. Aí eu coloquei o número de cada página. Aí veio na minha cabeça que eu queria escrever uma história do leão e do gato. Eu nem tenho livro lá na minha casa. Agora eu tenho, tô escrevendo um tantão.
}

Havia abertura das professoras às iniciativas de Murilo e a valorização de suas ações neste campo, geradoras de bem estar e favorecedoras da continuidade da construção de seus caminhos próprios. Ao longo do segundo ano, ele produziu mais de dez livros com diferentes títulos e em todos se colocou como autor e ilustrador. A escrita das histórias de Murilo estimava um valor para ele mesmo, afinal, era importante conseguir criar e ter seus próprios 
livros em casa, assim como se constituía como um processo de realização pessoal, num exercício pleno de composição. O valor da produção não se encontrava apenas na finalização do livro, mas no processo de sua elaboração. Isso pode ser exemplificado por uma das expressões de Murilo: "Eu fico fazendo o livro e aí eu fico pensando e pensando. Depois que está pronto parece tudo diferente do que eu pensei. Tem vez que eu só penso e não faço livro não." (Diário de ideias).

A imaginação funcionou como força motriz que possibilitava a Murilo extrapolar suas experiências concretas, constituindo um recurso subjetivo para realizar experiências imaginárias, que podiam ou não se concretizar em sua escrita. Aspecto que se vincula às construções de González Rey (2011c), quando expôs um exemplo sobre a experiência da escrita de um autor, a qual não se esgota na escrita em si, mas está perpassada por momentos imaginativos de elaborações que podem se expressar em escrita tempos depois. Murilo mantinha uma forma interativa de relação com possíveis leitores e buscava escrever algo que fosse diferente do que habitualmente conhecia, em um processo de combinar elementos diversos, manipulá-los e elaborar algo que mudava o inicialmente vivido, o que demonstrava para nós o papel da imaginação na produção e geração de algo que está para além do contexto real (MITJÁNS MARTÍNEZ, 2012a). Para ilustrar, citamos os trechos abaixo:

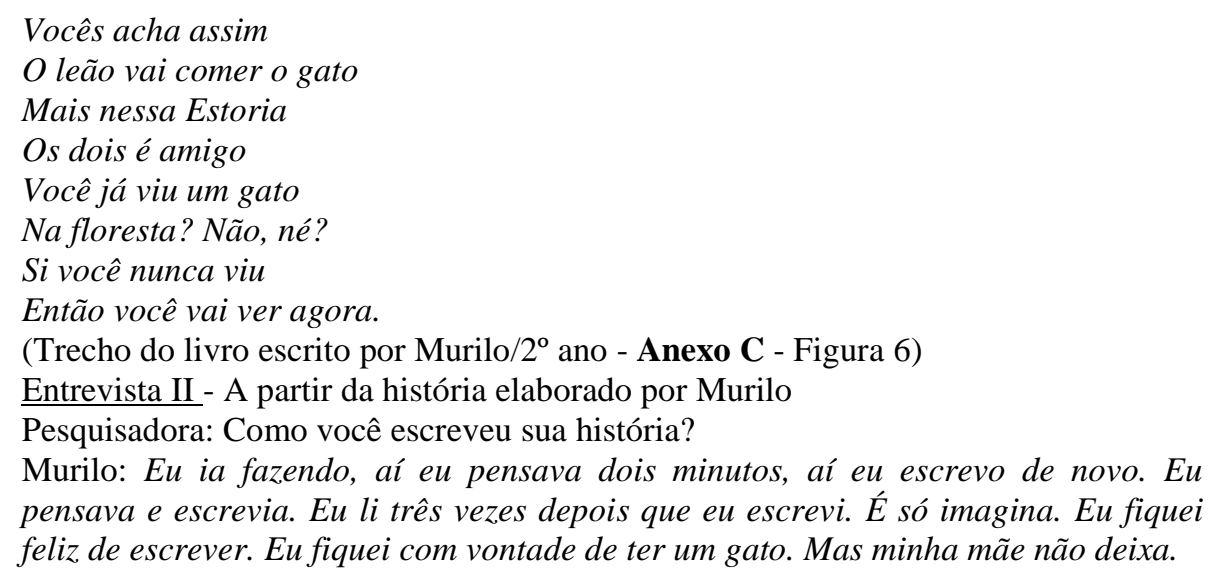
feliz de escrever. Eu fiquei com vontade de ter um gato. Mas minha mãe não deixa.

Murilo transformava diferentes experiências em oportunidades de aprendizagem, como sua própria ação de escrever e de ler que, de forma recursiva partia de suas reflexões e era geradora de novas reflexões e novas ações, processo associado ao caráter gerador do novo de outras possibilidades de produção de novidade nas possibilidades de empreender ações.

\subsubsection{A relação lúdica no processo de aprendizagem criativa da leitura e da escrita}

O processo de experienciar de forma lúdica a aprendizagem, esteve associado às possibilidades de Murilo se inscrever no processo de aprender de forma plena e gratuita. 
Havia, em Murilo, uma relação completa, voluntária, próxima, instantânea e investigativa no processo de viver a experiência de aprender a ler e a escrever, que de espontânea se lançava nas atividades e buscava, em alguma medida, transcendê-las. Como pode ser exemplificado pela fala de Murilo: "Quando tem uma tarefa eu fico pensando o que que eu posso fazer. Os meninos fazem de qualquer jeito e eu fico um tempão fazendo a tarefa e aí eu vejo um tanto de coisa que pode aprender que nem tá na tarefa." (Oficina de leitura e escrita).

Neste processo Murilo brincava com suas ideias e experienciava cada momento de aprender como possibilidade de realização pessoal, como podemos exemplificar em uma de suas falas: "Sabia que quando eu tô escrevendo e até desenhando eu acho que tô brincando de palavras, de inventar ideias? (risos)" (Diário de ideias). Expressão que nos remete ao que Huizinga (1999, p. 11) defende como uma importante característica do jogo: “[...] atividade temporária, que tem uma finalidade autônoma e se realiza tendo em vista uma satisfação que consiste nessa própria realização.”

Para Murilo, a experiência da leitura e da escrita era deleite, uma entrega à atividade que lhe permitia em um único momento, trabalhar de forma intensa, séria e, ao mesmo tempo, pelo caráter desafiante de um registro pessoal, de forma instantânea criava, como um artista no trabalho com sua obra. Havia total envolvimento e assim, como em uma brincadeira, como experiência plena não havia, para Murilo, etapas que postergavam a ação, a atividade era iniciada, realizada e concluída de uma só vez: "Eu faço o livro rapidão. Quando eu vô escrever eu faço tudo de uma vez. Eu não deixo para terminar depois. No outro dia já é outra história que eu quero." (Entrevista I). Tal como explicita Vigotski (2009, p. 93), a criança “[...] cria a obra numa sentada. Sua criação lembra, nesse caso, a brincadeira que surge de uma forte necessidade e permite, quase sempre, uma descarga rápida e completa dos sentimentos que dominam a criança."

A relação lúdica esteve resguardada pela intensidade e despreocupação com que Murilo experienciava a aprendizagem. A sala de aula pulsava em agitação dos alunos, um intenso barulho, porém, Murilo não se distraía e não gostava de ser incomodado, principalmente nos momentos de escrita espontânea. A conclusão de suas ações no campo da leitura e da escrita estava na completude do que se propunha a realizar. "Eu só vou entregar minha frase quando eu fazer o que eu tô pensando." (Observação).

Interpretamos que havia uma relação de comunicação nas ações de ler e escrever, em que se admirava com os livros e recorria à estratégia de autorregulação da prática de contar ao outro o que aprendeu, seja o colega ou mesmo a professora. É como se ao estabelecer uma relação com o outro de querer dividir as suas descobertas e o seu encantamento por algo, lhe 
proporcionasse bem estar e realização pessoal. Podemos ilustrar nossa elaboração por uma das expressões de Murilo: "Escrevi sobre a borboleta e eu mostrei pra Amanda. Ela achou que não fui eu que fiz (risos). Eu vou fazer mais história." (Diário de ideias).

A relação de comunicação esteve acompanhada de mudanças que envolveram o objetivo dos registros escritos de Murilo. Nossas construções podem ser subsidiadas pelas expressões de Murilo no instrumento "Diário de ideias", no qual identificamos que seus registros iniciais se baseavam em palavras que ele gostava de copiar, pois considerava interessante e curioso o contorno das letras e o significado das mesmas, num desejo de registrar para si o mundo ao seu redor. Essa função se modificou e se reorganizou para a expressão de seus sentimentos, desejos e ideias. Ele buscava na escrita, um recurso de se comunicar com o outro, a partir da criação de histórias que passaram a ser lidas pelos colegas da turma, pela professora e coordenadora pedagógica. Surgiam novos interesses diante deste aprendizado, como poder se expressar por estas vias, como canal de comunicação.

Ao mesmo tempo, a própria leitura lhe proporcionava uma comunicação consigo mesmo e com o outro, o que observamos no decorrer da pesquisa, tal quando leu a história "Matar sapo dá azar", em que conversava com o livro: "Foi você sapo que estava na casa?" (Momento informal). Esse tipo de comunicação lhe favorecia investigar e até mesmo questionar o próprio enredo das histórias. Isso pode ser ilustrado por uma de suas falas: “ $E u$ invento história que eu vejo que não está no livro. Aí eu vejo que pode ser diferente, que no livro está de um jeito, mas vira outra história" (Diário de ideias). A curiosidade de Murilo e seu caráter empreendedor possibilitava a ele descobertas no campo da leitura, que envolviam investigar as informações em um processo de comunicação, como no exemplo que selecionamos para subsidiar nossas elaborações: "Nossa, eu tô doidinho pra ler aquilo ali. Eu tô curioso tentando ler ali naquela caixa pra saber o que tem ali” (Diário de ideias).

A relação lúdica também se expressou na criação de regras próprias de Murilo no percurso de aprender a ler e a escrever. Ele conhecia as regras que envolviam a escrita e a leitura, como podemos exemplificar por uma de suas falas: "Tem que escrever linha por linha. Só que aí vou fazer de um jeito bem esquisito. Vai ser uma história do final para cima. Será que vai dá certo?" (Oficina de leitura e escrita). Interpretamos que para Murilo, a aprendizagem da leitura e da escrita era um momento vivo, disponível para o inusitado, para o diferente do habitualmente realizado. $\mathrm{O}$ que lhe permitia realizar ações para além do que as regras sociais fixavam. $\mathrm{Na}$ condição de sujeito da aprendizagem, Murilo realizava as atividades de escrita ou mesmo de leitura como se buscasse elaborar novas possibilidades de ações sobre as mesmas. Como ressalta Brougère (1998a) a elaboração de regras se constitui 
em articulação às possibilidades de faz de conta na criação de um contexto próprio e imaginário pelo aprendiz.

Em articulação à criação de regras, identificamos, nas ações de ler e escrever de Murilo, a criação de um cenário imaginário próprio, em que se transportava para um mundo para além de suas experiências vividas, que lhe permitia estabelecer relações com experiências e outras criadas que não se limitavam ao tempo e espaço concreto da ação. Nossa construção pode ser exemplificada a partir da fala de Murilo, frente à escrita da palavra TATU no segundo ano: "Eu nunca vi um tatu. A tia falou na sala e eu fiquei pensando no tatu que passou lá na televisão. E aí eu fiz ele do jeito que eu acho que é. Eu sei que ele mora na terra e acho que por isso que ele é daquela cor lá, marrom igual terra (risos)."

Esta forma investigativa de Murilo, mediante a escrita, esteve associada às estratégias de autorregulação de buscar conhecer o significado das palavras, o que lhe despertava o desejo de se expressar por outras linguagens, como o desenho. Interpretamos que a possibilidade de evasão da vida cotidiana, era um elemento fundamental, que permita Murilo ousar em suas produções e criar suas próprias elaborações sobre elementos que passava a conhecer. Ele imaginava o animal TATU e realizava a produção de um desenho, frente às relações que havia estabelecido. Criava-se um cenário imaginativo dinamizador de estados emocionais de alegria, surpresa e encantamento, expressos na forma como sorria ao realizar a atividade, bem como por outras expressões diante de sua produção. Neste cenário, Murilo imitava, inventava, organizava o universo adulto da escrita e da leitura num cenário social próprio, aspectos destacados por Benjamin (2002).

Existia também uma relação com o faz de conta na personificação de sua escrita, que dinamizava a forma que Murilo inventava histórias, com a consciência de fazer de conta, e conferir aos animais e outros objetos, características próprias dos seres humanos, em unidade com outras estratégias de autorregulação de procurar realizar as atividades propostas associadas à ludicidade. Interpretamos ser este um elemento fundamental da forma como a imaginação favoreceu a liberdade, a segurança e as possibilidades de novas construções. Podemos exemplificar essa construção a partir de uma fala de Murilo: "Eu sei que é só brincadeira. Mas fica bem divertido assim. Eu tô só fazendo de conta que o leão vai ser amigo do gato." Interpretamos que as ações de ler e escrever eram favorecidas pela condição de fazer de conta, pela consciência de que suas ações não modificariam a realidade, elemento caracterizador do caráter frívolo do lúdico (BROUGÈRE, 1998b).

Diante do processo construtivo-interpretativo, compreendemos que a criatividade se expressou na confluência das características, no vínculo destas com as estratégias de 
aprendizagem, assim como pela força motriz da imaginação e do pensamento na sua constituição. Também identificamos em consonância com a concepção de Mitjáns Martínez (1997, 2008a, 2008c, 2012b) da criatividade como princípio funcional da aula que envolve todos os aspectos do trabalho pedagógico do professor, que a criatividade se expressou na aprendizagem de forma sistêmica e não como processo pontual, em um ou outro elemento, dos quais citamos a relação com: o contexto de aprendizagem, a avaliação, os conteúdos curriculares, a utilização de materiais escolares, o trabalho pedagógico, os sistema atividadecomunicação e com as próprias produções. O quadro a seguir constituiu a síntese da relação entre a expressão da criatividade e as estratégias de aprendizagem.

Quadro 3 - Relações entre a expressão da criatividade na aprendizagem da leitura e da escrita e as estratégias de aprendizagem de Murilo

\begin{tabular}{|c|c|}
\hline $\begin{array}{c}\text { Características da criatividade na aprendizagem da } \\
\text { leitura e da escrita }\end{array}$ & Estratégias de aprendizagem \\
\hline $\begin{array}{l}\text { Personalização da informação: } \\
\text { - personalizava o modo de ensinar das professoras; } \\
\text { - personalizava as atividades propostas em sala de aula; } \\
\text { - personalizava o contexto de aprendizagem. }\end{array}$ & $\begin{array}{l}\text { Estratégias de autorregulação: } \\
\text { - atenção deliberada às explicações; } \\
\text { - associa o conteúdo aprendido com as suas experiências; } \\
\text { - utiliza o aprendido em situações cotidianas. }\end{array}$ \\
\hline $\begin{array}{l}\text { Confrontação com o dado: } \\
\text { - confrontação com suas próprias produções; } \\
\text { - confrontação de ideias com o outro e consigo mesmo; } \\
\text { - confrontação com o instituído como estrutura dos } \\
\text { livros. }\end{array}$ & $\begin{array}{l}\text { Estratégias de autorregulação: } \\
\text { - faz supervisão autônoma de suas atividades; } \\
\text { - faz reflexão sobre suas próprias produções; } \\
\text { - utiliza planejamento para as atividades de leitura e } \\
\text { escrita; } \\
\text { - realiza inferências sobre o lido; } \\
\text { - busca de forma autônoma respostas para suas dúvidas; } \\
\text { - busca aprofundar conhecimentos sobre temas de seu } \\
\text { interesse para atuar de forma diferenciada com o mesmo. } \\
\text { Estratégias cognitivas: } \\
\text { - estabelece relações entre letras, sílabas e palavras; } \\
\text { - contrapõe o que sabe com o que foi escrito em outros } \\
\text { lugares; } \\
\text { - faz relações entre a forma como culturalmente fala e a } \\
\text { escrita. }\end{array}$ \\
\hline $\begin{array}{l}\text { Produção, geração de ideias próprias e novas que } \\
\text { transcendem o dado: } \\
\text { - para além do que era solicitado; } \\
\text { - para além das histórias que conhecia e que culminava } \\
\text { na criação de livros. }\end{array}$ & $\begin{array}{l}\text { Estratégias de autorregulação: } \\
\text { - procura formas diferenciadas de criação de situações } \\
\text { próprias de registro; } \\
\text { - utiliza o próprio vocabulário cotidiano para conferir } \\
\text { dinamicidade à sua produção. }\end{array}$ \\
\hline $\begin{array}{l}\text { - relação completa, voluntão lúdica: } \\
\text { investigativa; próxima, instantânea e } \\
\text { - relaçãa de comunicação; } \\
\text { - criação das próprias regras; } \\
\text { - criação de um cenário imaginário próprio. }\end{array}$ & $\begin{array}{l}\text { Estratégias de autorregulação: } \\
\text { - prática de contar ao outro o que aprendeu; } \\
\text { - busca o significado das palavras; } \\
\text { - realiza as atividades propostas associadas à ludicidade. }\end{array}$ \\
\hline
\end{tabular}

Fonte: elaborado pela autora, 2015.

No próximo item, abordaremos a configuração subjetiva da ação de aprender criativamente de Murilo, em suas múltiplas relações com a expressão das características apresentadas no presente eixo. 


\subsubsection{Configuração subjetiva da ação de aprender criativamente a leitura e a escrita de} Murilo

Do ponto de vista teórico, a configuração subjetiva da ação se constitui pela subjetivação da ação pela pessoa, o que envolve a dinâmica de sentidos subjetivos configurados historicamente na trajetória de vida da pessoa que se atualizam na ação e de novos sentidos subjetivos produzidos na experiência, vinculados a elementos dos sistemas relacionais e da subjetividade social do contexto da ação (GONZÁLEZ REY, 2012a). Em Murilo, sua configuração subjetiva da ação de aprender criativamente se organizou em torno de três núcleos de sentidos subjetivos, os quais foram elaborados nos próximos tópicos.

4.1.3.1 Núcleo de sentidos subjetivos associados à mudança da educação infantil para o ensino fundamental

Pelo processo construtivo-interpretativo, compreendemos que se organizou um núcleo de sentidos subjetivos associados à mudança da educação infantil para o ensino fundamental no âmbito da configuração subjetiva da ação de aprender criativamente de Murilo. Para iniciarmos nossas elaborações, apresentamos um conjunto de informações que, dentre outras, foram importantes vias para nossas elaborações iniciais:

Brincando de escolinha

Murilo: Antes a gente brincava tanto! Tinha cola, livro, tinta, caderno e um tantão de coisa na mesa. Eu gostava muito de brincar lá. Tinha um montão de brinquedo na estante. A gente ficava um tempão brincando no chão lá daquela sala.

Dinâmica conversacional I

Murilo: Eu tô amando aqui no primeiro ano. Aqui a gente aprende a lê e a escreve. Quando eu tô escrevendo no meu caderno eu acho que eu tô brincando de fazer as letras.

Nas expressões acima, Murilo, ao se referir às suas experiências escolares, remete-se a elementos do brincar e aos materiais utilizados na educação infantil e enfatiza mudanças deste nível de ensino para o ensino fundamental. Por um lado, ressalta momentos prazerosos experienciados na educação infantil, com ênfase na forma completa com que se imbuía em suas brincadeiras. Por outro, destaca o prazer em estar no $1^{\circ}$ ano e poder ampliar suas possibilidades de aprendizagem, que além do brincar, incluem a leitura e a escrita. Isso parece indicar estreitos vínculos entre elementos do brincar e o novo momento experienciado por Murilo, o que pode ser fonte de produções de sentidos subjetivos associados à familiarização com a dinâmica do ensino fundamental.

Reconhecemos ser este um indicador inicial que precisa se alinhavar a novas elaborações, as quais podem estar relacionadas à temporalidade, que passava pelas mudanças 
quanto à quantidade de atividades a serem realizadas e o tempo disponibilizado para tal ação, e que ilustramos pela informação abaixo:

Dinâmica conversacional I

Murilo: Um tanto de coisa mudou no primeiro ano. Agora a gente escreve mais e quase não dá tempo para brinca. Só brinco no recreio. Eu acho tudo rápido. A gente faz tarefa e já tem outra, tem muita coisa. Agora tem que saber a hora de falar. Eu queria fazer mais coisa naquela tarefa das letra e até saber o que que era aquela palavra que estava lá naquele pedacinho.

Nesta fala, Murilo expressava preocupações com a dinâmica experienciada na sala de aula do ensino fundamental, associadas a estados emocionais relacionados à insegurança e receio. Esses se expressavam na gestão do tempo de conclusão das tarefas, que dinamizavam possibilidades de atuar de forma própria em suas produções, o que lhe demandava se organizar de maneira diferenciada para conseguir realizar com afinco suas atividades.

\section{Brincando de escolinha}

Murilo: Meu caderno está cheião de tarefa. A tia falou que tem que fazer todas as tarefa, que se não não vai aprender.

Pesquisadora: E o que você acha?

Murilo: Eu acho que tem que fazer mesmo para aprender. Só que eu queria fazer uma a cada dia e aí eu ia aprender mais daquela lá.

Do nosso ponto de vista, Murilo se confrontava com elementos da subjetividade social, associados à crença de que quantidade de atividades era sinônimo de aprendizagem, e em contraposição a esta crença, se preocupava com a qualidade de suas produções. Ocorriam produções subjetivas atuais relacionadas à subjetividade social da sala de aula associadas ao vínculo entre aprender e entrega plena às atividades propostas, como processo que participa de sua subjetividade individual, articulado por produções subjetivas configuradas historicamente vinculadas à relação com o brincar. Interpretamos que formava parte de sua aprendizagem recursos subjetivos de exploração e curiosidade diante de suas atividades. As informações abaixo podem subsidiar nossas elaborações:

\footnotetext{
Brincando de escolinha

Murilo: Tem muita tarefa de letra e de escrever. A gente copia do quadro e aí tem que fazer rápido e sem olhar para o colega. Se tivesse mais tempo eu ia escrever uma coisa bem legal na minha tarefa. As tarefa é tudo diferente. Eu nem vou no banheiro para dá tempo de terminar a tarefa. Um dia eu fui beber água e quando eu voltei, já era outra tarefa.
}

O excerto acima, unido a outras informações da pesquisa, expressam a condição de sujeito de Murilo frente ao aprender, na criação de rotas alternativas para poder experienciar a aprendizagem em sua completude, como a contenção do movimento corporal, o que estava para ele, atrelado à qualidade de suas produções. Compreendemos que, pelas novas demandas de atividades, o movimento que antes era comum, passa a se converter em algo não mais necessário e que atrapalhava a própria aprendizagem. Em nossas observações identificamos a 
forma como as professoras solicitavam que os alunos realizassem as atividades propostas sem conversar com os colegas, assim como insistiam para que ficassem sentados. Existiam elementos da subjetividade social da sala de aula, associados à crença de que a contenção do movimento favorecia a aprendizagem, em uma relação que, para aprender, era necessário estar em silêncio e quieto.

Do nosso ponto de vista, em Murilo se produziam sentidos subjetivos atuais vinculados à subjetividade social da sala de aula associados à contenção do movimento corporal como possibilidade de realizar atividades de leitura e escrita pelo caráter inédito e desafiante das mesmas. Estas produções subjetivas podem ter estreitas relações com a gênese do lúdico na aprendizagem da leitura e da escrita e constituem processos dinamizadores para que a criatividade emerja na aprendizagem, mediante recursos subjetivos constituídos na sua história de vida, relacionados ao brincar, dentre os quais citamos: flexibilidade, autonomia, capacidade de imersão na atividade e de se distanciar da vida cotidiana ou dela se aproximar de forma diferenciada. Inferimos que a condição de sujeito de Murilo se relacionava a mudanças em seu comportamento, em prol de novas aprendizagens. As informações abaixo podem subsidiar nossas elaborações:

\footnotetext{
Momento informal

Murilo: A gente fica sentado na carteira. Tem muita coisa para fazer. Agora a gente só levanta quando a tia passa jogo e quando está no recreio. Mas eu gosto assim, sabe por quê? Porque aí eu faço a tarefa e aprendo as letras e nem parece que eu tô na escola, eu até acho que tô brincando de pensar outras coisas.

Mapa do tesouro

Murilo: A minha prima lê rápido, ela já tem quatorze anos [...] Eu vou ler rapidão. E aí vou fazer as tarefa que a tia passa rapidão. Quase não dá tempo de fazer o que eu quero na tarefa, a tia já passa pegando o caderno. Agora é que eu tô brincando de escolinha, é muito legal.
}

Murilo foi capaz de abrir novas possibilidades de relação com o processo de aprendizagem que se estendeu para mudanças em seus próprios interesses relacionados ao brincar. Ele expressava emoções de alegria e descontração ao se referir a como seus primos realizavam leituras e a partir do brincar de escolinha com eles, pela congruência destas experiências com as da escola, favoreceram a constituição de estados emocionais de segurança e autoconfiança em experienciar as mudanças com que se deparava no início do ensino fundamental. Segundo González Rey (2007b), a criança não experiencia o contexto escolar de forma neutra, mas sim mediante um conjunto de expectativas e estados subjetivos que fazem parte de sua constituição subjetiva e que se expressam de distintas formas na ação de aprender. 
A contradição entre ter mais brincadeiras e mais movimento na educação infantil e menos destas experiências no ensino fundamental, configurou-se subjetivamente em Murilo como algo que o desafiava a novas ações e que lhe favoreciam uma relação afetiva com seu aprender. Do nosso ponto de vista, Murilo se relacionava com a leitura e a escrita espontaneamente com alto grau de envolvimento, o que pode estar vinculado à significação da infância, não relacionada a obrigações, o que dinamizavam estados emocionais de alegria e descontração. As informações abaixo podem ser ilustrativas:

\footnotetext{
Entrevista IV

Pesquisadora: Por que você quer ser sempre criança?

Murilo: Ah, é bom. A gente pode brincar hora que quiser e pode fazer um tantão de coisa. Eu brinco de escrever, de fazer continha, de fazer livro. Eu sei que a tia Melissa não deixa brincar, ela é brava, mas ela nem vê que eu estou brincando.

Diário de ideias

Murilo: Eu brinco de escolinha e tem vez que não tem do que brincar, aí eu vou lá no quintal e faço fazenda na terra com animais e tudo.

Brincando de escolinha

Murilo: Eu prefiro hoje com a tia Melissa. Na sala tem mais coisa escrita na parede. A gente pode escrever o que está pensando e tem até livro.

Trilha das frases

30 - ESTOU FELIZ QUANDO - Quando a tia passa ditado, quando a gente joga na sala de aula e quando nós copia do quadro. Ontem a tia passou uma tarefa tão facinha eu copiei rapidão e a tia falou que eu estava com um motor na mão (risos).
}

A relação entre o brincar e o processo de aprender era algo que perpassava as ações de Murilo, mesmo que fosse em um processo não totalmente consciente para ele. A subjetivação do novo momento de aprendizagem, em sua vida, vinculava-se às mudanças que se faziam necessárias para novos processos de expressão pela escrita, mediante produções subjetivas historicamente constituídas, associadas ao caráter inventivo que o brincar ocupava em sua vida com distintas reverberações na aprendizagem criativa da leitura e da escrita. Essas produções se expressaram na geração de ideias próprias e novas que transcenderam o dado, como por exemplo, a criação de suas histórias, como característica da aprendizagem criativa. Estas vinculadas a recursos subjetivos de abertura ao novo e gosto pelo desafio.

Neste viés, interpretamos que, em Murilo, a aprendizagem criativa se constituiu como um modelo intelectual-subjetivo, o qual é definido por González Rey (2014a), como a possibilidade de produção de conhecimento no âmbito da configuração subjetiva da experiência, em que as ideias são portadoras de sentidos subjetivos e, de certa forma, apareceram distintamente na criação de livros e histórias, em relação aos sentidos subjetivos destacados anteriormente.

Nesse ponto de nossas elaborações, compreendemos que, de certa forma, Murilo subjetivava as atitudes da professora Melissa em sala de aula. Havia processos contraditórios que envolviam o reconhecimento de Murilo da maneira ríspida, controladora e às vezes 
"brava" com que a professora se portava diante da turma e, ao mesmo tempo, a dinâmica criada por ele para experienciar o processo de aprender como algo próprio. As informações abaixo, juntamente com outras, foram importantes para subsidiar nossas elaborações:

\footnotetext{
Brincando de escolinha

Murilo: A tia Melissa fala brava com os menino. Eu também vou fala assim. Assim é que eles vai aprende. Dá até medo.

Montando minha história

Murilo: Eu sou educado. Eu levanto o dedo para falar na sala. A tia deixa falar só quem levanta o dedo. Não pode conversar com o colega. A tia fala que tem que levantar o dedo para falar, aí eu levanto as vezes, quando eu quero falar, se não eu fico só para mim. Tem que saber aquelas regras. Tem menino que leva grito da tia. Trilha das frases

6 - ME DEIXA TRISTE - Chorar. Levar advertência.

29 - EU MUDARIA - Eu mudaria os meninos. Para eles não gritar e a gente jogava. Porque a tia não deixa jogar se tem bagunça. Eu gosto de jogar aquele jogo do bingo.
}

É interessante observar, nos trechos acima, que Murilo valorizava as ações da professora que envolviam manter a disciplina na sala de aula, mesmo pela forma como experienciava as punições mediante estados emocionais de medo e tristeza. $\mathrm{O}$ que, do nosso ponto de vista, vincula-se à subjetivação de valores morais como algo próprio, personalizando as atitudes e exigências da professora. Murilo sentia como seus os valores que experienciava, os quais organizavam suas ações por um processo de reflexão, tal como enfatiza González Rey (1995), como processo favorecedor de viver novas experiências de aprender. Essas produções, que dinamizavam ações de aprender pautadas pela concentração, atenção, e pelo envolvimento e o tempo dedicado às ações de ler e escrever, envolviam a utilização de estratégias de aprendizagem. Também favoreciam a personalização do modo de ensinar das professoras e a relação lúdica como características da criatividade.

Consideramos que o próprio processo de personalização dos valores morais produzidos no âmbito da subjetividade social da aula por Murilo, pode ser caracterizador da dimensão funcional de criatividade (MITJÁNS MARTÍNEZ, 2012a) pela possibilidade do sujeito de, na tensão com o que era imposto no cotidiano da sala de aula, criar caminhos alternativos para experienciar a aprendizagem de forma plena, capazes de configurar novas produções subjetivas. Murilo buscava conhecer as regras e normas da escola para experienciar situações de aprendizagem, o que pode estar relacionado a produções de sentidos subjetivos atuais, vinculados à subjetividade social da sala de aula, associados à autoproteção, para garantir um espaço confiável de possibilidades para se expressar de forma própria. Isso, certamente, constituiu-se em elementos fundamentais para a relação lúdica com a aprendizagem, articuladas às possibilidades de criar um cenário imaginário. 
Esta relação com o espaço de punição também passava por produções subjetivas historicamente constituídas associadas às experiências em outros contextos sociais, como a família. Para ilustrar nossa construção, apresentamos algumas das expressões de Murilo ao instrumento "Montando minha história", em que, ao registrar momentos que gostaria de mudar de sua vida, escolheu duas situações de punição, uma experienciada por um colega da sala de aula e um conflito com a tia, irmã de sua mãe. Ele não havia experienciado uma situação de punição na escola, mas lhe gerava tensão observar os colegas serem punidos sem poder usufruir de alguma atividade, como o recreio, a leitura de um livro ou outra consequência. Momentos em que observamos expressões de medo e receio, pela forma como fixava o olhar na professora e nas reações dos colegas. Murilo destacou uma situação em que a tia lhe colocou de castigo no quarto e enfatizou que ficou sozinho, no escuro e que não lhe foi conferido o direito de expressar sua posição frente ao ocorrido. Interpretamos que havia produções subjetivas historicamente constituídas e atuais associadas à punição como algo que privava a pessoa do diálogo e de novas experiências e configurava uma relação de poder que eliminava as possibilidades de uma relação autêntica.

Frente ao exposto, compreendemos que o núcleo de sentidos subjetivos associados às mudanças da educação infantil para o ensino fundamental se constituiu por produções subjetivas relacionadas: a) à familiarização com a dinâmica do ensino fundamental; b) ao vínculo entre aprender e entrega plena às atividades propostas; c) à relação com o brincar; d) à contenção do movimento corporal como possibilidade de realizar atividades de leitura e escrita pelo caráter inédito e desafiante das mesmas; e) à personalização dos valores morais; f) à autoproteção; e g) à punição como algo que privava a pessoa do diálogo.

4.1.3.2 Núcleo de sentidos subjetivos associados à necessidade de estabelecer vínculos afetivos com o outro

O núcleo de sentidos subjetivos vinculados à necessidade de estabelecer vínculos afetivos com o outro, se constituiu em inter-relação aos outros núcleos, em que um mesmo sentido subjetivo forma parte simultaneamente de diferentes núcleos no âmbito da configuração subjetiva da ação. Iniciamos nossas elaborações trazendo algumas informações:

\section{Momento informal}

Murilo: A tia dos menino pequeno dá muito música. Só que agora a tia escreve a letra no cartaz e dá para a gente saber a hora que quiser. Cada dia é uma coisa diferente.

Dinâmica conversacional I

Murilo: Fazer pouca tarefa é para os menino pequeno. A gente tem um tantão de tarefa. Os menino pequeno gosta só de brincar. Eu brinco e aprendo, é tanta coisa para sabe. Eu vou aprende um tantão de coisa. E quando eu erro eu apago e faço de novo. 
Os trechos anteriores expressam a forma como Murilo relacionava tipos de atividades específicas como músicas, brincadeiras, assim como realizar uma quantidade menor de atividades de registros, às crianças mais novas que ele. Nessa situação, interpretamos que Murilo buscava se diferenciar das mesmas a partir da inclusão em seu dia a dia de uma quantidade maior de atividades de ler e escrever que, para ele, significavam a possibilidade de crescer e se desenvolver. Interpretamos que Murilo experienciava sua aprendizagem como um processo vinculado ao seu desenvolvimento, o que envolvia se diferenciar das crianças mais novas pelas possibilidades de novas experiências e desafios. Ele, emocionalmente, experienciava sua aprendizagem a partir de recursos subjetivos de busca pelo novo e gosto pelo desafio, o que pressupomos estar relacionado à sua relação positiva com o erro, como possibilidade de aprendizagem, com ênfase ao caráter confrontador do sujeito como característica de sua aprendizagem.

Cabe, neste momento, problematizar esta necessidade de Murilo em se diferenciar das crianças menores. Outras informações subsidiaram nossas elaborações e se referem às ações de Murilo em outros contextos sociais, dentre as quais citamos:

\footnotetext{
Momento informal

Murilo: Minha irmã fica só chamando minha mãe. Ela que fica só no colo.

Pesquisadora: E o que você fica fazendo?

Murilo: Eu fico vendo televisão, mas minha mãe só dorme com a Larisse.

Diário de ideias

Murilo: $O$ pai da Larisse só briga comigo. Eu nem posso andar descalço. Tem dia que está um calorão e ele só deixa a Larisse ficar do jeito que ela quer.
}

As falas de Murilo expressam um conflito, não consciente para ele, experienciado no âmbito familiar, que envolvia a disputa pela atenção da mãe. Ele produzia estados emocionais de ciúmes, que lhe geravam descontentamento, assim como emoções relacionadas a se sentir injustiçado por não poder fazer as mesmas coisas que a irmã. A subjetivação do espaço de carência, que Murilo experienciava no contexto familiar, reverberou de forma singular e diferenciada no processo de aprender. Interpretamos que esta relação de conflito vinculava-se à elaboração de sua própria autoimagem. O trecho abaixo subsidia nossas elaborações:

\footnotetext{
Montando minha história (Anexo D - Figura 7)

Murilo: Eu sou um pouquinho bonito. Mas nem sei que cor é meu olho e nem meu cabelo, acho que é castanho [...] Todo mundo fala que a minha irmã é linda! Têm olho lindo. De mim fala pouco [...] Minha irmã fica linda de vestido, fica linda. Teve um dia que eu ia sentar no colo da minha mãe, aí a Larisse chegou e minha disse que ela era pequena e que era para ela sentar no colo. Eu fui ver televisão.
}

Essa fala de Murilo apresenta uma posição de se sentir menos valorizado em relação à irmã no âmbito familiar. A informação acima unida a outras da pesquisa nos possibilita compreender que a relação com a irmã favorecia produções subjetivas historicamente 
constituídas associadas à disputa por um espaço de ser valorizado no âmbito familiar, que envolvia a busca de atenção da mãe. Produções que reverberavam para sua autoimagem negativa em relação a si mesmo com impactos em seu processo de aprender, relacionadas à dificuldade de estabelecer vínculos afetivos com os colegas. Dentre outras informações, a expressão de Murilo em um momento informal pode ilustrar nossas construções: "Eu acho todo mundo da sala bonito, sei lá se eles acham que eu sou também. Eu nem tenho brinquedo e eu uso óculos e só mais um menino usa também."

A subjetivação da exclusão como processo não consciente em Murilo, de não se sentir parte de um grupo, gerava distanciamento dos colegas, dificuldade de interação, o que pressupomos reverberava para o seu envolvimento com ações mais individuais de leitura e escrita. O que podemos exemplificar por uma de suas falas: "Eu gosto muito quando a tia passa tarefa de escrever. Aqui a gente fica um tempão fazendo a tarefa. O lugar que eu mais gosto na escola é a sala. Pode escrever muito e muito." (Dinâmica conversacional I). Interpretamos que havia produções subjetivas atuais associadas à sua preocupação em não ser aceito pelo outro. O que compreendemos serem favorecedoras do seu distanciamento dos colegas, como uma fuga para não se expor em situações mais coletivas que envolviam estar com o outro. Essa preferência de Murilo por experiências que envolviam a escrita, de certa forma, favoreceram processos de imaginação e do pensamento em seu caráter reflexivo, elementos constituintes de sua aprendizagem criativa.

Tais produções subjetivas têm estreitas relações com sentidos subjetivos que tiveram sua gênese no âmbito das experiências no contexto familiar e que se expressaram de forma distinta no processo de Murilo se relacionar com os colegas. Isso ocorreu, segundo nossas análises, porque "Os sentidos subjetivos integram momentos e experiências anteriores da pessoa no contexto atual, só que esses sentidos atuais sempre tomam formas diferentes na configuração subjetiva em que eles são gerados.” (GONZÁLEZ REY, 2011c, p. 85). Podemos ilustrar nossas elaborações a partir das informações a seguir:

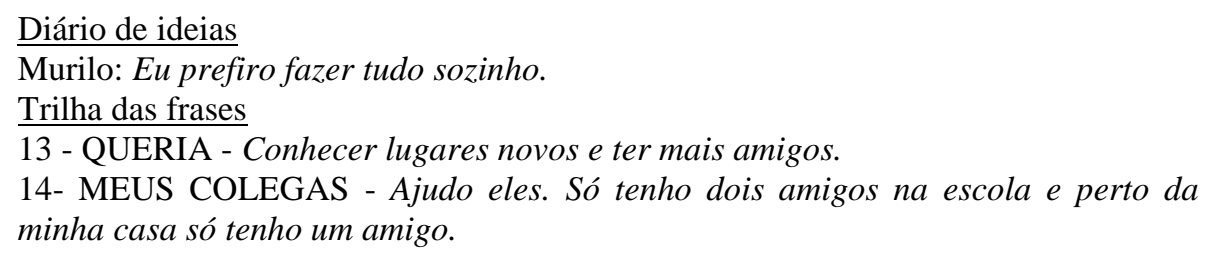

As expressões acima constituíram um apelo de Murilo ao seu desejo de fazer novas amizades, pois possuía poucos amigos. São informações que conferem valor à amizade para Murilo. Interpretamos que ele enfrentava processos contraditórios em relação a querer ter amigos e sua dificuldade em tê-los em meio à organização de sentidos subjetivos constituídos 
na sua história de vida. Tal dificuldade foi reconhecida por sua mãe que relatava que Murilo sempre se queixava dizendo: "Tem vez que eu levo lanche e todo mundo quer ficar perto de mim. Quando eu não levo lanche ninguém fica perto de mim.' Mas isso é coisa de criança, mesmo." (Dinâmica conversacional I).

Em nossas observações no cotidiano escolar, foram vários os momentos que, no recreio, presenciamos a ação de Murilo em oferecer lanche para os colegas e tentar uma aproximação. Este desejo de fazer amizade também se expressava nos enredos de suas produções escritas, o que se articula à nossa elaboração de que, na aprendizagem criativa, a produção de conhecimento se organiza por um modelo intelectual-subjetivo, o que pode ser exemplificado mediante uma das produções escritas de Murilo:

\footnotetext{
O passarinho beija-flor

O passarinho voou no céu e começou a chover e ele molhou a asa dele e caiu no chão e depois o Sol veio e a asa dele secou e ele voou.

Ele voou para seu ninho e ele estava com fome e ele fez comida e depois ele voou lá no céu e depois ele voou lá nos seus amigos.

(Transcrição de produção escrita de Murilo - Oficina de leitura e escrita/2013).
}

Compreendemos que estas produções subjetivas possibilitavam uma nova preferência de Murilo pelo campo da aprendizagem da leitura e da escrita. Dentre outras informações da pesquisa, o trecho abaixo pode ser ilustrativo de nossas elaborações:

\footnotetext{
Dinâmica conversacional I

Murilo: Eu brinco no recreio sozinho. Eu gosto de ficar lá com meu lanche. Tem dia que os menino brinca comigo e eu fico feliz. Mas na sala eu só faço as tarefa e eu adoro aprender as letra e a lê os cartaz da sala, ai eu falo para os menino o que que eu tô lendo.
}

A fala de Murilo expressa processos contraditórios experienciados por ele, em que, ao mesmo tempo que se sentia confortável nos momentos em que estava sozinho, buscava formas se relacionar com o outro pelas suas conquistas no campo da leitura e da escrita. Foram nos momentos de atividades de leitura e escrita, que Murilo demonstrava estados emocionais de alegria e encantamento, o que, interpretamos formar parte de produções subjetivas atuais associadas à aprendizagem da leitura e da escrita como uma via de relação com o outro. Esses processos subjetivos, do nosso ponto de vista, favoreciam a personalização da informação com impactos no modo de vida de Murilo, pelo seu posicionamento como sujeito orientado às mudanças em suas ações. Em concordância com González Rey (2011c), ele estava se disponibilizando a estar mais com o outro.

Nos momentos de nossas observações em sala de aula, Murilo buscava se aproximar dos colegas ao pedir material escolar emprestado, e se dispunha a ajudar os colegas na execução das atividades propostas pelas professoras. Outra informação que pode ser 
adicionada à ilustração de nossas elaborações é uma das falas de Murilo: "Eu tô aprendendo tanto! Já ensino até os menino da sala." (Diário de ideias). Interpretamos que Murilo subjetivou a aprendizagem da leitura e da escrita como possibilidade de novas formas de se relacionar com o outro, por algo que se reconhecia fazer bem, em que precisava se sentir incluído ao ajudar o outro.

Compreendemos como os processos de comunicação foram dinamizadores de sua própria relação com a escrita e com a leitura, o que corrobora González Rey (1995), ao destacar o papel da comunicação como força motriz do desenvolvimento da personalidade. As informações abaixo exemplificam nossas elaborações:

\footnotetext{
Momento informal

Murilo: Eu já li meu livro para o Felipe. Ele ficou rindo da história do macaco e até falou que vai fazer um livro para ele. Agora está todo mundo querendo escrever livro.

Pesquisadora: O que você acha dos colegas quererem escrever?

Murilo: Eu acho bom. Eu acho que eles gostaram dos meu livro. É tão legal a gente pode fazer história igual um livro.
}

Os trechos acima expressam a forma como Murilo se encantava com a reação de seus colegas em relação às suas histórias. Percebemos estados emocionais de alegria e prazer quando produzia suas próprias histórias, o que se apresentava de forma declarativa em suas expressões atuais. O que, de certa forma, estava associado à produção de sentidos subjetivos atuais, vinculados ao sistema relacional com os colegas, associados à necessidade de novas produções de livros, a necessidade de ter reconhecimento em suas possibilidades, bem como à sua segurança nas ações de ler e escrever. Essa construção da qual corrobora Mitjáns Martínez (2012a), explica que a aprendizagem criativa se nutre de sentidos subjetivos nela produzidos. De acordo com González Rey (2003), a aprendizagem é um processo subjetivo que se organiza mediante emoções e processos simbólicos engendrados no próprio curso em que a ação se realiza.

A necessidade de ser reconhecido socialmente, mobilizava produções subjetivas contraditórias em Murilo. Tal construção pode ser exemplificada a partir de uma de nossas observações no segundo ano do ensino fundamental, em que Murilo, a pedido da professora Flávia, fazia a leitura oral para a turma de um de seus livros. Na situação, percebemos sua satisfação pessoal expressa pelo sorriso ao ser parabenizado por todo o grupo, mas também, estados emocionais relacionados a medo e receio, expressos na forma como leu em tom extremamente baixo, balançando o corpo e a respiração ofegante. Em tal momento, entendemos que havia processos emocionais contraditórios de insegurança vinculados à 
produção de sentidos subjetivos atuais associados à necessidade de obter a valorização social do grupo.

Ao receber o retorno positivo dos colegas e da professora sobre sua produção, Murilo se fortaleceu e não demonstrou mais os estados emocionais iniciais. Uma de suas falas pode ilustrar nossa elaboração: “Ufa! Todo mundo gostou do meu livro. Agora todo mundo quer fazer livro. Os menino nem acreditou que eu que escrevi o livro (risos). Agora eu vou ensina eles." Demonstrou expressão de alívio ao ser reconhecido em suas produções, o que reverberava para novas possibilidades de se relacionar com o outro e de novas produções de histórias.

Em vários momentos da pesquisa, conversamos com Murilo sobre a ajuda aos colegas. Destacamos uma de suas falas para subsidiar nossas elaborações: “Ah! Sei lá! Eu acho bom! A Camila fala que eu sei tudo, mas eu não sei não. Ela tá quase aprendendo a lê." Essa informação, unida a outras da pesquisa, nos possibilitou compreender que o processo de ajudar o outro e vê-lo aprendendo, favorecia a própria aprendizagem de Murilo, e lhe gerava satisfação e confiança em si mesmo. O que se associava à produção de sentidos subjetivos atuais, vinculados ao sistema relacional com os colegas, associados à possibilidade de estabelecer novos vínculos afetivos como processo favorecedor de aprendizagem.

O presente núcleo de sentidos subjetivos, associados à necessidade de Murilo em estabelecer vínculos afetivos, se organizou mediante produções subjetivas históricas e atuais, em meio aos sistemas relacionais e elementos da subjetividade social. Ocorriam sentidos subjetivos associados: a) à aprendizagem como um processo vinculado ao seu desenvolvimento; b) à necessidade de se diferenciar das crianças menores; c) à autoimagem negativa de si mesmo na relação com o outro; d) à disputa por ser valorizado no âmbito familiar; e) à preocupação em não ser aceito pelo outro; f) à aprendizagem como possibilidade de interagir com o outro, como processo relacional; g) à necessidade de obter a valorização social do grupo; e h) à possibilidade de estabelecer novos vínculos afetivos como processo favorecedor de aprendizagem.

4.1.3.3 Núcleo de sentidos subjetivos relacionados à aprendizagem da leitura e da escrita como processo relacional

Nesta parte do estudo, abrimos novos questionamentos e diálogos com as informações da pesquisa, que nos permitiram configurar, em elo com os núcleos anteriores, o núcleo de sentidos subjetivos associados à aprendizagem da leitura e da escrita como processo relacional. Do nosso ponto de vista, a relação com a mãe se constituiu como um importante 
processo relacional produtor de sentidos subjetivos vinculados à aprendizagem de Murilo. Elencamos algumas informações para ilustrar nossas elaborações:

\footnotetext{
Momento informal

Murilo: A minha mãe me ajuda nas tarefa que a tia passa. Eu até espero ela chegar para fazer com ela a tarefa. Aí ela fala para minha irmã não atrapalhar a gente. Mapa do tesouro (Anexo D - Figura 8)

Murilo: Eu fiz minha mãe aqui comigo. Ela me ensina a lê e a escrever. Eu adoro quando ela sai comigo e fala assim: Murilo lê ali, aí eu falo para ela não falar o que que é até eu dar conta de lê. Eu ajudo a minha mãe num tantão de coisa. Eu até lavo vasilha.
}

Em suas expressões, Murilo referia-se à mãe como alguém que o ajudava em suas atividades da escola e que também precisava de apoio em situações cotidianas. Pelas informações da pesquisa, interpretamos que a mãe de Murilo acompanhava sua aprendizagem, de forma a fazê-lo buscar caminhos próprios para aprender. Construção que pode ser ilustrada por uma das falas de sua mãe, em um momento de Dinâmica conversacional I: "Você tem que descobrir sozinho. Eu ajudo ele, mas falo que Murilinho você tem que tentar primeiro e depois eu vejo se tá certo." Interpretamos que, nesta relação, participavam sentidos subjetivos historicamente constituídos associados à necessidade de parceria, de estabelecer vínculo com a mãe mediante a aprendizagem, que reverberava pelo gosto de Murilo em se sentir desafiado em novas oportunidades de ler e escrever, que envolviam apoio e atenção da mãe.

Nesta significação da leitura e da escrita no âmbito da relação com a mãe, outros contextos sociais, que não apenas a escola, se apresentaram como importantes, como, por exemplo, suas experiências no âmbito da igreja. Um dos momentos felizes, o qual ele relatou no instrumento "Montando minha história" esteve relacionado à igreja como uma oportunidade de ficar perto de sua mãe e ter novas experiências com a leitura e a escrita. Elegemos o trecho abaixo para subsidiar nossas elaborações:

\footnotetext{
Montando minha história

Momento feliz

Murilo: Lá na igreja a minha mãe fica numa sala e eu na outra, mas ela está lá pertinho de mim. Gosto das música da igreja. Eu já tô aprendendo uma lá. Tô quase sabendo escreve e aí eu vou escrever a música e guardar para sempre. E toda vez que eu quiser cantar eu posso até olhar lá. Tem uma música que eu mudo a palavra e fica até engraçada (risos).
}

A fala de Murilo expressa a significação da aprendizagem da leitura e da escrita como possibilidade de engendrar novas práticas e, de certa forma, configurava este processo como algo que lhe permitia "guardar para sempre", para ter algo para si mesmo e poder retomar experiências que lhe despertavam interesse. Outras informações podem ilustrar nossas elaborações como no instrumento "Diário de ideias" em que Murilo destacou a existência de 
um livro que existia na igreja que, segundo ele, ninguém conseguia ler "De tanto que é grosso", o qual é denominado por ele como "O livro grandão de Jesus", bem como nos disse: "Minha mãe lê a bíblia e também aqueles papel do supermercado."

Pressupomos que a materialidade do livro, bem como a observação de Murilo da condição leitora de sua mãe da Bíblia, formaram condições favorecedoras de produções subjetivas historicamente constituídas associadas à subjetivação do processo de ler como algo que o desafiava a querer aprender a ler e movimentava sua curiosidade na sua relação com o entorno, em diferentes contextos de ação. Essas produções foram dinamizadoras da personalização da informação, com impactos em seu modo de vida. Assim como, favoreceram a confrontação com o dado como característica da criatividade em sua aprendizagem, pela sua relação com suas próprias produções e com as trocas de ideias com o outro, consigo mesmo, e com o instituído como estrutura nos livros.

Compreendemos como as condições objetivas de vida tomam forma para o sujeito em uma dimensão emocional e simbólica. O vínculo com a mãe, pela aprendizagem, pode ter estreita relação com a representação de Murilo em relação à escola. As informações a seguir, dentre outras da pesquisa, podem exemplificar nossa elaboração:

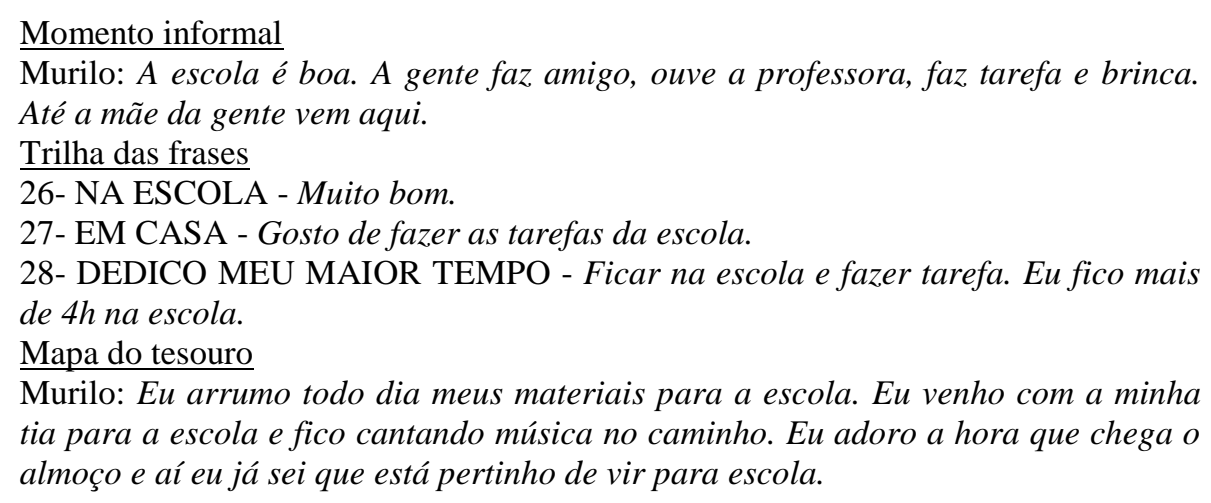

As falas acima expressam que Murilo sentia prazer em estar na escola, o que se alinhava às nossas observações no cotidiano escolar, ao reconhecermos estados emocionais de alegria, disposição, animação em experienciar o contexto escolar. Pressupomos que Murilo significava a escola como um local em que sentia vontade de viver experiências de aprender e não constituiu para ele uma obrigação. Do nosso ponto de vista, Murilo estabeleceu uma relação afetiva com o contexto escolar, ao relacioná-lo a elementos que já faziam parte de sua vida como o brincar e a presença da mãe, assim como ao reconhecer este cenário social como local de aprender, fazer amigos e brincar. A valorização da escola, em suas múltiplas possibilidades de aprendizagem e desenvolvimento, foi algo presente tanto na forma como Murilo significava a escola, bem como na relação que sua mãe estabelecia com a 
escola. Tal elaboração pode ser ilustrada por uma das falas da mãe de Murilo em um momento informal: "Aqui na escola é muito bom, ele aprende muito. Eu não pude estudar tanto e a escola é muito boa pra ele aprender a lê e a escrever."

Nossas elaborações anteriores nos possibilitaram abrir novos questionamentos investigativos sobre a constituição desta subjetivação da escola por Murilo. Outras informações subsidiaram novas construções:

\section{Trilha das frases}

22- MINHA PROFESSORA - Gosto dela. Ela me ensina um tantão de coisa.

38- O QUE EU MAIS QUERO - Queria ter ficado com a professora Melissa no $1^{\circ}$ ano, mesmo já sabendo ler eu queria ficar com ela.

Dinâmica conversacional I

Murilo: A tia me acha muito inteligente.

Alinhavamos, ainda, novas elaborações que colocaram em relevo a relação com a professora do primeiro ano do ensino fundamental. A docente aparece como favorecedora de produções subjetivas em Murilo, vinculadas ao aprender, em que subjetivava as atitudes da professora em relação aos colegas. Interpretamos que há uma contradição, em que, ao mesmo tempo que significava o espaço de punição engendrado em meio às atitudes da professora, Murilo configurava novas produções subjetivas a partir de uma relação próxima e afetiva com ela, acompanhada pela valorização da docente em relação à sua aprendizagem. Isso indicava um novo momento de produção de sentidos subjetivos atuais, vinculados ao sistema relacional com a professora, associados à confiança na professora como parceira para aprender em um espaço de se sentir seguro para se expressar. $O$ que, de certa forma, favorecia seu empenho e concentração nas ações de ler e escrever, processos dinamizadores da utilização de estratégias de aprendizagem de autorregulação e cognitivas.

Neste momento de nossas elaborações, compreendemos o movimento e a dinâmica da configuração subjetiva da ação de aprender de Murilo, em que mudanças qualitativas foram desencadeadas por novas produções subjetivas advindas da relação com a professora Melissa. Sendo assim, o que observamos no início do primeiro ano eram reações de Murilo que expressavam estados emocionais de medo, de insegurança em se comunicar com o outro, perpassados por produções subjetivas relacionadas à subjetivação do espaço de carência e do sentimento de inferioridade produzidos do âmbito familiar. Nesta relação, outras informações podem alinhavar novas elaborações, dentre as quais citamos a fala abaixo:

\section{Diário de ideias}

Murilo: Os menino fala que é só a tia que pode ensinar a gente. Sabia que eu mostro para a tia meu texto e ela fica assim com o olho arregalado e fala que não sabe como eu fiz aquilo (risos). 
As produções subjetivas destacadas anteriormente puderam ser modificadas pelo clima relacional e comunicacional como elemento da subjetividade social, vinculados às professoras e alunos, em que o reconhecimento da aprendizagem de Murilo no campo da leitura e da escrita foi favorecedor para que se sentisse capaz de aprender, o que, de certa forma, lhe gerava confiança em si mesmo, formando recursos subjetivos fundamentais para que a criatividade emerja na aprendizagem. Foi possível compreender como elementos da subjetividade social da sala de aula vinculados à crença de que o saber é conferido apenas à professora e é ela o canal único capaz de ensinar, foi algo que Murilo rompeu para buscar uma relação mais próxima com a professora, ao se colocar como sujeito de seu processo de aprender. A relação de Murilo com a professora se instaurou na confiança mútua, o que, segundo Tacca (2006), pode se constituir como um elemento favorecedor de desenvolvimento subjetivo.

Um momento relevante nessa construção, que consideramos ser uma forma de Murilo firmar a sua relação com a professora como alguém que lhe dava apoio, foi em uma atividade proposta pela professora Melissa, que envolvia a escrita espontânea de palavras que iniciavam com a letra M. Na situação, Murilo observava um cartaz exposto no painel da sala e ao identificar a palavra BALÃO, formou outra: MELÃO. Imbuído da alegria de sua conquista, expressa em seu sorriso, ele se levantou e pegou timidamente na mão da professora e a conduziu até o cartaz, apontando para a palavra BALÃO e dizendo: "Tia, eu formei MELÃO. Eu fiquei olhando essa palavra e aí eu fiz outra."

A reação de reconhecimento da professora, expressa em seu olhar de satisfação e pela forma como parabenizou Murilo e o indagou sobre como ele havia realizado a escrita da palavra, em um processo dialógico, permitiu que ele lhe explicasse o seu percurso até a escrita final da palavra, gerador de estados emocionais de alegria e bem estar. Ele não queria simplesmente realizar uma atividade de forma mecânica e terminá-la rápido, mas pelo seu envolvimento com a atividade e a forma como, inicialmente, ocorreu uma realização pessoal ao conseguir criar uma palavra. Interpretamos que ocorreram produções subjetivas atuais associadas à abertura e necessidade de compartilhar com o outro, suas conquistas, mediante o seu empenho no campo da aprendizagem da leitura e da escrita, relacionadas à necessidade de reconhecimento social, o que, certamente, reverberava para a relação de comunicação como expressão da relação lúdica.

Em momentos informais, Murilo nos falava sobre a sua satisfação em ter uma professora que: "A tia sabe um tantão de palavra. Ela cuida da gente. Teve um dia que ela achou que eu estava com febre e até colocou a mão na minha testa, mas eu estava quase 
gripado." Interpretamos que, por Murilo experienciar conflitos no campo da subjetivação do espaço de carência, e por experienciar situações de ser cuidado, elogiado e estabelecer uma relação dialógica com a professora, gerava bem estar emocional favorecedor de seu empenho e dedicação no âmbito da aprendizagem.

A professora Melissa trabalhava também como enfermeira no contra turno e nos relatava muitas experiências de perdas e também de superação de muitos pacientes. Ela demonstrou ser uma pessoa muito dedicada ao seu trabalho e com a aprendizagem dos alunos, ao buscar o bem estar dos mesmos na sala de aula e, por isso, em muitos momentos da aula, ela chamava um ou outro aluno que estava mais disperso para conversar e saber o que estava acontecendo. Pelas análises das informações dos diferentes instrumentos que contaram com a expressão da professora Melissa, elaboramos indicadores de que a orientação ao cuidado e a preocupação com o outro parecia se constituir sentidos subjetivos configurados na história de vida da professora que configuravam seu trabalho pedagógico e a dinâmica da subjetividade social da sala de aula.

A relação entre a expressão da criatividade na aprendizagem de Murilo e a atenção das professoras para cada aluno em sua singularidade favoreceu produções subjetivas nos envolvidos na relação. Dentre as várias informações, podemos citar:

\footnotetext{
Dinâmica conversacional I

Professora Melissa: O Murilo quando eu vou para copiar no quadro ele já copiou. Inclusive eu estava questionando com ele que eu estou mudando um pouco o cabeçalho que a gente faz né? Aí então, eles estão acostumados lá Uberlândia e tal, né? Outro dia eu coloquei lá, vamos pô DATA, DIA DA SEMANA, PROFESSORA e os dois pontinhos. E eles questionaram, tia por que você está mudando? Eu disse que a gente tem que mudar, não pode ficar só uma coisa, vocês têm que aprender coisas diferentes. E ele é muito observador, então ele já está ligando, ontem eu vi que foi a segunda vez que ele está fazendo ele não conversa não. Ele sempre termina a atividade para depois fazer outra coisa.

Dinâmica conversacional III

Professora Flávia: Estou aprendendo com cada um deles, tento na medida do possível mudar algumas coisas e transformar outras para atendê-los é [...] A cada nova atividade, principalmente as de produção de texto eu me surpreendo com o empenho e imaginação deles e aprendo uma forma nova de lidar com as situações que vivencio durante o trabalho, como foi o caso do Murilo com o seu livro.
}

Interpretamos que a expressão da criatividade na aprendizagem, pela forma implicada e geradora do aprendiz, teve impactos na própria dinâmica da subjetividade social da sala de aula. Essa situação nos possibilitou compreender como um sistema relacional pode impactar subjetivamente os sujeitos da relação com implicações nas ações que se delineavam e constituíam a própria relação. A expressão da criatividade, na aprendizagem de Murilo, como a criação de seus livros, engendrou mudanças na dinâmica configuracional da sala de aula, que envolvia a realização de atividades de escrita apenas estipuladas pelas professoras. 
Ocorreram novas ações das professoras em prol de atividades de escrita espontânea dos alunos, assim como dos colegas que passaram a se envolver e se desafiarem a escreverem histórias.

Enfatizamos o papel da subjetividade social da sala de aula como elemento essencial para a promoção da criatividade e o próprio impacto que este tipo de aprender tem na subjetividade social. Buscamos a contribuição de Mitjáns Martínez (2008b), para a elaboração de que, quando o professor atua como produtor de sentidos subjetivos favoráveis ao desenvolvimento do estudante como sujeito de sua aprendizagem, o aprendiz torna-se capaz de perceber que a aprendizagem deve ser um objetivo assumido também por ele. Interpretamos que, na dinâmica de sentidos subjetivos que configuravam sua aprendizagem, Murilo criava uma relação próxima com a leitura e a escrita. As informações a seguir podem ilustrar nossa construção:

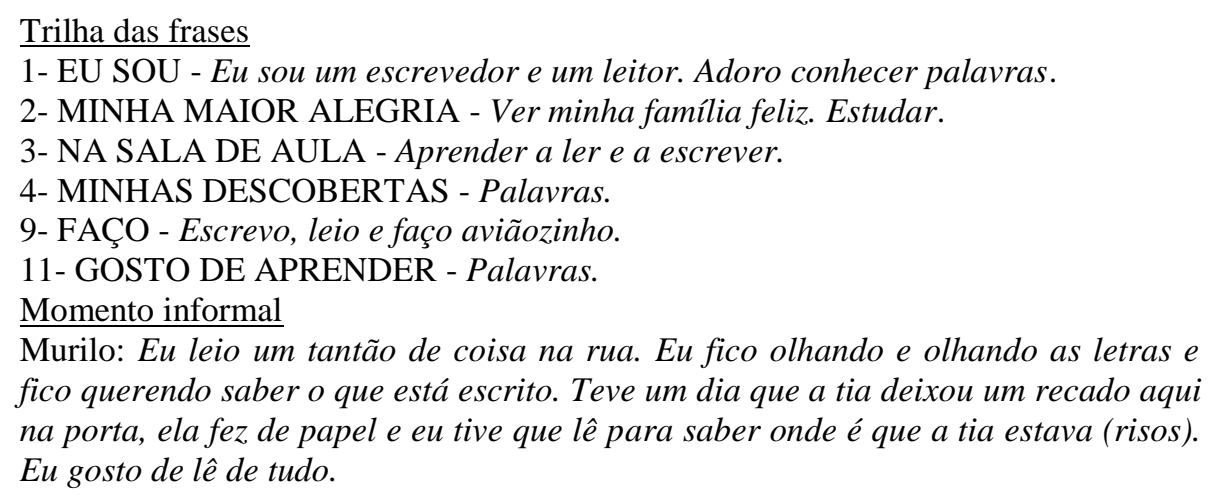

Pelas expressões anteriores, Murilo coloca em evidência o papel importante que a leitura e a escrita assumia em sua vida. Era como algo ligado à dinâmica de seu cotidiano e não limitada à escola, em que a mesma configurava relevância emocional, capaz de envolver suas alegrias, gostos e ações. Interpretamos que havia, em Murilo, disponibilidade e engajamento intencional para atuar com a leitura e a escrita de forma espontânea, associado ao seu protagonismo em que havia sentidos subjetivos atuais associados ao interesse por experienciar as ações de ler e escrever de forma autônoma, assim como à necessidade de vincular a aprendizagem à sua vida, que, de certa forma, reverberava em sua aprendizagem pela personalização da informação, na própria relação que estabelecia com as palavras do entorno, para além da escola.

A expressão de Murilo "Eu sou escrevedor e um leitor" apresentou-se como relevante para ilustrar nossa elaboração de como a aprendizagem se configurou, ou seja, como processo de pertencimento, inclusão, realização pessoal e autoafirmação no campo da leitura e da escrita. Tudo isso nos parecia aliado ao vínculo com a professora, configurado na confiança 
que ele tinha em suas possibilidades de aprendizagem, ao se dispor dialogar e apresentar para a professora suas produções e ideias. Outras informações ilustram nossas elaborações:

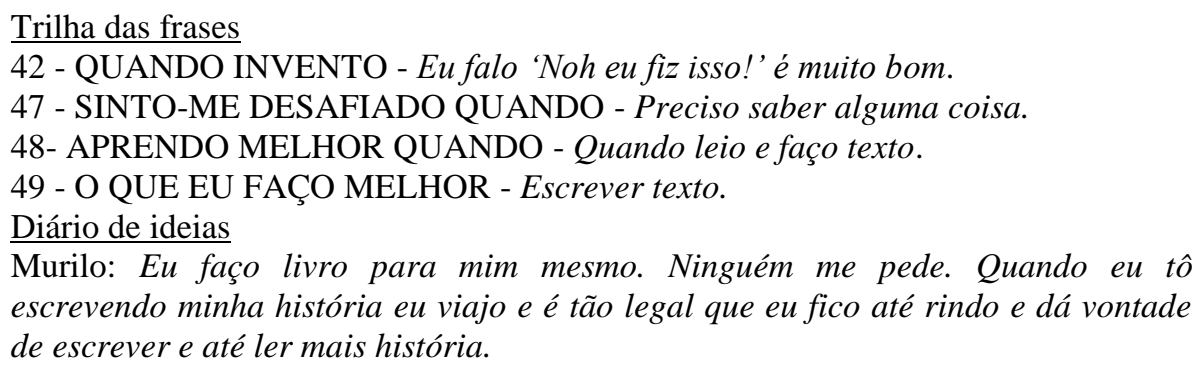

É significativo perceber nas frases apresentadas acima o encantamento de Murilo com suas próprias produções, assim como a forma ativa de se imbuir nas ações de ler e escrever. Murilo parecia estar em uma condição proativa para aprender vinculada a sentidos subjetivos atuais associados à autovalorização de suas próprias conquistas, relacionados à satisfação pessoal. Ler e escrever eram processos geradores de produções subjetivas vinculadas ao bem estar e à procura por novos desafios, as quais foram fundamentais para a expressão da criatividade na aprendizagem, aliada ao próprio caráter gerador do novo. Esta construção articula-se ao caráter funcional da criatividade na aprendizagem, tal como tem sido enfatizado por Mitjáns Martínez (2009a, 2012a), isto é, quando o próprio processo de criar se configura com valor para o desenvolvimento do indivíduo e emerge como resultado de produções subjetivas que se configuraram em contextos específicos de ação do sujeito.

O protagonismo de Murilo, em sua aprendizagem, pode estar vinculado à forma como se configurou pelo papel da reflexão como processo subjetivo que demandava elaboração e implicação do sujeito com sua aprendizagem. A reflexão pode se expressar em qualquer idade, uma vez que está atrelada à assunção da condição de sujeito, na forma como se confronta, duvida, questiona suas próprias construções, não estando assim, limitada à idade (GONZÁLEZ REY, 2012a). O trecho abaixo, pode subsidiar nossas elaborações:

\footnotetext{
Montando minha história

Murilo: Toda vez que eu tô escrevendo eu fico pensando que que eu quero fazer. Não dá para escreve qualquer coisa. A tia explica a tarefa e aí eu vou pensando como é que eu vou fazer. Eu fiquei rindo no dia que eu pensei assim, que ia escrever que eu tenho medo de barata. Mas eu não escrevi isso não, eu só pensei.
}

A fala de Murilo expressa o como a ação de escrever era significada por ele como possibilidade de expor suas ideias. Interpretamos que a experiência de escrever estava perpassada pelo funcionamento do pensamento em seu caráter reflexivo, capaz de gerar emoções e não se restringia ao registro como fim em si mesmo, em que a experiência de ler e 
escrever era um processo gerador de novas produções subjetivas. Outras informações podem subsidiar nossas elaborações:

Trilha das frases

31 - CONSIDERO QUE POSSO - Imaginar coisas e escrever um livro.

Dinâmica conversacional II

Pesquisadora: Essa história existe de verdade?

Murilo: Acho que não. Só existe na minha cabeça. Eu queria falar uma coisa que não existe.

Nas expressões apresentadas acima, Murilo ressaltava o papel da imaginação no seu processo de aprender a ler e a escrever, como uma possibilidade de atuar em um plano que extrapolava suas experiências concretas, transcendendo a vida cotidiana. Tais elementos são constitutivos da criatividade mediante sua expressão pelas quatro características destacadas no primeiro eixo do presente caso. Do nosso ponto de vista, a imaginação se constituiu como processo subjetivo que, unida à reflexão, relacionavam-se à produção de sentidos subjetivos atuais associados ao interesse por novas experiências e pelas possibilidades de transcendência da realidade.

A imaginação, na aprendizagem de Murilo, não era apenas uma dimensão que acontecia momentaneamente, ela constituiu o próprio funcionamento da aprendizagem, ao configurá-la de uma forma mais geral, tal como Mitjáns Martínez (2014) tem ressaltado em seus trabalhos. A experiência de aprender a ler e a escrever de Murilo constituiu um processo caracterizado pelo funcionamento da imaginação como processo subjetivo, gerador de emoções de alegria, satisfação e prazer, inseparável do caráter gerador do pensamento (GONZÁLEZ REY, 2012a). O funcionamento da imaginação também se fez presente em outras informações da pesquisa e nos mobilizou para novas elaborações:

\section{Brincando de escolinha}

Murilo: Vou fazer uma história que não existe. Eu ainda tô imaginando como é que vai ser. Tem coisa que eu nem conheço, mas posso escrever e aí vai ser igual se eu tivesse ido lá. Tem história que eu fico feliz e tem hora que é triste. Mais é quase tudo alegre.

A fala de Murilo expressa a sua relação com a leitura e a escrita em um movimento imaginativo, em seu caráter gerador de produções subjetivas atuais associadas a poder criar novas experiências, capazes de lhe gerar estados emocionais de alegria, tristeza e outros. São produções que reverberavam para a criação de cenário imaginário em sua aprendizagem. Diante de nossas elaborações, compreendemos que o núcleo de sentidos subjetivos associados à aprendizagem como processo relacional, foi constituído por produções subjetivas associadas: a) à necessidade de parceria com a mãe mediante a aprendizagem; b) à professora como parceira para aprender em um espaço de se sentir seguro para se expressar; 
c) à leitura e à escrita como processos que o desafiavam e movimentavam sua curiosidade; d) à possibilidade de compartilhar com o outro sua aprendizagem; e) à escola como espaçotempo de viver novas experiências; f) à necessidade de reconhecimento social; g) ao vínculo da aprendizagem com sua vida; h) à autovalorização de suas próprias conquistas; e i) ao interesse por novas experiências e transcender a realidade.

Frente ao exposto, compreendemos que a constituição e o movimento da configuração subjetiva da ação de aprender criativamente de Murilo se organizou nas relações entre produções subjetivas históricas e atuais, em consonância com os processos relacionais e elementos da subjetividade social que, em recursividade com as ações de ler e escrever, se organizou como potencialmente favorecedora do desenvolvimento da subjetividade. E é sobre isso que trataremos no próximo tópico.

\subsubsection{Mudanças e novas constituições subjetivas vinculadas ao processo de aprendizagem criativa da leitura e da escrita de Murilo}

Ao longo da pesquisa em que tivemos a oportunidade de acompanhar Murilo em sua aprendizagem da leitura e da escrita, foi possível compreender como a criatividade emerge neste processo, relacionada à condição de sujeito, ao contexto e à organização subjetiva de Murilo. Nesta articulação complexa, elaboramos construções sobre a recursividade entre a aprendizagem criativa da leitura e da escrita e as mudanças na subjetividade de Murilo.

No processo construtivo-interpretativo, compreendemos que o movimento da subjetividade se organizou pela constituição da configuração subjetiva da ação de aprender criativamente. Interpretamos que, pela estabilidade que as produções subjetivas adquiriram na organização subjetiva de Murilo e o caráter desenvolvimental das mesmas, a configuração subjetiva da ação se engendrou como unidade subjetiva do desenvolvimento. Essa teve implicações para o crescimento de Murilo na vida de forma mais ampla, capaz de integrar e estimular um conjunto de recursos e processos subjetivos (GONZÁLEZ REY, 2004c).

Elaboramos indicadores sobre as mudanças na configuração subjetiva da ação de aprender de Murilo relacionadas à produção de novos sentidos subjetivos associados aos três núcleos de sentidos subjetivos. Assim como à forma como as novas produções de sentidos subjetivos constituíram novos núcleos de sentidos subjetivos. Processos que se organizaram por mudanças qualitativas na organização atual da configuração subjetiva da ação, em recursividade com as ações do sujeito em contexto - mediante a experiência de aprender favorecedoras do desenvolvimento da subjetividade de Murilo. 
Identificamos que ocorreu uma importante mudança associada às produções subjetivas vinculadas à necessidade de reconhecimento social em Murilo. A relação que Murilo estabeleceu com a professora do primeiro ano lhe favoreceu novas configurações de sua confiança em si mesmo em sua capacidade de aprender, que tornaram este processo cada vez mais uma conquista pessoal com uma qualidade tal que assumia valor para ele e não mais dependia da aprovação do outro. Ocorriam novas produções subjetivas associadas à necessidade de trocar ideias com o outro como possibilidades de argumentação sobre suas elaborações. A fala de Murilo pode subsidiar nossas elaborações: Murilo: Eu levanto o dedo para falar na sala. Antes eu ficava quieto e nem falava. A tia faz pergunta, igual no dia da cobra eu falei que eu já vi cobra e que é perigoso (Minhas mudanças).

Em nossas observações, identificamos que Murilo participava mais em sala de aula e em vários momentos procurava os colegas para falar sobre suas produções e ideias. Ações vinculadas à reconfiguração da organização subjetiva pela produção de novos sentidos subjetivos na ação de aprender vinculados à autovaloração positiva neste campo, implicando mudanças no núcleo de sentidos subjetivos associados à mudança da educação infantil para o ensino fundamental. Podemos ilustrar nossa elaboração pelos trechos abaixo:

\footnotetext{
Minhas mudanças

Murilo: A tia nem precisa ver minha tarefa. Eu já sei fazer tudo. Agora eu já olho e vejo se está certo. Eu gosto mesmo é de ver o que eu fiz.

Diário de ideias

Murilo: Vou fazer histórias de livro para conta para os menino. A gente senta no chão do pátio, quando chega na escola, e eu leio a história.
}

A confiança em si mesmo passou a se constituir em Murilo um processo mais estável e lhe permitiu reconfigurar a relação com o reconhecimento social. Mudança que esteve atrelada às possibilidades de novas relações com os colegas em sala de aula e à familiarização com o novo contexto de aprendizagem. Tais possibilidades foram geradoras de novas produções subjetivas associadas ao reconhecimento de suas potencialidades por ele mesmo e o prazer em dividir a aprendizagem com os colegas que se configuram como produções mais estáveis de sua personalidade, associadas ao núcleo de sentidos subjetivos vinculados à necessidade de estabelecer vínculos afetivos com o outro.

Em vários momentos da pesquisa, identificamos que Murilo passou a ter mais amigos, o que pode ser exemplificado pela qualidade emocional representada pelo seu sorriso ao nos dizer: "Eu tinha dois amigos. Agora eu tenho a sala inteira" (Minhas mudanças). Em nossas observações realizadas nos momentos de recreio, no início da pesquisa, percebemos que Murilo era extremamente recatado e tentava se aproximar dos colegas por meio do oferecimento do seu próprio lanche. No entanto, durante a pesquisa, notamos mudanças na 
forma como ele buscava se relacionar mais com os colegas e se permitia brincadeiras coletivas, sem preocupação com o tempo de término do recreio.

As novas produções subjetivas favoreceram outras possibilidades de expressão da criatividade na aprendizagem de Murilo, configuradas na autenticidade de gerir o seu tempo pessoal de forma autônoma. Isso ocorria em contraposição ao tempo institucional, que demarcava limites de tempo para cada atividade realizada. Murilo gerou seus próprios caminhos de atuação com o tempo, que lhe permitiram novas experiências de estar com o outro de forma plena. Dessa forma, ocorriam novas produções subjetivas associadas a elementos da subjetividade social da sala de aula vinculadas a desfrutar do tempo escolar para se relacionar com os colegas.

Interpretamos que esta mudança se interligava às experiências de Murilo na sala de aula, em que passou a ser mais requisitado para ajudar os colegas e a se sentir cada vez mais enturmado. Do nosso ponto de vista, as distintas ações se constituíram em recursividade às novas produções subjetivas relacionadas à subjetivação do sentimento de inferioridade mediante o reconhecimento da singularidade do processo de aprender de cada um. Podemos exemplificar essa mudança por uma de suas falas: "O Felipe não sabe lê e tem que ficar chamando a tia e eu já tô sabendo. Sabia que eu sou mais alto que o Lucas? (risos)." (Diário de ideias). Interpretamos que Murilo marcava novas percepções de si e do outro, gestando novas produções subjetivas relacionadas ao reconhecimento de suas próprias qualidades, identificando-as na relação com o outro.

A relação com os colegas favoreceu a sua autonomia no campo da aprendizagem, ao deixar de se reportar à professora nos momentos de dúvidas, passando a perguntar mais aos colegas. Construção que pode ser ilustrada pela fala de Murilo: "Eu perguntava para a tia Melissa como é que era aquela palavra lá, agora eu pergunto para o Felipe, para qual colega que estiver perto." (Minhas mudanças). Compreendemos que havia novas produções subjetivas associadas a sentir-se incluído e pertencente ao grupo que lhe geravam ações de estar com o outro de forma autêntica em que as possíveis diferenças passam a potencializar suas relações. Produções estas, vinculadas às mudanças no núcleo de sentidos subjetivos associados à necessidade de estabelecer vínculos afetivos.

A aprendizagem criativa da leitura e da escrita de Murilo, no movimento de sua organização subjetiva, oportunizou o processo de individualização, de autoafirmação nos gostos e preferências de Murilo, de expor cada vez mais o seu ponto de vista, de autoconhecimento de suas potencialidades e possibilidades diante da vida. Assim, como destaca González Rey (1995, p. 90, tradução nossa), a individualização pressupõe a 
implicação do sujeito com as atividades "[...] através de formas e expressões pessoais irrepetíveis, que tem um profundo sentido pessoal para ele." O que se expressou em Murilo pela realização plena diante das atividades de leitura e escrita, sem necessariamente, se preocupar com a questão do tempo e do próprio movimento corporal.

Tais produções subjetivas favoreceram um novo processo de expressão da criatividade na aprendizagem de Murilo, que se sustentava no como ele buscava defender suas ideias perante os colegas e as professoras. O que, de certa forma, reverberava para a sua transcendência às informações iniciais e a conquista de uma autoafirmação em suas ações.

\footnotetext{
Minhas mudanças

Murilo: Aquele dia eu tive que explicar para o Luiz o que que en estava pensando. Ele disse que na história do macaco o pai estava sempre na cama contando história. Eu falei que tinha hora que o pai vai trabalhar, mas não está na história e eu sei.
}

O processo de independência que Murilo constituiu, em seu percurso de aprendizagem, se efetivava nas ações ou atividades em que deixava de recorrer ao apoio das professoras e de sua mãe. Essa construção pode ser ilustrada pela expressão de Murilo: “Eu perguntava muito para a tia e agora eu quase não pergunto. Eu já faço minha tarefa de casa sozinho. Às vezes minha mãe me ajuda." (Minhas mudanças). Podemos compreender o quanto o desenvolvimento da subjetividade se constituiu pela reconfiguração subjetiva a partir da produção de novos sentidos subjetivos associados a ver-se capaz de ousar e buscar realizar as atividades sem dependência do outro, vinculada às mudanças no núcleo de sentidos subjetivos associados à aprendizagem como processo relacional.

$\mathrm{Na}$ relação com a família, interpretamos que se organizava um novo núcleo de sentidos subjetivos associados ao status diferenciado que Murilo assumia no âmbito do sistema relacional com seus familiares, experienciando novas funções conquistadas pela aprendizagem da leitura e da escrita. Nas constantes ajudas à mãe, Murilo foi afirmando o seu lugar e se sentindo cada vez mais próximo de sua mãe. Ele estabeleceu uma nova posição com seu conhecimento e se responsabilizou por papéis que antes eram destinados apenas à sua mãe. Podemos ilustrar tal construção a partir das informações:

\section{Dinâmica conversacional II}

Mãe: Ele sabe mexer mais no celular do que eu. Ele fala 'Nossa, mamãe. Você desse tamanho e não sabe mexer no celular?' (risos) eu falo para ele eu que não sei mesmo não. Ele envia mensagens para mim e eu nem sei mexer nisso. Eu só levo ele direto para o supermercado. Ele olha para mim os preço, olha para mim os nome das embalagens, as coisas mais barata. Eu falo para ele 'Vai lá Murilinho pega isso e isso e ele pega direitinho e vem cá e mostra pra mim.' Ele me ajuda muito.

Minhas mudanças

Murilo: Eu ajudo minha mãe a fazer a compra do mercado. Eu já sei lê tudo que tem lá. Ela fica feliz quando eu leio o que está no arroz e eu falo para ela. Já descobri que nem precisa lavar o arroz (risos). 
A aprendizagem de Murilo no campo da leitura e da escrita favoreceu novas possibilidades de relação com a mãe associadas à forma como ela incentivava ações de leitura e descobertas de Murilo no seu dia a dia. Essa construção pode ser ilustrada pelos trechos a seguir:

\begin{abstract}
Momento informal - Após reunião de pais, diante das produções de Murilo Mãe: Nossa que lindo! Ele está desenvolvendo bastante, né? Ele está lendo tudo lá em casa. Ele fica me mostrando o que está escrito nos lugares e lendo para mim. Tudo que ele vê ele quer ler, na rua em casa e em todos os lugares. Ele tenta ler primeiro e só depois se estiver muito difícil ele pede ajuda para mim. Ele pede para não contar o que está escrito, que ele vai lê primeiro e depois eu falo se está certo ou errado. Aí, depois que ele lê, ele pergunta para mim se está certo.

Diário de ideias

Murilo: Minha pede para lê mensagem do celular para ela. Teve um dia que era minha tia que falou que ia atrasar para chegar em casa e não ia para igreja. Aí minha mãe falou que era para a gente ir sem a tia. Minha irmã não entende o que está lá no celular. Eu falo para ela o que que é.
\end{abstract}

Pela expressão acima, unida a outras informações, interpretamos que, mediante a leitura e a escrita, Murilo ocupava uma relação mais próxima com a mãe e se diferenciava da irmã, ao criar possibilidades de diálogo. Havia novas produções subjetivas associadas às possibilidades de atuação com o aprendido em situações na vida, como oportunidade de ocupar um lugar diferenciado na relação com a mãe e com a irmã. Murilo lidava com processos contraditórios, em meio a novas produções subjetivas capazes de reconfigurar a forma como se relacionava com a irmã, se autoafirmando nesse processo.

Tais processos subjetivos favoreceram formas diferenciadas com que a criatividade emergisse em sua aprendizagem, agora com ênfase não apenas no registro de suas próprias ideias, mas também na forma como se inseria de maneira atuante na leitura do entorno. Ele não apenas lia o que estava nos produtos do supermercado ou outros lugares, Murilo atuava com esta leitura em sua vida, o que o direcionava a orientar a mãe à compra de um ou outro produto pela qualidade das informações dispostas nos rótulos dos produtos.

Podemos exemplificar essa construção a partir de duas de suas falas. A primeira relacionada à ajuda à mãe no supermercado: "Quase que a minha mãe comprou aquele macarrão errado. Não estava escrito que tinha ovo. Aí eu fui lá e troquei para ela." (Minhas mudanças). A segunda estava associada à leitura de informações nos murais da escola em que, cada novo cartaz afixado nos painéis da escola era fonte para aprender novas palavras, o que lhe gerou possibilidades de organizar para si as informações dos mesmos: "Aquela palavra lá REUNIÃO parece aquela que eu escrevi, que era REGIÃO. Vai ter reunião na escola. Eu vou avisar minha mãe. Agora eu já tô sabendo tudo que vai acontecer na escola. Eu passava aqui 
diretão e ia para a sala, agora eu vejo o que vai acontecer." (Brincando de escolinha). O excerto a seguir, dentre outros, também fornece subsídios para ilustrar nossa elaboração:

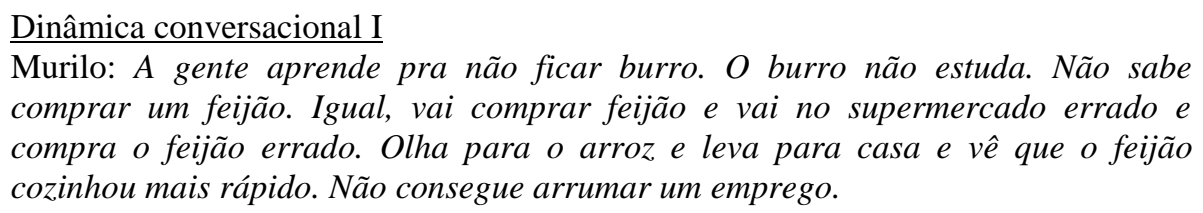
comprar um feijão. Igual, vai comprar feijão e vai no supermercado errado e compra o feijão errado. Olha para o arroz e leva para casa e vê que o feijão cozinhou mais rápido. Não consegue arrumar um emprego.

A representação de Murilo sobre a necessidade de aprender a ler e a escrever indicava novas produções subjetivas associadas a ser esta uma conquista pessoal que lhe garantiria um status social diferenciado de atuar com o saber. Essa construção se organiza pelo que culturalmente experienciava no contexto familiar. A mãe de Murilo cursou até o quarto ano do ensino fundamental e dispunha de um linguajar regional. Na escola, foram vários os momentos em que observamos Murilo descobrir novas palavras e dizer: "Еu vou ensina essa aqui pra minha mãe." (Observação). Ensinar a mãe era uma forma de estabelecer uma relação próxima com ela e também uma maneira de mostrar a ela os seus conhecimentos neste campo, o que se constituiu mediante recursos subjetivos associados à autonomia, flexibilidade e autodeterminação. A informação abaixo pode ilustrar nossas elaborações:

\section{Diário de ideias}

Murilo: Minha mãe é cozinheira. Eu vou todo dia com ela no supermercado. Eu já levei uma receita que eu copiei para minha mãe fazer um bolo. Estava escrito lá naquele cartaz que a tia colocou.

O trecho acima refere-se a um momento de observação em sala de aula, no segundo ano. Nessa situação, Murilo copiou a receita e, em seguida, inseriu outros ingredientes, fazendo experiências no campo das ideias, momento em que disse: "Se eu colocar chocolate aqui deve ficar gostoso." Compreendemos que havia a utilização do que o estudante aprendia no contexto escolar em outros contextos sociais de sua vida, e indicavam, de certa maneira, uma transcendência com impacto ao seu modo de vida, ao inserir novas possibilidades de experiências. Essa construção pode ser ilustrativa da aprendizagem em Murilo como um processo associado à criação própria e não apenas para reprodução ou memorização. A guisa de exemplificar nossa construção, apresentamos a expressão de Murilo ao indutor "36Escrever é" do instrumento "Trilha das frases": "Criar ideias e copiar".

Tal aspecto é enfatizado por Mitjáns Martínez (2012a), como elemento fundamental da expressão da criatividade na aprendizagem, configurado na representação da aprendizagem orientada para a criação. O desejo de criar esteve configurado na busca de atenção da mãe, relacionada ao seu interesse pela profissão dela, pelo distanciamento que gerava em relação a estar com Murilo. Interpretamos que havia sentidos subjetivos atuais associados ao desejo 
de aprender a ler e a escrever para se inserir de forma mais efetiva nas ações da mãe, em meio a ações empreendedoras do ser sujeito na aprendizagem, como as idas ao supermercado, a leitura dos rótulos de embalagens, que vinculavam o aprender e sua própria vida.

Na relação com a irmã, Murilo iniciava um processo de ensiná-la a ler e a escrever e, em muitos momentos de nossas conversas, ele dizia: "Eu estou até ensinando a Larisse a lê e a escrever. Eu pego aquele livro que eu fiz e vou mostrando para ela as letra. Ela tá quase sabendo, mas ela ainda faz muita bagunça." (Minhas mudanças). Ele assumiu um lugar de que era capaz de ensinar algo para sua irmã, o que, de certa forma, o fortalecia e lhe permitia gerar uma autoimagem positiva de si mesmo no âmbito familiar, se autoafirmando sobre algo que sabia fazer bem. Havia novas produções subjetivas associadas a atuar com o saber em prol de ensinar ao outro. Nesta dinâmica subjetiva, se engendravam novos processos de expressão da criatividade em sua aprendizagem, pela forma como Murilo empreendia ações para ensinar a ler e a escrever, momentos em que criava caminhos metodológicos próprios para ensinar a irmã e avaliar a sua aprendizagem, que transcendiam o que experienciava na escola. A fala abaixo, dentre outras, pode subsidiar nossas elaborações:

\footnotetext{
Minhas mudanças

Murilo: Eu pego umas folhas lá do meu caderno e aí eu faço um desenho e ela tem que falar o nome do desenho. Tem dia que a gente escrever até no quintal, lá na terra. Ela já está quase aprendendo o nome dela. A tia usa só os livros da sala, eu pego aqueles que eu escrevi e mostro para ela as palavra.
}

Do nosso ponto de vista, ocorreu recursividade entre a aprendizagem criativa da leitura e da escrita e o desenvolvimento da subjetividade de Murilo, em um processo em que um está no outro de forma distinta e se constituem. Favoreceu-se uma relação diferenciada com a questão da cor dos olhos da irmã que, segundo Murilo, todos admiravam em detrimento da cor dos seus. Ele se encontrava num processo questionador e passou a procurar respostas mais científicas sobre a cor dos olhos, o que pode ser exemplificado pela escrita de Murilo no instrumento "Minhas mudanças": "Eu quero descobrir se a gente vê verde quando o olho da pessoa é verde. Vou ver se tem um livro que tem isso."

Interpretamos que se gestava outro núcleo de sentidos subjetivos associados ao interesse por novas aprendizagens. Nesse havia novas produções subjetivas vinculadas à resolução científica de conflitos pessoais, associados às possibilidades que Murilo encontrava em exercer um processo questionador frente aos seus conflitos e buscar respostas para os mesmos nos livros ou mesmo no diálogo com o outro. Eram produções que passaram a constituir a sua configuração subjetiva da aprendizagem na dinâmica de desenvolvimento com repercussão em novos caminhos consolidados pelo sujeito. 
Do nosso ponto de vista, a forma investigativa de Murilo, no contexto escolar, foi favorecida pela constituição de sua autonomia e independência no campo da aprendizagem. Havia mudanças em Murilo na forma de se relacionar com a escrita da escola e também com o entorno, em uma busca intencional pela leitura que lhe permitiu formas conscientes de agir sobre o meio ambiente, tema que passa a ser de grande interesse para Murilo. Ele começa a se interessar por livros e leituras de painéis com tais informações. Interpretamos que se constituía um novo núcleo de sentidos subjetivos vinculados à aprendizagem de temas de seu interesse que reverberava para a constituição de novos valores morais que envolviam o cuidado com o meio ambiente e com o próprio ser humano. Em seu dia a dia na escola, Murilo era enfático em proteger as plantas, passarinhos e também a água na escola.

As novas produções subjetivas de Murilo favoreceram novas expressões de sua criatividade, pela forma espontânea de criar mensagens de cuidado ao meio ambiente. O aprendiz registrava mensagens sobre o assunto em pequenos pedaços de papéis, como uma forma de conscientizar os colegas. Interpretamos que tais processos foram possíveis mediante o desenvolvimento da condição de sujeito no processo de aprender, tendo em vista recursos subjetivos constituídos na sua história de vida, as produções subjetivas produzidas na ação, numa intrincada relação sujeito-contexto-organização subjetiva.

Percebemos o envolvimento de Murilo com a busca intencional pela descoberta de novas palavras e a maneira como ele inseria estas palavras em seu vocabulário. Essa construção pode ser ilustrada por um momento de leitura de uma história, em sala de aula, pela professora Flávia e de sua explicação do significado da palavra SISUDO, em que Murilo estabeleceu relação com sua tia e disse: “Então minha tia é sisuda, ela quase não ri, só de vez. em quando. Às vezes eu até faço gracinha para ver se ela ri e nada, ela fica séria. Ela não ri nem se fizer cosquinha nela (risos). Agora eu vou chamar ela de sisuda." (Dinâmica conversacional II). Havia produções subjetivas atuais associadas à contextualização da aprendizagem nas ações cotidianas.

Esta forma personalizada de lidar com a aprendizagem era singular da subjetividade de Murilo em que conteúdos constituíram-se a nível personológico com capacidade de se integrarem aos "[...] distintos sistemas da subjetividade de forma simultânea, e aparece como determinante da expressão do sujeito ante situações diversas" (GONZÁLEZ REY, 1995, p. 80, tradução nossa). O quadro a seguir ilustra nossas elaborações sobre as inter-relações entre a expressão da criatividade e o desenvolvimento da subjetividade de Murilo: 
Quadro 4 - Inter-relações entre a expressão da criatividade e o desenvolvimento da subjetividade de Murilo

\begin{tabular}{|c|c|c|c|}
\hline $\begin{array}{l}\text { Configuração subjetiva da ação de } \\
\text { aprender }\end{array}$ & Expressão da criatividade & $\begin{array}{l}\text { Mudanças na } \\
\text { constituição subjetiva }\end{array}$ & $\begin{array}{c}\text { Novas } \\
\text { expressões da } \\
\text { criatividade }\end{array}$ \\
\hline \multicolumn{3}{|c|}{ Núcleo de sentidos subjetivos associados à mudança da educação infantil para o ensino fundamental } & \multirow{6}{*}{$\begin{array}{c}\text { - Forma } \\
\text { autêntica de } \\
\text { gerir o seu } \\
\text { tempo pessoal } \\
\text { de forma } \\
\text { autônoma, em } \\
\text { contraposição } \\
\text { ao tempo } \\
\text { institucional, } \\
\text { que } \\
\text { demarcava } \\
\text { limites de } \\
\text { tempo para } \\
\text { cada atividade } \\
\text { realizada. }\end{array}$} \\
\hline $\begin{array}{l}\text { Produções subjetivas associadas: } \\
\text { - ao vínculo entre brincar e entrega } \\
\text { plena às atividades propostas; } \\
\text { - à contenção do movimento corporal } \\
\text { para aprender; } \\
\text { - às relações entre o caráter inventivo } \\
\text { do brincar com a aprendizagem da } \\
\text { leitura e da escrita; } \\
\text { - à personalização dos valores morais; } \\
\text {-à punição como privação de diálogo; } \\
\text { - à autoproteção. }\end{array}$ & $\begin{array}{l}\text { - Relação lúdica: relação } \\
\text { completa, voluntária e } \\
\text { próxima com } \text { suas } \\
\text { experiências de ler e } \\
\text { escrever. } \\
\text { - Geração de ideias próprias } \\
\text { e novas que transcendem o } \\
\text { dado: a criação de suas } \\
\text { próprias histórias. }\end{array}$ & $\begin{array}{l}\text { Novas produções } \\
\text { subjetivas associadas: } \\
\text { - à confiança em si mesmo, } \\
\text { em sua capacidade para } \\
\text { aprender; } \\
\text { - à necessidade de trocar } \\
\text { ideias com o outro como } \\
\text { argumentação sobre suas } \\
\text { elaborações; } \\
\text { - à autovaloração positiva } \\
\text { na aprendizagem. }\end{array}$ & \\
\hline \multicolumn{3}{|c|}{ Núcleo de sentidos subjetivos associados à necessidade de estabelecer vínculos afetivos com o outro } & \\
\hline $\begin{array}{l}\text { Produções subjetivas associadas: } \\
\text { - ao vínculo entre aprendizagem e } \\
\text { desenvolvimento; } \\
\text { - à diferenciação das crianças menores; } \\
\text { - à valorização na família; } \\
\text { - à autoimagem negativa; } \\
\text { - às preocupações em não ser aceito; } \\
\text { - à aprendizagem como via de relação } \\
\text { com o outro; } \\
\text { - à necessidade de ser reconhecido; } \\
\text { - à necessidade de valorização social. }\end{array}$ & $\begin{array}{l}\text { - Confrontação com o dado: } \\
\text { a relação positiva com o } \\
\text { erro. } \\
\text { informação com impactos no } \\
\text { modo de } \\
\text { disponibilidade em estar } \\
\text { mais com o outro. }\end{array}$ & $\begin{array}{l}\quad \text { Novas produções } \\
\quad \text { subjetivas associadas: } \\
\text { - a sentir-se incluído no } \\
\text { grupo e estar com o outro } \\
\text { de forma autêntica; } \\
\text { - a desfrutar do tempo } \\
\text { escolar para se relacionar } \\
\text { com colegas. }\end{array}$ & \\
\hline \multicolumn{3}{|c|}{$\begin{array}{c}\text { Núcleo de sentidos subjetivos associados à aprendizagem da leitura e da escrita como processo } \\
\text { relacional }\end{array}$} & \\
\hline $\begin{array}{l}\text { Produções subjetivas associadas: } \\
\text { - a estabelecer vínculo com a mãe } \\
\text { mediante a aprendizagem; } \\
\text { - à leitura e a escrita como algo que o } \\
\text { desafiava a querer aprender; } \\
\text { - à escola como local de viver } \\
\text { experiências de aprender; } \\
\text { - à professora como parceira para } \\
\text { aprender em um espaço de se sentir } \\
\text { seguro para se expressar; } \\
\text { - ao reconhecimento social; } \\
\text { - ao vínculo da aprendizagem à vida; } \\
\text { - à autovalorização das conquistas; } \\
\text { - à necessidade de novas experiências. }\end{array}$ & $\begin{array}{l}\text { - Personalização da } \\
\text { informação: relação com } \\
\text { palavras do entorno. } \\
\text { - Confrontação com o dado: } \\
\text { relação com suas próprias } \\
\text { produções; trocas de ideias; } \\
\text { estrutura dos livros. } \\
\text { - Estratégias } \\
\text { aprendizagem. } \\
\text { - Relação lúdica: relação de } \\
\text { comunicação; criação de } \\
\text { cenário imaginário. } \\
\text { - Geração de ideias próprias } \\
\text { e novas além do dado. } \\
\end{array}$ & $\begin{array}{l}\text { Novas produções } \\
\text { subjetivas associadas: } \\
\text { - a ver-se capaz de ousar } \\
\text { em suas produções sem } \\
\text { dependência do outro; } \\
\text { - à autoafirmação de seus } \\
\text { gostos, preferências, } \\
\text { expondo cada vez mais o } \\
\text { seu ponto de vista; } \\
\text { - ao reconhecimento de } \\
\text { suas potencialidades no } \\
\text { campo da aprendizagem. }\end{array}$ & \\
\hline \multicolumn{3}{|c|}{ Novos aspectos da constituição subjetiva } & \multirow{5}{*}{$\begin{array}{c}\text { - Criação de } \\
\text { mensagens de } \\
\text { cuidado ao } \\
\text { meio } \\
\text { ambiente. }\end{array}$} \\
\hline \multicolumn{3}{|c|}{$\begin{array}{c}\text { Novo núcleo de sentidos subjetivos associados ao status diferenciado no âmbito do sistema } \\
\text { relacional com seus familiares }\end{array}$} & \\
\hline \multicolumn{3}{|c|}{$\begin{array}{ll}\text { - à relação do que aprende com a vida; } & \text { - a aprender como form } \\
\text { - a atuar com o que aprende; } & \text { - a assumir o lugar de e }\end{array}$} & \\
\hline \multicolumn{3}{|c|}{ Novo núcleo de sentidos subjetivos vinculados à aprendizagem de temas de seu interesse } & \\
\hline & duções subjetivas associadas: & & \\
\hline
\end{tabular}

Fonte: elaborado pela autora, 2015. 


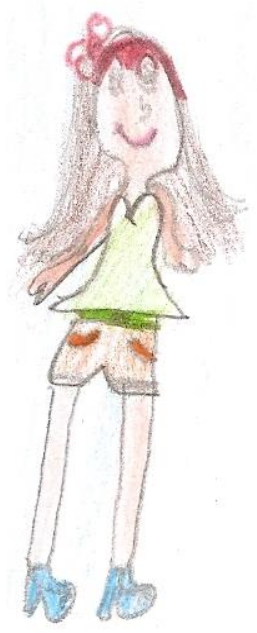

Figura 2: Produção de Adriana a partir do instrumento "Montando minha história" - 2013

\subsubsection{Caracterização de Adriana}

Adriana iniciou o primeiro ano do ensino fundamental com seis anos de idade e completou nove anos no curso do terceiro ano da referida etapa de ensino. Era uma criança alegre, crítica e contestadora. De pele morena clara, cabelos longos e castanhos; era a mais alta das meninas da turma. Morava com sua mãe, seu pai e seu irmão mais velho. No decorrer da pesquisa, seu irmão se casou e mudou de residência. Adriana dispunha de livros e outros materiais escolares em sua casa, bem como todo o seu material era comprado por seus pais. Sua mãe era diarista e seu pai jardineiro. Ao analisarmos a sua história escolar por meio de documentos, identificamos que ela era uma aluna extremamente participativa, responsável e estava sempre à frente dos colegas em termos de aprendizagem da leitura e da escrita. Segundo avaliação diagnóstica realizada pelas professoras regentes, Adriana iniciou o $1^{\circ}$ ano do ensino fundamental na hipótese alfabética ${ }^{44}$ de escrita e concluiu o $2^{\circ}$ ano em um novo nível da hipótese alfabética ${ }^{45}$. Chamou nossa atenção a sua expressiva participação em sala de aula, o seu empenho e dedicação para com a leitura e da escrita.

\footnotetext{
${ }^{44}$ De acordo com Ferreiro (1995), neste nível de escrita, a criança faz correspondência dos fonemas e sílabas para a escrita.

${ }^{45}$ Para Ferreiro (1995), a escrita ortográfica se organiza conforme as regras que regem nosso sistema de escrita.
} 


\subsubsection{Expressão da criatividade na aprendizagem da leitura e da escrita e suas relações com as estratégias de aprendizagem de Adriana}

No presente tópico organizamos nossas construções sobre a expressão da criatividade na aprendizagem da leitura e da escrita de Adriana e suas relações com as estratégias de aprendizagem. Nossas elaborações nos permitiram qualificar sua aprendizagem como eminentemente criativa, a qual se expressou pela personalização da informação, pela confrontação com o dado, pela geração de ideias próprias e novas que transcenderam o dado e pela relação lúdica. Essas quatro características estiveram vinculadas às estratégias de aprendizagem utilizadas por Adriana. Assim como compreendemos a expressão sistêmica da criatividade na aprendizagem, ao emergir de forma mais ampla na aprendizagem.

\subsubsection{Personalização da informação}

Adriana personalizava os conteúdos trabalhados em sala de aula, pela forma como procurava relacionar o que estava aprendendo com sua vida, o que lhe permitia atuar com este conhecimento em diferentes contextos. Tal processo estava articulado à estratégia de autorregulação de associar o que aprende com situações cotidianas. Dentre outros exemplos, os trechos abaixo podem ser ilustrativos de nossas elaborações:

\footnotetext{
Entrevista I

Adriana: Eu gostei dessa também que tinha que desenhar dois meninos comendo coisa saudável. Eu fiz comendo um lanche de fruta e um almoço. Eu também gostei dessa dos sentidos. A gente teve que recortar o que era paladar, audição e tudo. Eu amei essa sobre o meio ambiente. Eu tive que inventar uma história bem legal e sabe que eu vi que a gente pode faze coisa tão fácil como varrer as folhas do quintal de casa para não dá bicho e isso eu faço agora.

Diário de ideias

Adriana: Sabia que eu fiz um lixinho de copo descartável? Minha mãe ia jogar fora e eu peguei e fiz um lixo que tem até tampa. E também eu fiz um potinho para o meu pai colocar pimenta. Eu estou ajudando o meio ambiente.

Dinâmica conversacional II

Adriana: Também agora eu fico lendo os textos e já fico pensando o que eu não sabia. Eu aprendo tanto coisa lendo os textos. Eu até falei para minha mãe que tem que cortar unha para não dá bicho, estava lá naquele que eu li.

Momento informal

Adriana: A criança tem direito a educação gratuita, e eu sei que é que não precisa pagar, igual a minha escola. Eu agora sei que é meu direito estar aqui.
}

O conhecimento configurava as ações de Adriana para além do contexto escolar, gerador de possibilidades de organizar o conteúdo como algo próprio, o que pode ser ilustrado pela forma como criava objetos que facilitavam o seu cotidiano, como lixinho de garrafa pet para não deixar lixo no chão da sala de aula, bem como a orientação que fazia às pessoas 
sobre cuidados com o corpo humano. Ela transformava os conteúdos aprendidos em processos qualitativos para sua vida, que implicava atuar de forma efetiva e crítica com o saber.

A leitura e a escrita lhe favoreceram empreender novas ações orientadas às mudanças em seu modo de vida, que envolveram, dentre outras, novas possibilidades de experienciar uma relação mais saudável com sua alimentação, novos processos relacionais de ensinar ao outro, e os cuidados com o meio ambiente. Do nosso ponto de vista, a personalização dos conteúdos relacionava-se ao como Adriana vivia o seu cotidiano e estava vinculada ao caráter empreendedor do sujeito pela abertura a novas possibilidades de viver experiências que lhe garantissem qualidade de vida. O excerto abaixo, dentre outros da pesquisa, pode ilustrar nossa elaboração:

Diário de ideias (Anexo F - Figura 12)

Adriana: Eu comia tudo errado. Sabia que eu era é gulosa? Tem coisa que faz mal para gente e eu comia tudo. Agora eu vou comer muita fruta e verdura. Eu adoro doce mais não pode se não eu vou ficar doente. Mas eu como só um pouco, né?

Havia interesse de Adriana em atuar com o que estava aprendendo em contextos distintos, como processo que lhe permitia aprofundar seus conhecimentos e associar sua aprendizagem à sua vida. Identificamos em Adriana expressões de surpresa diante das possibilidades de utilizar o que aprendia: “Eu vo canta essa música pra minha mãe, ela vai ama. Parece a que eu fiz um dia. Eu vo usa essa música lá na minha casa e vo coloca no meu diário. E depois eu vo usa essa palavra aí amor, pra faze outra música." (Diário de ideias).

Também se associa a este processo de personalização dos conteúdos, estratégias de autorregulação relacionadas à busca por aprofundar seus conhecimentos. Adriana apresentava um aguçado interesse por novas descobertas sobre o que aprendia que envolvia a forma independente, com que buscava respostas para suas dúvidas e questionamentos, ao empreender processos autônomos de pesquisas. O exemplo a seguir ilustra nossa construção:

Diário de ideias

Adriana: Eu vou pesquisar mais sobre as árvores. Não sei direito o que é adubo, mas acho que é o que minha mãe coloca na flor lá de casa e ela fala que faz crescer e ficar forte.

A ação de personalizar os conteúdos envolvia outras estratégias de autorregulação que Adriana lançava mão para aprender, associadas à deliberação de atenção e concentração nas ações de ler e escrever. Isso era percebido em sua observação às explicações da professora e nas ações de ler e escrever. Podemos exemplificar nossa elaboração com uma de suas falas na Entrevista I, em que se expressou diante da pergunta de como havia se sentido no momento de escrever seu livro: "Eu estava concentrada para escrever. Falei para a Júlia que depois eu respondia para ela." 
A personalização do que lia e escrevia se configurou pelas relações que estabelecia com suas próprias experiências, movimento de contextualização e de transcender o fixado na escrita, por meio da formação de opinião própria e de utilização do que lia em diferentes contextos, muitas vezes criando algo que se diferenciava do inicialmente lido. Podemos exemplificar tal construção a partir da sua leitura, na sala de aula do segundo ano, de um livro sobre sapos, em que Adriana se posicionou da seguinte forma:

\section{Entrevista III}

Pesquisadora: O que você achou da história?

Adriana: Eu não gostei do final dessa história. Para mim não tem que matar sapo não. A gente devia criar uma regra para acabar com isso, de não matar mais sapo. Eu vou fazer uma história com tudo diferente dessa e vai ser sobre como o sapo ajuda a natureza.

A leitura configurava-se na ação de se posicionar frente ao escrito, de estranhamento e de buscar a familiarização, assim como propor soluções para o que lhe incomodava. A criatividade se expressava na leitura e na escrita pela maneira como Adriana transgredia, subvertia o dito e propunha ações para além do que estava posto. Essa ação de ler, assim como nos aponta Certeau (2011), não era passiva, mas representou processo de metamorfose do texto pelo leitor, ou seja, Adriana imprimia mudanças que passavam dos significados atribuídos às palavras, à organização de suas próprias ideias que se diferenciavam do texto.

Nesta personalização da leitura, se associava a estratégia de autorregulação de fazer inferências nas leituras que realizava. Para ilustrar nossa construção, apresentamos a fala de Adriana em um momento de realização da Provinha Brasil de Língua Portuguesa, no segundo ano, na qual após ler um texto instrucional de uma receita, em Entrevista III nos disse: “Hum! Achei aquela receita uma delícia! Vou pedir para minha mãe me ajudar a fazer essa receita, mas vou colocar chocolate para ver se fica mais gostoso." Compreendemos que, para Adriana, o escrito não continha uma verdade absoluta, mas sim, algo repleto de possibilidades de interpretações. Nessa direção corroboramos Cantú (2011, p. 97, tradução nossa), para o qual "Um sujeito pode julgar as palavras escritas pelo caráter de certeza ou pode conceder ao escrito o caráter de verdade provisória, na qual se apoiará para construir saberes próprios”.

A partir do exemplo anterior, compreendemos que, a partir da leitura, Adriana criava, gerava algo próprio e que estava para além do escrito. No exemplo acima, ela realizou a leitura, identificou o tipo de texto (solicitado na atividade), gerou algo novo (a busca por realizar a própria receita com sua mãe) e transcendeu o que estava posto em dois processos: no que foi solicitado na atividade (não se restringindo a apenas responder) e ao envolver-se com o que estava escrito, implicando-se e trazendo para uma experiência que queria realizar, transcendia a receita ao incluir ingredientes que não estavam no inicialmente dado. A própria 
ação de escrever era geradora de processos de personalização em que a escrita lhe possibilitava transformar sua própria escrita. Os trechos abaixo ilustram nossas construções:

Diário de ideias (Anexo E - Figura 9)

Adriana: Eu estava escrevendo sobre moda e depois que eu li (risos) eu pensei assim, que podia fazer um tantão de modelos de vestido.

Entrevista IV

Pesquisadora: O que você escreveu nesta atividade?

Adriana: Eu escrevi sobre doces e falei que é muito bom come. Mais aí, eu estava lendo de novo e acho que vou mudar.

Pesquisadora: Por quê?

Adriana: Eu acho que eu tenho que falar que o doce pode fazer mal para saúde.

Pesquisadora: O que você aprende quando escreve ou lê?

Adriana: Eu aprendi a escrever mais certo e a lê. Eu aprendi a cria história.

A personalização se constituiu na possibilidade dos conteúdos de sua própria escrita, formarem parte de recursos subjetivos de Adriana e configurarem suas ações em distintos contextos, essas ações vinculadas a estratégias de autorregulação de utilização do aprendido em situações cotidianas, o que se expressava no modo de vida, como por exemplo, empreender novas ações de utilizar o seu tempo livre para produzir um caderno com desenhos de modelos de roupas, assim como a sua relação com a alimentação. Interpretamos que, o processo de mudança no modo de vida impactava a sua escrita, em um processo recursivo. Foi nestes processos de personalização que o pensamento constituiu-se como processo subjetivo, motivador em si mesmo. Receber uma informação, transformá-la e transcendê-la, requer um funcionamento do pensamento em seu caráter reflexivo (GONZÁLEZ REY, 2012a).

\subsubsection{Confrontação com o dado}

Identificamos que Adriana confrontava-se com elementos do trabalho pedagógico desenvolvido pelas professoras pela forma como observava as solicitações das docentes, para estar à frente, o que, de certa forma, facilitava sua iniciativa perante as atividades propostas, ao realizá-las sem aguardar explicações. Nesta forma ativa, intencional e transgressiva, Adriana criava maneiras próprias para realizar as atividades propostas, construção que pode ser ilustrada pelas informações abaixo:

Momento informal

Adriana: Eu sei tudo que a tia vai perguntar. Já sei até a tarefa que ela vai dar.

Entrevista IV

Pesquisadora: Como você compreendeu o que é para ser realizado? Você mudou alguma coisa?

Adriana: Nem precisa da tia falar que é para fazer um texto e eu já sei o que vou escrever. Eu coloco a história do meu jeito.

Pesquisadora: Você fez algo a mais na atividade ou cumpriu o que foi pedido?

Adriana: Eu fiz um texto bem grande e acho que nem era para ser grande. 
Nesta independência em relação às professoras, Adriana ousava em suas produções escritas e se permitia registros que não se limitavam ao solicitado. Atuava de forma investigativa e explorava as atividades propostas de leitura e escrita para identificar possibilidades de fazer diferente do proposto, o que pode ser exemplificado pelo trecho abaixo:

\author{
Entrevista IV \\ Pesquisadora: Como você está realizando a atividade proposta? \\ Adriana: Estou fazendo uma música. Eu estou inventando agora. \\ Pesquisadora: Como você compreendeu o que é para ser realizado? Você mudou \\ alguma coisa? \\ Adriana: A tia falou para fazer um texto, mas eu quis fazer uma música. Eu também \\ fiz mais linhas para colocar mais música. \\ Pesquisadora: Você fez algo a mais na atividade ou apenas cumpriu o que foi \\ pedido? \\ Adriana: Fiz uma música. \\ Pesquisadora: Fez alguma descoberta? \\ Adriana: Vi que sei fazer música. \\ Pesquisadora: O que você aprendeu com esta atividade? \\ Adriana: Aprendi que pode imaginar e fazer tanta coisa. \\ Pesquisadora: O que esta atividade lhe impulsionou a querer descobrir mais? \\ Adriana: Eu vou pesquisar se existe uma uva que não cai do pé. \\ Pesquisadora: Você tem interesse em realizá-la novamente? \\ Adriana: Pode até ser, mas eu vou fazer outra coisa. \\ Pesquisadora: O que você mudaria na atividade? \\ Adriana: Eu colocaria mais linha, para gente escrever mais.
}

Em muitos momentos da pesquisa, identificamos que Adriana se confrontava com as ações realizadas pelas professoras no cotidiano da sala de aula. Nesses momentos, a aprendiz fazia críticas aos tipos de atividades propostas e também à forma de explicações. As informações abaixo podem ilustrar nossas elaborações:

\title{
A professora Isadora
}

Era uma vez uma mulher ela era uma professora ela se-chamava Isadora todos os dias ela faz uma bricadeira deferente um dia de rodo, de jogos teve um dia que uma menina falou professora prorque a gente é deferente. A professora respondeu porque foi Deus que nos fez tem gente defisiente igual a juca, tem cadeirante, tem mudo cego tambem tem os idoso a menina fala oque é idoso e as pessas velhas em vez de ce-chamar velho se-chama idoso carla fala foi Deus que nos criou a professora fala treine as palavras do para casa amanhá tem ditado Livia falou quando eu crecer eu quero cer professora eles bricam de corda eels vouta para a sala de aula e o sinau bate eles forma a fila e vai para o recrei as meninas comverçam uma fala quando eu crecer eu quero ser medica eles vouta para sala e passou us minutos e eles foi em bora e viveirom felizem para sempre.

Entrevista IV a partir da produção de texto acima

Pesquisadora: Como você está realizando a atividade proposta?

Adriana: Eu estou pensando se eu fosse a professora.

Pesquisadora: $\mathrm{O}$ que você não gostou na atividade?

Adriana: Da tia do desenho. Ela podia estar brincando na roda também.

Pesquisadora: O que esta atividade lhe impulsionou a querer descobrir mais?

Adriana: Eu quero saber mais atividade que a tia pode fazer com a gente.

(Transcrição de produção de texto de Adriana - atividade de sala de aula/2 ${ }^{\circ}$ ano) 
Adriana reconfigurava o trabalho pedagógico das professoras, em um processo empreendedor de descobrir possibilidades de experiências que eram possíveis de serem realizadas. Neste contexto, ela se confrontava com o já existente e experienciado, ao questionar e criar novas possibilidades de experiências e gerar caminhos próprios de atuação, como a produção de um caderno denominado por ela de "Plano de aula".

Momento informal

Adriana: Eu nunca vi um caderno de plano de aula da professora, eu pensei que fosse igual ao dos alunos. Eu faço meu plano de aula do jeito que eu acho que a professora tinha que fazer com a gente. Eu coloco brincadeiras e também outras formas de poder ensina a mesma coisa que a tia dá para gente. Tem até dia que a gente vai lá no parque e olha as plantas e depois aprende o nome de cada uma.

Interpretamos que, criar um plano de aula para si mesma, com a intencionalidade de experienciar possibilidades de novos processos de aprendizagem a partir de diferentes maneiras de ensinar, esteve constituído pelo funcionamento da imaginação como processo gerador de novas experiências que transcendiam o vivido por Adriana. Esse processo pode ser constitutivo da assunção do ser sujeito na aprendizagem, com ênfase à confrontação com o instituído nas práticas pedagógicas de sala de aula e na busca de caminhos próprios de subjetivação. Ao não se conformar com os tipos de atividades, desprovidas de experiências práticas, por não envolverem brincadeiras, jogos e movimento, Adriana criava suas próprias maneiras de viver tais experiências em busca de lhe gerar bem estar e satisfação em aprender.

Nestes embates pessoais, identificamos a confrontação de ideias que Adriana estabelecia com as explicações das professoras, associada à estratégia cognitiva de buscar participar oralmente em sala de aula, ao emitir respostas às perguntas das professoras e fazer novos questionamentos. Pela sua expressiva participação em sala de aula, contestava explicações das professoras e enfatizava seus próprios pontos de vista. O que pode ser exemplificado por um dos momentos de nossas observações em que a professora Flávia, do segundo ano, explicava para a turma sobre o dia do trabalhador. A docente citou alguns nomes de profissões e após terminar, Adriana levantou a mão e pediu a vez para falar: "Você não falou diarista. Minha mãe é diarista e isso é trabalho!"

Para Adriana, participar oralmente favorecia a aprendizagem, ao expressar suas e pelas possibilidades de poder mudar a sua ideia inicial, mantê-la ou mesmo transcendê-la. Essa construção pode ser exemplificar com uma de suas falas:

Diário de ideias

Adriana: A tia perguntou se alguém sabia alguma coisa sobre a árvore. Aí eu levantei o dedo e falei tudo que eu sei. Quando eu estou respondendo pra tia eu aprendo comigo mesma. Teve um dia que eu falei que CHUVA era com X e aí quando eu estava falando (risos) eu vi que era com $\mathrm{CH}$. 
A confrontação de ideias também se expressou na relação com as atividades propostas pelas professoras, em que Adriana buscava verificar se estavam corretas. Isso pode ser ilustrado a partir do momento de observação em sala de aula em que a professora Flávia apresentava o livro criado pela turma, dizendo que os nomes dos alunos estavam em ordem alfabética. Ao receber o livro, Adriana abriu na página referida pela professora e buscou identificar os nomes dos colegas com a ordem alfabética. Adriana identificou uma troca na ordem de dois nomes de seus colegas e disse: "Não está não na ordem alfabética. Aqui está errado." A professora validou a fala de Adriana, porém, disse que não teria como arrumar. No entanto, Adriana riscou seu próprio livro e organizou na ordem alfabética.

O confronto de Adriana também se apresentou com suas próprias produções, o que estava para uma relação com o erro, pautada pela busca do acerto em prol de obter reconhecimento do outro. Adriana recorria à estratégia de autorregulação de revisar, de forma autônoma, suas produções. Em vários momentos de escrita, ela dialogava consigo mesmo e questionava seu próprio registro, como podemos exemplificar por uma de suas falas: "Será que BLUSA é com S? Tem SOPA, NARIZ, AZUL, ASA, ah eu estou achando que é mesmo com S. Depois eu corrijo se precisar mudar. A tia vai olhar e eu tenho que acertar." Adriana se colocava em um processo investigativo frente à escrita, o que interpretamos fazer parte de um modelo hipotético em andamento, no qual a aprendiz assumia responsabilidade frente às suas produções de modificar, melhorar e corrigir. O que pode ser ilustrado pelo trecho abaixo:

\section{Entrevista II}

Adriana: E se eu vejo uma palavra errada eu sei que está errada e apago. Eu mesmo olho e sei que está errada. É porque eu já vi a palavra NASCI em minha certidão. Eu fiz uma atividade ano passado e lembrei que o $S$ era antes o $C$. Pesquisadora: Como você avalia seu processo de escrita? Adriana: Eu acho legal. É sempre divertido. Nossa! Eu escrevi 22 linhas.

Adriana também utilizava estratégias cognitivas associadas ao cuidado com a estética de suas atividades, sendo extremamente caprichosa, ao colorir, enfeitar e refazer letras. Processos associados ao próprio confronto com sua produção, sendo a conclusão da atividade, algo que passava por sua avaliação, o que pode ser ilustrado por uma de suas falas: "Precisa ficar bem colorido e bem bonito. Eu não gostei dessa letra, vou faze outra." (Diário de ideias). Outras informações podem ilustrar nossa construção:

\section{Diário de ideias}

Pesquisadora: Qual dica você daria para alguém escrever um livro?

Adriana: Copiar com a letra bonita. Todo mundo vai ler e tem que saber o que está escrito. Quando a letra está grande eu apago. Tem que imaginar o que quiser inventar. Pode ser qualquer coisa. É só deixar a imaginação fala pra ela. 
Identificamos que, no confronto com sua produção, Adriana também utilizava estratégias cognitivas de estabelecer relações entre os sons e grafemas, relações entre palavras e outras associadas às relações entre a forma como culturalmente falava e a escrita das palavras. Como, por exemplo, ao escrever a palavra CAMINHONETE, Adriana grafou como CAMIONETI e disse: “Ah, já sei o que é. Igual LEITE. Eu fazia com I e agora sei que é com E. Acho que aqui também é isso. A gente fala desse jeito e tem fazer diferente."

Tais processos, geradores de dúvidas e confrontos com sua própria escrita, favorecia a utilização de outras estratégias de autorregulação, associadas à busca independente para encontrar respostas para suas dúvidas, seja recorrendo aos seus próprios materiais, ou mesmo no diálogo com a professora. Em sala de aula, observamos, em distintos momentos, que Adriana passava as folhas de seus cadernos contemplando suas próprias produções, o que lhe permitia conhecer em profundidade seus materiais. Em vários momentos de realizar atividades de leitura e escrita, ela recorria a tais materiais para consultar uma ideia, palavra, ou mesmo uma história que gostaria de reler. Esta função expressava o caráter ativo e subversivo do sujeito no contexto da sala de aula, uma vez que não constituía uma prática em sala de aula, a retomada das atividades pelas professoras. Ela estabeleceu uma relação íntima com seu próprio material e o atribuía um significado de apoio à aprendizagem.

Vale destacar que, na relação de Adriana com as leituras que realizava, pelo processo de personalização, em que não assumia o escrito como verdade única, havia o movimento de se confrontar com o dito em busca de gerar suas próprias ideias. Para ilustrar nossa construção, apresentamos um dos momentos em que Adriana realizava a leitura da letra da música "A sopa dos dez indiozinhos" em que disse: "Eu não acho que essa sopa ficou boa não. Se eu fosse fazer uma música de sopa eu ia pôr o que usa mesmo na sopa e não ia ter couve e abóbora."

\subsubsection{Produção, geração de ideias próprias e novas que vão além do dado}

Adriana confrontava-se com as ideias das professoras e com as atividades propostas e isso lhe favorecia gerar ideias próprias e novas que estiveram presentes nas ações de ler e escrever capazes de ir além do que era proposto. Podemos citar um dos momentos da Entrevista IV, em que ela disse: "Nossa! Cada vez que eu leio o que eи escrevo eи vejo uma coisa diferente e quero escrever e até ler outra coisa aí eu quero fazer outra história." Pressupomos que a originalidade da escrita de Adriana, realizada pela forma como se imbuía 
em um processo de autoria em seus registros, estiveram em unidade com estratégias de autorregulação de reflexão sobre suas próprias ideias registradas.

Em um processo aliado ao caráter empreendedor de necessidade de gerar ideias novas, Adriana demonstrava flexibilidade e o caráter reflexivo do pensamento na escrita, como algo que não se fixava como imutável após o seu registro, mas como possibilidade de empreender novas ações a partir do produzido, capazes de ir além do próprio novo. Sendo assim, o novo se constituiu como processo gerador de outros caminhos empreendidos para outras novidades, pois na aprendizagem criativa o novo não era um fim em si mesmo, mas dinamizava novas produções que transcendiam o dado.

O caráter empreendedor se configurou no como Adriana aproveitava suas experiências para novas oportunidades de aprendizagem, na busca em assumir metas e concretizar suas ideias, em sua autonomia em criar materiais pessoais para escrever, como o "Diário" criado para registrar receitas, declarações de carinho para com seus pais e colegas, operações matemáticas e também relatar experiências próprias. Adriana gerava ideias próprias e novas que organizavam a forma de compor o seu diário, transcendendo a relação com a escrita que perpassava a subjetividade social da sala de aula, de que a escrita está para a relação com atividades propostas. Havia confrontação de Adriana com o instituído e nesta luta encontrava caminhos próprios, geradores de bem estar e satisfação. Para ilustrar nossas elaborações, destacamos uma de suas falas: "Eu adoro escrever no meu diário. Eu escrevo, desenho e também colo adesivo. Tudo que eu gosto está lâ’. (Diário de ideias).

Ao registrar a expressão abaixo, Adriana se remete à criação de materiais para registros pessoais como o diário, o caderno de plano de aula e outros materiais, pelo caráter empreendedor em ter metas para a concretização de sua escrita e, buscar ativamente a sua realização, superando dificuldades e obstáculos: "Pra fazer minhas coisas eu não tenho tudo não. Quando eu quis fazer o Diário eu que procurei o que eu podia usar. Eu sei que não tem tudo, mas eu dou um jeito e faço."

A geração de ideias próprias e novas se apresentou também na sua relação com a cópia. Adriana demonstrava prazer em copiar atividades da lousa.

Entrevista IV

Adriana: A tia copia muito e aí eu copio e fico lendo. O que eu acho bem legal, mas bem legal mesmo eu copio no meu caderno lá de casa. Lá tem tudo da escola que eu acho interessante. Tem aquela coisa das aranhas, mas eu descobri que tem aranha lá em casa que não é perigosa. Eu vi até o jeito que elas faz a casa delas e aí eu escrevi isso lá. Acho que a tia nem sabe.

Adriana significava a cópia como processo que lhe permitia gerar ideias a partir da própria ação de escrever, frente às situações que expressavam o caráter reprodutivo de 
utilização da escrita no contexto escolar, como a cópia. Adriana empreendeu novas relações com esta atividade, geradoras de caminhos próprios de aprendizagem que lhe permitiam atuar com a escrita como processo pessoal, pois, quando copiava, ela se colocava como sujeito da ação, em um processo que lhe demandava refletir sobre as informações. Adriana criava caminhos próprios de realizar novas cópias de seus materiais escolares, de textos e palavras, que eram escolhidos por ela mediante uma relação pessoal com as informações. Tal processo demandava uso de seu tempo livre, o que pode ser ilustrado pela criação de seu Plano de aula:

\footnotetext{
Entrevista I

Pesquisadora: Como você teve esta ideia de escrever o que você gosta?

Adriana: Eu inventava as atividades e de vez enquanto eu copiava do meu caderno, mas eu gostava mesmo é de fazer tarefas do meu jeito. Eu olhava os livros lá da minha casa e meus caderno da escola e o que eu gostava eu copiava. Eu escrevo aqui tudo que eu quero aprender mais.
}

$\mathrm{Na}$ ação de copiar, Adriana encontrava possibilidades de modificar o inicialmente posto, trocando palavras, assim como a ordem das ideias. Em seu caderno, criado para registrar o que era do seu interesse, identificamos que havia produções em que sempre inseria um elemento pessoal, que passava pela geração de ideias próprias e novas frente ao escrito e que o transcendia. Isso pode ser exemplificado por uma de suas falas: "A tia escreveu naquele texto que a barata tinha sete saias, aí eu coloquei que só tem uma mesmo. Até aquele da aranha eu não quis usar a palavra teimosa, eu fiz que ela é muito sabida de não querer ficar subindo a parede." (Diário de ideias). Neste processo, o novo se constituiu como processo gerador de outras possibilidades de geração de novas ideias. Era, a partir da cópia e da geração de ideias próprias e novas para suas produções, que Adriana empreendia ações que envolviam, dentre outras: a busca por textos para realizar novas cópias, pesquisas para aprofundar seus conhecimentos. Ilustramos nossas elaborações pelo trecho abaixo:

Brincando de escolinha

Adriana: $O$ dia que eu copiei no meu caderno esse texto da chuva eu já pesquisei no computador se o raio vem antes do trovão. Aí já aprendi que tem raio que cai e pode até matar a gente. Eu fiz um monte de palavra diferente que tinha lá no texto.

Identificamos que a geração de ideias próprias e novas que vão além do dado, também se expressou na criação de situações artísticas, dentre as quais podemos citar as produções de histórias e músicas, cadernos com finalidades diferentes, diário pessoal, assim como a produção de vídeos. Em unidade com tal característica, interpretamos que Adriana utilizava estratégias de autorregulação de procurar formas diferenciadas de realização das atividades propostas e a criação de situações de aprendizagem diferenciadas das já experienciadas.

A produção de livros, por Adriana, se constituiu mediante a estratégia de aprendizagem de autorregulação associada a contar ao outro suas experiências. Ela recorria ao 
registro das histórias, porém com algo diferenciado: eram histórias reconfiguradas a partir de suas próprias experiências. Podemos exemplificar essa construção, por uma de suas falas: “ $E u$ fiz que minha vida é ao contrário. Mais aí eu pensei em tudo ao contrário da minha vida e fiz a história. Ficou tão diferente da minha vida." (Diário de ideias - Anexo E - Figura 10).

A geração de ideias, a partir de suas experiências e sua transcendência, se expressaram nos mais de seis livros de autoria de Adriana. Cada história, que escrevia, era geradora de novos enredos, momento em que o novo assume o caráter gerador de outras possibilidades de produção de novidade. Podemos ilustrar essas considerações, por uma de suas falas: “Quando eu terminei a história da minha vida eu já pensei assim que ia fazer uma história da sopa. Eu adoro sopa e tinha sopa na parte da minha vó." (Diário de ideias). Assim como a própria confecção do livro, o formato do papel que utilizava, ou mesmo as imagens que recortava de revistas para colar em suas produções, lhe oportunizavam refletir sobre o que iria escrever. Para exemplificarmos, apresentamos uma das falas de Adriana: "Esse livro é sobre a árvore. Ele parece uma árvore. Vou colar folhinhas da árvore." (Diário de ideias).

Vale destacar o caráter empreendedor de Adriana em confeccionar os seus livros que envolvia a busca por pedaços de papéis no próprio lixinho da sala de aula, bem como seu empenho em se preocupar com detalhes que poderiam tornar as capas dos seus livros mais atraentes para o leitor. Para tanto, utilizava folhas de árvore, pontas de lápis e outros materiais que encontrava para enfeitá-los. Seus vídeos também eram elaborados a partir de situaçõesproblema de seu próprio cotidiano. Nestes ela inseria músicas que inventava e também que escolhia, tendo em vista seu próprio repertório. Ela era a personagem principal de suas gravações e contava com o apoio de sua mãe para fazer as filmagens.

\footnotetext{
Montando minha história

Adriana: Eu invento vídeo lá minha casa. Até hoje eu sei a música que eu inventei sobre os dentinhos. Foi quando eu perdi meus dentes. Eu dei o nome pra ela: Eu arranquei meu dente e fiz o vídeo. No dia que eu fiz um vídeo sobre as plantas, eu peguei a planta e ela estava cheia de formiga (risos).
}

Interpretamos que os vídeos de Adriana eram uma expressão de sua criatividade, por serem organizados a partir de suas próprias ideias que advinham de suas experiências no campo da leitura e da escrita. Como por exemplo o vídeo que criou para tratar sobre a temática da falta de água, sobre a qual escreveu um texto em sala de aula. Se expressar por meio de vídeos, era uma ideia original que não passava pelo experienciado por Adriana na escola, mas ela foi capaz de unir sua aprendizagem às novas possibilidades de expressão, que não apenas o registro escrito. Além dos vídeos, Adriana demonstrava interesse por dramatizações e sempre participava em sala de aula de momentos de apresentações musicais e 
teatrais para os familiares e para a escola como um todo, bem como para a própria turma. Para ilustrar apresentamos o trecho abaixo:

Diário de ideias

Adriana: $O$ dia que eu mais gostei na minha vida foi o dia daquele teatro. Eu li tudo que eu tinha que falar e aprendi rapidinho. No dia que apresentou eu sabia tudo que era pra falar e fazer e todo mundo bateu palma pra gente. Eu maquiei e coloquei aquela fantasia lá preta (risos).

A fala acima expressa o entusiasmo de Adriana por atividades que de se apresentar para o outro, que lhe favorecia envolvimento e facilitava sua aprendizagem. Nos momentos em que observamos Adriana atuando em peças teatrais, identificamos o como ela buscava ser autêntica em suas ações e a facilidade com que aprendia as falas. Chamou nossa atenção a forma como personalizava as falas ao adentrar como se fosse a própria personagem da história e transcendia a relação de apenas decorar um texto para apresentar aos colegas e professores.

Em seus cadernos pessoais, destacamos a criação de modelos de roupas e a forma como inventava uma denominação para os mesmos, conforme a sua utilização no dia a dia. Sua criatividade se expressava na forma autêntica como elaborava os modelos e principalmente estava relacionada à espontaneidade de sua criação, para além do ritual de atividades de leitura e escrita. Era um exercício pleno de algo pessoal que transcendia o que estava posto, na forma como imaginava modelos que não existiam em sua realidade. A fala de Adriana pode ilustrar nossas elaborações: "Na minha imaginação eu inventei sapatos $e$ roupas. Aí eu dei um nome pra cada um. Eu escrevi aí em cada um” (Diário de ideias).

\subsubsection{A relação lúdica no processo de aprendizagem criativa da leitura e da escrita}

A relação lúdica esteve constituída como uma relação pessoal e gratuita de Adriana no percurso de aprender em prol de novas experiências e descobertas, associadas ao brincar de escolinha e à aprendizagem da leitura e da escrita. Processos vinculados à disponibilidade de Adriana em utilizar o seu tempo livre e também o tempo institucional para exercer a escrita e a leitura de forma plena. Interpretamos que Adriana experienciava sua aprendizagem da leitura e da escrita como uma relação completa, voluntária, próxima, instantânea e investigativa. Tal construção pode ser exemplificada a partir do trecho abaixo:

Dinâmica conversacional I

Adriana: Para mim brincar de escrever é viajar pelas letras. Eu fico feliz de escrever. Eu invento as coisas e nem vejo a hora passar. Quando eu estou brincando de escolinha vai a tarde toda.

A aprendizagem da leitura e da escrita estava associada ao caráter inventivo de Adriana, de sua disponibilidade espontânea para criar espaços de realizar tais ações. Ela não 
se limitava ao exercício da escrita e da leitura apenas estipulado pelas professoras na escola, mas criava momentos investigativos de se deleitar em novas produções escritas e novas leituras. Adriana não se preocupava com o tempo de término de suas produções, sejam aliadas ao solicitado na escola, ou no que se envolvia espontaneamente, como expresso em uma de suas falas: "Eu nem vi que a tia já estava pegando a tarefa. Eu queria escrever mais." Desta forma, ler e escrever eram processos voluntários de entrega à própria ação de forma plena.

Nos momentos em que lia ou escrevia, Adriana demonstrava estar totalmente envolvida e evitava conversar com o outro. Do nosso ponto de vista, este processo de imersão esteve associado às estratégias de autorregulação de recorrer ao planejamento para realizar as atividades de leitura e escrita. Este não ocorria apenas antes de iniciar a atividades, ele se organizava a partir do próprio curso da ação de ler e escrever de Adriana. Em um momento de sua expressão no instrumento "Oficina de leitura e escrita", ela nos disse: "Vou escrever até aqui." (Adriana apontou para a última linha da folha). Quando estava quase no final da folha, Adriana disse: "Já? Nossa quanta coisa eu escrevi! Vou escrever até mais."

Adriana gostava de expressar suas ideias sem limites impostos por linhas ou mesmo pela estrutura das atividades, o que se relaciona à criação de regras próprias. Essa associada ao seu conhecimento das regras de composição escrita. Ela procurava incluir mais linhas nas atividades ou mesmo escrevia no verso das folhas. No seu planejamento, Adriana também estruturava sua atividade da forma que lhe era mais adequada para realizá-la, tal qual ilustramos a partir de um trecho da Entrevista II:

Pesquisadora: Como você organizou o que queria escrever?

Adriana: Eu fiz linhas, porque eu escrevo muito torto. Aí eu pensei tudo antes e depois eu escrevi, como é que ia ser a história, como é que eu ia fazer minha letra. É só imaginar e escrever.

Adriana conhecia as regras da escrita e da leitura, mas se permitia criar novas possibilidades de experiências que lhe permitiam contrapor e também transcender as regras estipuladas. O que pode ser ilustrado pelos seus questionamentos em relação aos padrões de utilização dos cadernos, uma vez que, para Adriana, poderiam existir formas diferenciadas de registrar a escrita nos mesmos. No entanto, ela reconhecia que não poderia modificar o que estava posto na sala de aula, mas como sujeito de sua aprendizagem, ela criava seus próprios materiais, como livros e cadernos de registro de modelos de roupa, modificando regras, como ressaltado por ela: "Eu gosto de começar o caderno de trás pra frente. É diferente do jeito que faz na escola." (Diário de ideias).

Interpretamos que a experiência de escrever e ler foi constituída pela possibilidade de criação de um cenário imaginário, no qual Adriana transformava ou criava novas 
experiências, em um processo de faz de conta, ao se permitir ousar em suas ideias. O que ocorreu em unidade com as estratégias de autorregulação associadas à prática de realizar as atividades propostas vinculadas à ludicidade. Um exemplo que ilustra nossas construções refere-se à criação espontânea por Adriana, de uma história sobre a temática sopa, a qual era um dos pratos prediletos. Em sua história, ela não apenas escrevia sobre o que já sabia sobre sopa, mas inseria ingredientes em um exercício pleno e investigativo de suas próprias ideias.

As ações de ler e escrever eram organizadas de forma instantânea por Adriana, que as realizava de uma vez só. Em seu envolvimento, não havia preocupações com o entorno, com barulhos ou mesmo com as ações dos colegas. Ela imergia em suas leituras e escrita, ao ponto de, quando algum colega chegava para perguntar algo para ela, a sua resposta era, dentre outras: "Espera só um pouquinho, eu estou pensando aqui." (Observação). Interpretamos que, para Adriana, havia satisfação em experienciar possibilidades de se aventurar em suas invenções de histórias, pela forma como utilizava palavras desconhecidas em um percurso investigativo aliado às estratégias de autorregulação de busca pelo significado das palavras e sua contextualização. A própria ação de escrever favorecia a criação de um cenário para ser experienciado apenas no campo das ideias. O trecho abaixo subsidia nossas elaborações:

\section{Entrevista IV}

Pesquisadora: O que você aprendeu com esta atividade?

Adriana: Eu aprendi que pode imaginar. Eu mudaria o nome das frutas que eu achei estranho. Se eu fosse a tia eu levava as frutas pra todo mundo ver e até chupar.

Pressupomos que criar um cenário imaginário próprio relacionava-se à dimensão poética com que Adriana inseria em sua escrita. Ao brincar com as palavras, ela criava músicas e também rimas nos enredos de suas histórias.

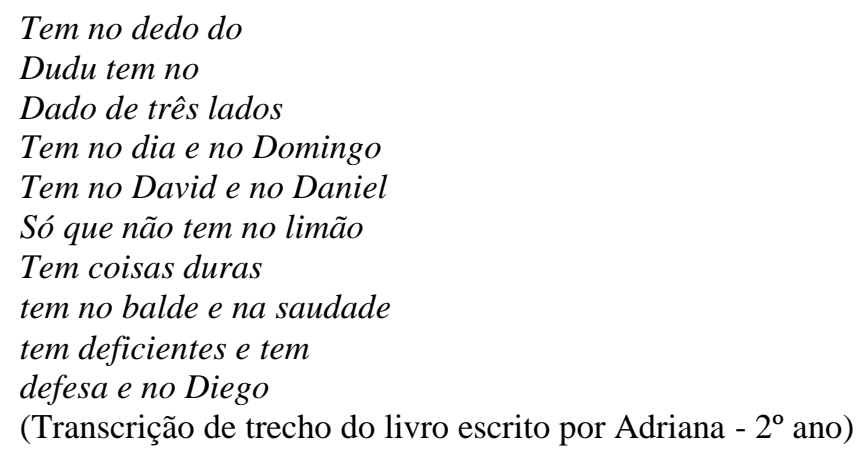

Adriana excedia os limites da própria razão e da lógica da organização da escrita, capaz de criar novas regras em um mundo imaginário, em que colocava ritmo e melodia em sua escrita caracterizando a criação de suas músicas e também pela composição de suas poesias com ênfase à tendência ao exagero, à ousadia de composição escrita pela própria sonoridade das palavras, o que tem sido definido como uma importante característica da 
imaginação lírica e consequentemente da relação lúdica (HUIZINGA, 1999). Nesta relação com a escrita, Adriana sentia este momento como possibilidade de se distanciar da vida cotidiana ou dela se aproximar de forma diferenciada e se implicar em um mundo em que podia inventar, a partir de regras e leis também singulares.

Frente às características delineadas neste trabalho, foi possível compreender como estas se organizaram de forma dinâmica e em confluência. Essas características estiveram vinculadas às estratégias de aprendizagem e tiveram como força motriz a imaginação e o pensamento. $\mathrm{O}$ quadro a seguir consiste em uma síntese da relação entre a expressão da criatividade na aprendizagem da leitura e da escrita e as estratégias de aprendizagem de Adriana.

Quadro 5 - Relações entre a expressão da criatividade na aprendizagem da leitura e da escrita e as estratégias de aprendizagem de Adriana

\begin{tabular}{|c|c|}
\hline $\begin{array}{c}\text { Características da criatividade na } \\
\text { aprendizagem da leitura e da escrita }\end{array}$ & Estratégias de aprendizagem \\
\hline $\begin{array}{l}\text { Personalização da informação: } \\
\text { - personalização dos conteúdos; } \\
\text { - personalização do que lia e escrevia. }\end{array}$ & $\begin{array}{l}\text { Estratégias de autorregulação: } \\
\text { - associa o que aprende com situações cotidianas; } \\
\text { - utiliza o aprendido em situações cotidianas; } \\
\text { - busca por aprofundar seus conhecimentos } \\
\text { - faz inferências nas leituras que realizava; } \\
\text { - deliberação de atenção e concentração nas ações de ler e escrever. }\end{array}$ \\
\hline $\begin{array}{l}\text { Confrontação com o dado: } \\
\text { - confrontação com elementos do } \\
\text { trabalho pedagógico desenvolvido } \\
\text { pelas professoras; } \\
\text { - confrontação de ideias com o outro; } \\
\text { - confrontação com suas próprias } \\
\text { produções. }\end{array}$ & $\begin{array}{l}\quad \text { Estratégias de autorregulação: } \\
\text { - faz revisão autônoma de sua própria produção; } \\
\text { - busca independente de respostas para suas dúvidas. } \\
\text { Estratégias de cognitivas: } \\
\text { - busca participar oralmente em sala de aula; } \\
\text { - cuida da estética de suas atividades; } \\
\text { - estabelece relações entre sons e letras; } \\
\text { - estabelece relações entre palavras; } \\
\text { - faz relações entre a forma como culturalmente fala e a escrita das } \\
\text { palavras. }\end{array}$ \\
\hline $\begin{array}{l}\text { Produção, geração de ideias próprias e } \\
\text { novas que transcendem o dado: } \\
\text { - nas ações de ler e escrever capazes de } \\
\text { ir além do que era proposto; } \\
\text { - na sua relação com a cópia; } \\
\text { - na criação de situações artísticas. }\end{array}$ & $\begin{array}{l}\text { Estratégias de autorregulação: } \\
\text { - faz reflexão sobre seus registros; } \\
\text { - a contar ao outro suas experiências; } \\
\text { - procura formas diferenciadas de realização das atividades } \\
\text { propostas; } \\
\text { - criação de situações de aprendizagem diferenciadas das já } \\
\text { experienciadas. }\end{array}$ \\
\hline $\begin{array}{l}\text { - } \quad \text { relação completa, } \\
\text { próximão lúdica: } \\
\text { - criação de regras próprias; } \\
\text { - criação de um cenária, } \\
\text { - crio imaginário. }\end{array}$ & $\begin{array}{l}\text { Estratégias de autorregulação: } \\
\text { - faz planejamento para realizar as atividades de leitura e escrita; } \\
\text { - realiza as atividades propostas associadas à ludicidade; } \\
\text { - busca o significado das palavras e sua contextualização. }\end{array}$ \\
\hline
\end{tabular}

Fonte: elaborado pela autora, 2015.

No próximo tópico, buscamos desenvolver nossas elaborações sobre a configuração subjetiva da ação de aprender criativamente de Adriana. 


\title{
4.2.3 A configuração subjetiva da ação de aprender criativamente a ler e a escrever de
}

\section{Adriana}

No presente item, construímos a configuração subjetiva da ação de aprender criativamente a leitura e a escrita de Adriana. Mediante o processo construtivo-interpretativo, organizamos três núcleos de sentidos subjetivos constituídos por um conjunto de sentidos subjetivos associados à história de vida de Adriana - que se atualizam na ação de aprender -, por outros produzidos na experiência, assim como por elementos da subjetividade social e dos processos relacionais.

4.2.3.1 Núcleo de sentidos subjetivos associados à relação com a mãe: alto grau de exigência

No processo construtivo-interpretativo, a relação com a mãe se configurou como fundamental para que a criatividade emergisse na aprendizagem de Adriana. Chamou nossa atenção a consideração feita, por Adriana, da mãe como a pessoa responsável pela sua aprendizagem da leitura e da escrita, o que se manifestou em diferentes instrumentos e pode ser ilustrado, dentre outras, pelas informações a seguir:

\begin{abstract}
Mapa do tesouro (Anexo E - Figura 11)
Adriana: Eu aprendi letra de imprensa separadas. A minha mãe falava cada letra e me ensinava lá na minha casa. Eu comecei a estudar na outra escola, quando eu tinha uns dois ou três anos. Foi lá que eu aprendi a ler, mas foi minha mãe que me ajudou. Eu também aprendi a letra cursiva nessa escola. Além da minha mãe que me ajudou. Aí eu fui juntando as letras, por exemplo, a minha mãe falava, que palavra é essa? Aí eu falava, é essa. Às vezes eu acertava e às vezes eu errava. Aí eu comecei a aprender palavras novas. Teve uma vez que foi um idoso lá em casa, amigo da minha mãe, aí eu não lembro o que eu falei, mas eu falei velho e minha mãe disse que não pode falar velho, que é idoso. E eu nem sabia que tinha outro nome para velho. Antes eu gostava muito de desenhar, agora eu gosto muito de escrever. Foi com a minha mãe que eu aprendi a letra cursiva. É tão bom quando ela me ensina.

Trilha das frases

4 - MINHAS DESCOBERTAS - Minha mãe me falou que no Brasil fica São Paulo. Eu amo aprender com ela. Eu tenho muita coisa pra descobri.
\end{abstract}

As informações acima expressam o vínculo entre a aprendizagem e a relação com a mãe. Percebíamos estados emocionais de alegria e satisfação de Adriana em aprender a ler e a escrever com sua mãe, que se relacionavam às proposições de situações que envolviam a filha em novas descobertas. Interpretamos que havia produções subjetivas historicamente constituídas associadas à relação de confiança e de valorização do saber da mãe, que, de certa forma, favorecia a busca de Adriana por novas descobertas, assim como a significação da aprendizagem em uma dimensão mais ampla e não necessariamente restrita à escola. 
Neste processo, interpretamos que a subjetivação da aprendizagem também se organizou mediante novas produções subjetivas que poderiam estar associadas aos sonhos e desejos de Adriana.

\author{
$\underline{\text { Mapa do tesouro }}$ \\ Pesquisadora: Você tem algum sonho? \\ Adriana: Eu quero ser médica, polícia, estilista e professora. Eu sei que tem que \\ estudar muito. A minha mãe vai me ajudar e eu vou estudar bastante. \\ Diário de ideias \\ Adriana: Se eu estudar muito eu vou ser o que eu quiser. Quando não estuda aí não \\ tem jeito. A pessoa vai fazer o que ela não gosta, vai ser diarista e não queria isso, \\ tem que ganhar pouco e não vai saber nada.
}

As informações acima expressam que Adriana vinculava a aprendizagem com suas possibilidades de formação futura, de conseguir um emprego do seu interesse e que fosse rentável em termos financeiros. Havia, assim, produções subjetivas historicamente constituídas associadas à necessidade de esforço para aprender vinculada ao apoio da mãe, que se apresentavam de forma diferenciada na aprendizagem de Adriana. Estavam caracterizados pelo seu envolvimento e dedicação neste campo, os quais, de certa forma, favoreceram a expressão da criatividade na aprendizagem e estiveram vinculados a recursos subjetivos, dentre os quais podemos citar: visão de futuro, abertura ao novo, autodeterminação e gosto pelo desafio.

A orientação para o futuro pode estar relacionada ao status fundamental que sua mãe conferia à aprendizagem, como possibilidade de garantir aos filhos uma profissão que lhes daria retorno financeiro melhor do que o que ela experienciava como diarista e o marido como jardineiro. Esta construção pode ser exemplificada a partir de uma das expressões da mãe ao ressaltar que, mesmo com dificuldades financeiras, investia na educação dos filhos:

\begin{abstract}
Dinâmica conversacional I
Mãe: Com seis anos a Adriana já sabia ler, a escola anterior de educação infantil, tinha muitos livros e ela aprendeu muito lá. Tudo que ensina aqui na escola ela aprende. Eu não tenho condições de pagar uma escola particular, às vezes não dá valor no que os pais fazem. O próprio irmão foi assim, ele não deu valor, não foi tão obediente, hoje eu pago com muita dificuldade a Faculdade. Ele teve mais oportunidade do que a Adriana e não deu valor. A Adriana não fica muito com o irmão pela diferença de idade, mais ou menos 12 anos de diferença. A escola não puxa muito, tem uma prima que está na escola particular que já está vendo sinônimo e a Adriana ainda não está aprendendo isso e eu deixo, deve ser assim, mas a escola podia ensinar mais, pois ela quer muito aprender mais.
\end{abstract}

A informação acima expressa o envolvimento da mãe com a aprendizagem e o desenvolvimento da filha, vinculados à necessidade de exigência e obediência. Para a mãe, a aprendizagem estava dependente da ação da escola, a qual deveria se pautar pelas necessidades dos alunos que, no caso de Adriana, ansiava por novas aprendizagens. Mesmo que sua mãe considerava que era dever da escola ensinar a filha, a mãe se colocava como 
sujeito deste processo e buscava formas próprias para suprir as possíveis lacunas que identificava, o que pressupomos, se relaciona com uma visão mais ampla, de que aprender não é um processo de decorar e nem se restringe à escola. Podemos exemplificar esta construção a partir da criação, pela mãe, de um modo de ensinar notas musicais à filha:

\begin{abstract}
Dinâmica conversacional I
Mãe: Eu penso assim, não pode agir com dó, com coisa. Tem vez que vê assim, um tantão de exercício, aí eu fico repetindo, tem hora que dá dó. É que tinha um dia lá, que tinha as notas de música pra aprende e não decorar. Eu falo assim, pra na hora que ela vê aquele simbolizinho da música ela sabe qual que é. E tem uns exercícios que vem pra ela fica repetindo. Aí ela estava decorando, mas quando ela olhava no símbolo ela não sabia qual era. Então eu falei pra ela que a gente ia aprende a desenhar os símbolos, porque DÓ é 2. Porque agora que ela aprendeu ela não precisa mais fica decorando, porque quando olha ela já vai sabe qual é a nota. Aí ele chegou (pai) e estava achando isso meio sofrido. Aí eu penso assim, porque agora ela está pequena, eu não penso assim com dó não, eu penso assim, que agora ela está nova e quando tive 12 ou 13 anos e que for querer ver os meninos (risos) pelo menos essa parte já está pronta. Tem coisa que parece ser sofrida, mas no fundo não é não. Porque hoje ela foi de 14 até o 20 sem erra nenhuma nota, daquelas listas. Porque coloca os símbolos tudo misturado. Porque antes ela estava decorando, agora não, não precisa nem escreve o nome, ela olha o símbolo e já sabe. Aí ele (pai) age mais com dó, eu não.
\end{abstract}

Havia uma preocupação da mãe de Adriana de que a filha aprendesse e isso passava por uma relação diferenciada com o objeto de conhecimento que demandava envolvimento e reflexão. Para sua mãe, a aprendizagem não era algo que deveria passar pela reprodução ou pela decoreba. Pressupomos que importantes recursos subjetivos constituídos na relação com a mãe foram extremamente importantes para que a criatividade emergisse na aprendizagem, dentre os quais podemos citar: a capacidade de reflexão e o envolvimento com o que se propunha a realizar. Outras informações podem ilustrar nossas construções:

Diário de ideias (Anexo F - Figura 13)

Adriana: Eu estou aprendendo a toca órgão. Eu já sei as notas. Um dia eu inventei uma música bem legal e aí eu fiz um som pra ela. Aquele dia na sala com a professora Flávia eu também inventei uma música. Eu adoro música e dança. Minha mãe que me ensina e eu mostro que eu fiz sozinha música.

Montando minha história

Adriana: Eu quero que minha mãe tenha orgulho de mim. Ela vai ver que eu vou aprender muito e muito. Ela fala que tem tarefa que está feia e outra bonita. Eu quero que fica tudo bonita e ela vai achar bom.

A relação de Adriana com a música pode estar vinculada a sentidos subjetivos historicamente constituídos associados ao compromisso com sua aprendizagem, ao desejo de ser reconhecida pela mãe e conseguir com êxito aprender para além do que a mãe ensina. Tais produções, de certa forma, reverberavam para sua aprendizagem, na forma como se permitia brincar com suas ideias, na necessidade de inventar ritmos e melodias para sua própria escrita e leitura, bem como na necessidade de extrapolar a lógica de combinações 
possíveis entre as palavras, estas dinamizadoras da criação de situações artísticas na geração de ideias próprias e novas que transcendiam o dado.

No entanto, estas produções subjetivas estiveram assistidas por importantes confrontos com elementos da subjetividade social da sala de aula, em que era solicitado silêncio, pouca interação entre os alunos, bem como eram limitados os momentos de brincadeiras. Para exemplificarmos tal construção, citamos as informações abaixo:

\section{Brincando de escolinha}

Adriana: Aqui na sala não pode conversar, e também nada de brincar. A gente tem que escrever tudo que a tia quer e não pode fazer de outro jeito. Mais eu gosto mesmo é de fazer do jeito que eu gosto aí eu aprendo mais.

Diário de ideias

Adriana: Eu fiz a minha sala de aula, do jeito que eu imagino. Tem os menino brincando com o jogo de letra. Aí formou a palavra ALEGRIA. Mas a minha sala de verdade é bem diferente. Nem pode jogar muito e nem conversar com o coleguinha. A gente podia escrever as palavra que a gente quer aprender e que é difícil.

Pelas informações acima compreendemos que Adriana necessitava expressar suas próprias ideias em suas atividades. Havia produções subjetivas atuais associadas à necessidade interação com o outro para aprender, assim como à liberdade de se expressar. Processos que podem estar relacionadas à forma como seus pais instigavam sua aprendizagem em várias direções apresentadas na participação em atividades diversas como aula de música, bem como o interesse em matriculá-la no inglês. As informações abaixo podem subsidiar nossas elaborações e abrir novas zonas de sentido:

\footnotetext{
Dinâmica conversacional

Pai: Ela foi lá no banheiro pego papel higiênico pra fazer uma coisa diferente e pediu pra mim colocar o rolo de volta no banheiro. Eu nem sabia o que que ela ia fazer. Eu levei o papel no banheiro e depois ela trouxe o potinho pra coloca minhas pimenta. Ela é muito inteligente. Ela chegou a fazer uns desenhos de vestido estilista que eu nem a mãe dela não dá conta de fazer. Aí eu peguei e comprei umas bonequinhas pra ela de troca de roupa, depois ela guardou e eu falei pra Ana que ela não está querendo mais a bonequinha. Mas assim, ela faz as coisas da cabeça dela mesma. Aí ela está fazendo dever da escola e aí eu falo 'deixa eu ver o que você está fazendo' e era sobre hora e aí eu perguntei 'onde ela tinha aprendido a olha a hora' e ela falou que não aprendeu e que estava tentando faze. Eu olhei a tarefa e estava tudo certo.

Trilha das frases

31- CONSIDERO QUE POSSO - Imaginar tudo e inventar tudo.

32 - O QUE EU MAIS GOSTO NA ESCOLA - Ter ideias pra escrever um texto.

36 - ESCREVER É - Escrever um texto é inventar o mundo.

42 - QUANDO INVENTO - Eu acho divertido. Eu fico feliz e descubro mais.

44 - APRENDER É DIVERTIDO QUANDO - A gente está alegre quando a gente está escrevendo e lendo.

48 - APRENDO MELHOR QUANDO - Quando eu estou concentrada.

50 - MINHAS ATIVIDADES - Ficam lindas e são muito bem feitas.
}

Adriana experienciava um contexto familiar favorável para expressar suas ideias o que, de certa forma, dinamizava o seu prazer em se permitir ousar em suas produções escritas no contexto escolar. Elementos fundamentais da expressão da criatividade na aprendizagem, 
constituído por recursos subjetivos de se autodesafiar e de capacidade de reflexão, os quais constituíram fontes essenciais para o processo de confrontação com suas próprias produções e com as ideias do outro. Havia produções subjetivas historicamente constituídas associadas à leitura e à escrita como possibilidade de brincar com suas ideias e de se autorrealizar mediante suas elaborações. Aprender para Adriana implicava criação, invenção e imaginação, o que, de certa forma, constituía a gênese do lúdico em sua aprendizagem. Outas informações podem ilustrar nossas elaborações:

\footnotetext{
Dinâmica conversacional I

Mãe: Eu acho que aos trancos e barrancos a gente sempre ajudou. Eu lia os textos pro meu filho pra ele tirar nota boa nas provas. Agora, eu não pego tanto no pé da Adriana, eu deixo ela mais livre pra tentar fazer a tarefa. A Adriana nunca foi de errar. Eu não leio muito, mas a Adriana tem algumas coleções que ela lê e ela já sabe até de cor. Eu ajudo ela nas tarefa mas só peço pra ver a tarefa e quando vejo que ela dá conta de fazer sozinha eu deixo. Eu queria que ela aprendesse mais. Eu acho que ela está nova, mas que eu vejo que ela ainda escreve umas coisas erradas, mas acho que ela não chegou lá ainda, é normal [...] Mas ela também é esperta, a Adriana é custosa. Igual assim, ela vai só uma vez na semana, na aula de música e vem muito dever pra ela estuda e eu fico lá estudando com ela. Eu fico lá repetindo as notas com ela. E tem hora assim, que ela não quer estudar e que ela quer brincar. Aí eu pego firme com ela. Umas vezes lá, ela ficou meio chorosa, aí eu falo então não precisa fazer agora não. Mas eu penso assim, está pequena, não trabalha, não está fazendo nada e não tem interesse de aprender enquanto está pequena, mas eu elogio, mas não é tanto assim não.

Trilha das frases

39 - SOFRO QUANDO - Quando minha mãe me bate.

Diário de ideias

Adriana: Minha mãe olha todo dia meu caderno e fala assim que eu fiz errado e que tem que melhorar. Tem dia que está certo. Tem dia que ela até briga comigo. Eu fico triste, mas eu sei que eu vou melhorar. A tia olha minha tarefa e fala que está tudo certo e eu fico até mais feliz.
}

Pelas expressões acima, a mãe de Adriana acompanhava diariamente seu processo de aprendizagem, mediante cobrança de mais empenho e dedicação da filha para aprender. Interpretamos que ocorriam processos contraditórios que constituíam sua aprendizagem, que passavam pela sua abertura a aprender com a mãe e ao mesmo tempo o receio em não satisfazê-la. Do nosso ponto de vista, havia produções subjetivas historicamente constituídas associadas à necessidade de satisfazer os anseios da mãe - tendo em vista o elevado grau de exigência em relação à sua aprendizagem - que se configuravam no como se empenhava em aprender sempre mais em sala de aula, na busca por reconhecimento social da professora, assim também no como a aprendiz utilizava-se de estratégias de aprendizagem de autorregulação e cognitivas.

Interpretamos que as exigências da mãe em relação à filha favoreceram o posicionamento de Adriana como sujeito de sua aprendizagem, pela forma como encarava a aprendizagem como um desafio que demandava empenho, dedicação e esforço, em uma 
postura ativa. São processos que podem estar associados a sentidos subjetivos historicamente constituídos no âmbito familiar, associados à autoimagem positiva de si mesma como aprendiz, certamente relacionados à busca por se sobressair ao irmão.

\section{Montando minha história}

Adriana: Eu sou uma artista. Até tenho um caderno que escrevo tudo que eu quero. Eu já sei lê e escrever. Tem tanta coisa que eu sei. A minha mãe disse que eu sou a filha mais linda dela. Mas meu irmão também é legal. Só que eu estudo mais.

Trilha das frases

1 - EU SOU - Legal e inteligente. Sapeca, esperta, inteligente.

A autoimagem positiva de si mesma configurada no âmbito familiar, mais especificamente na relação com a sua mãe, também poderia estar vinculada por um conflito não consciente para Adriana, pela possibilidade de ausência do irmão, o qual se preparava para se casar e morar em outra residência. Adriana subjetivou este momento de forma contraditória em que expressava ao mesmo tempo alegria de poder ficar com dois quartos na casa e, por outro lado, sentiria a falta do irmão. Diante da escolha de momentos que gostaria de mudar em sua vida, no instrumento "Montando minha história", Adriana optou pelo dia do casamento do irmão. Interpretamos que o estado emocional de tristeza em relação à saída de casa do irmão pode estar vinculado à preocupação dela com a nova configuração familiar. Outras informações podem subsidiar nossas construções:

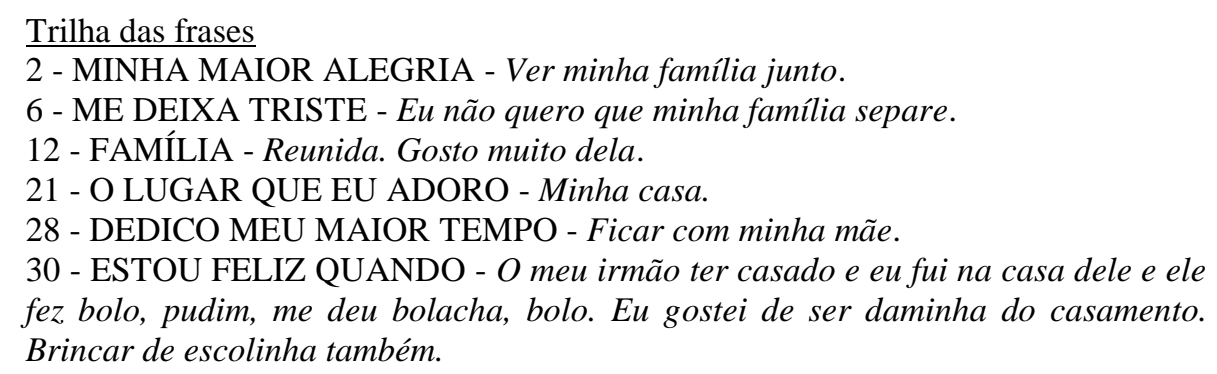

Outros momentos tristes que Adriana fez referência foram relacionados a perdas de entes queridos de sua família. Interpretamos que a constituição de uma autoimagem positiva de si mesma, como aprendiz no âmbito familiar, foi configurada em meio a produções subjetivas historicamente constituídas associadas à necessidade de se sobressair sobre o outro. Essas estavam relacionadas à própria subjetivação do espaço de perda e separação, experienciado no âmbito familiar como um processo que lhe gerava estados emocionais de sofrimento. Tais elementos se configuravam na busca em ser a melhor nas atividades de sala de aula, de não aceitar perder durante atividades de jogos, demonstrado por expressões de agitação, de não conformar com os resultados que podiam não ser satisfatórios para ela. As informações a seguir, dentre outras, são ilustrativas de nossas elaborações: 


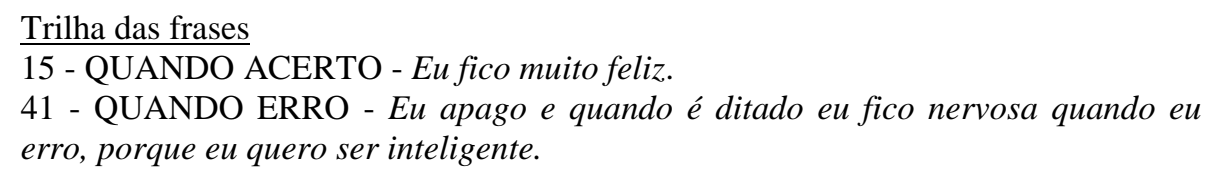

Adriana expressava estados emocionais de insatisfação, tristeza, apatia diante de situações de perda e erros. Estes foram identificados por nós nos momentos em que não era ouvida pela professora ou mesmo por não ter uma ideia aceita no grupo, por não ser sempre a escolhida para ajudar a professora em situações cotidianas, dentre outras situações, que reverberavam em sua forma de recusar a realizar atividades, ou a fazê-las sem apreço, por ter experienciado uma situação de conflito. Havia produções subjetivas atuais associadas ao erro de desvalorização de si mesma e pelo outro como algo que lhe privava de estados emocionais de alegria e de se sentir realizada. Informações importantes, dentre outras, podem possibilitar novas construções:

Dinâmica conversacional I

Mãe: Sabe o que eu penso dela, é que ela quer ser grande. Quando ela faz essa chantagem assim é só teatro, igual o irmão dela é só pra gente dá atenção. Ela lá em casa também faz umas chantagens emocionais também. Ela pensa que quer ser elogiada o tempo todo e quando fica pra traz, né.

Pai: Ela quer ser sempre a primeira.

Diário de ideias

Adriana: Eu acho tão bom quando a minha mãe olha minha tarefa e fala que está certa. Teve um dia que eu fiz tudo certo. A tia também olha minha tarefa. Eu gosto quando ela coloca tudo certo.

As falas acima expressam a necessidade de Adriana em ser reconhecida em suas ações, em querer se destacar de alguma forma, o que pode ter estreitas relações com o elevado nível de exigência da mãe sobre sua aprendizagem. Observamos em vários momentos da pesquisa que sua mãe ia à escola para ver seus trabalhos, momento em que fazia exigências quanto à melhora da filha, assim como valorizava e dialogava com a filha sobre as produções. Interpretamos que a exigência da mãe pode estar relacionada às produções subjetivas historicamente constituídas em Adriana relacionadas à dificuldade de lidar com o erro, como processo relacionado à necessidade de reconhecimento social.

\section{Entrevista I}

Adriana: A tia corrige minha tarefa e faz aquele certo bem legal. Eu fico feliz quando ela escreve que eu estou fazendo tudo certo. Quando eu erro, aí ela não deixa mais corrigir, mas eu vou lá e corrijo mesmo assim. Eu gosto que fica tudo certo.

Tais produções subjetivas podem estar associadas a recursos subjetivos vinculados à liderança, pela forma como Adriana buscava se destacar em relação ao outro, ser a primeira a responder oralmente em sala de aula, na maneira como orientava a organização dos trabalhos em grupo. No recreio, Adriana comandava o grupo de meninas que se reuniam para vê-la 
dançar e também para usar sua maquiagem. Mesmo exercendo liderança, Adriana não criava vínculos mais próximos com os colegas, o que pode ser exemplificado por um de suas falas: "Eu gosto de fazer tudo sozinha mesmo." (Diário de ideias).

Chamou-nos a atenção a independência e autonomia com que Adriana organizou uma festa surpresa para a professora Flávia. No final do segundo ano, Adriana conversou com os colegas no recreio e os mobilizou a trazerem refrigerantes e também comida para fazerem uma festa. Os colegas se envolveram e ouviram atentamente os comandos de Adriana, que confeccionou cartazes e também fez várias poesias para serem lidas pelos colegas para a professora. Para exemplificarmos, apresentamos a seguir uma de suas poesias:

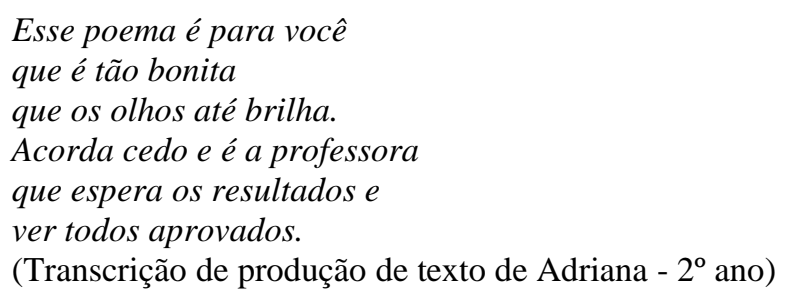

Interpretamos que as ações de Adriana, para organizar a festa, estiveram assistidas pelo apoio de sua mãe, a qual comprou o bolo e participou da comemoração. Podemos ilustrar nossa construção a partir de uma fala de Adriana: "Minha mãe que me ajudou. Eu fiz os cartaz pra tia e escrevi um tanto de poesia pra ela. Aí eu fiz nuns papel bem pequeno pros menino ler. Eu pensei em tudo, até na bexiga." No momento da festa, observamos que Adriana comandava tudo, de forma a dispor os cartazes nos locais que achava mais adequado e distribuía funções entre os colegas (servir o lanche, ler as poesias, tirar fotos e outras). Interpretamos que a iniciativa de Adriana e seu empenho na organização da festa estiveram assistidos por produções subjetivas atuais associadas à utilização do que aprendia para expressar sentimentos, o que reverberava em suas produções do diário pessoal, de suas poesias e músicas, como característica da geração de ideias próprias e novas que transcendem o dado.

Do nosso ponto de vista, a aprovação do outro fazia parte das necessidades de Adriana, relacionada às suas conquistas no campo da aprendizagem, expressos em estados emocionais de alegria e satisfação com suas conquistas, como relatou em um dos momentos felizes de sua vida no instrumento "Montando minha história": "Ah! Um momento feliz, muito feliz mesmo foi quando eu brinquei de estátua na sala e eu ganhei. Eu gritei muito quando eu ganhei. A professora Melissa me elogiou muito."

Frente ao exposto, a relação com a mãe se constituiu como um núcleo de sentidos subjetivos vinculados: a) à confiança e valorização do saber da mãe; b) à necessidade de 
esforço para aprender vinculada ao apoio da mãe; c) à necessidade de reconhecimento social; d) à necessidade de se sobressair sobre o outro; e) à dificuldade de lidar com o erro; e f) à utilização do que aprendia para expressar sentimentos.

\subsubsection{Núcleo de sentidos subjetivos relacionados à experiência de brincar de ser professora}

Fazia parte da subjetividade individual de Adriana produções subjetivas advindas da ação de brincar de ser professora. Essa atividade estava relacionada ao uso do seu tempo livre, o que pode ser ilustrado pela sua escolha deste momento como o mais feliz, expressa no instrumento "Montando minha história", no qual ela se desenhou como professora e disse: "Eu vou usa um lindo vestido e vou toda maquiada pra escola." A aprendizagem se configurava como um processo da vida de Adriana e a envolvia em seus gostos e preferências, assim como estavam associadas à escola e a outros contextos sociais de atuação. Outras informações subsidiaram nossas elaborações:

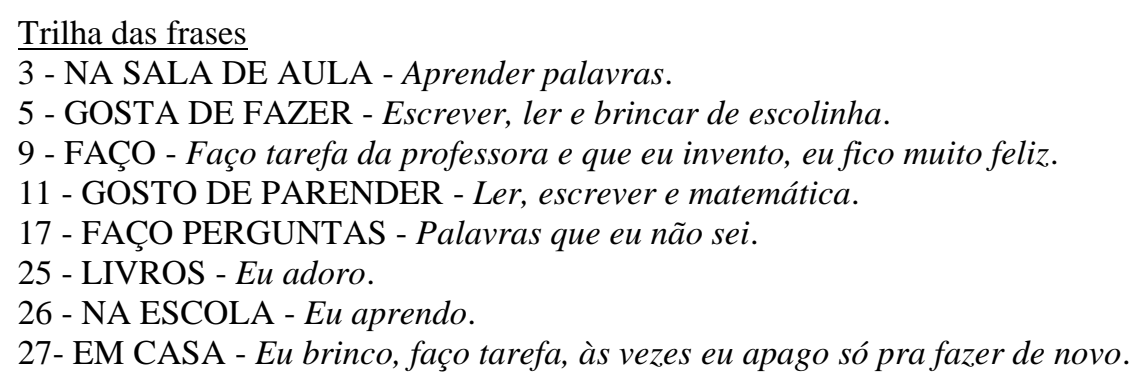

As informações acima expressam a relação próxima que Adriana tinha com a aprendizagem da leitura e da escrita vinculada às produções subjetivas historicamente constituídas associadas à sua implicação para realizar ações que envolviam leitura e escrita, vinculadas ao uso do seu tempo livre para ler e escrever, o que, certamente, dinamizava a forma gratuita, completa e voluntária com que se imbuía em suas ações neste campo, configurando a relação lúdica com sua aprendizagem.

Neste viés, no instrumento "Brincando de escolinha" Adriana pediu para representar a professora. Naquele instante, ela se mostrou amiga dos alunos, tratando-os com respeito. Escolheu alguns livros e entregou para os colegas lerem enquanto organizava as atividades de registro. Havia uma preocupação de Adriana com o tipo de atividade a ser realizada: "Eu quero fazer uma coisa legal pros menino." Outro elemento fundamental de sua aula foi a forma como solicitava a participação de todos na aula, seja para lhe ajudar a entregar as atividades ou mesmo para realizar leituras para a turma. Também identificamos sua preocupação com a forma de avaliação das atividades, o que pode ser ilustrado por uma de suas falas: "PARABÉNS! Vou colocar um certo na sua tarefa." Adriana também era solícita 
em tirar as dúvidas dos colegas: “Murilo! Olha pra mim! É pra fazer um desenho aqui, sobre uma planta." Outras informações podem subsidiar novas elaborações:

\section{Diário de ideias}

Adriana: A tia corrigiu minha tarefa e estava quase tudo certo. Eu só errei uma palavra. Mas eu queria que a tia visse que eu sabia. Aí eu fui lá e falei pra ela olhar de novo, que eu fiz certo. Eu mesma olhei e já sabia como é que era.

Interpretamos que, no processo de brincar de escolinha, configuravam-se sentidos subjetivos atuais relacionados à ação de aprender, associados à necessidade de valorização social das professoras, à necessidade de relações autênticas, o que nos permite compreender que a aprendizagem criativa se nutre de sentidos subjetivos nela produzidos (MITJÁNS MARTÍNEZ, 2012a). A própria valorização social, que Adriana esperava ter das professoras, configurava-se na forma como reconhecia a importância de ter os seus trabalhos corrigidos por elas. Observamos esse movimento em vários momentos experienciados por Adriana: pelo sorriso em receber os cadernos e ver o que as professoras escreveram para ela. Interpretamos que se configuravam produções subjetivas atuais associadas à necessidade de dialogar com as professoras sobre as correções de suas produções, que reverberavam na confrontação com as ideias do outro e com sua própria produção.

Compreendemos que a necessidade de valorização social estava associada tanto às produções subjetivas advindas da relação com a mãe, quanto por um conflito não consciente para Adriana, que envolvia a dificuldade de estabelecer uma relação próxima com as professoras, vinculadas a, pelo menos, dois aspectos: aos tipos de atividades propostas e a dificuldade em estabelecer uma relação autêntica. Na produção espontânea do texto abaixo, realizada por Adriana em sala de aula, como atividade solicitada pela professora Flávia, identificamos importantes elementos, que unidos a outras informações, subsidiaram nossas construções:

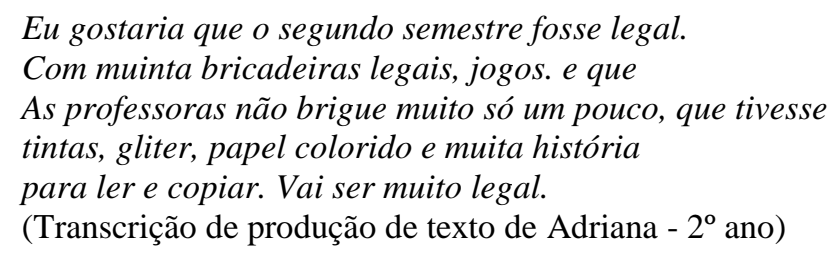

Em articulação às construções anteriores em conjunto com outras informações do instrumento "Oficina de leitura e escrita", em que espontaneamente Adriana optou pela escrita de uma história sobre a escola, interpretamos que ela significava a escola como lugar de viver experiências diversas relacionadas à aprendizagem como processo decorrente de geração de bem estar. 
A escola da Leitura

Era uma vez uma menininha queria se professora todo dia ela brincava de Escolinha com as amigas tinha [...]livros para ler passava atividades de colorir de copiara de pintar e recortar otro dia ela bricava de novo elas creseram ela fez curso de professora, Elas dava aula para todas as salas eles também dava iguau na brincadeira de Escolinha Eles liam livros de portuges, história de toda matéria, eles Bricava de tinta masinha e de desenhar ia para a quadra bincar de uma bricadeira nova ovia música bicava de briquedos eles também copiava texto condos os meninos que teima ela briga a professora Lara montou um teatro e escolheo quatro crianças para ser os participantes teve pipoca palhaço pula-pula a pesa foi a linda Rosa Juvenio eles cantaram e também teve outra sala que partisipou a deles foi a melhor e eles ganharam e foram felisez Para sempre.

(Transcrição da produção de texto de Adriana/ $2^{\circ}$ ano - Oficina de leitura e escrita).

A produção de texto pode ser considerada um apelo de Adriana ao que não encontrava no cotidiano escolar, pois, no contexto de sala de aula, foram poucos os momentos em que presenciamos a utilização de materiais diversificados como tintas, giz de cera, massinha, brinquedos, jogos que favoreciam a interação. Interpretamos que a inclusão de tais elementos para Adriana, eram dinamizadores de possibilidades de expressão por outras vias, que não apenas lápis, folhas de atividades e cadernos. Adriana subjetivava este conflito como algo que poderia ser modificado e experienciado em outros espaços, como na brincadeira de escolinha, ao representar uma escola sem hierarquias entre professor e aluno.

Compreendemos que a experiência de aprender para Adriana esteve configurada por sentidos subjetivos relacionados à subjetividade social da sala de aula associados à aprendizagem da leitura e da escrita como possibilidade de expressão própria por diferentes linguagens. Pressupomos que tais produções subjetivas se constituíram no próprio confronto entre a subjetividade individual de Adriana e elementos da subjetividade social. Outras informações podem ilustrar nossas construções: "Tem dia que eu pego papel que a tia joga no lixo e aí eu recorto e faço flor pra colar na minha tarefa. Teve um dia que eu fiz uma história só com papel picado." (Diário de ideias).

Neste processo, também consideramos que ocorriam produções subjetivas atuais relacionadas à possibilidade que a imaginação lhe permitia de criar caminhos alternativos para novas experiências, geradoras de estados emocionais de alegria, bem estar e realização pessoal. Uma das falas de Adriana ilustra nossa construção: "Na minha brincadeira de escolinha eu posso fazer pintura, inventar brincadeira com as letra. Eu fico feliz, a escola podia ser assim. É tão bom, eu aprendo muito. Eu pinto e escrevo o que eu pintei. Não precisa só fazer palavra fácil, a gente quer mais coisa." (Diário de ideias). Nesse caso, a criatividade se expressou em sua dimensão funcional, uma vez que Adriana, no confronto com elementos da subjetividade social, foi capaz de criar alternativas para aprender 
para além do que experienciava, em um processo subversivo do sujeito, foi capaz de gerar novas experiências, como a própria criação do cenário imaginário.

Nossas elaborações do conflito existente na relação com as professoras, alinhava-se à subjetivação das atividades propostas em sala de aula, como desprovidas de desafio e que não se ensejavam como próprias para o nível de aprendizagem em que Adriana se encontrava. Tal construção pode ser exemplificada a partir de uma de suas falas: "A tia dá tudo fácil e nem pede coisa que eu não dou conta." (Momento informal). Havia produções subjetivas atuais vinculadas ao sistema relacional com as professoras associadas ao desejo de ser mais desafiada e cobrada em suas produções, dinamizadoras para que a criatividade emergisse na aprendizagem expressas nas ações de confrontação com elementos do trabalho pedagógico das professoras, assim como relacionadas à personalização dos conteúdos e à geração de ideias próprias e novas que transcendem o dado, na sua relação com a cópia.

Em um momento da Entrevista I, em que Adriana comentava sobre como ela seria se pudesse ser a professora, ela expressou: "Eu não ia brigar ia só explicar, dar brincadeiras, dar tintas, ser amiga, dar massinha. Eu levaria histórias em quadrinhos". No cotidiano da sala de aula, foram vários os momentos que presenciamos as professoras chamarem a atenção de Adriana por ela estar em pé conversando com os colegas nos momentos de atividade, por ela não deixar espaço para a fala de outros, dentre outros comportamentos. Adriana demonstrava estados emocionais de tristeza quando recebia "broncas" das professoras. Do nosso ponto de vista, Adriana não estabelecia uma relação próxima com as professoras, mas buscava esta proximidade por meio de ações como a festa que organizou para a professora Flávia.

Adriana utilizava-se da escrita para a elaboração de cartas para as professoras, na busca de obter uma aproximação das mesmas. Ela escrevia: "Eu te amo"; "Você é a melhor professora do mundo". Entregava as cartinhas e esperava um retorno de agradecimento das professoras. Adriana gostava de dar beijos nas professoras, ao buscar uma relação afetiva e próxima. No segundo ano, ela foi nomeada como a beijoqueira da turma e gostou muito de receber este apelido, o que se expressou em uma de suas falas: "Eu sou mesmo beijoqueira. Toda hora eu beijo a professora."

O conflito com as professoras também pode ser ilustrado, a partir da dificuldade que Adriana teve em se expressar frente à situação que colocamos em um momento da Dinâmica conversacional I: CONTE UMA SITUAÇÃO EM QUE VOCÊ PRECISOU DA PROFESSORA. Ainda assim, sua resposta pode ilustrar nossa construção em que ela disse que desde o primeiro ano, as professoras "Gritam e briga muito comigo" o que se articula a 
outras informações como no instrumento "Trilha das frases" em que, diante do indutor “ABORRECE-ME” disse: “Quando alguém não gosta de mim.” Unidas a estas informações, outras podem subsidiar nossas elaborações:

\begin{abstract}
Diário de ideias
Adriana: A professora Melissa não deixa eu falar na sala. Eu queria falar, aí eu até levantei o dedo, mas nada. Eu gosto de responder e perguntar pra tia as coisas. Ela não gosta que eu fico falando, mais eu tenho tanta coisa que eu sei e ela só vai saber se eu sei, se ela deixar eu falar. E se eu não falar, eu não vou aprender tanto. Quando eu falo a tia responde outras coisas.
\end{abstract}

Interpretamos que, para Adriana, a relação com o outro deveria se fundar em bases dialógicas e priorizar o respeito, o que pressupomos que, em sua relação com as professoras, participavam produções subjetivas atuais associadas ao desejo de garantir um espaço dialógico para expressar suas ideias e ser ouvida pelo outro, subjetivando a aprendizagem como processo que se efetivava pela comunicação com o outro.

$\mathrm{Na}$ formação do núcleo de brincar de ser professora, configuraram-se sentidos subjetivos associados: a) ao uso do seu tempo livre para ler e escrever; b) à necessidade de valorização social; c) à possibilidade de expressão por diferentes linguagens; d) ao desejo de ser mais desafiada em suas produções; e e) à necessidade de relações autênticas e dialógicas.

4.2.3.3 Núcleo de sentidos subjetivos associados à relação com o conhecimento: a dimensão proativa para a pesquisa

A relação com o conhecimento se expressou nos instrumentos com forte significação e emocionalidade que sinalizava para uma relação proativa de Adriana para a pesquisa. Nossa construção pode ser exemplificada a partir das informações a seguir:

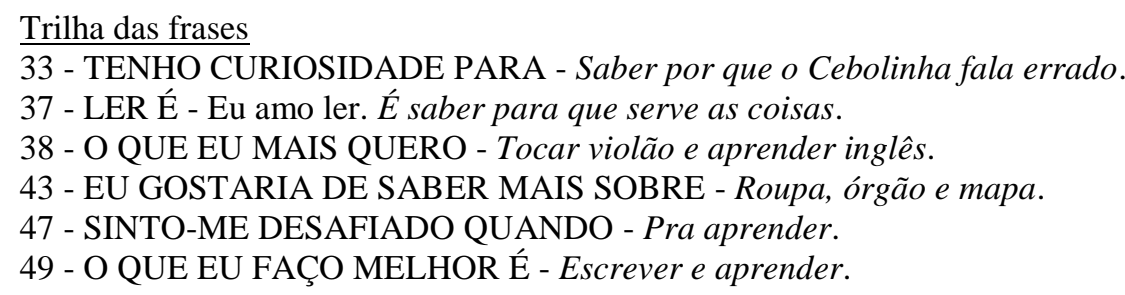

Havia uma relação emocional de Adriana com suas experiências de ler e escrever, que envolviam sua curiosidade para novas aprendizagens e interesses diversos, que não estavam para uma relação direta com os conteúdos escolares, mas com outras possibilidades, como aprender um novo idioma, a tocar um instrumento. Assim como a formulação de perguntas que não se relacionavam ao escrito ou ao proposto para ser realizado, como o seu questionamento sobre a maneira como o personagem Cebolinha falava. Interpretamos que a aprendizagem de Adriana estava constituída pela dimensão proativa, associada a produções 
subjetivas atuais relacionadas ao interesse por diferentes áreas do conhecimento, o que, de certa forma, reverberava para a geração de ideias próprias e novas capazes de ir além do que era proposto nas atividades da escola.

Nesta abertura a novas experiências e aprendizagens, Adriana se envolvia em uma condição proativa de realizar pesquisas sobre temas de seu interesse. Suas pesquisas estiveram relacionadas às buscas na internet, livros de outros anos de ensino, diálogos com professores e também pessoas conhecidas, dentre outras. Havia um envolvimento de Adriana em processos relacionados a aprender algo. Nos momentos informais que conversávamos sobre suas aulas de música, na maioria das vezes, expressava estados emocionais de alegria, apresentados pelo entusiasmo com que relatava os momentos em que aprendia. Dos quais citamos: "Aprender música é viajar pelos sons. Quero inventar uma música. Eu já olho as notas na internet e quando é a aula eu já sei muita coisa (risos)." (Diário de ideias).

Interpretamos que havia produções subjetivas historicamente constituídas relacionadas à autodeterminação para gerir suas necessidades de aprendizagens que indicava autonomia e independência ao realizar pesquisas. A pesquisa fazia parte da dimensão proativa de Adriana em buscar informações científicas para temas de seu interesse. Interpretamos que ela assumia sua aprendizagem, como um processo que dependia de suas ações. Pressupomos que tais produções subjetivas estavam relacionadas a recursos subjetivos constituídos na relação com a família, dos quais podemos citar: abertura para o novo, independência e autonomia.

Adriana mantinha uma relação com o conhecimento vinculado às suas próprias necessidades, assim como o próprio conhecimento era gerador de novas preocupações. Como exemplo, podemos citar os vários momentos de observação em sala de aula, em que percebemos que Adriana, por vezes, comia o lanche que trazia de casa, escondido da professora, uma vez que só era permitido lanchar no horário do recreio, momento em que ela comia também o lanche da escola e de outros colegas. No entanto, esta organização do modo de vida de Adriana, configurava produções subjetivas atuais associadas à insatisfação com o sobrepeso, de se considerar diferente de suas colegas da turma e de atrizes. No entanto, a preocupação com o corpo lhe permitiu atuar como sujeito de sua própria vida, na busca de caminhos próprios, ao realizar pesquisas científicas para elaborar um cardápio saudável:

Dinâmica conversacional II

Mãe: Ela pesquisa as coisa pra emagrecer. Aí ela fica pesquisando, tudo ela quer sabe. Aí ela fez uma lista de tudo que é saudável pra ela comer. (risos). Ela foi lá e pesquisou do jeito dela o que é pra comprar.

Pai: É, ela faz a lista e fala que já tem a lista das compra. 
Adriana, não apenas identificava informações, como também atuava com este conhecimento no seu dia a dia, no intuito de estabelecer mudanças em seu modo de vida, o que percebemos pela forma como a aprendiz passou a levar mais frutas em seu lanche e comê-lo apenas no horário do recreio. Do nosso ponto de vista, sua aprendizagem se constituía por sentidos subjetivos atuais associados à aprendizagem como processo da própria vida, dinamizadores do funcionamento da personalização da informação como característica da criatividade, pela capacidade subjetiva do sujeito em produzir alternativas em seu modo de vida. Tais produções subjetivas reverberavam para as ações de Adriana de ajuda aos pais a terem novos conhecimentos sobre assuntos do cotidiano. Isso pode ser ilustrado a partir de uma de suas falas: Agora eu vou ajudar minha mãe na casa. Eu já falei pra ela das aranha, que tem que cortar unha. Tudo que eu aprendo eu ensino pra minha mãe e pro meu pai. A lista de compra é pra todo mundo ficar mais saudável. (Entrevista I).

Interpretamos que a relação com o conhecimento também se organizou por sentidos subjetivos atuais associados a auxiliar os pais em novos processos de ação, vinculados à qualidade de vida, o que se expressou também ao ensinar a mãe a cuidar das unhas e ao confeccionar objetos de sucata para ajudar o meio ambiente. Para Adriana, a aprendizagem criativa da leitura e da escrita se constituiu como modelo intelectual-subjetivo (GONZÁLEZ REY, 2014a). Uma vez que este processo se configurou por produções subjetivas favorecedoras da produção de conhecimento em uma dimensão vinculada à sua própria dinâmica cotidiana de vida. Havia uma relação mais ampla de Adriana com a produção de conhecimento, o qual não estava limitado à escola, livros e internet, mas também se estabelecia na relação com o outro.

Tais considerações podem ser ilustradas pela sua relação com a arrumação dos seus cabelos cacheados, em que dizia: "Teve um dia que a mulher lá na casa que a minha mãe trabalha, falou assim que meu cabelo estava igual palha. Eu passei secador, mas eu quero ficar sempre linda pra mim mesma e eu não gostei de ficar com o cabelo liso demais." (Diário de ideias). Na relação com o outro, Adriana formava sua própria opinião e também se imbuía em novas ações. No entanto, em vários momentos da pesquisa, ela ressaltava: "Eu sou linda do jeito que eu sou!'”.

Do nosso ponto de vista, a comunicação com o outro favorecia os posicionamentos de Adriana frente a assuntos diversos, aspecto relevante para que a criatividade emerja na aprendizagem. Nos processos de comunicação, Adriana organizava sua opinião sobre assuntos diversos, o que pressupomos se relacionava à forma como o conhecimento e a 
pesquisa se constituíam para ela, como possibilidades de novas aprendizagens. As informações abaixo podem ilustrar nossas elaborações:

\footnotetext{
Dinâmica conversacional I

Mãe: Ela tem opinião própria. Os meninos fica falando que o cabelo dela é de Bombril e ela fala assim 'Eu tenho mas o que importa é que eu estou viva', ela já tem uma opinião própria.

Pai: Só sei que ela é uma pessoa muito rápida pra aprender, você entendeu? A opinião dela é bem formada.

Pai: Ela assiste jornal comigo, dá opinião. Se eu preciso dela na Internet ela me ajuda 'Pai é isso aqui', se entendeu? Ela ensina um tanto de coisa pra mim. Quando eu fico com ela de manhã, eu não cobro muito dela não, eu pergunto 'Adriana, fez os dever?', termino os dever ela vai ver desenho.

Dinâmica conversacional I

Professora Flávia: Adriana é muito participativa, questiona muito e apresenta sua opinião em todas as explicações, e pergunta muito. Gosta de questionar sobre historias e sempre procura mudar alguma coisa apresentando novas possibilidades.
}

Interpretamos que havia sentidos subjetivos atuais associados ao desejo de Adriana em formar e expor opiniões próprias, à procura por constantes questionamentos e necessidade de colocar o seu ponto de vista, assim como elaborar novas ideias, que se sobressaia em sua aprendizagem na forma como se confrontava com as explicações da professora, pela necessidade de participação oral em sala de aula. Tais questionamentos se expressaram também em sua escrita espontânea de livros, pela forma problematizadora com que Adriana se relacionava com o mundo e a capacidade de elaborar possibilidades diferenciadas para o que estava posto o que constituiu importantes recursos subjetivos para que a criatividade emergisse na aprendizagem, dinamizadores da transcendência ao dado. Para ilustrarmos nossas construções, destacamos uma de suas e produções:

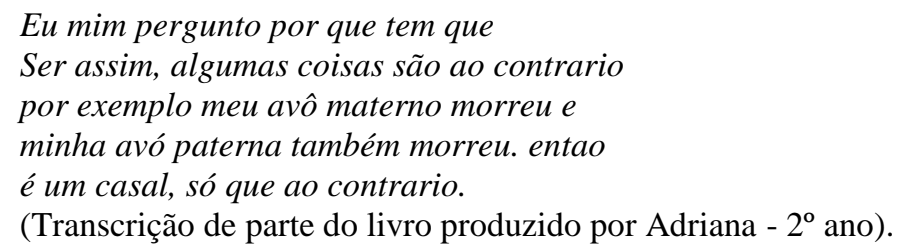

Interpretamos que havia uma dimensão proativa de Adriana que também se configurou na forma como consultava livros de anos escolares posteriores ao seu, na busca de novas informações sobre temas que lhe eram de seu interesse, tais como alimentação, animais peçonhentos como aranhas e outros. Esta dimensão proativa de se imbuir na busca por novas aprendizagens pode estar configurada por sentidos subjetivos atuais associados a querer ser mais desafiada, uma vez que no contexto escolar, sentia-se estar além do que lhe era solicitado. Em um momento da Entrevista I, Adriana expressou que as atividades da escola "São para bebês" e que ela considerava tudo muito fácil de realizar. 
Esta busca por ser mais desafiada, como expressão de sentidos subjetivos produzidos na ação de aprender e inter-relacionados a produções subjetivas constituídas no âmbito familiar, favoreceu a produção de sentidos subjetivos atuais associados à necessidade de se expressar pela arte, como processo que lhe desafiava e incluía na experiência de escrever um nível maior de dificuldade, os quais foram dinamizadores do caráter gerador de ideias novas que transcendiam o dado, pelas suas produções de livros, vídeos e modelos de roupas. As informações abaixo, dentre outras, podem subsidiar nossas elaborações:

\section{Diário de ideias \\ Adriana: Eu gosto mesmo é de pintar e usar coisas das árvores, papéis que ninguém mais usa pra fazer um tanto de coisa. É super legal ver uma capa de livro cheia de coisas. Eu coloquei até fita colorida. Quando a gente faz assim, fica bem mais difícil. É fácil usar só lápis e papel pra fazer um livro. Difícil é fazer outras coisas pro livro ficar mais bonito e alegre.}

Na constituição do núcleo da relação com o conhecimento formou parte um conjunto de sentidos subjetivos que favoreceram que a criatividade de Adriana emergisse na aprendizagem da escrita, associados: a) à necessidade de se expressar pela arte; b) a buscar por aprofundar o que já sabia e ter novos olhares; c) à utilização do aprendido em outros contextos de sua vida; d) à comunicação com o outro; e) à procura por constantes questionamentos; e f) ao desejo de empreender pesquisas para além do contexto escolar. Compreendemos que, a organização e a processualidade da configuração subjetiva da ação de aprender criativamente de Adriana, se constituiu em recursividade com a experiência de aprender criativamente.

\subsubsection{Mudanças e constituição de novos aspectos na subjetividade de Adriana vinculados ao processo de aprendizagem criativa da leitura e da escrita}

A configuração subjetiva da ação de aprender criativamente se constituiu, pelo caráter desenvolvimental das produções subjetivas e dos impactos na vida de Adriana em diferentes direções, como uma unidade subjetiva do desenvolvimento (GONZÁLEZ REY, 1991, 1995, 1999b, 2004a, 2008a). Neste movimento complexo da subjetividade, ocorreram mudanças que, pela estabilidade adquirida, favoreceu mudanças nos núcleos de sentidos subjetivos, bem como a constituição de um novo núcleo (GONZÁLEZ REY, 2003a, 2007b). Para iniciarmos nossas elaborações, destacamos as informações a seguir:

Diário de ideias

Adriana: Agora minha mãe está brigando mais comigo. Eu acho que eu ela está certa eu tenho que melhorar. 


\begin{abstract}
Minhas mudanças
Adriana: Depois que meи irmão saiu de casa mudou muita coisa. Agora eu tenho dois quarto, mas minha mãe está danando comigo toda hora. Ela agora só liga pro meu irmão e pra mulher dele.

Dinâmica conversacional II

Mãe: Meu outro filho caso e então a gente fica assim, né. O Michel era grande então a gente só via os defeitos dele (risos) e a Adriana era perfeita. Agora é diferente. Não, é assim, quando a Adriana chegava em casa, ela já ia correndo fazer os dever. Agora não, ela já quer ver Chiquititas, aquelas coisas assim primeiro. Eu agora estou trabalhando todo dia e ela está ficando mais é com o pai dela. Mas aí, aquele dia lá que a professora me chamou, a diretora também me encontrou e disse que ela estava custosa, que ela estava brincando de correr com os meninos, que já tinha falado com ela, mais eu nem tenho observado isso muito não.
\end{abstract}

Interpretamos que Adriana experienciava um momento de contradição na relação com a mãe, associado a embates e a conflitos que configuravam novas produções subjetivas vinculadas à subjetivação da saída do irmão de casa. Adriana sentia que a mãe lhe tratava de forma diferenciada e isso lhe gerava estados emocionais de tristeza, que, de certa forma, se expressavam nas ações na escola. Observamos que, em sala de aula, Adriana estava mais dispersa e demonstrava desinteresse pelas atividades, empreendendo novas ações para ter a atenção de todos voltada para ela. Podemos exemplificar nossa elaboração por umas das falas de Adriana: "Eu vou só conversar na sala. Minha mãe nem liga pra mim." (Diário de ideias).

No entanto, ela passou a ficar mais tempo com o pai em casa, uma vez que a mãe começou a trabalhar em todos os dias da semana. Interpretamos que a relação com o pai, pela forma dialógica com que se inseria na relação com a aprendizagem da filha, pode ter favorecido que Adriana produzisse novos sentidos subjetivos associados à aprendizagem como processo dialógico sobre as próprias elaborações, de respeito ao saber do outro pela possibilidade de experienciar novas relações de valorização de suas produções e ser menos exigida de um resultado almejado por alguém, favorecedores de sua autoconfiança. Produções que empreenderam mudanças nos núcleos de sentidos subjetivos associados à relação com a mãe e à relação com o conhecimento. Outras informações podem exemplificar nossas elaborações:

Minhas mudanças

Adriana: Eu conto tudo que eu sei pro meu pai. Tem coisa que ele fica assim falando que nem sabia. Igual o dia que eu falei que nadar é bom pra saúde e pra crescer. É engraçado a gente ensinar os adulto. Um sabe uma coisa e pode ensinar o outro. Não tem como saber tudo tudo. Aí eu aprendo com meu pai e ele comigo.

Buscando entender melhor a situação, perguntamos à Adriana se ela também poderia aprender com os colegas da turma. Ela nos disse que talvez poderia aprender algo com a turma, pois os colegas sabiam menos que ela. Interpretamos que Adriana se sentia segura em aprender com os adultos, o que, de certa forma, estava associado a não se reconhecer no 
mesmo nível de desenvolvimento dos colegas, o que não permitiria aprender com um outro que não estava no mesmo nível que ela. Outras informações podem subsidiar novas elaborações e vincular nossa construção anterior com a forma como Adriana acompanhava seu próprio processo de aprendizagem:

\footnotetext{
Momento informal

Adriana: Meu pai ele deixa eu fazer as coisas que eu quero inventar. Ele me leva pra natação e a gente conversa sobre o que eu faço na escola e também em casa. Quando eu erro ele fala que é assim mesmo. Quem não erra pra aprender?

Diário de ideias

Adriana: Eu errei pra escrever LARANJA. Aí eu sei que faltava uma letra. É só a gente ver que está errado e aí descobrir. Pode olhar no caderno e perguntar. Minhas mudanças

Adriana: Antes eu ficava brava quando eu errava uma letra na palavra. Agora eu fico rindo do que eu erro. Fica engraçada a palavra e aí eu sei como é que arruma.
}

Havia, em Adriana, novas produções subjetivas relacionadas ao erro como fonte de aprendizagem, como algo que faz parte do processo de aprender e lhe permitia agir em novas direções em busca de superá-los. As novas produções subjetivas se configuravam e favoreceram novas formas de expressão da criatividade na aprendizagem de Adriana. Para exemplificarmos apresentamos a forma como Adriana criou um caderno com palavras, frases e textos que eram copiados de suas próprias produções em que havia algum erro identificado por ela. Caderno que ela utilizava para acompanhar o seu desenvolvimento no campo da aprendizagem. Para ilustrar destacamos uma de suas falas: "Tudo que tem aqui eu sei que eu já errei. Olha quanta coisa eu já sei!’" (Entrevista I).

O acompanhamento de Adriana de seu próprio desenvolvimento na aprendizagem pode estar associado a novas produções subjetivas vinculadas à aprendizagem como um processo próprio que não se associava à opinião do outro, mas se efetivava em seu reconhecimento do percurso de aprender como algo pessoal que lhe gerava bem estar e realização pessoal. Tais produções subjetivas possibilitaram mudanças no núcleo de sentidos subjetivos associados à relação com a mãe e à experiência de brincar de ser professora. As informações abaixo podem ilustrar nossas construções:

\footnotetext{
Minhas mudanças

Adriana: Eu adoro ver o que eu já aprendi. Já sei tanta coisa. Você quer ver meu caderno de palavras? Olha o tanto de palavra difícil que eu já sei. Eu escrevo sem olha em lugar nenhum. No ano passado eu não sabia quase nada.
}

Processo que configurou na segurança, autonomia e independência de Adriana para com sua aprendizagem, formando recursos subjetivos importantes para a expressão da criatividade. Esses se alinhavaram com mudanças na relação com as professoras, uma vez que, em sala de aula, Adriana demonstrava desinteresse pelas atividades propostas e pela própria busca de aproximação com as professoras. Outras informações podem ser ilustrativas: 


\begin{abstract}
Momento informal
Adriana: Estou nem aí pra aula. Eu já sei tudo isso. A professora não dá nada difícil. Eu sei mais que todo mundo da sala. Eu vou estudar tanto que vou saber mais que a professora.

Dinâmica conversacional II

Professora Flávia: Adriana ainda tem conversado muito na sala de aula, porém está mais calma e batendo menos de frente comigo. Ela está muito dispersa e gosta de aparecer o que atrapalha um pouco o trabalho na sala, por ler fluentemente, não quer dar oportunidade para seus colegas, e fica criticando eles o tempo todo.
\end{abstract}

Interpretamos que ocorriam mudanças que se relacionavam ao distanciamento de Adriana da dinâmica escolar, principalmente na relação com os colegas e com as professoras. Havia novas produções subjetivas associadas à aprendizagem como possibilidade de se diferenciar dos outros. Ela não conseguia estabelecer vínculo próximo com as professoras e houve uma mudança importante, uma vez que deixou de escrever cartas para as professoras, passou a criticar os colegas, por se sentir diferente em sua aprendizagem, elaboração que pode ser exemplificada a partir de uma de suas falas: "Eu já sei tanta coisa. Eu acho que eu sei mais do que todo mundo, mas a professora não me dá outra tarefa." (Minhas mudanças).

A aprendizagem criativa da leitura e da escrita favoreceu sua autoafirmação, configurando novas atitudes frente ao aprender, processo que caracterizou a individualização, em se firmar em suas decisões de buscar no contexto da sala de aula um trabalho mais individual, sem necessariamente ficar dependente de um reconhecimento nas ações de ler e escrever. Esse distanciamento, de certa forma, foi identificado por seus pais que, em na Dinâmica conversacional II, destacaram a possibilidade de transferi-la para uma escola particular com o intuito de oferecer mais oportunidades de aprendizagem. Nestes impasses, identificamos que a criatividade na aprendizagem da leitura e da escrita confluía para outros campos de sua vida e gestava-se um novo núcleo de sentidos subjetivos associados à relação com a aprendizagem para além do contexto escolar. Ocorriam mudanças em Adriana na sua relação com a escola que, em sua condição de sujeito, assumia responsabilidade por sua aprendizagem, na criação de caminhos alternativos, capazes de lhe gerar bem estar e que lhe possibilitavam se sentir desafiada a aprender.

Interpretamos que as relações de Adriana na escola constituíram elementos de incentivo à sua criatividade, tanto na dimensão funcional, pela criação de seus próprios caminhos de seguir aprendendo para além deste contexto social, que possibilitaram reconfigurar a organização subjetiva, quanto na expressão desta dimensão funcional em seu caráter instrumental, associada às novas expressões da criatividade, como suas publicações no facebook, as quais assumiram importância em sua vida e a envolvia emocionalmente, como possibilidades de registrar emoções, opiniões e dialogar com o outro: 
Minhas mudanças

Adriana: Eu gosto de escrever o que eu quero. No facebook eu coloco foto, escrevo, pego imagem e muito mais. Na escola só pode fazer como a professora pede. As tarefas são facinha. Aqui no face eи converso com quem eи quero e fala de tudo.

Na página virtual, Adriana publicava fotos, nas quais inseria algo escrito para explicar os acontecimentos, mensagens que inventava e também vídeos e imagens de programas de televisão que gostava. Ela buscava inserir algo próprio que estava além das imagens e textos, do habitualmente acessado nas páginas online que conhecia, ao sempre incluir um comentário sobre o que publicava. Para ela, a página do facebook era: "É como brincar de escrever da gente. Eu coloco tudo que acontece comigo que eu gosto. Até parece meu diário. Eu ponho foto, vídeo meu e coloco foto com coração e outras coisa. Depende da foto. Tem até texto da escola que eu acho legal que eu coloco lá.” (Minhas mudanças).

Também identificamos que a criatividade se expressava em novas formas de elaboração de seus vídeos. Agora com enredos de cunho mais científico e envolvia pesquisas para empreende-los. Como exemplo apresentamos um vídeo criado por Adriana, em que ela problematiza a questão das altas temperaturas de sua cidade e indica ações que poderiam minimizar o calor. Uma de suas falas pode subsidiar nossas construções: "Eu fiz o vídeo pra ajudar as pessoas. Todo dia no jornal está falando da falta de água e do calor. Eu sei que a gente pode ajudar o outro e isso eu faço com meus vídeo. Eu fiz uma pesquisa e já sei tudo sobre o calor." Havia, em Adriana, novas produções subjetivas associadas à problematização de temas de seu cotidiano em que se sentia capaz de fazer algo para contribuir.

Identificamos o caráter de autoria e empreendedor de postar suas produções, que envolvia se dispor de tempo para a escolha de suas publicações e a forma como inseria elementos novos que transcendiam o que conhecia. Havia novas produções subjetivas vinculadas à leitura e à escrita como recursos para solucionar problemas do cotidiano, como processo de comunicação com o outro. Processo que nos possibilitou compreender o caráter recursivo entre a criatividade na aprendizagem e a própria dinâmica de desenvolvimento da subjetividade. O que confluiu para a expressão da criatividade nas produções escritas de Adriana em sala de aula, que contaram com enredos voltados à solução de problemas que ela identificava em seu dia a dia (Anexo F - Figura 14).

A experiência com o esporte, o qual Adriana passou a realizar a partir do segundo ano do ensino fundamental, parecia envolvê-la emocionalmente. Interpretamos que Adriana necessitava vencer seus próprios desafios de nadar, o que, de certa forma, foi relevante para a configuração de sua autonomia no campo da aprendizagem da leitura e da escrita. A natação 
favoreceu novas produções subjetivas associadas a se sentir desafiada a aprender em diferentes campos da vida, vinculadas ao fortalecimento de sua confiança em si mesma, muitas vezes abalada pela realização de atividades na escola que não eram de seu interesse.

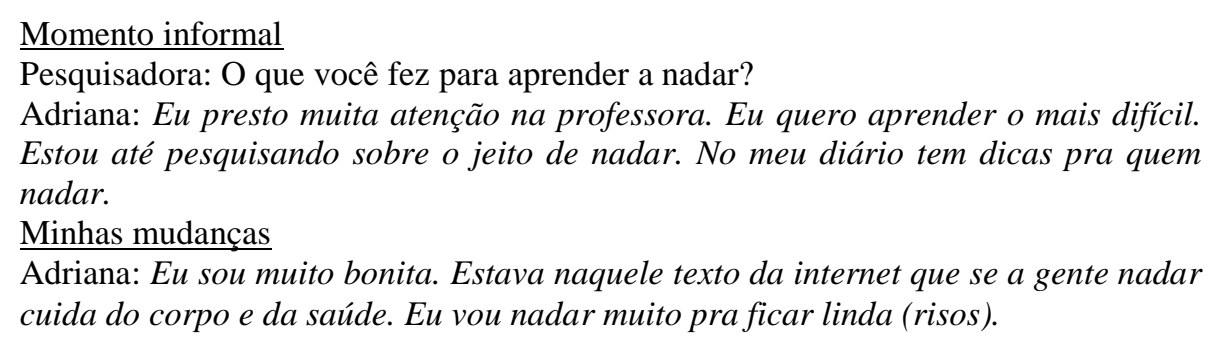

As informações acima expressam que a dedicação e o empenho de Adriana para atividades que lhe desafiavam, a instigavam a avançar mais. Do nosso ponto de vista, havia, em Adriana, novas produções de sentidos subjetivos vinculados ao esporte como possibilidade de ter saúde e um peso ideal. Produções que se vinculam ao núcleo de sentidos subjetivos associados à relação com o conhecimento e a outras produções subjetivas também associadas ao núcleo de sentidos subjetivos vinculados à experiência de brincar de ser professora, relacionados à necessidade de Adriana em se sentir desafiada em sua aprendizagem em meio a novas produções subjetivas associadas à aprendizagem como algo que requer um nível de dificuldade para o aprendiz, que lhe tire da zona de conforto. Outras informações podem subsidiar nossas elaborações:

\footnotetext{
Minhas mudanças

Adriana: Já estou nadando de costas. Agora eu quero mergulhar fundo e ficar muito tempo. Igual o dia que a tia me disse que era difícil escrever COELHO e eu fui lá no meu caderno e descobri que era só usa o L e o $H$.

Diário de ideias

Adriana: Eu nado, estudo, brinco, tudo eu amo. Eu gosto de fazer de tudo.
}

Interpretamos que havia, em Adriana, uma autodeterminação para aprender que se organizava para além do campo do esporte, o que reverberou para sua própria aprendizagem, pela busca, cada vez mais, da leitura e da escrita como processos que faziam parte de sua vida. Processos que formavam parte de novas produções subjetivas associadas à leitura e a escrita como veículo para empreender oportunidades de aprendizagens. Como unidade subjetiva de desenvolvimento, a configuração subjetiva da ação de aprender criativamente a ler e a escrever se expressou tanto no contexto escolar como nos contextos não formais de educação. $\mathrm{O}$ quadro abaixo consiste em uma tentativa de ilustrar as inter-relações entre a expressão da aprendizagem criativa e o desenvolvimento da subjetividade de Adriana. 
Quadro 6 - Inter-relações entre a expressão da criatividade e o desenvolvimento da subjetividade de Adriana

\begin{tabular}{|c|c|c|c|}
\hline $\begin{array}{r}\text { Configuração subjetiva } \\
\text { aprender }\end{array}$ & Expressão da criatividade & & $\begin{array}{c}\text { Novas } \\
\text { expressões da } \\
\text { criatividade }\end{array}$ \\
\hline \multicolumn{3}{|c|}{ Núcleo de sentidos subjetivos associados à relação com a mãe: alto grau de exigência } & \multirow{4}{*}{$\begin{array}{l}\text { - Criação de } \\
\text { um caderno } \\
\text { para registrar } \\
\text { os seus erros, } \\
\text { como forma } \\
\text { de } \\
\text { acompanhar o } \\
\text { seu na } \\
\text { desenvolvime } \\
\text { nto na na } \\
\text { aprendizagem } \\
\text { da leitura e da } \\
\text { escrita. }\end{array}$} \\
\hline $\begin{array}{l}\text { Produções subjetivas associadas: } \\
\text { - à confiança e valorização do saber da } \\
\text { mãe; } \\
\text { - à necessidade de esforço para aprender } \\
\text { vinculada ao apoio da mãe; } \\
\text { - ao compromisso com sua aprendizagem, } \\
\text { ao desejo de ser reconhecida pela mãe; } \\
\text { - à necessidade de se sobressair sobre o } \\
\text { outro; } \\
\text { - à necessidade de interação com o outro; } \\
\text { - à dificuldade de lidar com o erro; } \\
\text { - à necessidade de valorização social. }\end{array}$ & $\begin{array}{l}\text { - Geração de ideias próprias } \\
\text { e novas que transcendem o } \\
\text { dado: criação de situações } \\
\text { artísticas. } \\
\text { - Confrontação com o dado: } \\
\text { com suas próprias produções } \\
\text { e com as ideias do outro. } \\
\text { - Estratégias de } \\
\text { aprendizagem: de } \\
\text { autorregulação e cognitivas. }\end{array}$ & $\begin{array}{l}\frac{\text { Novas produções }}{\text { subjetivas }} \\
\text { associadas: } \\
\text { - ao respeito ao } \\
\text { saber do outro; } \\
\text { - à aprendizagem } \\
\text { não vinculada à } \\
\text { opinião do outro; } \\
\text { - à relação com o } \\
\text { erro como algo que } \\
\text { faz parte da } \\
\text { aprendizagem. }\end{array}$ & \\
\hline \multicolumn{3}{|c|}{ Núcleo de sentidos subjetivos associados à experiência de brincar de ser professora } & \\
\hline $\begin{array}{l}\quad \text { Produções subjetivas associadas: } \\
\text { - ao uso do tempo livre para ler e escrever; } \\
\text { - ao reconhecimento social; } \\
\text { - à necessidade de relações autênticas com } \\
\text { o outro; } \\
\text { - à necessidade de se expressar por outras } \\
\text { linguagens. } \\
\text { - à imaginação como possibilidade de criar } \\
\text { novas experiências; } \\
\text { - a querer ser mais cobrada e desafiada em } \\
\text { suas produções; } \\
\text { - à aprendizagem como processo que se } \\
\text { efetiva no diálogo com o outro. }\end{array}$ & $\begin{array}{l}\text { - Confrontação com o dado: } \\
\text { com as ideias do outro e com } \\
\text { sua própria produção; com o } \\
\text { trabalho pedagógico das } \\
\text { professoras. } \\
\text { - Relação lúdica: criação de } \\
\text { cenário imaginário; relação } \\
\text { completa e voluntária. } \\
\text { - Personalização da } \\
\text { informação: dos conteúdos } \\
\text { escolares. } \\
\text { - Geração de ideias próprias } \\
\text { e novas que transcendem o } \\
\text { dado: a relação com a cópia. }\end{array}$ & $\begin{array}{l}\frac{\text { Novas produções }}{\text { subjetivas }} \\
\text { associadas: } \\
\text { - a estabelecer com } \\
\text { o pai um processo } \\
\text { dialógico sobre suas } \\
\text { sobre sua } \\
\text { aprendizagem; } \\
\text { - à aprendizagem } \\
\text { como um processo } \\
\text { próprio que não se } \\
\text { vinculava à opinião } \\
\text { do outro. }\end{array}$ & \\
\hline \multicolumn{3}{|c|}{$\begin{array}{c}\text { Núcleo de sentidos subjetivos associados à relação com o conhecimento: a dimensão proativa } \\
\text { para a pesquisa }\end{array}$} & \multirow{2}{*}{$\begin{array}{l}\text { - Enredos de } \\
\text { suas } \\
\text { produções } \\
\text { escritas com } \\
\text { caráter } \\
\text { propositivo de } \\
\text { ações para } \\
\text { solucionar } \\
\text { problemas do } \\
\text { cotidiano. }\end{array}$} \\
\hline $\begin{array}{l}\text { Produções subjetivas associadas: } \\
\text { - à autodeterminação; } \\
\text { - à pesquisa para aprofundar } \\
\text { conhecimentos; } \\
\text { - à insatisfação com o sobrepeso; } \\
\text { - a aprender para ajudar os pais em dir } \\
\text { à qualidade de vida; } \\
\text { - à comunicação com o outro; }\end{array}$ & $\begin{array}{l}\text { - Personalização da } \\
\text { informação: dos conteúdos; } \\
\text { do que lia e escrevia. } \\
\text { - Geração de ideias próprias } \\
\text { e novas capazes de ir além } \\
\text { do que era proposto nas } \\
\text { atividades da escola; a } \\
\text { criação de situações } \\
\text { artísticas. }\end{array}$ & $\begin{array}{l}\frac{\text { Novas produções }}{\text { subjetivas }} \\
\quad \underline{\text { associadas: }} \\
\text { - ao respeito ao } \\
\text { saber do outro; } \\
\text { - à autoconfiança } \\
\text { no seu processo de } \\
\text { aprender. }\end{array}$ & \\
\hline \multicolumn{3}{|c|}{ Novos aspectos da constituição subjetiva } & \multirow{3}{*}{$\begin{array}{l}\text { - Enredos de } \\
\text { seus vídeos, os } \\
\text { quais } \\
\text { passaram a ter } \\
\text { cunho mais } \\
\text { científico e } \\
\text { demandar-lhe } \\
\text { pesquisas para } \\
\text { empreende- } \\
\text { los. }\end{array}$} \\
\hline \multicolumn{3}{|c|}{$\begin{array}{c}\text { Novo núcleo de sentidos subjetivos associados à relação com a aprendizagem para além do } \\
\text { contexto escolar }\end{array}$} & \\
\hline \multicolumn{3}{|c|}{$\begin{array}{l}\qquad \frac{\text { Novas produções subjetivas associadas: }}{\text { - a se sentir capaz de aprender em diferentes campos da sua vida; }} \\
\text { - à autodeterminação para aprender; } \\
\text { - a se sentir desafiada a aprender; } \\
\text { - à problematização de temas de seu cotidiano em busca de ações para contribuir; } \\
\text { - à aprendizagem como algo que tire da zona de conforto; } \\
\text { - como possibilidade de diferenciar-se do outro; } \\
\text { - ao esporte como possibilidade de ter saúde e um peso ideal; } \\
\text { - à leitura e a escrita como veículo para empreender oportunidades de aprendizagens. }\end{array}$} & \\
\hline
\end{tabular}

Fonte: elaborado pela autora, 2015. 


\subsection{O CASO DE GABRIEL}

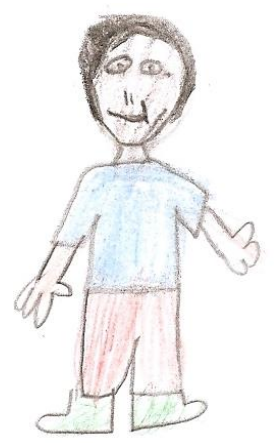

Figura 3: Produção de Gabriel a partir do instrumento "Montando minha história" - 2013

\subsubsection{Caracterização de Gabriel}

Gabriel era filho caçula de uma família de dois filhos e morava com seus pais e o irmão mais velho. Ele adorava desenhar e assistir ao telejornal com o pai. Gabriel era alegre, amigo de todo mundo, prestativo e sensível. Tinha cabelos bem pretos e pele branca. Sua mãe trabalhava como assistente de limpeza em um hospital e seu pai era pedreiro. No decorrer da pesquisa, sua mãe adoeceu e precisou ficar afastada definitivamente do trabalho, passando a ficar maior parte do tempo em casa, assim como seu pai ficou desempregado. Em casa, Gabriel dispunha de livros e jogos, com os quais gostava de passar boa parte de seu tempo livre. No período extraescolar, fazia natação e se envolvia com seus desenhos e brincadeiras. Pela análise documental, identificamos que sua história escolar indica ser ele um aluno dedicado, educado, responsável e tímido. Pela avaliação diagnóstica de escrita realizada pelas professoras regentes, Gabriel iniciou o $1^{\circ}$ ano na hipótese pré-silábica e terminou o $2^{\circ}$ ano no nível alfabético. Em sala de aula, Gabriel demonstrava envolvimento com a leitura e a escrita e uma aguçada curiosidade por este campo de aprendizagem.

\subsubsection{Expressão da criatividade na aprendizagem da leitura e da escrita e suas relações com as estratégias de aprendizagem de Gabriel}

A aprendizagem da leitura e da escrita de Gabriel se constituiu em sua complexidade e singularidade, por características e estratégias de aprendizagem que a qualificam como uma aprendizagem criativa. No processo construtivo-interpretativo, identificamos que a criatividade na aprendizagem de Gabriel se expressou pela personalização da informação, pela confrontação com o dado, pela produção de ideias próprias e novas que transcendem o inicialmente posto e pela relação lúdica. Tais características estiveram vinculadas às 
estratégias de aprendizagem da leitura e da escrita. Como nos outros casos em Gabriel também identificamos que na aprendizagem da leitura e da escrita de Gabriel a criatividade emergiu de forma sistêmica ao envolver de forma geral os múltiplos processos que subjazem à aprendizagem.

\subsubsection{Personalização da informação}

Em nossas observações em sala de aula, identificamos que Gabriel personalizava seu próprio processo de ler e escrever, vinculado à relação com as atividades propostas. Ele nem sempre prestava atenção às explicações da professora e gostava de observar a estrutura da atividade para poder criar uma forma própria de fazê-la. Assim como também, não começava a atividade imediatamente ao recebê-la, mas a observava primeiro e depois fazia tentativas de leitura para descobrir o que era para ser realizado. Ele também ficava atento à forma como os colegas desenvolviam a atividade. Interpretamos que Gabriel não necessitava copiar dos colegas, mas lhe instigava ver as diferentes possibilidades de realizar uma mesma atividade, o que lhe inspirava em suas criações próprias. Os trechos abaixo podem ilustrar nossas construções:

\footnotetext{
Diário de ideias

Gabriel: Eu fico olhando os menino lá na sala e aí eu já sei como que eu vou fazer minha tarefa. Aí eu fico pensando que o GATO que a tia pois na tarefa gosta de leite e tem pêlo macio.

Entrevista I

Pesquisadora: Como você faz as suas atividades?

Gabriel: Eu fico esperando a tia entregar a tarefa e aí eu olho ela primeiro. Eu olho, olho e aí eu fico pensando o que eu vou escrever.

Pesquisadora: Você olha a atividade dos colegas?

Gabriel: Até que eu olho. Mas eu não copio não. Teve um dia que eu olhei a tarefa do André e aí eu pensei assim, já sei, que que eu possa fazer.
}

Do nosso ponto de vista, se alinhava à personalização das atividades propostas, a utilização por Gabriel de estratégias de autorregulação associadas à deliberação de atenção e concentração nas ações de ler e escrever, assim como ao planejamento para realizar as atividades de leitura e escrita. Isso pela organização de como iniciar uma atividade, análise da estrutura da tarefa, assim como pela escolha do tipo de letra que utilizaria em seus registros.

\section{Entrevista II}

Pesquisadora: O que você precisou para iniciar a sua escrita?

Gabriel: Eu pensei em tudo que eu fiz antes. Até o Tales já tinha começado, mas enquanto eu não pensei eu não comecei escrever. Eu também pensei na minha letra, ela estava pequena e eu apaguei pra fazer maior.

Pressupomos que Gabriel também utilizava estratégias de autorregulação de busca pelo significado das palavras. Podemos ilustrar nossa construção pela forma como Gabriel, no 
primeiro ano, diante de uma atividade de cópia da lousa de palavras com a letra $\mathrm{C}$, em que, ao terminar a escrita das palavras, se colocou, espontaneamente, a conversar com os colegas sobre os significados das mesmas. Processo em que a personalização lhe favorecia empreender novas ações de diálogo com o outro. Podemos exemplificar nossa elaboração, a partir da descoberta por Gabriel do significado da palavra ARTE, o qual o mobilizou ao registro de palavras por meio de desenho, o que pode ser ilustrado por uma de suas falas: "Já que arte é o que todo mundo pode fazer, eu consigo fazer quando eu desenho e agora vou fazer quando eu inventar palavra. Vou fazer mais arte na minha casa agora, um tanto de desenho meu. Aí eu vou fazer uma palavra e um desenho dela." (Diário de ideias).

Neste processo de personalização das palavras, Gabriel também criava um novo formato das letras do alfabeto. Ele se dispunha a novas ações que implicavam mudanças em seu modo de vida, uma vez que passou a se interessar pela observação de traçados de letras em diferentes locais, assim como buscava descobrir novas palavras e seus significados. Isso lhe demandava um olhar mais atento aos lugares que frequentava com seus familiares. Era mais uma estratégia de autorregulação que se unia ao processo de personalização, relacionada à utilização do aprendido em situações cotidianas, favorecedora de novos processos de comunicação com seus familiares. Esses o apoiavam e também passaram a dedicar tempo aos momentos de saídas com Gabriel, para descobertas de novos traçados de letra. Nossa elaboração pode ser exemplificada por uma das falas de sua mãe:

\begin{abstract}
Momento informal
Mãe: Gabriel olha tudo que é palavra na rua. Antes ele nem se interessava. Mas agora é diferente. Ele quer ver como é que escreve e aí quer saber o que significa. Quando eu sei eu falo. Teve um dia que era DMAE ${ }^{46}$ e aí eu expliquei da água pra ele. Ele não parou de falar que precisava limpar os bueiros por causa da chuva. Quando chove ele já fica preocupado.
\end{abstract}

A partir da expressão de Gabriel ao instrumento "Mapa do tesouro", interpretamos que ele aprendeu algumas palavras pela observação de lugares como: caminhões, lojas, supermercados e outros. Cada palavra que ele lia ou escrevia, era um desencadeador de novas elaborações e a busca por outras descobertas. Processo capaz de favorecer diferenciadas ações de Gabriel vinculadas à qualidade de vida. Essa construção pode ser exemplificada por um momento, no segundo ano, em que realizava uma produção de texto com a temática "Dia do trabalhador" em que disse: "Mas pedreiro não parece nada com grama. Eu vou ter que usar outra palavra aqui. Eu vou colocar aqui cimento." Após a escrita do seu texto, Gabriel conversava com um colega: "Agora eu vou ajudar meu pai a fazer uma lista do que ele usa

\footnotetext{
${ }^{46}$ Departamento Municipal de Água e Esgotos é o órgão responsável pela captação, tratamento e distribuição de água, bem como pela coleta e tratamento do esgoto sanitário da cidade.
} 
pra trabalha e aí eu vou juntar tudo pra ele levar pro serviço e vai ficar bem mais fácil. Tem dia que ele nem sabe onde está a pá."

Interpretamos que a personalização do seu próprio processo de escrita e leitura engendrava-se na possibilidade de Gabriel atuar com o saber em diferentes contextos, com impactos na vida. Havia, em Gabriel, um posicionamento como sujeito frente a sua aprendizagem orientado à mudança em seu modo de vida e essa ação intencional o implicava em busca de novas ações em seu cotidiano.

Havia, em Gabriel, um movimento de personalização dos conteúdos trabalhados no cotidiano da sala de aula e outros que faziam parte de seu cotidiano. Como exemplo, apresentamos um dos momentos do primeiro ano, em que a professora Melissa trabalhava com o tema água, a partir de uma história. Gabriel observava atentamente o livro e a própria história. No momento do recreio, observamos sua preocupação com o desperdício de água nos bebedouros: "Que coisa chata! É tanta água indo embora." Mediante seu interesse, Gabriel passou a pegar livros na biblioteca da escola com a temática água, assim como a conversar mais com sua mãe sobre o sistema de tratamento de água e esgoto da cidade.

Em um processo investigativo de ação de cuidar do meio ambiente, Gabriel não apenas observava os colegas desperdiçarem água, como passou a conversar com os próprios colegas, assim como reduzir o tempo de seus banhos, o que pode ser ilustrado por uma de suas falas: "Eu tomo banho e aí eu fecho o chuveiro pra passar o sabonete. Depois é só abrir e terminar." (Diário de ideias). Era importante perceber como as informações personalizadas passavam a formar parte da vida do aprendiz com impactos no modo de vida, configurando novas ações, relações, curiosidades e interesses.

Além disso, havia, em Gabriel, uma forma de personalização dos conteúdos curriculares voltada para a integração dos mesmos. Neste ponto, chamou nossa atenção a sua busca por estabelecer associações entre o que aprendia em diferentes conteúdos curriculares como Matemática, História, Geografia, Ciências e Português. Não havia para ele uma distinção entre os conteúdos, o que pode ser exemplificado por uma de suas falas:

\section{Entrevista I}

Gabriel: A tia já deu essa palavra FAMÍLIA lá no caderno que tem História. Agora está aqui pra gente separar a sílaba (risos). A gente era pra estudar tudo junto. Aquele dia que fiz a conta de $5+2$ que deu 7 eu pensei assim, nossa eu já tenho sete anos e aí eu fiz um desenho e escrevi uma história do dia meu aniversário só que foi no outro caderno.

Tal integração dos conteúdos curriculares, em uma forma personalizada, tinha impactos na vida de Gabriel. Podemos exemplificar nossa construção a partir de uma de suas falas: "Eu vou no supermercado com a minha mãe e olho os nome dos produto e tem o preço 
e eu já sei somar e lê. Eu falo pra minha mãe a marca que é mais boa de preço e aí a gente sabe o nome. Antes eu nem sabia e só olhava o preço. Eu já fiz uma lista pra ajudar minha mãe." (Diário de ideias). Gabriel personalizava os conteúdos em uma forma de criar oportunidades de utilizar o aprendido com implicações para apoiar o outro.

\subsubsection{Confrontação com o dado}

Gabriel não participava muito oralmente em sala de aula, ele mantinha mais um diálogo com ele mesmo em sua própria atividade e com os colegas. Esta relação comunicativa com a atividade esteve assistida pela confrontação com suas próprias produções, que expressava o caráter reflexivo do pensamento na ação de aprender criativamente, como ressaltado por González Rey (2012a) e estava para uma relação positiva com o erro no processo de aprender.

Foram vários os momentos em que observamos Gabriel sussurrando ao realizar uma leitura e uma escrita, mesmo após já ter concluído sua atividade, em um processo de questionar sua própria produção. Interpretamos que a confrontação estava associada à utilização de estratégias de autorregulação relacionadas à reflexão sobre a própria escrita, assim como com a revisão autônoma de sua própria produção. Podemos exemplificar nossa construção a partir de um momento na "Oficina de leitura e escrita" em que ao escrever uma palavra que havia inventado, dizia para ele mesmo: "SOM - SOM, agora é BRA - BRA BRA, qual é o B na cursiva? Ah, já sei. Então fica SOMBRA-DOR-DOR, SOMBRADOR. Já fiz a palavra, mas parece que o $R$ tinha uma curva diferente." Havia um interesse de uma escrita a ser aprendida e não o simples registro de uma palavra.

\footnotetext{
Entrevista II

Pesquisadora: Você identificou algum erro durante a sua escrita? Gabriel: Eu estava escrevendo e olhei a palavra MUITO e achei que estava faltando uma letra e era o I e eu apaguei e coloquei o I.

Pesquisadora: Como você sabe que a sua escrita está certa?

Gabriel: Eu olho e vejo. Tem hora que está escrito diferente e eu penso, não é assim e aí eu sei que está errado.

Pesquisadora: Como você avalia seu processo de escrita?

Gabriel: Está boa, mas eu acho que está mais ou menos, está meio bagunçado.
}

Interpretamos que este processo de confrontação participava de um modelo hipotético em andamento, no qual a dúvida era algo constante nas ações de ler e escrever e envolvia se confrontar com suas produções e negociar consigo mesmo uma maneira de encontrar respostas, o que se articula a estratégias de autorregulação de buscar de forma autônoma respostas para suas próprias dúvidas. Podemos ilustrar nossa construção a partir de uma das expressões de Gabriel ao instrumento "Trilha das frases" frente ao indutor 35- QUANDO 
TENHO DÚVIDAS: “Eu penso, aí eu penso na minha cabeça se aquela resposta vai adiantar ou não."

São processos articulados a estratégias cognitivas de estabelecer relações entre sons e letras, outras relacionadas à própria relação da escrita com a forma visual da letra, assim como relações entre a forma como culturalmente falava e a escrita das palavras. Isso pode ser exemplificado a partir de um jogo em grupo, no primeiro ano, em que Gabriel e os colegas formavam a palavra TUCANO a partir de letras do alfabeto móvel, que ficou: ONACUT. Gabriel observava a palavra formada e parecia não estar satisfeito e disse: "Tem alguma coisa errada. Não está certo isso." No momento em que colocava o dedo sobre cada letra e ao descobrir que a palavra formada estava invertida, ele sorriu e disse: "Ah, eu sabia que TUCANO estava errado. A gente fez o começo no fim (risos)". Em outros momentos, Gabriel se confrontava com sua própria forma de falar e a escrita das palavras, o que pode ser exemplificado a partir de sua escrita da palavra CHOCOLATE, em que ele disse: "A tia escreve CHOCOLATE e é com I. Nossa! Eu só falo assim (risos). Eu vou ter que mudar e escrever assim agora." (Observação).

Nas leituras que realizava, em um diálogo com o próprio texto e, a partir de suas próprias ideias, buscava transcender o escrito. Ele se confrontava com as ideias dos textos e também com suas próprias ideias, no intuito de gerar uma opinião própria, o que interpretamos estava associado às estratégias de autorregulação referentes a realizar inferências sobre o lido. Interpretamos que ele mantinha uma relação com a escrita e com a leitura, não como verdades absolutas ou mesmo como processos diretivos de suas ações, mas como possibilidades para formar própria opinião. Dentre diversas informações que subsidiam nossa construção, mostramos o momento em que Gabriel realizava a leitura de uma atividade em sala de aula do primeiro ano, na qual constava: "Noé é o leão do zoológico. Ele vive na jaula". A partir da leitura do texto Gabriel falou para o colega André: "Que coisa feia. Se eu fosse fazer uma história eu colocava o leão na floresta. Pra que colocou ele aqui na jaula."

$\mathrm{Na}$ relação com os colegas, Gabriel procurava estabelecer um diálogo em que demonstrava flexibilidade em expor suas ideias e ouvir os posicionamentos dos colegas. Era extremamente exigente consigo mesmo, ou seja, Gabriel apresentava sua opinião sobre o que lia e também sobre o que escrevia, mas gostava de ouvir e conversar com os colegas para tentar descobrir novas formas de poder olhar para uma mesma situação. Esta relação de troca com os colegas se apresentou como um processo de confrontação com as ideias dos colegas.

Pressupomos que Gabriel lançava mão de outras estratégias de autorregulação, relacionadas à prática de contar ao outro o que aprendeu em busca de novas ideias. Podemos 
exemplificar tal construção a partir de um momento de observação em sala de aula em que a professora Melissa, do primeiro ano, leu uma história em sala de aula denominada: "A caminho da escola". Após ouvir atentamente a história, Gabriel levantou o dedo e esperou sua vez para falar, porém, outros colegas falaram primeiro, até que o momento do recreio chegou e Gabriel não pôde participar oralmente. No entanto, foi no recreio que observamos como ele procurava os colegas para conversar sobre o livro. Pela importância de tal exemplo, citamos a seguir o diálogo de um de nossos momentos de observação:

Gabriel: Eu já vi um bondinho no filme Rio. Eu queria andar de bondinho, eu acho que deve balançar muito lá em cima.

Fábio: Eu quero é andar de cavalo. Deve ser tão legal.

Gabriel: Mas eu também acho que tem outro jeito de vim pra escola. É de avião.

Fábio: Que que isso? Está doido. Não dá não.

Gabriel: Por quê??

Fábio: Ah, sei lá. É bem grande e onde vai parar aqui?

Gabriel: É mesmo. Mas se fizer uma pista aqui perto até que dá.

\subsubsection{Produção, geração de ideias próprias e novas que vão além do dado}

Gabriel respeitava a opinião dos colegas e também modificava suas próprias ideias ao longo dos diálogos que se engendravam no cotidiano da sala de aula. Para ele, trocar ideias com os colegas lhe favorecia produzir e gerar ideias próprias e novas que transcendiam sua própria ideia. Mediante a confrontação, Gabriel trabalhava com suas ideias iniciais a partir de processos de comunicação consigo mesmo e com o outro, que lhe permitiam manter, modificar ou mesmo transcender a ideia inicial.

Podemos exemplificar nossa construção por um momento em sala de aula, no primeiro ano, em que Gabriel realizava uma atividade de desenhar e escrever sobre sua brincadeira preferida. Ele estava concentrado em sua atividade, quando um colega lhe perguntou qual a brincadeira que ele tinha escolhido. Gabriel falou que gostava de jogar bola. Naquele momento, o colega explicou que só joga bola na rua ou na quadra, o que fez com que Gabriel ficasse pensativo sobre sua produção. Ele havia começado a fazer o seu desenho representando uma quadra de futebol, quando disse ao colega: "Eu acho que a gente pode jogar em todo lugar. Eu vou fazer um jogo de bola na floresta." O diálogo com o colega lhe possibilitou momentos de reflexão sobre sua ideia inicial e favoreceu novas formas de ver e experienciar imaginativamente a própria ação de jogar bola, aliado à estratégia de autorregulação citada no item anterior da prática de trocar ideias com o outro sobre o que aprendeu em busca de novas ideias.

Interpretamos que havia autoria em suas atividades que lhe permitia uma expressão própria de suas ideias, que demandava reflexão e envolvimento. A criatividade se expressava 
na forma como Gabriel se imbuía em criar uma produção própria que estivesse para além de suas experiências, como exercício de sua autonomia e responsabilidade pela sua criação. A imaginação constituía o funcionamento de Gabriel frente às suas produções, como processo que demandava profunda implicação emocional e favorecia transformações de situações experienciadas para novas formas de experiências, capazes de gerar novas emoções e o sentimento de realização pessoal frente à produção.

Essa construção pode ser exemplificada por uma de suas falas após a conclusão da atividade citada anteriormente: "Eu senti até o vento da floresta (risos). Jogar na floresta é mais alegre, a gente vê os animais e até chuta as folhas do chão. Parecia que eu estava lá." Compreendemos que há um funcionamento do novo em seu caráter gerador de novas possibilidades de geração de novidade, uma vez que Gabriel, além de um registro que envolveu o novo que transcendeu sua ideia inicial, produziu novas experiências imaginárias, produtoras de diferentes sensações e emoções.

Inferimos que a produção de ideias próprias e novas, que vão além do dado, também estiveram presentes na relação de Gabriel com as atividades propostas. A forma como se relacionava com as atividades era expressa pela procura de maneiras pessoais para realizá-las, favorecidas pelo seu envolvimento como sujeito da ação. Podemos exemplificar nossa construção a partir de uma atividade com o dicionário em sala de aula, em que a professora Flávia, do segundo ano, disponibilizou modelos de dicionários diferenciados para cada aluno. Ela pedia para a turma procurar o significado da palavra TOGA e Gabriel demonstrava curiosidade em conhecer todo o dicionário. Ele descobriu as bandeiras dos países no final do livro e demonstrou encantamento dizendo: "Nossa que legal! Tem até do Brasil? Eu quero conhecer todos os países. Eu vou desenhar essa bandeira aqui no meu caderno e vou escrever o nome do país. Eu vou fazer uma lista de lugares que eu quero conhecer. Um roteiro de viagem (risos)." (Observação). Em seguida, Gabriel chamou o colega André e lhe mostrou suas descobertas, na busca de contar ao outro o que aprendeu.

A ação de Gabriel nos chamou a atenção pela forma como extrapolava a atividade proposta em busca de novas aprendizagens. Ele também procurou a palavra que a professora solicitou, mas se imbuiu em investigar o material recebido e ir além do que foi solicitado ou mesmo dado como tarefa, o que lhe possibilitou gerar ideias próprias e novas de transcendência ao dado. Processo associado a estratégia de autorregulação de buscar conhecer profundamente a atividade a ser realizada e para além dela. A geração de ideias próprias e novas configurou-se pelo caráter empreendedor de Gabriel na busca de tornar possível suas elaborações. Havia, em Gabriel, iniciativa e o desejo de concretizar suas ideias em ações para 
além do aprendido, que lhe permitiam empreender caminhos próprios e significar a escrita como recurso para registrar seus sonhos, desejos, sentimentos, em um processo particular de se relacionar com a escrita que envolvia autoria e empreendedorismo.

Pressupomos que, na aprendizagem criativa, a autoria e o caráter empreendedor do sujeito estão em consonância com a proposta de Freire (2011b), relacionada à educação problematizadora, em que o aprendiz se insere na aprendizagem em um processo reflexivo que unifica o pensar a si mesmo e o mundo de forma simultânea, sem dicotomizar este pensar da ação de aprender, tornando a leitura e a escrita pessoal.

A transcendência ao dado também esteve presente na dinâmica entre desenhar, ler e escrever. Gabriel gostava muito de desenhar e sempre nos mostrava produções que havia criado e também copiado. Chamou nossa atenção o quanto seus desenhos favoreciam a geração de ideias próprias e novas no campo da leitura e da escrita, uma vez que, a partir de suas ilustrações, Gabriel se colocava a inventar histórias e a registrá-las. Estas histórias não constituíam uma forma de cumprir com uma obrigação em sala de aula, mas era algo particular que ele realizava de forma espontânea. Além da escrita de histórias, os registros pictóricos de Gabriel lhe instigavam à busca de leituras de livros com temas próximos aos seus desenhos, bem como suas leituras também o instigavam a novas produções pictóricas e escritas.

Para ilustrar nossa construção, transcrevemos uma produção de Gabriel no instrumento "Diário de ideias", em que ao fazer o desenho de um avião, no momento em que inseria os detalhes, ele optou por fazer uma produção de um texto, decidindo o enredo a partir da forma que o desenho assumia.

Diário de ideias (Anexo G - Figura 15)

Gabriel: Eu estava fazendo o avião e ai eu pensei 'já sei!' Posso escrever uma história do menino que nunca viajou. Aí eu fui fazendo o avião do jeito que eu já vi na televisão.

Aliado ao processo de autoria em seus registros, havia o caráter empreendedor de concretização de suas ideias, o que se realizava, em muitos momentos, no seu tempo livre, utilização que apresentou o caráter de gestor de suas ações, assumindo, como ressalta González Rey (2004c), responsabilidade pelos seus atos. Gabriel buscava realizar, de forma efetiva, suas ideias que lhe favoreciam atuar com o saber na dimensão de sua vida e que não ocorria apenas pela transposição do aprendido, mas pela geração de novas formas de ver suas próprias experiências e empreender novos registros e caminhos de atuação. Apresentamos a seguir, outro momento que pode exemplificar nossa construção: 
Diário de ideias (Anexo G - Figura 16)

Gabriel: Eu vi no jornal um tanto de país. Aí eu desenhei aí na folha pra ter eles pra mim. Eu vou viajar e conhecer tudo tudo. Minha mãe, meи pai e meu irmão vai também. Agora eu já sei onde é que é o Brasil. Eu escrevi o nome dos país na outra folha, mas eu vou ter que procurar outros, eu só sei uns.

No exemplo acima, identificamos o quanto uma descoberta era geradora de novas possibilidades de outras descobertas e elaborações, em que uma novidade era capaz de gerar outras novidades empreendida em novas ações. Gabriel descobriu o mapa e criou sua própria forma de registrá-lo, momento gerador de novos interesses e realizações. A autoria e o empreendedorismo se uniram no processo de produção e geração de ideias próprias e novas capazes de transcender o inicialmente dado que, em confluência com as características anteriores, favoreceram a busca por novos caminhos em prol de novas descobertas.

\subsubsection{A relação lúdica no processo de aprendizagem criativa da leitura e da escrita}

Em Gabriel, a relação lúdica também se constituiu como uma forma espontânea e gratuita de se imbuir nas ações de ler e escrever associadas à relação entre as experiências de desenhar, de ler e de escrever. Neste processo, identificamos a relação completa, voluntária, próxima, instantânea e investigativa de Gabriel com as situações de leitura e escrita. Para ele, aprender não era uma obrigação a ser cumprida, mas um processo pleno de realização pessoal em que se entregava às atividades propostas de forma espontânea, com despreocupação em relação ao tempo ou mesmo com as possíveis agitações do entorno da sala de aula. Podemos ilustrar nossa elaboração por uma de suas falas na Entrevista II: “Eu vou escrevendo e escrevendo e nem vejo quando chega a hora do recreio (risos)."

Chamou nossa atenção que a entrega de Gabriel às experiências de leitura e escrita envolviam um caráter cômico, em que o riso era algo presente, como uma das características do lúdico, de acordo com Huizinga (1999). Entendemos que eram experiências de divertimento, de descontração para Gabriel. Processo que pode ser ilustrado por uma de suas falas no momento da "Oficina de leitura e escrita": "Gente do céu! Eu fiz ÁRVORE assim ÁVURI (risos). Que coisa legal que virou. Até virou uma palavra que nem sei se existe (risos)." Outra, de suas falas, também é ilustrativa: "Quando eu estou muito cansado de correr, aí eu fico inventando palavra e escrevo nas folhas. Depois eu até desenho elas. Aí brinco de palavra." (Diário de ideias). Em sala de aula, observamos, em vários episódios de leitura e escrita que ele ria com suas produções e procurava dividir suas descobertas com os colegas. 
Para Gabriel, desenhar, ler e escrever era uma forma de brincar com suas ideias, o que pressupomos se alinhava à utilização de estratégias de autorregulação vinculadas à realização das atividades propostas relacionadas à ludicidade. Nossa elaboração pode ser ilustrada a partir de uma das falas de Gabriel: "Eu desenho e eu escrevo. Tudo isso é legal, está na minha cabeça. Eu fico brincando de fazer as curvas das letras e parece um desenho. Só muda um pouquinho." (Diário de ideias). Chamou nossa atenção a forma como Gabriel realizava suas produções escritas ou de desenho de uma só vez, ou seja, ele não retomava suas produções em momentos posteriores para dar continuidade a elas, mas sim, as concluía em um único momento. Havia em suas produções uma completude para ele mesmo. "É só fazer tudo na hora. Eu faço desenho e escrevo, nem precisa volta pra fazer nada." (Diário de ideias).

A relação lúdica também se expressou na forma como Gabriel se colocava desafios constantes a serem superados durante as ações de ler e escrever. Essas eram situações problemas que Gabriel se colocava como ativo em se autodesafiar constantemente. Interpretamos que tal característica estava aliada à estratégia de autorregulação associada à procura de formas diferenciadas para realizar as atividades propostas em busca de desafio. Gabriel se envolvia com suas produções de forma compenetrada e isso lhe favorecia um processo investigativo de novas descobertas.

Podemos exemplificar nossa construção por uma importante conquista na aprendizagem de Gabriel, que foi a sua escrita na letra cursiva. A professora Melissa e sua mãe relataram, em momentos informais, a dificuldade de Gabriel com o traçado da letra cursiva. No entanto, acompanhamos o empenho do aprendiz na escrita da letra cursiva, momentos em que apagava várias vezes sua própria escrita e também observava atentamente o traçado da letra, seja na lousa ou mesmo nos materiais escritos no contexto da sala de aula. De forma espontânea, ele registrava as letras em seu caderno como se brincasse de desenhálas. Pressupomos que não havia dificuldade em sua escrita, mas sim, a busca por um traçado diferenciado, ou seja, pessoal de cada letra.

Para Gabriel, não bastava cumprir o que as tarefas lhe exigiam, ele inseria novos desafios para aprendizagens que transcendiam o que estava sendo proposto. Podemos exemplificar tal característica, a partir de um momento de observação em sala de aula, em que Gabriel realizava uma atividade no primeiro ano. Nessa situação, a professora Melissa entregou uma folha de atividade com seis letras do alfabeto e para cada letra havia uma palavra escrita. A atividade consistia em ler as palavras e colorir os desenhos. Gabriel realizou a atividade e ao terminá-la, começou a formar novas palavras utilizando as letras das palavras 
da atividade. No momento da atividade, ele disse a um colega: "Ah, se eu colocar o A na FLOR vai formar FLORA (risos)." (Observação).

Outro elemento associado à relação lúdica foi a criação das próprias regras. Havia uma relação diferenciada de Gabriel com os materiais que eram distribuídos aos alunos no início do primeiro ano do ensino fundamental, sendo os mesmos compostos por fichas com o alfabeto e o nome completo do aluno. Ele era extremamente cuidadoso com estes materiais e sempre que chegava à escola colocava-os sobre a mesa. Em vários momentos em que realizava atividades de leitura e escrita, consultava espontaneamente tais materiais, assim como imprimia uma maneira diferenciada de utilização dos mesmos para além do que era estipulado pela professora.

Gabriel observava as letras das fichas, conhecia os formatos exigidos para a escrita e elaborava novos traçados para utilização em sua própria escrita. Esse processo estava associado às estratégias de autorregulação vinculadas ao cuidado com a estética de sua própria escrita. Podemos exemplificar nossa construção por uma das falas de Gabriel: “As letras da ficha são bem diferente das minha. Dá pra olha elas e muda. Olha aqui o meu D, tem uma curva bem aí. Tem maiúscula e minúscula. É grande e pequena." (Oficina de leitura e escrita). Ele apresentava curiosidade por conhecer diferentes tipos de traçados de letras e isso pode ser exemplificado pela forma como conhecia os traçados de letras dos colegas. Em vários momentos, identificamos Gabriel falando para os colegas: “Que letra bonita você tem!".

A relação de Gabriel com as letras do alfabeto na ficha lhe favorecia estabelecer uma relação de criação com a escrita de novos traçados das letras e não estava para cópia ou reprodução. A construção de uma estética própria para sua escrita extrapolava a função de consulta à ficha e lhe permitia criar algo próprio e novo para além do que estava posto, mediante um processo reflexivo. Para ilustrar nossas elaborações, trouxemos uma das falas de Gabriel no momento de escrita da palavra PINTINHO: "Não é assim não. Pera aí que eu vou apagar. Agora melhorou. Mas essa perna do P está muito grande (risos). Vou apagar. Acho que agora o P fico bom. Mas o H não. Vou fazer ele de novo." (Oficina de leitura e escrita).

Identificamos em Gabriel a criação de um cenário imaginário em que ele se permitia transcender a realidade posta mediante o funcionamento da imaginação e do pensamento. Esses se constituíram como processos subjetivos e, por isso, fontes para a produção de conhecimento novo, que envolvia a constituição de novas experiências capazes de desdobramentos em novas visões de mundo. Nos momentos de leitura de livros em sala de aula, ele fixava os olhos no livro e demonstrava encantamento com as imagens e com o que lia. Os trechos abaixo subsidiam nossas elaborações: 
Oficina de leitura e escrita

Gabriel: Eu fiquei lendo e imaginando cada coisa que ia acontecendo no livro. Aqui tem um gato igualzinho o que eu desenho lá em casa. Tem uma palavra aqui diferente, e aí eu fico imaginando o que pode ser. Eu olho o desenho e também a outra palavra e aí eu vou sabendo o que pode ser. Só tem jeito de ler se a gente imaginar. Eu imagino um tanto de coisa pra escrever e às vezes eu nem sei se existe. Entrevista I

Gabriel: Eu olho meus desenho do ano passado e fico pensando que eu não tinha imaginação não, os desenho ficava rabiscado, tinha linha pra fora. Acho que ano que vem eu vou ver meus desenho de agora e vou achar a mesma coisa, mas quando eu faço eu imagino tudo na hora (risos).

As leituras que Gabriel realizava em sala de aula eram formas de se transportar para um mundo de possibilidades de novos acontecimentos no âmbito da imaginação e do pensamento, em que sentia segurança de conscientemente atuar num mundo de faz de conta. Podemos exemplificar tal construção a partir da sua leitura do livro "Matar sapo dá azar"77" no momento da Oficina de leitura e escrita, em que Gabriel emitia diferentes comentários que além de modificar o enredo da história e seus personagens eram dinamizadores de novas buscas por outras aprendizagens:

\section{Oficina de leitura e escrita}

Gabriel: Eu quero saber mais de fazenda. Eu ia até colocar um cachorro lá. Eu fiquei pensando que a mulher não vai mais matar sapo e que a história podia terminar com todo mundo vivendo na natureza. Eu sei que isso só existe aqui na minha cabeça, mais é legal pensar que pode mudar a história.

Gabriel imergia em suas ações de ler e escrever e se distanciava da vida cotidiana, mesmo que partia de situações concretas de suas experiências, criando histórias que se concretizavam em sua escrita ou também em seus desenhos. Em vários momentos da pesquisa, observamos que as histórias de Gabriel continham possibilidades de transcender a realidade por ele experienciada, o que pode ser exemplificado a partir do excerto abaixo:

\section{Diário de ideias}

Gabriel: Nessa história aí eu contei que eu estava na praça e andando de bicicleta, mas no dia eu fui lá num lugar que não era praça e também eu nem tinha bicicleta. Mais assim ficou mais bonita a minha história.

Oficina de leitura e escrita

Gabriel: Eu vou fazer uma história que eu vou ser um menino que viaja muito de avião e conhece o mundo inteiro. Eu nunca viajei de avião.

Nas ações de ler e escrever de Gabriel, existiam características do lúdico que Brougère (1998b) destaca como essenciais, as quais se referem às possibilidades de inversão de papéis, de experienciar situações inéditas e a forma como estas ações não têm o objetivo de modificar a realidade em si.

As características identificadas nas ações de Gabriel se organizaram em confluência umas com as outras, com vínculo com as estratégias de aprendizagem, e se fizeram presentes

\footnotetext{
${ }^{47}$ GUEDES, Hardy. Matar sapo dá azar. Curitiba: Terra Sul, 2011.
} 
pelo funcionamento da imaginação e do pensamento como forças motrizes deste processo singular. O quadro a seguir consiste em uma síntese ilustrativa da relação entre as características da aprendizagem criativa da leitura e da escrita e as estratégias de aprendizagem de Gabriel.

Quadro 7 - Relações entre a expressão da criatividade na aprendizagem da leitura e da escrita e estratégias de aprendizagem de Gabriel

\begin{tabular}{|c|c|}
\hline $\begin{array}{c}\text { Características da criatividade na aprendizagem } \\
\text { da leitura e da escrita } \\
\end{array}$ & Estrateglas de \\
\hline $\begin{array}{l}\text { Personalização da informação: } \\
\text { - personalizava seu próprio processo de ler e } \\
\text { escrever, vinculado à relação com as atividades } \\
\text { propostas; } \\
\text { - personalização dos conteúdos. }\end{array}$ & $\begin{array}{l}\text { Estratégias de autorregulação: } \\
\text { - deliberação de atenção e concentração nas ações de } \\
\text { ler e escrever; } \\
\text { - faz planejamento para realizar as atividades de leitura } \\
\text { e escrita; } \\
\text { - busca pelo significado das palavras; } \\
\text { - utiliza o aprendido em situações cotidianas. }\end{array}$ \\
\hline $\begin{array}{l}\text { - confrontação com suas próprias produções; } \\
\text { - confrontação com as ideias dos colegas. }\end{array}$ & $\begin{array}{l}\text { Estratégias de autorregulação: } \\
\text { - faz reflexão sobre a própria escrita; } \\
\text { - faz revisão autônoma de sua própria produção; } \\
\text { - busca de forma autônoma respostas para suas próprias } \\
\text { dúvidas; } \\
\text { - realiza inferências sobre o lido; } \\
\text { - prática de contar ao outro o que aprendeu em busca } \\
\text { de novas ideias. } \\
\text { Estratégias de cognitivas: } \\
\text { - estabelece relações entre sons e letras; } \\
\text { - estabelece relações da escrita com a própria forma } \\
\text { visual da letra; } \\
\text { - faz relações entre a forma como culturalmente falava } \\
\text { e à escrita das palavras. }\end{array}$ \\
\hline $\begin{array}{l}\text { Produção, geração de ideias próprias e novas que } \\
\text { transcendem o dado: } \\
\text { - produzir e gerar ideias próprias e novas que } \\
\text { transcendiam sua própria ideia; } \\
\text { - produção de ideias próprias e novas que vão além } \\
\text { do dado na relação com as atividades propostas; } \\
\text { - produção de ideias próprias e novas que vão além } \\
\text { do dado na dinâmica entre desenhar, ler e escrever. }\end{array}$ & $\begin{array}{l}\text { - prática de contar ao outro o que aprendeu em busca } \\
\text { de novas ideias; } \\
\text { - buscar conhecer profundamente a atividade a ser } \\
\text { realizada e para além dela. }\end{array}$ \\
\hline $\begin{array}{l}\text { Relação lúdica: } \\
\text { - relação completa, voluntária, próxima, instantânea } \\
\text { e investigativa; } \\
\text { - se colocava desafios constantes a serem superados } \\
\text { durante as ações de ler e escrever; } \\
\text { - criação das próprias regras; } \\
\text { - na criação de um cenário imaginário. }\end{array}$ & \begin{tabular}{l}
\multicolumn{3}{c}{ Estratégias de autorregulação: } \\
- realiza as atividades propostas associadas à \\
ludicidade; \\
- procura de formas diferenciadas para realizar as \\
atividades propostas em busca de desafio; \\
- cuida da estética de sua própria escrita.
\end{tabular} \\
\hline
\end{tabular}

Fonte: elaborado pela autora, 2015.

No próximo tópico, apresentamos nossas elaborações sobre a configuração subjetiva da ação de aprender criativamente de Gabriel. 


\subsubsection{A configuração subjetiva da ação de aprender criativamente a ler e a escrever de}

\section{Gabriel}

Na construção da configuração subjetiva da ação de aprender criativamente a ler e a escrever de Gabriel, foi possível desenvolver três núcleos de sentidos subjetivos que constituíram a organização subjetiva de seu processo de aprendizagem criativa.

4.3.3.1 Núcleo de sentidos subjetivos associados à relação com a mãe: o cuidado com o outro

Pelo processo construtivo-interpretativo, compreendemos que se configurava em Gabriel um núcleo de sentidos subjetivos associados à relação com a mãe, que participava de forma particular de sua aprendizagem da leitura e da escrita. A presença da mãe foi marcante em vários instrumentos da pesquisa e se apresentou na espontaneidade e alegria com que Gabriel se referia à mãe. Ele vinculava a sua aprendizagem da leitura e da escrita a elementos desta relação, o que pode ser exemplificado pela expressão de Gabriel ao instrumento "Mapa do tesouro": "Minha mãe me ajuda nas tarefas, ela que me ensinou um tanto de letra."

Interpretamos que a relação de Gabriel com a mãe mobilizava seu empenho no campo da leitura e da escrita, uma vez que ela procurava instigar a curiosidade do filho em casa, pela abertura a perguntas sobre temas diversos. Para exemplificar nossa construção, transcrevemos uma das falas da mãe:

\footnotetext{
Dinâmica conversacional I

Mãe: $O$ Gabriel pergunta sobre tudo. Por que tem pessoas brancas e negras? Por que eu sou desta cor? E outras perguntas interessantes sobre o espaço. Ele queria saber se existia só um Sol e se era só esse que faz a pele da gente queimar. E eu falei pra ele que era só um mesmo. Um dia ele assistindo uma reportagem, aí ele falou assim pra mim: 'Um dia você falou pra mim que tinha só um Sol. É mentira. Tem muito sol, as estrelas são Sol.' Ai eu fiquei pensando assim, muitas perguntas interessantes mesmo, ele conversa assim comigo e eu ficava assim impressionada.
}

O excerto acima expressa o caráter investigador de Gabriel e o seu interesse por temas diversos. Pressupomos que havia abertura da mãe em relação aos questionamentos do filho, assim como ao diálogo sobre suas curiosidades. Era um processo que, para Gabriel, parecia se estabelecer pela confiança mútua e favorecedora de produções subjetivas historicamente constituídas associadas à relação com a mãe como companheira no caminho de suas descobertas. Gabriel confrontava-se com os próprios conhecimentos da mãe com o intuito de encontrar respostas para suas dúvidas, em um processo investigativo sobre o mundo ao seu redor. As informações a seguir constituem exemplos que subsidiam nossas elaborações: 
Diário de ideias (Anexo G - Figura 17)

Gabriel: Um dia minha mãe falou que o leão vivia só na floresta e aí eu fui ver se tinha no parque, e também tem em tanto lugar. Eu vou fala pra ela, ela fica feliz quando eu ensino pra ela. A gente anda toda hora junto e aí eu falo que se juntar uma letra e a outra faz JA, JO, JU e lê palavra.

Dinâmica conversacional I

Mãe: O Gabriel gosta de conversar com pessoas inteligentes que responde o que ele quer saber. Eu tenho um cunhado que faz faculdade e que o Gabriel adora falar com ele, porque ele responde na altura que ele quer saber. Igual, quando eu estou respondendo pra ele, às vezes ele me ignora. Ele sabe que eu vou dar a resposta errada. Eu fico até chateada com isso, por não poder corresponder a pergunta dele, na altura que ele quer saber. $O$ interesse dele é grande.

Os trechos acima expressam uma questão importante para nosso modelo teórico em andamento, que se refere à disponibilidade de tempo que a mãe tinha para se relacionar com o filho, o que gerava em Gabriel estados emocionais de se sentir confortável e tranquilo para recorrer à mãe para diálogos que envolviam suas curiosidades. Os confrontos existentes entre os dois parecia estar relacionado ao reconhecimento de sua mãe do amplo interesse do filho por temas diversos e pelo sentimento de incapacidade de não conseguir responder a algumas perguntas. Isso decorria, segundo a mãe, por ela ter cursado até o sétimo ano do ensino fundamental, o que apareceu em muitas informações da pesquisa, em que ressaltava o pouco conhecimento para auxiliar o filho. A preocupação da mãe relacionava-se às perguntas do filho sobre temas diversos, pois, para ele, a mãe era uma fonte importante de aprendizagem. Construção que pode ser ilustrada por uma das falas de Gabriel: "Minha mãe sabe muita coisa. Eu pergunto pra ela sobre o esgoto e ela falo do DMAE pra mim." (Diário de ideias).

Interpretamos que a confiança e a abertura para fazer perguntas à mãe dinamizavam produções subjetivas historicamente constituídas associadas à curiosidade por temas diversos e se configuravam na sua relação com a aprendizagem, pela forma investigativa, envolvida e questionadora com que Gabriel se relacionava com o seu aprender. Esses recursos subjetivos são dinamizadores da relação lúdica e de outras características da aprendizagem criativa, como a confrontação com o dado, elementos fundamentais para que a criatividade emergisse na aprendizagem da leitura e da escrita. Outras informações favoreceram novas elaborações:

Diário de ideias

Gabriel: Minha mãe vai no meu quarto e a gente conversa sobre tudo. Meu irmão nem pergunta. Mas eu quero saber umas coisas que não tem aqui com a tia. Aí eu falo com a minha mãe e ela me ajuda. Até quando ela está fazendo comida eu vou lá e pergunto sobre como é que faz a carne no supermercado.

Do nosso ponto de vista, a relação com a mãe contribuía para a constituição de importantes recursos subjetivos como a autodeterminação e a audácia, uma vez que ele mantinha uma busca intencional por novas aprendizagens. Ocorriam produções subjetivas 
associadas historicamente constituídas, relacionadas à aprendizagem como processo de conhecer e questionar o mundo, que reverberavam para a forma como Gabriel confrontavase com o dado, com suas próprias produções e com as ideias do outro, como característica da criatividade na aprendizagem, constituidoras de aspectos fundamentais para 0 desenvolvimento da condição de sujeito da aprendizagem. Outras informações podem ilustrar e nos possibilitar novas elaborações:

Dinâmica conversacional I
Mãe: O Gabriel pergunta muito. A gente vai de ônibus e ele fica perguntando sobre
tudo. Ele quer saber quanto tempo leva pra chegar em São Paulo, qual a
velocidade, então ele faz perguntas assim que ele quer saber detalhes e eu falo pra
ele, nossa você vai ter que procurar um profissional pra te ajuda que eu não sei isso
não. Mas eu tento responder. Acho que ele vai aprender isso mais pra frente na
escola. Ele vê as coisas que tão escritas na parede e lê pra mim e sempre fala
alguma coisa.

Interpretamos que havia, em Gabriel, conflitos relacionados ao que aprendia na escola e o que era possível aprender mais, para além da instituição escolar. Foi na relação com a mãe que Gabriel se viu diante de novas possibilidades de aprendizagem e, neste processo, a leitura e a escrita esteve configurada por sentidos subjetivos historicamente constituídos, associados à relação do aprender com sua vida, com implicação real, de vínculo da leitura e da escrita com ações no mundo. Tudo se alinhava à personalização da informação como processo articulado ao modo de vida do aprendiz, frente à capacidade subjetiva para produzir alternativas ao seu modo vida. Dessas podemos citar as ações que Gabriel empreendia para cuidar do meio ambiente, como mudanças na forma de tomar banho, constituindo o processo de aprender como modelo intelectual-subjetivo, que configura a produção de conhecimento no âmbito da configuração subjetiva (GONZÁLEZ REY, 2014a).

Gabriel parecia manter uma relação próxima e afetiva com a mãe e com o pai, o que pressupomos lhe gerava autoconfiança em suas possibilidades e, mediante a aprendizagem da leitura e da escrita, ele não apenas realizava perguntas aos pais, mas assumia a função de poder ajudá-los no encontro com novos conhecimentos, para os quais Gabriel sabia que precisaria do apoio da leitura e da escrita para alcançá-los. Dentre outras informações, transcrevemos uma de suas falas para subsidiar nossas construções: "Se eu aprender a ler e a escrever eu vou poder descobrir sobre os planetas e sobre os países. Aí eu vou poder levar minha mãe pra viajar e ela vai adorar." (Diário de ideias). O interesse de Gabriel por temas que não estavam presentes na escola era algo constante em seus diálogos com a família e conosco e, se apresentava em vários de seus registros. Havia, em Gabriel, um forte vínculo com sua aprendizagem como possibilidade de realizar seus sonhos de viajar e conhecer outros 
países, constituindo produções subjetivas historicamente constituídas, associadas à aprendizagem aliada à visão de futuro, de poder viver novas experiências, o que reverberava para criação do cenário imaginário para aprender, no âmbito da relação lúdica, assim como para a forma como buscava integrar os conteúdos escolares.

A mãe acompanhava muito a aprendizagem do filho e sempre ia à escola espontaneamente para conversar com as professoras e saber como Gabriel estava se desenvolvendo. Ele gostava muito da presença de sua mãe na instituição e parecia estabelecer uma relação positiva com a escola pela possibilidade da participação da mãe. Dentre as várias informações que subsidiaram nossa construção, destacamos como exemplo, uma de suas falas em um momento que sua mãe foi à escola: "Minha mãe está aqui na escola. Oba! Ela vai falar com a tia Melissa." Havia, em Gabriel, sentidos subjetivos historicamente configurados associados à escola como vinculada à sua vida, que envolvia a atuação da mãe em sua aprendizagem, que, certamente, reverberava para a personalização dos conteúdos e dos seus processos de ler e escrever.

A abertura ao diálogo com a família era um elemento subjetivo que configurava a subjetividade social da escola e isso foi extremamente cuidado pelas professoras Melissa e Flávia. Ambas realizavam um trabalho de convidar os familiares para comparecer à escola não apenas em dias pré-estabelecidos, ou seja, em reuniões agendadas coletivamente, mas também recorriam aos horários de módulos, para agendar momentos individuais que também não se limitavam a diálogos sobre a aprendizagem de conteúdos, mas ao bem estar dos alunos. A mãe de Gabriel firmou esta parceria com a escola e, no primeiro ano do ensino fundamental, ela comparecia na escola quinzenalmente para saber sobre a aprendizagem do filho e o que ela poderia fazer para ajudá-lo ainda mais.

Entretanto, observamos que a mãe de Gabriel se distanciou um pouco da escola, durante o segundo semestre, enquanto cursava o primeiro ano e, juntamente, a este aspecto, identificamos algumas mudanças no comportamento de Gabriel em sala de aula. O aprendiz demonstrava estados emocionais de tristeza e apatia, se contrapondo a outros momentos em que, no contexto da sala de aula, estava sempre sorrindo e demonstrando disposição para aprender. Em momentos informais, Gabriel nos relatava que sua mãe não estava mais trabalhando, por estar muito doente, por conta de um tumor no pescoço e passou a ficar boa parte do seu tempo em casa. A mudança de Gabriel foi sentida pela professora Melissa, o que pode ser ilustrado, pelo trecho de nossa conversa: 


\begin{abstract}
Momento informal
Professora Melissa: Fico pensando, mеu Deus, o que eu posso fazer para ajudar o Gabriel. Mas também eu penso que preciso trazer a mãe dele para conversar, a vó, que representa um papel muito importante na vida de Gabriel. Está mais no mundinho dele. Às vezes eu fico pensando, vou trazer ele mais pra perto de mim, né? Mas aí depois eu pensei, mas aí eu estou muito sentimental, talvez esteja querendo até, assim, suprir esta questão da mãe, assim, esteja agindo assim, muito com a emoção. E talvez assim, no ano que vem eu não sei se a gente vai está junto, talvez isso não vai ser bom pra ele, né? Eu pensei por esse lado, que acontece muito. E ele vai sofrer mais. Aí eu vou conversar com a mãe primeiro, entender a situação pra poder agir.
\end{abstract}

A preocupação de Melissa estava relacionada à mudança de comportamento de Gabriel em sala de aula. Havia produções subjetivas novas em Gabriel, produzidas no âmbito familiar, que dinamizavam novas relações com sua aprendizagem e que poderiam estar relacionadas à subjetivação da doença da mãe. Isso mobilizou novas ações da professora Melissa que, após conversar com a mãe de Gabriel e, descobrir seu estado de saúde, optou por se aproximar mais de Gabriel, conferir a ele algumas tarefas na sala de aula, tais como a entrega de materiais para os colegas e a participação oral para expor suas respostas. Outras informações nos possibilitaram novas elaborações, dentre as quais destacamos:

\footnotetext{
Diário de ideias

Gabriel: A tia é amiga da gente. Eu faço um tanto de coisa pra ela. Ela até falou com a minha mãe sobre mim e minha mãe fica feliz. Sabia que ela sabe tudo que a minha mãe tem? Ela falou que é coisa que o médico vai cuida e ela vai fica boa. Eu quero agora saber mais, eu acho que vou ajudar ela. Momento informal

Gabriel: Eu estava sem fazer nada e a tia me pediu pra ajuda. Eu fui e dei os caderno pros menino. A tia até gosto da minha tarefa. Ela disse que está muito bonita a letra. No recreio ela até falo que era pra brinca com os menino. Eu brinquei. Foi legal.
}

As informações acima expressam o reconhecimento por Gabriel em ter o apoio da professora. Pressupomos que as ações da professora Melissa favoreceram em Gabriel, produções subjetivas atuais vinculadas ao sistema relacional associadas a tê-la como parceira em momentos distintos do cotidiano escolar e em assuntos para além dos conteúdos escolares, as quais foram geradoras de satisfação e de sentir-se acolhido frente a emoções diversas que estavam sendo produzidas em relação à mãe. Interpretamos que Gabriel subjetivou o espaço da doença como algo que precisava de seu apoio e isso lhe gerou ações em busca de novos conhecimentos sobre o tipo da doença e seu tratamento, mediante um engajamento como sujeito no empenho em encontrar nos diálogos com a professora, com a própria mãe, respostas para seus questionamentos. As informações a seguir podem subsidiar nossas elaborações: 
Trilha das frases

6 - ME DEIXA TRISTE - Minha mãe morrer.

31- CONSIDERO QUE POSSO - Tomar banho sem minha mãe pedir.

37 - LER É - Pra saber lê um bilhete, a mãe deixa um bilhete escrito: "Hoje eu vou viajar" ai você entra em casa e não sabe o que aconteceu com sua mãe, mas se você não ler não vai saber.

38 - O QUE EU MAIS QUERO - Tocar bateria e que a minha avó e minha mãe sara.

39 - SOFRO QUANDO - Quando eu machuco e vejo minha vó e minha mãe doente. Minha mãe está com um caroço no pescoço e não pode pegar peso e aí eu vou lá e ajudo ela. Eu até lavo vasilha.

40 - NO FUTURO - A minha mãe e minha avó sarar. Também eu quero nadar sozinho e aí não precisa da minha mãe ficar lá comigo.

Gabriel descobriu que sua mãe não poderia mais pegar peso e isso o mobilizou a ajudá-la nas atividades de casa. Do nosso ponto de vista, houve impactos subjetivos da doença na aprendizagem de Gabriel favorecedores de produções subjetivas historicamente constituídas associadas a ajudar a mãe na melhora de seu quadro e de garantir o seu bem estar, o que, de certa forma, configurou-se na dimensão funcional da criatividade, pela forma como Gabriel foi capaz de abrir caminhos de atuação próprios, geradores de novas produções subjetivas capazes de reconfigurar a organização subjetiva atual. Ver a avó e sua mãe doente mobilizava emoções diversas em Gabriel, expressas por estados emocionais de tristeza, angústia, pela forma como ficava mais calado e isolado em sala de aula.

No entanto, a busca em ajudar a mãe, na melhora da doença, pode estar constituída por recursos subjetivos de capacidade de superação e de reflexão, os quais foram essenciais para a expressão da criatividade na aprendizagem, principalmente no que se refere às características de personalização, confrontação como dado e geração de ideias que transcendem o que está posto. Para exemplificar, apresentamos a forma como Gabriel gostava de assistir jornais e, em um dia, ao ouvir uma notícia sobre amnésia dialogou com a mãe sobre o assunto, o que, segundo ela, estava associado ao interesse em ajudar a avó. Outro exemplo, que ilustra nossa elaboração, refere-se à expressão de Gabriel ao instrumento "Montando minha história" em que destacou três momentos que gostaria de sua vida, associados à perda e a machucados. Podemos ilustrar com uma de suas falas: "Eu vi ela no cachão. Ela tinha cabelo branquinho. Eu vou encontrar ela lá no céu." Compreendemos que havia produções subjetivas historicamente constituídas relacionadas ao espaço de perda e que se apresentaram de distintas formas em sua aprendizagem na escola, pela forma como cuidava de suas amizades, a necessidade de ajudar os colegas, o respeito em relação ao outro e às solicitações da professora.

As produções subjetivas de Gabriel, associadas à relação com o outro, podem estar relacionadas aos momentos de leitura com a mãe. Mesmo quando trabalhava, a mãe de 
Gabriel oportunizava momentos de leitura com o filho e estes eram experienciados a partir de estados emocionais de alegria, descontração e prazer. Neste processo, a mãe solicitava que Gabriel realizasse as leituras para ela e, em alguns momentos, ela o auxiliava. Outras informações podem ser importantes para novas elaborações, dentre as quais citamos:

\section{Diário de ideias}

Gabriel: Sabe esse desenho que eu fiz aqui, foi minha mãe que me ajudou. Ela pediu pra ler aquele livro de Noé lá, e eu li pra ela. Aí ela falou 'Gabriel, desenha aí esse barco e aí eu fiz. Quando ela lê pra mim eu até sonho com história.

Mesmo com a descoberta da doença, a mãe de Gabriel manteve a leitura para o filho, o que pressupomos foi extremamente relevante. Interpretamos que a mãe de Gabriel se desdobrava para proporcionar ao filho o que não teve oportunidade de experienciar. Tal construção pode ser exemplificada a partir de uma fala da mãe em Dinâmica conversacional I, na qual a mãe relatou que, quando tinha 8 anos de idade, ela teve as duas pernas totalmente queimadas e ficou hospitalizada por 3 meses e meio, sem poder ter contato com outras pessoas e, principalmente, com a família. Ela ainda relatou que sentia muitas dores e que presenciou muitas mortes e não tinha ninguém para conversar e explicar para ela o que estava acontecendo. Por isso, ela só conseguiu aprender a ler e a escrever com 10 anos de idade e sofreu muito preconceito na escola e, hoje, ela usa apenas calça, pois ainda tem vergonha das pernas. Para ela, Gabriel precisava experienciar a infância em plenitude, construção que pode ser exemplificada por uma de suas falas: "Quero que o Gabriel seja a criança que eu não pude ser."

Neste contexto, de vínculo com a mãe, a leitura foi significada por Gabriel pela forma carinhosa com que ela o acolhia e o incentivava a ler sempre mais. Mesmo com poucas condições financeiras, sua mãe comprava livros de literatura infantil para Gabriel e o incentivava a ler. As informações abaixo, dentre outras da pesquisa, permitem alinhavar novas elaborações:

\footnotetext{
Diário de ideias

Gabriel: A minha mãe leu aquele livro do Noé pra mim. Tem tantos animais que vão viajar. Aí ela senta lá minha cama e lê o livro. Tem vez que ela fala assim, Gabriel o que que está escrito aqui? Aí eu leio e ela fala, muito bem. Teve um dia que ela contou a história de um macaco e eu sonhei (risos) que o macaco morava lá na minha casa. Tem até palavra que ela não sabe e eu ensino. Igual CROCODILO. Brincando de escolinha

Gabriel: Gente, senta com o colega pra lê o livro junto. Pode ajudar o colega.
}

Gabriel assumia um lugar de que sabia muito e que podia ensinar algo para sua mãe. Do nosso ponto de vista, havia produções de sentidos subjetivos historicamente constituídos relacionados à leitura como possibilidade de estar com o outro e ajudar, o que se apresentou, de certa forma, na maneira como Gabriel se empenhava em ajudar os 
colegas em situações de leitura e escrita. Interpretamos que o cuidado com o outro era uma produção subjetiva que passava pela relação dialógica com a mãe. Tal relação autêntica configurou a relevância dos processos de comunicação como força motriz na configuração da subjetividade individual de Gabriel. Esta reverberou para as ações dele em outros contextos, como a escola, uma vez que, interpretamos que a relação com a mãe pode ter sido favorecedora da sensibilidade de Gabriel aos problemas dos colegas, mediante o desenvolvimento de valores morais destinados ao apoio ao outro. As informações abaixo podem ilustrar nossas elaborações:

Brincando de escolinha

Gabriel: Eu vi que a Carolina precisava de ajuda. Ela estava tentando escrever PIRULITO e aí ela olhava pro lado e chamava a tia. Só que a tia estava lá nos menino e não ouviu. Eu fui lá e falei as letra pra ela.

Em vários momentos de nossas observações em sala de aula, identificamos o quanto Gabriel demonstrava estados emocionais de alegria, satisfação e euforia por ser solicitado a ajudar alguém. Presenciamos um momento em que o colega Flávio lhe pediu ajuda para a escrita de uma frase e nos chamou a atenção a forma solícita com que Gabriel deixou de fazer sua própria atividade para ajudar o colega. Gabriel não fazia a atividade para o colega, ele perguntava o que ele queria escrever, falava as letras e observava a escrita do colega. Gabriel lia a palavra que Flávio escreveu e dizia: "Eu falei que era com I? Não é não, é com E. Você viu que está errado? Vou falar de novo e aí você escreve."

Gabriel dialogava com os colegas e respeitava o saber do outro. Havia produções subjetivas atuais de relação com os colegas associadas ao desejo de ver o outro aprendendo e de aprender na relação com o outro. Como podemos ilustrar por uma das falas de Gabriel: "Eu ajudo todo mundo da sala. Sabia que o Flávio aprendeu a fazer futebol? (risos). Aquele dia ele me falou que PORTA tem o R." (Diário de ideias). Esta forma comunicativa com o outro esbarrava no conflito de Gabriel com elementos que configuravam a subjetividade social da sala de aula, uma vez que se exigia silêncio e a atenção voltada totalmente para a professora. Foram poucos os momentos, nos dois anos da pesquisa, em que se favorecia a interação entre os alunos, o que pressupomos estar associado à visão de a aprendizagem está diretamente relacionada ao saber da professora. Gabriel subjetivava de forma singular este processo, em que informações formaram parte de nossas elaborações, dentre as quais citamos uma de suas falas ao instrumento "Montando minha história" (Anexo H - Figura 18): “A tia estava gritando com o menino. Olha o tamanho da boca dela. Ela nunca gritou comigo. Tem que prestar atenção na tia. Ela que ensina. Tem que fazer tudo que ela pede. Eu também ajudo os colega. Minha mãe fala que todo mundo sabe um pouco." 
Do nosso ponto de vista, Gabriel produzia sentidos subjetivos associados à subjetividade social da sala de aula vinculados à sala de aula como espaço-tempo de aprendizagem relacionada à necessidade de silêncio e de reconhecimento da professora como autoridade que ensina. Em sala de aula, observamos que Gabriel demonstrava estados emocionais de insegurança e receio que configuravam a sua excessiva preocupação em corresponder às solicitações da professora, mesmo que mantinha com ela uma relação baseada no respeito e diálogo. Tais estados emocionais podem estar relacionados por observá-la chamando a atenção dos colegas. Gabriel compreendia a necessidade de atitudes mais enfáticas das professoras com os colegas e experienciava esta relação de forma conflituosa, uma vez que, ao mesmo tempo em que reconhecia a relevância destas atitudes, ele criava formas de se sentir seguro, respeitando as solicitações da professora.

No confronto com elementos da subjetividade social da aula, que se referiam ao cumprimento das exigências das professoras, Gabriel atuava como sujeito de sua aprendizagem, em que a criatividade se expressava em sua dimensão funcional pela capacidade de se relacionar com o outro para aprender, com ênfase ao diálogo, ao encontrar caminhos próprios de mudança na condição de ensinar o colega e privá-lo de ser punido pela professora. Neste processo, Gabriel se colocava como alguém que respeitava o outro e não ocupava o lugar de que sabia mais. Havia produções subjetivas atuais vinculadas à relação com o outro associadas à troca de saberes e cuidado com o outro, que reverberavam para ações de ajudar os colegas em sala de aula, o que, às vezes, implicava abrir mão de suas próprias atividades para auxiliar o outro, representando momento de expressão da criatividade em sua dimensão funcional. Para ele, não havia nenhum colega da turma que não fosse seu amigo e ele ajudava a todos indistintamente.

Trilha das frases

8 - AJUDO - Minha mãe e meu pai. Eu ajudo os colegas na sala.

14 - MEUS COLEGAS - Ajudo eles. Eu tenho muitos colegas. Na sala de aula, tem um punhado de gente, todo mundo.

Brincando de escolinha

Gabriel: Se você quiser pode ajudar a Adriana. E se alguém precisar de ajuda pra escrever BOLA pode falar.

Pelas informações acima, unida a outras da pesquisa, interpretamos que a relação de ajuda com o outro, constituiu uma forma de estar e se comunicar com o outro como processo de aprender, gerador de sua autoconfiança como aprendiz. Mesmo em conflito com elementos da subjetividade social da sala de aula, Gabriel conferia valor ao papel de ensinar da professora Melissa e a ela atribuía a responsabilidade de proporcionar caminhos diferenciados para a aprendizagem da leitura e da escrita. A relação de Gabriel com a professora Melissa 
passava pela relação dela com os seus colegas. Foram poucos os momentos em que ele citava experiências em que conversava com a professora, sempre se referindo à forma como ela tratava os outros, no entanto, ele demonstrava estabelecer com ela uma relação afetiva, conforme se pode ilustrar pelo excerto abaixo:

\section{Trilha das frases}

22 - MINHA PROFESSORA - Ensina muito bem, eu gosto dela.

Mapa do tesouro

Gabriel: A tia Melissa que me ensino o alfabeto. Ela ia falando as letra e eu ficava olhando. Tem que te silêncio e prestar atenção na tia. Não pode ficar conversando se não, não respeita a tia. Os menino que conversa lá sala nem aprendi e a tia tem que ficar gritando.

Do nosso ponto de vista, Gabriel reconhecia a importância das regras e normas da sala de aula como algo necessário para a sua aprendizagem e isso favorecia que suas ações fossem direcionadas ao cumprimento de tais exigências. No entanto, Gabriel se confrontava com outros elementos da subjetividade social da sala de aula, que se referiam à maneira como as professoras corrigiam a sua escrita, uma vez que frisavam apenas o produto final. Em vários momentos da pesquisa, Gabriel relatava:

\section{Diário de ideias}

Gabriel: A tia não sabia o que que eu estava falando aqui. Ela leu que eи e meu irmão estava jogando bola e aí ela corrigiu. Que eu escrevi IMÃO.

Brincando de escolinha

Gabriel: Deixa eu te explicar que que eu escrevi aqui. Era um leão que não gostava de fazenda. Aí ele teve que morar lá e depois ele conheceu muito amigos.

A informação acima, unida a outras da pesquisa, convergem com nossas construções anteriores de que a forma de correção da professora tinha um significado para Gabriel. Processo em que havia produções subjetivas relacionadas à subjetividade social da sala de aula associadas à necessidade de diálogo sobre o processo de composição de sua escrita, o que, certamente, estavam vinculadas à geração de ideias próprias e novas que transcendiam sua própria ideia, no diálogo com o outro. Gabriel não se limitava a escrever para cumprir uma função e nem se quer desejava que sua escrita expressasse de forma completa as suas ideias. Ele necessitava complementar sua escrita pelo diálogo.

No entanto, a ação de sujeito da aprendizagem possibilitou que Gabriel experienciasse esse processo com os colegas da turma, atribuindo significado à escrita como processo de comunicação. Em concordância com Geraldi (1997), compreendemos que a função do professor, na leitura dos textos dos alunos, se organiza como sendo interlocutor, na medida em que pode favorecer o diálogo sobre o conteúdo elaborado pelo aprendiz ao realizar perguntas sobre o texto. Isso deve ocorrer em um processo em que, na leitura, haja envolvimento do leitor que, neste caso, está representado pelo professor. 
Frente ao exposto, o núcleo de sentidos subjetivos associados à relação com a mãe nos permitiu configurar a dinamicidade e a processualidade com que os sentidos subjetivos se produzem em diferentes contextos da vida do sujeito e se expressaram de forma distinta no contexto de aprendizagem da leitura e da escrita. Havia sentidos subjetivos associados: a) ao desejo de novas descobertas e aos questionamentos sobre temas diversos; b) à valorização da mãe e ser ela sua parceira na aprendizagem; c) a ajudar a mãe na melhora de sua doença e de garantir o seu bem estar; d) ao desejo de ver o outro aprendendo e de aprender na relação com o outro; e) à parceria na relação com a professora; e f) à escola vinculada à vida.

\subsubsection{Núcleo de sentidos subjetivos relacionados à relação com o desenho: o vínculo com o} pai

A forma como a ação de desenhar fazia parte da vida de Gabriel foi algo que observamos e também se expressou em diversos instrumentos da pesquisa. Conhecemos Gabriel, em um momento de aula, em que ele fazia um desenho de uma árvore e desde este momento, observamos a riqueza de detalhes de seus registros e a espontaneidade e concentração com que ele se colocava a desenhar. A relação com o desenho parecia estar associada ao vínculo afetivo com o pai, construção que pode ser exemplificada a partir das informações a seguir:

\section{Montando minha história}

Gabriel: Todo mundo gosta dos meus desenho. Meu pai que me ensinou a fazer prédios, ele é um artista. Eu aprendi a desenhar sozinho.

Diário de ideias

Gabriel: Meu pai que fez esse leão. Eu já faço sozinho também. Quando eu faço um desenho e meu pai vê, ele já fala 'Está faltando alguma coisa' aí eu já sei o que é. Brincando de escolinha

Gabriel: Meu pai fala que tem que desenhar bem de leve e que não pode ficar tudo reto. Se precisa eu apago e faço de novo. Ele é um desenhista igual eu.

Gabriel reconhecia o pai como um artista no campo do desenho, gestando uma admiração que fortalecia o seu vínculo e empenho em desenhar cada vez mais e se superar em suas produções, mediante produções subjetivas historicamente constituídas vinculadas ao desejo ser reconhecido pelo pai, o que favorecia ações de engajamento neste campo. Neste processo, percebemos em muitos momentos da pesquisa que, ao falar sobre os seus desenhos, Gabriel expressava-se com euforia e sua fala era enriquecida com detalhes de suas produções. Outras informações podem subsidiar nossas elaborações e abrir novas construções:

\section{Diário de ideias}

Gabriel: Eu escrevo igual desenho. É só deixa a mão desenhar as letra. Tem que prestar atenção e ai é só a imaginação fala pra gente.

Brincando de escolinha

Gabriel: É só apagar quando precisar fazer a letra mais bonita. Quando eu desenho eu apago e faço de novo. O nariz do leão não ficou bom e aí eu fiz de novo. 
Interpretamos que havia inter-relação entre a ação de desenhar e as ações de ler e escrever, em que recursos subjetivos se expressavam nas diferentes formas de expressão de Gabriel, dentre os quais citamos: autonomia, concentração, euforia e também atitude investigativa, sendo os mesmos essenciais para que a criatividade emergisse na aprendizagem da leitura e da escrita, pela utilização de diferentes tipos de estratégias de aprendizagem. As informações abaixo, dentre outras, ilustram nossas elaborações:

Montando minha história

Gabriel: Eu escrevo todo dia e desenho também. Aí eu escrevo as letras e fico fazendo cada uma bem devagar. Quando eu desenho sozinho eu pego o lápis assim, não pode ser forte. Tem desenho que eu copio do livro e aquele eu fiz sozinho. Meu pai fala que tem que olha até o risquinho de fora do desenho, aí eu faço bem devagar.

Aprender com o pai lhe favoreceu o desenvolvimento de recursos subjetivos fundamentais para a sua aprendizagem, associados à observação atenta aos detalhes e também às possibilidades de criação própria, os quais foram extremamente relevantes para a relação de Gabriel com o designer das letras do alfabeto. Nesta relação com o pai, Gabriel desenvolveu valores morais que envolvia o respeito à forma de registro de cada um, a necessidade de valorizar cada pessoa nas suas possibilidades. Tais valores se expressaram em atitudes de Gabriel nos momentos em que era chamado pelos colegas para apreciar suas produções e também era solicitado a fazer desenhos para os próprios colegas. Foram vários os momentos em que Gabriel ajudava colegas a desenhar, momento em que ensinava e não simplesmente fazia o desenho para o colega.

Para subsidiar nossas elaborações, transcrevemos uma de suas falas: "Todo mundo gosta do meu desenho e da história que eu faço do desenho. Agora eu estou desenhando pra tanta gente. A tia fala que ficou tudo lindo e até pediu pra eu fazer um pra ela." (Diário de ideias). Se sentir útil e querido pelos colegas, e valorizado pelas professoras, pode ter gerado em Gabriel produções subjetivas atuais vinculadas à necessidade de ser reconhecido pelo outro, associadas à forma como Gabriel demonstrava estados emocionais de entusiasmos e alegria, ao ter seu desenho valorizado pelas professoras. Para Gabriel, a ação de desenhar ocupava uma importante função em sua vida, tal como podemos exemplificar:

Trilha das frases

28 - DEDICO MEU MAIOR TEMPO - Eu desenho.

36 - ESCREVER É - Mesma coisa que eu estar brincando. Por causa que eu gosto de fazer a letra bem devagarzinho para eu fazer bem bonito. Eu brinco de desenhar as letras. Eu escrevo o que eu gosto de pensar.

46 - PENSO MUITO EM - Um tantão de coisa e desenhar.

49 - O QUE EU FAÇO MELHOR É - Desenhar e escrever. 
A inter-relação entre as ações de desenhar, ler e escrever, foi possível mediante a produção de sentidos subjetivos na relação com o pai, pela confiança que lhe depositava e os ensinamentos, bem como por novas produções subjetivas produzidas na ação de aprender. Estas estiveram relacionadas à forma como as produções de Gabriel, vinculadas à expressão da criatividade da aprendizagem, como a articulação de seus desenhos com a escrita foram capazes de mobilizar mudanças na dinâmica da subjetividade social da sala de aula.

A professora Melissa, do primeiro ano, reconhecia o gosto de Gabriel pelos desenhos e se encantava com suas produções, ao passo que, passou a inserir nas atividades de escrita, espaços para o desenho. Como ela expressou em uma de nossas conversas informais: "Eu sei que o Gabriel gosta de desenhar e escrever histórias dos desenhos. Os meninos ficam doidinhos pra aprender a desenha com ele. Eu faço atividades que eles podem desenhar e isso ajuda os outros aprenderem. Os desenhos do Gabriel são tão reais, ele parece um desenhista profissional mesmo." Pressupomos que houve um impacto da expressão da criatividade de Gabriel, tendo em vista seus desenhos vinculados à escrita, e elementos da subjetividade social da sala de aula, uma vez que passou a se configurar como um tipo de atividade proposta tanto pelas professoras, como espontaneamente realizada pelos colegas. Foi um processo favorecedor da valorização dos desenhos e histórias de Gabriel.

Neste viés, adquire relevância o contexto da ação de Gabriel, no qual eram conferidas oportunidades de registros pictóricos relacionados à escrita. Essas oportunidades favoreciam que Gabriel conferisse à escrita uma possibilidade de traçar letras e formar novos contornos. Não obstante, ele se lançava à aprendizagem da letra cursiva como um processo de brincar de desenhar. Havia assim, sentidos subjetivos historicamente configurados, na relação com os desenhos, associados à liberdade para expressar suas ideias, que se vinculavam às produções de sentidos subjetivos atuais associados ao desejo de uma escrita própria e com traços que tivessem caráter inédito. Dentre outras, as informações abaixo podem ilustrar nossas elaborações:

\footnotetext{
Diário de ideias

Gabriel: Essa letra D eu já fiz de tanto jeito. Agora está até parecendo um desenho (risos). Olha que tanta volta eu dei nela. Eu nunca vi uma letra assim não. Meu pai nem sabe que eu desenho letra também. Vou contar pra ele. Até minha mãe vai querer aprender. Gente! Eu posso fazer do jeito que eu quiser as letra.
}

Foram vários os momentos em que Gabriel nos mostrava seus desenhos representando o animal leão, em que enfatizava as mudanças realizadas em cada nova produção. Esta forma de se relacionar com o desenho também se apresentou em sua singularidade na forma como escrevia, o que se expressou, dentre outros momentos, na Entrevista I sobre seus próprios 
registros em que ressaltava mudanças de sua letra ao longo do primeiro ano. Nesta relação com seus desenhos, pressupomos que Gabriel constituía uma autoimagem positiva de si mesmo no campo da aprendizagem da leitura e da escrita, tal como podemos exemplificar, dentre outras, pelas informações a seguir:

Trilha das frases

1 - EU SOU - Artista. Alegre.

45 - EU SEI QUE SOU - Inteligente e sou um artista.

Montando minha história

Gabriel: Eu sou alegre e gosto de muita coisa [...] eu gosto de escrever do meu jeito [...] eu gosto de inventar coisas e gosto de desenhar e fazer amizades.

Diário de ideias

Gabriel: Eu pareço mesmo um desenhista. Desenho de tudo até as letras. Meu pai é inventor mesmo. Ele me ensina e eu faço em um tantão de lugar.

Do nosso ponto de vista, a autoimagem positiva de si mesmo, no campo da aprendizagem, envolvia sentidos subjetivos historicamente configurados relacionados à ação de desenhar e ao desejo de inventar associados ao sistema relacional com o pai de confiança, dinamizadores da geração de ideias próprias e novas que transcendiam o dado, como característica da criatividade em sua aprendizagem. Assim como no desenho, Gabriel inventava a sua própria escrita e isso favorecia uma aproximação com a leitura e a escrita, tal como ele se relacionava com o desenho. Os desenhos de Gabriel ganhavam novos contornos, geravam o desejo de escrever sobre o que havia produzido, de forma que ambos recursivamente organizavam a sua aprendizagem e constituíram recursos subjetivos fundamentais para que a criatividade emergisse na aprendizagem da leitura e da escrita.

Esta autoimagem positiva de si mesmo, no campo de sua aprendizagem, pode estar relacionada à própria valorização do pai e da mãe das habilidades do filho. A mãe de Gabriel afixava os desenhos do filho nas paredes do quarto dele e demonstrava apreço por tais produções. Ele reconhecia a valorização de sua mãe, o que pode ser ilustrado por uma de suas falas na Entrevista I: "Eu tenho um quarto cheio de desenho meu. Minha mãe deixa eu pregar tudo na parede." Tanto o vínculo com o pai e, a abertura da mãe às elaborações do filho, podem ter favorecido a autodeterminação de Gabriel na busca por se autodesafiar em suas produções.

Havia, em Gabriel, coragem para ousar em suas produções, demonstrada pela forma livre e espontânea na composição de seus registros pela atenção aos elementos que escolhia para registrar em seus desenhos e em suas histórias. Eram temas selecionados por ele e que participavam da própria relação com o pai, uma vez que Gabriel gostava de assistir telejornais e dialogar com o pai sobre as notícias. A relação com o pai nos momentos de assistir jornal com o filho assumia importância emocional para Gabriel, o que pode ser ilustrado por uma de 
suas falas: "Eu vi no jornal que está tendo muita dengue aqui. Eu já falei pro meu pai pra gente olha no quintal e tirar tudo que está com água." (Entrevista I). Neste movimento, Gabriel se expressou por meio de um desenho do mosquito transmissor da dengue e escreveu: "Vamos acabar com a água que está parada." (Diário de ideias). Identificamos que, em seus registros, existiam elementos que perpassavam diferentes conteúdos escolares, em uma visão mais ampla de organização de sua aprendizagem. Interpretamos que estes registros caracterizavam a forma como Gabriel se relacionava com seus pais, na liberdade de trocar informações diversas sobre temas de seu interesse, assim como pela forma como se imbuía em assistir aos jornais com o pai e dialogar sobre as reportagens.

Em sala de aula, os registros de Gabriel também ensejavam essa integração, que, no confronto com a subjetividade social da sala de aula, em que não havia tal unidade entre os conteúdos, trabalhados de forma fragmentada, Gabriel, em sua condição de sujeito subversivo e confrontador, criava alternativas de ações para experienciar uma aprendizagem mais integradora. E é nesse momento que a criatividade se expressava em sua dimensão funcional, favorecedora de novas produções subjetivas relacionadas à subjetividade social da sala de aula, associadas à integração dos conteúdos como necessária para sua aprendizagem. Integração que, de certa forma, pode estar vinculada à relação com o pai e os constantes diálogos das notícias do jornal. Outras informações formaram parte de nossas elaborações e se alinhavaram com novas construções:

Trilha das frases

20 - ASSISTO - Desenho e filme. TV Globinho e Jornal com meu pai.

Mapa do tesouro (Anexo H - Figura 19)

Gabriel: Eu tive um tanto de ajuda pra aprender. Meu tesouro é um tanto de letra e livro. Meu pai me ajudou e o jornal também.

Durante o registro de Gabriel no instrumento "Mapa do tesouro", identificamos a expressão de alegria com que ele se referia à sua aprendizagem da leitura e da escrita como uma conquista que lhe demandou esforço, bem como reconhecia a importância de outras pessoas e contextos para sua aprendizagem. Para Gabriel, aprender era realmente algo mais amplo que não se limitava ao que a escola ensinava construção que pode ser exemplificada, dentre as várias informações da pesquisa, pela qualidade da expressão de Gabriel ao referido instrumento, indicada pela sua alegria e espontaneidade em dizer: "Eu aprendi com tanta gente. Pra saber lê eu tive que passar por muita coisa. Teve vez que eu ajudava a Lúcia e ela me ajudava. Também tinha as letras do alfabeto que eu ficava desenhando. Eu via jornal com meu pai e aí eu sabia um tanto de coisa." 
Do nosso ponto de vista, havia sentidos subjetivos atuais associados à aprendizagem como processo relacional. Gabriel significava o desenho e a escrita como formas de registrar suas ideias e como oportunidade de reelaborá-las em um processo que envolvia diálogos com o outro. Tal construção pode ser exemplificada pela forma como ele se colocava a escrever como um processo investigativo que lhe proporcionava novos questionamentos e novas ações, como pode ser ilustrado, dentre outras, pelas seguintes falas de Gabriel: “Quando escrevi aí da dengue e tinha esse desenho aí do pneu eu já tinha falado com meu pai sobre isso e aí eu fui lá no quintal e olhei se tinha água na garrafa lá." (Diário de ideias). "Toda vez que eu leio aí eu falo pro Flávio o que que é que eu aprendi. Depois eu escrevo um texto e conto pra todo mundo minha ideia." (Montando minha história).

Havia, em Gabriel, necessidade de se expressar por meio de diferentes linguagens, as quais se constituíam como espaço de realização pessoal diante das possibilidades de aprendizagem que engendravam. Tal elaboração pode ser exemplificada a partir de uma das falas de Gabriel: "A minha vida é escrever e desenhar. Eu faço isso todo dia. Até meus lápis já está tudo pequeno. Eu pedi pra minha mãe uma lapiseira e eu estou achando legal usar pra escrever e desenhar." (Diário de ideias). Interpretamos que ocorriam sentidos subjetivos constituídos historicamente associados à relação da aprendizagem com sua vida, com suas ações cotidianas, a ter em seus registros uma forma de brincar com suas ideias, que dinamizavam a relação completa e voluntária, característica da relação lúdica de sua aprendizagem. Na escola, Gabriel construiu uma relação íntima com a leitura e a escrita que possibilitava a expressão de seu interesse e sua garra para aprender sempre mais:

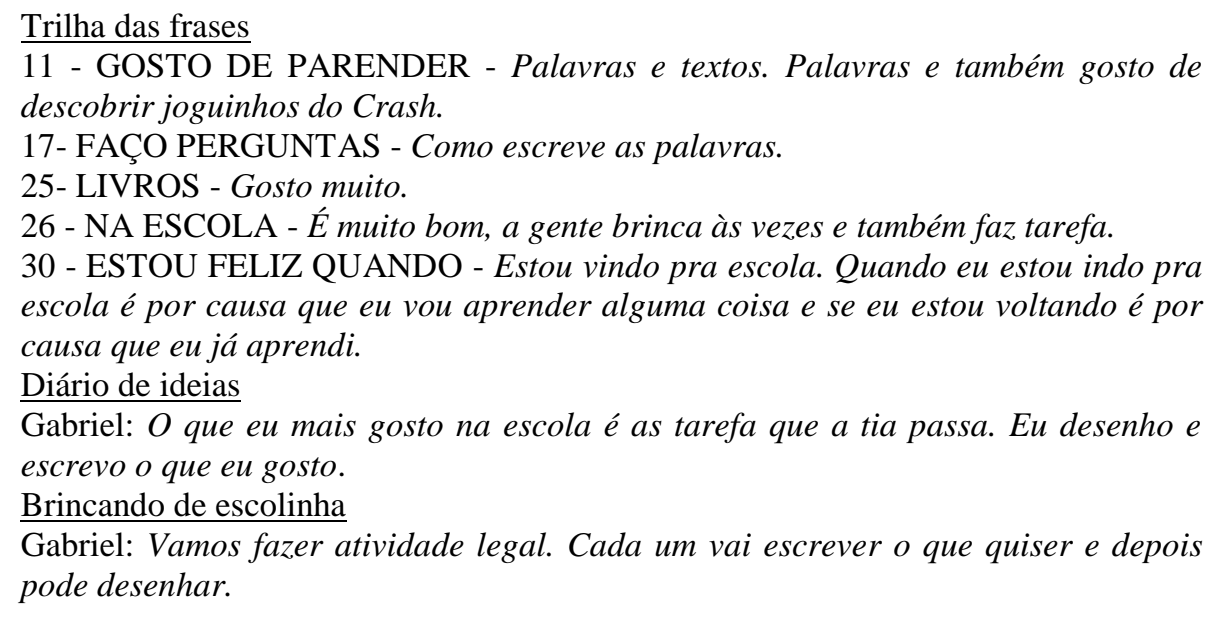

As falas acima expressam a relação positiva de Gabriel com a leitura e a escrita, em um processo que envolve sua vida de forma mais ampla, configuradas por produções subjetivas atuais associadas à significação da escola como espaço-tempo de aprender, fazer atividades, brincar e de novas descobertas. A alegria de Gabriel em experienciar o 
contexto escolar se apresentou em suas expressões aos diversos instrumentos da pesquisa e esteve relacionada aos tipos de atividades que realizava, pois muitas envolviam tanto o desenho quanto a escrita espontânea, o que o implicava em se expressar de forma própria.

$\mathrm{Na}$ subjetividade social da sala de aula, existiam elementos subjetivos favorecedores do respeito à expressão espontânea da criança, o que foi destacado pelas professoras Melissa e Flávia, ao ressaltarem a importância de atividades que priorizassem tais aspectos. Essa forma de trabalho constituía elemento fundamental favorecedor de produção de sentidos subjetivos atuais relacionados à necessidade de ser autor em suas próprias produções, que reverberavam para a transcendência de suas próprias ideias, como característica da aprendizagem criativa.

Frente às construções anteriores, foi possível configurar que, na aprendizagem criativa de Gabriel, participaram sentidos subjetivos associados: a) ao desejo de ser reconhecido pelo pai e pelo outro de forma geral; b) à observação atenta aos detalhes; c) à integração dos conteúdos como necessário para sua aprendizagem; d) às possibilidades de criação própria; e e) à aprendizagem como processo relacional. Destacamos que houve um processo recursivo entre produções subjetivas relacionadas ao desenho e à aprendizagem da leitura e da escrita.

\subsubsection{Núcleo de sentidos subjetivos associados à relação com o esporte}

Durante o primeiro ano do ensino fundamental, Gabriel iniciou uma prática esportiva: a natação. Esta passou a constituir elementos importantes em sua subjetividade individual, ao ocupar um lugar essencial em sua vida e a participar de seus diálogos com os colegas, e de seus registros no cotidiano da escola. Havia, em Gabriel, autodeterminação para aprender a nadar, de se empenhar em conseguir uma nova aprendizagem. Tal construção pode ser ilustrada, dentre outras, pelas informações a seguir:

\footnotetext{
Diário de ideias

Gabriel: Eu fiz eu nadando. Eu já estou quase aprendendo a nadar sozinho e rápido. Montando minha história

Gabriel: Eu aprendi a nadar de costas. Agora eu já mergulho bem fundo. Eu vou com meu pai pra natação. Ele me leva de ônibus e até de bicicleta e aí eu vou lendo tudo, tudo que tem pelo caminho.
}

Pela análise do conjunto das informações da pesquisa interpretamos que a conquista da aprendizagem de Gabriel, no campo da natação, favoreceu produções subjetivas atuais relacionadas à superação de seus próprios limites e à necessidade de criar independência em relação ao outro, que reverberam na forma como ele se colocava desafios constantes a 
serem superados, como no momento da relação lúdica, assim como pela forma busca de independência na relação com as tarefas:

\section{Diário de ideias}

Gabriel: Eu não preciso mais da minha mãe pra me ajuda a fazer a tarefa da escola. Agora eu já faço sozinho. Eu já sei até nada sozinho.

Montando minha história

Gabriel: Eu vou nadando e nadando e a tia fala que eu estou nadando super bem, igual a tia Melissa, ela fala que eu já sei lê e escreve. Eu quero ser muito inteligente e eu vou ser.

A prática de esporte mobilizou recursos subjetivos de autoconfiança que se desdobraram na forma como criava um cenário de responsabilidade, de empenho e dedicação para com sua aprendizagem. Interpretamos que houve uma recursividade entre sentidos subjetivos advindos da experiência de aprender criativamente a ler e a escrever e sentidos subjetivos da ação de aprender a nadar. Nesta relação, Gabriel firmava seu gosto e desejo por novas aprendizagens e demonstrava ser este um processo mais amplo que abarcava ações para além da leitura e da escrita no contexto escolar. Gabriel reconhecia o esforço de seus pais para lhe levar duas vezes na semana para a natação, o que pode ser exemplificado a partir de sua expressão: "Pode ta chovendo que meu pai me leva na natação." (Diário de ideias). Havia produções subjetivas historicamente constituídas relacionadas à família, de valorização das ações que seus pais lhe dedicavam, do empenho dos mesmos em buscarem oportunidades de aprendizagem. Isso pode ser ilustrado pelas informações abaixo:

\section{Diário de ideias}

Gabriel: Eu gosto de ir pra natação com meu pai e minha mãe. Tem vez que não tem dinheiro pro ônibus mas meu pai me leva de bicicleta. Eu acho que ele cansa.

Montando minha história

Gabriel: Minha mãe nem pode pegar peso, mas ela vem na escola e me leva pra natação também. Eu acho que meu pai e minha mãe quer ver eu aprendendo de tudo e eu vou aprender.

Do nosso ponto de vista, houve uma subjetivação da prática de esporte como algo que precisava corresponder ao esforço dos seus pais, o que Gabriel já experienciava no campo da aprendizagem da leitura e da escrita. Percebemos que Gabriel, ao reconhecer as dificuldades financeiras da família e o esforço dos pais, pode ter subjetivado o esporte como algo difícil de conseguir e que precisava ser experienciado com empenho. O que, de certa forma, pode estar perpassado pelo significado que a leitura e a escrita assumiam para Gabriel:

\section{Entrevista I}

Gabriel: Aprender é pra aprender a ler, igual assim, tem que ler o ônibus que tem que pegar e é tudo verde, e se pegar errado? Você vai pra outro lugar que você nunca viu.

Pesquisadora: O que acontece quando não aprende?

Gabriel: Não sabe nadar e nem andar de bicicleta. Não sabe falar direito. Vira mendigo. Não sabe o que é viajar. 
Pelo conjunto de informações da pesquisa, interpretamos que havia produções subjetivas historicamente constituída, associadas à aprendizagem da leitura e da escrita vinculada à vida, a uma utilização prática do que aprendia na escola, o que passava pela relação com seus pais, pela associação que faziam de saber ler e escrever para uso cotidiano. Essa relação que dinamizava a condição de sujeito de Gabriel em relação à sua aprendizagem, pela capacidade de produzir caminhos próprios para atuar com o aprendido associado ao seu modo de vida, elemento fundamental da expressão da personalização dos conteúdos escolares como característica da criatividade na aprendizagem. Dentre as várias informações, uma fala bastante ilustrativa de Gabriel pode subsidiar nossa construção: "Minha mãe me fala que eu vou ser um engenheiro e que eu vou poder desenhar um tanto de coisa. Eu quero fazer prédio e também viajar muito. Teve um dia que meu pai deixou eu saber qual o ônibus que tinha que pegar e eu dei conta." (Diário de ideias).

Nesta relação com a vida, a experiência da leitura e da escrita para Gabriel parecia se expressar mediante produções subjetivas atuais associadas à necessidade de vincular suas ações a seus interesses e experiências tanto já realizadas, quanto outras apenas imagináveis. Tais construções podem ser ilustradas pelo próprio enredo das produções pictóricas e escritas de Gabriel, as quais envolviam, dentre outros temas, a prática de esporte, a relação com o irmão e a amizade. Nesta relação subjetiva com seus registros, Gabriel incluía seu irmão nas histórias e sempre o colocava como alguém que brincava com ele. A referência ao irmão mais velho foi algo recorrente nas expressões de Gabriel aos instrumentos da pesquisa. Para subsidiar nossas construções, elencamos as informações a seguir:

\footnotetext{
Entrevista IV

Pesquisadora: Por que você escolheu falar sobre futebol?

Gabriel: Eu gosto de jogar bola com meu irmão e aí eu fiz um jogo bem legal que tem até o gol, uniforme e uma bola especial. Eu jogo no quintal e o gol é a parede. Mas aqui ficou parecendo de verdade.

Pesquisadora: Você gosta de aprender a nadar?

Gabriel: Eu acho muito legal. Eu sou muito rápido. Eu escrevi aí que eu vou ser um atleta. Tem que treinar muito.
}

Nas ações de escrever, ler e desenhar, configuravam-se sentidos subjetivos atuais associados a processos subjetivos como a imaginação e o pensamento. Pressupomos que, pelo caráter gerador das emoções, a imaginação e o pensamento se expressavam como sentidos subjetivos atuais vinculados ao sonho de se tornar um atleta, bem como possibilitavam que Gabriel experienciasse um jogo de futebol com todos os elementos que o compõem, como algo apenas imaginável, porém, que não era experienciado na vida real, mas foi capaz de lhe gerar bem estar e um sentimento de realização pessoal frente ao seu registro. 
Consideramos os processos vinculados à criação de um cenário imaginário próprio na relação com a aprendizagem, como característica da criatividade.

A relação com o irmão aparecia sempre em suas produções escritas, referindo-se à forma como brincavam de futebol, jogavam vídeo game e também como conversavam sobre a escola. Para Gabriel, o irmão seguia como um exemplo de aluno e constituía um importante produtor de sentidos subjetivos historicamente constituídos, relacionados ao interesse por conhecimentos que não eram destinados à sua faixa etária na escola. As informações abaixo podem ilustrar nossas construções:

Diário de ideias

Gabriel: Eu já sei faze continha de vezes. Meu irmão que me ensinou. No ano que vem tem prova e é muito difícil. Vai mudar muita cosia.

Momento informal

Gabriel: Meu irmão não sabe desenha direito. Só eu gosto. Ele faz um tanto de tarefa. Agora ele já está escrevendo na cursiva e um tantão de texto.

Montando minha história

Gabriel: Eu estou aprendendo a nadar e meu irmão ainda não sabe. Ele gosta é de futebol. A gente jogo bola e eu faço gol.

Do nosso ponto de vista, Gabriel estabelecia uma relação próxima com o irmão que lhe colocava desafios na busca por novos conhecimentos. Reconhecer que o irmão sabia mais do que ele, favorecia que Gabriel se relacionasse com ele, como alguém capaz de lhe ensinar. Nesta relação, havia sentidos subjetivos historicamente configurados associados à confiança no outro com quem pode aprender algo. Isso, de certa forma, dinamizava as ações de Gabriel em sala de aula em ajudar o outro e estar aberto a novas aprendizagens. Interpretamos que havia recursos subjetivos constituídos na relação com o irmão que favoreciam com que a criatividade emergisse na aprendizagem. Dentre os quais, podemos citar: a abertura ao novo, o gosto pelo desafio e a autodeterminação.

Desta forma, o núcleo de sentidos subjetivos associados à prática do esporte se organizou por produções subjetivas associadas: a) à superação de seus próprios limites; b) à necessidade de criar independência; c) à autoconfiança; d) a valorização das ações que seus pais lhe dedicavam; e) à necessidade de corresponder ao esforço dos seus pais; f) ao sonho de se tornar um atleta; g) ao interesse por conhecimentos que não eram destinados à sua faixa etária na escola; e h) à confiança no outro com quem pode aprender algo. Na trama da configuração subjetiva da ação de aprender criativamente, compreendemos que sua constituição se organizou na relação recursiva entre o movimento da configuração subjetiva da ação e a experiência de aprender criativamente, se caracterizando como processo de desenvolvimento da subjetividade, o que aprofundaremos no próximo tópico. 


\subsubsection{Mudanças e constituição de novos aspectos na subjetividade de Gabriel vinculados ao processo de aprendizagem criativa da leitura e da escrita}

Compreendemos o movimento da subjetividade de Gabriel, mediante a relação entre elementos da personalidade, a condição de sujeito e o contexto de aprender do qual participava. Mediante o processo construtivo-interpretativo, interpretamos que ocorreram mudanças na subjetividade de Gabriel, em meio a novas produções subjetivas que reconfiguraram a organização subjetiva da ação de aprender. Mudanças substanciais ocorreram nos três núcleos de sentidos subjetivos, bem como se configurou um novo núcleo de sentidos subjetivos vinculados à leitura e a escrita como possibilidades de conquistar e aprofundar novos conhecimentos. Tais processos se constituíram pela recursividade entre a aprendizagem criativa da leitura e da escrita e o desenvolvimento da subjetividade.

A conquista da letra cursiva foi um marco importante para a aprendizagem de Gabriel e representou um processo de produções subjetivas. Ele havia criado traçados específicos para cada letra do alfabeto e isso passou a fazer parte da sua forma de registro. Esses se tornaram mais frequentes nas ações de Gabriel e por lhe demandar mais dedicação implicou em redução do tempo dedicado a desenhar, o que lhe envolveu de forma criativa na reorganização do próprio tempo livre. Havia mudanças nas ações de Gabriel que envolviam seus interesses, gostos e preferências, bem como se relacionavam a novas conquistas em sua aprendizagem da leitura e da escrita. Tal construção pode ser exemplificada a partir das informações abaixo:

\footnotetext{
Minhas mudanças

Gabriel: Já sei ler e escrever. Agora eu posso ler o que a minha mãe não consegue. Teve um dia que era um médico, estava num papel lá na geladeira, mas aí ninguém leu e perdeu. Agora eu posso fazer muita coisa, posso saber como é que é aquele jogo lá que eu não sei, lá do vídeo game do meu irmão, eu posso ler o manual.
}

No momento da expressão acima, indagamos Gabriel sobre a importância que conferia em ajudar o outro e se este era um processo mais geral em suas ações. Ele nos respondeu que poderia ajudar qualquer pessoa indistintamente. Interpretamos que havia novas produções subjetivas associadas à utilização da leitura e da escrita em sua vida, como forma de poder ajudar o outro. Produções associadas às mudanças nos núcleos de sentidos subjetivos relacionados à relação com a mãe e à relação com o desenho que envolvia o vínculo com o pai. Gabriel inseria em novas ações que apenas eram destinadas ao irmão mais velho, geradoras de sua autoconfiança. Tais produções podem estar relacionadas a contradições que envolviam a relação de Gabriel com o reconhecimento de dificuldades financeiras que os pais, em alguns momentos da pesquisa, passaram. Outras informações são ilustrativas: 
Dinâmica conversacional II

Mãe: O Gabriel não está mais fazendo desenhos como antes. Eu falo assim, vai Gabriel faz um leão pra eu poder colorir, pra ver se incentiva ele. Mas mesmo assim ele não quer fazer. Eu acho que ele está mais preocupado agora. Antes eu não via isso não, mas agora ele fica falando que eu não estou trabalhando e que o pai está desempregado. Eu acho que ele está escrevendo mais e agora está lendo e vê as contas.

Diário de ideias

Gabriel: Eu empresto meu material pros menino, mas tem que devolve. Um dia sumiu o lápis azul e aí eu fiquei sem. Eu não vou pedir pra minha mãe comprar não. Eu sei que ela não pode. Meu pai já está quase arrumando um serviço.

Novas preocupações passaram a compor a organização subjetiva de Gabriel e estavam configuradas pela subjetivação da falta de emprego dos pais como algo que precisava de seu apoio e isso o mobilizava em novas ações. Pressupomos que, na dinâmica recursiva entre as produções subjetivas e a aprendizagem criativa da leitura e da escrita, se favoreceu novas formas de relação de Gabriel com o mundo. Essas passavam pelos impactos que a leitura assumia em sua vida, como algo que o mobilizava a uma nova visão de mundo, da situação econômica de seus pais e isso lhe gerava ações em prol de ajudá-los.

A criatividade emergia em sua dimensão funcional, na forma como Gabriel foi capaz de aliar o seu conhecimento da leitura e da escrita às novas ações em sua vida, que lhe demandaram abrir espaços próprios de atuação para ajudar os familiares, em meio a novas produções subjetivas. Processo que lhe possibilitou assumir status diferenciado no âmbito familiar, se envolvendo com assuntos, como a condição financeiras dos pais. Interpretamos que havia novas produções subjetivas associadas à utilização da leitura e da escrita na vida, como apoio à família. Produções vinculadas aos três núcleos de sentidos subjetivos que compõem a configuração subjetiva da ação de Gabriel. A forma como Gabriel relatava sobre as contas de energia e de água de sua residência, sempre se referindo à leitura das mesmas de forma preocupada, pode ser ilustrada por uma de suas falas: "A conta de água é muito cara. Lá naquele papel que o correio deixou lá na minha casa estava escrito que tem que pagar senão eles corta a água. Eu vou lembrar meu pai." (Diário de ideias).

Interpretamos que as novas produções subjetivas associadas à relação com a aprendizagem criativa, desencadeavam novos processos de expressão da criatividade. Pela forma como a utilização da leitura lhe permitia se inserir em novos assuntos e, de certa forma, lhe demandavam atitudes de apoio à família, ao conhecer as consequências caso haja uma falta de pagamento. Conhecimento que gerou ações de buscar correspondências, assim como realizar a leitura das mesmas e, além de avisar aos pais, Gabriel criou um sistema de agendamento de datas para acompanhar o pagamento, momento em que a dimensão funcional da criatividade se expressava também, em seu caráter instrumental. 
A mudança nos interesses de Gabriel, que passou a desenhar menos e a escrever mais, pode estar associada às novas produções subjetivas vinculadas à experiência da escrita como possibilidade de expressar suas ideias e como forma de comunicação com o outro. O que envolvia nova organização subjetiva do núcleo de sentidos subjetivos associados à relação com o desenho. Gabriel dedicava o seu tempo livre na sala de aula para escrever sobre o que imaginava e não recorria ao desenho para complementar suas ideias ou mesmo para se nutrir de ideias para escrever. As informações abaixo podem ilustrar nossas elaborações:

\footnotetext{
Minhas mudanças

Gabriel: Eu agora estou desenhando mais as letras e acho que estou até fazendo pouco desenho. Eu acho que eи quase não estou desenhando mais. Só fiz aquela onça. Eu estou gostando de inventa histórias e aí eu escrevo.

Diário de ideias

Gabriel: Teve uma vez que eu desenhei um leão na floresta e todo mundo achou que era só um lugar da cidade. Aí eu pensei, já sei, vou escrever aqui e ninguém mais vai ficar falando o que não está no desenho. Agora eu escrevo e todo mundo sabe o que que eu estou imaginando.
}

Na relação com a escrita e com a leitura como processos capazes de comunicar ao outro suas ideias, pressupomos que havia novas produções subjetivas associadas ao desejo de ser compreendido em seus registros. Tal processo desencadeava novos interesses pela escrita e por ser este um veículo em que era possível detalhar mais suas ideias e estabelecer um canal de comunicação com o outro de forma mais explícita. Nesta configuração da escrita para Gabriel, sobressaía-se o processo de individualização, ao buscar se afirmar pela escrita e neste processo se diferenciar do outro, tanto pela personalização do traçado da sua letra como pelos interesses de escrita de histórias inéditas e diferentes do cotidianamente visto.

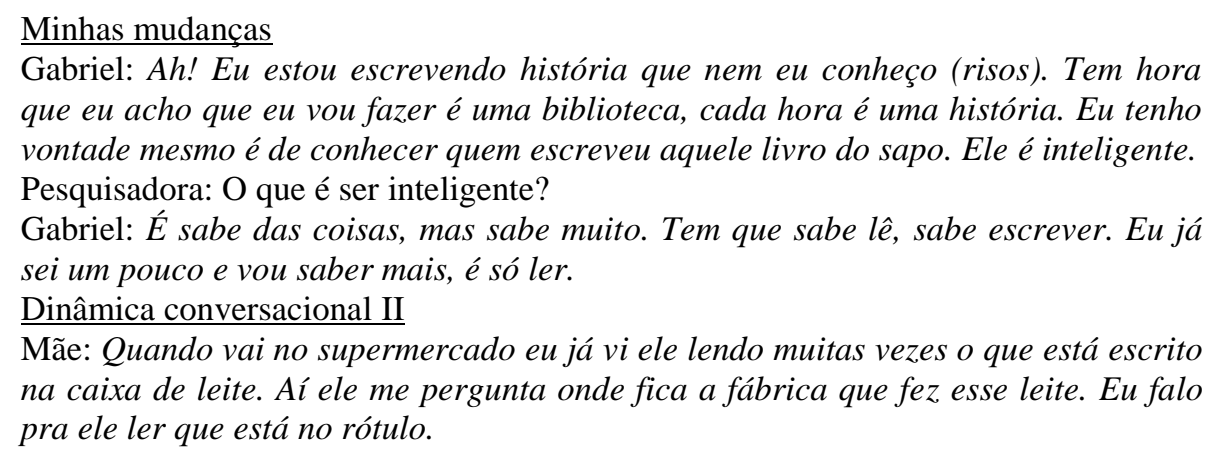

Novos interesses e novas ações passaram a compor a organização subjetiva de Gabriel, que envolveu a subjetivação dos livros como um processo que demandava conhecer em profundidade temas diversos. Ele mantém a necessidade de questionamentos, a curiosidade sobre assuntos diversos. Estes foram gerados, pelo que Gabriel visualmente observava em seu dia a dia, mediante a produções subjetivas atuais associadas à leitura, vinculadas à necessidade de buscar novos conhecimentos. Produções que participavam da constituição 
de um novo núcleo de sentidos subjetivos associados à leitura e a escrita como possibilidades de conquistar e aprofundar novos conhecimentos.

\author{
Minhas mudanças \\ Gabriel: Eu faço minha tarefa sozinho. Eu já sei lê tudo que estou lá e é facinho \\ faze. Eu estou querendo descobrir sobre os países é só pegar um livro e descobrir. \\ Dinâmica conversacional II \\ Mãe: Eu pergunto pra ele se ele que ajuda na tarefa e ele fala 'Deixa eu fazer \\ sozinho, eu já sei se eu não souber eu te pergunto'. Isso aí a gente vê que ele está \\ crescendo, que ele está se tornando mais independente. Ele pega as coisas do \\ correio e me entrega e fala assim, oh mãe aí tem uma promoção. Antes ele via só a \\ gravura, agora ele lê e faz comentário. Hoje ele faz mais sozinho, ele fala 'nossa \\ que coisa fácil!' Ele estou achando tudo muito fácil hoje.
}

Interpretamos que havia, neste novo núcleo, outros sentidos subjetivos atuais relacionados à independência em relação ao outro para aprender, o que se alinhavou a recursos subjetivos como autonomia, segurança e independência nas ações em prol de novos conhecimentos. Esses favoreceram uma relação próxima de Gabriel com os livros e a possibilidade desses instrumentos de ensino lhe conferirem respostas para suas dúvidas ou, ainda, para buscar informações científicas sobre seus questionamentos e formar novas perguntas. Em meio a novas produções subjetivas, a criatividade também assumia novas formas de expressão, como a organização das histórias de Gabriel, que contaram com novos enredos, agora mais científicos. Nelas, ele buscava aprofundar conhecimentos para poder escrever, em um movimento diferenciado, pois no início da pesquisa, os enredos de seus registros se associavam às suas experiências. Abaixo um trecho de uma de suas histórias:

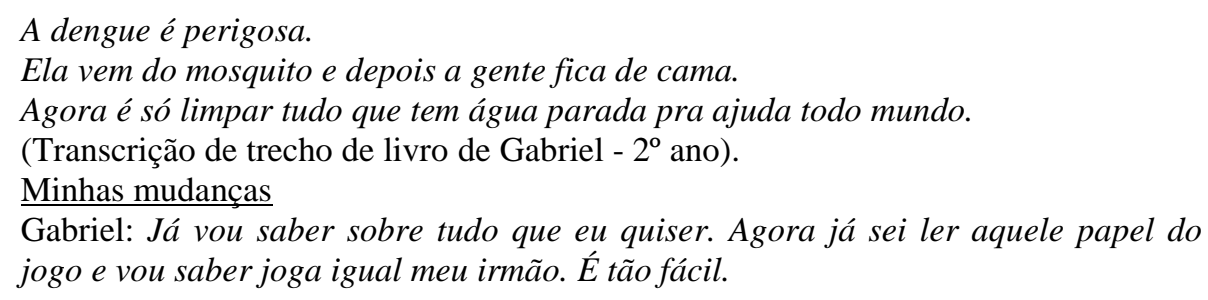

Interpretamos que havia novas produções subjetivas associadas a se sentir capaz de empreender ações com apoio da leitura, em meio à sua utilização como possibilidade de novas descobertas e de inserção em ações que antes estavam dependentes do outro. $O$ quadro a seguir constitui uma síntese da relação recursiva entre aprender criativamente e o desenvolvimento da subjetividade de Gabriel. No próximo capítulo, discorremos sobre a análise integrativa dos três casos estudados. 
Quadro 8 - Inter-relações entre a expressão da criatividade e o desenvolvimento da subjetividade de Gabriel

\begin{tabular}{|c|c|c|c|}
\hline $\begin{array}{c}\text { Configuração subjetiva da ação de } \\
\text { aprender }\end{array}$ & Expressão da criatividade & $\begin{array}{l}\text { Mudanças na } \\
\text { constituição } \\
\text { subjetiva } \\
\end{array}$ & $\begin{array}{l}\text { Novas expressões } \\
\text { da criatividade }\end{array}$ \\
\hline \multicolumn{3}{|c|}{ Núcleo de sentidos subjetivos associados à relação com a mãe: o cuidado com o outro } & \multirow{4}{*}{$\begin{array}{l}\text { - Buscar } \\
\text { correspondências } \\
\text { na caixa de } \\
\text { correios, realizar } \\
\text { leitura das } \\
\text { mesmas e, além } \\
\text { de avisar aos pais, } \\
\text { criar um sistema } \\
\text { de agendamento } \\
\text { de datas para } \\
\text { acompanhar o } \\
\text { pagamento. }\end{array}$} \\
\hline $\begin{array}{l}\text { Produções subjetivas associadas: } \\
\text { - à relação com a mãe como companheira na } \\
\text { aprendizagem; } \\
\text { - à curiosidade por temas diversos; } \\
\text { - à aprendizagem como processo de } \\
\text { conhecer e questionar o mundo; } \\
\text { - à relação do aprender com a vida; } \\
\text { - à visão de futuro; } \\
\text { - à integração dos conteúdos; } \\
\text { - à leitura como estar com o outro; } \\
\text { - a ver o outro aprender e de aprender na } \\
\text { relação com o outro; } \\
\text { - à parceria na relação com a professora. }\end{array}$ & $\begin{array}{l}\text { - Confrontação com o dado: } \\
\text { com suas próprias produções } \\
\text { e com as ideias do outro. } \\
\text { - Relação lúdica: criação do } \\
\text { cenário imaginário. } \\
\text { - Personalização da } \\
\text { informação: do próprio } \\
\text { processo de ler e dos } \\
\text { conteúdos. } \\
\text { - Geração de ideias próprias } \\
\text { e novas que transcendem o } \\
\text { dado: transcender as } \\
\text { próprias ideias. }\end{array}$ & $\begin{array}{l}\frac{\text { Novas produções }}{\underline{\text { subjetivas }}} \\
\text { - à utsociadas: } \\
\text { leitura e da escrita } \\
\text { como apoio à } \\
\text { família; } \\
\text { - a ajudar o outro; } \\
\text { - a estabelecer } \\
\text { com a escrita um } \\
\text { canal de } \\
\text { comunicação. }\end{array}$ & \\
\hline \multicolumn{3}{|c|}{ Núcleo de sentidos subjetivos associados à relação com o desenho: o vínculo com o pai } & \\
\hline $\begin{array}{l}\text { Produções subjetivas associadas: } \\
\text { - ao desejo de ser reconhecido pelo pai e } \\
\text { colegas; } \\
\text { - ao desejo de uma escrita própria e com } \\
\text { traços com caráter inédito; } \\
\text { - à relação com o desenho e com a escrita } \\
\text { como possibilidades de novas criações; } \\
\text { - à aprendizagem como processo relacional; } \\
\text { - à integração dos conteúdos como } \\
\text { necessário para sua aprendizagem; } \\
\text { - às possibilidades de registrar suas ideias } \\
\text { por desenhos e escrita e poder reelabora-las; } \\
\text { - à significação da escola como espaço- } \\
\text { tempo de aprender, fazer atividades, brincar; } \\
\text { - à necessidade de ser autor. }\end{array}$ & $\begin{array}{l}\text { - Estratégias de } \\
\text { aprendizagem. } \\
\text { - Relação lúdica: se colocava } \\
\text { desafios a serem superados; } \\
\text { relação completa, voluntária. } \\
\text { - Geração de ideias próprias } \\
\text { e novas que vão além do } \\
\text { dado: na relação com as } \\
\text { atividades propostas e com } \\
\text { seus próprios desenhos. } \\
\text { - Confrontação com o dado: } \\
\text { a relação positiva com o } \\
\text { erro. Personalização da } \\
\text { - Pação: dos conteúdos. } \\
\text { informaça }\end{array}$ & $\begin{array}{l}\frac{\text { Novas produções }}{\text { subjetivas }} \\
\underline{\text { associadas: }}\end{array}$ & \\
\hline \multicolumn{3}{|c|}{ Núcleo de sentidos subjetivos associados à relação com o esporte } & \multirow{4}{*}{$\begin{array}{l}\text { - Elaboração de } \\
\text { histórias, com } \\
\text { enredos } \\
\text { científicos. }\end{array}$} \\
\hline $\begin{array}{l}\text { Produções subjetivas associadas: } \\
\text { - à superação dos seus limites; } \\
\text { - à valorização das ações dos pais à sua } \\
\text { aprendizagem; } \\
\text { - a corresponder o esforço dos pais; } \\
\text { - ao vínculo da aprendizagem com a vida; } \\
\text { - a associar suas ações a interesses e } \\
\text { experiências; } \\
\text { - ao sonho de se tornar atleta; } \\
\text { - ao interesse por conhecimentos além do } \\
\text { que aprendia no ano em estudo; } \\
\text { - à confiança no outro para aprender. }\end{array}$ & $\begin{array}{l}\text { - Relação lúdica: a forma } \\
\text { como se colocava desafios } \\
\text { constantes a serem } \\
\text { superados durante as ações } \\
\text { de ler e escrever. } \\
\text { - Personalização da } \\
\text { informação: dos conteúdos. }\end{array}$ & $\begin{array}{l}\frac{\text { Novas produções }}{\underline{\text { subjetivas }}} \\
\text { - à utsociadas: } \\
\text { leitura e da escrita } \\
\text { em sua vida, } \\
\text { como apoio à } \\
\text { família. } \\
\text { - a estabelecer } \\
\text { com a escrita um } \\
\text { canal de } \\
\text { comunicação. }\end{array}$ & \\
\hline \multicolumn{3}{|c|}{ Novos aspectos da constituição subjetiva } & \\
\hline $\begin{array}{r}\text { Novo núcleo de sentidos subjetivos associc } \\
\text { conquistar e aprofur } \\
\text { Novas produções }\end{array}$ & $\begin{array}{l}\text { dos à leitura e a escrita como p } \\
\text { dar novos conhecimentos } \\
\text { subjetivas associadas: }\end{array}$ & ossibilidades de & \\
\hline
\end{tabular}

Fonte: elaborado pela autora, 2015. 


\section{PRODUÇÃo TEÓRICA DA PESQUISADORA II: ANÁlise INTEGRATIVA DOS CASOS}

No presente tópico, apresentamos nossas construções teóricas derivadas da análise integrativa dos casos. É importante frisar que cada um dos três casos desenvolvidos guarda sua singularidade e nosso intuito não é fazer generalizações, mas abrir novas zonas de sentido sobre como a criatividade emerge na aprendizagem da leitura e da escrita e suas inter-relações com o desenvolvimento da subjetividade da criança. Para isso, estruturamos nossas ideias em três sessões que se integram e respondem aos nossos objetivos específicos de pesquisa. $\mathrm{Na}$ primeira parte, abordamos como os casos nos auxiliaram a compreender a expressão da criatividade na aprendizagem da leitura e da escrita e suas relações com as estratégias de aprendizagem. No segundo tópico, apresentamos elaborações sobre a caracterização da configuração subjetiva da ação, mediante os casos estudados. No terceiro e último item, tratamos das mudanças e constituição de novos aspectos da subjetividade da criança vinculados ao processo de aprendizagem criativa da leitura e da escrita, o qual finalizamos com a tese fundamentada e defendida no presente trabalho.

\subsection{PRODUÇÃO TEÓRICA SOBRE A EXPRESSÃO DA CRIATIVIDADE NA APRENDIZAGEM DA LEITURA E DA ESCRITA E SUAS RELAÇÕES COM AS ESTRATÉGIAS DE APRENDIZAGEM}

De acordo com Mitjáns Martínez (2009b, 2012a, 2012b, 2014), em seus estudos com aprendizes de ensino médio e ensino superior, a criatividade se expressa na aprendizagem a partir de, no mínimo, três elementos que se articulam: a personalização da informação, a confrontação com o dado e a produção, geração de ideias próprias e novas que vão além do dado. Nosso estudo corrobora as elaborações da referida autora e avança em três aspectos:

a) ao compreender como estas três características constituíram a aprendizagem criativa de crianças nos dois primeiros anos do ensino fundamental;

b) ao trazer uma nova característica que se une às supracitadas, que denominamos de relação lúdica; 
c) ao precisar como as estratégias de aprendizagem se vincularam às características destacadas.

A partir da pesquisa, foi possível identificar, nos três casos analisados, a forma singular com que as características anteriormente ressaltadas se apresentaram na aprendizagem criativa da leitura e da escrita de cada participante da pesquisa e a confluência com que as mesmas se expressaram na aprendizagem, aspectos que corroboram Mitjáns Martínez (2014). A personalização da informação se expressou na forma como cada aprendiz se relacionava com os processos que envolviam a leitura e a escrita, transformando em alguma medida informações com as quais lidava para um processo pessoal capaz de configurar ações próprias em diferentes contextos de atuação o que ratifica estudos desenvolvidos por Mitjáns Martínez e González Rey (1989).

Nosso trabalho contribuiu com os estudos dos autores supracitados, na medida em que apresentou elementos que expressaram a qualidade com que o aprendiz atuava com a informação personalizada, orientada às possibilidades de mudanças no seu modo de vida. Assumimos o conceito de modo de vida como uma categoria definida por González Rey (2004c, 2011c), a qual sempre se organiza como uma produção subjetiva relacionada às ações, relações e preferências que, na sua inter-relação formam a maneira de viver. Do nosso ponto de vista, informações personalizadas se constituíram como recurso subjetivo e impactaram o modo de vida, configurando novas ações, relações, curiosidades e interesses.

Nessa direção, concordamos com os estudos de González Rey (2004c), quando este expressa o potencial que uma informação personalizada tem para a autorregulação do comportamento do indivíduo. Compreendemos a forma como o aprendido impactou o modo de vida dos participantes da pesquisa como princípio norteador do funcionamento da personalização da informação na aprendizagem criativa da leitura e da escrita.

Em Murilo, a personalização esteve associada ao modo de ensinar das professoras, às atividades propostas em sala de aula e ao próprio contexto de aprendizagem. Essas se vincularam às estratégias de autorregulação de atenção deliberada às explicações da professora, à associação do conteúdo aprendido com suas experiências, assim como à utilização do aprendido em situações cotidianas. A personalização de tais elementos constituiu motor para empreender ações com implicações para qualidade de vida, que envolveu a possibilidade de novas relações com o entorno, de buscar se inteirar mais com o mundo ao seu redor, de novos processos relacionais com impactos na temporalidade e mudanças em sua forma de aprender. 
A personalização da informação, em Adriana, esteve associada à sua relação com os conteúdos escolares e ao próprio ato de ler e escrever. Processos que se organizaram mediante o vínculo com estratégias de autorregulação de associar o que aprende com situações cotidianas, de utilizar o aprendido em sua vida, de buscar aprofundar seus conhecimentos e fazer inferências nas leituras, assim como a deliberação de atenção e concentração. $O$ trabalho, a transformação e a organização dos conteúdos de uma maneira própria, favoreceu que Adriana atuasse com os mesmos para além do contexto escolar de forma efetiva e crítica, que envolveu mudanças em seu modo vida, em novas possibilidades de experienciar uma relação saudável com a alimentação e diferenciados processos relacionais de ensinar ao outro.

Em Gabriel, a personalização se apresentou na sua relação com o próprio processo de ler e escrever, vinculado às atividades propostas, assim como pela relação com os conteúdos. Processos relacionados às estratégias de aprendizagem de deliberação de atenção e concentração nas ações de ler e escrever, planejamento para realizar ações neste campo, a utilização do aprendido em situações cotidianas, assim como o cuidado com a estética de sua própria escrita. Gabriel empreendeu ações com o saber de forma diferenciada com implicações no seu modo de vida, o que envolveu mudanças em ações cotidianas, como a questão do banho e os cuidados com a utilização da água.

Nos três casos analisados, também identificamos a forma como a confrontação com o dado se expressou nos questionamentos, nas constantes dúvidas, pela maneira pessoal com que cada aprendiz investigava o objeto a ser conhecido. Nossa pesquisa nos permitiu compreender que as ações de ler e escrever constituíram processos que envolviam a condição ativa, intencional, subversiva e transgressora do sujeito que aprende, corroborando Mitjáns Martínez (2012a), quando a autora destaca características que envolvem a ação do sujeito no processo de aprender criativamente.

Nossa investigação contribuiu com os estudos de Mitjáns Martínez (2012a, 2012b) ao compreendermos que a confrontação com o dado se configurou como um modelo hipotético em andamento, o qual definimos como um processo investigativo de flexibilidade e abertura a possíveis mudanças do próprio saber e do que se propõe a conhecer. O que favorecia aos aprendizes estabelecer relações, fazer perguntas ao outro, confrontar com outras escritas, dentre outras ações que expressavam um caminho engendrado por possibilidades de produzir e gerar mudanças na forma inicial de pensar. Neste processo, os aprendizes lançavam mão de estratégias de autorregulação de supervisão autônoma da escrita e de busca independente por respostas para as dúvidas. 
Neste modelo hipotético em andamento, também identificamos a utilização de estratégias cognitivas na busca por estabelecer relações entre sons, letras, palavras, assim como pelas relações entre a forma como culturalmente falavam e a escrita das palavras, processo que envolveu confrontação com o escrito e com a própria escrita. Do nosso ponto de vista, a utilização destas estratégias no âmbito da característica de confrontação com o dado, esteve relacionada ao envolvimento dos aprendizes com seu processo de aprendizagem, na busca de uma relação próxima, viva e atuante.

Havia, nos sujeitos da pesquisa, uma relação com a leitura e a escrita não como verdade absoluta, mas como possibilidade de formação de opinião própria, o que demandava estabelecer relações com os conhecimentos prévios, assim como uma relação profunda e pessoal com o objeto de conhecimento, em um processo investigativo de produzir novas possibilidades de reflexões. $O$ pensamento, assim como destaca González Rey (2012a), se expressou em seu caráter reflexivo constituído nos embates e questionamentos que envolviam processos comunicativos dos participantes nas ações de ler e escrever tanto consigo mesmos, quanto com o outro.

O que se expressou em Adriana, Murilo e Gabriel na forma como as ações de ler e escrever estiveram organizadas pela geração de opinião própria, por estratégias de autorregulação de inferências nas leituras, nos questionamentos sobre a própria escrita, nas relações com suas experiências, assim como no processo de modificar ou criar novas experiências. Nosso trabalho contribuiu com os estudos de González Rey (2011f), ao compreendemos que o pensamento, em seu caráter reflexivo, se configurou antes, durante e após o ato de ler e escrever, constituindo o aprender um processo que não tem na escrita ou no ato de ler um fim em si mesmo. Interpretamos que houve um processo recursivo entre refletir para realizar a atividade, quanto a própria ação de escrever e ler era geradora de reflexão

Outro elemento comum aos três casos desenvolvidos foi a confrontação de ideias com o outro, na qual os aprendizes questionavam as ideias do outro e as suas próprias, modificavam, confirmavam ou mesmo se propunham a novas elaborações a partir do diálogo. Assim como a confrontação também se expressou mediante aspectos que foram mais específicos, que, em Murilo se organizou pela confrontação com o instituído como estrutura dos livros e em Adriana, a confrontação com elementos do trabalho pedagógico das professoras.

A produção, geração de ideias próprias e novas que vão além do dado foi expressa também como característica singular em cada caso analisado, em que o novo transcendeu em 
alguma medida o objeto a ser conhecido. No âmbito da referida característica, nossa pesquisa possibilitou contribuir com os trabalhos de Mitjáns Martínez (2012a, 2012b, 2014) em três dimensões:

a) ao destacar o caráter empreendedor do sujeito nas ações de ler e escrever, termo definido por nós como possibilidade de elaborar metas, assumir riscos, encontrar caminhos próprios orientado a realizar, concretizar, tornar suas ideias exequíveis, as quais destoam do inicialmente dado, assim como se propõe ações, que possibilitam seguir em direções diferenciadas com suas criações;

b) ao trazer o novo além da possibilidade de transcender o dado, em seu caráter gerador de outras possibilidades de produção de novidade;

c) ao compreendemos a dimensão instrumental da criatividade na aprendizagem da leitura e da escrita, corroborando Mitjáns Martínez (2008a), que apresenta esta dimensão como não vinculada apenas ao produto em si, mas como relacionada ao processo de produção de novidade com valor para o próprio aprendiz, o qual esteve associado: a) à efetiva aprendizagem; b) ao desenvolvimento da condição de sujeito; c) às mudanças no modo de vida; e d) à realização pessoal.

É importante frisar também que corroboramos a tese de Amaral (2011), para a qual a constituição da aprendizagem criativa requer o desenvolvimento da autoria. Neste viés, avançamos em relação às ideias da referida autora ao compreendermos que, na aprendizagem criativa da leitura e da escrita a criança se constituiu como autora deste processo, em unidade ao caráter empreendedor do sujeito, capaz de assumir um caminho alternativo em que suas ideias extrapolavam, de alguma maneira, o dado. Do nosso ponto de vista, a partir dos casos estudados, compreendemos que a pessoa pode ser autora sem necessariamente empreender um caminho gerador de possibilidades de ir além do que já conhece, porém, na aprendizagem criativa estes elementos se unem para a geração do novo, que transcende o objeto a ser conhecido.

Murilo gerava ideias próprias e novas que transcendiam o que era solicitado como atividade de registro em sala de aula, na forma como criava uma relação próxima com o significado das palavras e empreendia ações de escrita de histórias, as quais formavam ações espontâneas de engajamento em registrar suas elaborações. Murilo criava seus próprios livros e também buscava conseguir materiais para concretizar suas ideias. Neste processo, a ação de escrever suas histórias eram processos geradores de novas ideias e novas produções de enredos para outros livros. 
Em Gabriel, identificamos que, a produção e a geração de ideias, que transcenderam o dado se expressou na relação com suas próprias elaborações, com as atividades propostas, assim como com seus desenhos. Havia abertura para novas experiências que poderiam ocorrer apenas no campo das ideias, o que lhe permitia, no diálogo com o outro, transcender uma elaboração inicial. A própria relação com o desenho era um processo que ocorria em recursividade com a ação de escrever, em que o caráter do novo se configurava como gerador de possibilidades de outras novidades.

Para Adriana, a geração de ideias próprias e novas se configurou em sua própria ação de ler e escrever, em que transcendia suas próprias elaborações. Assim como, na sua relação com a cópia, ao empreender ações e produções na criação de espaços próprios de atuar com a escrita como processo pessoal que participava da sua vida. Outro elemento foi a criação de situações artísticas que estiveram presentes na forma como criava livros com enredos reconfigurados de suas experiências, na produção de vídeos e músicas. Neste processo, o novo assumia o caráter gerador de outros processos de produções, como por exemplo, nas situações de cópia de atividades que lhe favoreciam novas buscas de informações.

Vale destacar, ainda, que compreendemos a forma como a geração de ideias próprias e novas estiveram associadas também, ao próprio uso do tempo livre pelos sujeitos da pesquisa, corroborando González Rey (2004c) de que o sujeito se constitui como gestor de suas ações, assumindo responsabilidade sobre seus atos. Nos três casos analisados, foi possível explicitar como os aprendizes fizeram uso do seu tempo livre, pela gestão do próprio tempo em favorecer possibilidades de geração do novo que transcendeu o dado, empreendido em diferentes contextos e direções. Nos três casos, o processo gerador se organizou em momentos distintos, tanto no contexto escolar, nos momentos de recreio, intervalos e outros, assim como em distintos espaços sociais de atuação dos participantes.

Como elemento novo ao campo teórico da aprendizagem criativa, mais especificamente aos trabalhos de Mitjáns Martínez (2009a, 2009b, 2012a, 2012b, 2014), em confluência com as características supracitadas, ressaltamos a expressão da relação lúdica. Essa foi definida por nós como a relação pessoal, espontânea, gratuita, investigativa e voluntária do sujeito com a aprendizagem. Relação que possibilita a evasão da vida real, pela consciência de um faz de conta, de poder ousar nas produções e exceder as experiências vividas, pela criação de regras próprias e de um cenário imaginário.

Compreendemos que, na aprendizagem criativa da leitura e da escrita estão metamorfoseados os processos que envolvem o jogo e o brincar, na singularidade de cada caso. Elaboramos intricadas relações da relação lúdica com a aprendizagem criativa e, dentre 
os vários autores que tratam o tema, nossa base teórica incidiu naqueles em que o lúdico não é dado pela especificidade da atividade de jogo em si, mas pela relação que se estabelece com qualquer atividade (BENJAMNIN, 2002; BROUGÈRE, 1998b).

Huizinga (1999) define elementos essenciais que caracterizam uma atividade como lúdica: a) uma atividade voluntária, em que a liberdade constitui um fator fundamental; b) o caráter desinteressado, gratuito que favorece uma evasão da vida real, tendo consciência de estar fazendo de conta; c) se caracteriza também pelo isolamento e a limitação, se processando em campos delimitados de maneira material ou mesmo imaginária, deliberada ou espontânea; e d) bem como reina uma ordem específica e absoluta. Neste viés, tal autor nos possibilitou estabelecer relações com a aprendizagem criativa da leitura e da escrita, a qual se realizou, dentre outras, pelas características que configuram uma atividade lúdica.

Assim como no jogo, nesse trabalho também entendido como lúdico, na escrita e na leitura, a criança está diante de uma atividade constituída socialmente, que tem regras próprias, porém, estas podem ser recriadas pelas próprias crianças no decurso da ação. Aproximamo-nos cada vez mais da relação lúdica na aprendizagem da leitura e da escrita e ressaltamos a concepção de Brougère (1998a, 1998b, 2002, 2008), para o qual o jogo é este espaço social que supõe regras em que a escolha e a decisão constituem partes que iniciam e caminham com o desenvolvimento do jogo e "A regra produz um mundo específico marcado pelo exercício, pelo faz de conta, pelo imaginário. Sem riscos, portanto, o jogo não é somente um meio de exploração, mas também de invenção" (BROUGÈRE, 1998a, p. 193).

Muniz (2010) aponta uma interessante discussão sobre a questão da produtividade na atividade de jogo, considerando a produtividade um elemento importante para a definição de jogo. Com isso, contrapõem a visão de Caillois, o qual propõe a improdutividade na ação de jogar. Para Muniz (2010), o jogo é improdutivo em termos materiais, ou seja, em algo que se concretiza materialmente, porém ressalta que o jogo é produtivo na ordem psicológica dos jogadores. Para nós, há produtividade no jogo e a situação lúdica constitui um processo subjetivo que, na aprendizagem da leitura e da escrita, pode ter produtividade material também, que estaria dada na processualidade da ação de criar, assim como pode assumir um processo de desenvolvimento subjetivo que não necessariamente se materializa em produto.

Aspecto que nos interessa sobremaneira para explicitar o potencial que as características do lúdico imprimem à criatividade. Em consonância com Vigotski (2009), destacamos dois elementos das marcas da brincadeira na criação infantil: a) o caráter instantâneo da criação da obra pela criança, ou seja, de realizar de forma intensa e de uma só vez a sua criação; e b) a ligação com o interesse e a experiência da criança. O caráter 
inventivo do aprendiz é enriquecido pelas suas experiências da vida cotidiana, sendo por elas orientado (KISHIMOTO, 2011). É nesta perspectiva que consideramos que, nas elaborações escritas, a criança brinca ao registrar (BARBATO, 2008; COSTA; SILVA; SOUZA, 2013).

A relação lúdica, assumiu expressões únicas em cada caso, associadas à aprendizagem da leitura da escrita e outros processos particulares de cada aprendiz. Em Murilo, identificamos que este processo esteve associado a elementos do brincar; em Adriana, às suas brincadeiras de ser professora e, em Gabriel, à dinâmica de elaboração de seus desenhos. Nos três casos analisados, entendemos que a imersão dos aprendizes nas ações de ler e escrever estava para uma relação gratuita e voluntária, em que a própria agitação do entorno, não os privava de se entregarem à atividade de forma completa. Assim como destacamos o caráter instantâneo com que realizavam suas produções, ou seja, produziam seus registros de uma só vez, o que demandava envolvimento e manterem-se ativos no processo com liberdade para expressarem suas próprias ideias.

A criação de regras próprias e de um cenário imaginário foram comuns aos casos estudados, se expressando de forma particular em cada um. Gabriel modificava suas próprias experiências e elaborava outras que não havia experienciado, como possibilidade de brincar com suas ideias. Murilo se colocava a criar histórias que culminaram na elaboração de seus livros, em que cada escrita era um momento inédito de modificar histórias já conhecidas e produzir outras. Adriana brincava com palavras conhecidas e desconhecidas por ela, em uma busca investigativa de conhecer os seus significados e colocava ritmo e melodia em sua escrita caracterizando a criação de suas músicas e também pela composição de suas poesias.

Como especificidade, a relação lúdica também se expressou em processos diferenciados em cada caso. Em Gabriel, por exemplo, na forma como colocava desafios constantes para si, a serem superados durante as ações de ler e escrever, como um processo que realizava, como se estivesse diante de uma brincadeira. Em Murilo, esteve relacionada à comunicação pela função que a escrita assumia, como processo de registrar o mundo e posteriormente como possibilidade de expressar suas próprias ideias.

No âmbito das características apresentadas anteriormente, corroboramos o pensamento de Mitjáns Martínez (2014), de que o funcionamento da imaginação visto, em cada caso, constituiu força motriz para a produção de conhecimento novo, assim como favoreceu a transformação de experiências próprias e a criação de novas experiências. Nosso trabalho também permitiu compreender outras formas de expressão da imaginação na aprendizagem criativa da criança: como possibilidade de atuar em um processo de faz de conta e como processo de comunicação consigo mesmo e com a própria produção. 
Nos três casos analisados, compreendemos que o processo de faz de conta se constituiu na elaboração das histórias, que culminaram na criação de livros. Importante destacar que esse processo foi permeado pelo diálogo consigo mesmo e pelas trocas de ideias com o outro. Em Murilo, podemos exemplificar nossas elaborações pela forma como se empenhava na escrita de enredos de histórias que fosse diferente do habitualmente conhecido. Em Adriana e Gabriel, a criação de histórias que reconfiguravam suas próprias experiências vividas, para outras que não tinham experienciado.

Pelo exposto, trazemos outra contribuição ao campo científico que aborda a criatividade na aprendizagem, ao compreendermos o vínculo das características supracitadas com as estratégias de aprendizagem que se organizaram como caminho empreendido pelos participantes para aprender. Identificamos a singularidade das estratégias de aprendizagem utilizadas em cada caso, em consonância com a expressão das características da criatividade. Foi comum nos três casos analisados a ênfase na utilização de estratégias de autorregulação, assim como a utilização, em menor quantidade, de estratégias cognitivas e a não observância de estratégias de gestão de recursos e motivacionais, o que convalida estudos já desenvolvidos neste campo (MITJÁNS MARTÍNEZ, 2009b, 2012a; OLIVEIRA, C. 2010). Interpretamos que, mesmo em crianças, na aprendizagem criativa, o sujeito não precisa utilizar estratégias para se manter orientado neste processo, como também não necessita gerir recursos, pela própria disponibilidade para aprender em diferentes contextos de atuação, pela autonomia, independência e o caráter empreendedor do sujeito.

Compreendemos a forma como cada estratégia expressava a significação da experiência de aprender pela criança, o que nos permitiu afirmar que não houve uma relação linear entre as estratégias utilizadas pelo aprendiz e o ensino do professor, pois na aprendizagem criativa, o sujeito cria formas próprias de empreender o como aprende. Vale destacar que, nos três casos estudados, a utilização das estratégias de aprendizagem nem sempre se constituíram como processo intencional e consciente pelos aprendizes, o que corrobora Mitjáns Martínez (2012b) de serem estas produções subjetivas. Em momentos de diálogos com os participantes da pesquisa e de nossas observações, identificamos que eles recorriam a determinadas estratégias sem necessariamente estarem conscientes de seu uso no decorrer das ações de ler e escrever.

Também foi possível compreender como as mesmas estratégias de aprendizagem, utilizadas pelos três aprendizes da pesquisa, se expressaram de forma singular e associadas a características diferenciadas. Para exemplificarmos citamos as estratégias de autorregulação relacionadas ao planejamento para realizar atividades propostas, que em 
Murilo estiveram vinculadas à característica da relação lúdica, em Adriana à confrontação com o dado e em Gabriel à personalização da informação. Interpretamos que essa singularidade das estratégias de aprendizagem se articula à organização subjetiva do aprendiz no contexto da experiência por expressarem a configuração subjetiva da ação do sujeito.

Em consonância com o que Mitjáns Martínez (1997, 2008a, 2008c, 2012b) destaca sobre a criatividade como princípio funcional da aula, ao ressaltar a necessidade de mudanças em todos os aspectos do trabalho pedagógico, nossa pesquisa contribuiu com as elaborações da referida autora ao trazer a forma como a criatividade se expressou na aprendizagem. Essa não ocorreu de forma pontual em um ou outro aspecto da aprendizagem, mas se configurou de forma sistêmica nas múltiplas dimensões que envolveram a aprendizagem, dentre as quais citamos as relações da criança com:

a) o contexto de aprendizagem: envolveu o reconhecimento de ser este um espaço-tempo a ser explorado;

b) as produções: envolveram expressões escritas, orais, pictóricas em um processo articulado de autoria e empreendedorismo. Abrangeu o caráter ativo, implicou esforço, dedicação e energia do aprendiz. Estiveram associadas à reflexão, à imaginação, à curiosidade e ao caráter investigativo;

c) os conteúdos curriculares: associados a uma postura problematizadora, questionadora, frente aos conteúdos, não como verdades absolutas, mas como possibilidades de novas inserções e novas elaborações. Envolveu reconhecer o potencial do que aprende nas suas múltiplas relações com a vida cotidiana;

d) a utilização dos materiais escolares: envolveu abertura para novas possibilidades de suas funções, como a própria criação de cadernos para registros pessoais;

e) a avaliação: vinculada à responsabilização do aprendiz pelo acompanhamento da própria aprendizagem e desenvolvimento;

f) o trabalho pedagógico: associado a elementos como a metodologia, a avaliação, dentre outros. Demandou uma relação aberta e problematizadora diante do que era proposto;

g) os sistemas de atividade-comunicação: envolveu tanto as relações entre professor-aluno, aluno-aluno, assim como da criança com o livro, com as atividades propostas e com um outro imaginário. Demandou um clima comunicativo-emocional de troca de ideias, defesa do próprio ponto de vista e flexibilidade para mudanças.

Em cada um dos elementos supracitados, identificamos a expressão das quatro características destacadas anteriormente. Compreendemos que a criatividade emergiu de 
forma sistêmica na aprendizagem da leitura e da escrita, se configurando como processo da subjetividade humana, sobre o qual apresentamos a seguir nossas elaborações.

\subsection{PRODUÇÃO TEÓRICA SOBRE A CARACTERIZAÇÃO DA CONFIGURAÇÃO SUBJETIVA DA AÇÃO DE APRENDER CRIATIVAMENTE A LER E A ESCREVER}

Nosso estudo destacou que a aprendizagem criativa da leitura e da escrita pelo tipo de relação que os aprendizes estabeleceram com este processo, reuniu qualidades que a constituiu como uma configuração subjetiva da ação. Em consonância com González Rey (2011a, 2012a,), interpretamos que não havia uma configuração subjetiva da personalidade $a$ priori que explicasse a ação criativa de aprender. Essa se organizou, mediante a ação do sujeito no contexto da aprendizagem, na dinâmica entre sentidos subjetivos constituídos na história de vida, que se atualizaram na ação, e outros produzidos no devir da experiência, em meio a sistemas relacionais e elementos da subjetividade social do contexto. Processo conformado por núcleos de sentidos subjetivos.

Na singularidade dos três casos, desenvolvemos três núcleos de sentidos subjetivos no âmbito da configuração subjetiva da ação de aprender criativamente a leitura e a escrita. Em Murilo, havia núcleos de sentidos subjetivos associados: a) à mudança da educação infantil para o ensino fundamental; b) à necessidade de estabelecer vínculos afetivos com o outro; e c) à aprendizagem da leitura e da escrita como processo relacional. Em Adriana, formaram-se núcleos de sentidos subjetivos relacionados: a) à relação com a mãe, tendo em vista o seu alto grau de exigência; b) a experiência de brincar de ser professora; e c) à relação com o conhecimento, em uma dimensão proativa para a pesquisa. Em Gabriel, configuraram núcleos de sentidos subjetivos vinculados: a) às relações associadas à mãe, tendo em vista o cuidado com o outro; b) à relação com o desenho, associado ao vínculo com o pai; e c) à relação com o esporte.

Nestes casos, havia produções subjetivas constituídas na história de vida, que se atualizarem na ação e participaram de forma diferenciada da aprendizagem de cada aprendiz, na dinâmica entre o histórico e o atual na ação de aprender. Em Murilo, por exemplo, sentidos subjetivos historicamente constituídos associados ao brincar, reverberavam para novas produções subjetivas vinculadas à necessidade de experienciar de forma plena suas produções. Em Adriana, ocorriam sentidos subjetivos historicamente constituídos associados a corresponder às exigências da mãe, que dinamizavam novas produções subjetivas 
vinculadas à aprendizagem orientada à visão de futuro. Em Gabriel, por exemplo, destacamos os sentidos subjetivos constituídos historicamente associados à necessidade de reconhecimento social do pai em relação aos seus registros que, de certa forma, favoreceu novas produções subjetivas vinculadas à escrita como produção própria e com traços inéditos.

Nossa pesquisa corrobora estudos de Mitjáns Martínez (2012a), ao compreender que a aprendizagem criativa foi nutrida por sentidos subjetivos nela produzidos. Também realizamos elaborações que nos permitiram entender que este processo se apresentou tanto no contexto escolar, como nos contextos não formais de educação. Corroboramos González Rey (2012a), tendo em vista que os três casos estudados nos possibilitaram compreender a motivação como a própria organização da configuração subjetiva da ação de aprender criativamente, sendo que nela se articulam sentidos subjetivos e operações envolvidas na ação.

Em Murilo, por exemplo, parte da força motivacional da aprendizagem criativa como configuração subjetiva da ação, se alinhava às produções subjetivas relacionadas às experiências na igreja, em meio a sentidos subjetivos associados à leitura como algo que o desafiava a querer aprender e movimentava sua curiosidade, o que dinamizava a confrontação com o dado como característica da criatividade em sua aprendizagem. Em Adriana, sentidos subjetivos produzidos na ação de brincar de ser professora, dinamizavam o funcionamento da imaginação como possibilidade de gerar caminhos para novas experiências. Na relação com o esporte, havia produções subjetivas em Gabriel que reverberavam para a busca de superação de seus próprios limites no campo da leitura e da escrita.

A configuração subjetiva da ação, mediante os casos estudados nessa pesquisa, se caracterizou também pela dinâmica dos núcleos de sentidos subjetivos, em que um mesmo sentido subjetivo formou parte simultaneamente de diferentes núcleos de sentidos subjetivos. Como exemplo, podemos citar que, em Murilo, as produções subjetivas do núcleo de sentidos subjetivos associados à mudança da educação infantil para o ensino fundamental, mais especificamente, relacionados às produções subjetivas vinculadas ao espaço de punição, essas formaram parte do núcleo de sentidos subjetivos relacionados à aprendizagem da leitura e da escrita como processo relacional, associado às produções subjetivas de busca de se sentir seguro para realizar seus registros.

Em Gabriel, compreendemos esta dinâmica de sentidos subjetivos associados ao vínculo da aprendizagem com sua vida, em sua configuração no núcleo de sentidos subjetivos relacionados à relação com a mãe e também no núcleo de sentidos subjetivos associados à relação com o desenho. Em Adriana, por exemplo, essa dinâmica se apresentou pelas 
produções subjetivas do núcleo de sentidos subjetivos vinculados à relação com a mãe, associadas à necessidade de reconhecimento social, e o núcleo de sentidos subjetivos relacionados ao brincar de escolinha, que reverberavam para ações que envolviam ser reconhecida socialmente em sala de aula.

Outro elemento que caracterizou a configuração subjetiva da ação, frente aos três casos estudados, que corrobora Mitjáns Martínez e González Rey (2012), foi o funcionamento das características e estratégias de aprendizagem, como expressão desta configuração subjetiva na ação. Foi possível compreender como sentidos subjetivos configurados historicamente que se atualizaram na ação de aprender e outros produzidos nessa ação, mobilizaram a expressão de características e estratégias de aprendizagem. Em um movimento recursivo, estas também favoreciam novas produções subjetivas, na dinâmica de constituição da configuração subjetiva da ação em que as características e estratégias de aprendizagem se organizaram como produções subjetivas.

Para ilustrar nossa elaboração, citamos as produções subjetivas de Murilo, associadas à experienciar a aprendizagem de forma segura. Produções que reverberava em seu empenho e concentração nas ações de ler e escrever, dinamizadoras da utilização de estratégias de autorregulação e cognitivas neste processo. Tais elementos favoreciam novas produções subjetivas associadas à entrega plena em suas produções. Em Adriana, as produções subjetivas associadas ao desejo de ser mais desafiada e cobrada em suas produções, reverberavam para os processos de confrontação com o dado em sua aprendizagem, que favoreciam produções subjetivas associadas à aprendizagem como processo que se efetivava na comunicação com o outro. Interpretamos que, em Gabriel, este processo pode ser ilustrado mediante produções subjetivas associadas ao registro escrito como uma forma de brincar com suas ideias, favorecedoras da relação lúdica com a aprendizagem, dinamizadora de novas produções subjetivas associadas à imaginação como transcendência de experiências.

Neste viés, nosso trabalho contribuiu com elementos empíricos da forma como o conhecimento é produzido no âmbito da configuração subjetiva, em consonância com González Rey (2014a) de ser este um processo que se constitui como modelo intelectualsubjetivo no qual o conhecimento se organizou como produção subjetiva libertadora, sadia e facilitadora do desenvolvimento, ao representar novos caminhos de produção subjetiva que foi assumido de forma ativa pelos aprendizes como sujeitos da ação. A título de exemplificação, em Murilo, a própria criação de suas histórias se constituiu como expressão de produções subjetivas diversas, dentre as quais podemos citar o caráter inventivo do brincar e suas relações com a leitura e a escrita. Em Adriana, por exemplo, havia sentidos subjetivos 
associados a auxiliar os pais em novos processos de ação, vinculados à qualidade de vida, que configuravam a sua busca por pesquisas e a criação de listas de compras. Em Gabriel, havia produções subjetivas associadas à relação do aprender com a vida, favorecedoras da geração de novas ações frente aos cuidados com o meio ambiente.

Na relação com a produção de conhecimento, em sua singularidade, nos três casos da pesquisa, identificamos que houve subjetivação do erro de forma diferenciada, o que nos permitiu compreender que, nem sempre, para que a criatividade emerja na aprendizagem da leitura e da escrita se faz necessária uma relação permeada apenas por estados emocionais positivos frente ao erro. Para Adriana, o erro estava para uma relação com produções subjetivas associadas à necessidade de reconhecimento social e também ao elevado grau de exigência da mãe sobre à sua aprendizagem, o que, lhe gerava estados emocionais de insegurança e tristeza, frente ao erro. No entanto, este processo favorecia o seu empenho em suas atividades, assim como a confrontação com as correções das professoras, em uma busca de superar os próprios erros. Para Murilo e Gabriel, o erro fazia parte do processo de aprendizagem e estava para uma relação positiva com o mesmo, gerador de estados emocionais de surpresa, alegria e desejo de superá-los com empenho e reflexão.

Vale ressaltar que elementos da subjetividade individual constituíram, de forma singular, a configuração subjetiva da ação e, na mesma direção, compreendemos o caráter único que elementos da subjetividade social da sala de aula se configuraram em cada aprendiz, momento em que, dentre outros, também foi possível entender a criatividade em sua dimensão funcional. Nosso trabalho corrobora Mitjáns Martínez (2008b) para quem a aprendizagem criativa não está associada a um tipo ou outro de contexto social, mas às produções subjetivas que se geram na relação sujeito-contexto-organização subjetiva.

Adriana, por exemplo, se confrontava com os tipos de atividades que veiculavam no contexto da sala de aula, por reconhecer o caráter limitador das mesmas das várias possibilidades de expressão, o que lhe favoreceu a geração de caminhos próprios de atuação, na criação de suas brincadeiras de escolinha. Murilo estabeleceu uma relação personalizada com as regras e normas da sala de aula, ao buscar conhecê-las para experienciar a aprendizagem de forma segura e plena. Em Gabriel, esteve presente os impactos que a forma de avaliação das atividades de escrita era desprovida de processos de comunicação sobre o processo da escrita, conflito gerador de diálogos com os colegas sobre os processos de sua escrita.

Neste viés, algo comum, aos três casos estudados, foi que a criatividade emergiu na aprendizagem, em sua dimensão funcional, que representou, em consonância com Mitjáns 
Martínez (2012a), um processo particular de desenvolvimento do sujeito na criação de caminhos alternativos frente ao estabelecido, capazes de reconfigurar a organização subjetiva. Processo que se configurou pela capacidade do sujeito em gerar alternativas diante de situações experienciadas, na tensão entre a subjetividade individual e a subjetividade social. Nosso trabalho contribui com as elaborações da referida autora, ao trazer que a dimensão funcional da criatividade também se constituiu pela própria dinâmica de mudanças qualitativas na configuração subjetiva da ação de aprender criativamente capazes de constituí-la como unidade subjetiva do desenvolvimento.

Por exemplo, a produção de livros de Murilo foi dinamizada por produções subjetivas associadas à sua necessidade de se relacionar com o outro, em que foi capaz de abrir novos espaços de atuação na busca de gerar novos vínculos afetivos por meio de suas produções. Essas produções traziam a Murilo satisfação em se reconhecer pela sua própria aprendizagem. Nas criações artísticas de Adriana, expressas em suas produções de vídeos, participavam sentidos subjetivos associados à experienciar novas oportunidades de aprendizagem e ser mais desafiada a aprender, empreendendo caminhos próprios para realizar atividades diferenciadas do cotidiano da sala de aula, que lhe geravam bem estar. Em Gabriel, a relação dos seus desenhos com a leitura e a escrita, em um processo gerador de novas ideias para além de suas experiências, esteve dinamizada por sentidos subjetivos associados ao desejo de uma escrita própria e com traços que tivessem um caráter inédito, processo gerador de subversão de seus registros, configurados pela realização pessoal frente às suas elaborações.

Como elemento constitutivo da configuração subjetiva da ação, esteve a singularidade com que os aprendizes subjetivaram os sistemas relacionais vinculados à expressão da criatividade que, nos três casos envolveu a relação com as professoras. Em Adriana, esta relação se constituiu por constantes confrontos, nos quais experienciava estados emocionais de tristeza, na busca por estabelecer uma relação mais próxima com as professoras, em meio às produções subjetivas associadas ao desejo de um espaço dialógico, de ser mais desafiada a aprender. Interpretamos que essa dinâmica relacional, foi favorecedora de importantes recursos subjetivos para que a criatividade emergisse na aprendizagem de Adriana, no seu envolvimento autônomo em suas produções em que foi capaz de criar caminhos próprios para aprender, como no modo como brincava de ser professora.

Neste viés, nosso trabalho corrobora Mitjáns Martínez (2012a), por contribuir com a ruptura de ideias do senso comum, de que a criatividade está associada a um professor bonzinho, que sempre elogie o aprendiz, assim como relacionada estritamente a estados emocionais positivos. Compreendemos que a relação com o professor pode não se estabelecer 
sob bases dialógicas e favorecer com que a criatividade emerja, pois se considera a organização subjetiva da pessoa no contexto da ação e as possibilidades de produções subjetivas.

A relação de Murilo com a professora Melissa foi um elemento fundamental na reconfiguração de produções subjetivas associadas ao sentimento de inferioridade, uma vez que ela, ao valorizar a aprendizagem dele, ao estabelecer uma relação dialógica, favoreceu novas produções subjetivas relacionadas a se sentir seguro para aprender. Relação que também foi possível com Gabriel, na forma como a professora buscou apoiá-lo, frente às mudanças que se geravam nele com relação à doença de sua mãe.

Nos dois últimos casos apresentados acima, a relação dialógica pautada pelo respeito mútuo, constituiu-se como fundamental para que existissem impactos em duas direções: na subjetividade individual dos aprendizes e na subjetividade social da sala de aula. Para exemplificarmos, mencionamos a forma como a professora Melissa, diante da relação com Murilo e de suas produções de livros, promoveu mudanças na própria dinâmica de atividades de sala de aula, uma vez que, a escrita estava subordinada às atividades propostas pela professora. Ela passou a desenvolver um trabalho que valorizava a escrita espontânea dos aprendizes. Na mesma direção, as professoras constituíram outras formas de trabalho com a escrita em sala de aula, associadas a registros pictóricos relacionados à escrita, elementos da relação com Gabriel.

A partir do exposto e dos casos estudados, compreendemos que, na aprendizagem criativa, em consonância com González Rey (2011b), a condição de sujeito da aprendizagem emergiu e se desenvolveu pela geração de espaços próprios de subjetivação, na tensão permanente entre a organização subjetiva de cada aprendiz e sua produção subjetiva ante suas ações de aprender. Em Adriana, por exemplo, a condição de sujeito emergiu pela própria produção de sentidos subjetivos associados à possibilidade que a imaginação lhe permitia de criar caminhos alternativos para novas experiências, favorecedores da atuação de Adriana na ruptura com o instituído como atividades padronizadas em sala de aula, produzindo seu próprio cenário imaginário de viver novas experiências.

Murilo, por exemplo, assumia a condição de sujeito associada à subjetivação do processo de ler como algo que o desafiava a querer aprender, o que reverberava para sua busca de uma escrita espontânea, rompendo com a dinâmica da subjetividade social da sala de aula, em que a escrita estava subordinada às solicitações das professoras. Em Gabriel, a tensão gerada entre elementos da subjetividade social, associados à fragmentação dos conteúdos escolares, e suas produções subjetivas associadas ao interesse por conhecimentos na vida, 
permitiram ao aprendiz gerar alternativas ao articular os conteúdos curriculares nos momentos de suas produções.

Nos três casos analisados, identificamos a importância da relação com a mãe como espaço constituidor de recursos subjetivos favorecedores da assunção do sujeito na aprendizagem criativa dentre os quais podemos citar: autodeterminação, abertura ao novo e gosto pelo desafio. A condição de sujeito da aprendizagem se expressou, nos três casos, mediante: a) a confrontação com o instituído e com suas próprias produções; b) a subversão e criação de caminhos próprios para exercer a leitura e a escrita; c) a capacidade reflexiva com que se imbuíam na aprendizagem; d) o caráter autônomo e questionador; e) a forma como utilizavam o aprendido em distintos contextos; f) o uso do tempo livre; g) a intencionalidade que perpassava as ações de ler e escrever; $h$ ) o protagonismo no processo de aprender; e i) a autoria e o caráter empreendedor. Neste viés, nosso estudo corrobora González Rey (2008a, p. 32), ao enfatizar que "O sujeito só vai desenvolver-se na tensão de sua produção singular ante a possibilidade de alimentar com sua experiência o que aprende e de alimentar o seu mundo com aquilo que aprende."

Frente ao exposto, convalidamos Mitjáns Martínez (2012a, 2012b) que a aprendizagem criativa emerge como uma forma de funcionamento subjetivo que a especifica como um tipo complexo de aprendizagem. Além disso, dentre seus elementos constitutivos, nosso trabalho corrobora os já destacados pela referida autora e avança com outros elementos: a) corroboramos o exercício da condição de sujeito no processo de aprender, em seu caráter de autor, empreendedor, gerador, de ruptura e de subversão;

b) corroboramos a produção de sentidos subjetivos favorecedores de geração de novidade que recursivamente nutrem essa forma de aprendizagem;

c) acrescentamos a participação de sentidos subjetivos históricos - que se atualizam na ação - e atuais, associados a elementos da subjetividade social e dos sistemas relacionais que constituem a aprendizagem criativa como configuração subjetiva da ação;

d) corroboramos a atualização na configuração subjetiva da ação de aprender, tendo em vista a produção de sentidos subjetivos, e acrescentamos as mudanças qualitativas na mesma capazes de a organizar como unidade subjetiva do desenvolvimento;

e) corroboramos o caráter subjetivo dos elementos considerados operacionais, como as estratégias de aprendizagem e acrescentamos o vínculo entre as características e as estratégias de aprendizagem;

f) acrescentamos a expressão sistêmica da criatividade nos elementos constituidores do processo de aprendizagem; 
g) corroboramos a imaginação e o pensamento como processos subjetivos dinamizadores da constituição da aprendizagem criativa;

h) corroboramos a produção de ideias como um modelo intelectual-subjetivo.

Do nosso ponto de vista, o movimento de constituição da configuração subjetiva da ação, envolveu organização na processualidade de expressão e produção de sentidos subjetivos históricos e atuais, em recursividade com a ação de aprender criativamente do sujeito, o que a configurou como processo de desenvolvimento da subjetividade, sobre o que aprofundaremos no próximo tópico.

\subsection{PRODUÇÃO TEÓRICA SOBRE MUDANÇAS E CONSTITUIÇÃO DE NOVOS} ASPECTOS NA SUBJETIVIDADE VINCULADOS AO PROCESSO DE APRENDIZAGEM CRIATIVA DA LEITURA E DA ESCRITA: FUNDAMENTAÇÃO DA TESE

Corroboramos González Rey (2012a) que a configuração subjetiva da ação atualizou a organização subjetiva das experiências vividas em devir e pôde promover o desenvolvimento da subjetividade, quando não apenas atualizou, mas promoveu mudanças qualitativas. Essas se tornaram mais estáveis e passaram a integrar os núcleos de sentidos subjetivos e constituir novos núcleos, se organizando como unidade subjetiva do desenvolvimento.

Nosso trabalho apresentou contribuições ao campo teórico da Teoria da Subjetividade ao exemplificarmos empiricamente a configuração subjetiva da ação de aprender criativamente como unidade subjetiva do desenvolvimento. Organizamos a discussão deste tópico em dois aspectos que se articularam: o como ocorreu o desenvolvimento da subjetividade e o que o promoveu, momento em elaboramos um mecanismo desse processo.

Sobre como ocorreu o desenvolvimento da subjetividade, em consonância com González Rey (2007b), nossa pesquisa possibilitou compreender que o mesmo se organizou por mudanças nos núcleos de sentidos subjetivos, as quais se tornaram relativamente estáveis, geradas pela produção de sentidos subjetivos capazes de reconfigurar os núcleos de sentidos subjetivos já existentes, assim como pela geração de novos núcleos de sentidos subjetivos.

Nos casos estudados, em suas singularidades, ocorreram mudanças qualitativas que envolveram, de certa forma, todos os núcleos de sentidos subjetivos da configuração subjetiva da ação de aprender criativamente. Em Murilo, como exemplo, as produções 
subjetivas, associadas à relação com a professora Melissa, foram dinamizadoras da produção de novos sentidos subjetivos associados à autovaloração no campo da aprendizagem. Em Adriana, citamos as mudanças associadas à relação com a mãe e ao brincar de ser professora, vinculadas à relação com o pai, dinamizadora de novas produções subjetivas de sua autoconfiança no seu processo de aprendizagem, o que envolveu uma relação positiva com seus erros. Em Gabriel, podemos citar novas produções subjetivas associadas à escrita e a leitura como expressão de suas ideias.

Assim como novas produções de sentidos subjetivos foram capazes de compor novos núcleos de sentidos subjetivos, os quais passaram a se organizar de forma mais estável na subjetividade dos participantes da pesquisa. Em Murilo, se constituíram dois novos núcleos, um esteve relacionado às produções subjetivas associadas ao status diferenciado que passou a ocupar no âmbito familiar e o outro vinculado a sentidos subjetivos relacionados à resolução científica de seus conflitos pessoais. Em Adriana, se gestou o núcleo de sentidos subjetivos vinculados à relação com a aprendizagem para além do contexto escolar. Em Gabriel, o novo núcleo associou-se às produções subjetivas relacionadas à leitura e à escrita como possibilidade de conquistar e aprofundar novos conhecimentos.

Também corroboramos González Rey (1995) e Rossato (2009) que outros elementos como a processualidade e a temporalidade caracterizaram o desenvolvimento da subjetividade. Em Murilo, estas dimensões se expressaram na forma como as produções subjetivas associadas à relação com os colegas demandou tempo para que novas produções subjetivas se tornassem mais estáveis e lhe permitissem estabelecer vínculos afetivos mais próximos com o outro. Acompanhamos também em Gabriel, na relação que estabelecia entre o desenho e a escrita, uma processualidade de produções subjetivas que demandaram tempo para se tornarem mais estáveis. Em Adriana, este processo se configurou nas produções subjetivas associadas à relação com as professoras que, com o tempo, foram capazes de novas ações e novas produções subjetivas associadas ao distanciamento de Adriana da escola.

Nesta perspectiva, interpretamos que houve um mecanismo de desenvolvimento da subjetividade em que, a produção de sentidos subjetivos capazes de promover mudanças e a constituição de novos núcleos de sentidos subjetivos, como destacamos anteriormente, se organizou em recursividade com as ações do sujeito em contexto mediante a experiência de aprender criativamente e a organização subjetiva atual. Corroboramos González Rey (2007b), que o que promoveu mudanças reconfiguradoras da organização subjetiva dos aprendizes, favorecedoras de novas ações, esteve associada à 
produção de sentidos subjetivos nas ações e relações do sujeito nos diferentes contextos de atuação.

Em Murilo, podemos exemplificar o mecanismo de desenvolvimento da subjetividade, pela condição de sujeito frente aos conflitos experienciados com a irmã, favorecedores de produções subjetivas associadas a se sentir menos valorizado pelos familiares, que pela autoconfiança relacionada ao campo da aprendizagem criativa, empreendeu ações de buscar ensiná-la a ler e a escrever, favorecedoras de novas produções subjetivas associadas à resolução científica de conflitos.

Em Adriana, a assunção da sua condição de sujeito frente à tensão gerada na relação com as professoras, em meio a produções subjetivas de necessidade de reconhecimento social, dinamizaram a criação de novos caminhos de atuação para além do contexto escolar, favorecedoras de novas expressões da criatividade e também de novas produções subjetivas associadas à autoconfiança. Em Gabriel, a assunção do sujeito na vida, na relação com a questão financeira dos pais, em meio a produções subjetivas capazes de associar a aprendizagem à vida, esteve presente nas ações empreendidas para encontrar caminhos de ajudar os pais, em um processo criativo que envolveu novas ações que transcendiam o vivido por novas produções subjetivas associadas à autoconfiança.

A relação recursiva entre a aprendizagem criativa da leitura e da escrita e o desenvolvimento da subjetividade dos sujeitos da pesquisa, de acordo com González Rey (2007b, 2011a), se associa à produção de sentidos subjetivos pela processualidade geradora dos mesmos em confluência com a organização subjetiva da ação e relações do sujeito na dinâmica da experiência de aprender. Desta forma, corroboramos González Rey (2007b), Rossato (2009) e Santos (2010) que o que caracterizou as mudanças favorecedoras do desenvolvimento da subjetividade, além da relativa estabilidade adquirida, foi o impacto que tiveram tanto na organização subjetiva, capazes de gerar rupturas na dinâmica subjetiva dominante, quanto no desenvolvimento da condição de sujeito. Nosso trabalho permitiu avançar em relação aos referidos autores ao trazermos as mudanças como espaços geradores de novas possibilidades de expressão da criatividade.

Como exemplo, em Adriana, o novo núcleo de sentidos subjetivos foi constituído em recursividade às produções subjetivas da configuração subjetiva da ação e a aprendizagem criativa, momento em que produz novos sentidos subjetivos associados à aprendizagem aliada a outros contextos sociais, que configuram novas formas de expressão da criatividade, como suas publicações no facebook. Em Murilo, novas produções subjetivas associadas à resolução científica de seus conflitos, dinamizaram a expressão da criatividade como a sua defesa ao 
meio ambiente, abrindo para uma atuação efetiva no mundo. Em Gabriel, por exemplo, as novas produções subjetivas, associadas a aprofundar seus conhecimentos diante da relação com os livros, engendrava novos enredos para suas histórias, de cunho mais científicos, em que buscava aprofundar conhecimentos para escrever.

Nos três casos analisados, identificamos que o desenvolvimento da subjetividade em relação às ações vinculadas à aprendizagem criativa da leitura e da escrita favoreceu, dentre outros aspectos, o processo de individualização dos sujeitos, associado à autoafirmação na aprendizagem, o que corrobora González Rey (1995) e Rossato (2009) de que o desenvolvimento da subjetividade requer uma relação pessoal com a experiência. A título de exemplificação, em Adriana identificamos sua autoafirmação em suas produções, sem necessariamente depender de reconhecimento social. Gabriel passou a significar a leitura e a escrita como processos próprios de se afirmar pela personalização de sua escrita e a escrita de histórias com caráter inédito. Em Murilo, havia produções subjetivas associadas ao conhecimento de suas potencialidades e possibilidades de atuar com a leitura e a escrita na vida.

Temos apresentado até então, nesse trabalho, os argumentos que nos possibilitaram fundamentar a tese de que, na aprendizagem da leitura e da escrita, a criatividade emerge de forma sistêmica e constitui-se processo de desenvolvimento da subjetividade da criança. Frente às nossas elaborações, compreendemos que a aprendizagem criativa da leitura e da escrita como processo de desenvolvimento da subjetividade, se organizou como um caminho relacional, integrada à vida, pela capacidade geradora do sujeito de se colocar como atuante, fazendo dos processos da linguagem uma possibilidade de expressão própria e constituidora de novos processos de subjetivação. Por fim, ressaltamos que, em Murilo, Adriana e Gabriel, a criatividade permitiu a exploração de suas possibilidades, atuando como protagonistas de sua aprendizagem, de inscrição e criação no mundo, na busca de conhecê-lo e, em alguma medida, transcendê-lo. 


\section{CONSIDERAÇÕES FINAIS}

Para desenvolvimento do presente estudo, foi necessário atuar como sujeito pesquisador, no movimento de nossa própria constituição subjetiva, em meio às possibilidades de nos inserirmos como autores e empreendedores de nossas elaborações, na busca de gerar inteligibilidade aos objetivos propostos. No percurso da pesquisa, pela trajetória reflexiva, construtora e produtora que a constituiu, consideramos ter alcançado o objetivo geral que propusemos à pesquisa, qual seja: compreender como a criatividade emerge na aprendizagem da leitura e da escrita e suas inter-relações com o desenvolvimento da subjetividade da criança, fundamentando a tese de que, na aprendizagem da leitura e da escrita, a criatividade emerge de forma sistêmica e constitui-se processo de desenvolvimento da subjetividade da criança.

Reconhecemos que, no desenvolvimento da pesquisa, deparamo-nos com, pelo menos, três desafios que nos inquietaram e mobilizaram ações em busca de superá-los. Um dos desafios foi a construção de inteligibilidade que envolveu relacionar três temas que, no âmbito do campo científico, ainda não havia dialogado, quais sejam, aprendizagem da leitura e da escrita, aprendizagem criativa e subjetividade. Outro foi o processo construtivo-interpretativo, que na perspectiva da Epistemologia Qualitativa, demandava, ao mesmo tempo, conhecer profundamente a teoria e produzir ideias no fluxo da pesquisa empírica. Por último, destacamos o desafio de caracterizar a criatividade na aprendizagem da leitura e da escrita da criança, uma vez que, não identificamos no campo científico, trabalhos sobre tal processo, o que conferiu responsabilidade de alinhavar esta elaboração de forma inédita, embasados por características e estratégias identificadas em aprendizes criativos de outros níveis de ensino.

A pesquisa gerou contribuições ao campo da aprendizagem da leitura e da escrita, as quais organizamos no presente momento em inter-relação aos eixos que elaboramos na parte referente à revisão bibliográfica. Vale destacar que nosso trabalho guarda suas especificidades em relação ao campo científico da aprendizagem da leitura e da escrita, principalmente por tratarmos deste processo associado à criatividade e, por consonância à subjetividade; no entanto, identificamos possibilidades de diálogos com os trabalhos que versam sobre a leitura e a escrita, pelo valor que conferimos às nossas elaborações.

No eixo referente às pesquisas de revisões bibliográficas ao campo da aprendizagem da leitura e da escrita, interpretamos que há uma tendência, no campo científico, ao estudo e 
aspectos em separado, dentre os quais estão: emoções, processos simbólicos, culturais e sociais. Nosso trabalho contribuiu para a compreensão da aprendizagem da leitura e da escrita em uma dimensão mais complexa, capaz articular os processos citados em separados, em seu funcionamento para além de dicotomias. Desta forma, foi possível explicitar a unidade do simbólico e do emocional no processo de aprendizagem da leitura e da escrita, assim como trazer a cultura e o social como processos de produção da criança frente ao contexto da ação. Ademais, nosso trabalho, realizado no contexto escolar, contribuiu para entender como sentidos subjetivos produzidos pelo aprendiz em diferentes contextos sociais de atuação, se atualizaram e participaram de forma diferenciada de seu processo de aprendizagem.

Em relação às pesquisas com ênfase nos estágios e processos operacionais da aprendizagem, nosso estudo favoreceu entender que, na aprendizagem criativa da leitura e da escrita, o aprendiz se ensejou como produtor de conhecimento em uma dimensão geradora do sujeito, processo que envolveu mudanças e não se constituiu como únicas e vinculadas a etapas universais, mas sim, à singularidade de aprender de cada um. Neste processo, o aprendiz lançou mão de diferentes estratégias de aprendizagem, em que prevaleceram as de autorregulação, que estiveram vinculadas às características da criatividade, constituindo processo subjetivo, em meio à relação sujeito-contexto-organização subjetiva.

No campo das pesquisas com foco no caráter inventivo, no significado e no sentido, nossa pesquisa contribuiu ao mostrar que, na aprendizagem criativa, há uma unidade entre autoria e o caráter empreendedor do sujeito na ação de aprender. Assim como destacou o funcionamento da imaginação e do pensamento como processos subjetivos, o que, pode ou não se expressar no registro escrito. Desta forma, contribuímos para a compreensão de que a aprendizagem da leitura e da escrita não se limita ao caráter simbólico, ou seja, à reificação da linguagem, mas em unidade estão as emoções, caracterizando a aprendizagem como processo subjetivo. Também apresentamos elementos que caracterizam, na singularidade de cada aprendiz, a criatividade na aprendizagem da leitura e da escrita.

No que tange às pesquisas com foco nos processos interacionais e contextuais nosso estudo possibilitou destacar a aprendizagem da leitura e da escrita associada a elementos da subjetividade individual da criança, da subjetividade social e dos sistemas relacionais. Foi possível compreender que não há um impacto unidirecional das formas de ensinar e a aprendizagem dos alunos, mas processos singulares de subjetivação que não se limitam ao espaço-tempo da sala de aula, rompendo com dicotomias presentes no campo da alfabetização associadas à relação interno e externo, individual e social. Nossa pesquisa destacou que a 
qualidade dos sistemas relacionais, pela forma como o outro se torna produtor de sentidos subjetivos para o aprendiz, pode impactar a aprendizagem.

Em relação às pesquisas com foco no desenvolvimento humano e nos processos subjetivos, interpretamos que nossa contribuição se efetiva pela inter-relação entre aprender criativamente a leitura e a escrita e o desenvolvimento da subjetividade da criança. Isso traz significativos aportes do movimento ativo, produtor e protagonista que o aprendiz pode assumir frente à sua própria aprendizagem e ao seu desenvolvimento. Consideramos que compreender como a criatividade emerge na aprendizagem da leitura e da escrita possibilitou abrir novas zonas de sentido e gerar inteligibilidade sobre a qualidade com que a criança atua com este aprender em sua vida, rompendo com o caráter utilitário e prático da leitura e da escrita. Pressupomos ter contribuído com as discussões no campo do letramento, ao vincularmos a utilização do aprendido com impactos no modo de vida do aprendiz.

Outra contribuição da presente pesquisa se alinhava à perspectiva históricocultural e em seu âmbito à Teoria da Subjetividade de González Rey, em que reconhecemos três importantes colaborações. Uma vinculada ao valor heurístico da categoria configuração subjetiva da ação, em sua possibilidade de produzir inteligibilidade sobre a dinâmica que organiza a experiência, que, em nosso caso foi aprender. Neste processo, se configuraram elementos da subjetividade individual, produções subjetivas da experiência de aprender, aspectos da subjetividade social e dos sistemas relacionais da ação de aprender. O valor da categoria configuração subjetiva da experiência está justamente na possibilidade que nos mune de compreender a experiência de aprender em sua complexidade.

Uma segunda contribuição, à referida teoria, relaciona-se às nossas construções empíricas acerca da categoria unidade subjetiva de desenvolvimento, a qual tem sido tratada teoricamente por González Rey. Pelo processo construtivo-interpretativo que permeou a pesquisa, apresentamos elementos significativos tanto para o como se constituiu, como o mecanismo que a organizou, momento em que definimos a recursividade entre a aprendizagem criativa e o desenvolvimento da subjetividade da criança. A terceira contribuição de nossa pesquisa está associada ao delineamento de instrumentos, tendo em vista que os participantes da pesquisa foram crianças. $O$ que demandou aprofundar o conhecimento sobre os instrumentos já elaborados no campo científico, no âmbito da teoria de González Rey, além da simultaneidade entre o envolvimento com os participantes e a produção instrumentos que favoreceram a expressão dos mesmos.

A pesquisa também trouxe contribuições ao campo da aprendizagem criativa, principalmente aos trabalhos de Mitjáns Martínez. Nossas contribuições estão desde a 
compreensão da expressão da criatividade na aprendizagem em um campo específico, que foi a leitura e a escrita, assim como pelos participantes, por se tratarem de crianças. Outras colaborações estiveram associadas ao vínculo entre estratégias de aprendizagem e as características da aprendizagem criativa. Sobre essas, nosso trabalho adiciona aos estudos da referida autora: a relação da personalização da informação com o modo de vida dos aprendizes; na geração de ideias próprias e novas que transcendem o dado, além do caráter gerador do novo, apresentamos a forma como o novo favoreceu a abertura de outras possibilidades de produção de novidade e a dimensão empreendedora do sujeito.

Neste processo, ainda, alinhavamos uma nova característica da aprendizagem criativa que se une às demais, como especificidade da expressão da criatividade na criança, a qual denominamos relação lúdica. Ainda assim, outras contribuições aos estudos de Mitjáns Martínez, referem-se às nossas construções empíricas sobre a dimensão funcional da criatividade na aprendizagem da leitura e da escrita. Isso envolveu a ação do sujeito na criação de caminhos próprios de atuação e, em consonância, produções subjetivas que reconfiguravam a organização subjetiva. Essa dimensão também se expressou em seu caráter instrumental, articulada às produções dos aprendizes com valor para sua própria aprendizagem, para o desenvolvimento da condição de sujeito, como processo de realização pessoal e com impactos em seu modo de vida.

Diante do exposto, podemos retomar as perguntas feitas na introdução do presente trabalho e avançar sobre algumas possibilidades de respostas, uma vez que, a partir do nosso trabalho compreendemos que a alfabetização é um processo que se alonga pela vida da criança. Desta forma, não tem uma idade certa para que se efetive, pois está organizada por reflexões, questionamentos, que não se findam em etapas ou idades determinadas. Assim como trouxemos elementos de que as próprias crianças, em sua condição de sujeitos da aprendizagem, geravam caminhos alternativos à uma prática pedagógica que se limitava à decodificação e à codificação.

Frente ao trabalho realizado, destacamos também os desdobramentos dos seus resultados: Para a implementação das políticas públicas: por fornecer subsídios para a elaboração de projetos educacionais cuja preocupação reside na qualidade do processo de alfabetização das crianças. Nosso trabalho destaca como um tipo de aprendizagem complexa, como a aprendizagem criativa, pode favorecer tanto uma aprendizagem efetiva da leitura e da escrita, como se constituir como processo de desenvolvimento da subjetividade da criança. Nessa perspectiva, a aprendizagem criativa é uma condição para contribuir com as propostas mais atuais das políticas públicas tendo em vista garantir a qualidade do processo de aprender. 
Para a prática pedagógica do professor: por apresentar elementos que configuram o como a criança aprende criativamente, em um processo associado à própria relação com o professor, subsidiando sua prática em direção a favorecer a constituição de recursos subjetivos que dinamizam esta forma de aprender como: gosto pelo desafio, abertura ao novo, autodeterminação, autoconfiança, flexibilidade, autonomia. A pesquisa fornece elementos para compreender aspectos importantes que devem ser conhecidos no aprendiz, tendo em vista elementos históricos, atuais, contextuais e subjetivos, que poderão ser o alicerce para a organização do trabalho pedagógico. Pelo processo construtivo-interpretativo, foi possível pontuar alguns elementos que participaram do trabalho pedagógico das professoras da pesquisa, favoráveis para que a criatividade emergisse na aprendizagem da leitura e da escrita:

a) conhecer o aprendiz em seus gostos, preferências, interesses e história de vida;

b) vincular o ensino e a aprendizagem com as experiências da vida da criança;

c) favorecer um espaço dialógico e instigador de novas inquietações dos aprendizes;

d) valorizar as ideias dos aprendizes e de suas conquistas;

e) estabelecer uma relação com alto grau de exigência quanto às possibilidades dos aprendizes na escrita e na leitura;

f) respeitar à linguagem oral e escrita dos alunos, como ponte para reflexões;

g) favorecer um clima investigativo na relação dos aprendizes com suas próprias produções;

h) estimular a dúvida, questionamentos e participação efetiva dos aprendizes;

i) proporcionar experiência de leitura e contação de histórias com ênfase na fantasia e na imaginação;

j) utilizar a biblioteca como espaço para leitura e pesquisa;

k) diversificar os tipos de atividade e sua realização: individual, dupla e de forma coletiva;

1) favorecer momentos de escrita espontânea em sala de aula articulada ao diálogo com o outro e consigo mesmo;

m) propor situações desafiadoras, geradoras de tensões, provocações que possam surpreender e instigar a reflexão e a busca por novas descobertas;

n) personalizar o contexto de aprendizagem e as atividades propostas, para que sejam desafiadoras e coloque o aprendiz como autor e empreendedor de suas elaborações;

o) utilizar os livros como recursos de possibilidades de pensamento, de formação de opinião própria, como possibilidade de transcender, em alguma medida, o que foi lido;

p) propiciar relação de parceria entre a escola a família.

Para o processo de formação inicial e continuada de professores: com subsídios para a compreensão de um tipo de aprendizagem complexa, como a aprendizagem criativa e sua 
expressão na aprendizagem da leitura e da escrita, trazendo as múltiplas nuances que acompanham este processo, tendo em vista a sua relação com o desenvolvimento da subjetividade da criança. Consideramos que essa contribuição favorece um diálogo entre diferentes áreas de conhecimento: Pedagogia, Psicologia, Sociolinguística, Linguística e outras. Nossa pesquisa também fornece elementos para a relação do professor como sujeito pesquisador do contexto da sala de aula, espaço gerador de elaborações sobre o aprendiz no movimento da aprendizagem como produção subjetiva. No campo da avaliação, nosso trabalho também contribuiu com elementos substanciais para que reflexões sobre como conhecer o aprendiz tendo em vista o seu desenvolvimento de forma mais integral, ou seja, para além de atividades diagnósticas que avaliam apenas a leitura e a escrita como um fim em si mesmas, atentar-se para processos simbólicos-emocionais.

Consideramos que o trabalho com uma perspectiva que envolva desenvolvimento da subjetividade pode guardar algumas limitações, dentre as quais destacamos a temporalidade que mudanças podem necessitar para se vincular ao sistema subjetivo da pessoa. Na presente pesquisa, experienciamos o trabalho de campo por vinte e dois meses, em que acompanhamos os participantes por dois anos escolares consecutivos; no entanto, precisamos entender que o tempo das mudanças envolve a singularidade de cada aprendiz, o que pode requerer mais ou menos tempo para adquirir certa estabilidade na organização subjetiva da pessoa. No entanto, pela qualidade do que foi possível produzir na relação com os participantes, nos permitiu compreender o movimento deste processo e trazer mudanças que, do nosso ponto de vista, se tornaram mais estáveis, e que estas continuam em pleno devir.

Como proposta para pesquisas futuras, nosso trabalho abre dois importantes caminhos investigativos que envolvem: a) aprofundar as possibilidades de como o trabalho pedagógico, desenvolvido em sala de aula, pode ser favorecedor para que a criatividade emerja na aprendizagem da leitura e da escrita; e b) investimentos de pesquisas na compreensão da criatividade como princípio funcional da aprendizagem da leitura e da escrita. Nosso estudo apontou para alguns elementos essenciais destes processos, que merecem aprofundamentos em sua especificidade. A partir da presente investigação também nos propomos à escrita de dois artigos como desdobramentos do presente trabalho, assim intitulados: a) Aprendizagem criativa da leitura e da escrita como processo de desenvolvimento da subjetividade da criança; e b) A criatividade na aprendizagem da leitura e da escrita: diálogos com a prática pedagógica do professor. 


\section{REFERÊNCIAS}

ABAURRE, Maria Bernadete Marques. Uma história individual. In: ABAURRE, M. B. M.; SALEK FIAD, R.; MAYRINK-SABINSON, M. L. T. Cenas da aquisição da escrita: o sujeito e o trabalho com o texto. Campinas: Mercado das letras: Associação de Leitura do Brasil, 1997. cap. 6, p. 79-115.

ABAURRE, Maria Bernadete Marques; FIAD, Raquel Salek; MAYRINK-SABINSON, Maria Laura T. Em busca de pistas. In: ABAURRE, M. B. M.; SALEK FIAD, R.;

MAYRINK-SABINSON, M. L. T. Cenas da aquisição da escrita: o sujeito e o trabalho com o texto. Campinas: Mercado das letras: Associação de Leitura do Brasil, 1997. cap. 1, p. 13 36.

ALVES, Janete Fassini. Implicações do processo de alfabetização na formação do leitor competente. 2006. 167 f. Dissertação (Mestrado em Letras e Cultura Regional) Universidade de Caxias do Sul, Caxias do Sul, 2006.

AMARAL, Ana Luiza S. N. O sentido subjetivo da aprendizagem para alunos universitários criativos. 2006. 194 f. Dissertação (Mestrado em Educação) - Universidade de Brasília, Brasília, DF, 2006.

. A constituição da aprendizagem criativa no processo de desenvolvimento da subjetividade. 2011. 243 f. Tese (Doutorado em Educação) - Universidade de Brasília, Brasília, DF, 2011.

AMARAL, Ana Luiza S. N.; MITJÁNS MARTÍNEZ, Albertina. Aprendizagem criativa no ensino superior: a significação da dimensão subjetiva. In: MITJÁNS MARTÍNEZ, A.; TACCA, M. C.V. R. (Org.). A complexidade da aprendizagem: destaque ao ensino superior. Campinas: Alínea, 2009. cap. 6, p. 149-192.

ANDRADE, Beatriz Gracioli. Impactos de práticas pedagógicas centradas no letramento em crianças pré-escolares. 2011. 249 f. Dissertação (Mestrado em Educação) - Universidade Estadual de Campinas, Campinas, 2011.

ANDRÉ, Marli Eliza Dalmazo Afonso de. Etnografia da prática escolar. 10. ed. Campinas: Papirus, 2003.

ANDRÉS, Maria Laura et al. Disponibilidad de recursos materiales en el hogar y adquisición de habilidades pre-lectoras. Revista Semestral da Associação Brasileira de Psicologia Escolar e Educacional, São Paulo, v.14, n. 1, p. 139-148, jan./jun. 2010.

ANTUNES, Irandé. Muito além da gramática: por um ensino de línguas sem pedras no caminho. São Paulo: Parábola, 2007.

ARENA, Dagoberto Buim. Relações entre ler e fazer locução no ensino fundamental. In: Congresso de leitura do Brasil, 16, 2007, Campinas. Anais... Campinas: ALB, 2007. Disponível em: http://alb.com.br/arquivomorto/edicoes_anteriores/anais16/sem10pdf/sm10ss09_01.pdf>. Acesso em: 14 set. 2014. 
. Ensinar a ler em debate: vozes de professores. In: FONSECA, S. G. (Org.). Ensino fundamental: conteúdos, metodologias e práticas, 2009. cap. 1, p. 25-48.

ARENA, Dagoberto Buim; ARENA, Adriana Pastorello Buim; SANTOS, S. O. O. Escolhas de letras nas primeiras escritas infantis: função e unidade no discurso. Ensino em Re-vista, Uberlândia, v. 18, p. 67-80, 2011.

BADIA, Montserrat Castelló. Las estrategias de aprendizaje en el proceso de composición escrita. In: FONT, C. M. (Org.). Estrategias de Aprendizaje. Madrid: Visor Dis, 2000a. cap. 4, p.147-184.

. Las estrategias de aprendizaje en el área de lectura. In: FONT, C. M. (Org.). Estrategias de Aprendizaje. Madrid: Visor Dis, 2000b. cap. 5, p.185-218.

BAJARD, Élie. Caminhos da escrita: espaços de aprendizagem. 2. ed. São Paulo: Cortez, 2002.

Ler e dizer: compreensão e comunicação do texto escrito. São Paulo: Cortez, 2005.

BAKHTIN, Mikhail. Marxismo e filosofia da linguagem: problemas fundamentais do Método Sociológico na Ciência da Linguagem. São Paulo: Hucitec, 2010.

BARBATO, Silviane Bonaccorsi. Letramento: Conhecimento, imaginação e leitura de mundo nas salas de inclusão de crianças de seis anos no ensino fundamental. In: CHOLZE, L.; ROSING, T. M. K. (Org.). Teorias e práticas de letramento. Brasília, DF: Inep, 2007. p. 273-287.

. Integração de crianças de 6 anos ao ensino fundamental de nove anos. São Paulo: Parábola, 2008.

BARRERA, Sylvia Domingos; MALUF, Maria Regina. Consciência metalinguística e alfabetização: um estudo com crianças da primeira série do ensino fundamental. Psicologia: reflexão e crítica, Porto Alegre, v. 16, n.3, p. 491-502, 2003.

BASSO, Fabiane Puntel. A estimulação da consciência fonológica e sua repercussão no processo de aprendizagem da lecto-escrita. 2006. 172 f. Dissertação (Mestrado em Educação) - Universidade Federal de Santa Catarina, Santa Maria, 2006.

BENJAMIN, Walter. Reflexões sobre a criança, o brinquedo e a educação. São Paulo: 34, 2002.

BERNARDIN, Jacques. As crianças e a cultura escrita. Porto Alegre: Artmed, 2003.

BEZERRA, Cláudia Santos Gonçalves. O sentido subjetivo do aprender. 2004. 216 f.

Dissertação (Mestrado em Psicologia) - Universidade Católica de Goiás, Goiânia, 2004.

BOA, Rubia Barroso. Estratégias reveladas pelas crianças na elaboração da escrita. 2002. 83 f. Trabalho de Conclusão de Curso (Graduação) - Universidade Federal de Campinas, Campinas, 2002. 
BORTONI-RICARDO, Stella Maris. Variação linguística e atividade de letramento em sala de aula. In: KLEIMAN, Ângela B. (Org.). Os significados do letramento: uma nova perspectiva sobre a prática social da escrita. Campinas: Mercado de letras, 1995. cap. 4, p. 119-143.

. Educação em língua materna: a sociolinguística na sala de aula. São Paulo: Parábola, 2004.

Métodos de alfabetização e consciência fonológica: o tratamento de regras de variação e mudança. SCRIPTA - Linguística e Filologia, Belo Horizonte, v. 9, n. 18, p. 201$220,2006$.

BORTONI-RICARDO, Stella Maris; SOUSA, Maria Alice Fernandes de. Andaimes e Pistas de Contextualização: um estudo do processo interacional em sala de alfabetização. In: TACCA, M. C. V. R. (Org.). Aprendizagem e trabalho pedagógico. Campinas: Alínea, 2008a. cap. 8, p. 167-180.

BORTONI-RICARDO, Stella Maris; SOUSA, Maria Alice Fernandes de. Falar, ler e escrever em sala de aula. São Paulo: Parábola, 2008b.

BORTONI-RICARDO, Stella Maris; MACHADO, Veruska Ribeiro; CASTANHEIRA, Salete Flôres. Formação do professor como agente letrador. São Paulo: Contexto, 2010.

BORTONI-RICARDO, Stella Maris et al. Leitura e mediação pedagógica. São Paulo: Parábola, 2012.

BORTONI-RICARDO, Stella Maris; OLIVEIRA, Tatiana de. Corrigir ou não variantes não padrão na fala do aluno? In: BORTONI-RICARDO, S.; MACHADO, V. R. (Org.). Os doze trabalhos de Hércules: do oral para o escrito. São Paulo: Parábola, 2013. cap. 3, p. 45-62.

BRASIL. Lei no 9.394 de 20 de dezembro de 1996. Lei de diretrizes e bases da Educação (LDB). 1996.

. Congresso Nacional. Câmara dos Deputados. Grupo de trabalho alfabetização infantil: os novos caminhos: relatório final. 2. ed. Brasília, DF, 2007. Disponível em: <http://bd.camara.gov.br/bd/bitstream/handle/bdcamara/1924/grupo_alfabetizacao_infantil_e ducacao_cultura.pdf?sequence=1>. Acesso em: 14 dez. 2012.

. Ministério da Educação. Ensino fundamental de nove anos: orientações gerais. Brasília, DF: Secretaria de Educação Básica, 2004.

Lei $\mathbf{n}^{\mathbf{0}} \mathbf{1 1 . 1 1 4}$, de 16 de maio de 2005. Altera os artigos $6^{\circ}, 30,32$ e 87 da Lei ${ }^{\circ}$ 9394, de 20 de dezembro de 1996, com o objetivo de tornar obrigatório o início do ensino fundamental aos seis anos de idade, 2005.

Lei $\mathbf{n}^{\mathbf{0}}$ 11.274, de 06 de fevereiro de 2006. Altera a redação dos artigos 29, 30, 32 e 87 da Lei no 9394, de 20 de dezembro de 1996, que estabelece as diretrizes e bases da educação nacional, dispondo sobre a duração de 9 (nove) anos para o ensino fundamental, com matrícula obrigatória a partir dos 6 (seis) anos de idade, 2006 . 
. Ministério da Educação. Ensino fundamental de nove anos: orientações para a inclusão da criança de seis anos de idade. Brasília: FNDE, Estação Gráfica, 2006b.

. Pacto Nacional pela Alfabetização na idade certa. 2012. Disponível em:

<http://pacto.mec.gov.br/index.html>. Acesso em: 10 dez. 2012.

BROUGÈRE, Gilles. Jogo e educação. Porto Alegre: Artes Médicas, 1998a.

. A criança e a cultura lúdica. Revista da Faculdade de Educação, São Paulo, v. 24, n. 2, p. 103-116, 1998b.

. Lúdico e educação: novas perspectivas. Linhas Críticas, Brasília, v. 8, n. 14, p. 520, 2002.

. Brinquedo e cultura. São Paulo: Cortez, 2008.

CABANAH et al. Autorregulación del aprendizaje y estratégias de estúdio. In: GONZÁLEZPIENDA J. A. et al. (Org.). Estrategias de Aprendizaje: Concepto, evaluación e intervención. Madrid: Pirámide, 2002. p.17-35.

CAGLIARI, Luiz Carlos. Alfabetizando sem o ba-bé-bi-bó-bu. São Paulo: Scipione, 2009.

CANTÚ, Gustavo. Lectura y subjetividad en el diagnóstico psicopedagógico. Buenos Aires: Noveduc, 2011.

. A experiência de ler: teoria, clínica, pesquisa. In: MITJÁNS MARTÍNEZ, A.; ÁLVAREZ, P. (Org.). O sujeito que aprende. Brasília, DF: Liber Livro, 2014. cap. 5, p. 123-150.

CAPOVILLA, Alessandra G. S.; CAPOVILLA, Fernanda C. Alfabetização: método fônico. São Paulo: Memnon, 2004.

CARDOSO-MARTINS, Cláudia. Existe um estágio silábico no desenvolvimento da escrita em português? Evidência de três estudos longitudinais. In: MALUF, M. R.; CARDOSOMARTINS, C. Alfabetização no século XXI: como se aprende a ler e a escrever. Porto Alegre: Penso, 2013. cap. 3, p. 82-108.

CARDOSO-MARTINS, Cláudia; BATISTA, Anna Cláudia Eutrópio. O conhecimento do nome das letras e o desenvolvimento da escrita: evidência de crianças falantes do Português. Psicologia: Reflexão \& Crítica, v. 18, p. 299-306, 2005.

CARDOSO-MARTINS, Cláudia; CORREA, Marcela Fulanete. O desenvolvimento da escrita nos anos pré-escolares: questões acerca do estágio silábico. Psicologia: Teoria e Pesquisa. v. 24, n. 3, p. 279-286, 2008. Brasília.

CARNOY, Martin. A vantagem acadêmica de Cuba: por que seus alunos vão melhor na escola. São Paulo: Ediouro, 2009. 
CARVALHO, Lina Maria de Moraes. Consciência fonológica e sucesso na aprendizagem da leitura e da escrita: melhor prevenir do que remediar. 2010. 320 f. Tese (Doutorado em Psicologia) - Pontifícia Universidade Católica de São Paulo, São Paulo, 2010.

CASTANHO, Ana Flavia Alonça. A formação do leitor: aspectos afetivos e cognitivos. 2006. 110 f. Dissertação (Mestrado em Educação) - Universidade de São Paulo. São Paulo, 2006.

CASTRO, Flávia da Silva. Letramento e alfabetização: sociogênese e/ou psicogênese, quais os caminhos da apropriação da escrita? 2010. 165 f. Dissertação (Mestrado em Educação) Pontifícia Universidade Católica do Rio Grande do Sul, Porto Alegre, 2010.

CAVATON, Maria Fernanda Farah. A mediação da fala, do desenho e da escrita na construção de conhecimento da criança de seis anos. 2010. $174 \mathrm{f}$. Tese (Doutorado em Processos de Desenvolvimento Humano e Saúde) - Universidade de Brasília, Brasília, DF, 2010.

CAVATON, Maria Fernanda Farah; BARBATO, S. A fala egocêntrica da criança de seis anos na construção coletiva da escrita. Revista Acolhendo a Alfabetização nos Países de Língua Portuguesa. v. 1, n. 11, p. 78-102, set. 2011. Disponível em:

<http://www.acoalfaplp.net>. Acesso em: 23 jul. 2012. São Paulo.

CAXANGÁ, Maria do Rosário Rocha. Práticas de letramento da família e apropriação da escrita e da leitura por crianças alfabetizandas. 2007. 214 f. Dissertação (Mestrado em Educação) - Universidade de Brasília. Brasília, DF, 2007.

CERTEAU, Michel de. A invenção do cotidiano: Artes de fazer 1. 17. ed. Petrópolis: Vozes, 2011.

COELHO, Cristina Madeira. Sujeito, linguagem e aprendizagem. In: MITJÁNS MARTÍNEZ, A.; TACCA, M. C.V. R. (Org.). A complexidade da aprendizagem: destaque ao ensino superior. Campinas: Alínea, 2009. cap. 2, p. 31-52.

. Linguagem, fala e audição nos processos de aprendizagem: desafios e estratégias. In: MITJÁNS MARTÍNEZ, A.; TACCA, M. C. V. R. (Org.). Possibilidades de aprendizagem: ações pedagógicas para alunos com dificuldade e deficiência. Campinas: Alínea, 2011. cap. 6 , p. 153-174.

COLLINS, James; BLOT, Richard. Literacy and literacies: texts, power, and identity.

Cambridge University Press, 2003.

CORREA, Jane; MACLEAN, Morag. Aprendendo a ler e a escrever: a narrativa das crianças sobre a alfabetização. Psicologia reflexão e crítica, Porto Alegre, v. 12, n. 2, p. 273-286, 1999.

COSTA, Marina Teixeira Mendes de Souza; SILVA, Daniele Nunes Henrique; SOUZA, Flavia Faissal de. Corpo, atividades criadoras e letramento. São Paulo: Summus, 2013. 
COUTO, N. S.; ARENA, D. B.; MELLO, S. A. Desenvolvimento da função simbólica da criança e apropriação da leitura e da escrita na infância: conceitos e implicações pedagógicas da teoria histórico-cultural. In: ENCONTRO DE PESQUISA EM EDUCAÇÃO DA REGIÃO SUDESTE, 8., 2007, Vitória. Desafios da educação básica: a pesquisa em educação. Vitória: UFES, 2007. v. 1, p. 367-368.

CHAMBERLAIN, Liz. Creativity and literacy. In: WILSON, A. (Org.). Creativity in Primary Education. Exeter: Learning Matters, 2005. cap. 6, p. 68-76.

CHEN, Si; ZHOU, Jing. Creative writing strategies of young children: Evidence from a study of Chinese emergent writing. Thinking Skills and Creativity, China, v. 5, p. 138-149, 2010.

CRAFT, Anna. Changes in the landscape for creativity in education. In: WILSON, A. (Org.). Creativity in Primary Education. Exeter: Learning Matters, 2005. cap. 1, p. 5-21.

Creative learning and possibility thinking. American Educational Research Association Conference, New York, March, 2008.

A criatividade e os ambientes da educação infantil. In: PAIGE-SMITH, A.; CRAFT, A. (Org.). O desenvolvimento da prática reflexiva na educação infantil. Porto Alegre: Artmed, 2010. cap. 6, p. 120-135.

CUPOLILLO, Mercedes Villa. Os entrelaces dos cachinhos de Gabriela: reflexões sobre psicoterapia, educação e cidadania. Rio de Janeiro: Multifoco, 2013.

DREHER, Simone Aparecida de Souza. As estratégias metacognitivas de alunos em processo de alfabetização: uma reflexão sobre o aprender do aluno e o ensinar do professor. 2009. 159 f. Dissertação (Mestrado em Educação) - Universidade Católica do Paraná, Curitiba, 2009.

EGAN, Kieran. Por que a imaginação é importante na educação? In: FRITZEN, C.; CABRAL, G. da S. (Org.). Infância: imaginação e educação em debate. São Paulo: Papirus, 2009. cap. 1, p. 11-38.

EGLER, Valdívia de L. P. A aprendizagem de professores na Pós-Graduação: três estudos de caso. 2013. 182 f. Dissertação (Mestrado em Educação) - Universidade de Brasília, Brasília, DF, 2013.

EHRI, Linnea C. Aquisição da habilidade de leitura de palavras e sua influência na pronúncia e na aprendizagem do vocabulário. In: MALUF, M.; CARDOSO-MARTINS, C.

Alfabetização no século XXI: como se aprende a ler e a escrever. Porto Alegre: Penso, 2013, cap. 2, p. 49-81.

FONT, C. M. El Asesoramiento en el Ámbito de las Estrategias de Aprendizaje. In: FONT, C. M. (Org.). Estrategias de Aprendizaje. Madrid: Visor Dis, cap. 1, p.15-45, 2000.

FARIAS, Maria Cilvia Queizoz. Significados e dimensões da leitura - escrita no contexto familiar de crianças de seis a sete anos. 2006. 150 f. Dissertação (Mestrado em Educação) Universidade Federal do Ceará, Fortaleza, 2006. 
FERREIRO, Emília. A representação da linguagem e o processo de alfabetização. Cadernos de Pesquisa, São Paulo, n. 52, p. 1-17, fev. 1985.

Reflexões sobre alfabetização. São Paulo: Cortez, 1995.

FERREIRO, Emília; TEBEROSKY, Ana. Psicogênese da língua escrita. Porto Alegre: Artes Médicas, 1999.

FRANCO, Marco Antonio Melo. Práticas discursivas e construção da participação e da fala em uma turma de alfabetização. 2002. 156 f. Dissertação (Mestrado em Educação) Universidade Federal de Minas Gerais, Belo Horizonte, 2002.

FREINET, Celestin. As Técnicas Freinet da Escola Moderna. Lisboa: Estampa, 1975. O método natural III: a aprendizagem da escrita. Lisboa: Estampa, 1977.

FREIRE, Paulo. A importância do ato de ler: em três artigos que se completam. 51. ed. São Paulo: Cortez, 2011a.

. Pedagogia do oprimido. 50. ed. Rio de Janeiro: Paz e Terra, $2011 \mathrm{~b}$.

GARCÍA, Jesús G. S.; FUERTES, Ana de Caso. Estrategias cognitivas en la composición escrita: ilustración de un programa de intervención. In: GONZÁLEZ-PIENDA, J. A. et al. (Org.). Estrategias de Aprendizaje: concepto, evaluación e intervención. Madrid: Pirámide, 2002. p. 141-162.

GERALDI, João Wanderley. Portos de passagem. São Paulo: Martins Fontes, 1997.

. Alfabetização e letramento: perguntas de um alfabetizado que lê. In: ZACCUR, E.

(Org.). Alfabetização e letramento: o que muda quando muda o nome? Rio de Janeiro: Rovelle, 2011. cap. 2, p. 13-32.

GIROTTO, C. G. G. S; SOUZA, R. J. Estratégia de leitura: para ensinar alunos a compreender o que leem. In: SOUZA, R. J. de et al. Ler e compreender: estratégias de leitura. Campinas: Mercado das Letras, 2010. cap. 2, p. 45-114.

GOMBERT, J. E. Reflechir sur 1'oral pour apprendre 1'ecrit. Lead/CNRS, Université de Bourgogne, 2003.

GOMES, Milena Soares. Interação entre professor e aluno durante o desenvolvimento de estratégias de aprendizagem da linguagem escrita. 2006. 130 f. Dissertação (Mestrado em Educação) - Universidade do Vale do Itajaí. Itajaí, 2006.

GONDIM, Márcia Regina Alves. Práticas de letramento em classes de alfabetização de crianças e desenvolvimento da consciência fonológica. 2007. 156 f. Dissertação (Mestrado em Educação) - Universidade de Brasília, Brasília, DF, 2007.

GONTIJO, Cláudia Maria Mendes. Letramento: os desafios do ensino. Conjectura, Caxias do Sul, v. 14, n. 2, p. 13-30, maio/ago. 2009. 
GONTIJO, Cláudia Maria Mendes; LEITE, Sérgio A. da S. A escrita como recurso mnemônico na fase inicial de alfabetização escolar: uma análise histórico-cultural. Educação \& Sociedade, Campinas, ano 23, n. 78, p.143-167, abril, 2002.

GONTIJO, Cláudia Maria Mendes; SCHWARTZ, Cleonara Maria. (Des)caminhos da alfabetização no Brasil. In: ZACCUR, E. (Org.). Alfabetização e letramento: o que muda quando muda o nome? Rio de Janeiro: Rovelle, 2011. cap. 3, p. 33-50.

GONZÁLEZ-PUMARIEGA, Soledad; PÉREZ, José Carlos Nuñez; RODRÍGUEZ, Marta S. García. Estrategias de aprendizaje en comprensión lectora. In: GONZÁLEZ-PIENDA, J. A. et al. (Org.). Estrategias de aprendizaje: concepto, evaluación e intervención. Madrid: Pirámide, 2002. cap. 5, p. 117-140.

GONZÁLEZ REY, Fernando Luis. La personalidad y su importância en la educación. Educación y Ciencia, v.1, n. 3, enero/junio, p. 25-29, 1991.

Comunicación, personalidad y desarrollo. La Habana: Pueblo y Educación, 1995.

. Epistemología cualitativa y subjetividad. São Paulo: Educ, 1997.

. Psicologia e educação: desafios e projeções. In: RAYS, O. A. (Org.). Trabalho pedagógico: realidades e perspectivas. Porto Alegre: Sulina, 1999a. p. 102-117.

. Personality, subject and human development: the subjective character of human activity. In: CHAIKLIN, S.; HEDEGAARD, M.; JENSEN, U. J. (Org.). Activity theory and social pratice: cultural-historical approaches. Oxford: Arhus University Press, 1999b. cap. 14, p. 253-275. 1999c.

. La investigación cualitativa en Psicología: rumos e desafios. São Paulo: Educ,

. La categoría sentido y su significación en la construcción del pensamiento psicológico. Contrapontos, ano I, n. 2, 2000a.

. El lugar de lãs emociones em la constitución social de lo psíquico: El aporte de Vigotski. Educação \& Sociedade, ano 21, n. 70, abril, p. 132-148. 2000 b.

. Psicologia y lenguaje: el lugal de los significados en la vida psíquica. Revista Saberes, v. 2, n. 1, p. 2-9, 2001.

. La subjetividad: su significación para la ciencia psicológica. In: FURTADO, O.; GONZÁlEZZ REY, F. (Org.). Por uma epistemologia da subjetividade: um debate entre a teoria sócio-histórica e a teoria das representações sociais. São Paulo, 2002. cap. 7, p. 19-42. 2003a.

Sujeito e subjetividade: uma aproximação histórico-cultural. São Paulo: Thomson,

. El aprendizaje en el enfoque histórico-cultural: sentido y aprendizaje. In: ARANTES, Eliana F.; CHAVES, M. S. (Org.). Concepções e práticas em formação de professores: diferentes olhares. Rio de Janeiro: DP\&A, 2003b. cap. 4, p. 75-86. 
. O sujeito, a subjetividade e o Outro na dialética complexa do desenvolvimento humano. In: SIMÃ̃O, L. M.; MITJÁNS MARTÍNEZ, A. (Org.). O outro no desenvolvimento humano: diálogos para a pesquisa e a prática profissional em Psicologia. São Paulo: Thomson, 2004a. cap. 1, p. 1-28.

Sobre a Rede de Significações, o sentido e a pessoa: uma reflexão para o debate. In: ROSSETTI-FERREIRA, M. C. et al. (Org.). Rede de Significações: e o estudo do desenvolvimento humano. Porto Alegre: Artes Médicas, 2004b. p. 59-68.

. Personalidade, saúde e modo de vida. São Paulo: Thomson, 2004c.

. Pesquisa Qualitativa e Subjetividade: os processos de construção da informação. São Paulo: Thomson, 2005a.

. El sujeto y la subjetividad: algunos de los dilemas actuales de su estúdio. In: GÓMEZ MESA, G.; BAHIA BOCK, A. M.; RIBEIRO FERREIRA, M. (Org.). Aportaciones Brasileñas a la Psicologia Latinoamericana. México, D.F.: Universidad Autônoma de México, $2005 b$.

O valor heurístico da subjetividade na investigação psicológica. In: GONZÁLEZ REY, F. (Org.). Subjetividade, Complexidade e Pesquisa em Psicologia. São Paulo: Thomson, 2005c. cap. 2, p.27-52.

. As categorias sentido, sentido pessoal e sentido subjetivo: sua evolução e diferenciação na teoria histórico-cultural. Psicologia da Educação, São Paulo, v. 24, p. 155179, 2007a.

Psicoterapia, subjetividade e pós-modernidade: uma aproximação históricocultural. São Paulo: Thomson, 2007b.

. O sujeito que aprende: desafios do desenvolvimento do tema da aprendizagem na Psicologia e na prática pedagógica. In: TACCA, M. C. V. R. (Org.). Aprendizagem e trabalho pedagógico. 2. ed. Campinas: Alínea, 2008a. cap. 2, p. 29-44.

. Psicología y Arte: razones teóricas y epistemológicas de un desencuentro. Tesis Psicológica, Colômbia, n. 3, p. 140-159, 2008 b.

O social na Psicologia e a Psicologia social: a emergência do sujeito. 2. ed. Petrópolis: Vozes, 2009a.

. Questões teóricas e metodológicas nas pesquisas sobre a aprendizagem: a aprendizagem no nível superior. In: MITJÁNS MARTÍNEZ, A.; TACCA, M. C. V. R. (Org.). A complexidade da aprendizagem: destaque ao ensino superior. Campinas: Alínea, 2009b. cap. 5, p. 119-148.

. La significación de Vygotsky para la consideración de lo afectivo em la educación: las bases para la cuestión de la subjetividad. Actualidades Investigativas en Educación, Costa Rica, v. 9, p. 1-24, nov. 2009c. 
. Os aspectos subjetivos no desenvolvimento de crianças com necessidades especiais: além dos limites concretos do defeito. In: MITJÁNS MARTÍNEZ, A.; TACCA, M. C. V. R. (Org.). Possibilidades de aprendizagem: ações pedagógicas para alunos com dificuldade e deficiência. Campinas: Alínea, 2011a. cap. 1, p. 47-70.

El pensamiento de Vigotsky: contradicciones, desdoblamientos y desarrollo. México: Trilhas, 2011b.

. Subjetividade e saúde: superando a clínica da patologia. São Paulo: Cortez, 2011c.

. Sentidos subjetivos, lenguaje y sujeto: avanzando em una perspectiva postracionalista en psicoterapia. Rivista di psichiatria, Brasília, v. 46, p. 310-314, 2011d.

. Psicologia Social: fronteiras e conexões. In: TOMANIK, E. A.; CANIATO, A. M. P. (Org.). Psicologia Social: desafios e ações. Maringá: ABRAPSO, 2011e. cap. 1, p. 12-31.

. Pesquisa Qualitativa em Psicologia: caminhos e desafios. 2. reimpr. da 1. ed. de 2005, São Paulo: Cengage Learning, $2011 f$.

. Sentidos subjetivos, lenguaje y sujeto: avanzando en una perspectiva postracionalista en psicoterapia. Rivista di psichiatria, v. 46, p. 310-314, nov. $2011 \mathrm{~g}$.

. A configuração subjetiva dos processos psíquicos: avançando na compreensão da aprendizagem como produção subjetiva. In: MITIJÁNS MARTÍNEZ, A.; SCOZ, B. J. L.; CASTANHO, M. I. S. (Org.). Ensino e aprendizagem: a subjetividade em foco. Brasília: Liber Livros, 2012a. cap. 1, p. 21-42.

. Advancing on the concept of sense: subjective sense and subjective configurations in human development. In: Motives in children's development: Cultural Historical approaches. Cambridge University Press, 2012b. cap. 3, p. 45-62.

. A imaginação como produção subjetiva: as ideias e os modelos da produção intelectual. In: MITJÁNS MARTÍNEZ, A.; ÁLVAREZ, P. (Org.). O sujeito que aprende. Brasília: Liber Livro, 2014a. cap. 2, p. 35-62.

. Ideias e Modelos Teóricos na Pesquisa Construtivo-Interpretativa. In: MITJÁNS MARTÍNEZ, A.; NEUBERN, M.; MORI, V. D. Subjetividade contemporânea: discussões epistemológicas e metodológicas. Campinas: Alínea, 2014b. cap. 1, p. 13-34.

. Human motivation in question: discussing emotions, motives, and subjetictivity from a cultural-historical standpoint. Journal for the Theory of Social Behaviour, 2014c.

GONZÁLEZ REY, Fernando Luis; MITJÁNS MARTÍNEZ, Albertina. La personalidad su educación y desarrollo. Ciudad de La Habana, Cuba: Editorial Pueblo y Educación, 1989.

GOULART, Cecília. Letramento e modos de ser letrado: discutindo a base teóricometodológica de um estudo. In: Revista Brasileira de Educação, Rio de Janeiro, 2006, v. 11, n.33, p. 450-460. 
. Cultura escrita e escola: letrar alfabetizando. In: MARINHO, M.; CARVALHO, G. T. (Org.). Cultura escrita e letramento. Belo Horizonte: UFMG, 2010. cap. 16, p. 438-456.

GOULART, Cecília; KRAMER, S. Alfabetização, leitura, escrita: 25 anos da ANPED e 100 anos de Drummond. Revista Brasileira de Educação, Caxambu, n. 21, p. 127-146, set./out./nov./dez. 2002.

GRAINGER, Teresa; GOOUCH, Kathy; LAMBIRTH, Andrew. Creativity and writing: developing voice and verve in the classroom. New York: Routledge, 2005.

GROSSI, Esther Pillar. Didática do nível alfabético III. Rio de Janeiro: Paz e Terra, 1990.

GUIMARÃES, Márcia Campos Moraes. Estado do conhecimento da alfabetização no Brasil (1944 - 2009). 2011. 213 f. Dissertação (Mestrado em Educação). Pontifícia Universidade Católica de Goiás. Goiânia, 2011.

GUIMARÃES, Sandra Regina Kirchner; PAULA, Fraulein Vidigal. O papel da consciência morfossintática na aquisição e no aperfeiçoamento da leitura e da escrita. Educar em Revista, Curitiba, n. 38, p. 93-111, set./dez. 2010.

HOYER, Alice Rodrigues. A expressão da criatividade infantil em atividades lúdicas. Brasília, DF, 2010. 206 f. Dissertação (Mestrado em Educação) - Universidade de Brasília, Brasília, DF, 2010.

HUIZINGA, J. Homo Ludens: o jogo como elemento da cultura. 7. ed. São Paulo: Perspectiva, 1999.

ISAIA, Tatiane Peixoto. Interação grupal entre pares e sua repercussão no processo de construção da lecto-escrita. 2008. 207 f. Dissertação (Mestrado em Educação) Universidade Federal de Santa Maria, Santa Maria, 2008.

KISHIMOTO, T. M. et al. Jogo e letramento: crianças de 6 anos no ensino fundamental. Educação Pesquisa. 2011, v. 37, n.1, p. 191-210. Disponível em: <http://www.scielo.br/pdf/ep/v37n1/v37n1a12.pdf >. Acesso em: 07 jan. 2014. São Paulo.

KLEIMAN, Ângela B. Modelos de letramento e as práticas de alfabetização na escola. In: KLEIMAN, Ângela B. (Org.). Os significados do letramento: uma nova perspectiva sobre a prática social da escrita. Campinas: Mercado de letras, 1995. cap.1, p. 15-61.

KOCH, Ingedore Villaça; ELIAS, Vanda Maria. Ler e compreender: os sentidos do texto. São Paulo: Contexto, 2012.

KRAMER, Sônia (Org.). Alfabetização: dilemas da prática. Rio de janeiro: Dois Pontos, 1986.

. Escrita, experiência e formação - múltiplas possibilidades de formação de escrita. In: CANDAU, V. M. (Org.). Linguagens, espaços e tempos no ensinar e aprender. Rio de Janeiro, DP\&A, 2000a. cap. 8, p. 105-121. 
Leitura e escrita como experiência: seu papel na formação de sujeitos sociais.

Presença Pedagógica, v. 6, n.31, p. 17-27, jan./fev. 2000b. Belo Horizonte. Ática, 2001.

Alfabetização, leitura e escrita: formação de professores em curso. São Paulo:

LANDSMANN, Liliana Tolchinsky. Aprendizagem da linguagem escrita: processos evolutivos e implicações didáticas. Trad. Cláudia Schilling. 4. ed. São Paulo: Cortez, 2006.

LARROSA, Jorge. La experiencia de la lectura: estúdios sobre literatura y formación. México: FCE, 2003.

2010 .

. Pedagogia profana: danças, piruetas e mascaradas. Belo Horizonte: Autêntica,

LEITE, Sérgio Antonio da Silva. Alfabetização e fracasso escolar. São Paulo: Edicon, 1988.

Alfabetização: repensando uma prática. Leitura: Teoria \& Prática, Campinas, n.19, p. 21-27, 1993.

O processo de alfabetização escolar: revendo algumas questões. Revista

Perspectiva, Florianópolis, v. 24, n. 2, p. 449-474, 2006.

. A afetividade no processo de constituição do leitor. Atos de pesquisa em educação, Blumenau, v. 6, n.1, p. 25-52, jan./abr. 2011.

Afetividade e práticas pedagógicas. In: LEITE, S. A. da S. (Org.). Afetividade e práticas pedagógicas. São Paulo: Caso do Psicólogo, 2011, cap. 1, p. 15-46.

LERNER, Delia. Ler e escrever na escola: o real, o impossível e o necessário. Porto Alegre, Artmed, 2002.

LIMA, Fernanda Fernandes P. de A. L.. A aquisição da linguagem: um olhar discursivo sobre a escrita espontânea na $1^{a}$ série. REVELLI: revista de educação, linguagem e literatura da UEG, Inhumas, v. 1, n. 2, out. 2009.

LUIZE, Andréa. O processo de apropriação da escrita na infância: situações interativas na produção textual. 2007. 196 f. Dissertação (Mestrado em Educação). Universidade de São Paulo, São Paulo, 2007.

LURIA, A. R. O desenvolvimento da escrita na escrita. In: VIGOTSKI, L.S.; LURIA, A. R.; LEONTIEV, A. N. Linguagem, desenvolvimento e aprendizagem. São Paulo: Ícone, 2006.

MACEDO, Maria do Socorro Alencar Nunes; MORTIMER, Eduardo Fleury. A dinâmica discursiva na sala de aula e a apropriação da escrita. Educação e Sociedade, Campinas, v.21, n.72, p. 153-173, 2000.

MACHADO, Veruska Ribeiro. Compreensão leitora no PISA e práticas escolares de leitura. Brasília, DF: Liber Livro, 2012. 
MALUF, Maria Regina. Ciência da leitura e alfabetização infantil: um enfoque metalinguístico. Boletim. Academia Paulista de Psicologia, São Paulo, v. 25, n. 2, p. 55-62, 2005.

. Do conhecimento implícito à consciência metalinguística indispensável na alfabetização. In: GUIMARÃES, S. R. K.; MALUF, M. R. (Org.). Aprendizagem da linguagem escrita: contribuições da pesquisa. São Paulo: Vetor, 2010. cap. 1, p. 17-32.

MALUF, Maria Regina; GOMBERT, Jean Emile. Habilidades implícitas e controle cognitivo na aprendizagem da linguagem escrita. In: MALUF, M. R; GUIMARÃES, S. R. K. (Org.). Desenvolvimento da linguagem oral e escrita. Paraná: UFPR, 2008. cap. 6, p. 123-136.

MALUF, Maria Regina; ZANELLA, M. S. Alfabetização e Metalinguagem: revendo contribuições brasileiras no período de 2000 a 2009. In: SEMINÁRIO INTERNACIONAL DE ALFABETIZAÇÃO NA PERSPECTIVA COGNITIVA DA LEITURA, 2011, São Paulo, Anais: SEMINÁRIO INTERNACIONAL DE ALFABETIZAÇÃO NA PERSPECTIVA COGNITIVA DA LEITURA. São Paulo, 2011.

MALUF, Maria Regina; ZANELLA, Maura S.; PAGNEZ, Karina Soledad Maldonado Molina. Habilidades metalinguísticas e linguagem escrita nas pesquisas brasileiras. Boletim de Psicologia, v. 56, p. 67-92, 2006. São Paulo.

MANGUEL, Alberto. À mesa com o Chapeleiro Maluco: ensaios sobre corvos e escrivaninhas. São Paulo: Companhia das Letras, 2009.

MARCHESANO, Lauren Souza do Nascimento. Como crianças de 4 a 6 anos constroem sentido lendo livros de literatura infantil: como a lua foi ao cinema? 2010. $143 \mathrm{f}$. Dissertação (Mestrado em Educação) - Universidade Federal Fluminense, Niterói, 2010.

MARCUSCHI, Luiz Antônio. Produção textual, análise de gêneros e compreensão. São Paulo: Parábola, 2008.

MAREC-BRETON, Nathalie; BESSE, Anne-Sophie; ROYER, Carine. Consciência morfológica é uma variável importante na aprendizagem da leitura? Educar em Revista, Curitiba, n. 38, p. 73-91, set./dez. 2010.

MATURANA, Humberto R.; VARELA, Francisco J. A árvore do conhecimento: as bases biológicas da compreensão humana. São Paulo: Athena, 2001.

MEIER, Bruno. Uma geração descobre o prazer de ler. Veja, São Paulo, ano 40, n. 20, p. 212, 18 maio 2011.

MENDES, Angelita. Implicações da cultura grafocêntrica na apropriação da escrita e da leitura em dois diferentes contextos. 2009. 162 f. Tese (Doutorado em Educação) Universidade de São Paulo, São Paulo, 2009.

MITJÁNS MARTÍNEZ, Albertina. La escuela y el desarrollo de la creatividad. Revista Educación, Habana, n. 85, p. 18-24, 1995a. 
. Como desarollar la creatividad na escuela. In: MITJÁNS MARTÍNEZ, A. et al. (Org.). Pensar y crear: estrategias, métodos y programas. Havana: Academia, 1995b. cap. 6, p. 156-208.

Criatividade, personalidade e educação. 3. ed. Campinas: Papirus, 1997.

. La escuela como organización sus possibilidades criativas e innovadoras. Revista

Linhas Críticas da Faculdade de Educação da UnB, Brasília, DF v. 4, n. 7-8, p. 45-56, 1999.

. Pensar, crear y transformar: desafios para la educación. Anais I Simpósio

Multidisciplinar pensar, criar e transformar. São Paulo: Unimarco, p. 15-26, 2000.

- Trabajo infantil y subjetividad: una perspectiva necesaria. Estudos de Psicologia, Natal, v. 6, p. 235-244, 2001.

. A criatividade na escola: três dimensões de trabalho. Revista Linhas Críticas da Faculdade de Educação UnB, Brasília, DF, v. 8, n. 15, 2002.

. Desenvolvimento infantil e práticas pedagógicas: a procura de uma coerência necessária. In: Simpósio de educação infantil: construindo o presente, 2002, Brasília. Brasília: UNESCO, 2003a. p. 237-244.

. El professor como sujeito: elemento essencial de la formación de professores para la educación inclusiva. Revista Movimento. Niterói, n. 7, p. 137-149, 2003 b.

. O outro e sua significação para criatividade: implicações educacionais. In: SIMÃO, L. M.; MITJÁNS MARTÍNEZ, A. (Org.). O outro no desenvolvimento humano: diálogos para a pesquisa e a prática profissional em psicologia. São Paulo: Thomson, 2004. cap. 5, p. 77-99.

. A Teoria da Subjetividade de González Rey: uma expressão do Paradigma da Complexidade. In: GONZÁLEZ REY, F. (Org.). Subjetividade, complexidade e pesquisa em Psicologia. São Paulo: Thomson, 2005. cap. 1, p. 1-26.

. Creatividad y Subjetividad. In: TORRE, S.; VIOLANT, V. (Org.). Compreender y Evaluar a criatividade: um recurso para mejorar la calidad de la enseñanza. Málaga: Aljibe, 2006. cap. 9, p. 115-122.

. Criatividade e saúde nos indivíduos e nas organizações. In: VIRGOLIM, A. M. R. (Org.). Talento criativo: expressão em múltiplos contextos. Brasília: Universidade de Brasília, 2007. cap. 2, p. 53-64.

. Criatividade no trabalho pedagógico e criatividade na aprendizagem: uma relação necessária? In: TACCA, M. C. V. R. (Org.). Aprendizagem e trabalho pedagógico. Campinas: Alínea, 2008a. cap. 4, p. 69-94.

. A criatividade como princípio funcional da aula: limites e possibilidades. In: VEIGA, I. P. A. (Org.). Aula: gênese, dimensões, princípios e práticas. Campinas: Papirus, $2008 \mathrm{~b}$. cap. 5, p. 115-143. 
. El dialéctico perfil de las personas creativas. In: FERREIRO, R. et al. La creatividad: un bien cultural de la humanidad - La dimensión social de la creatividad - la impronta artística de la creatividad. México: Trilhas, 2008c.

. Subjetividad, complejidad y educación. Revista Latino-Americana de Psicologia, v. 13, p. 5, 2008d. Bogotá.

. Vygotsky e a criatividade: novas leituras, novos desdobramentos. In: GIGLIO, Z. G.; WECHSLER, S. M.; BRAGOTTO, D. (Org.). Da criatividade à inovação. Campinas: Papirus, 2009a. cap. 1, p. 11-38.

. Processos de aprendizagem na Pós-graduação: um estudo exploratório. In: MITJÁNS MARTÍNEZ, A.; TACCA, M. C.V. R. (Org.). A complexidade da aprendizagem: destaque ao ensino superior. Campinas: Alínea, 2009b. cap. 8, p. 213-262.

. Consecuencias de la obra de Vygotsky para la comprensión de la creatividad. In: MORALES, S. A.; PEÑA, C. M. (Org.). Tutorial para el desarrollo: enfoques. 1. ed. Monterrey: Universidad Autónoma de Nuevo León, 2010. v. 1, p. 93-129,

. Aprendizagem criativa: uma aprendizagem diferente. In: MITIJÁNS MARTÍNEZ, A.; SCOZ, B. J. L.; CASTANHO, M. I. S. (Org.). Ensino e aprendizagem: a subjetividade em foco. Brasília: Liber Livros, 2012a. cap. 4, p. 85-109.

. Aprendizagem criativa: desafios para a prática pedagógica. In: NUNES, C. Didática e formação de professores. Ijuí: Unijuí, 2012b, p. 93-124.

O lugar da imaginação na aprendizagem escolar: suas implicações para o trabalho pedagógico. In: MITJÁNS MARTÍNEZ, A.; ÁLVAREZ, P. (Org.). O sujeito que aprende. Brasília: Liber Livro, 2014. cap. 3, p. 63-98.

MITJÁNS MARTÍNEZ, Albertina et al. Aprendendo a aprender. Brasília: UniCEUB, 2003.

MITJÁNS MARTÍNEZ, Albertina; GONZÁLEZ REY, Fernando. O subjetivo e o operacional na aprendizagem escolar: pesquisas e reflexões. In: MITIJÁNS MARTÍNEZ, A.; SCOZ, B. J. L.; CASTANHO, M. I. S. (Org.). Ensino e aprendizagem: a subjetividade em foco. Brasília: Liber Livros, 2012. cap. 3, p. 59-84.

MONTEIRO, Sara Mourão; SOARES, Magda. Processos cognitivos na leitura inicial: relação entre estratégias de reconhecimento de palavras e alfabetização. Educação e Pesquisa, São Paulo, v. 40, n. 2, p. 449-466, abr./jun. 2014.

MORAIS, Antônio Manuel P. A relação entre consciência fonológica e as dificuldades de leitura. São Paulo: Vetor, 1997.

MOREIRA, C. M. Os estágios de aprendizagem da escritura pela criança: uma nova leitura para um antigo tema. Revista Linguagem em (Dis)curso, v. 9, n. 2, maio/set. 2009. Palhoça.

MORIN, Edgar. Introdução ao pensamento complexo. Porto Alegre: Sulina, 2011. 
MOTA, Márcia da et al. Consciência morfossintática, alfabetização e contextos do desenvolvimento. Psico-USF, v. 14, n. 1, p. 11-18, jan./abr. 2009. São Francisco.

MOTA, Márcia da. Algumas considerações sobre o letramento e o desenvolvimento metalinguístico e suas implicações educacionais. Estudos e Pesquisas em Psicologia, Rio de Janeiro, v. 7, n. 3, p. 477-489, dez. 2007.

MOUSINHO, Renata; CORREA, Jane. Habilidades linguístico-cognitivas em leitores e não-leitores. Pró-Fono R. Atual. Cient., n. 21, p. 13-118, 2009. Barueri.

MOZZER, Geisa Nunes de Souza. A criatividade infantil na atividade de contar histórias: uma perspectiva hisórico-cultural da subjetividade. 2008. 213 f. Tese (Doutorado em Psicologia). Universidade de Brasília, Brasília, DF, 2008.

MUNHOZ, Silmara Carina Dornelas. Ler, escrever, inscrever: discursos de alunos e professoras sobre a (im)possibilidades de relações estéticas com a linguagem escrita. 2008. 177 f. Tese (Doutorado em Psicologia) - Universidade Federal de Santa Catarina, Florianópolis, 2008.

MUNHOZ, Silmara Carina Dornelas; ZANELLA, Andréa Vieira. Linguagem escrita e relações estéticas: algumas considerações. Psicol. Estud, Maringá, v.13, n.2, p. 287-295, 2008.

MUNIZ, Cristiano Alberto. Brincar e jogar: enlaces teóricos e metodológicos no campo da educação matemática. Belo Horizonte: Autêntica, 2010.

MUNIZ, Luciana Soares. O Fórum de Classe na escola pública: significados e práticas direcionados à construção de uma coletividade. 2006. 150 f. Dissertação (Mestrado em Educação) - Universidade Federal de Uberlândia, Uberlândia, 2006.

NAZARI, Gracielle Tamiosso. Panorama de pesquisas sobre consciência fonológica de crianças com desenvolvimento normal realizadas no Brasil no período de 1991 a 2009. Letrônica, Porto Alegre, v.3, n.1, p. 3-21, jul. 2010.

NEUBERN, Maurício S. Complexidade \& psicologia clínica: desafios epistemológicos. Brasília: Plano, 2004.

OLIVEIRA, Carolina Torres. Estratégias de aprendizagem e subjetividade em estudantes criativos do ensino superior. 2010. 177 f. Dissertação (Mestrado em Educação) Universidade de Brasília, Brasília, DF, 2010.

OLIVEIRA, João Batista Araujo. Cartilhas de alfabetização: a redescoberta do Código Alfabético. Ensaio: avaliação e políticas públicas em educação, Rio de Janeiro, v.18, n.69, p. 669-709, 2010.

OLIVEIRA, Maria Inesila Montenegro Garcia de. As dimensões subjetivas contidas no processo de aprendizagem da leitura e da escrita de crianças que apresentam dificuldades de aprendizagem escolar. 2011, 191 f. Tese (Doutorado em Educação) Universidade Federal de Mato Grosso do Sul, Campo Grande, 2011. 
OLIVEIRA, Paula Gomes de. Histórias inventadas: narrativas, imaginação e infância nos primeiros anos do ensino fundamental. 2014. 236 f. Tese (Doutorado em Educação). Universidade de Brasília, Brasília, 2014.

OSTROSKY, Michaelene, GAFFNEY, Janet S.; THOMAS, Dawn V. The interplay between literacy and relationships in early childhood settings. Reading \& Writing Quarterly, v. 22, p.173-191, 2006. USA.

PEREIRA, Rosangela. Interação de sala de aula: alfabetização e letramento no primeiro ciclo do ensino fundamental. 2007. 146 f. Dissertação (Mestrado em Linguística) Universidade Católica de São Paulo, São Paulo, 2007.

PÉREZ, Carmen Lúcia Vidal; ARAÚJO, Mairce. A "palavramundo" como conteúdo alfabetizador: problematizando o conceito de letramento. In: ZACCUR, E. (Org.).

Alfabetização e letramento: o que muda quando muda o nome? Rio de Janeiro: Rovelle, 2011. cap. 7, p. 117-148.

PORTILHO, Evelise Maria Labatut; KÜSTER, Sonia Maria Gomes de Sá. Estratégias de aprendizagem da criança em processo de alfabetização. Revista Psicopedagógica, São Paulo, v. 23, n. 70, p. 9-23, 2006.

RAMOS, Mozart Neves. Alfabetização: a pedra angular da educação. Correio Braziliense, Brasília, DF, p. 19, 5 abr. 2012.

RODARI, Gianni. Gramática da fantasia. São Paulo: Summus, 1982.

REIS, Regina Mary Cesar. Dando voz ao sujeito da aprendizagem: um estudo com crianças no primeiro ano do ensino fundamental. 2000. Tese (Doutorado em Educação - Psicologia da Educação) - Pontifícia Universidade Católica de São Paulo, São Paulo, 2000.

RIBEIRO, Alina do Rocio Pacheco e Silva. Alfabetização: o estado da arte em periódicos científicos (1987-2008). 2011. 210 f. Dissertação (Mestrado em Educação). Universidade Estadual de Campinas, Campinas, 2011.

ROJO, Roxane. Alfabetização e letramento: perspectivas linguísticas. Campinas, SP: Mercado de Letras, 1998.

ROSSATO, Maristela. O movimento da subjetividade no processo de superação das dificuldades de aprendizagem escolar. Brasília, DF, 2009. 209 f. Tese (Doutorado em Educação). Universidade de Brasília, Brasília, DF, 2009.

ROSSATO, Maristela; MITJÁNS MARTÍNEZ, Albertina. A subjetividade da criança. In: SANTIAGO, A. L.; CAMPOS, R. H. de F. (Org.). Educação de crianças e jovens na contemporaneidade/pesquisas sobre sintomas na escola e subjetividade. Belo Horizonte: PUC Minas, 2011. p. 323-335.

ROWE, Deborah Wells; NEITZEL, Carin. Interest and agency in 2-and 3-year-old's participation in emergent writing. Reading Research Quarterly. v. 45, n. 2, p. 169-195, 2010. USA. 
SANTOS, Geandra Claudia Silva. Os impactos dos alunos com desenvolvimento atípico na subjetividade do professor e a configuração do trabalho pedagógico. Brasília, DF, 2010. 221 f. Tese (Doutorado em Educação). Universidade de Brasília, Brasília, DF, 2010.

SANTOS, Maria José dos; MALUF, Maria Regina. Nomes e coisas: o pensamento de crianças pré-escolares. In: REUNIÃO ANUAL DA ANPED, 23, 2000, Caxambú. Anais: REUNIÃO ANUAL DA ANPED. São Paulo: Associação Nacional de Pós-Graduação em Educação, 2000.

. Intervenções em consciência fonológica e aprendizagem da linguagem escrita.

Boletim Academia Paulista de Psicologia, São Paulo, v. 27, p. 95-108, 2007.

SANTOS, Solange Maria Senem dos. A linguagem escrita como produção de sentidos no contexto da sala de aula. 2005. 197 f. Dissertação (Mestrado em Educação) - Universidade Regional de Blumenau, Blumenau, 2005.

SCHEUER, Nora; CRUZ, Montserrat de la; POZO, Juan Ignacio. Aprender a dibujar y a escribir: las perspectivas de los niños, sus familias y maestros. Buenos Aires: Noveduc, 2010.

SEIBT, Rosane Simon. Leitura de textos em uma classe de alfabetização: a construção dos sentidos. 2004, 129 f. Dissertação (Mestrado em Linguística) - Universidade Federal de Santa Catarina, Florianópolis, 2004.

SILVA, Ana Cristina. Descobrir o princípio alfabético. Análise Psicológica, Lisboa, n. 1, v. 22, p. 187-191, 2004.

SILVA, Daniele Nunes Henrique. Imaginação, criança e escola. São Paulo: Summus, 2012.

SILVA, Ezequiel Theodoro da. Partilha e conflito de interpretações: um caminho para o desenvolvimento da linguagem do leitor infantil. In: SMOLKA, A. L. B. et al. Leitura e desenvolvimento da linguagem. Campinas: ALB, 2010. cap. 3, p. 67-80.

SILVA, Lúcia Maria Leite da. Brasil, Cuba e Finlândia: um diálogo entre práticas docentes pela excelência do letramento. 2012. 221f. Dissertação (Mestrado em Educação).

Universidade de Brasília, Brasília, 2012.

SMITH, Frank. Compreendendo a leitura: uma análise psicolinguística da leitura e do aprender a ler. Porto Alegre: Artes Médicas, 1991.

SMOLKA, Ana Luiza B. A criança na fase inicial da escrita: alfabetização como processo discursivo. 3 ed. São Paulo: Cortez/UNICAMP, 1991.

. A dinâmica discursiva no ato de escrever: relações oralidade-escritura. In:

SMOLKA, A. L. B.; GOÉS, M. C. R. (Org.). A linguagem e o outro no espaço escolar:

Vygotsky e a construção do conhecimento. 13. ed. Campinas: Papirus, 1993. cap. 2, p. 33-62.

. O (im)próprio e o (im)pertinente na apropriação das práticas sociais. In: SMOLKA,

A. L. B. Cadernos Cedes - Relações de ensino: análises na perspectiva histórico-cultural. São Paulo, n. 50, p. 26-40, 2000. 
. A criança na fase inicial da escrita: a alfabetização como processo discursivo. 13. ed. São Paulo: Cortez, 2008.

. A atividade de leitura e o desenvolvimento das crianças: considerações sobre a constituição de sujeitos-leitores. In: SMOLKA, A. L. B.; SILVA; E. T.; ZILBERMAN, R. Leitura e desenvolvimento da linguagem. Campinas: ALB, 2010a. cap. 2, p. 37-66.

Ensinar e significar: as relações de ensino em questão ou da (não) coincidências nas relações de ensino. In: SMOLKA, A. L. B.; NOGUEIRA, A. L. H. (Org.). Questões de desenvolvimento humano: práticas e sentidos. Campinas: Mercado das Letras, 2010b. cap. 5 , p. 107-128.

SOARES, Magda. Alfabetização no Brasil: o estado do conhecimento. Brasília: Inep/MECReduc, 1989.

Letramento: um tema em três gêneros. 2. ed. Belo Horizonte: Autêntica, 2005.

Práticas de letramento e implicações para a pesquisa e para políticas de alfabetização e letramento. In: MARINHO, M.; CARVALHO G. T. (Org.). Cultural escrita e letramento. Belo Horizonte: UFMG, 2010. cap. 3, p. 54-67.

SOARES, Magda; MACIEL, Francisca. Alfabetização. Brasília: MEC/INEP/Comped, 2000.

SOLÉ, Isabel. Estratégias de leitura. Porto Alegre: Artmed, 1998.

SOLOVIEVA, Yulia; QUINTAMAR ROJAS, Luis. Enseñanza de la lectura: método prático para la formación lectora. México: Trilhas, 2008.

SOUSA, Édiva de Oliveira; MALUF, Maria Regina. Habilidades de leitura e de escrita no início da escolarização. Psicologia da Educação, São Paulo, v. 19, p. 55-72, 2004.

SPINILLO, Alina Galvão. Alfabetização e consciência metalinguística: da leitura da palavra à leitura do texto. In: MALUF, M. R.; CARDOSO-MARTINS, C. Alfabetização no século XXI: como se aprende a ler e a escrever. Porto Alegre: Penso, 2013. cap. 6, p. 138-154.

SPINILLO, Alina Galvão; MOTA, Márcia Maria P. E. da; CORREA, Jane. Consciência metalinguística e compreensão de leitura: diferentes facetas de uma relação complexa.

Educar em Revista, Curitiba, v. 38, p. 157-171, 2010.

STREET, Brian V. Literacy in theory and practice. Cambridge: Cambridge University Press, 1984.

TACCA, Maria Carmen Villela Rosa. As relações sociais na escola e desenvolvimento da subjetividade. In: SCOZ, B. et al. (Org.). Aprendizagem: Tramas do conhecimento, do saber e da subjetividade. São Paulo: Vozes, 2006. cap. 4, p.60-85.

Relação pedagógica e desenvolvimento da subjetividade. In: GONZÁLEZ REY, F. (Org.). Subjetividade, complexidade e pesquisa em Psicologia. São Paulo: Thomson, 2005. cap. 9, p. 215-239. 
TACCA, Maria Carmen Villela Rosa; GONZÁLEZ REY, Fernando. Produção de sentido subjetivo: as singularidades dos alunos no processo de aprender. Psicologia: Ciência e Profissão, Brasília, DF, v. 28, n. 1, p. 138-161, 2008.

TASSONI, Elvira Cristina Martins. Afetividade e produção escrita: a mediação do professor em sala de aula. 2000. 246 f. Dissertação (Mestrado em Educação) - Universidade Estadual de Campinas, Campinas, 2000.

. A afetividade e o processo de apropriação da linguagem escrita. In: LEITE, S. A. da S. (Org.). Alfabetização e letramento: contribuições para as práticas pedagógicas. Campinas: Komedi, 2008. cap. 8, p. 223-260.

TFOUNI, Leda V. Letramento e alfabetização. São Paulo: Cortez, 1997.

. Letramento e alfabetização: colocações para uma reflexão sobre distúrbios de aprendizagem. Revista Psicopedagogia, São Paulo, v.14, n.32, p. 41-44, 1996.

TUNES, Elizabeth; TACCA, Maria Carmen Villela Rosa; MITJÁNS MARTÍNEZ, Albertina. Uma crítica às teorias clássicas da aprendizagem e a sua expressão no campo educativo.

Revista Linhas Críticas, v. 12, n. 22, p. 109-130, jan./jun. 2006. Brasília.

URQUIJO, Sebastián. Funcionamento cognitivo e habilidades metalinguísticas na aprendizagem da leitura. Educar em Revista. Curitiba, n. 38, p. 19-42, set./dez. 2010.

VALENTE, Fátima; MARTINS, Margarida Alves. Competências metalinguísticas e aprendizagem da leitura em duas turmas do $1 .^{\circ}$ ano de escolaridade com métodos de ensino diferentes. Análise Psicológica, Lisboa, v.22, n.1, p. 193-212, 2004.

VELASQUEZ, Maria Gabriela Morais de Castro Fernandes. Percursos desenvolvimentais de leitura e escrita: estudo longitudinal com alunos do $1^{\circ}$ ciclo do ensino básico. 2007. $518 \mathrm{f}$. Tese (Doutorado). Universidade do Minho, Portugal, 2007.

VIGOTSKI, Lev Semenovich. Obras escogidas: psicología infantil. Madrid: Visor Distribuciones, 1984. tomo 4.

Obras escogidas. Problemas del desarrollo de la psique. Madrid: Visor Distribuciones, 1995. tomo 3.

Obras escogidas. Fundamentos de defectologia. Madrid: Visor Distribuciones, 1997. tomo 5.

1922.

. Psicologia da arte. São Paulo: Martins Fontes, 1999. Texto original publicado em

Sobre a análise pedológica do processo pedagógico. In: VIGOTSKI, L. S.

Psirrologuia razvitia rebionka. Moskva: Eksmo, 1933/2004, p. 479-506.

. Pensamiento y habla. Buenos Aires: Colihue Clásica, 2007.

. Imaginação e criação na infância. São Paulo: Ática, 2009. 
VILLAS BOAS, Isabela de Freitas. A contribuição do processo de ensino-aprendizagem de produção textual em língua inglesa para o letramento do aluno. Brasília, DF, 2008. 292 f. Tese (Doutorado em Educação). Universidade de Brasília, Brasília, DF, 2008.

WILCE, James M. Language and emotion: studies in the social and cultural foundations of language. Cambridge: Cambridge University Press, 2009.

ZANELLA, Maura Spada; MALUF, Maria Regina. Contraponto entre a leitura e a escrita de crianças durante os primeiros anos de aprendizagem escolar. Psicologia da educação, São Paulo, n. 18, p. 55-75, 2004.

ZASSO, Silvana Maria Belle. A produção de cultura e subjetividade no entre-lugares da escrita das crianças em processo de alfabetização. 2008. 207 f. Tese (Doutorado em Educação) - Universidade Federal do Rio Grande do Sul, Porto Alegre, 2008.

ZILBERMAN, Regina. O escritor lê o leitor, o leitor escreve a obra. In: SMOLKA, A. L. et al. Leitura e desenvolvimento da linguagem. São Paulo: Global, 2010. cap. 2, p. 17-36. 
APÊNDICES 
APÊNDICE A - Elementos para a criação do cenário social de pesquisa

Convidamos os aprendizes a participarem da pesquisa e, para isso, utilizamos os vídeos abaixo, assim como promovemos um momento de diálogo com as crianças.

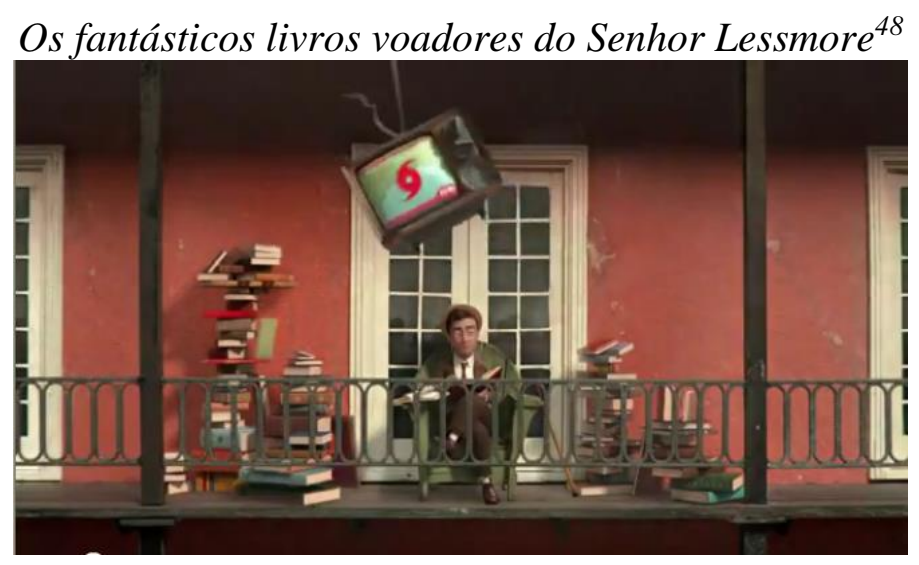

Fonte: <https://www.youtube.com/watch?v=8CMt6-xwAls> Acesso em: fevereiro/2012.

\section{A menina que odiava livros ${ }^{49}$}

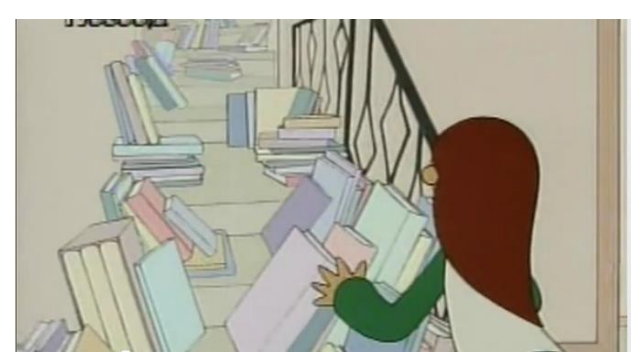

Fonte: <http://www.youtube.com/watch?v=geQ12cZxR7Q> Acesso em: fevereiro/2012.

\section{Eixos da conversação}

a) Explicar para a criança em que consiste a pesquisa;

b) Dialogar sobre os aspectos que achou interessante nos vídeos;

c) Conversar sobre o interesse pela aprendizagem da leitura e da escrita;

d) Falar da importância do diálogo entre pesquisadora e participantes;

e) Perguntar sobre a disponibilidade e interesse de participação na pesquisa.

\footnotetext{
${ }^{48}$ Ficha técnica: Gênero: Animação/Aventura. Direção: Brandon Oldenburg; William Joyce. Duração: 15min. Ano: 2011. País: Estados Unidos da América.

${ }^{49}$ Ficha técnica: Gênero: Animação. Duração: 8 min. Ano: 2012.
} 
APÊNDICE B - Roteiro da observação participante

\section{Observação em sala de aula, laboratório de informática e biblioteca}

Elementos contextuais

a) Tipos de materiais específicos de leitura e escrita utilizados;

b) Tipos de atividades;

c) Clima interativo, relação professor-aluno, relação aluno-aluno;

d) Sistema de atividade-comunicação;

e) Orientações da professora ao aluno de forma coletiva ou individual;

f) Estilo da professora:

- tom de voz;

- formas de incentivo ao aluno;

- respeito às diferenças;

- tipos de correções feitas;

- organização do trabalho pedagógico;

- reações às conquistas e erros das crianças;

- valorização da expressão das ideias das crianças;

- favorece o registro espontâneo e próprio da criança;

- instiga a reflexão.

Expressões de criatividade

a) O comportamento da criança frente ao seu processo de aprender;

b) A relação lúdica no processo de aprender;

c) Momentos de silêncio/momento consigo mesma;

d) Maneira de se organizar corporalmente para aprender;

e) Perguntas que realiza durante as aulas;

f) Reflexões próprias e hipóteses sobre o sistema de escrita;

g) Reações da criança frente às descobertas e ao erro;

h) Disposição para aprender;

i) Interesses mais relevantes para aprendizagem;

j) Observações realizadas pela criança na sala de aula;

k) Necessidade de mostrar para outra pessoa o que lê e escreve;

1) Estratégias de leitura e de escrita;

m) Utilização e função que a escrita e a leitura assumem para a criança; 
n) Posicionamentos frente ao aprender: ativa, reflexiva, dentre outros;

o) Flexibilidade, independência, autonomia e envolvimento no processo de aprender;

p) Tipo de solução aos problemas e atividades propostas;

q) Personalização da informação;

r) Geração de ideias próprias e novas que transcendem o dado;

s) Confrontação com as informações;

t) Necessidade de ir além do que é solicitado pela professora;

u) Posicionamentos frente às solicitações da professora e dos colegas;

v) Posicionamentos da criança frente aos possíveis conflitos;

w) A curiosidade, imaginação, fantasia e o próprio brincar no aprender;

x) Utilização do que aprendeu em situações diversas da escola e fora do âmbito escolar;

y) Interesse pela leitura e escrita em outros espaços.

\section{Observação dos momentos de lanche/recreio}
a) Gostos e preferências por brincadeiras;
b) Colegas que gosta de conversar e brincar;
c) Posicionamentos frente a possíveis conflitos.

\section{Observação da entrada e saída das crianças na escola}
a) Relação com colegas;
b) Tipos de brincadeiras preferidas;
c) Tipos de leitura e escrita que faz fora do ambiente da sala de aula;
d) A leitura e a escrita na sua vida de forma espontânea;
e) Gostos e preferências de leitura e escrita.

\section{Observação da escola}
a) Tipo de informações escrita dos murais;
b) Participação dos familiares na escola;
c) Tipo de escrita que veicula pela escola: bilhetes, atividades e outras.

\section{Observação das reuniões pedagógicas}
a) Concepção de aprendizagem da leitura e da escrita;
b) Os diferentes olhares sobre a criança, sobre a sua aprendizagem.

\section{Observação das reuniões pedagógicas e reuniões com familiares}

a) Vínculo entre família e escola;

b) Preocupações dos familiares sobre as crianças. 
APÊNDICE C - Roteiro da entrevista I com as crianças participantes da pesquisa

\section{$1^{\circ}$ Momento}

Mediante a análise documental prévia da produção da criança realizada nos cadernos utilizados em sala de aula, bem como em produções próprias utilizadas na pesquisa, promovemos diálogos como a criança a partir de algumas questões. Este processo ocorreu ao final de cada ano letivo.

\section{Questões norteadoras da conversação:}

a) Quais atividades você mais gostou de realizar? Por quê?

b) Você percebe alguma mudança nos seus registros? O que seria?

c) Você precisou de ajuda em alguma atividade? Qual foi? Quem lhe ajudou?

d) Qual atividade você inventou alguma coisa? O que você inventou?

e) Você mudaria alguma atividade ou mesmo a forma como respondeu? Qual seria?

f) Qual(is) atividade(s) você achou mais fácil(eis)? E mais difícil(eis)? Por quê?

g) Quais atividades você gostaria de fazer novamente?

h) Escolha alguma atividade que você utilizou escrita e conte como fez para realizá-la.

i) Qual atividade você teve vontade de mostrar para alguém?

j) O que você fará com o seu caderno quando ele acabar as páginas em branco?

k) Escolha as atividades que você mais gostou e conte os motivos de sua escolha.

1) Qual o papel da professora na sua forma de registro?

m) Qual o papel dos seus colegas em suas produções?

\section{$2^{\circ}$ Momento}

A partir do material escrito de forma espontânea pelas crianças no decorrer dos dois anos da pesquisa, sem exigência externa, realizamos diálogos que envolviam algumas questões.

\section{Questões norteadoras da conversação:}

a) O que você escreveu?

b) Por que você escreveu? Em que momento você escreveu?

c) Como foi esse momento de escrita para você?

d) O que você escreveu existe?

e) O que você sentiu ao escrever?

f) Escrever representa o que para você? Para quem você escreveu? 
APÊNDICE D - Roteiro da entrevista II com as crianças participantes da pesquisa

Entrevista com foco nas estratégias de aprendizagem desenvolvidas na realização de tarefas de escrita espontânea realizadas em sala de aula ${ }^{50}$.

\section{Questões norteadoras da entrevista:}

Estratégias de autorregulação:

Planejamento:

a) O que você precisou para iniciar a sua escrita?

b) Como você organizou o que queria escrever?

c) O que você precisou para escrever suas próprias ideias?

Supervisão:

a) O que facilitou e o que foi difícil no momento da escrita?

b) O que você fez quando encontrou uma dificuldade na escrita?

Revisão:

a) Você identificou algum erro durante a sua escrita?

b) O que você faz quando identifica um erro?

c) Como você sabe que a sua escrita está certa?

Valoração/avaliação:

a) Como você avalia seu processo de escrita?

b) Quem mais avalia sua escrita?

Estratégias cognitivas:

a) Como você contaria para alguém sobre a forma como você fez para realizar a atividade?

b) O que você faz quando não sabe alguma palavra que precisa escrever?

Estratégias motivacionais:

a) $\mathrm{O}$ que te levou a escrever?

b) Você escreveu para você mesmo ou para mostrar para alguém?

c) Como você se sentiu no momento da escrita?

Estratégias de gestão de recursos:

a) Você se preocupou com os materiais que precisava para a sua escrita?

b) Você se preocupou com o tempo para terminar a atividade?

${ }^{50}$ Instrumento adaptado de Oliveira, C. (2010) e Egler (2013). Vale destacar que as atividades foram selecionadas pela pesquisadora a partir do que era proposto pelas professoras em sala de aula. 
APÊNDICE E - Roteiro da entrevista III com as crianças participantes da pesquisa

Entrevista com foco nas estratégias de aprendizagem desenvolvidas na realização de uma atividade concreta de leitura realizada em sala de aula ${ }^{51}$.

\section{Questões norteadoras da entrevista:}

Estratégias de autorregulação:

Planejamento:

a) O que você precisou para iniciar a sua leitura?

b) Como você organizou para ler?

c) O que você precisou para ter suas próprias ideias?

Supervisão:

a) O que facilitou e o que foi difícil no momento da leitura?

b) O que você fez quando encontrou uma dificuldade na leitura?

Revisão:

a) Você identificou algum erro durante a sua leitura?

b) O que você faz quando identifica um erro?

c) Como você sabe que a sua leitura está certa?

Valoração/avaliação:

a) Como você avalia seu processo de leitura?

b) Quem mais avalia sua leitura?

Estratégias cognitivas:

a) Como você contaria para alguém a forma como você fez para realizar a leitura?

b) O que você faz quando não sabe alguma palavra que precisa ler?

Estratégias motivacionais:

a) O que te levou a ler?

b) Você lê para você mesmo ou para mostrar para alguém?

c) Como você se sentiu no momento da leitura?

Estratégias de gestão de recursos:

a) Você se preocupou com os materiais que precisava para a sua leitura?

b) Você se preocupou com o tempo para terminar a leitura?

${ }^{51}$ Instrumento adaptado de Oliveira, C. (2010) e Egler (2013). 
APÊNDICE F - Roteiro da entrevista IV com as crianças participantes da pesquisa

Realizadas nos momentos de atividades ${ }^{52}$ de escrita e leitura em sala de aula durante os dois anos da pesquisa.

\section{Questões norteadoras da conversação:}

a) Como você está realizando a atividade proposta?

b) Como você compreendeu o que é para ser realizado? Você mudou alguma coisa?

c) Você fez algo a mais na atividade ou apenas cumpriu o que foi pedido?

d) Fez alguma descoberta?

e) Você teve alguma dúvida? Como você solucionou?

f) Para quem você quer mostrar sua atividade?

g) Você gostou de realizar a atividade (individualmente, em dupla, em grupo, coletivamente)?

h) O que você não gostou na atividade?

i) O que esta atividade lhe impulsionou a querer descobrir mais?

j) Você tem interesse em realizá-la novamente?

k) O que você mudaria na atividade?

1) O que você sente quando lê ou escreve?

m) A imagem te ajuda na leitura?

n) O que te faz ler um livro? O que te faz escrever algo?

o) Para quem você quer contar o que você leu ou escreveu?

p) O que você tem vontade de fazer a partir da leitura de uma história ou de sua própria escrita?

${ }^{52}$ As atividades foram selecionadas pela pesquisadora a partir do interesse das crianças pelo que era proposto em sala de aula que envolvia leitura e escrita. 
APÊEDICE G - Eixos temáticos da dinâmica conversacional I com os familiares das crianças participantes da pesquisa

\section{Eixos da conversação:}

a) Relato da história de vida da criança e experiência escolar.

b) Relato da história de vida dos familiares e suas experiências escolares.

c) Relato da história pessoal de aprendizagem da leitura e da escrita dos familiares mais próximos da criança.

d) Escolha do nome do filho.

e) Eixos temáticos gerais que possam gerar indicadores da constituição da subjetividade:

- Necessidades/desejos;

- Organização temporal;

- Atividades realizadas cotidianamente;

- Dificuldades;

- Alegrias;

- Relacionamentos.

f) Participação da família na aprendizagem do filho.

g) O que valorizam na aprendizagem do filho?

h) Reações às descobertas e aos erros do filho.

i) Preferências de leitura e escrita no dia a dia do filho e dos familiares.

j) Mudanças necessárias no cotidiano do filho.

k) Momentos que gostam de estar juntos.

1) Rotina familiar.

m) Forma como são realizadas as tarefas de casa enviadas pela escola.

n) Expectativas em relação ao filho neste ano.

o) Gostos e preferências do filho.

p) Relação família e escola. 
APÊEDICE H - Eixos temáticos da dinâmica conversacional II com os familiares das crianças participantes da pesquisa

Conversas com familiares sobre aspectos de mudanças e novos elementos percebidos na criança, tendo em vista o processo de aprendizagem da leitura e da escrita. Realizada ao final de cada ano letivo em que estivemos na escola em que foi desenvolvida a pesquisa.

\section{Eixos da conversação:}
a) Mudanças gerais percebidas na criança;
b) Relação entre familiares e criança;
c) Participação na aprendizagem do filho;
d) Mudanças nos gostos, preferências e outras;
e) Curiosidades e interesses por aprender coisas novas;
f) A leitura e a escrita hoje para a criança. 
APÊNDICE I - Eixos temáticos da dinâmica conversacional I com as professoras ${ }^{53}$ das crianças participantes da pesquisa

Conversas com as professoras sobre a aprendizagem das crianças realizadas no início do ano letivo tanto no $1^{\circ}$ ano e quanto no $2^{\circ}$ ano do ensino fundamental.

\section{Eixos da conversação:}
a) História escolar do aprendiz;
b) Percepções em relação ao aprendiz;
c) A aprendizagem do aluno no contexto escolar;
d) Características gerais das crianças;
e) Gostos e preferências das crianças;
f) Atividades que mais se interessam;
g) Relação professor-aluno;
h) Relação aluno-aluno;
i) Curiosidades apresentadas;
j) As inter-relações entre o trabalho pedagógico do professor e a aprendizagem dos alunos;
k) Necessidades da criança no processo de aprender;
1) Participação da família.

${ }^{53}$ Professoras: Melissa e Flávia. 
APÊNDICE J - Eixos temáticos da dinâmica conversacional II com as professoras ${ }^{54}$ das crianças participantes da pesquisa

Conversas com as professoras sobre as possíveis mudanças das crianças que participaram da pesquisa mediante o processo de aprendizagem da leitura e da escrita. Realizada ao final de cada ano letivo em que estivemos na escola em que foi desenvolvida a pesquisa.

\section{Eixos da conversação:}
a) Mudanças gerais percebidas pela professora no aluno;
b) Atividades que o aluno mais se interessa hoje;
c) Relação professor-aluno e suas relações com o aprender;
d) Relação com os colegas e suas relações com a aprendizagem;
e) Mudanças na relação com os outros;
f) Mudanças nas estratégias de aprendizagem;
g) Participação da família;
h) Trabalho pedagógico e as mudanças na aprendizagem;
i) Participação de outros integrantes da escola na aprendizagem e mudanças.

\footnotetext{
${ }^{54}$ Professoras: Melissa e Flávia.
} 
APÊNDICE K - Eixos temáticos da dinâmica conversacional III com as professoras das crianças participantes da pesquisa

\section{Eixos da conversação:}

a) Relato da história pessoal, escolar e profissional da professora.

b) Relato da história pessoal de aprendizagem da leitura e da escrita da professora.

c) Eixos temáticos gerais que possam gerar indicadores da constituição da subjetividade:

- Necessidades/desejos;

- Organização temporal;

- Atividades realizadas cotidianamente;

- Dificuldades/Facilidades;

- Alegrias/Tristezas;

- Relacionamentos;

d) Relação professor-aluno.

e) As diferentes aprendizagens das crianças.

f) Organização do trabalho pedagógico.

g) Hipóteses de escrita da criança.

h) Tipos de leitura realizada em sala de aula.

i) Metodologia para o ensino da leitura e da escrita.

j) Organização do espaço-tempo da sala de aula.

k) Organização do trabalho pedagógico.

1) Avaliação da aprendizagem.

m) Reações às descobertas dos alunos.

n) Utilização da escrita da criança no cotidiano escolar.

o) Gostos e preferências de leitura e escrita.

p) Tipos de atividades (dupla, individual, coletiva) que prioriza.

q) As inter-relações entre o trabalho pedagógico do professor e a aprendizagem dos alunos. 
APÊNDICE L - Eixos temáticos da dinâmica conversacional I com as crianças participantes da pesquisa sobre os seus próprios registros

\section{Eixos da conversação:}

\section{$1^{\circ}$ Momento}

a) Personalização: das informações emitidas pelo professor; do contexto de aprendizagem associado à leitura e à escrita na escola de forma geral e na sala de aula; das atividades realizadas e outras opções;

b) Gostos e preferências relacionadas aos tipos de atividades de sala de aula;

c) Emoções geradas a partir das ações que envolvem a leitura e a escrita, bem como às situações gerais de aprendizagem (atividades individuais, em grupo, coletivas; explicação verbal da professora; explicação individual da professora à criança)

d) Relação que estabeleceu com a escrita espontânea;

e) Leituras que realizou por conta própria;

f) Conhecimentos e descobertas que chegou por si mesmo;

g) Recursos e caminhos que utiliza para aprender.

\section{$2^{\circ}$ Momento}

a) Situações em que necessitou da ajuda do professor e dos colegas;

b) Momentos de aprendizagem com o professor e com os colegas;

c) O papel do professor e dos colegas na aprendizagem, com ênfase à qualidade dos vínculos;

d) Reações quanto à avaliação e forma de correção da professora. 


\section{APÊNDICE M - Diário de ideias}

Cada criança da pesquisa recebeu um caderno com as páginas em branco para registros espontâneos durante o decorrer da pesquisa, podendo ser curiosidades, aprendizagens diversas, lembretes ou outras ideias que achar relevantes. O caderno ficou com a criança durante todo o processo da pesquisa, podendo ser levado para sua residência.

Desta forma, os registros pictóricos e/ou escritos, foram realizados tanto no contexto escolar quanto em outros espaços sociais experienciados pelo participante. Em cada encontro com a criança, que ocorreram no decorrer dos dois anos da pesquisa de campo, com foco nas produções no Diário de ideias, foram exploradas oralmente descobertas e registros realizados, com o objetivo de compreender a significação da escrita pela criança. Os encontros com as crianças tinham duração de aproximadamente $1 \mathrm{~h} 30 \mathrm{~min}$, momentos que muitas vezes eram solicitados pelas próprias crianças e outros organizados pela pesquisadora. Era um espaçotempo para que a criança explorasse a sua própria produção, em que ela ficava livre para falar sobre seus registros e também sobre o processo de elaboração.

\section{Eixos da conversação:}
a) Gostos e preferências;
b) Escolhas do tipo de registro;
c) Autoria no processo de registro;
d) Os vínculos afetivos na relação com os registros espontâneos;
e) Emoções geradas pelo processo de registro;
f) Motivação para registrar;
g) Temas que foram registrados;
h) Interesse espontâneo em aprender coisas novas;
i) Estratégias de leitura e escrita;
j) Iniciativa para escrever;
k) Tipos de materiais que recorre para realizar seus registros. 


\section{APÊNDICE N - Oficina de leitura e escrita}

\section{$1^{\circ}$ Momento - Leitura ${ }^{55}$}

Entregamos uma caixa de livros ${ }^{56}$ para que a criança escolhesse um livro para ler. Explicamos para o aprendiz que ele poderá interromper a leitura para fazer qualquer comentário, correção ou expor alguma ideia. Para isso, a cada página lida, pela pesquisadora ou pela criança, era feito um momento conversacional, o que ocorria também ao final da história:

Eixos norteadores da conversação:

Para cada página lida:

a) Compreensão da leitura.

b) Descobertas realizadas.

c) Momentos imaginativos sobre o que pode ocorrer na história.

d) Ideias que surgem no decorrer da leitura e ao final da leitura.

\section{Ao final da leitura:}

a) Impressões sobre o livro e a história.

b) Elaboração de um resumo da história.

c) Sugestões de mudanças no enredo da história.

d) Invenção de um novo título para a história.

e) Experiências vividas que são próximas ao enredo da história.

f) Colocar-se no lugar da personagem principal e indicar ações que realizaria.

g) Explicitar a personagem que mais se identificou.

\section{$2^{\circ}$ Momento - Escrita}

Perguntamos se a criança teria vontade de ler ou ouvir a história "Você troca?" da autora Eva Furnari. Durante a leitura, realizada pela pesquisadora ou pela criança, e após a mesma, ouvimos suas impressões sobre a história. Em seguida, perguntamos ao aprendiz: Você trocaria de lugar? Deixaria de ser o leitor para ser o escritor? Depois, solicitamos que o participante escrevesse uma história com um tema de seu interesse.

\section{Eixos da conversação:}

a) Dificuldades e facilidades encontradas;

b) Iniciativa, audácia, caráter ativo e inventivo;

c) Estratégias de leitura e escrita;

d) Motivos da escolha do tema;

e) Imaginação e fantasia que emergem;

f) Geração de ideias próprias e novas que transcendem o dado;

g) Confrontos com a escrita e com a leitura;

h) A autoria e personalização de informação;

i) Flexibilidade de pensamento;

j) Hipóteses de escrita;

k) Emoções que emergem.

\footnotetext{
55 Momento do instrumento inspirado pelas contribuições de Gustavo Cantú, no livro "Lectura y subjetividad en el diagnóstico psicopedagógico" (2011). Os livros utilizados no instrumento compõem diferentes títulos do acervo disponibilizado às escolas pelo Programa Nacional Biblioteca na Escola (PNBE/FNDE).

${ }^{56}$ Os livros foram escolhidos na biblioteca da escola e fazem parte da lista do Programa Nacional Biblioteca da Escola PNBE.
} 
APÊNDICE O - Montando minha história

\section{$\mathbf{1}^{\circ}$ Momento}

Solicitamos que cada criança criasse seu autorretrato, utilizando argila e/ou massas de modelar coloridas, bem como imagens diversas de revistas e outras.

Eixos da conversação:

a) A visão que tem de si mesmo;

b) O que gosta em si mesmo e o que não gosta.

\section{$2^{\mathbf{0}}$ Momento}

Inicialmente a pesquisadora leu a história "As Memórias da Bruxa Onilda" de Roser Larreula e propôs um diálogo com a criança sobre a sua própria história de vida, enfatizando suas preferências, gostos, características e outros aspectos que queriam destacar. O aprendiz pôde registrar este momento usando massa de modelar, recortes e colagem de imagens de revistas, bem como escrita e desenho.

\section{Eixos da conversação:}
a) História de vida da criança;
b) Os vínculos afetivos na família;
c) As emoções no âmbito familiar e escolar;
d) As relações com o outro;
e) A importância da aprendizagem da leitura e da escrita na vida da criança;
f) Gostos e preferências da criança;
g) Sonhos e realizações da criança;
h) Curiosidades diversas;
i) Lugares que gosta de estar.

\section{$3^{\circ}$ Momento $^{57}$}

Realizamos a leitura do livro "Pintor de Lembranças" do autor José Antonio del Cañizo e pedimos à criança que expressasse, por meio da massa de modelar e/ou de tinta, três momentos felizes de sua vida familiar ou escolar e três que gostaria de modificar em algum aspecto.

\section{Eixos da conversação:}

Momentos felizes:
a) Explicar o porquê os momentos escolhidos são felizes.
b) Pessoas participantes com a criança.
c) Ações empreendidas pela criança.
d) Elementos do momento que gostaria de explicitar mais.

Momentos que quero modificar:

a) Explicar as possíveis mudanças que gostaria de empreender em alguns momentos.

b) Elementos que compõem o momento a ser modificado.

c) Ações empreendidas antes, durante e depois da mudança.

d) Explicar como a mudança foi empreendida.

\footnotetext{
${ }^{57}$ Momento elaborado a partir do instrumento Túnel do tempo elaborado por Amaral (2011).
} 
APÊNDICE P - Brincando de escolinha

Expressão pela criança de seus pensamentos, medos, emoções e sentimentos através do tema "Minha vida na escola". Disponibilizamos, em um primeiro momento, fantoches para que as crianças pudessem se expressar por meio dos mesmos. Em outro momento, levamos materiais escolares, dentre os quais estão: livros, lápis de escrever, borrachas, folhas em branco, cadernos, revistas e outros, para que as crianças pudessem realizar uma dramatização sobre o tema.

\section{Eixos da conversação:}

a) Forma de expressão: por fantoches e dramatização;

b) O tipo de história representada;

c) A imaginação e a fantasia no processo de aprender;

d) Momentos felizes e tristes da história;

e) A relação professor-aluno e aluno-aluno;

f) Mudanças na própria história;

g) Tipos de relações estabelecidas;

h) Vínculos afetivos;

i) Organização temporal/espacial;

j) Tipo de expressões orais utilizadas pela criança;

k) Imaginação e fantasia que emergem;

1) Aspectos destacados do trabalho pedagógico da professora;

m) Tipos de atividades utilizadas;

n) Momentos interativos na história;

o) A forma como o espaço-tempo escolar se configura para a criança. 
APÊNDICE Q - Trilha das frases ${ }^{58}$

Consiste em uma trilha numerada de um a trinta e na utilização de um dado de seis faces numerado com a quantidade um e dois, bem como cartinhas com inícios de frases e um pino para cada jogador. Na sua vez de jogar, o participante, lança o dado e move o pino pela quantidade de casas. Assim que parar, a criança retira uma carta, a qual deverá ser lida pela pesquisadora e respondida com a primeira coisa que vier à cabeça da criança. Organizamos abaixo os indutores norteadores para cada ficha que compõe o jogo:

1- Eu sou

2 - Minha maior alegria

3 - Na sala de aula

4 - Minhas descobertas

5 - Gosto de fazer

6 - Me deixa triste

7 - Sou rápido

8 - Ajudo

9 - Faço

10 - Não gosto

11 - Gosto de aprender

12 - Família

13 - Queria

14 - Meus colegas

15 - Quando acerto

16 - Meus sonhos

17 - Faço perguntas

18 - Animais que gosto
19 - Acho lindo

20 - Assisto

21 - O lugar que eu adoro

22 - Minha professora

23 - Acho feio

24 - Brincar

25 - Livros

26 - Na escola

27 - Em casa

28 - Dedico meu maior tempo

29 - Eu mudaria

30 - Estou feliz quando

31 - Considero que posso

32 - O que eu mais gosto na

escola

33 - Tenho curiosidade para

34 - Aborrece-me

35 - Quando tenho dúvidas
36 - Escrever é

37 - Ler é

38 - $\mathrm{O}$ que eu mais quero

39 - Sofro quando

40 - No futuro

41 - Quando erro

42 - Quando invento

43 - Eu gostaria de saber mais sobre

44 - Aprender é divertido quando

45 - Eu sei que sou

46 - Penso muito em

47 - Sinto-me desafiado quando

48 - Aprendo melhor quando

49 - O que eu faço melhor é

50 - Minhas atividades

51 - O que eu preciso melhorar é

${ }^{58}$ Instrumento adaptado do original elaborado por González Rey e Mitjáns Martínez (1989). 
APÊNDICE R - Mapa do tesouro

\section{$1^{\circ}$ Momento}

Realizamos a leitura do livro "Pirata de Palavras" da autora Jussara Braga. Após a leitura, dialogamos com cada criança, sobre qual é o tesouro que cada uma gostaria de encontrar e perguntamos se aprender a ler e a escrever era um tesouro que queriam descobrir. Em seguida, convidamos os aprendizes a construírem um mapa do tesouro, pensando no caminho que precisavam percorrer para encontrar a leitura e a escrita. O mapa foi construído em uma cartolina. Após a construção do mapa, cada criança recebeu um baú de plástico e colocou nele dicas para se alcançar o tesouro da aprendizagem da leitura e da escrita, como se estivessem escrevendo para um colega de outra turma.

\section{Eixos da conversação:}

a) A leitura e a escrita como um tesouro;

b) Elementos do caminho a ser percorrido para encontrar o tesouro;

c) Curiosidades pelo mundo;

d) Elaborações sobre como é o tesouro da leitura e da escrita;

e) Atitudes frente ao tesouro encontrado;

f) Envolvimento com a aprendizagem da leitura e da escrita;

g) Os vínculos afetivos no processo de aprender;

h) O brincar na aprendizagem;

i) A fantasia e a imaginação na aprendizagem.

\section{$\mathbf{2}^{\circ}$ Momento}

Solicitamos que cada criança contasse e/ou registrasse sua história de aprendizagem da leitura e da escrita, utilizando para isso desenho e/ou escrita. Nossa sugestão de tema norteador para a expressão da criança foi: "Minha aprendizagem da leitura e da escrita".

\section{Eixos da conversação:}

a) O outro no processo de aprendizagem;

b) Relação lúdica e inventiva na aprendizagem;

c) Autonomia e flexibilidade na aprendizagem;

d) Processos reflexivos na aprendizagem;

e) Interesse espontâneo em aprender coisas novas;

f) Imaginação e fantasia para aprender. 
APÊNDICE S - Minhas mudanças

\section{$\mathbf{1}^{\circ}$ Momento}

Assistimos ao filme "Robots" com a turma e após este momento realizamos um processo diálogo com os participantes da pesquisa tendo em vista os eixos abaixo:

\section{Questões norteadoras da conversação:}

a) Personagem que mais se identificou e outros que não gostou.

b) Observações sobre as mudanças nos personagens.

c) Mudanças identificadas pelo aprendiz no percurso da aprendizagem da leitura e da escrita.

d) Invenções realizadas no campo da leitura e da escrita.

e) A utilização da leitura e da escrita na vida.

f) Pessoas e elementos que participam da aprendizagem da leitura e da escrita.

g) Pessoas e momentos que gosta de trocar ideias.

h) Sonhos que já realizou e o caminho empreendido para conquista-los.

i) Desejos e sonhos que quer concretizar e o caminho que empreenderá.

\section{$2^{\mathbf{o}}$ Momento}

Solicitamos que cada aprendiz escolhesse uma mudança ${ }^{59}$ mediante os indutores da tabela abaixo, que havia sido significativa e representasse em forma de desenho e/ou escrita. As tabelas disponibilizadas às crianças da pesquisa, contaram com espaço suficiente para ser utilizado pela criança.

\begin{tabular}{|l|c|c|}
\hline \multicolumn{1}{|c|}{ Mudanças na... } & No ano passado & Agora \\
\hline Minha família & & \\
\hline Minha escola & & \\
\hline Meus amigos & & \\
\hline Minha professora & & $\begin{array}{c}\text { Agora que já sei ler e } \\
\text { escrever }\end{array}$ \\
\hline Minha sala de aula & $\begin{array}{c}\text { Aprendendo a ler e a } \\
\text { escrever }\end{array}$ & \\
\hline Mudanças... & & \\
\cline { 2 - 3 } & & \\
\hline
\end{tabular}

\section{$3^{\circ}$ Momento}

Escrita pelo participante de uma história com o tema: "Minhas mudanças".

\section{Eixos da conversação:}
a) Mudanças na autoimagem, autovaloração;
b) Mudanças nos gostos, preferências e interesses;
c) Mudanças nas atitudes frente à aprendizagem;
d) Mudanças nos vínculos afetivos.

\footnotetext{
${ }^{59}$ Instrumento adaptado do original elaborado por Rossato (2009).
} 
APÊNDICE T - Termo de Consentimento Livre e Esclarecido para familiares responsáveis pelas crianças participantes da pesquisa

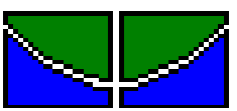

Universidade de Brasília

Faculdade de Educação

Programa de Pós-Graduação em Educação

\section{$\underline{\text { Termo de Consentimento Livre e Esclarecido }}$}

Você e seu filho(a) estão sendo convidados(as) a participar da pesquisa intitulada: "Aprendizagem criativa da leitura e da escrita e suas inter-relações com o desenvolvimento da subjetividade" com o objetivo de "Compreender como a criatividade emerge na aprendizagem da leitura e da escrita e suas inter-relações com o desenvolvimento da subjetividade" que está sendo realizada pela Doutoranda Luciana Soares Muniz sob a orientação da Profa Dra Albertina Mitjáns Martínez e será apresentada na Universidade de Brasília como requisito parcial para obtenção do título de Doutor em Educação.

Os participantes voluntários da referida investigação deverão expressar-se quanto aos processos e estratégias envolvidos na aprendizagem da leitura e da escrita através de entrevistas e da realização de outros instrumentos, os quais poderão ser realizados na escola ou mesmo em espaços extraescolares. A autorização para participação na pesquisa será documentada através deste Termo de Consentimento Livre e Esclarecido. Se decidir participar, leia cuidadosamente este termo e esclareça eventuais dúvidas.

Se vocês concordarem em participar da pesquisa, seus nomes e identidades serão mantidos em sigilo. Serão agendados previamente o local e o horário em que acontecerão os encontros. Ocasionalmente as entrevistas serão audiogravadas, com a autorização prévia dos participantes. Periodicamente vocês serão informados(as) de qualquer alteração no procedimento, podendo desistir da pesquisa a qualquer momento. Não haverá ônus financeiro aos participantes da pesquisa.

Declaramos que entendemos os objetivos e como será a nossa participação na pesquisa e concordamos em participar.

Pesquisadora: Doutoranda Luciana Soares Muniz

Ass.:

Data:

Contato: lucianasoares.muniz@gmail.com

Orientadora: Profa Dra. Albertina Mitjáns Martínez

Ass.:

Data:

Contato: (61)3307-2123/UnB

Pais e/ou Responsáveis:

Ass.:

Data:

Nome do(a) filho(a):

Contatos: Telefone:

E-mail: 
APÊNDICE U - Termo de Consentimento Livre e Esclarecido para as professoras participantes da pesquisa

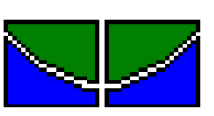

Universidade de Brasília

Faculdade de Educação

Programa de Pós-Graduação em Educação

\section{$\underline{\text { Termo de Consentimento Livre e Esclarecido }}$}

Você está sendo convidado(a) a participar da pesquisa intitulada: "Aprendizagem criativa da leitura e da escrita e suas inter-relações com o desenvolvimento da subjetividade" com o objetivo de "Compreender como a criatividade emerge na aprendizagem da leitura e da escrita e suas inter-relações com o desenvolvimento da subjetividade" que está sendo realizada pela Doutoranda Luciana Soares Muniz sob a orientação da Profa Dra Albertina Mitjáns Martínez e será apresentada na Universidade de Brasília como requisito parcial para obtenção do título de Doutor em Educação.

Os participantes voluntários da referida investigação deverão expressar-se quanto aos processos e estratégias envolvidos na aprendizagem da leitura e da escrita através de entrevistas e da realização de outros instrumentos. A autorização para participação na pesquisa será documentada através deste Termo de Consentimento Livre e Esclarecido. Se decidir participar, leia cuidadosamente este termo e esclareça eventuais dúvidas.

Se você concordar em participar da pesquisa, seu nome e identidade serão mantidos em sigilo. Serão agendados previamente o local e o horário em que acontecerão os encontros. Ocasionalmente as entrevistas serão audiogravadas, com a autorização prévia do participante. Periodicamente você será informado(a) de qualquer alteração no procedimento, podendo desistir da pesquisa a qualquer momento. Não haverá ônus financeiro aos participantes da pesquisa.

Declaro que entendi os objetivos e como será a minha participação na pesquisa e concordo em participar.

Pesquisadora: Doutoranda Luciana Soares Muniz

Ass.: Data:

Contato: lucianasoares.muniz@gmail.com

Orientadora: Profa Dra. Albertina Mitjáns Martínez

Ass.: Data:

Contato: (61)3307-2123/UnB

Nome do participante:

Ass.:

Contatos: Telefone:

Data: E-mail: Local: 
ANEXOS 


\section{ANEXO A - Autorização para realização da pesquisa na escola I}
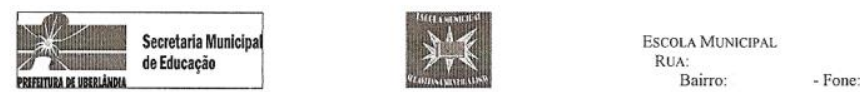

Uberlândia, 15 de março de 2012.

AUTORIZAÇÃO

$\mathrm{Eu}$, , na qualidade de Diretora Escolar dessa unidade de ensino

denominada Escola Municipal , autorizo Luciana Soares Muniz, a realizar

uma pesquisa de doutorado, "Aprendizagem Criativa da Leitura e da Escrita", com as salas dos primeiros anos do Ensino Fundamental, nos períodos da manhã e tarde, durante o ano letivo de 2012.

Autorizo por ser verdade, e firmo o presente. 
ANEXO B - Autorização para realização da pesquisa na escola II

\section{SECRETARIA MUNACPPAL DE EDUCAÇÃO

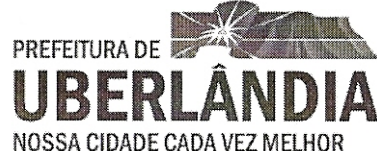

Assessoria Pedagógica do Ensino Fundamental

E-mail: asspedagogica@uberlandia.mg.gov.br Tel: (34) 3239262332392765

Uberlândia 20 de março de 2012

\section{AUTORIZACÃO No 006/12}

DE: Assessoria Pedagógica do Ensino Fundamental PARA: Diretora da EM Profa

Prezada Diretora,

Atendendo à solicitação em anexo, autorizamos a Pesquisadora, doutoranda do Curso de Pós-Graduação em Educação, pela Universidade de Brasília - UNB, a desenvolver um Projeto de Pesquisa, nesta referida instituição de ensino, com o tema: "Aprendizagem Criativa da Leitura e da Escrita".

A Pesquisa será desenvolvida por meio de entrevistas, instrumentos apoiados em indutores escritos e não escritos e observação.

O objetivo da referida pesquisa é compreender como ocorre a aprendizagem da leitura e da escrita, na qual o sujeito está envolvido, dentre elas a aprendizagem criativa e suas interrelações com o desenvolvimento da subjetividade da criança.

Informamos que este trabalho será realizado sem vínculo empregatício e sem ônus para o Município.

Cordialmente,
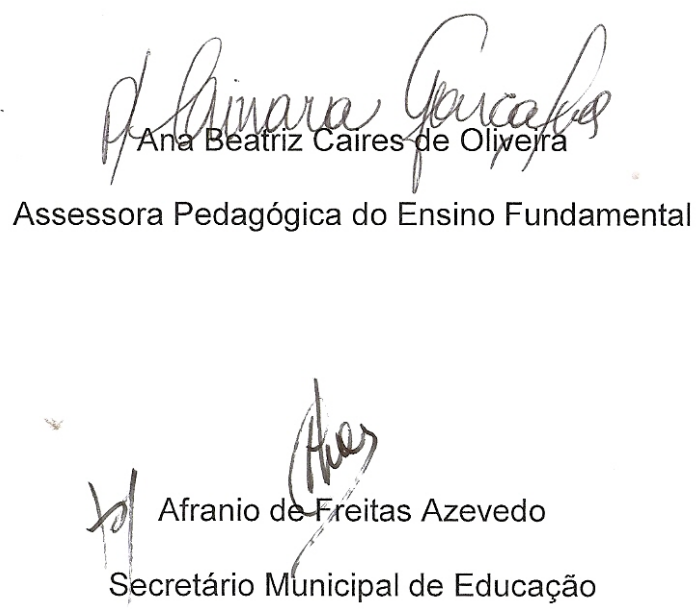
ANEXO C - Imagens I referentes ao estudo de caso Murilo

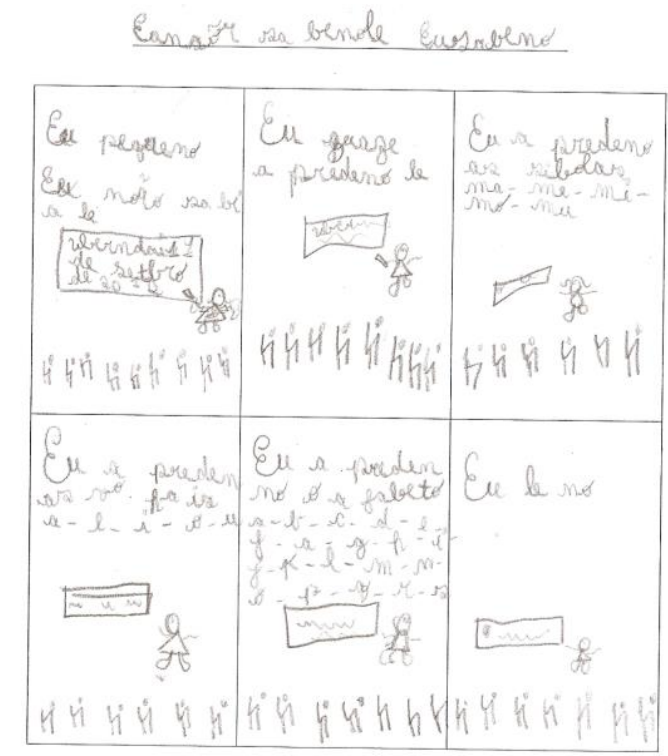

Transcrição da escrita de Murilo: Eu aprendendo a ler e eu sabendo ler - Eu pequeno. Eu não sabia ler. Eu quase aprendendo a ler. Eu aprendendo as sílabas. Eu aprendendo as vogais: $\mathrm{a}-\mathrm{e}-\mathrm{i}-\mathrm{o}-\mathrm{u}$. Eu aprendendo o alfabeto. Eu lendo.

Figura 4: Produção de Murilo a partir do instrumento "Mapa do tesouro" - 2012.

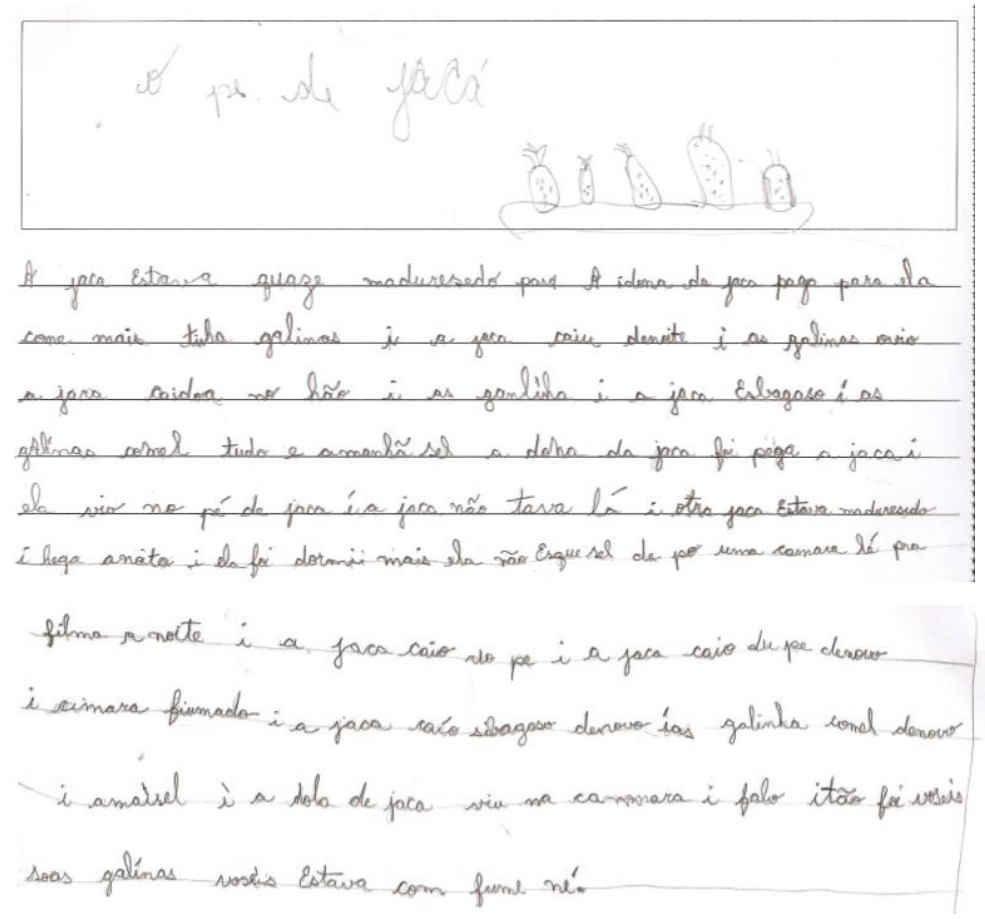

Transcrição do texto: A jaca estava quase amadurecendo para a dona da jaca pegar para ela comer. Mais tinha galinhas e a jaca caiu de noite e as galinhas viu a jaca caída no chão. $\mathrm{E}$ as galinha e a jaca esbagaçou e as galinhas comeu tudo e amanheceu e a dona da jaca foi pegar a jaca e ela viu no pé de jaca e a jaca não estava lá. E outra jaca estava amadurecendo e chegou a noite e ela foi dormir. Mais ela não esqueceu de pôr uma câmera lá pra filmar a noite e a jaca caiu do pé e a jaca caiu do pé de novo e a câmera filmou e a jaca caiu esbagaçou de novo e as galinhas comeu de novo. E amanheceu e a dona da jaca viu na câmera e falou: então foi vocês suas galinhas, vocês estava com fome, né?

Figura 5: Produção de Murilo a partir do instrumento "Diário de ideias" - 2013.

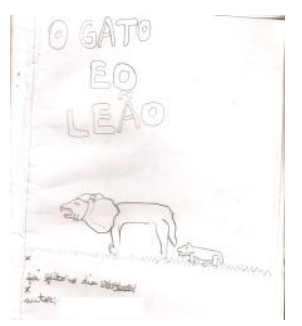

Figura 6: Capa do livro produzido por Murilo - 2013. 
ANEXO D - Imagens II referentes ao estudo de caso Murilo

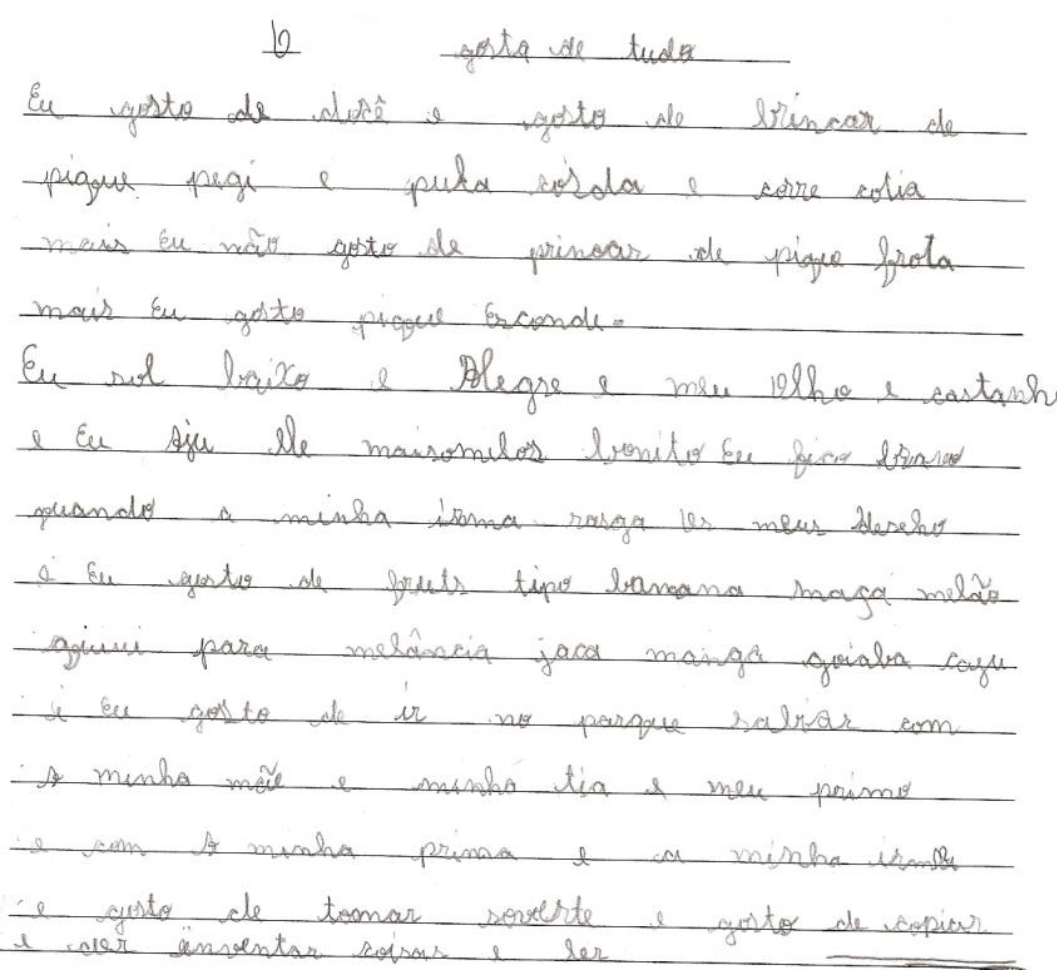

Transcrição do texto:

O Murilo gosta de tudo

Eu gosto de doce e gosto de brincar de pique pega e pular corda e corre cotia. Mais eu não gosto de brincar de pique fruta, mais eu gosto de pique esconde.

Eu sou baixo e alegre e meu olho é castanho e eu acho ele mais ou menos bonito. Eu fico bravo quando a minha irmã rasga os meus desenho e eu gosto de frutas tipo banana, maçã, melão, caqui, pêra, melancia, jaca, manga, goiaba, caju. E eu gosto de ir no parque sabiá com a minha mãe e minha tia e meu primo e com minha prima e a minha irmã. Eu gosto de tomar sorvete e gosto de copiar e de inventar coisas e ler.

Figura 7: Produção de Murilo a partir do instrumento "Montando minha história" - 2013.

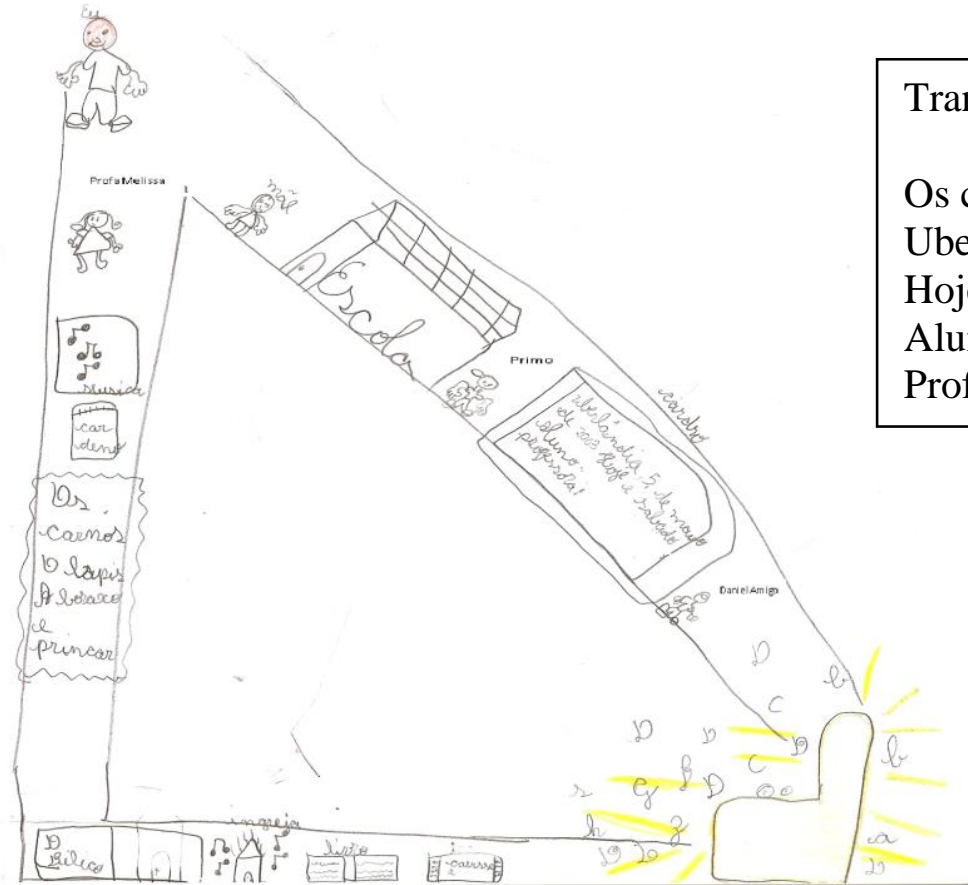

Transcrição de trechos da escrita de Murilo:

Os cadernos, o lápis, a borracha e brincar. Uberlândia, 5 de maio de 2013

Hoje é sábado

Aluno:

Professora:

Figura 8: Produção de Murilo a partir do instrumento "Mapa do tesouro" - 2013. 
ANEXO E - Imagens I referentes ao estudo de caso Adriana
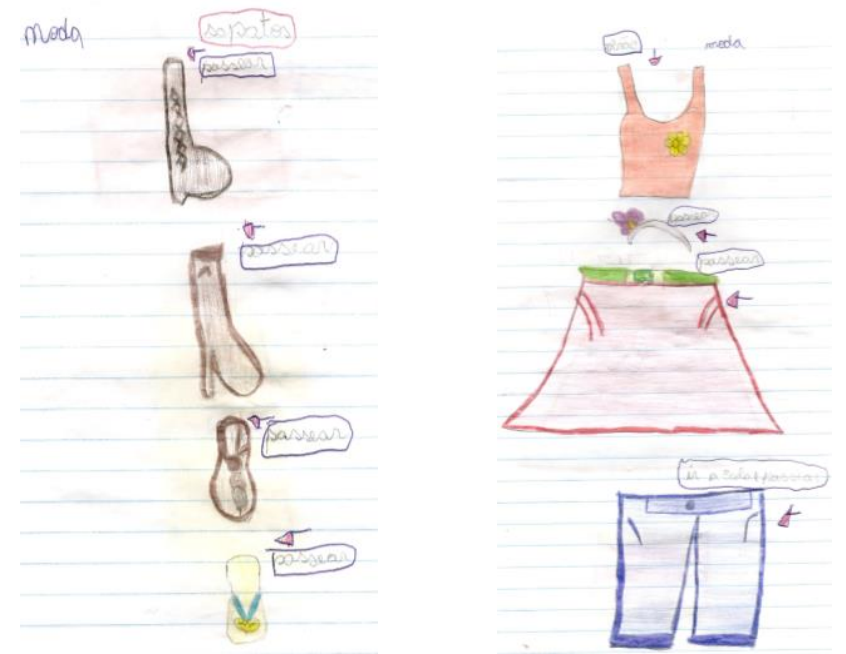

Figura 9: Produção de Adriana em seu caderno pessoal - 2012.

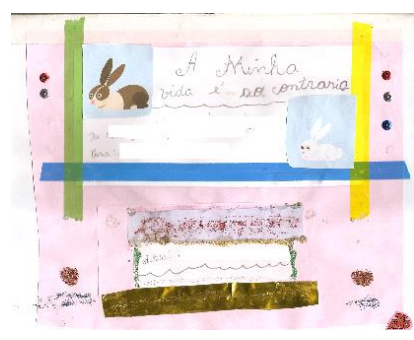

Figura 10: Capa do livro de autoria de Adriana - 2013.

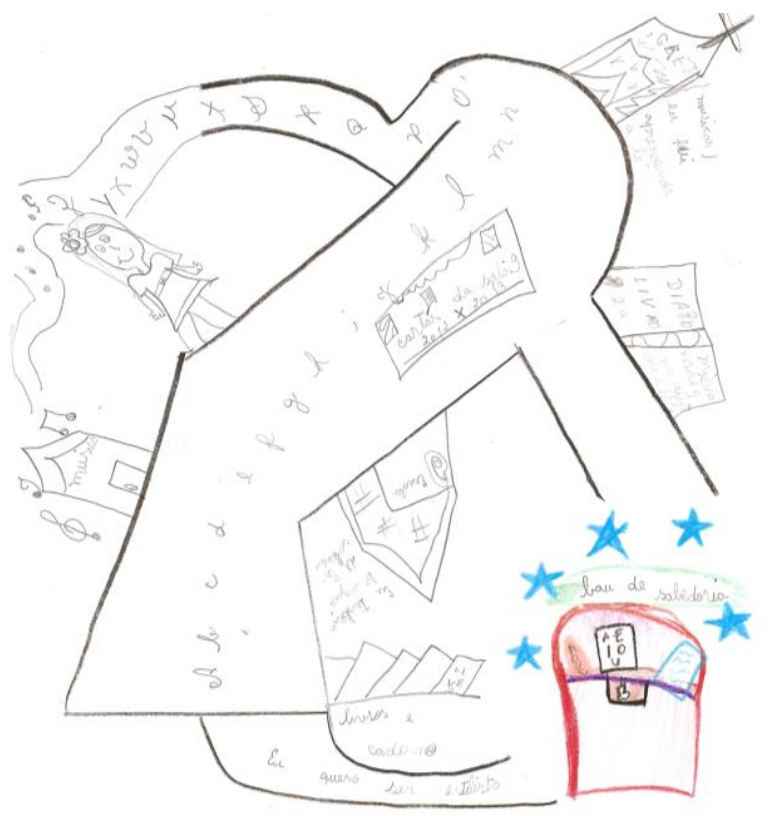

Transcrição de trechos da escrita de Adriana:

Eu quero ser estilista.

Igreja, música, eu feliz aprendendo.

Cartazes da sala.

Música.

Livros e cadernos.

Figura 11: Produção de Adriana a partir do instrumento "Mapa do tesouro" - 2013. 
ANEXO F - Imagens II referentes ao estudo de caso Adriana

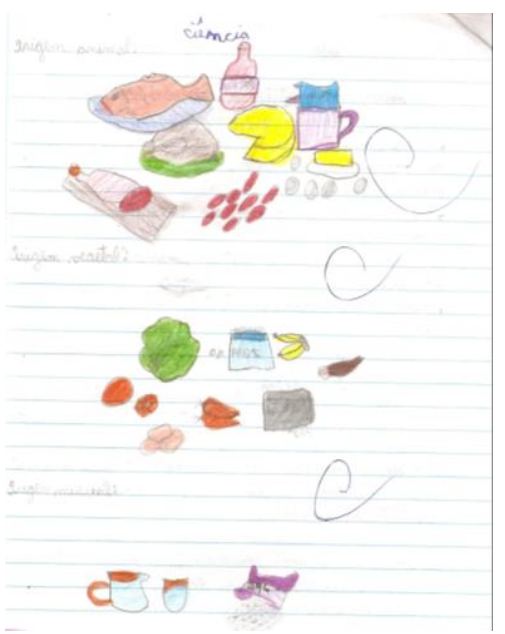

Figura 12: Produção de Adriana em seu caderno pessoal - 2013.

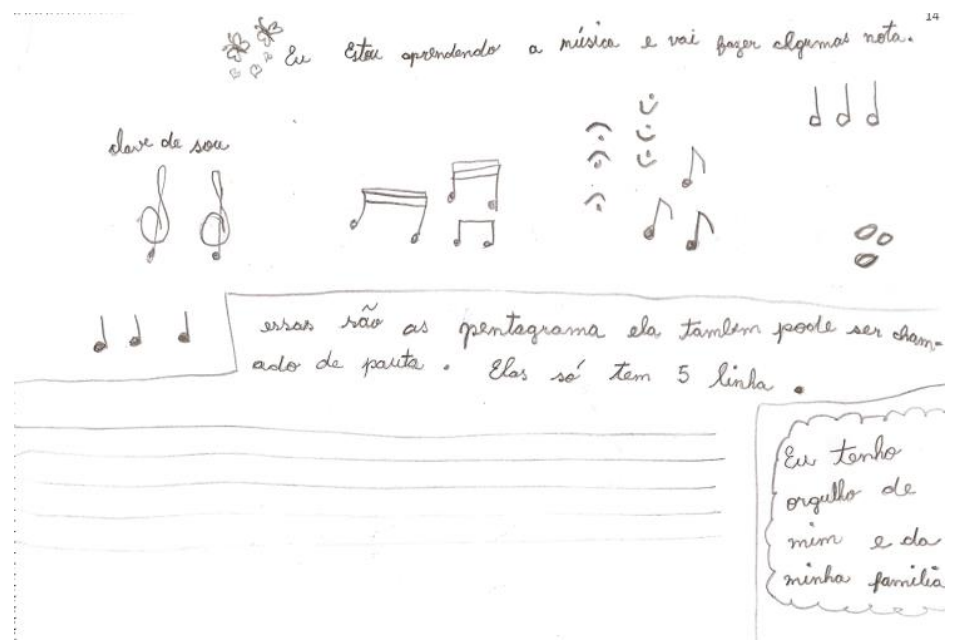

Figura 13: Produção de Adriana a partir do instrumento "Diário de ideias" - 2013.

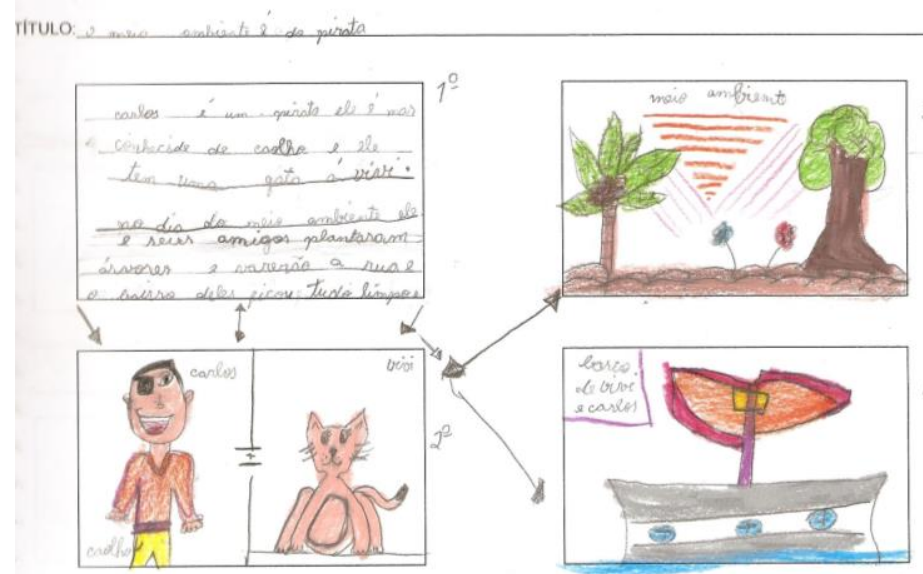

Transcrição de trechos da escrita de Adriana:

Carlos é um pirata. Ele é mais conhecido de caolho e ele tem uma gata a vivi.

No dia do meio ambiente ele e seus amigos plantaram árvores e varreram a rua. E o bairro deles ficou tudo limpo.

Figura 14: Produção de Adriana: atividade de escrita espontânea em sala de aula/2º ano/2013. 
ANEXO G - Imagens I referentes ao estudo de caso Gabriel

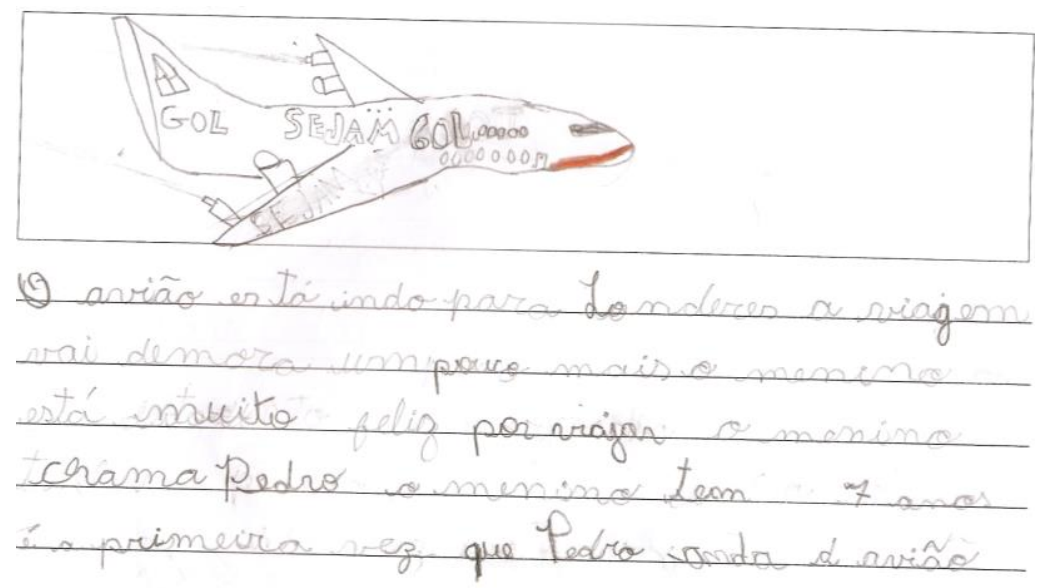

Figura 15: Produção de Gabriel a partir do instrumento "Diário de ideias" - 2013.

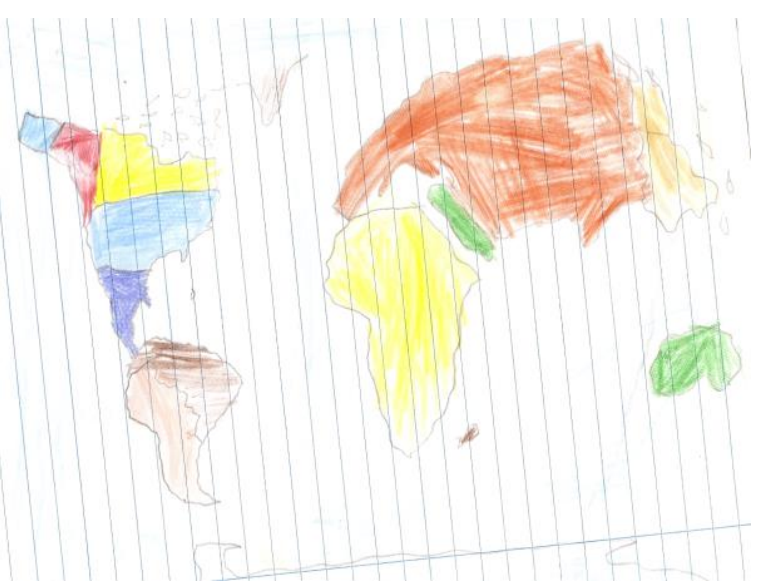

Figura 16: Produção de Gabriel em material de registro pessoal - 2012.

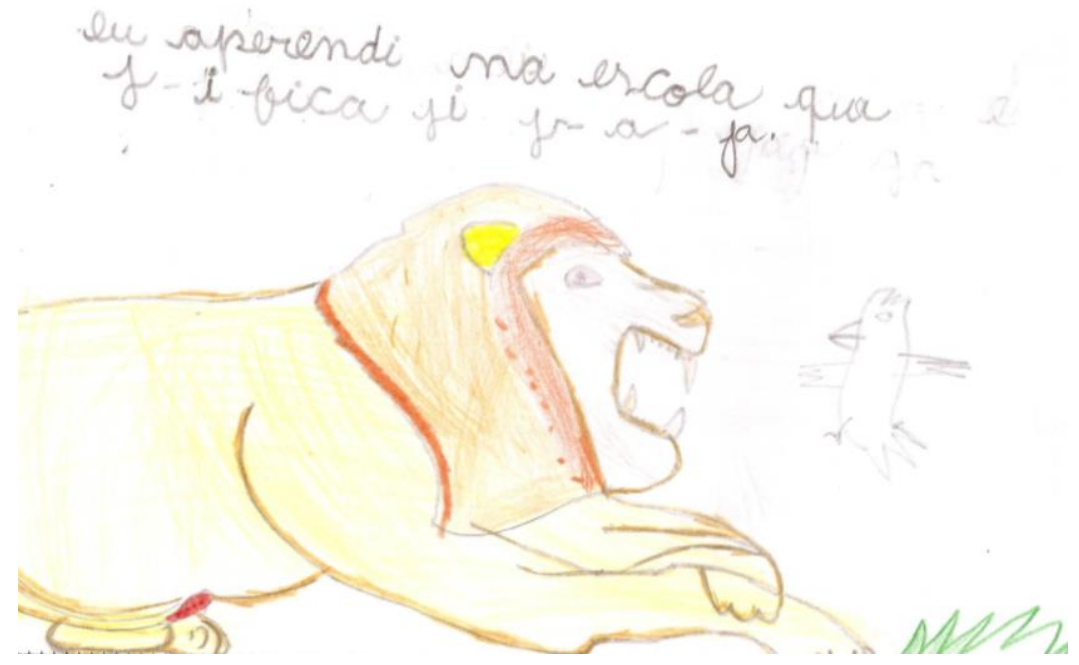

Figura 17: Produção de Gabriel a partir do instrumento "Diário de ideias" - 2013. 
ANEXO H - Imagens II referentes ao estudo de caso Gabriel

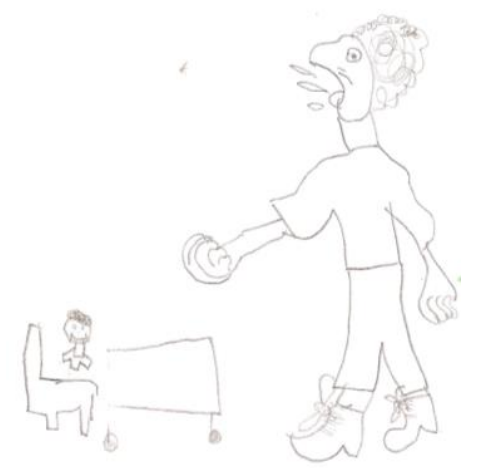

Figura 18: Produção de Gabriel a partir do instrumento "Montando minha história" - 2012.

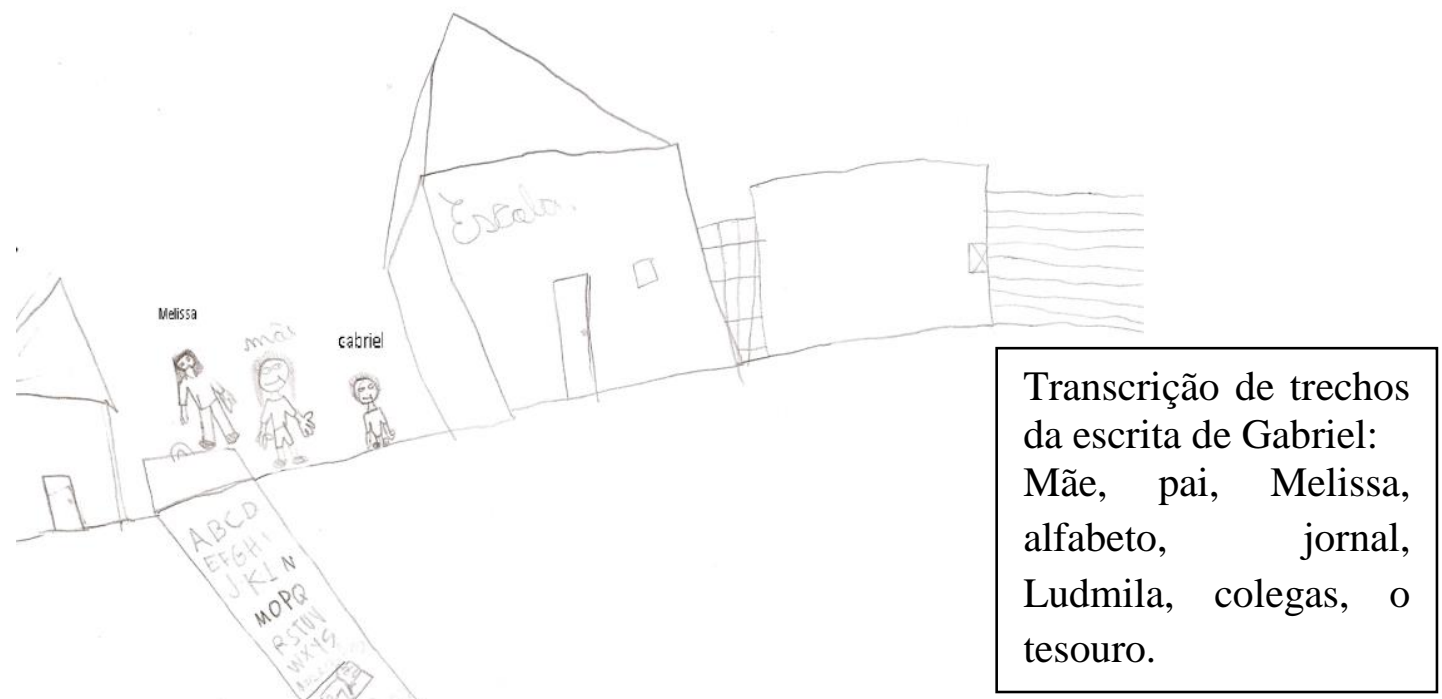

Figura 19: Produção de Gabriel a partir do instrumento "Mapa do tesouro" - 2013. 